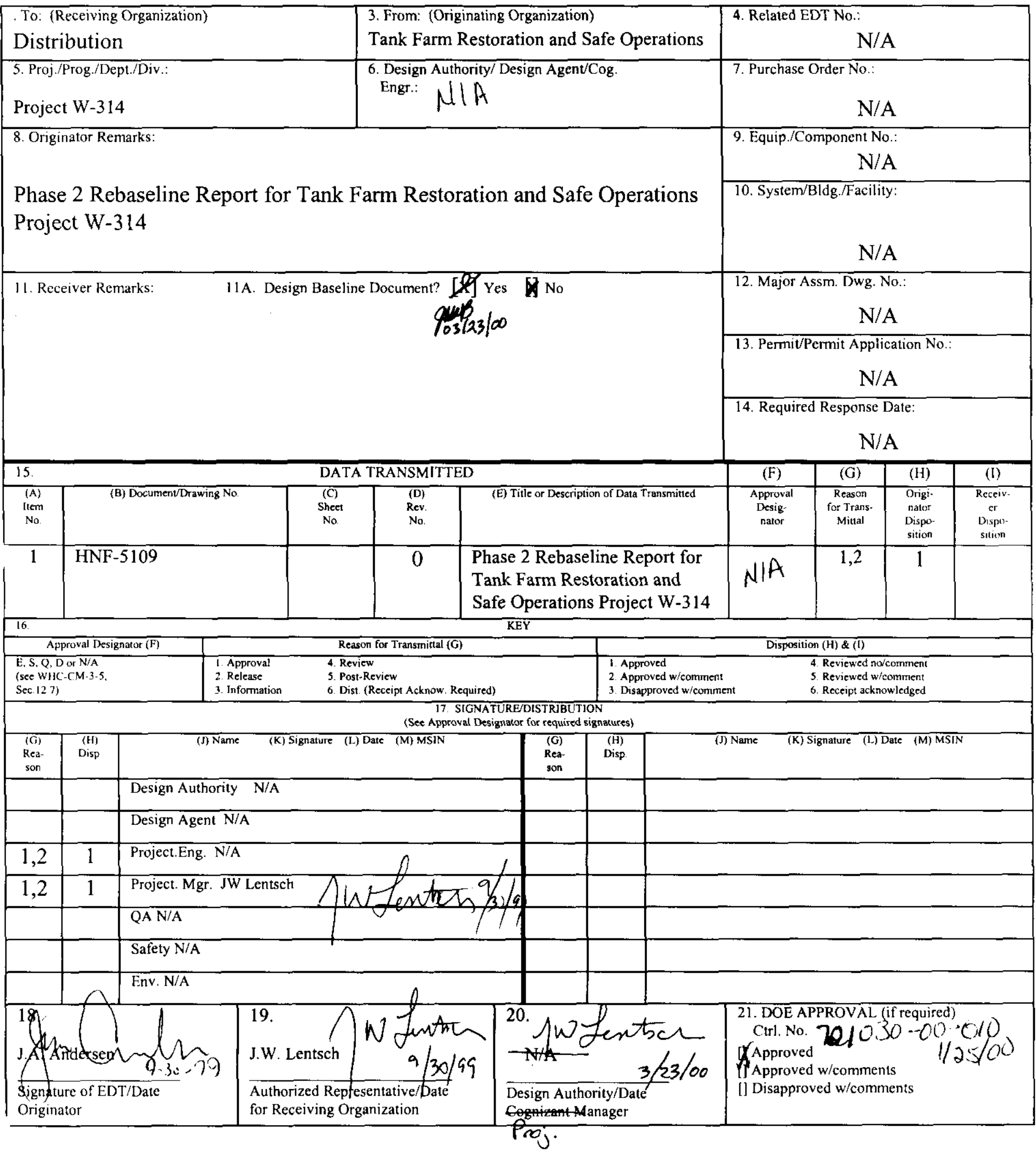

BD-7400-172-2 (05/96) GEF097 


\section{DISTRIBUTION SHEET}

To

Distribution

Project Title/Work Order

W-314, Tank Farm Restoration and Safe Operation:
From

TER \&SO
Page $\frac{1}{\text { of } 1}$ EDT No. 62 6448

ECN No

Name

J.B. Bailey

D.E. Bowers

T.J. Volkmán

J.D. Guberski

R.A. Dodd

R.E. Elder

J.D. Galbraith

J.T. Gilbert

R.P. Raven

R.J. Fogg

T.I. Jennings

R.W. Root

D.I. MCGrew

P.J. Bedell

B.I. Syverson

J.W. t.entsch

Project Files

Project Jibrary

\begin{tabular}{|c|c|c|c|c|}
\hline MSIN & $\begin{array}{c}\text { Text } \\
\text { With All } \\
\text { Attach. }\end{array}$ & Text Only & $\begin{array}{c}\text { Attach.l } \\
\text { Appendix } \\
\text { Only }\end{array}$ & $\begin{array}{c}\text { EDT/ECN } \\
\text { Only }\end{array}$ \\
\hline $\mathrm{R} 3-25$ & $x$ & & & \\
\hline$S 5-13$ & $x$ & & & \\
\hline R3-2b & $x$ & & & \\
\hline$R 1-51$ & $x$ & & & \\
\hline R3-73 & $x$ & & & \\
\hline$S 7-75$ & $x$ & & & \\
\hline R3 $3-73$ & $x$ & & & \\
\hline $\mathrm{R} .3-25$ & $x$ & & & \\
\hline SO-09 & $x$ & & & \\
\hline $85-12$ & $x$ & & & \\
\hline$R 2-3.3$ & $x$ & & & \\
\hline $\mathrm{R} 2-53$ & $x$ & & & \\
\hline R3-25 & $x$ & & & \\
\hline $63-12$ & $x$ & & & \\
\hline G3-12 & $x$ & & & \\
\hline R3-25 & $x$ & & & \\
\hline $\mathrm{R} 1-29$ & $x$ & & & \\
\hline R3-2.5 & $\mathrm{x}$ & & & \\
\hline & & & & \\
\hline & & & & \\
\hline & & & & \\
\hline & & & & \\
\hline & & & & \\
\hline & & & & \\
\hline & & & & \\
\hline & & & & \\
\hline & & & & \\
\hline & & & & \\
\hline & & & & \\
\hline & & & & \\
\hline & & & & \\
\hline
\end{tabular}




\title{
Phase 2 Rebaseline Report for Tank Farm Restoration and Safe Operations Project W-314
}

\author{
J.W. Lentsch \\ Richland, WA 99352 \\ U.S. Department of Energy Contract DE-AC06-96RL13200 \\ EDT/ECN: 626448 \\ Org Code: HN9A0021 \\ B\&R Code: EW 31200000 \\ UC: 2000 \\ Charge Code: 106051 \\ Total Pages: 311
}

Lockheed Martin Hanford Corporation, Richlard, WA 99352

Key Words:

\begin{abstract}
:
ACROMAG is a registered trademark of Modicon Corporation

ENRAF is a registered trademark of ENRAF Corporation

Gamewell is a registered trademark of "The Gamewell corporation"

HEMA is a registered trademark of National Electrical Manufacturers

Association

Micon is a registered trademark of Powell Industries, Inc.

Panalarm is a registered trademarkof Ametek, Inc.
\end{abstract}

TRADEMARK DISCLAIMER. Reference herein to any specific commercial product, process, or service by trade name, trademark, manufacturer, or otherwise, does not necessarily constitute or imply its endorsement. recommendation, or favoring by the United States Government or any agency thereof or its contractors or subcontractors

Printed in the United States of America. To obtain copies of this document, contact: Document Control Services, P.O. Box 950, Mailstop H6-08, Richland WA 99352, Phone (509) 372-2420; Fax (509) 376-4989.
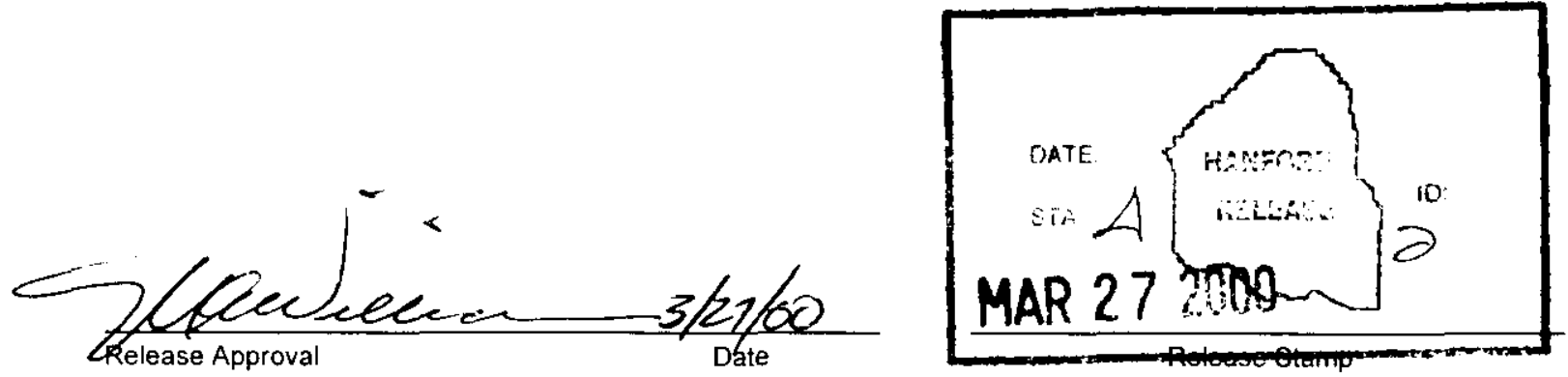

\section{Approved For Public Release}




\section{PHASE 2 REBASELINE REPORT}

FOR

\section{TANK FARM RESTORATION AND SAFE OPERATIONS \\ PROJECT W-314}

September 1999

Prepared by:

COGEMA Engineering Corporation

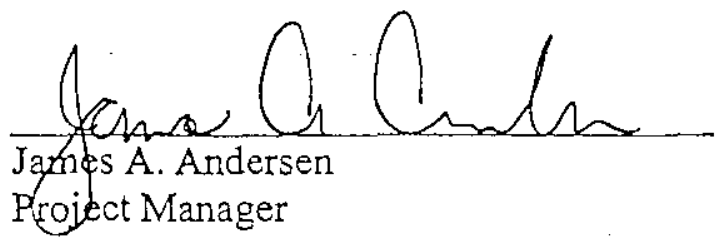

$\frac{9.29 .99}{\text { Date }}$

Approved by:

Lockheed Martin Hanford Corpgration

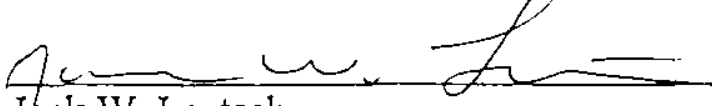

Jack W. Lentsch

$\frac{9-25-59}{\text { Date }}$

W-314 TFRSO Project Manager 


\section{TABLE OF CONTENTS}

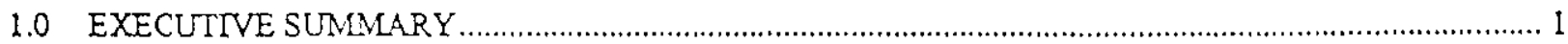

2.0 INTRODUCTION

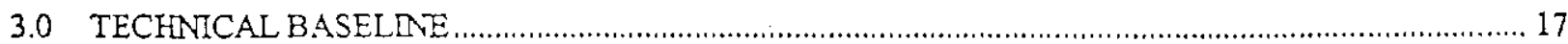

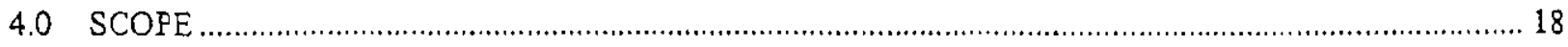

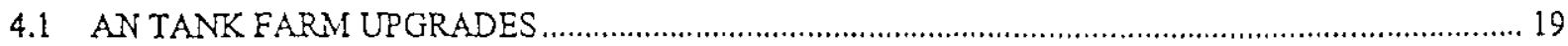

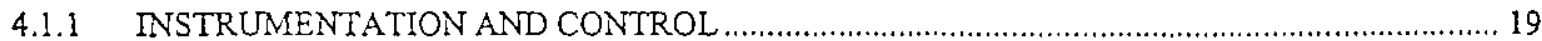

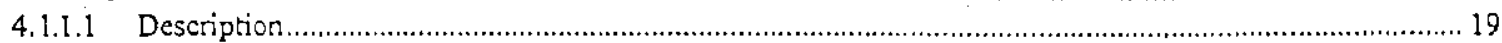

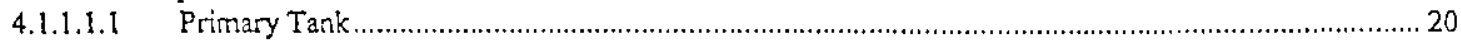

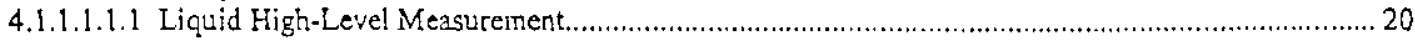

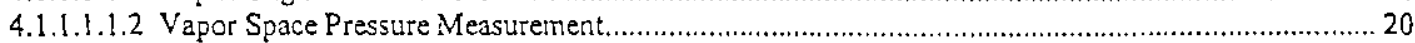

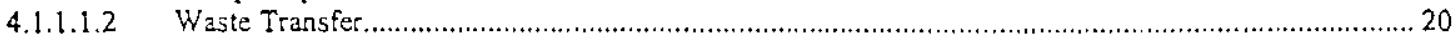

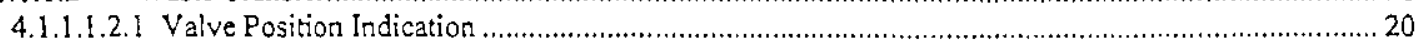

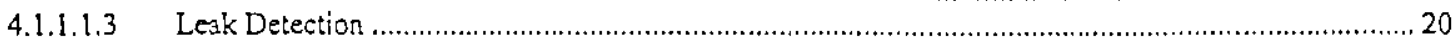

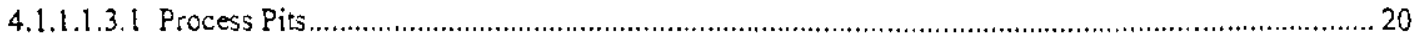

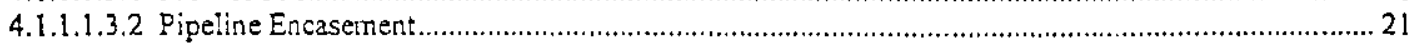

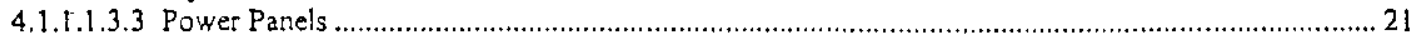

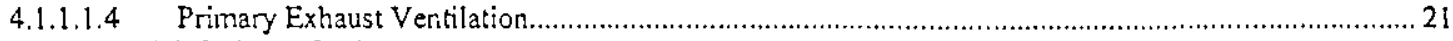

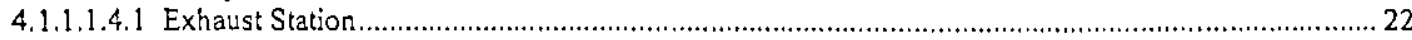

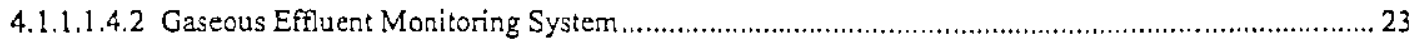

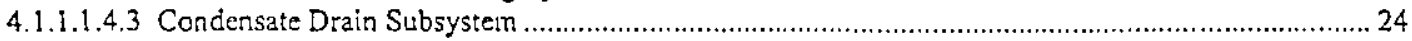

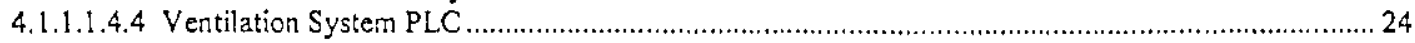

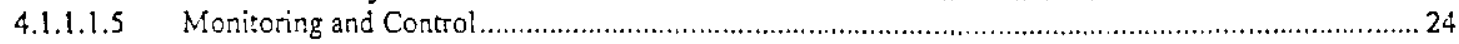

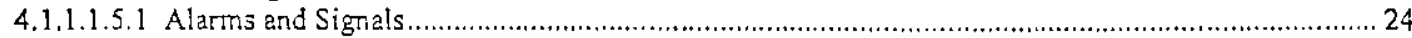

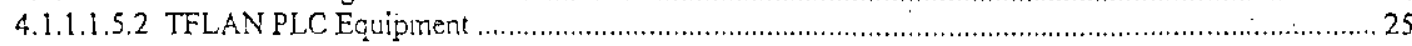

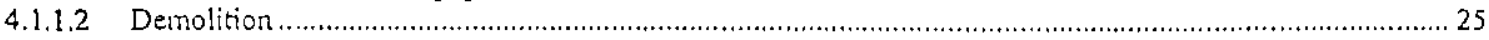

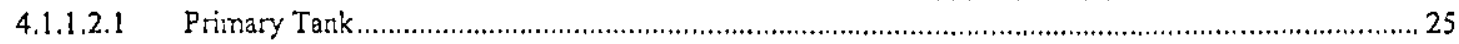

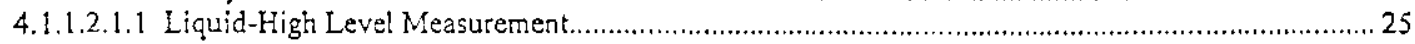

4.1.1.2.1.2 Vapor Space Pressure Measurernent......................................................................... 25

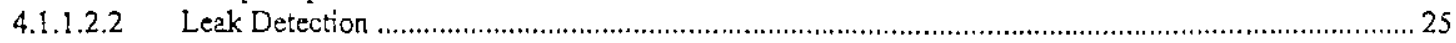

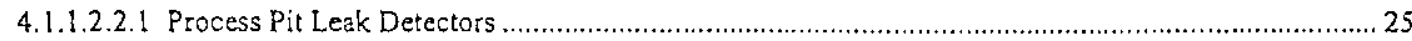

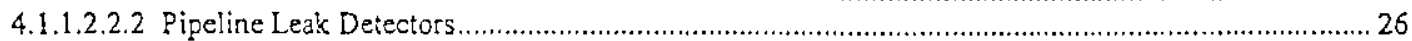

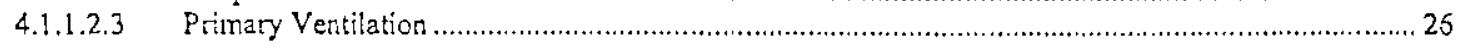

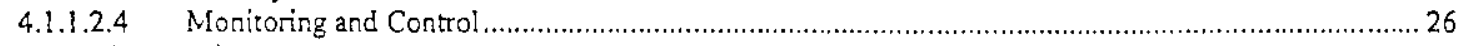

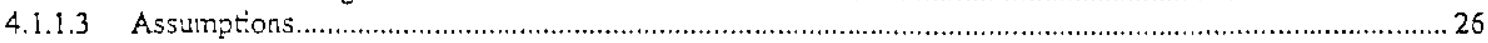

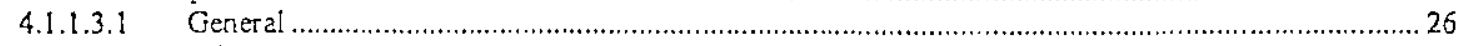

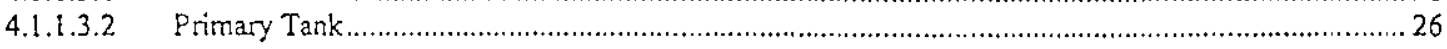

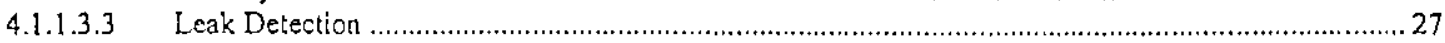

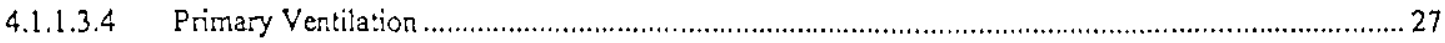

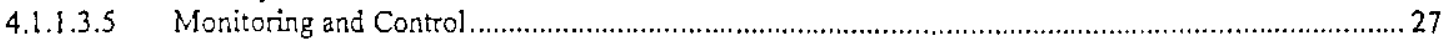

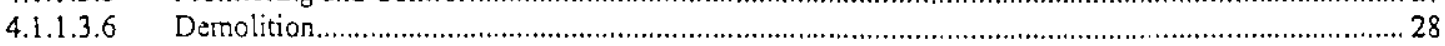

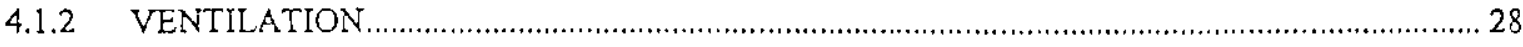

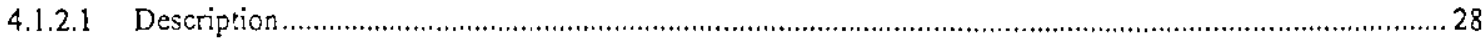

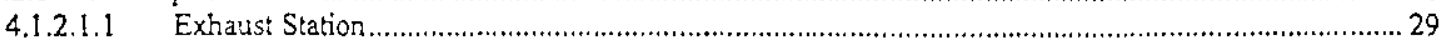

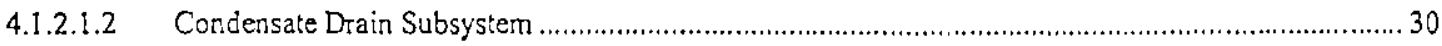

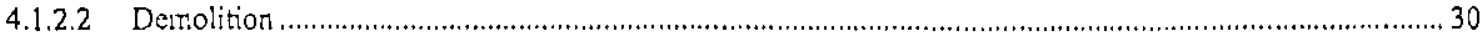

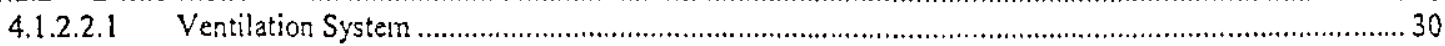

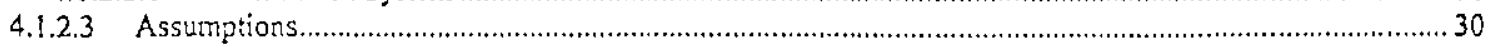

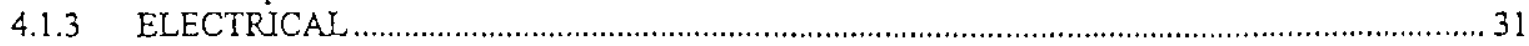

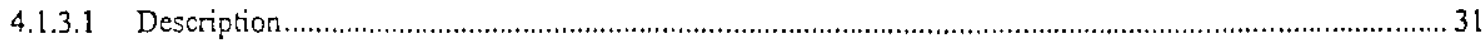

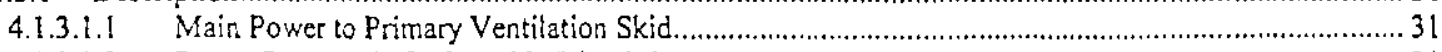

4.1.3.1.2 Power Receptacle for Portable Diesel Genetator...................................................................... 31

4.1.3.1.3 Spare Circuit Breaker for Loadcenter (F8X402) ............................................................. 31

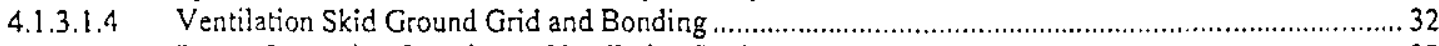

4.1.3.1.5 Freeze Protection for Primary Ventilation Drainage Systems ..................................................... 32 


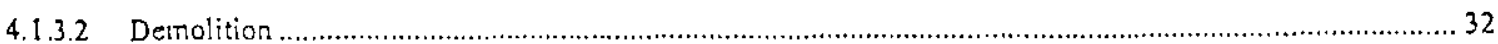

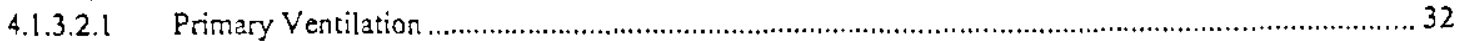

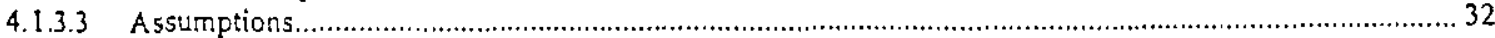

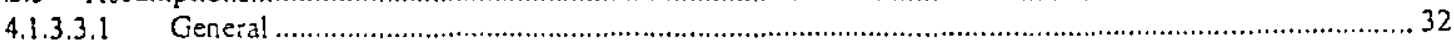

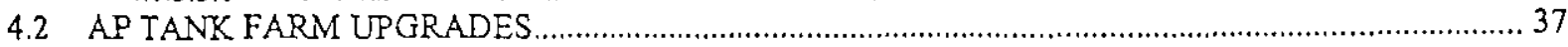

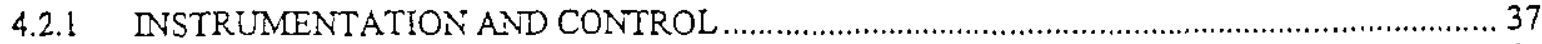

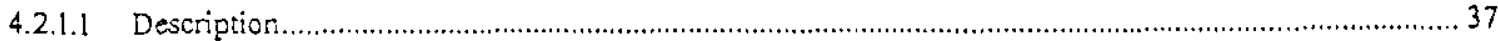

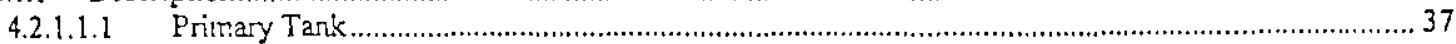

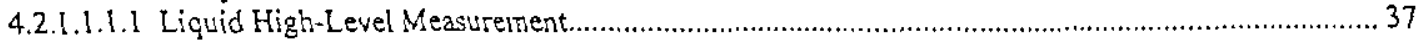

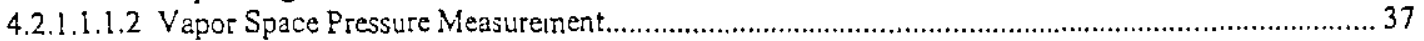

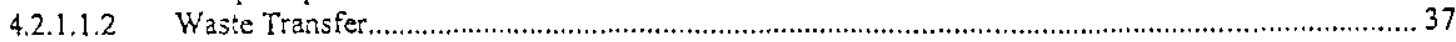

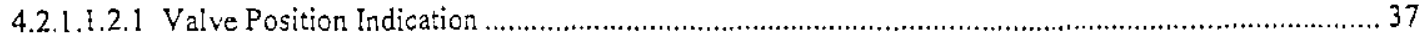

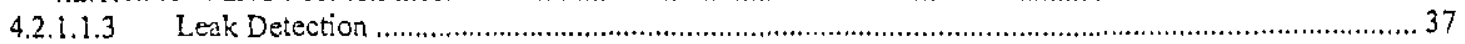

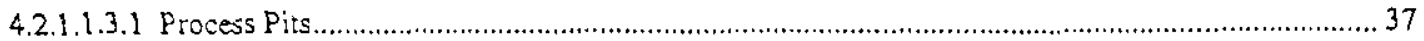

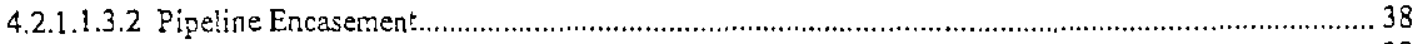

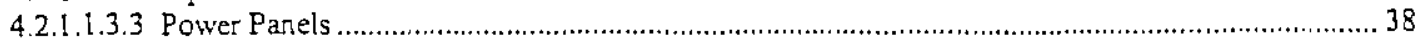

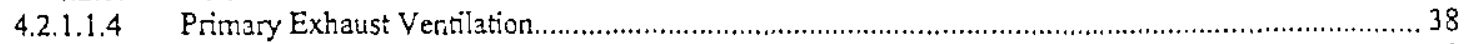

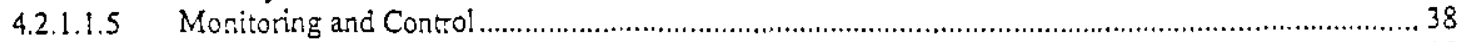

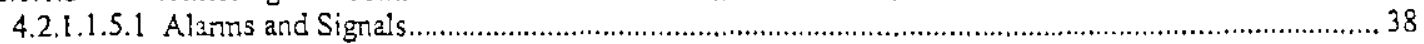

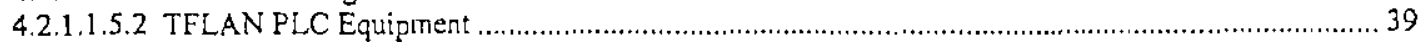

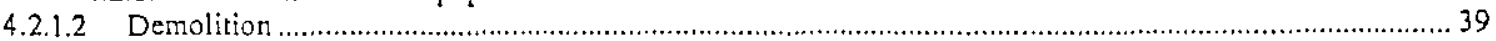

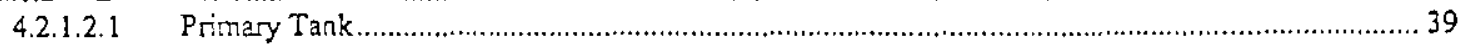

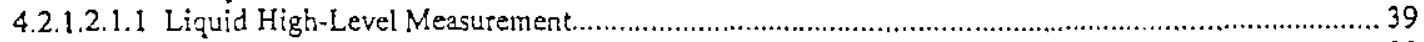

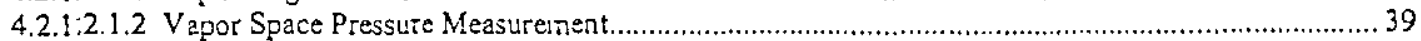

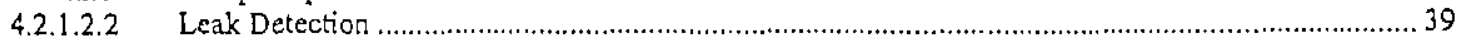

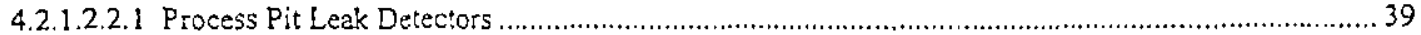

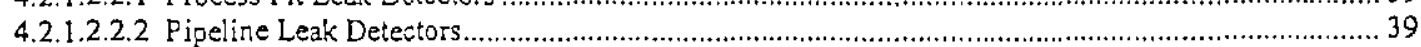

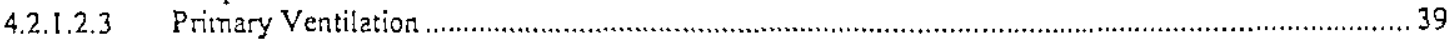

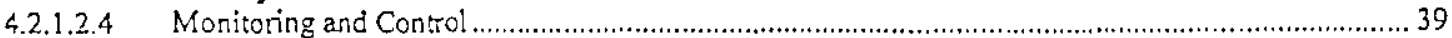

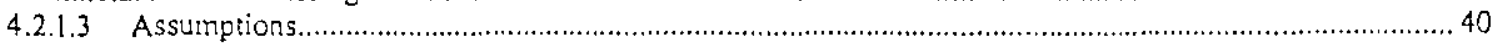

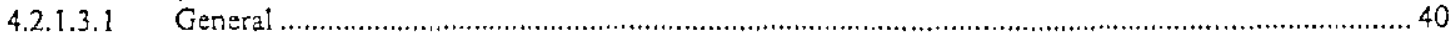

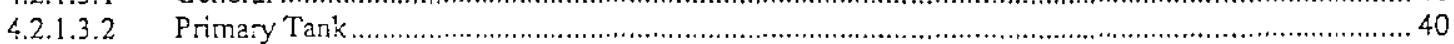

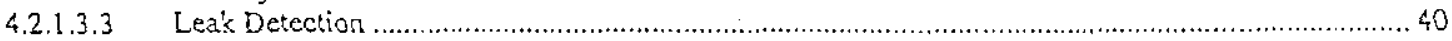

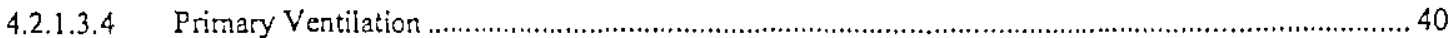

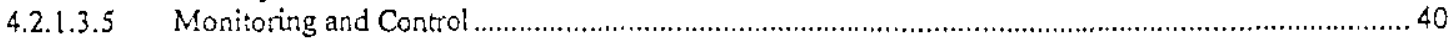

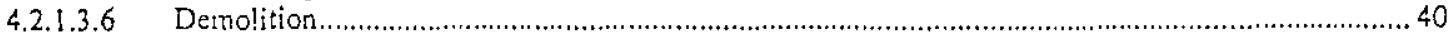

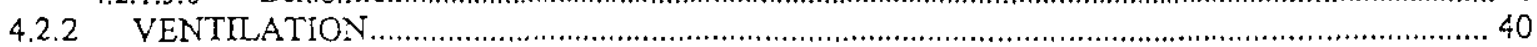

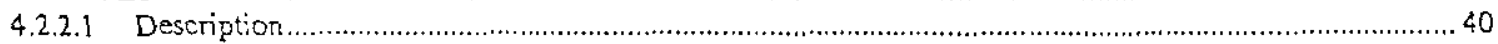

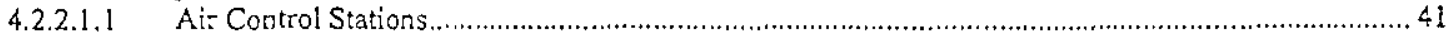

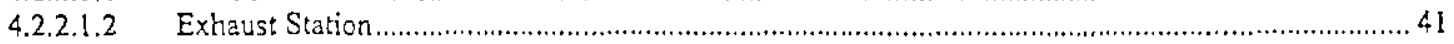

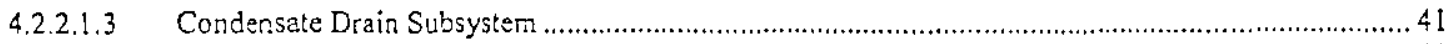

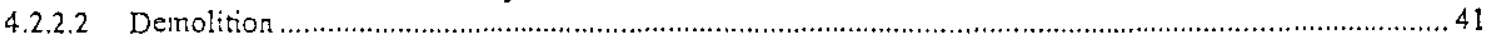

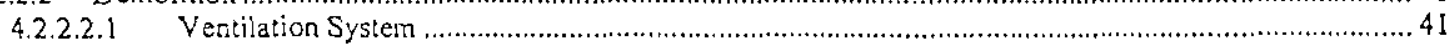

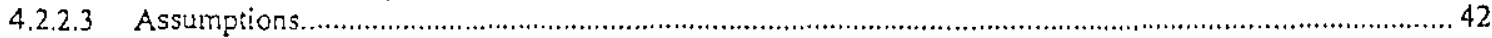

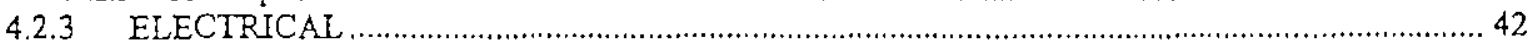

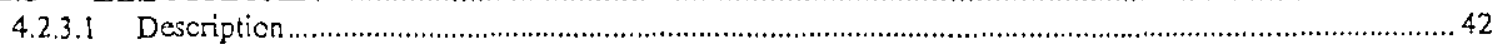

4.2.3.1.1 Main Power Feed to Primary Ventilation Skid...................................................................4.42

4.2.3.1.2 Power Receptacle for Portable Diesel Generator ........................................................................ 42

4.2.3.1.3 120 Vac Ground Fault Receptacle for Diesel Generator Battery Charger ....................................... 42

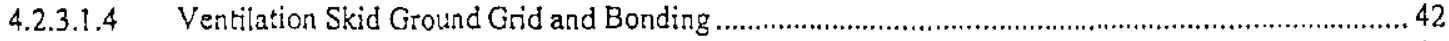

4.2.3.1.5 Freeze Protection for Primary Ventilation Drainage Systerns ...................................................... 42

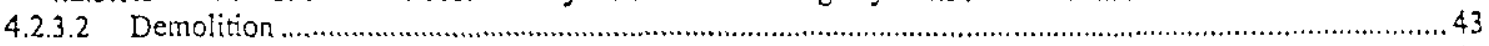

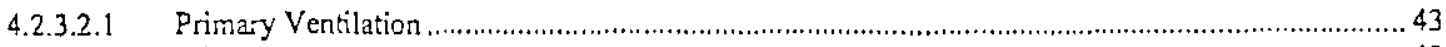

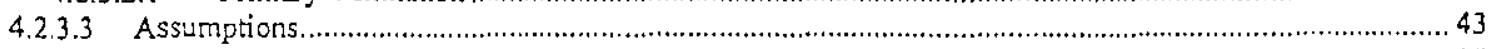

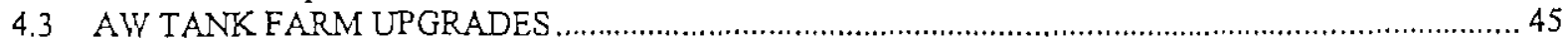

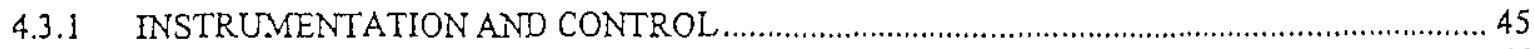

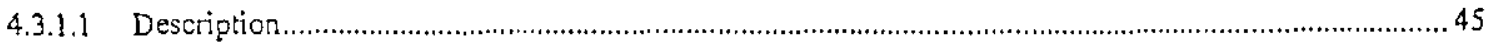

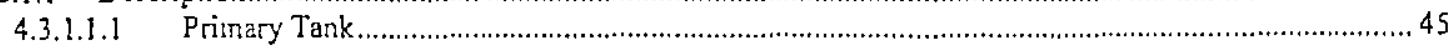

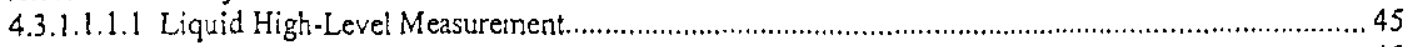

4.3.1.1.1.2 Vapor Space Pressure Measurement............................................................................. 45

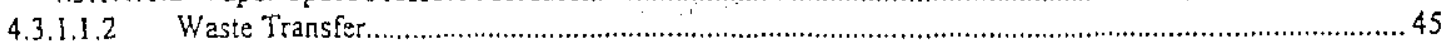




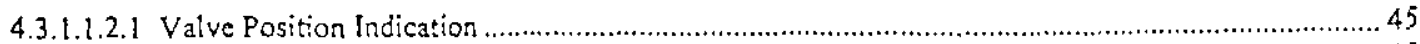

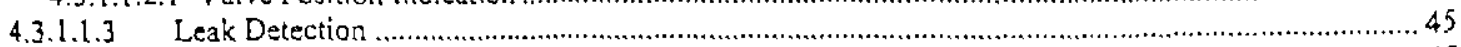

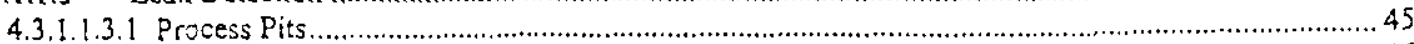

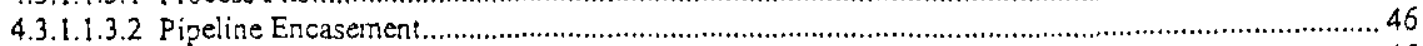

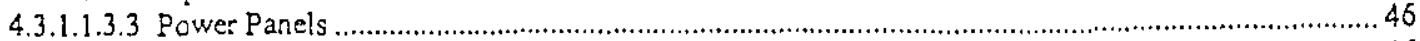

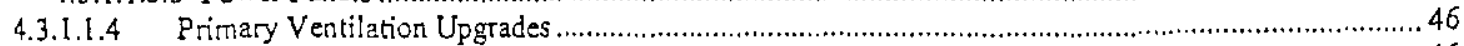

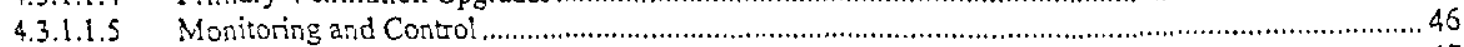

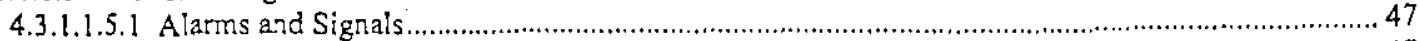

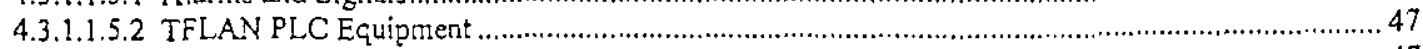

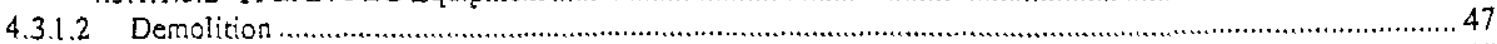

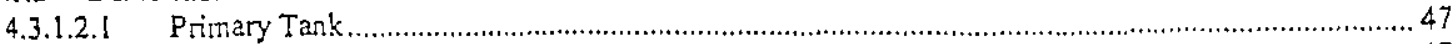

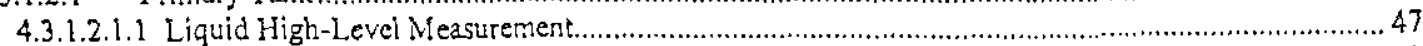

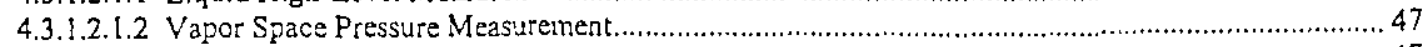

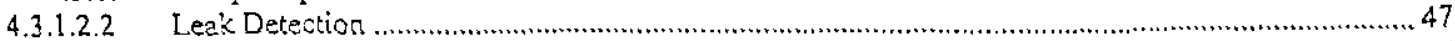

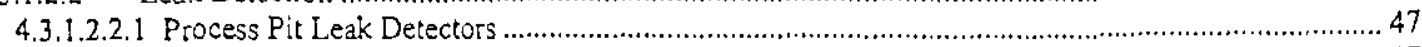

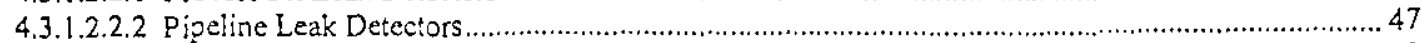

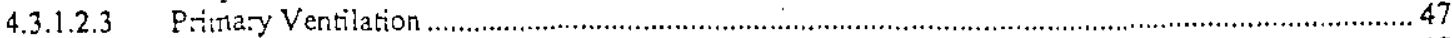

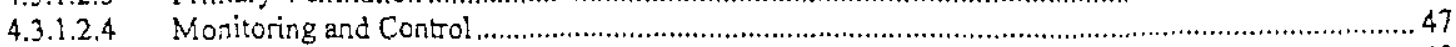

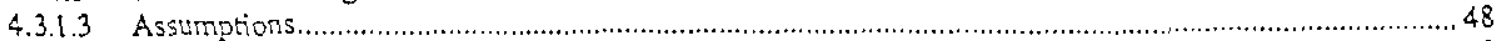

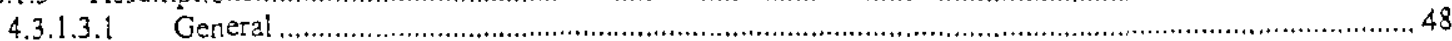

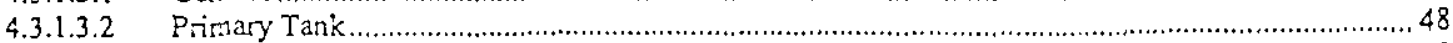

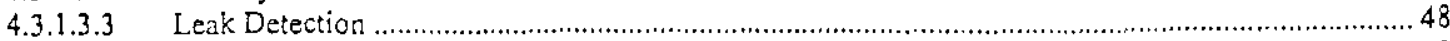

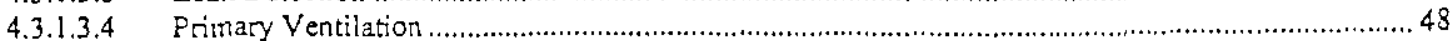

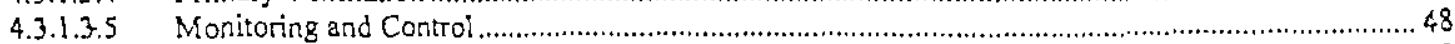

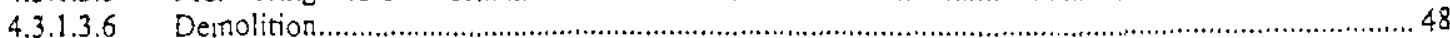

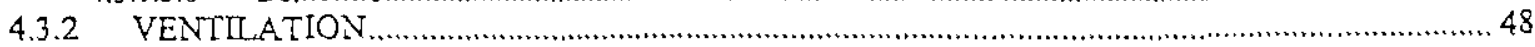

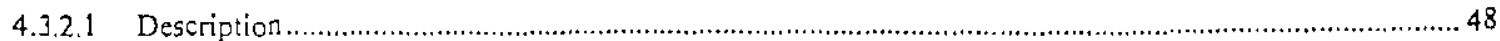

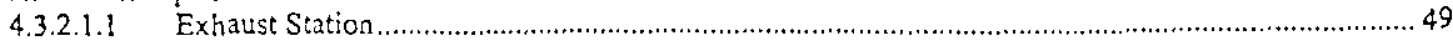

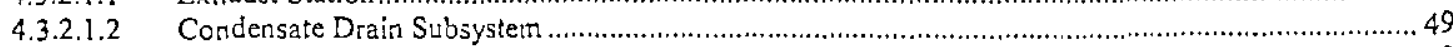

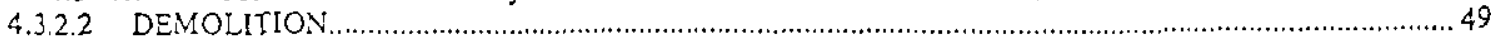

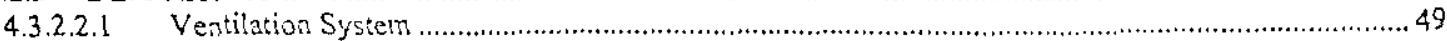

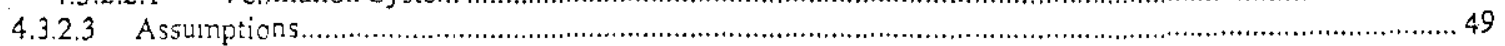

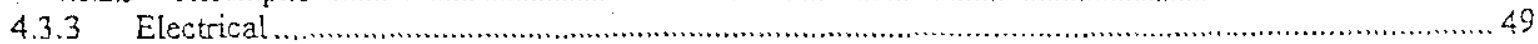

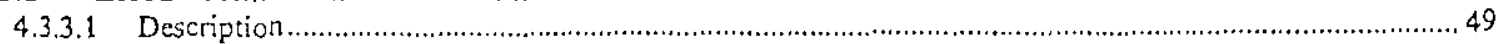

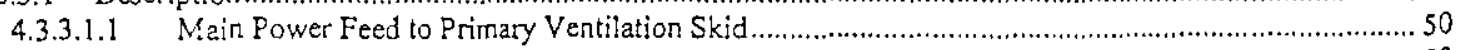

4.3.3.1.2 Power Receptacie for Portable Diesel Generator........................................................................50

4.3.3.1.3 Spare Circuit Ereaker for AW241-EDS-ENCL-100, 1000 kVA Loadcenter (C8S35) ......................50

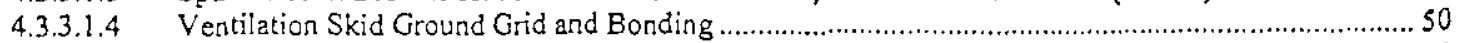

4.3.3.1.5 Freeze Protection for Primary Ventilation Drainage Systems .................................................... 50

4.3.3.1.6 Circuit Breakers for Paneiboard "AW271-EDS-DP-102A" ............................................................... 51

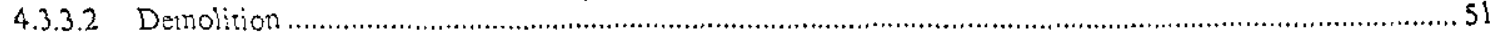

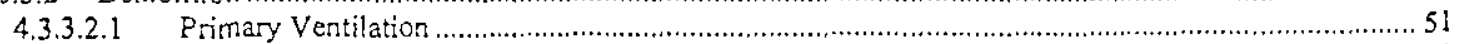

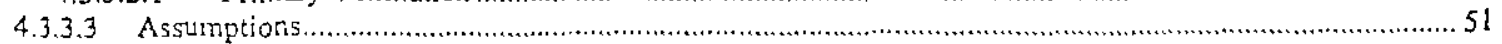

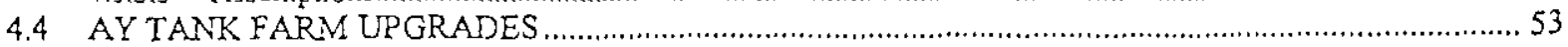

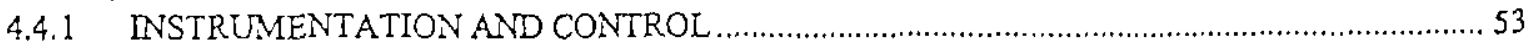

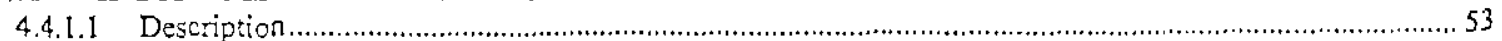

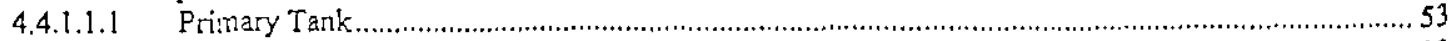

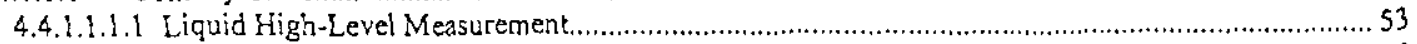

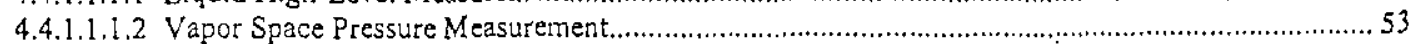

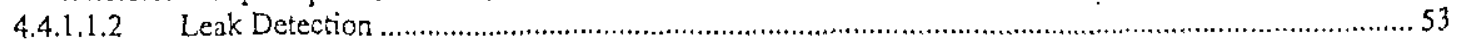

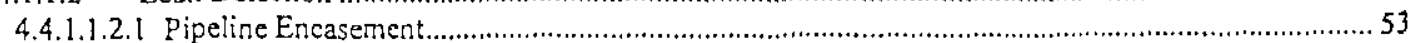

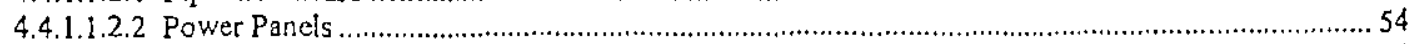

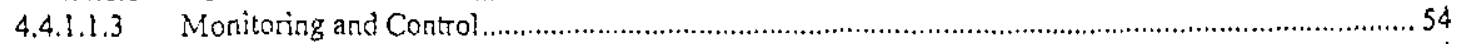

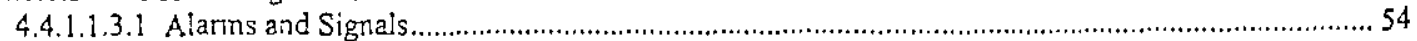

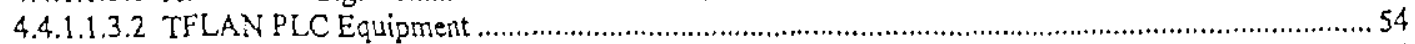

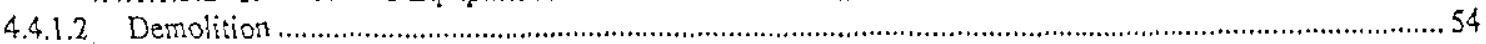

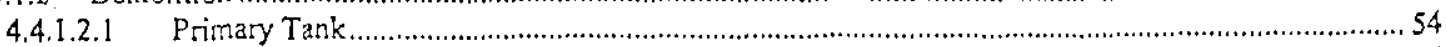

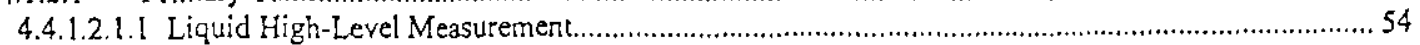

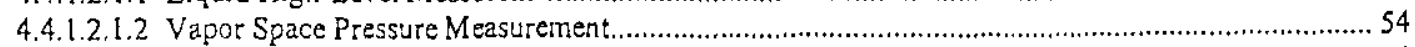

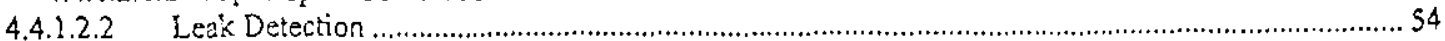

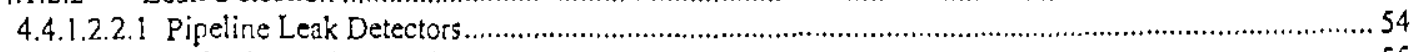

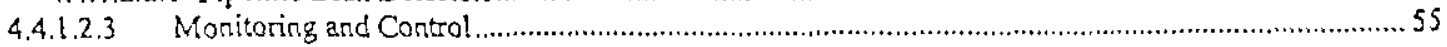




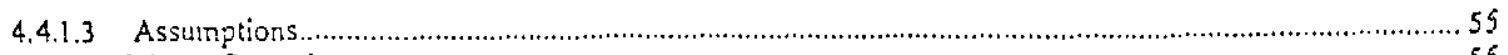

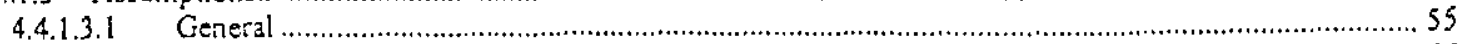

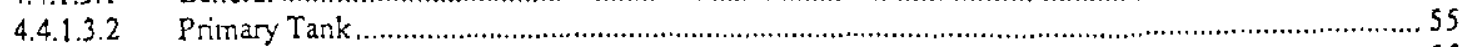

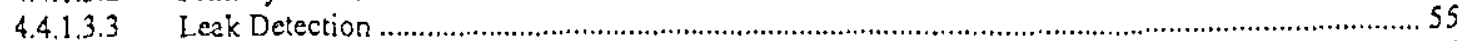

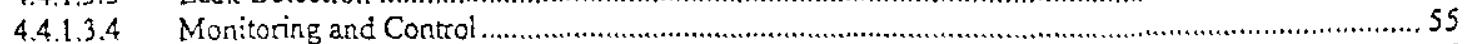

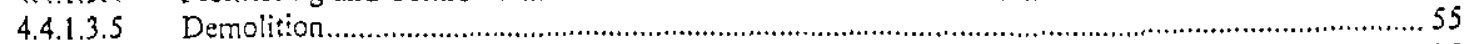

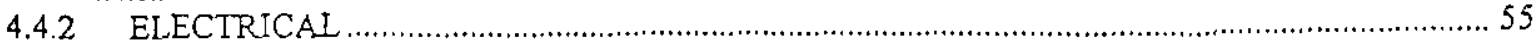

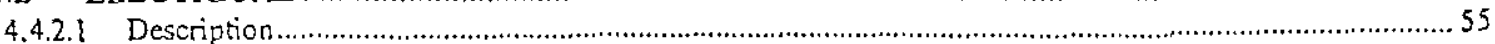

4.4.2.1.1 Motor Control Center for Primary Ventilation ...................................................................... 55

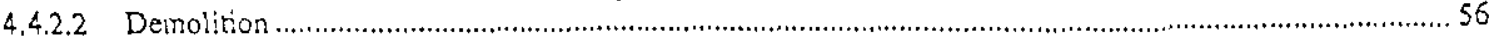

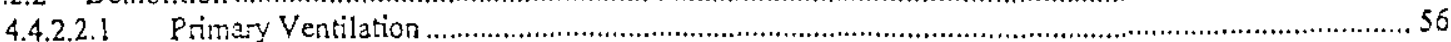

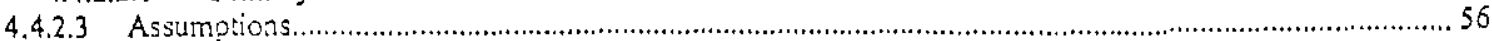

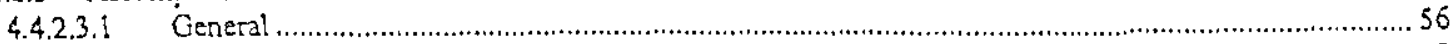

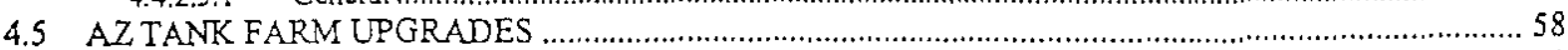

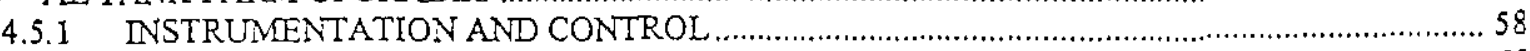

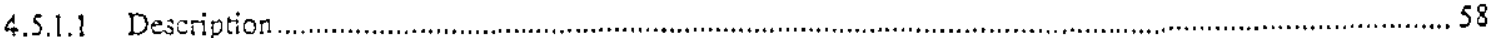

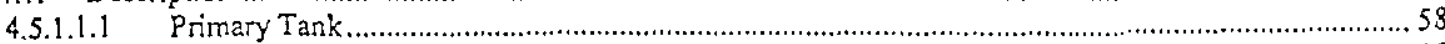

4.5.1.1.1.1 Liquid High-Level Measurement....................................................................................58

4.5.1.1.1.2 Vapor Space Pressure Measurement............................................................................... 58

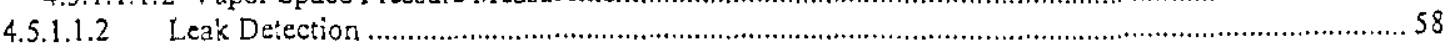

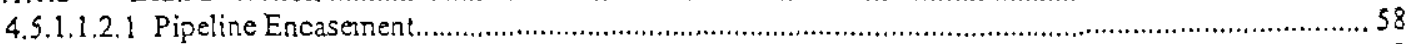

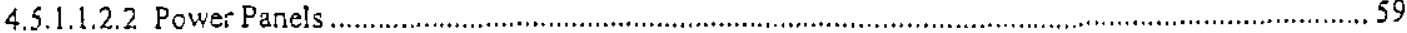

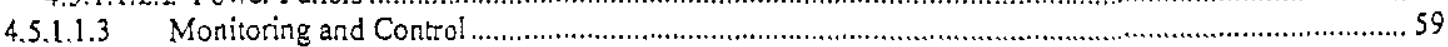

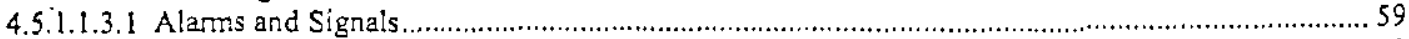

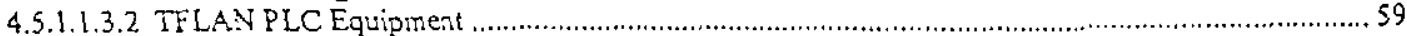

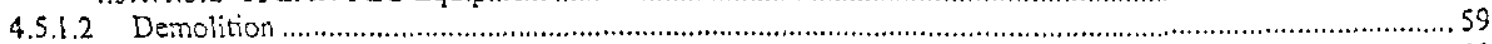

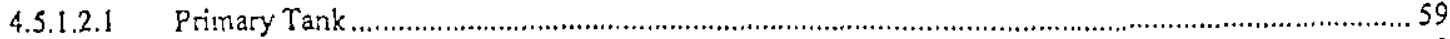

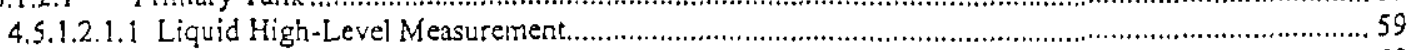

4.5 .1 .2 .1 .2 Vafor Space Pressure Measurement ................................................................................. 59

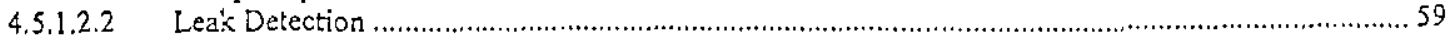

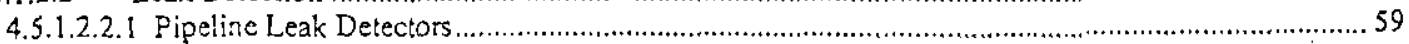

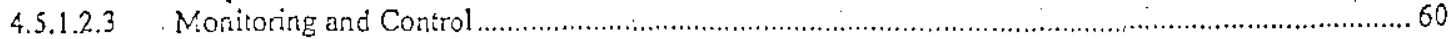

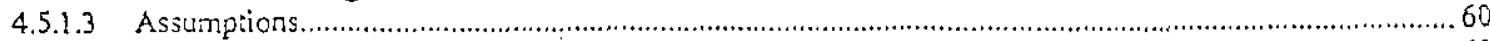

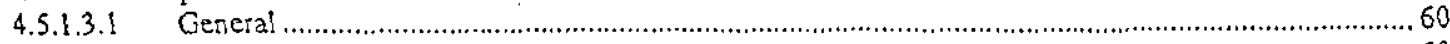

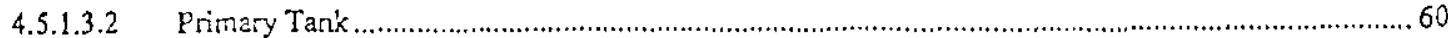

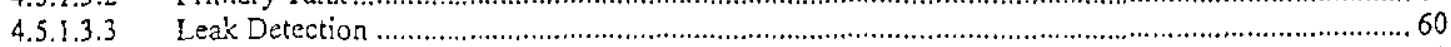

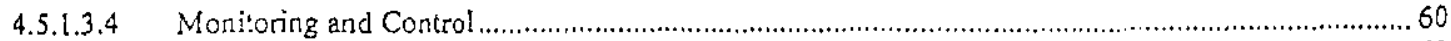

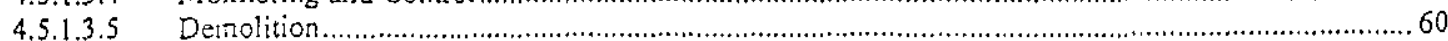

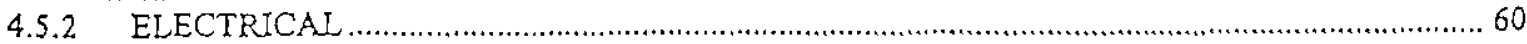

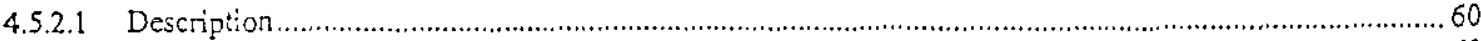

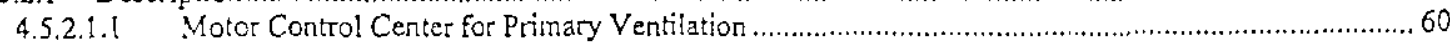

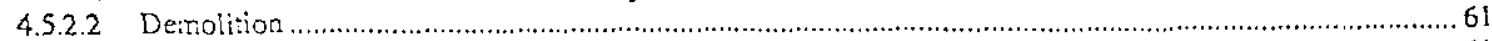

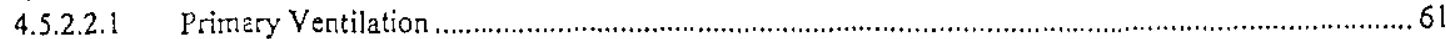

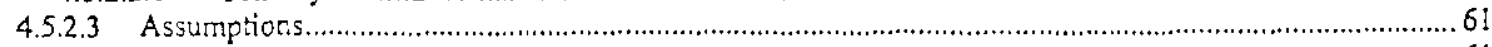

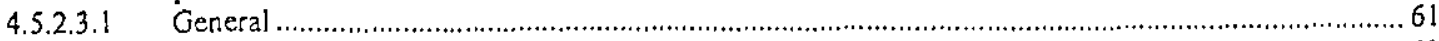

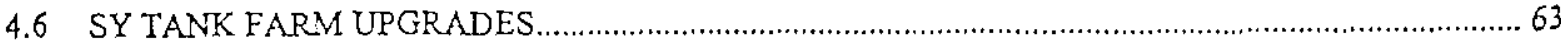

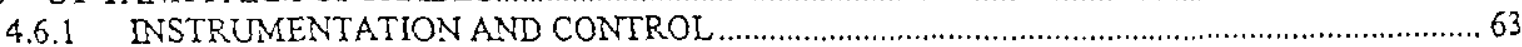

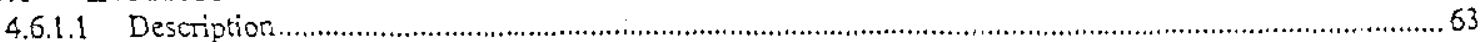

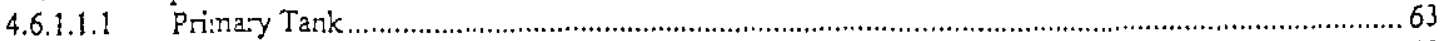

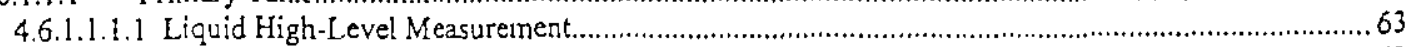

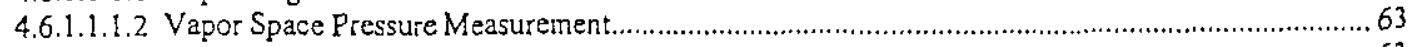

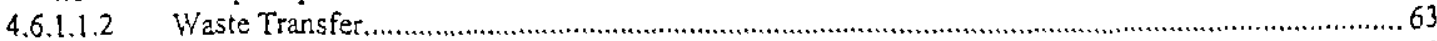

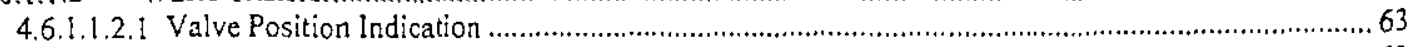

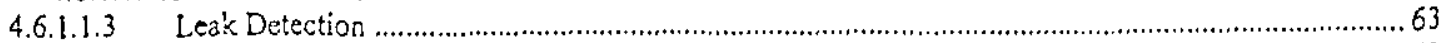

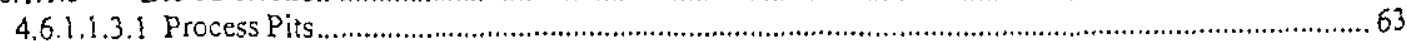

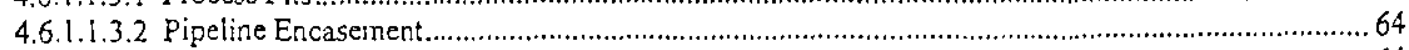

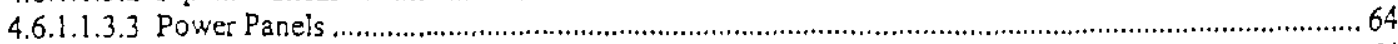

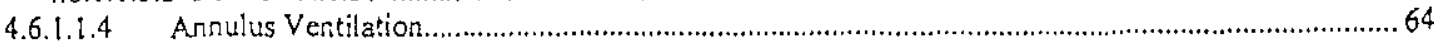

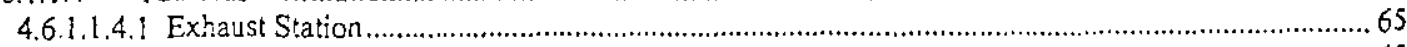

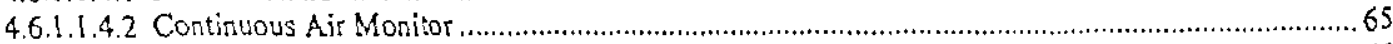

4.6.1.1.4.3 Ventilation System Monitoring and Control ......................................................................6 65 


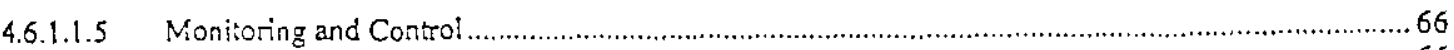

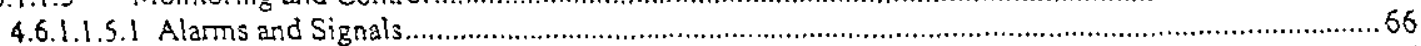

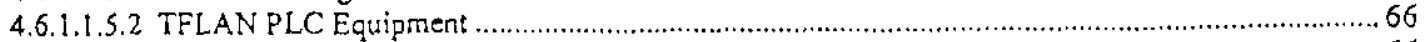

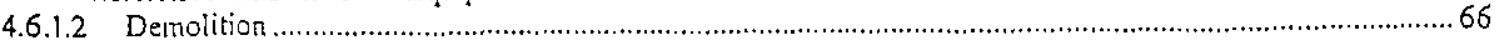

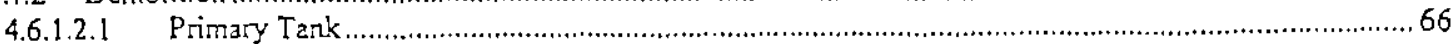

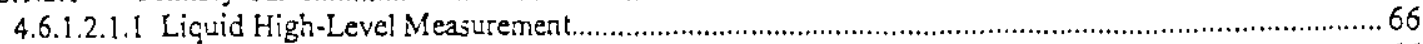

4.6.1.2.1.2 Vapor Space Pressure Measurement................................................................................66

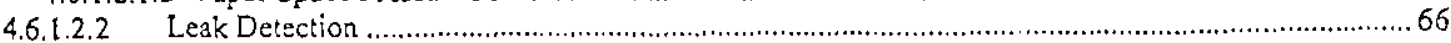

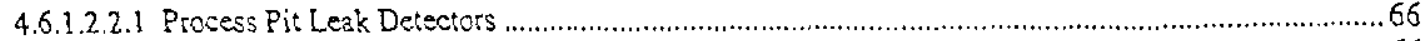

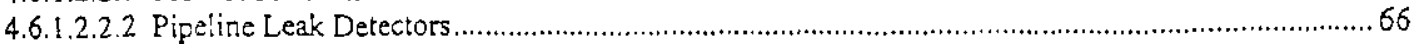

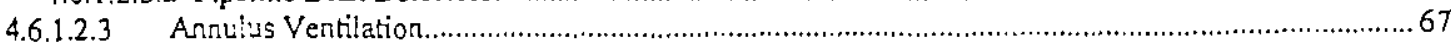

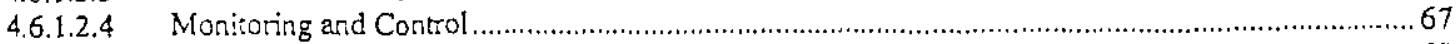

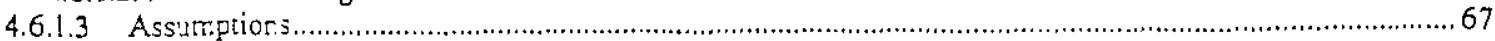

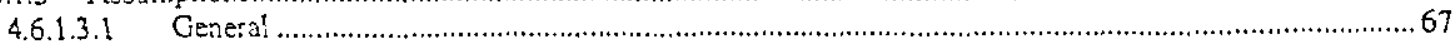

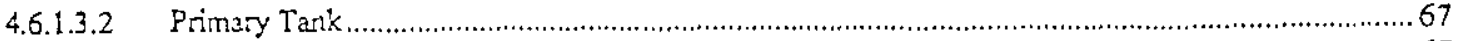

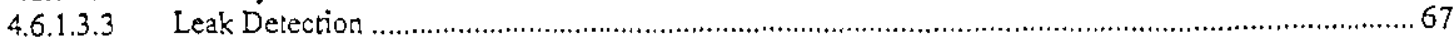

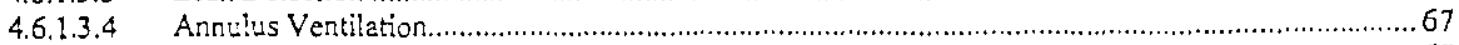

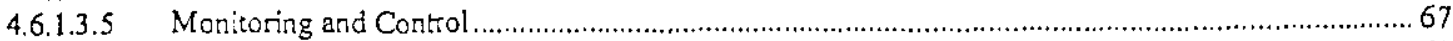

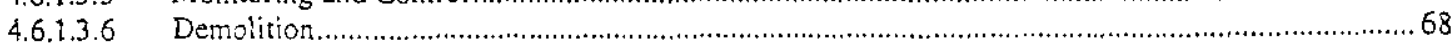

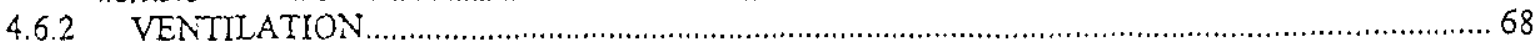

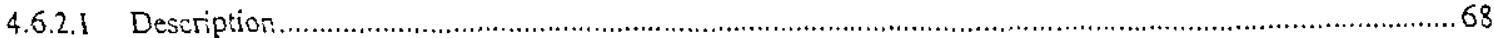

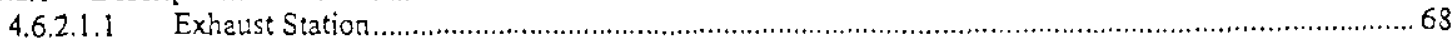

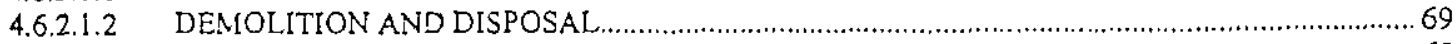

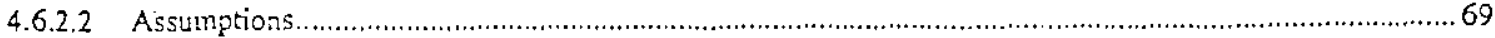

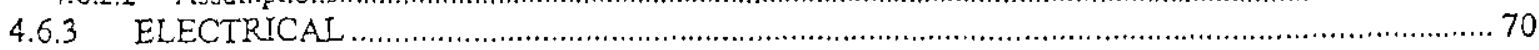

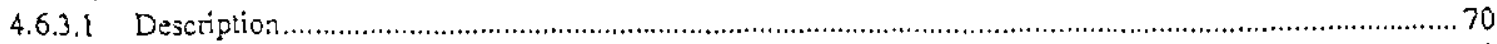

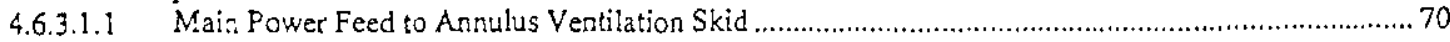

4.6.3.1.2 Power Receptacle for Portable Diesel Generator........................................................................ 70

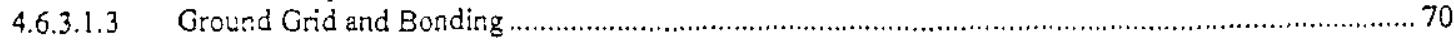

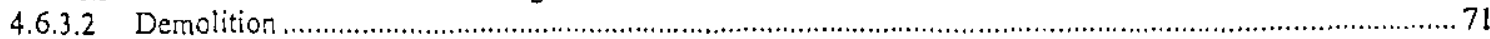

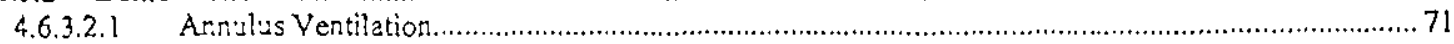

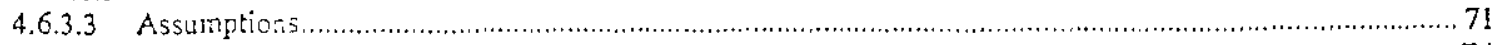

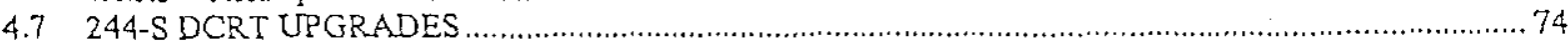

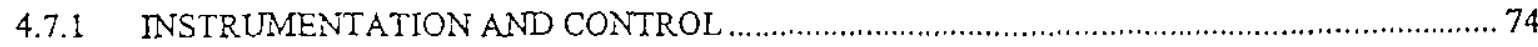

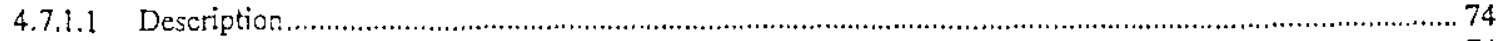

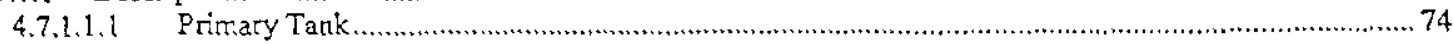

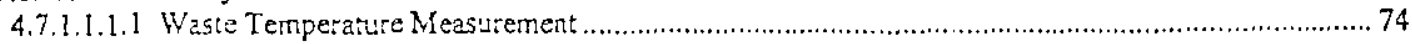

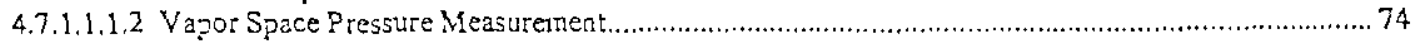

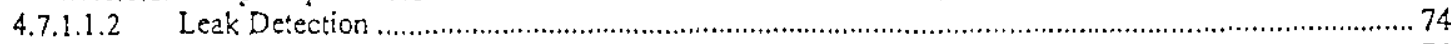

4.7.1.1.2.1 Tark Arnulus Liquid Presence Detector .......................................................................... 74

4.7.1.1.2.2 Tark Pump Pit Liquid Presence Detector ........................................................................... 75

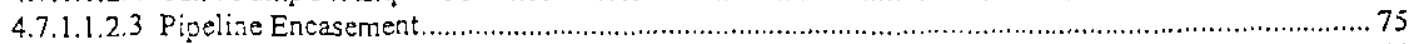

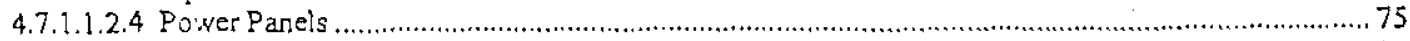

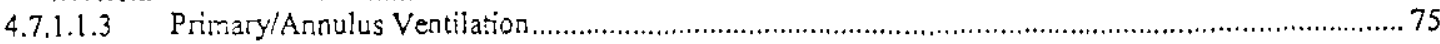

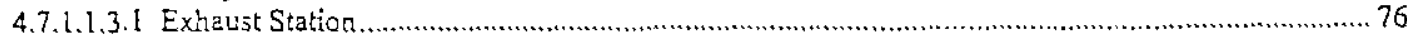

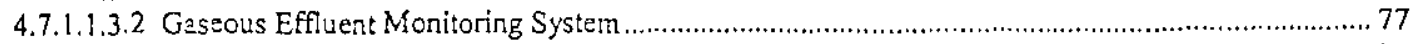

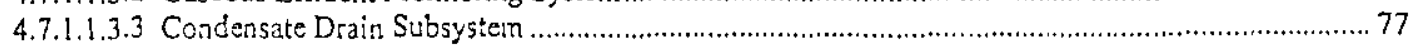

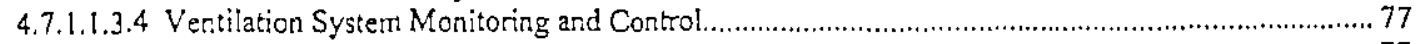

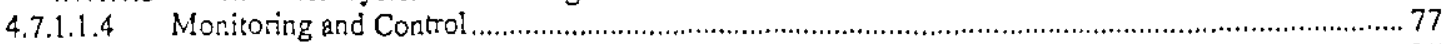

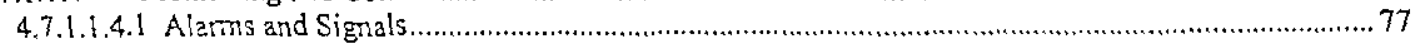

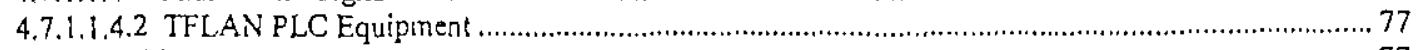

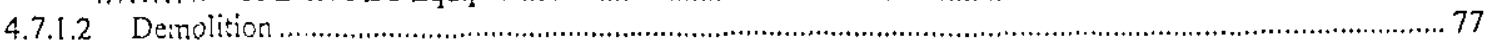

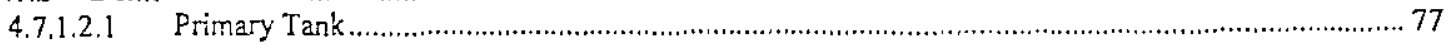

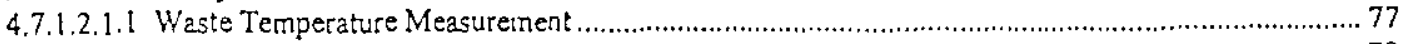

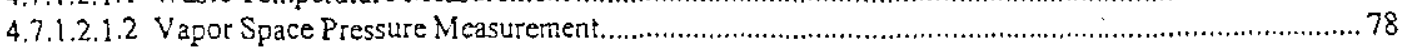

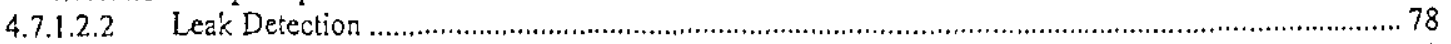

4.7.1.2.2.1 Tank Annulus Liquid Presence Detectors................................................................................... 78

4.7.1.2.2.2 Tark Pump Pit Liquid Presence Detectors ........................................................................... 78

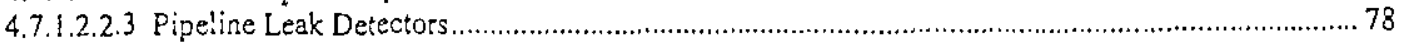

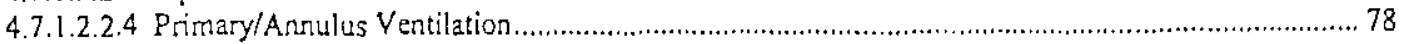

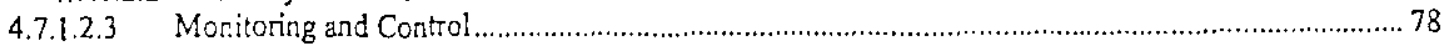

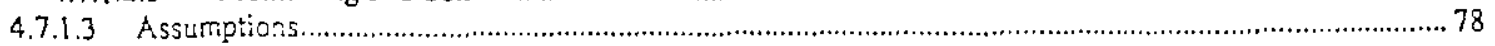




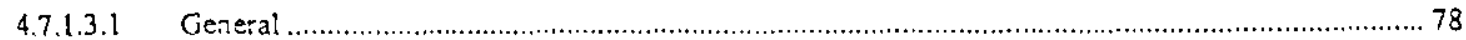

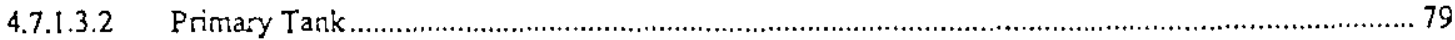

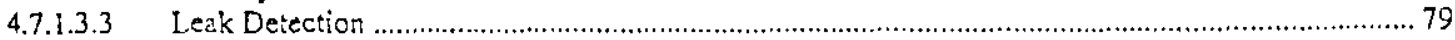

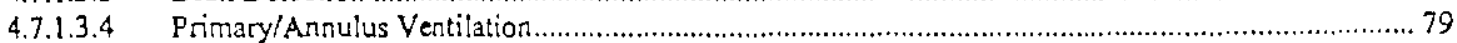

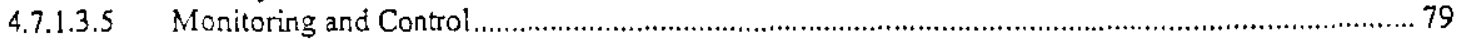

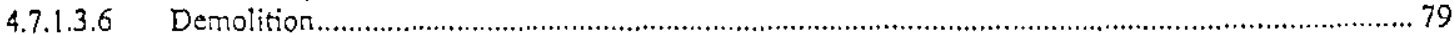

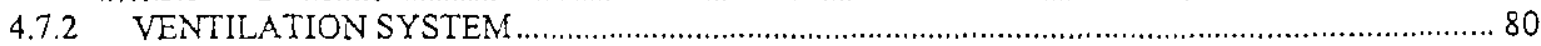

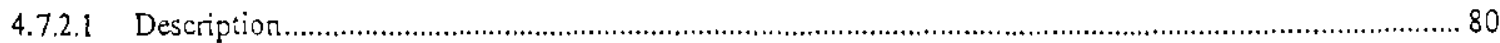

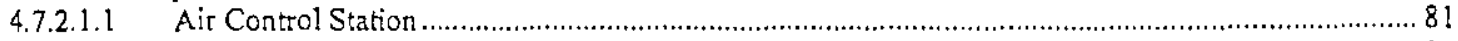

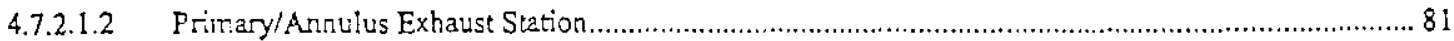

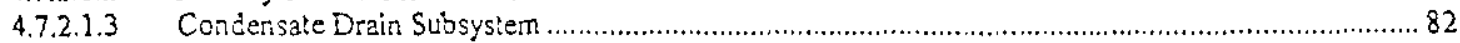

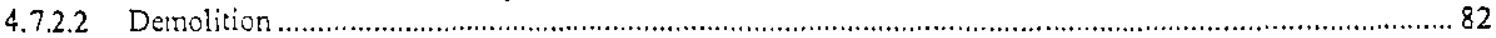

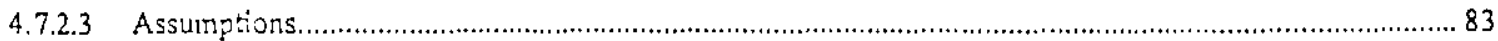

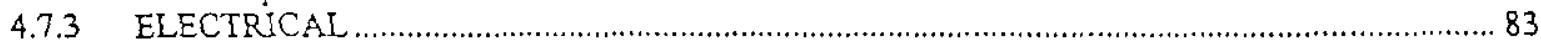

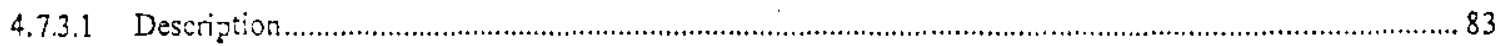

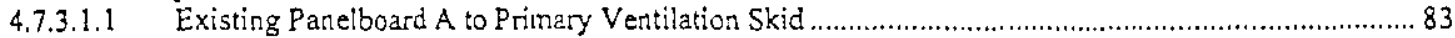

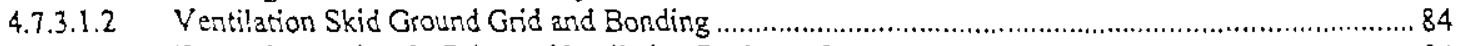

4.7.3.1.3 Freeze Protection for Primary Ventilation Drainage Systems ....................................................84

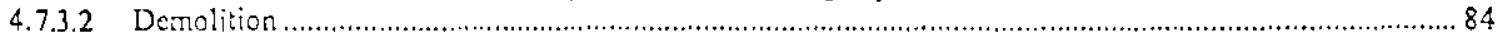

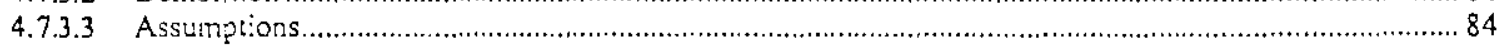

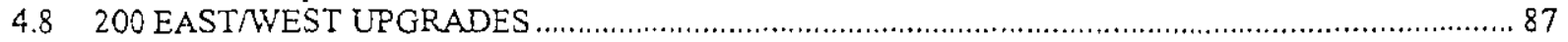

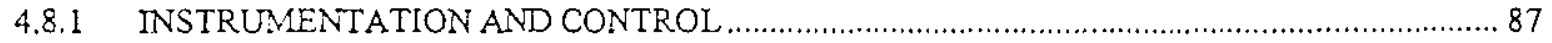

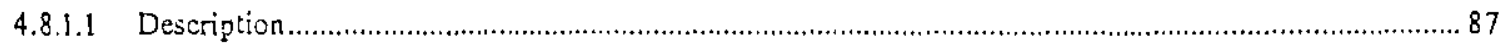

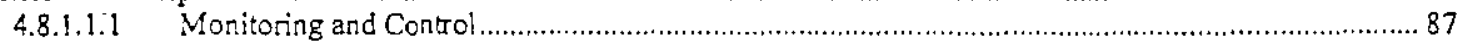

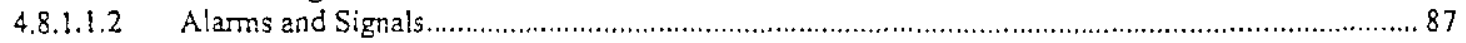

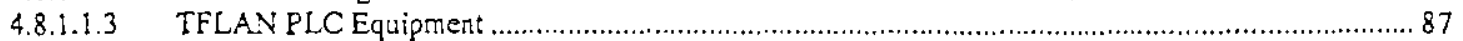

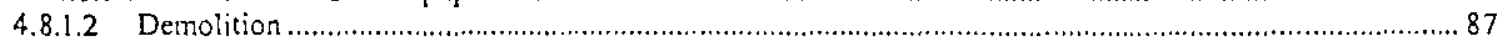

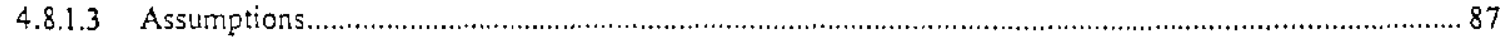

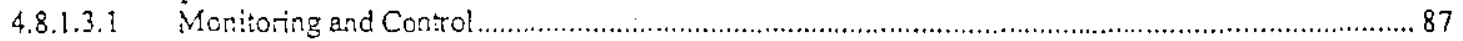

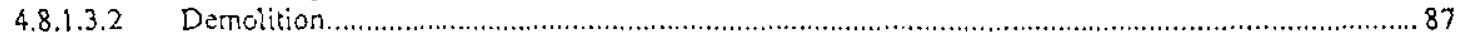

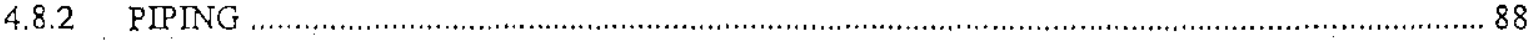

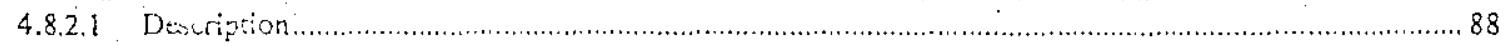

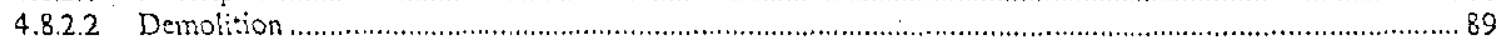

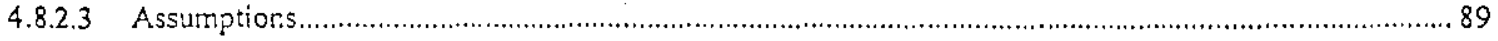

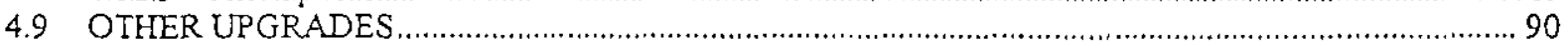

4.9.1 Instrumentation and Control - Miscellaneous Alarms and Signals ............................................90

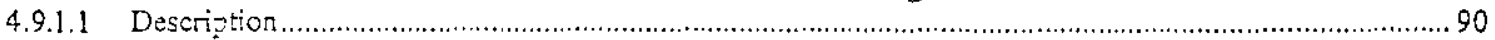

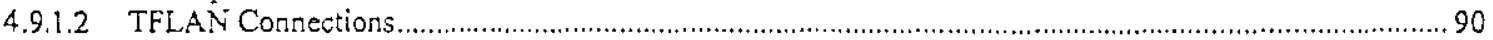

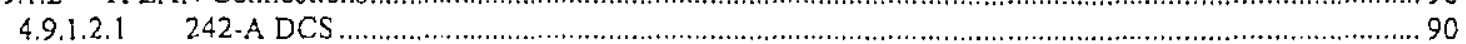

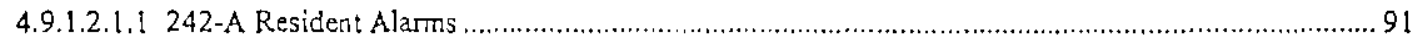

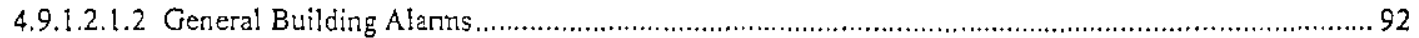

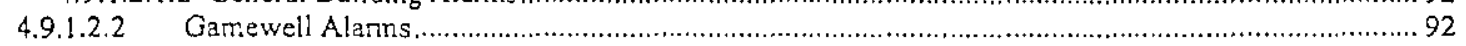

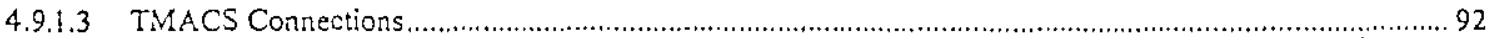

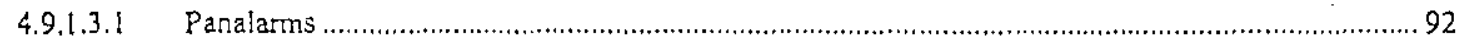

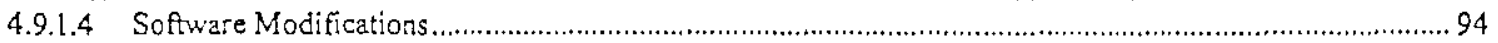

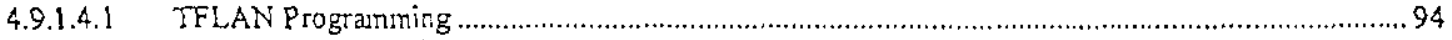

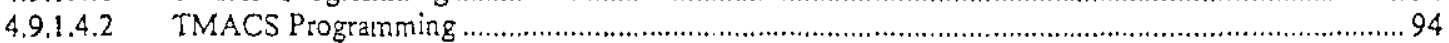

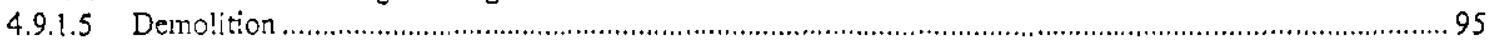

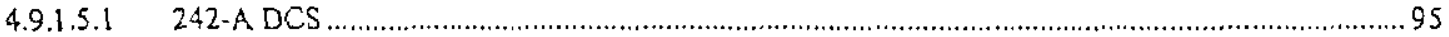

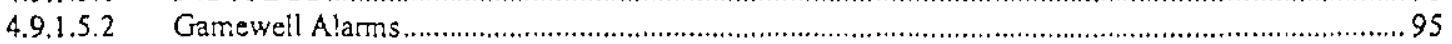

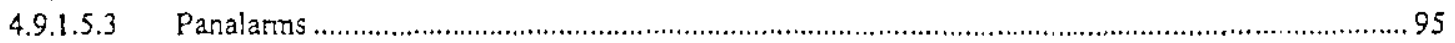

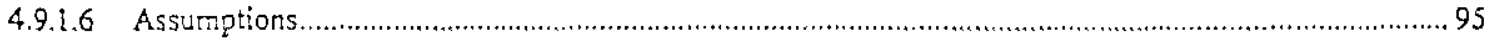

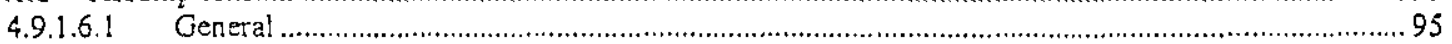

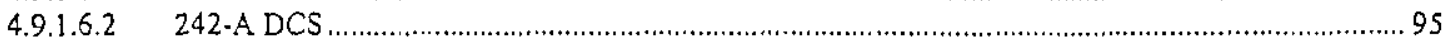

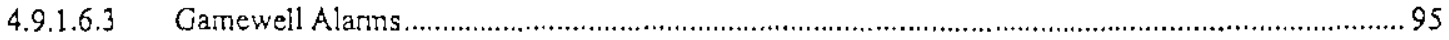

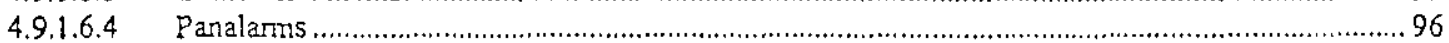

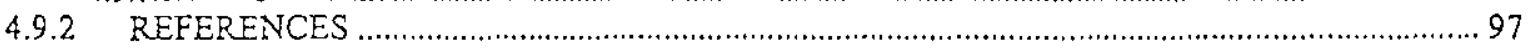

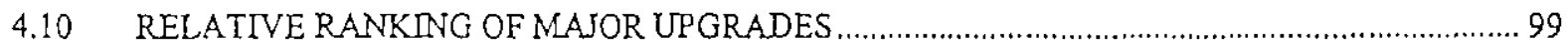

4.11 CHANGES FROM PREVIOUS BASELINE/TRACEABILITY AND JUSTIFICATION ............... 100

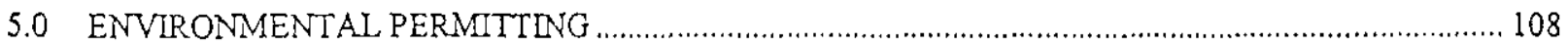




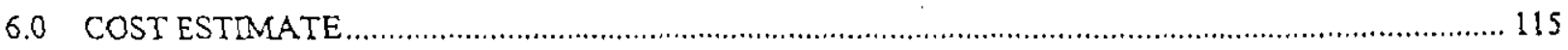

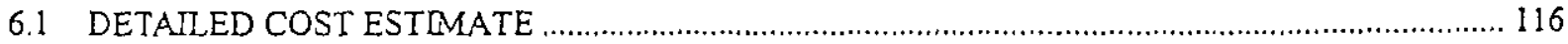

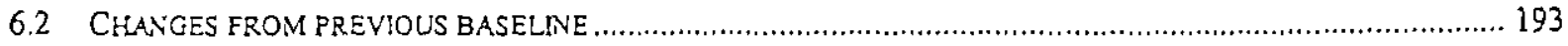

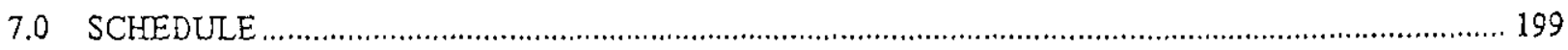

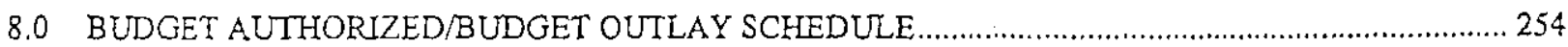

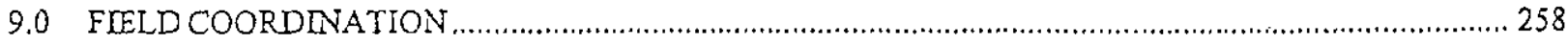

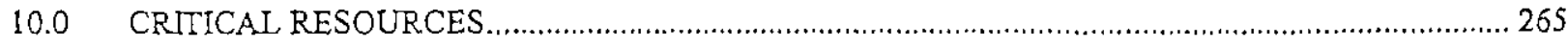

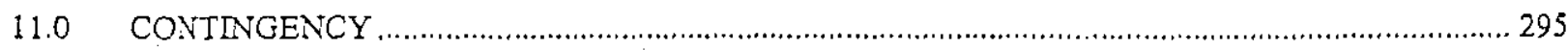

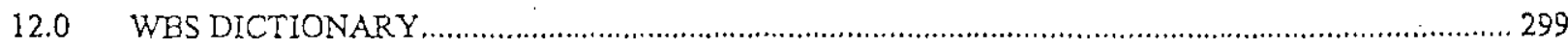

\section{List of Tables}

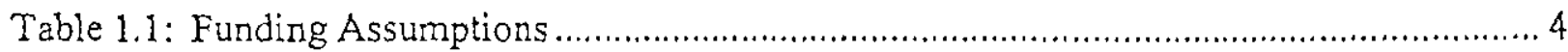

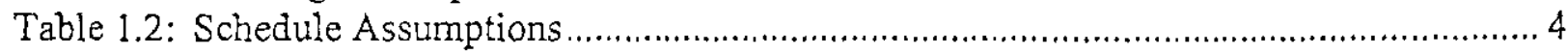

Table 1.3: Phase 2 Cost Estimate Summary ………............................................................ 5

Table 1.4 Required Budget Authority/Budget Outlay .......................................................... 13

Table 1.5: W-314 Updated Project Documentation............................................................ 15

Table 4.10.1: Relative Ranking of Major Scope Upgrades ................................................... 99

Table 4.11.1: Changes From Previous Baseline ………….................................................... 100

Table 5.1: Project W-314 Phase 2 Permits and Approvals ..................................................... 108

Table 5.2 Project W-314 Phase 2 Permits/Regulatory Tasks Planning Assumptions ................. 113

Table 6.2: Changes From Previous Baseline ................................................................... 194

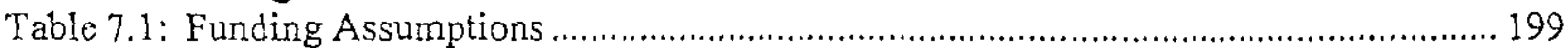

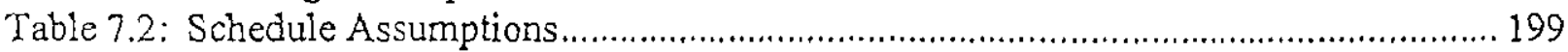

Table 9.1: Coordination of River Protection Projects' Pit Upgrades........................................ 258

Table 11.1 Contingency Presents The Contingency Spread By Major WBS Element. .............296

\section{List of Figures}

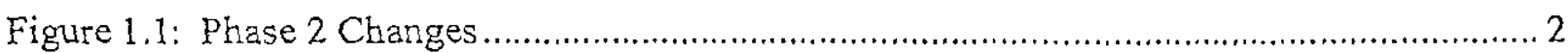

Figure 1.2: Work Breakdown Structure......................................................................... 3

Figure 1.3: Summary Rebaseline Schedule .................................................................... 7

Figure 1.4: Critical Resources (Construction Craft \& HPT's Only) ....................................... 11

Figure 4.1 AN Tank Farm Upgrades ............................................................................... 34

Figure 4.2 Primary Exhaust Station Flow Diagram - AN, AP and AW Tank Farms ...................35

Figure 4.3 Condensate Drain Subsystem - AN, AP, AW Tank Farms and 244-S DCRT ............36

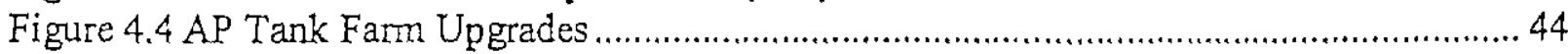

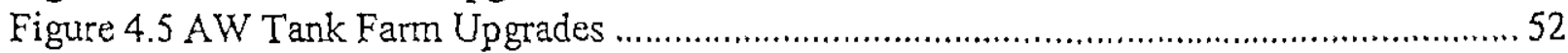

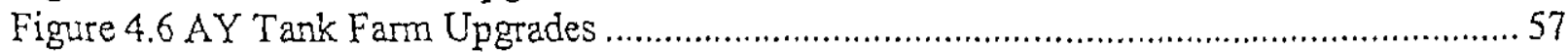

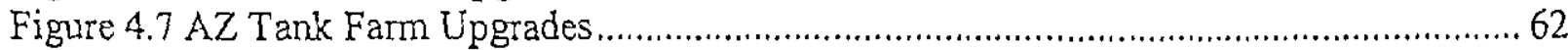

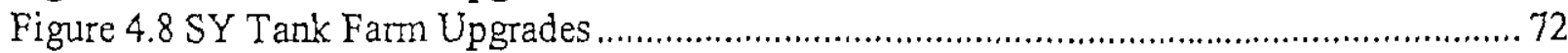

Figure 4.9 Annulus Exhaust Station Flow Diagram - SY Tank Farm.......................................73

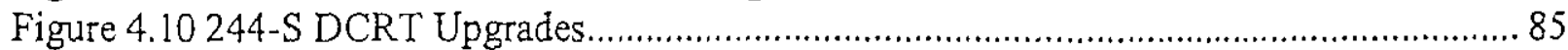

Figure 4.11 Primary/Annulus Exhaust Station Flow Diagram - 244-S DCRT........................... 86 
HNF -5109, REV 0

Figure 4.12. Project W-314 Monitoring and Control System Configuration ............................ 91

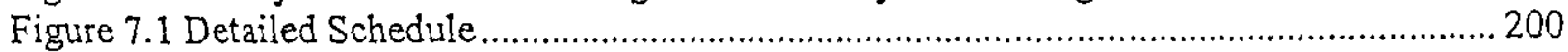




\section{ACRONYMS AND ABBREVIATIONS}

$\begin{array}{ll}\text { ABU } & \text { Acceptance for Beneficial Use } \\ \text { AVE } & \text { ArchitectEngineer } \\ \text { ASME } & \text { American Society of Mechanical Engineers } \\ \text { BA/BO } & \text { Budget Authority/Budget Outlay } \\ \text { CAM } & \text { Continuous Air Monitor } \\ \text { CDR } & \text { Conceptual Design Report } \\ \text { CES } & \text { Cost Estimating Schedule } \\ \text { CFR } & \text { Code of Federal Regulations } \\ \text { DCRT } & \text { Double-Contained Receiver Tank } \\ \text { DCS } & \text { Distributed Control System } \\ \text { DOE } & \text { U.S. Department of Energy } \\ \text { DRD } & \text { Design Requirements Document } \\ \text { DST } & \text { Double-Shell Tank } \\ \text { ECN } & \text { Engineering Change Notice } \\ \text { ENRAF } & \text { Enraf-Nonius Series 854 } \\ \text { FSAR } & \text { Final Safety Analysis Report } \\ \text { GEMS } & \text { Gaseous Effluent Monitoring System } \\ \text { HEPA } & \text { High-efficiency Particulate Air (filter) } \\ \text { HMI } & \text { Human-Machine Interface } \\ \text { HNF } & \text { Project Hanford Management Systern } \\ \text { HPT } & \text { Health Physics Technicians } \\ \text { I\&C } & \text { Instrumentation and Control } \\ \text { IO } & \text { Input/Output } \\ \text { KVA } & \text { Kilovolt Amperage } \\ \text { LMHC } & \text { Lockheed Martin Hanford Corporation } \\ \text { MCC } & \text { Motor Control Center } \\ \text { MPS } & \text { Master Pump Shutdown } \\ \text { MYWP } & \text { Multi-Year Work Plar } \\ \text { NEMA } & \text { National Electrical Manufacturers' Association } \\ \text { O\&M } & \text { Operations and Maintenance } \\ \text { OPC } & \text { Other Project Costs } \\ \text { ORP } & \text { Office of River Protection } \\ \text { ORR } & \text { Operational Readiness Review } \\ \text { PDC } & \text { Project Design Criteria } \\ \text { PICD } & \text { Project Interface Control Document } \\ \text { PDIS } & \text { Pressure Indicating Switch } \\ \text { PDS } & \text { Project Development Specification } \\ \text { P\&ID } & \text { Piping and Instrumentation (Design / Diagram / Drawing) } \\ \text { PLC } & \text { Programmable Logic Controller } \\ \text { RMW } & \text { Radioactive Mixed Waste } \\ \text { RPP } & \text { River Protection Project } \\ \text { RTD } & \text { Resistance Temperature Detector } \\ & \end{array}$


SD Supporting Document

SST Single-Shell Tank

SWP Special Work Permit (protective clothing)

TAP Toxic Air Pollutant

TCC Total Construction Cost

TECC Total Estimated Constructed Cost

TFLAN Tank Farm Local Area Network

TFRSO Tank Farm Restoration and Safe Operation

TIS Temperature Indicating Switch

TMACS Tank Monitoring and Control System

TPA Tli-Party Agreement

TPC Total Project Cost

USSR Upgrade Scope Summary Report

Vac Volts Alternating Current

VOC Volatile Organic Compound

WAC Washington Adninistrative Codes

WBS Work Breakdown Structure

WHC Westinghouse Hanford Company 
HNF-5109, REV. 0

\subsection{EXECUTIVE SUMMARY}

Project W-314, (97-D-402) Tank Farm Restoration and Safe Operations is a multi-year, multiphase project established to upgrade selected 200 East and West Area Tank Farms to support the long-term mission of waste storage, retrieval, and transfer for vitrification. Key drivers for these upgrades include the planned timetable for transfer of waste to the privatized vitrification facility, regulatory compliance requirements (i.e., Washington State and Federal Regulations), and the Tri-Party Agreement (TPA).

The previous baseline scope for Project W-314 was established based upon tank farm system assessments performed five to six years ago and was reflected in the previous baseline cost estimate, the Accelerated Replanning Estimate, completed in July 1997. The Accelerated Replanning Estimate splits the project into two phases: Phase 1 provides ungrades necessary to assure reliable waste retrieval and transfer to the anticipated vitrification plant. Phase 2 provides upgrades to selected primary and annulus tank farm ventilation systems that are required for compliant waste transfer, as well as other compliance-based upgrades to existing River Protection Project (RPP) facilities and systems. The Accelerated Replanning Estimate provided the basis for Baseline Change Request TWR 97-066, which identified Phases 1 and 2 as $\$ 95$ million and $\$ 206.5$ million, respectively.

Following completion of the Accelerated Replanning Estimate, several changes occurred that prompted a decision to rebaseline Phase 1, and subsequently Phase 2. Paramount among these was the delay in the Privatization schedule ( $90 \%$ case), lessons leamed (in the year since the Accelerated Planning Report had been completed), and the adoption of an alternate waste transfer system route. The rebaselined cost of $P$ hase $1, \$ 157$ million, was substantially higher than the Accelerated Replanning Estimate for a number of reasons more thoroughly discussed in the Phase 1 Rebaseline Report, HNF-3781, January 1999. Since the July 1997 Accelerated Replanning Estimate there have also been changes to the tark farm authorization basis and Programmatic needs. For example, Tank Farm Operations has been installing new Continuous Air Monitors (CAMs) and ENRAFs (liquid level measuring devices) in order to achieve desired monitoring improvernents years earlier than provided by Phase 2 .

In summary, the decision to rebaseline Phase 2 was prompted by: 1) the shifting of selected Phase 2 scope to Phase 1 during the Phase 1 rebaselining, 2) changes in the authorization basis, 3) programmatic needs, and 4) the dated nature of the existing scope definition.

Figure 1.1 presents a summary of the key changes from the previous baseline and their collective impact on the cost of Phase 2. 
HNF-5109, REV. 0

Figure 1.1: Phase 2 Changes

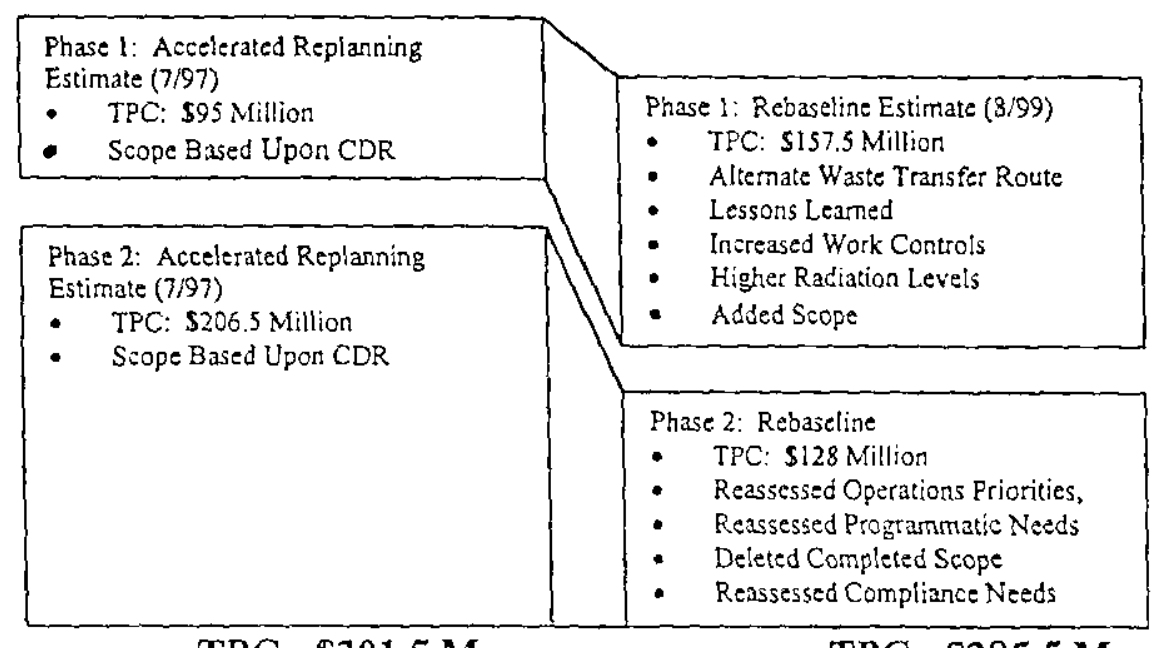

TPC: $\$ 301.5 \mathrm{M}$

TPC: $\$ 285.5 \mathrm{M}$

The key scope remaining in Phase 2 includes:

- The upgrade of the primary yentilation systems in the AN, AP, and AW farms, the annulus ventilation system in SY Farm, and the ventilation system of the 244-S doublecontained receiver tank (DCRT).

- The installation of a new leak detector and drain plug assembly, and repair of special protective coating (SPC) in selected process pits and pipeline encasements.

- The installation of new vapor space pressure-monitoring instrumentation in the AN, AW, AY, SY, AZ farms and the 244-S DCRT. The connection of the new instrumentation and the existing vapor space pressure-monitoring in AP Tank Farm to the Tank Farm Local Area Network

- Selected electrical upgrades in AN, AP, AW, SY, 244-S DCRT, AY, and AZ Farms

- The upgrade of the 244-S DCRT temperature monitoring

- Miscellaneous alarm upgrades.

This Rebaseline Report incorporates these Phase 2 changes and establishes a more current Phase 2 technical cost and schedule baseline upon which to monitor Phase 2 project performance. It revises the Project Work Breakdown Structure, identifies the rebaseline planning basis, establishes a new cost and schedule estimate, and identifies the needed critical resources and required annual Budget Authority and Budget Outlay (BA/BO). Associated management and technical bascline documents are revised as well and provided separately as stand-alone docurnents.

Work Breakdown Structure: The Work Breakdown Structure (WBS), Figure 1.2, was revised as part of the rebaselining effort. WBS 1.3.Q SY Farm Annulus Ventilation was added to reflect the expense funded nature of this work (WBS 1.3 includes all expense funded activities). A detailed definition of each of the WBS elements is included in the W-314 Project Execution Plan, HNF-SD-W314-PMP-001. REV. 3, Appendix A, Project Summary Work Breakdown Structure Description. 
Figure 1.2: Work Breakdown Structure

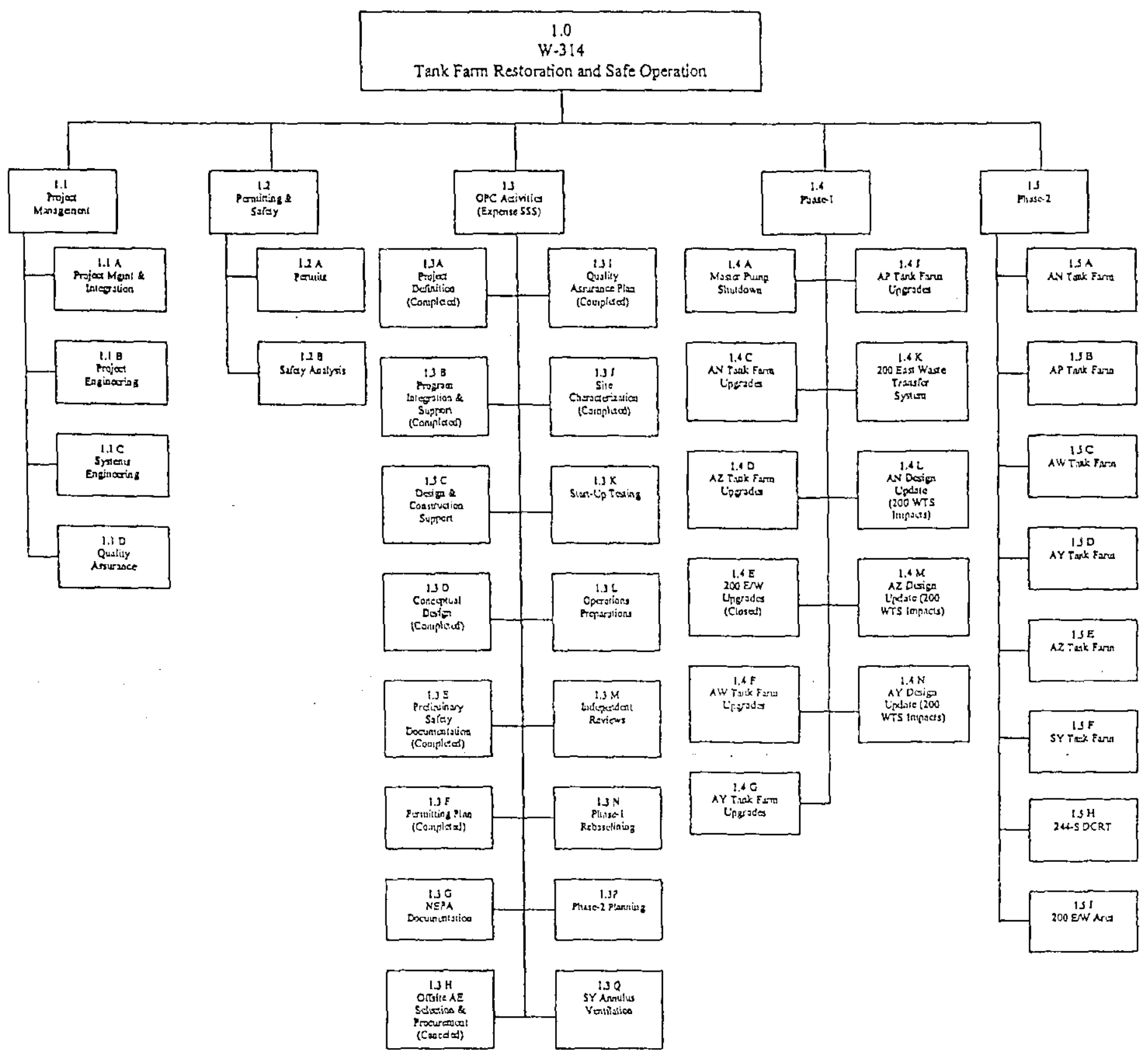


Planning Basis: Budget outlay scheduling for this Phase 2 rebaseline effort was based upon assumed funding constraints in the fiscal years 2000 and 2001, assumed schedule constraints posed by the planned timetable for transfer of waste to the privatized vitrification facility (and therefore the need date for upgraded ventilation systems), TPA milestone $M-43$, required integration with other ongoing RPP activities, and several key assumptions. Tables 1 and 2 below, identify funding and schedule assumptions.

Table 1.1: Funding Assumptions

\begin{tabular}{|l|l|}
\hline Fiscal Yeat & Funding Assumptions (\$1000s) \\
\hline 2000 & $\begin{array}{l}\$ 5.433 \mathrm{M}(2.941 \text { Capital }+2.492 \\
\text { Expense }\end{array}$ \\
\hline 2001 & $\begin{array}{l}\$ 8.477 \mathrm{M}(5.399 \text { Capital }+3.078 \\
\text { Expense })\end{array}$ \\
\hline
\end{tabular}

Table 1.2: Schedule Assumptions

\begin{tabular}{|l|c|}
\hline Complete AN Primary Ventilation Construction & Date \\
\hline Complete AY I\&C and Electrical Construction & 2003 \\
\hline Complete AZ I\&C and Electrical Construction & 2003 \\
\hline Complete 244-S DCRT Ventilation Construction & 2003 \\
\hline Complete AP Primary Ventilation Construction & 2004 \\
\hline Complete AW Primary Ventilation Construction & 2004 \\
\hline Complete SY Annulus Ventilation Construction & 2004 \\
\hline Complete "Other" AP Farm Construction & 2005 \\
\hline Complete "Other AW Farm Construction & 2006 \\
\hline Complete W-314 Project's Portion of TPA M-43-00* & 2006 \\
\hline * Compliance Upgrades & 2005 \\
\hline
\end{tabular}

The above construction completion dates allow enough time for subsequent startup, testing, and other readiness activities required to transfer waste per the current vitrification timetable.

Integration: Integration will be achieved with River Protection Projects (RPP) W-211 and W-521 to minimize Phase 2 pit upgrade costs, particularly four central pump pits, $A N-102, A N-$ 105, AN-106, and AN-107. W-314 Phase 2 plans to accomplish the installation of a leak detector and drain plug assembly, and repair of the SPC on the interior pit walls during the planned W-211 upgrade of central pump pit AN-105. Similarly, W-314 Phase 2 pit work will be coordinated during the planned W-521 upgrades of AN-102, 106, and 107. A more detailed discussion of the required integration is included in Section 8.0 .

Key Assumptions: The key assumptions taken in the process of refining the scope, and estimating the cost and schedule of Phase 2 are listed below. Assumptions are discussed in more detail in Sections 4.0 and 6.1. 
- Field work practices will be improved to the point where the opening of a process pit, the installation of a leak detector and drain plug assembly, and the repair of the special protective pit coating can be accomplished in 34 days.

- The Arrulus Emergency Pumping Plan recently submitted to the State Department of Ecology (requiring no upgrades to the Annulus Pump Pits) will be accepted.

- Phase 2 Panalarm work scope includes installation and connection of alarms to a signal converter and modem. Connecting the modems to phone lines and integrating signals to Tank Monitoring and Control System (TMACS) will be performed by others, if deemed necessary.

- Ventilation requirements as indicated in Section 6.1 are acceptable.

Status of Requirements Definition: There are a number of efforts curently underway by others to develop "upper level" tank farm system requirements. These include 12 double-shell tank (DST) Level 2 Specifications that may change currently identified W-314 requirements. In addition, Operations and Maintenance Philosophies are currently in development which may result in revised or additional requirements. Any changes in current requirements will be addressed through baseline change requests in scope.

Cost: The rebaselined Phase 1 cost estimate totals $\$ 128$ million as follows:

Table 1.3: Phase 2 Cost Estimate Summary

\begin{tabular}{|l|l|lr|}
\hline WBS & Prot Title & Total (\$MS) \\
\hline 1.1 & Project Management & $\$$ & 14.4 \\
\hline 1.2 & Permitting \& Safety Analysis & $\$$ & 1.2 \\
\hline 1.3 & Other Project Costs & $\$$ & 22.9 \\
\hline 1.5 & Phase 2 & $\$$ & 89.5 \\
\hline & Total & $\$$ & 128.0 \\
\hline
\end{tabular}

A more detailed cost estimate is presented in Section 6.0, Cost Estimate.

Contingency: The contingency for Phase 2 totals $\$ 30.6 \mathrm{M}$. The contingency was established using the DOE Order 430.1, Life-Cycle Asset Management (LCAM), GPG-FM-007 guidance. Functional subject matter experts performed a qualitative risk analysis using engineering judgment to establish the potential consequences and likelihood of risk events. Both technical and programmatic risks were analyzed. As a result of this analysis, the major project risks are identified as:

- Possibility of project failure due to the lack of financial support to the end of the project;

- Potential for changes to the project due to changed or new technical requirements;

- Potential for changes to the project from various programmatic and project documents and analyses yet to be completed that contain technical data affecting the project;

- Potential changes in scope implementation and interface by operational requests and other projects;

- Potential changes in turnover activities - may be raised to a higher level of inquiry (e.g., Readiness Assessments); 
- Potential changes in project scope due to inaccurate scoping/estimate assumptions and/or inaccurate, detailed, integrated planning; and

- Potential for qualified personnel or contractors to be unavailable when needed.

The risk analysis established the Phase 2 risks, associated frequencies, and potential consequences. Consequences were expressed in terms of cost and time impacts. Each of the risks were converted to contingency dollars by multiplying the median frequency times median consequence dollars. Finally, risk dollars were allocated to each of the project tasks. The allocation of contingency can be summarized as $\$ 3.1 \mathrm{M}$ to Project Maragement, $\$ 2.4 \mathrm{M}$ to Design, $\$ 22.6 \mathrm{M}$ to Construction, $\$ 2.2 \mathrm{M}$ to Test and Turnover, and $\$ 0.4 \mathrm{M}$ to Readiness.

A more detailed discussion of the risk analysis methodology can be found in the Project Execution Plan, HNF-SD-W-314-PMP-001, Rev 3, Appendix F, Risk Management Plan. Actual dollar values of the resultant contingencies at the project activity level can be found in the Phase 2 Rebaseline cost estimate, Section 6.0 .

Schedule: The Summary Rebaseline Schedule, Figure 1.3, provides five key ventilation system upgrades including "Tumover to Operations" (includes start up, testing, and tumover activities) by the required programmatic need date.

The Rebaseline Schedule also provides completion of all W-314 Phase 2 compliance related upgrades by June 2005, Tri-Party Agreement Milestone, M-43. It reflects best efforts to resource level the Phase 2 work (within the aforementioned planning constraints and the BA/BO requirements of W-314 Phase 1 so as to avoid human and funding resource peaks in any one year.

Section 7.0 Schedule, provides the Summary Project Schedule for Phase 2 activities.

Critical Resources: Figure 1.4, "Critical Resource Needs" summarizes the construction craft and health physics technicans (HPTs) required by Fiscal Year quarter. Section 10 "Critical Resources" presents detailed resource needs for each labor classification for: 1) Phase 2 total, 2) for each farm, and 3) for each pit.

Budget Authority/ Budget Obligation Outlay (BA/BO): Table 1.4, "Required Budget Authority/Budget Outlay" indicates the Phase 2 BA funding requirements along with those of Phase 1. The BA/BO requirements of both Phases taken together fall within the annual FYOO and FYO1 expense and capital targets currently in the Multi Year Wok Plan. A more detailed $\mathrm{BA} / \mathrm{BO}$ outlay is provided in Section 8.0, BA/BO.

Updated Management and Technical Baseline Documents: In addition, six project documents were revised as a part of the rebaselining effort. Table 1.5 provides a brief description of each. Collectively, these documents describe the management approach and technical baseline of Project W-314. These are stand-alone documents and are provided separately 
Figure 1.3: Summary Rebaseline Schedule

(consisting of the following four pages). 
F.TE-5109, REV. 0

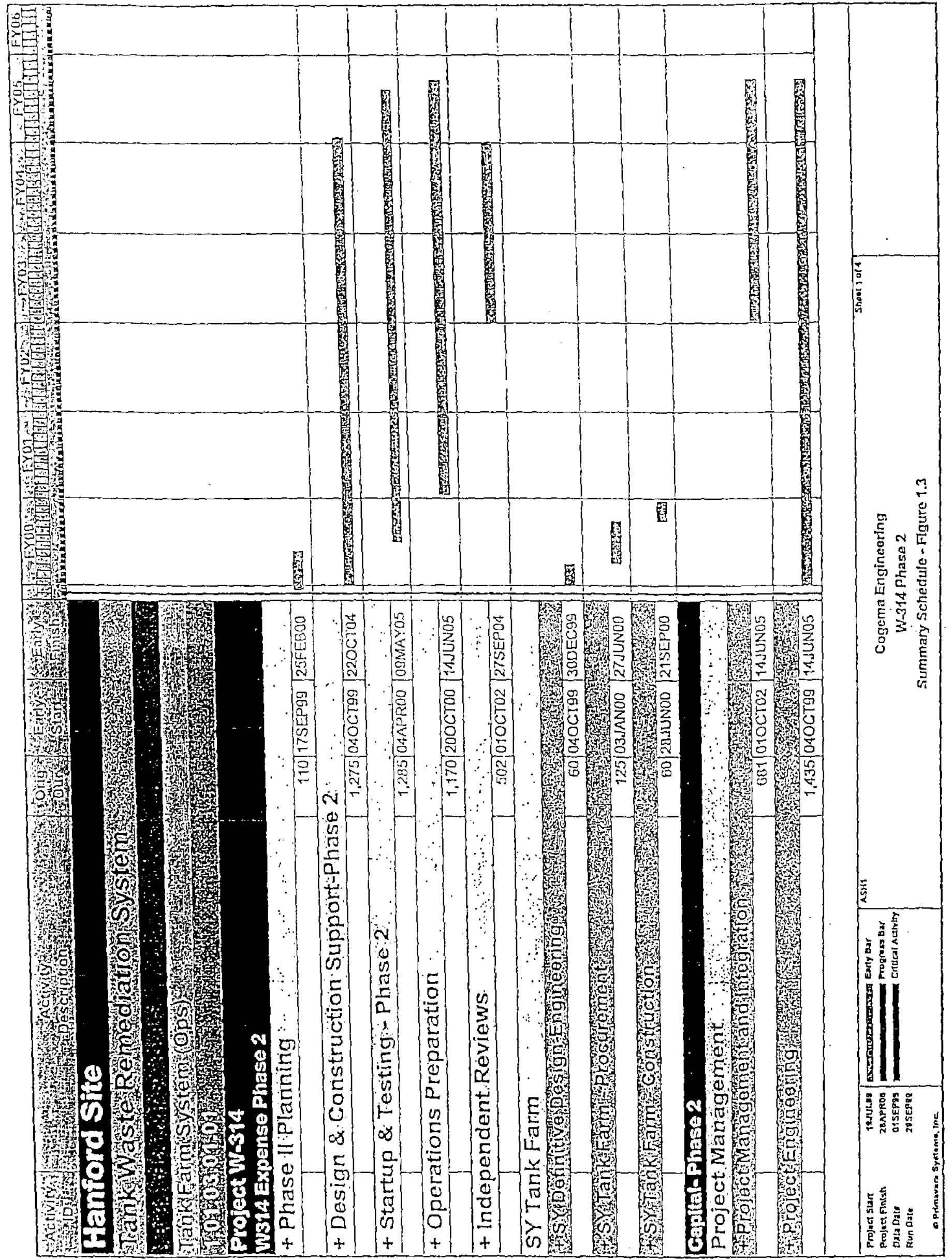


HNE-5109, KEV. 0

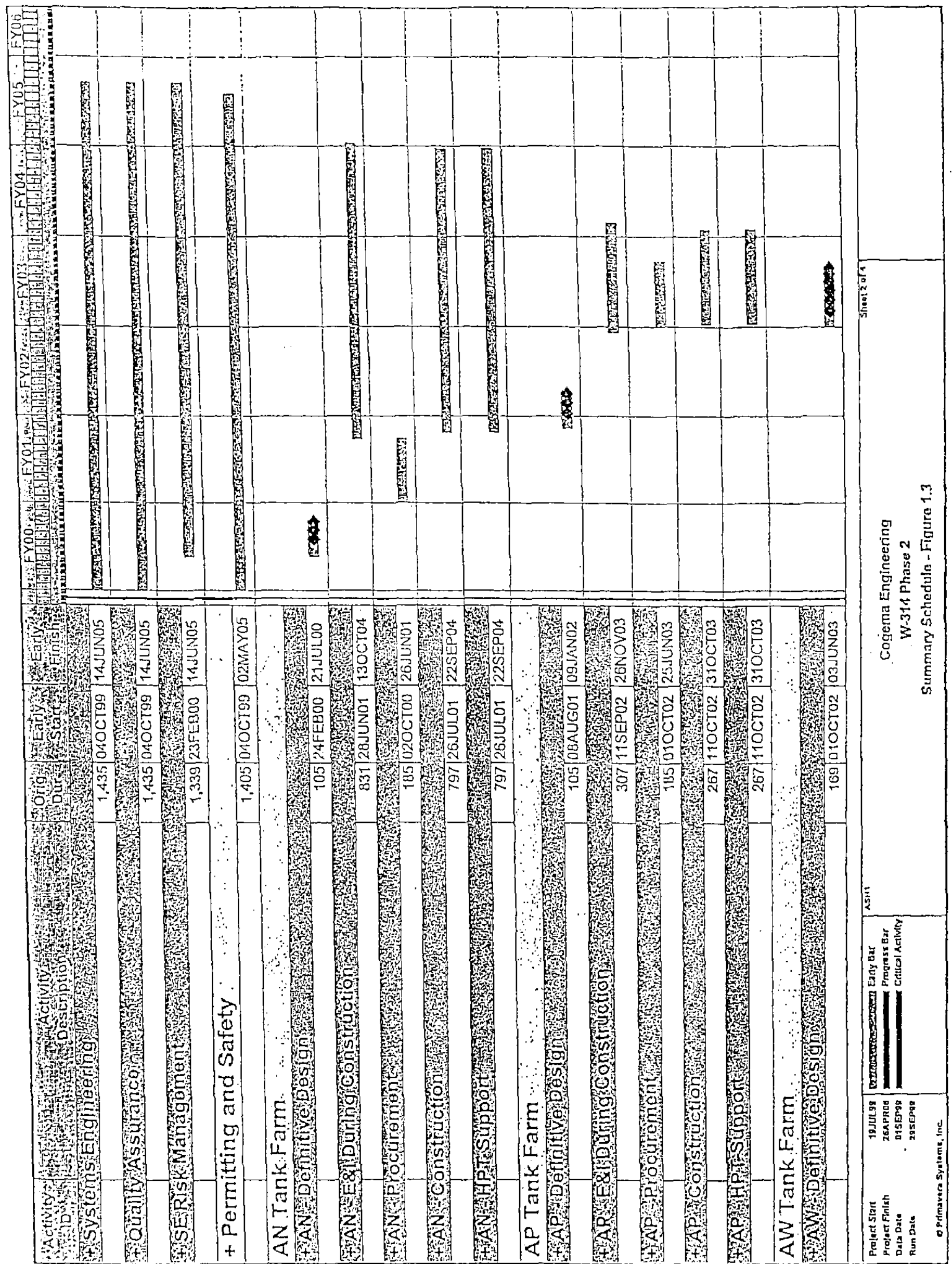


HNF-5109, REV. 0

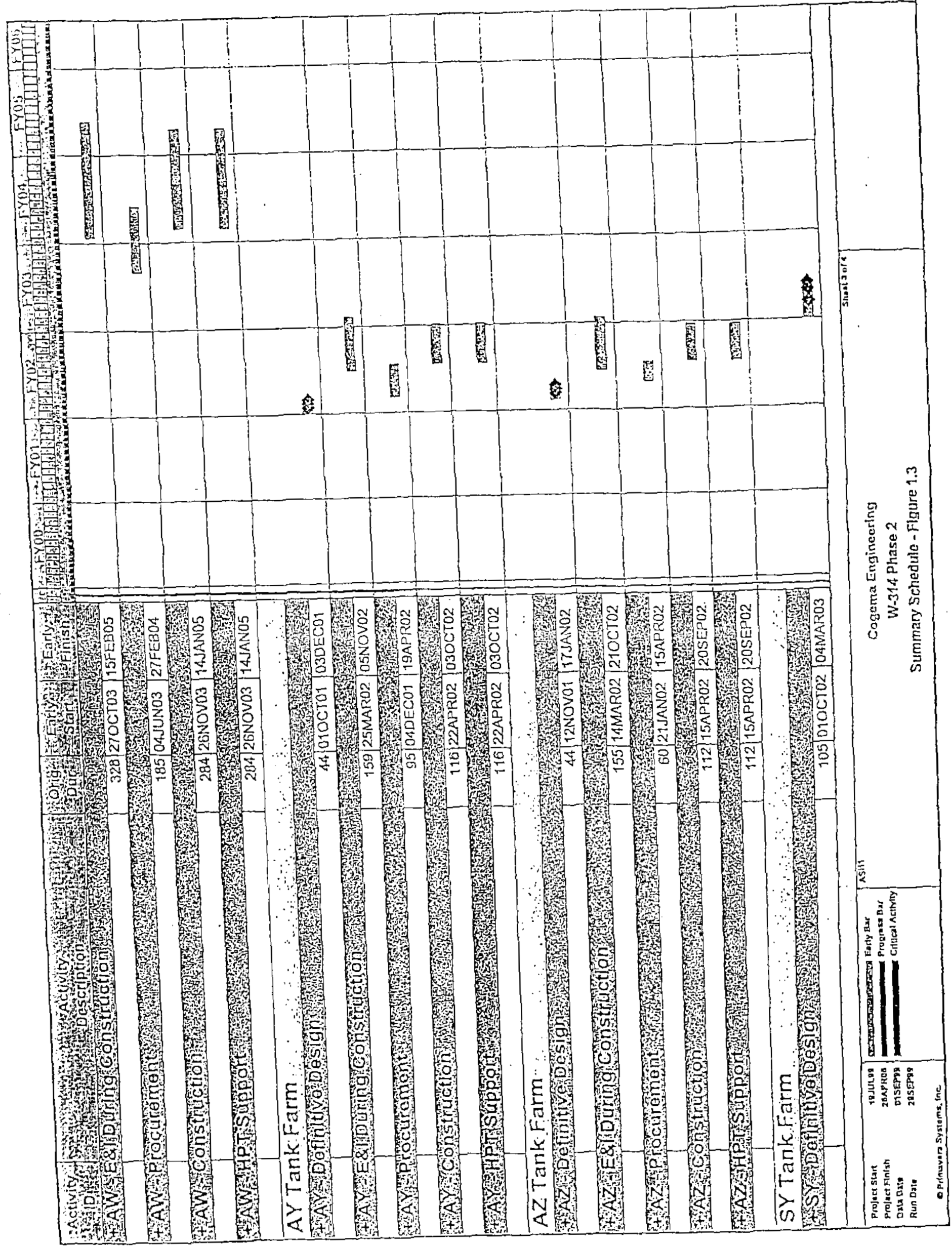


HNF-5109, REV. 0

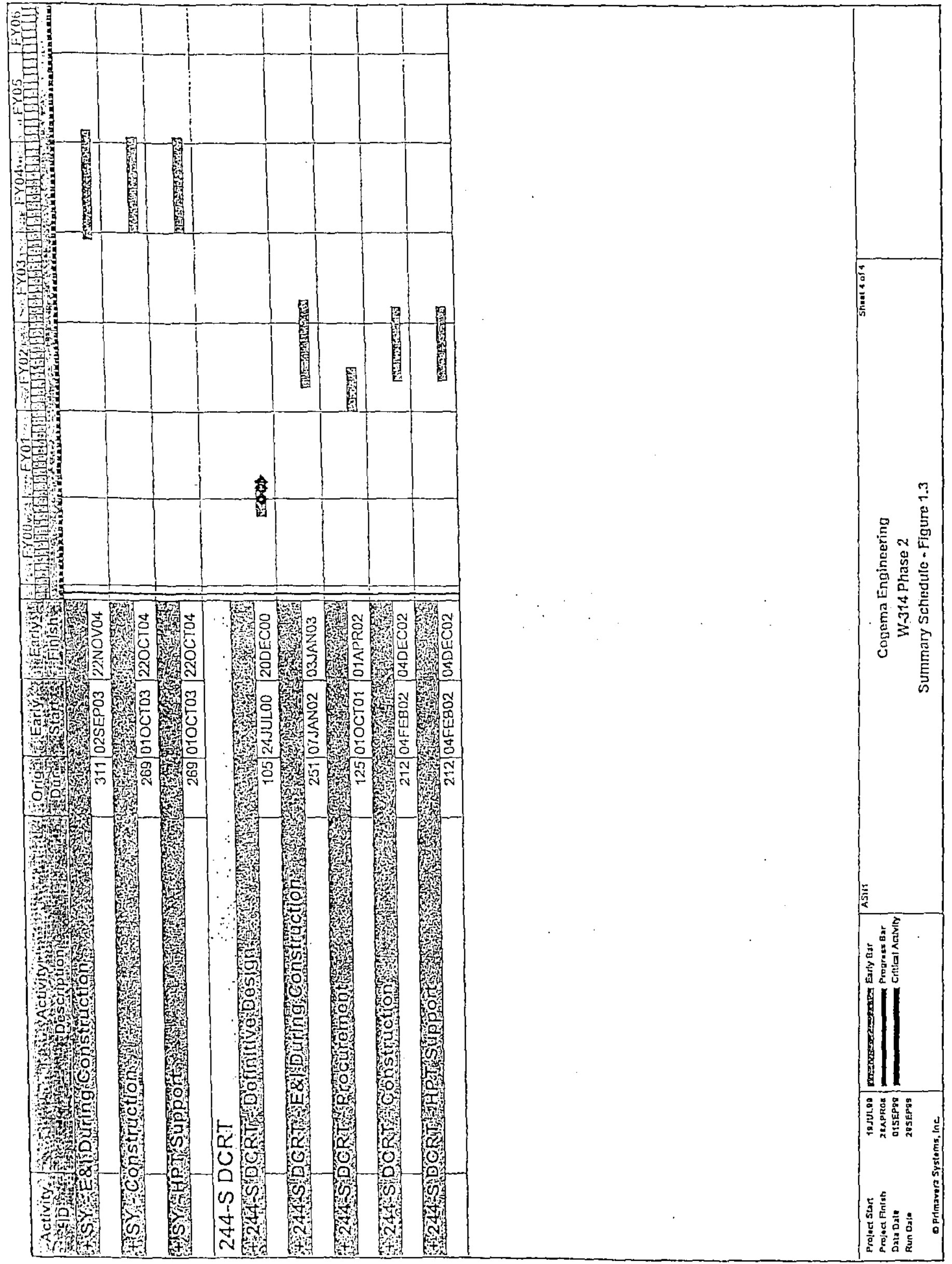


圈

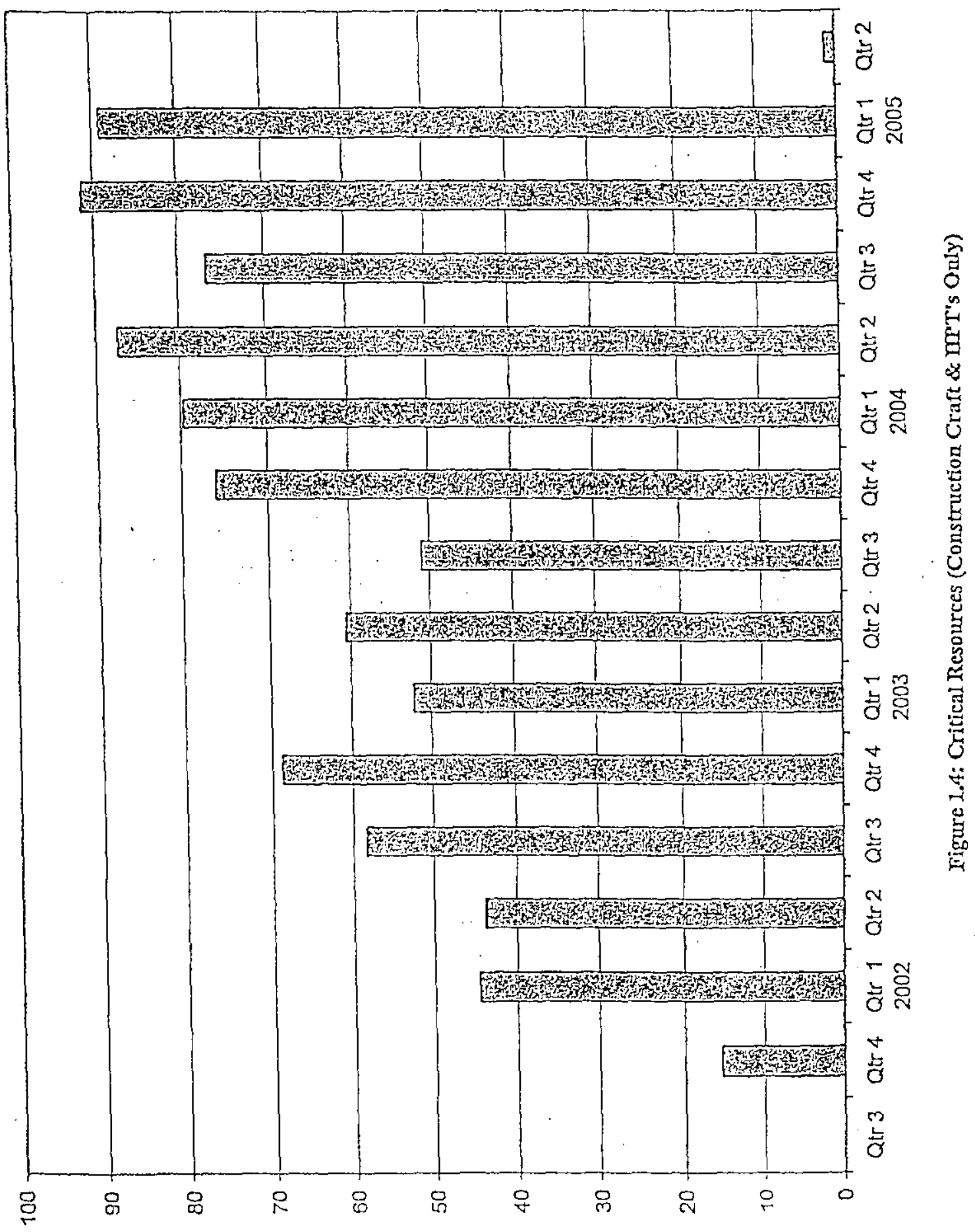


HNF-S109, REV. 0

Table 1.4 Required Budget Authority/Budget Outlay

(consisting of one page) 


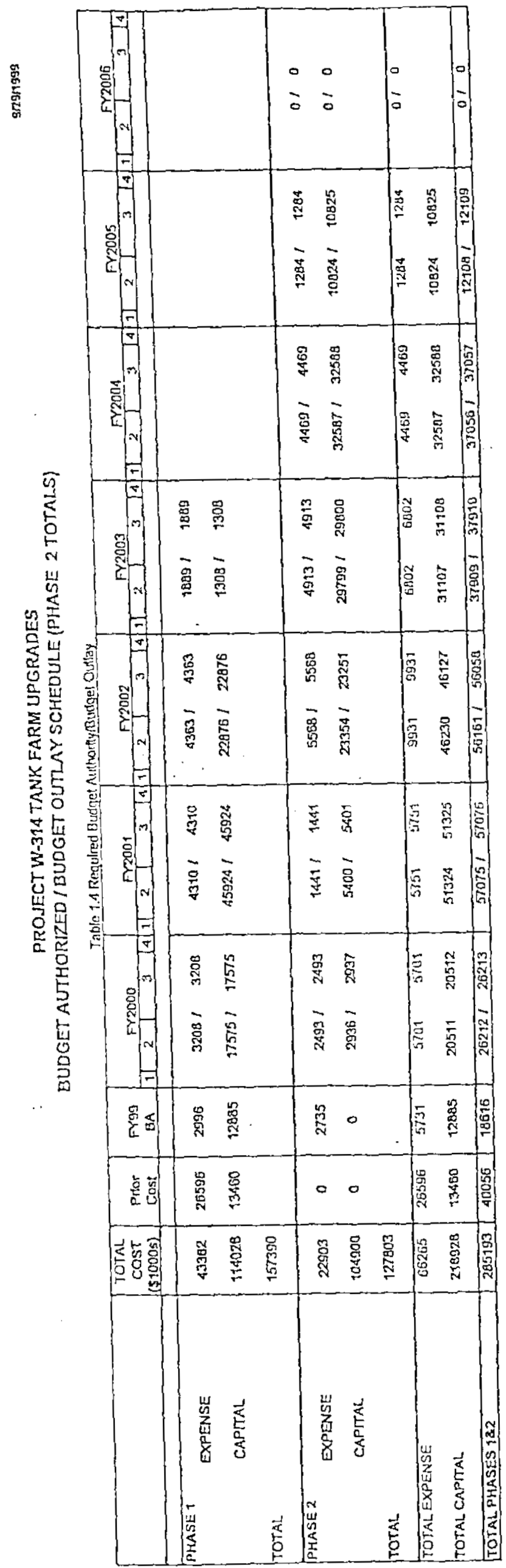

HNF-5109, REV. 0 


\section{Table 1.5: W-314 Updated Project Documentation}

\begin{tabular}{|c|c|}
\hline $\begin{array}{l}\text { Proje } \\
\text { Plan }\end{array}$ & $\begin{array}{l}\text { Describes the overall strategy, objectives, and contractor management } \\
\text { requirements in support of the established mission need. It also includes } \\
\text { as appendices the Systems Engineering Management Plan, the } \\
\text { Configuration Management Plan, and the Risk Management Plan. }\end{array}$ \\
\hline $\begin{array}{l}\text { Systems } \\
\text { Engineering } \\
\text { Management } \\
\text { Plan }\end{array}$ & $\begin{array}{l}\text { Identifies the requirements development and design activities needed for } \\
\text { completion of design, construction, startup, and tumover of hardware } \\
\text { upgraded by the project. This document supplements the Projects } \\
\text { Execution Plan's "technical planning activity." }\end{array}$ \\
\hline $\begin{array}{l}\text { Configuration } \\
\text { Management } \\
\text { Plan }\end{array}$ & $\begin{array}{l}\text { Defines the processes and procedures necessary to ensure technical } \\
\text { integrity through effective planning, documenting, controlling, and } \\
\text { validating the physical structures, systems, components, and } \\
\text { requirements (and associated information that contains these } \\
\text { requirements). }\end{array}$ \\
\hline $\begin{array}{l}\text { Risk } \\
\text { Maną } \\
\text { Plan }\end{array}$ & $\begin{array}{l}\text { Identifies risks to the project, and mitigation strategies to ensure } \\
\text { success ful completion of the project. }\end{array}$ \\
\hline & $\mathrm{ich}$ \\
\hline $\begin{array}{l}\text { Design } \\
\text { Require } \\
\text { Docume }\end{array}$ & $\begin{array}{l}\text { Identifi } \\
\text { Level } 1\end{array}$ \\
\hline
\end{tabular}




\subsection{INTRODUCTION}

This Rebaseline Report incorporates Phase 2 changes from work scope additions, deletions, and modifications, and establishes a more current Phase 2 technical cost and schedule baseline upon which to monitor Phase 2 project performance. It revises the Project Work Breakdown (WBS) Structure, identifies the rebaseline planning basis, establishes a new cost and schedule estimate, and identifies the needed critical resources and required annual Budget Authority and Budget Outlay $(\mathrm{BA} / \mathrm{BO})$. Associated management and technical baseline documents are revised as well and are provided separately as stand-alone documents.

Since the July 1997, Accelerated Re-Planning Estimate, there have been changes to the Tank Farm Authorization Basis and programmatic needs. For example,Tank Farm Operations has been installing new continuous air monitors (CAMs) and Enraf-Nonius Series 854 (ENRAFs) (liquid level measuring devices) in order to achieve desired monitoring improvements much earlier that could be provided by Phase 2 .

The decision to rebaseline Phase 2 was prompted by: 1) the shifting of selected Phase 2 scope to Phase 1 during the Phase 1 rebaselining, 2) changes in the authorization basis, 3) changes in programmatic need, and 4) the dated nature of the existing Phase 2 scope definition. 
HNE-5109, REV. 0

\subsection{TECHNICAL BASELINE}

The HNF-SD-W314-DRD-001 Rev. 1, Preliminary Design Requirements Document for Tank Farm Restoration and Safe Operations, Project W-314 is the Project's current, DOE-approved technical baseline. However, as a part of the Phase 2 rebaselining effort, this document has been updated, and provides the technical baseline for this Phase 2 Rebaseline Report. The Design Requirements Document (DRD) Rev. 2 is being presented to DOE for review and approval concurrently with this Rebaseline Report. Approval by DOE establishes revision 2 of the DRD as the new technical baseline for Project W-314.

The DRD update was necessary for a number of reasons. Revision 1 contained detailed performance requirements that have been determined by Lockheed Martin Hanford Corporation (LMHC) and Office of River Protection (ORP) to be inapp:opriate for an upper level requirements document. Many of the documents used in Revision 1 have been cancelled, replaced, or revised. In addition to correcting these deficiencies, the non-performance requirements were reviewed, verified, updated, or deleted as appropriate. Performance requirements were verified using the following documents: HNF-SD-WM-SAR-067, Rev. 0, Tank Waste Remediation System Final Safety Analysis Report, HNF-SD-WM-TSR-006, Rev. 0-S, Tank Waste Remediation System Technical Safety Requirements, HNF-1939, Waste Feed Delivery Technical Basis, Vol. IV, Rev. B (Draft), Waste Feed Delivery Operations and Mainienance Concept, and Draft Double-Shell Tank Level 2 Specifications. As before, source requirements include the Authorization Basis and documents such as Department of Energy (DOE) Orders, Code of Federal Regulations (CFRs), and Washington Administrative Codes (WACs).

Changes to requirements reflected in Revision 2 primarily involve ventilation requirements. Key changes include 1) maintaining the vapor space pressure in DSTs to within limits (Rev. 1 requirement imposed a limiting condition for operation); 2) maintaining DST gaseous effluent discharge to within limits (Rev. 1 requirement imposed a limiting condition for operation); and, 3) maintaining DST fiammable gas concentrations to within lower flammability limits (Rev. 1 requirement imposed a limiting condition for operation).

For a more thorough discussion of the design requirements than presented here, please see HNFSD-W314-DRD-001 Rev. 2, Preliminary Design Requirements Document for Tank Farm Restoration and Safe Operations, Project W-314. 


\subsection{SCOPE}

The mission of Project W-314 (WHC-SD-W314-MAR-001, Mission Analysis Report Project W314 Tank Farm Restoration and Safe Operation) is to upgrade the existing (DST) farm facilities and systems. This project will improve the reliability of safety-related systems, reduce onsite health and safety hazards, and support waste storage, waste retrieval, and disposal activities in support of the overall River Protection Project (RPP) mission.

Project W-314 has been divided into two phases for performing all of the identified work scope. Phase 1 supports work necessary to provide initial support to the waste retrieval efforts. Phase 2 provides significant upgrade modifications to RPP equipment and systems to ensure that they meet the following requirements:

- Regulatory compliance

- Safety

- Mission requirements

- Reliability

- Operational requirements

\section{Phase 1}

Project W-314 Phase 1 activities presently address upgrades and modifications to accommodate the 200 East Area waste transfer system in support of waste retrieval needs. The present status of Phase $I$ activities includes the completion of definitive design and construction in the AN Tank Farm. In addition, preparations are being made to start the installation of a new waste transfer pipeline that will connect the existing cross-site transfer line (Project W-058) to termination points in each of the DST farms in the A-Farm Complex. Phase 1 has completed the following Tri-Party Agreement (TPA) milestones:

- TPA-M-43-09: Submission of Conceptual Design Report

- TPA-M-43-10: Start of Definitive Design for Project W-314

- TPA-M-43-12: Start Construction Upgrades in First Tank Farm

- TPA-M-43-11: Provide W-314 Construction Schedule

Continuing Phase 1 construction will include pipeline connections, jumper and valve manifold installation, application of SPC, electrical upgrades, and leak detection instrumentation in each of the following tank farms: $\mathrm{AY}, \mathrm{AZ}, \mathrm{AW}$, and $\mathrm{AP}$.

A new Master Pump Shutdown (MPS) system will be installed with a programmable logic controller (PLC)/Human Machine Interface (HMI) based system connected through a Tank Farm Local Area Network (TFLAN). Further details of the Phase 1 scope are presented in the Phase 1 Rebaseline Report, HNF-3781.

\section{Phase 2}

The current Phase 2 work scope will address regulatory compliance upgrades from the CDR that support future waste storage, retrieval, and feed staging operations. The present status of Phase 2 
activities include, completion of a rebaselining of Phase 2 establishing up to date scope, cost, schedule, and technical baselines, and initiation of pre-design documentation.

Phase 2 supports TPA Milestone M-43-00, "Complete W-314 Tank Farm (Compliance related) Upgrades". Phase 2 activities continue to support this process for commencement of definitive design. This includes gathering necessary design level requirements and specifications; and developing specific documents to support design (i.e., Project Development Specifications [PDSs], Project Design Criteria [PDCs]; and Project Interface Control Documents [PICDs]). The key elements of the Phase 2 scope include the following tasks:

\section{Ventilation}

- Primary ventilation and stack monitoring upgrades/replacement in AN, AP, and AW tank fans and the 244-S double-contained receiver tank (DCRT)

- Annulus ventilation replacement for SY Tank Farm

- Installation of new primary inlet air filter stations for AP Farm and the 244-S DCRT

- Use existing primary ventilation de-entrainer.

Instrumentation and Control

- Upgrade the DST high-level probes

- Upgrade DST vapor space pressure instruments

- Upgrade waste temperature monitoring for 244-S DCRT

- Installation of new remotely testable, intrinsically safe leak detectors in the following: - Pipeline encasements

- Process pits

- Upgrades to alam and monitoring systems

\section{Electrical}

- Upgrades to DST electrical systems to support ventilation and instrumentation upgrades and allow maintenance on switchgear.

Piping

- Installation of a bypass waste transfer line around 241-A-A valve pit. The new waste transfer line will connect SN-220 and LIQW-702 lines together.

\subsection{AN TANK FARM UPGRADES}

Refer to Figure 4.1 for an overview of AN Tank Farm upgrades.

\subsubsection{INSTRUMENTATION AND CONTROL}

\subsubsection{Description}

Instrumentation and control upgrades to the AN Tank Farm inciude primary tank systems, leak detection systems, and the new primary exhaust ventilation system. Selected existing alarms and 
signals, and signals from Phase 2 upgraded systems will be connected to the TFLAN system, except for Panalarm signals, which will be connected to TMACS.

\subsection{Primary Tank}

\subsection{Liquid High-Level Measurement}

WBS: 5A4J22E

New liquid high-level probes, including electronic relays, have been installed by others for all seven 241-AN tanks. The existing current/conductivity probes have been replaced with intrinsically safe resistive/conductivity probes. The portion of liquid high-level measurement upgrades for Project W-314 Phase 2 work scope involves the connection of the existing highlevel alamn signals from the seven tanks to a TFLAN PLC. The connection to the TFLAN PLC will be made in the $241-\mathrm{AN}-271$ instrument building by routing signal cables between the instrument panel and a TFLAN PLC IO panel. The signals from the liquid high-level probes will be monitored by the TFLAN PLC and displayed on the TFLAN HMI.

\subsection{2 . Vapor Space Pressure Measurement}

WBS: 5A4A08A, 5A4B08A, 5A4C08A, 5A4D08A, 5A4E08A, 5A4F08A and 5A4G08A

The existing low and high range pneumatic pressure transmitters located in the transmitter enclosure next to the leak detection pit for each tank will be replaced with new electronic indicating pressure transmitters. Existing tank riser taps and tube assemblies will be used to convey tank vapor pressure levels to the new transmitters. Analog pressure signals from the new transmitters will be routed via a field terminal box to a TFLAN PLC Input/Output (I/O) panel located in the 241 -AN-271 instrument building. The vapor pressure signals will be parallelwired from the instrument building to the ventilation skid to allow the ventilation system to independently monitor tank pressure. Low and high range vapor space pressure status of all primary tanks will be monitored by both the TFLAN PLC and the ventilation system PLC, and displayed on the TFLAN HMI.

\subsection{Waste Transfer}

\subsection{Valve Position Indication}

Conduit and wire will be installed for selected pits requiring future installation of valve position indication. No connections will be made at the terminal box or at the pit.

\subsection{Leak Detection}

\subsection{Process Pits}

WBS: 5A4B02, 5A4C02, 5A4E02, 5A4F02, and 5A4G02

New leak detection systems will be installed for selected process pits. The sensor will be an intrinsically safe, conductive type. The system will provide a local and remote alam and be 
operationally testable. Process pits have been identified as safety-class; therefore, each system will have missile shielding. The existing cover blocks will require core drill modification to accept the new sensor assembly. Conduit will be run on top of the existing cover blocks from the sensor to a junction box located on the side of the cover block. A removable wiring jumper (pigtail) will be used to connect the junction box on the cover block to a junction box located on the side of the pit. The leak detection signals will be wired to a TFLAN PLC I/O panel via a terminal box to the 241-AN-271 instrument building. The TFLAN PLC will monitor the leak detection signals as well as provide input to the MPS system.

The new leak detection system will be installed in the following process pits:

- Central Pump Pits 01A - 07A (Except 01A and 04A)

In addition, drain plug assemblies will be installed in all pits not entered by Phase 1 . The following pits will require new drain plug assemblies:

- Central Pump Pits 01A - 07A (Except 01A and 04A)

\subsection{Pipeline Encasement}

WBS: 5A4J35

New leak detection systems will be installed in selected waste transfer pipe encasements. The sensor will be an intrinsically safe, conductive type. The system will provide a local and remote alarm and be operationally testable. The leak detection signals will be wired to a TFLAN PLC I/O panel via a terminal box to the 241-AN-271 instrument building. The TFLAN PLC will monitor the leak detection signals as well as provide input to the MPS system.

The following waste transfer pipe encasements will have a new leak detection system installed:

- DR-368 (near riser 020, 241-AN-101)

- SL-168 (Valve pit AN-A)

- SL-160 (Valve pit AN-B)

- SN-260 (Valve pit AN-B)

\subsection{Power Panels}

WBS: 5 A4J28

The leak detection panels require 120 Vac power. New local power panels will be installed to supply power to the leak detection panels.

\subsection{Primary Exhaust Ventilation}

WBS: 5A3A00, 5A4J02, 5A4J22A, 5A4J28 and 5A2131

Instrumentation and control (I\&C) equipment will be supplied with the new primary exhaust ventilation system to monitor the status and control the operation of the ventilation system. Refer to Figure 4.2, "Primary Exhaust Station Flow Diagram." 
The major ventilation system components are:

- Exhaust station (dual train)

- Gaseous effluent monitoring system

- Condensate drain subsystem

- Ventilation system PLC

The primary exhaust ventilation station will consist of an inlet section containing a glycol heater and control damper; and dual trains each containing an inlet plenum, test sections, HighEfficiency Particulate Air (HEPA) filters, an outlet plenum, and exhauster fan.

A single exhaust stack will be provided with connections to exhaust monitoring systems. A gaseous effluent monitoring system (GEMS) will be installed at the exhaust stack to monitor and trend the concentration of released radioactive materials. Trending information for both radionuclides will be available at the TFLAN HMI. Manual isolation valves will facilitate the connection of either train to the exhaust stack.

A new condensate drain subsystem will be installed to handle condensate from the exhaust housing sections. Included in the subsystem are a seal pot with level measurement equipment, drain piping, and an overflow pipe. Refer to Figure 4.3, "Condensate Drain Subsystem".

A ventilation system PLC will provide monitoring and control of the primary ventilation system and will connect to the TFLAN system in the instrument building to facilitate remote monitoring of the ventilation system by the TFLAN HMI. Some limited remote control of the ventilation system by the TFLAN HMI may also be provided. The need for remote control at the HMI will be evaluated during definitive design.

\subsection{Exhaust Station}

Sensors and associated transmitters for measuring inlet and differential pressures, and glycol heater system level and temperature will be installed on the exhaust station. Local control will be provided by the ventilation system PLC for the exhaust train damper, exhaust heaters, and exhauster fans.

Inlet pressure: The exhaust train inlet pressure will be measured with tespect to atmosphere. A pressure sense tap will be located on the exhaust manifold duct and routed to a local instrument rack. The inlet pressure tubing will connect to an indicating transmitter installed in the instrument rack and the analog signal from the transmitter will be wired to the ventilation system PLC.

Differential pressure: Differential pressures across the HEPA filters (two for each train) and exhauster fan (one for each train) will be measured. A pressure sense tap will be located on the housing on each side of the device measured and routed to a local instrument rack (one near each train). The pressure sensing tubing will connect to indicating transmitters installed in the instrument rack and the analog signals from the transmitters will be wired to the ventilation system PLC. 
Exhaust train temperature: Temperatures of the glycol heater, inlet plenum (one for each train), and test sections (two for each train) will be measured. Temperature elements will be installed in wells mounted on the housing of the device measured and the temperature signals from the sensors will be wired to temperature indicating transmitters installed in the local instrument racks. Analog signals from the transmitters will be wired to the ventilation system PLC.

Level detector: The coolant level in the glycol heater system will be measured. A level detector sensor installed in the heating system will be wired to a level transmitter installed in the local instrument rack. An analog signal from the level transmitter will be wired to the ventilation system PLC.

Exhaust heater: The heater controller will be controlled by an analog signal from the ventilation system PLC. Power to the heater controller will be interrupted, both locally and remotely, by a manual on/off switch or by deactivating a permissive interlock wired from the ventilation system PLC.

Exhaust fan: The exhaust fan will be controlled by a magnetic starter. Power to the exhaust fan starter will be interrupted, both locally and remotely, by a manual on/off switch or by deactivating a permissive interlock wired from the ventilation system PLC.

Inlet damper: The inlet damper position will be controlled by an analog signal from the ventilation system PLC to the damper motor controller.

\subsection{Gaseous Efflient Monitoring System}

A gaseous effiuent monitoring system (GEMS) will be supplied to continually monitor and trend the concentration of radioactive materials released into the environment through the exhaust stack. I \& C for the GEMS will consist of a sampler cabinet, pump cabinet, instrument cabinet, stack instruments, and a data collection system. The cabinets will be weatherproof and will maintain a controlled environment.

Sampler cabinet: The sampler cabinet will contain the record sample filter holder, Beta continuous air monitor (CAM) sample head, sample flow instruments and control, and space for an optional Alpha CAM sample head.

Pump cabinet: The vacuum system located in the pump cabinet will provide a steady, nonpulsating vacuum source to ensure collection efficiency over the full range of operating conditions.

Instrument cabinet: The instrument cabinet will contain the data collection system, including a Beta CAM, an (optional) Alpha CAM, and system controls.

Stack instruments: The stack instruments will include a stack flow measurement element and transmitter, temperature element and transmitter, and stack pressure transmitter.

Data collection system: The ventilation system PLC will perform all necessary data acquisition and control of the GEMS. Process signals will be transmitted between the GEMS instrument cabinet and the ventilation system PLC, including stack and sample flow rates; total stack and 
sample flow volumes; stack pressure and temperature; radiation measurement signals and alanns, and various data collection system inputs and outputs. In addition, remote monitoring and some control of the GEMS may be provided by the TFLAN HMI, including remote adjustment of the flow rate for the record sample filter holder, Beta CAM, and optional Alpha CAM.

Refer to GEMS Procurement Specification, HNF-S-0400, Rev. 1, Conceptual Design Report Stack Monitoring System, WHC-SD-W420-CDR-001, Rev. 0, and Gaseous Effluent Monitoring System Design Criteria, WHC-SD-WM-CR-058, Rev. 0, for detailed information on the GEMS.

\subsection{Condensate Drain Subsystem}

The seal pot condensate level will be continually monitored by a resistive/conductivity level measurement system installed in the seal pot. Seal pot low, high, and fill level information will be sent to the ventilation system PLC. Alarms for "low," "high," and "below fill" levels will be displayed locally and on the TFLAN HMI.

\subsection{Ventilation System PLC}

A single safety-class qualified PLC, including analog and discrete VO will be supplied with the primary exhaust ventilation station. The ventilation system PLC will monitor and control the primary exhaust ventilation trains and stack monitoring systems, and will monitor the seal pot level. In addition, the PLC will continually monitor all primary tark vapor space pressures and will initiate applicable alarms and corrective controls when operating limits are reached.

HEPA filter and other exhaust train differential pressure setpoints will be programmed into the ventilation system PLC. The PLC will compare the pressure differential measurements to the differential pressure set points and will modulate an exhaust damper to maintain the pressure at the set point levels.

Local indicators and manual controls, including hard-wired interlocks, will be provided to facilitate manual operation of the ventilation system independent of the PLC. At least one set of hard-wired interlocks (for high and low-pressure events) and a hard-wired relay for the CAM interlock will be provided to initiate an exhaust shutdown.

The ventilation system PLC will be connected to the TFLAN system by a coaxial cable routed between the ventilation skid and the $241-\mathrm{AN}-271$ instrument building. Operating as a separate node on the TFLAN system, the ventilation system PLC will communicate primary ventilation system status and alarms to the TFLAN HMI in the instrument building.

\subsection{Monitoring and Control}

\subsection{Alarms and Signals}

Miscellaneous alarms and signals will be connected to a TFLAN PLC and monitored on the TFLAN HMI. Included in this work scope are Gamewell and general local alarms originating in the AN Tank Farm and signals from instruments upgraded by W-314 Phase 2. In addition, existing Panalarm signals not addressed by other Phase 2 work scope will be connected to 
TMACS. Signals also required by the MPS system will be connected either to TFLAN or TMACS to accommodate MPS interlock logic.

Refer to "Miscellaneous Alarms and Signals" under "Other Upgrades" for additional AN Tank Farm work scope and associated WBS numbers.

\subsection{TFLAN PLC Equipment}

WBS: 5A 4 J22B

New cabinets will be installed in the 241-AN-271 instrument building to house I/O racks, panels, power supplies, and I/O cards. Communication cards and cables will be provided to connect Phase 2 installed TFLAN PLC VO equipment to an existing TFLAN PLC.

The existing TFLAN PLC programs and HMI screens will be modified to accommodate Phase 2 instrument upgrades. In addition to modifications to existing programs and HMI screens, new programs and HMI screens will be developed to monitor and control the new primary ventilation system and to interface it with TFLAN.

\subsubsection{Demolition}

\subsection{Primary Tank}

\subsection{Liquid-High Level Measurement}

WBS: $5 \mathrm{~A} 4 \mathrm{~J} 22 \mathrm{E}$

Remove associated relays and annunciators in the 241-AN-271 building.

\subsection{Vapor Space Pressure Measurement}

WBS: 5A4A08B, 5A4B08B, 5A4C08B, 5A4D08B, 5A4E08B, 5A4E08B, and 5A4G08B

For all seven tanks, remove and dispose of the existing 14 pneumatic pressure transmitters in the transmitter cabinets located next to the leak detection pits. Abandon conduit, wire, or piping not required for terminations. This equipment is assumed to be non-contaminated waste.

Remove associated pneumatic chart recorders, annunciators, and switches located in the 241 AN-271 building.

\subsection{Leak Detection}

\subsection{Process Pit Leak Detectors}

WBS: 5A4B024, 5A4C024, 5A4D034, 5A4E024, 5A4F024, and 5A4G024

Remove the existing leak detectors in the process pits. Demolish the existing relay panels located in the field. 
HNF-5 109, REV. 0

\subsection{Pipeline Leak Detectors}

WBS: $5 \mathrm{~A} 4 \mathrm{~J} 35 \mathrm{C}$

Remove the existing leak detectors in the pipe encasements. Demolish the existing relay panels located in the field.

\subsection{Primary Ventilation}

WBS: 5A4J26E

Remove the primary exhaust stack instrument enclosure as a unit and dispose of the enclosure as Radioactive Mixed Waste (RMW. The enclosure volume (non-reduced) is assumed to be 48 cubic feet. Dispose of the stack sample piping with the instrument. Consider the piping to be RMW.

Remove all associated relays, indicators, alarms, and readouts in the $241-\mathrm{AN}-271$ building.

\subsection{Monitoring and Control}

Remove cable, conduit, alarms, indicators, switches, and other components no longer needed for the miscellaneous alarms and signals that will be removed and reconnected to the TFLAN PLC or TMACS by Project W-314 Phase 2. These include Gamewell alarms originating in the AN Tank Farm, signals from instruments being upgraded in Phase 2 that are currently input to the 242-A DCS, including general local alarms, and existing Panalarm signal input to TMACS.

Refer to "Miscellaneous Alarms and Signals" section for additional AN Tank Farm work scope and associated WBS numbers.

\subsubsection{Assumptions}

\subsection{General}

It is assumed that:

1. A (Modicon Quantum Series or equivalent) TFLAN PLC and an HMI will be installed in the 241-AN-271 instrument building by Project W-314 Phase 1. No spare slots are available for Phase 2 upgraded instruments.

2. All new instruments installed by Phase 2 will be connected to the TFLAN system via a Phase 2 installed PLC I/O panel located in the 241-AN-271 instrument building unless otherwise noted.

3. All pits that are opened will have the coatings inspected and repaired as required.

\subsection{Primary Tank}

It is assumed that:

1. New liquid high-level probe systems have been installed by others, including signal wiring from associated electronic relays to the $241-\mathrm{AN}-271$ instrument building. 
2. The safety classification of the vapor space pressure measurement system is safety-class.

3. New safety-class qualified electronic pressure transmitters will be installed in the existing transmitter enclosures of each tank - one low range and one high range pressure transmitter per enclosure.

\subsection{Leak Detection}

It is assumed that:

1. The safety classification of the leak detection system for the process pits is safety-class and the other leak detection systems are general services.

2. The requirements for the process pit leak detection systems will be similar to those identified for Phase 1 and therefore, the same operationally testable system developed in Phase 1 will be used in Phase 2.

3. Existing structures to mount the panels are inadequate. New structures to mount the panels for the leak detection cabinets are needed.

4. The leak detection control panel requires a 10 -amp feed for panel power. New power panels will be installed. The required power for the panels are available.

5. All pit work will be remote.

6. Drain plugs will only be installed in pits entered in Phase 2. Per drawing H-14-020801, Sheets 1 - 4, Waste Transfer System O\&M System P\&ID, only pits that show floor drains are considered.

\subsection{Primary Ventilation}

It is assumed that:

1. The safety classification of the ventilation system is safety-class.

2. A safety-class qualified PLC will monitor and control all primary ventilation system instruments and subsystems. The PLC will operate as a separate node on TFLAN.

3. A stack monitoring system will be provided similar to the unit described in the "GEMS Procurement Specification," HNF-S-0400, Rev. 1.

4. Local displays, control devices, and hard-wired interlocks will be provided on the primary ventilation skid to facilitate manual operation and shutdown of the ventilation system.

\subsection{Monitoring and Control}

It is assumed that:

1. Sufficient floor space is available in instrument building 241-AN-271 for Phase 2 TFLAN PLC I/O cabinets and equipment, and no demolition or relocation of existing equipment is necessary.

2. TFLAN PLCS will be fully configured and programmed for all instruments installed during Project W-314 Phase 1. Phase 2 PLC programming, except for the ventilation PLC, will only involve the additions of new Phase 2 instrument $\mathrm{J} / \mathrm{O}$ to an existing program structure. 
3. Programming of the TFLAN PLC and HMI screen modification/development will be performed during the design phase. Implementation and acceptance testing will be performed during the construction phase.

4. For Panalarm work scope, the Acromag enclosure will be mounted inside the appropriate building within 50 feet of the Panalarm; and sufficient space exists for the Acromag enclosure.

\subsection{Demolition}

It is assumed that:

1. The existing leak detectors in the process pits leak detectors in the pipe encasements will be classified as RMW for waste management purposes.

2. The primary exhaust stack instrument enclosure and sample piping will be removed together and disposed as RMW.

3. All underground electrical and pneurnatic systems replaced by W-314 Phase 2 will be placed in a safe configuration and abandoned in place unless otherwise noted. Above ground electrical and signal wire, cable, and pneumatic tubing to be removed will be cut at the entrance point or just below grade. Wire, cable, conduit, and pneumatic tubing ends will be covered or otherwise sealed. Below grade portions of the wire, cable, and pneumatic tubing will be abandoned in place.

4. Cable, conduit, alams, indicators, switches, and other components no longer needed for the miscellaneous alarms and signals are to be removed. The demolition for alarms and signals will not produce hazardous or radiological waste. $P$ arts that can be re-used will be retained and reconnected to the TFLAN PLC or TMACS as part of Project W-314 Phase 2. Identification of these alams will be based on the Hanford Alarms Assessment Survey, currently in progress.

\subsubsection{VENTILATION}

\subsubsection{Description}

There are two ventilation systems for the AN Tank Farm, the primary ventilation systern and the annulus ventilation system. Planned upgrades only include the primary ventilation system. The functions of the AN Tank Farm primary ventilation system are:

1. Maintain a negative pressure within the vapor space of each of the seven primary tanks.

2. Control the build-up of flammable gases within the vapor space of each of the seven primary tanks.

3. Rernove heat from the vapor space of each of the seven primary tanks.

4. The AN Tank Farm primary ventilation system can be divided into five major subsystems. These five subsystems are:

5. Air control stations

6. The seven primary tanks in the tank farm 
HNF-5109, REV. 0

\section{Exhaust manifold \\ 8. Exhaust station \\ 9. Condensate drain subsystem}

The air control stations (see drawing H-2-85646), primary tanks, and exhaust manifold are existing and will not be modified or upgraded. The AN Tank Farm ventilation system upgrades include a new exhaust station and a new condensate drain subsystem. The new primary exhaust station is shown conceptually on Figure 4.2. The new condensate drain subsystem is shown conceptually on Figure 4.3. The new exhaust station and condensate drain subsystem are described in detail below.

\subsection{Exhaust Station}

WBS: 5A4J02, 5A4J05 and 5A4J09

Refer to Figure 4-2 (the conceptual flow diagram for the new exhaust station). Primary tank vapors will be pulled from the vapor space of each of the seven tanks of the AN Tank Farm by one of the induced draft fans. Moisture will be removed from the vapor by the chevron mist eliminator. The vapor will be cooled by the chiller/condenser unit and pass through a second mist eliminator to remove as much liquid from the vapor stream as possible. A glycol heater will next heat the vapor to raise its temperature above the dew point, which will prevent condensation and thereby protect the downstream filters.

A dual train of filters and dual induced draft fans, all ducted to a single exhaust stack, are employed to remove radioactive and other particulate and exhaust the cleaned up vapors to the atmosphere. A gaseous effluent monitoring system (GEMS) shall be installed in each exhaust stack to monitor and record any radionuclides emitted to the atmosphere. The GEMS will be standardized with that equipment used on Project W-420, Stack Monitoring System Upgrades (see HNF-S-0400 Rev. 1, Procurement Specification for Gaseous Effluent Monitoring System). Connections shall be installed in each train to facilitate the addition of possible carbon absorbers/dry scrubbers if needed. Various instruments, isolation valves, and control dampers shall be used to monitor and control the functioning of the exhaust station.

The ALARA requirement dictates that construction time is minimized in and around the tank farm. To accomplish this, the exhaust station shall be designed to be modularized. Fabrication and acceptance testing (in a fabrication shop) of the exhaust station prior to shipment to the AN Tark Farm will help achieve ALARA requirements. Lifting lugs will be installed on the modularized pieces of the exhaust station to facilitate erection on a concrete foundation. A SPC will be applied to the top surface of the exhaust station concrete slab and under the exhaust station equipment. The exhaust station equipment will be designed so they can easily be removed as radiologically contaminated waste at the end of its mission. A convenient tie-in location will be chosen to connect the new exhaust station to the old exhaust manifold. The design will locate the new exhaust station as close as possible to the chosen tie-in location to minimize the duct length from the tie-in location to the new exhaust station. Condensate generated from the vapor stream will be drained from the exhaust station via the condensate drain subsystem. 
HNF-5109, REV. 0

\subsection{Condensate Drain Subsystem}

WBS: 5A4J07 and 5A4J08

Refer to Figure 4.3 (the conceptual drawing for the new condensate drain subsystem). The new AN Tank Farm primary ventilation exhaust station equipment will require drains for the removal of condensate. Figure 4.2 shows drain lines needed to remove condensate from the exhaust station equipment.

The seal pot acts as a trap to prevent vapors from the primary tank migrating into the environment. The drain lines terminate under water in the seal pot. A fill pipe with hose connection and an overflow pipe control the water level in the seal pot. The overflow pipe drains excess water/condensate to a primary tank. Instruments shall be provided to detect the level of water/condensate in the seal pot. Piping shall be included to add water to the seal pot. Condensate shall drain to and from the seal pot by gravity. All condensate drain and overfow piping shall be heat-traced and insulated as necessary to prevent freeze-ups. The overflow piping shall be routed above ground as much as possible to a nearby receiver tank.

The old AN Tank Fam condensate drain subsystem is assumed to be unacceptable or is contaminated such that it is not economically feasible to use. However, an investigation of the actual conditions may permit the use of some or all of this subsystem.

\subsubsection{Demolition}

\subsection{Ventilation System}

WBS: $5 \mathrm{~A} 4 \mathrm{~J} 26 \mathrm{E}$

The existing primary ventilation exhaust station will be removed after installation and startup of the new exhaust station and condensate drain subsystem. The concrete foundations will be left in place. The old ventilation system equipment will be removed and treated as mixed waste unless investigation determines otherwise. The old drain pit, if not reused, will be retired in place with the old drain lines cut and capped at their point of entry into the drain pit.

\subsubsection{Assumptions}

1. The primary ventilation system will be classified as safety-class.

2. The system shall consist of dual exhaust trains that are modular with a standardized design and the ability to add additional treatment as needed.

3. Each exhaust train will be designed to handle a maximum flow rate of $2,400 \mathrm{scfm}$. The design flow rate shall be $2000 \mathrm{scfm}$. The velocity of the exhaust gases leaving the stack shall be $2,500 \mathrm{ft} / \mathrm{min}$ at all times, in all weather.

4. The new ventilation exhaust station and condensate drain subsystem will be constructed while the existing ventilation system is operating. 
5. After installation of the new ventilation exhaust station and condensate drain subsystem, the old exhaust station will be removed. This will involve the removal of the old exhaust station equipment from their concrete foundations; the foundations will be retired in place.

6. It is assumed that all primary ventilation exhaust station equipment that contacts the vapor stream and all condensate drain subsystem equipment is RMW for disposal purposes.

7. The radiological stack monitoring and recording equipment shall be standardized with the existing gaseous effluent monitoring system (GEMS) equipment developed by Project W420.

8. The exhaust station will include one 30 -foot high exhaust stack.

9. The existing exhaust manifold (duct connecting all seven primary tanks to the new exhaust station tie-in point) will not be replaced, double-contained, or altered as part of this project.

10. The new exhaust duct (from the tie-in point to the new exhaust station) will not be doublecontained or equipped with leak detection equipment.

11. The seal pot will be located above grade, on the exhaust station concrete pad.

\subsubsection{ELECTRICAL}

\subsubsection{Description}

The electrical system upgrades include procuring and installing a new electrical breaker at the existing motor control center as the main power source to the primary ventilation system and a 120 Vac panel including transformer. Local connections for a diesel generator to supply back-up power and transformer connected to a 120 Vac panel with duplex receptacles. A second breaker shall be procured and staged as a spare main breaker. Upgrading and connecting a new ventilation system ground grid to the existing ground grid, cathodic protection and freeze protection systems.

\subsection{Main Power to Primary Ventilation Skid}

WBS: $5 \mathrm{~A} 4 \mathrm{~J} 26 \mathrm{~A}$

A $480 \mathrm{Vac}, 60 \mathrm{~Hz}$ power system shall be provided to the primary ventilation system from the existing motor control center AN271 Building. A new circuit breaker will be installed in the compartment $\mathrm{Cl}$ to feed the new skid starters and mini-power center.

\subsection{Power Receptacle for Portable Diesel Generator}

WBS: 5A3A00

A new power receptacle will be provided for connection of an existing portable diesel generator as a backup power source to the primary ventilation system to allow preventive maintenance on electrical equipment.

\subsection{Spare Circuit Breaker for Loadcenter (F8X402)}


WBS: $5 \mathrm{~A} 4 \mathrm{~J} 26 \mathrm{~B}$

A main circuit breaker for the switchgear will be procured as a backup spare breaker so that the existing breaker can be maintained, tested, and calibrated to ensure acceptable performance of the device.

\subsection{Ventilation Skid Ground Grid and Bonding}

WBS: 5A4J26C

The new primary ventilation system will be bonded to a new ground grid that will be connected from the existing tank farm ground grid.

\subsection{Freeze Protection for Primary Ventilation Drainage Systems}

WBS: $5 A 4526 \mathrm{D}$

Freeze protection for the primary ventilation drainage system will be provided. The 120 Vac power for the freeze protection will be supplied from the mini-power center.

\subsubsection{Demolition}

\subsection{Primary Ventilation}

WBS: 5A4J26E

All underground electrical systems that are replaced by Project W-314 will be placed in a safe configuration and abandoned in place unless otherwise noted. Above-ground electrical conduit and cable to be removed and will be cut at the entrance point or just below grade. Wire, cable and conduit ends will be covered or otherwise sealed. Associated conduit, wiring, panels, and junction boxes shall be remove. The feeders of the primary fan motors shall be removed.

\subsubsection{Assumptions}

\subsection{General}

1. All modifications and installations will be to the 1999 National Electric Code.

2. Sufficient cubicle space is available and the bus ratings of the motor control centers are adequate in instrument building AN271 for Phase 2, cabinets and equipment, and no demolition or relocation of existing equipment is necessary.

3. Existing structures to mount the panels are adequate.

4. The required power for any new panel loads is available.

5. Implementation and acceptance testing will be performed during the construction phase.

6. All site plans are diagrammatic and conduit routings will be field routed to avoid obstructions. Pull boxes will be installed as necessary. 
7. Refer to the following drawings and sketches for systems configuration, equipment location, and cabling details as the best available design:

a) 241-AN Tark Farm One-Line Diagram, Figure E-1 (Ref. WHC-SD-W314-CDR-001, Rev. 1).

b) 241-AN Tank Farm Site Plan, Figure P-1. (Ref. WHC-SD-W314-CDR-001, Rev. 1).. 
HNF -5109, Rev. 0
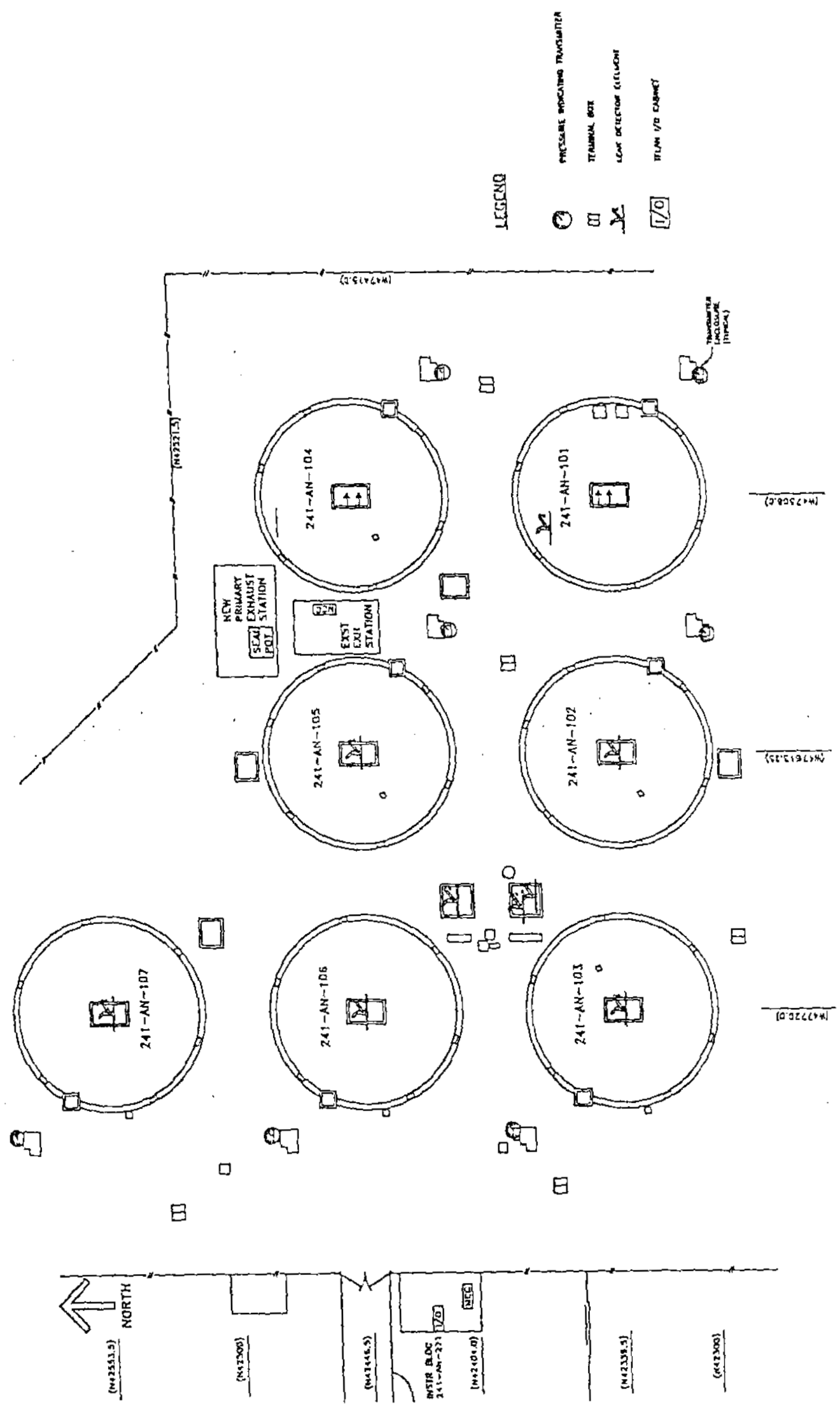

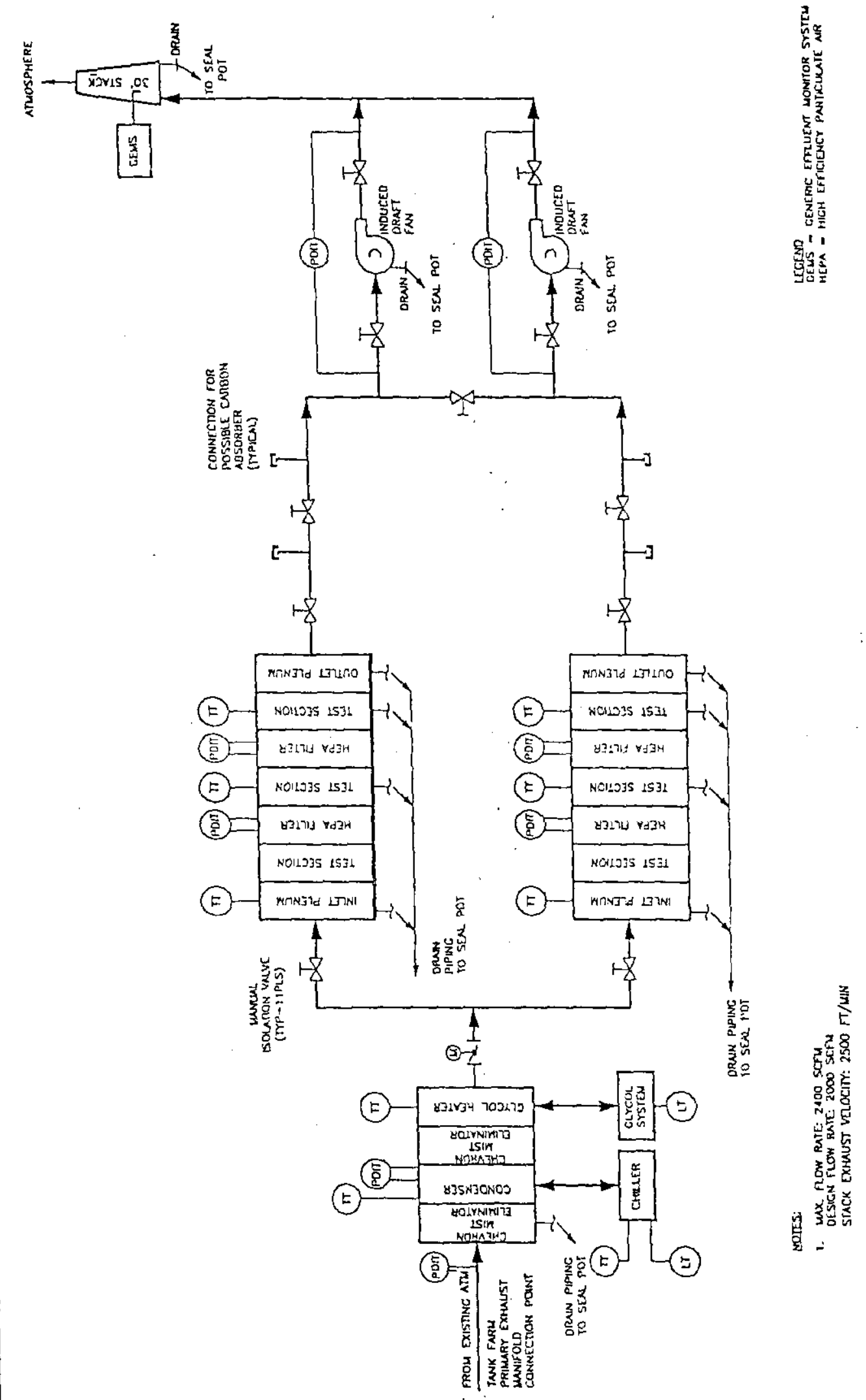
HNF-5109, Rev. 0

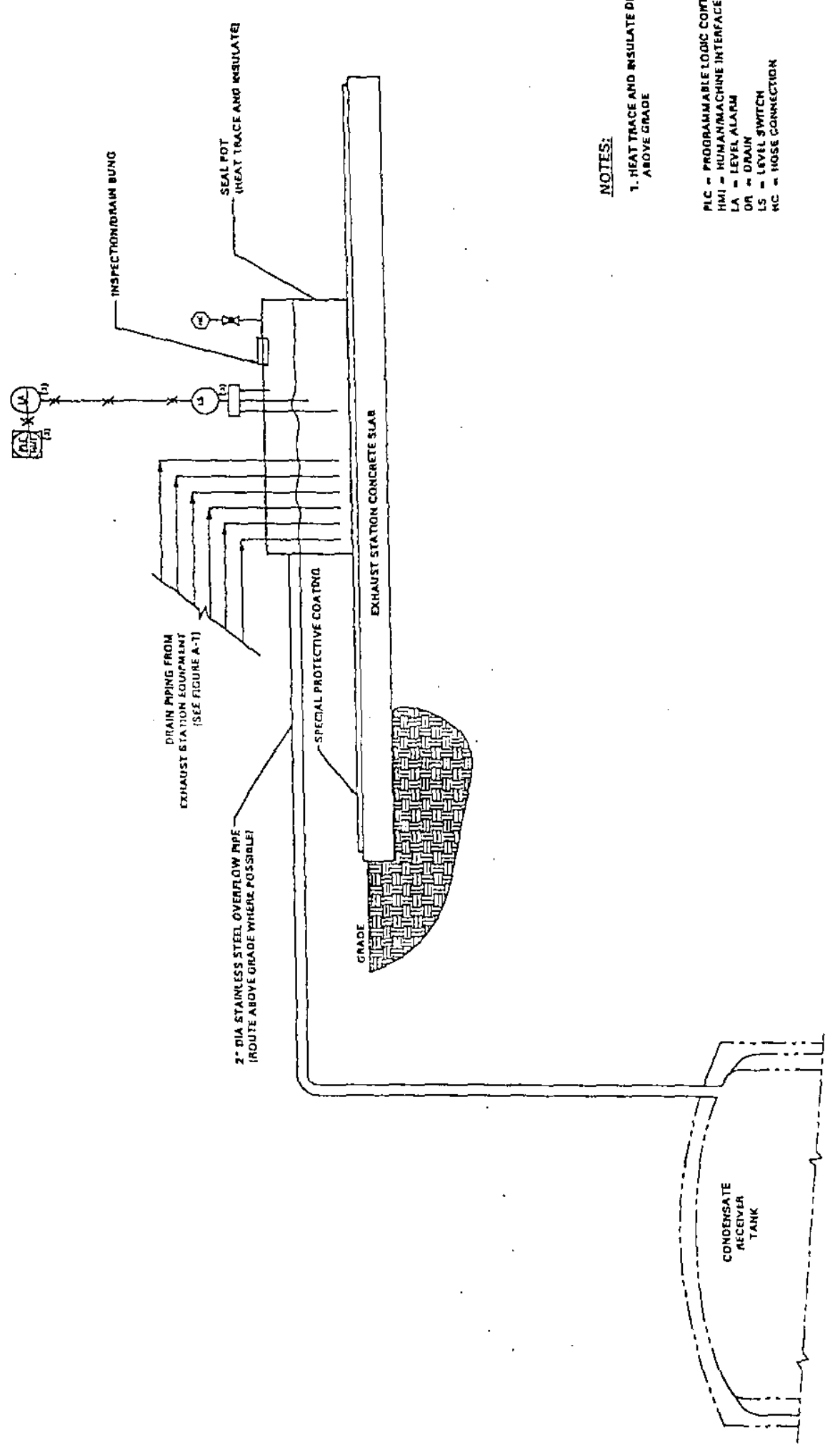

Oี 


\subsection{AP TANK FARM UPGRADES}

Refer to Figure 4.4 for an overview of AP Tank Farm Upgrades.

\subsubsection{INSTRUMENTATION AND CONTROL}

\subsubsection{Description}

I \& $C$ upgrades to AP Tank Farm include primary tank systems, leak detection systems, and the new primary exhaust ventilation system. Selected existing alarms and signals, and signals from Phase 2 upgraded systems will be connected to the TFLAN system, except for Panalarm signals, which will be connected to TMACS.

NOTE: For all statements "similar to the AN Tank Farm description," in this section, any references in the AN Tank Farm description to the "241-AN-271 instrument building" are replaced with "241-AP-271 instrument building."

\subsection{Primary Tank}

\subsection{Liquid High-Level Measurement}

WBS: 5B4J22F

Similar to the AN Tank Farm description except for all eight 241-AP tanks.

\subsection{Vapor Space Pressure Measurement}

WBS: 5BAJ22E

New electronic pressure transmitters have been instailed by others for all eight 241-AP tanks including signal wiring to the instrument panel in the 241-AP-271 building. Analog signals from the existing electronic pressure transmitters will be relocated from the associated chart recorders in the instrument panel to a TFLAN PLC VO panel in the instrument building. Low and high range vapor space pressure status of all primary tanks will be monitored by the TFLAN PLC and displayed on the TFLAN HMI.

\subsection{Waste Transfer}

\subsection{Valve Position Indication}

Similar to AN Tank Farm description.

\subsection{Leak Detection}

\subsection{Process Pits}

WBS: 5B4A02, 5B4B09, 5B4C02, 5B4C10, 5B4E02, 5B4F02, 5B4G02, and 5B4H02 
Similar to the AN Tank Farm description except for the new leak detection system will be installed in the following process pits:

- Central Pump Pits 01A-08A (Except 02A and 04A)

- Pump Pit 02D

- Drain Pit 03D

In addition, drain plug assemblies will be installed in all pits not entered by Phase 1 . The following pits will require new drain plug assemblies:

- Central Pump Pits 01A - 08A

- Pump Pit 02D

- Drain Pit 03D

\subsection{Pipeline Encasement}

WBS: 5B4J35

Similar to the AN Tank Farm description except for the following waste transfer pipe encasements. The pipe encasements will have a new leak detection system installed:

- SN-621 (Near pump pit 02D)

- SN-650 (Near riser 023, 241-AP-102)

- SN-609 (Near Valve pit)

- SN-610 (Near Valve pit)

- SL-509 (Near Valve pit)

- SL-510 (Near Valve pit)

\subsection{Power Panels}

WBS: 5B4J28

Similar to the AN Tank Farm description.

\subsection{Primary Exhaust Ventilation}

WBS: 5B3B00, 5B4J02, 5B4J22A, 5B4J28, and 5B2131

Similar to the AN Tank Farm description.

\subsection{Monitoring and Control}

\subsection{Alarms and Signals}

Similar to the AN Tank Farm description. Refer to "Miscellaneous Alarms and Signais" under "Other Upgtades" for additional AP Tank Farm work scope and associated WBS numbers. 


\subsection{TFLAN PLC Equipment}

WBS: 5B4J22B

Similar to the AN Tank Farm description.

\subsubsection{Demolition}

\subsection{Primary Tank}

\subsection{Liquid High-Level Measurement}

WBS: $5 B 4 J 22 \mathrm{G}$

Similar to the AN Tank Farm description.

\subsection{Vapor Space Pressure Measurement}

WBS: $5 B 4 \mathrm{~J} 22 \mathrm{G}$

Remove associated pneumatic chat recorders, annunciators, and switches located in the 241-AP271 building.

\subsection{Leak Detection}

\subsection{Process Pit Leak Detectors}

WBS: 5B4A024, 5B4B094, 5B4C024, 5B4C104, 5B4E024, 5B4F024, 5B4G024, and 5B4H024

Similar to the AN Tank Farm description.

\subsection{Pipeline Leak Detectors}

WBS: 5B4J35C

Similar to the AN Tank Farm description.

\subsection{Primary Ventilation}

WBS: 5B4J26E

Similar to the AN Tank Farm description.

\subsection{Monitoring and Control}

Similar to the AN Tank Farm description. Refer to "Miscellaneous Alarms and Signals" section for additional AP Tank Farm work scope and associated WBS numbers. 
HNF-5109, Rev. 0

\subsubsection{Assumptions}

\subsection{General}

Similar to the AN Tank Farm description.

\subsection{Primary Tank}

Similar to the AN Tark Fam description, except for the following:

It is assumed that:

1. The existing electronic vapor space pressure transmitters and signal wiring to the 241-AP271 instrument building will not be replaced by W-314 Phase 2 .

\subsection{Leak Detection}

Similar to the AN Tank Farm description, except for the following:

It is assumed that:

1. Drain plugs will only be installed in pits entered in Phase 2. Per drawing H-14-020803, Sheets 1- 5, Waste Transfer System (WT) O\&M System P\&ID, only pits that show floor drains are considered.

\subsection{Primary Ventilation}

Similar to the AN Tank Farm description.

\subsection{Monitoring and Control}

Similar to the AN Tank Farm description.

\subsection{Demolition}

Similar to the AN Tank Farm description.

\subsubsection{VENTLATION}

\subsubsection{Description}

There are two ventilation systems for the AP Tank Farm, the primary ventilation system and the annulus ventilation system. Planned upgrades only include the primary ventilation system. The functions of the AP Tank Farm primary ventilation system are:

1. Maintain a negative pressure within the vapor space of each of the eight primary tanks.

2. Control the build-up of flammable gases within the vapor space of each of the eight primary tanks.

3. Remove heat from the vapor space of each of the eight primary $\operatorname{tanks.}$ 
The AP Tank Farm primary ventilation system can be divided into five major subsystems. These five subsystems are:

1. Air control stations

2. The eight primary tanks in the tank farm

3. Exhaust marifold

4. Exhaust station

5. Condensate drain subsystem

The AP Tank Farm ventilation scope differs from AN Tank Farm in one way: the installation of new air control stations. The AP Tank Farn ventilation system upgrades include new air control stations, a new exhaust station, and a new condensate drain subsystem. The exhaust station and condensate drain subsystem are similar to the AN Tank Farm subsystems.

\subsection{Air Control Stations}

WBS: 5B4J09 .

The air control stations are shown on drawings $\mathrm{H}-2-85646$ and $\mathrm{H}-2-85647$. These stations will consist of an airflow controller, pre-filter, HEPA filter, and vacuum relief valve. Each tank will require one new air control station. The primary purposes of an air control station are to regulate airflow into the primary tank and to filter radioactive particulate in case of backflow from the primary tank if negative pressure is lost:

\subsection{Exhaust Station}

WBS: $5 B 4 J 02,5 B 4 J 05$ and 5B4J34

Similar to the AN Tank Farm exhaust station.

\subsection{Condensate Drain Subsystem}

WBS: 5B4J07 and 5B4J08

Sirmilar to the AN Tank Farm condensate drain subsystem.

\subsubsection{Demolition}

\subsection{Ventilation System}

\section{WBS: 5B4J26E}

The existing primary ventilation exhaust station will be removed after installation and startup of the new exbaust station and condensate drain subsystem. The concrete foundations will be left in place. The old ventilation system equipment will be removed and treated as mixed waste unless investigation determines otherwise. The old drain pit, if not reused, will be retired in place with the old drain lines cut and capped at their point of entry into the drain pit. 


\subsubsection{Assumptions}

The assumptions for the AP Tank Farm are similar to those for the AN Tank Farm.

\subsubsection{ELECTRICAL}

\subsubsection{Description}

The electrical system upgrades include a new electrical breaker as the power source to the primary ventilation system panel including transformer. Connections for a diesel generator to supply back-up power with panel with duplex receptacles including transformer. Purchasing of a spare main breaker. Upgrading and connecting to the existing ground grid, cathodic protection, and freeze protection systems.

NOTE : For all references stating "Similar to the AN Tank Farm description." in this section, the AN text referring to the AN271 Building is changed to the AP271 Building.

\subsection{Main Power Feed to Primary Ventilation Skid}

WBS: 5B4J26A

Similar to the AN Tank Fam description.

\subsection{Power Receptacle for Portable Diesel Generator}

WBS: $5 B 4326 B$

Similar to the AN Tank Farm description

\subsection{Vac Ground Fault Receptacle for Diesel Generator Battery Charger}

WBS: $5 B 4 J 26 B$

Ground fault duplex receptacles in a weatherproof enclosure for the diesel generator battery charger will be provided. The receptacle will be fence-mounted outside at the southeast comer of the AP Tank Farm where the existing support equipment is stored.

\subsection{Ventilation Skid Ground Grid and Bonding}

WBS: $584526 \mathrm{C}$

Similar to the AN Tank Farm description

\subsection{Freeze Protection for Primary Ventilation Drainage Systems}

WBS: 5B4J26D

Similar to the AN Tank Farm description 


\subsubsection{Demolition}

\subsection{Primary Ventilation}

WBS: 5B4J26E

Similar to the AN Tank Farm description

\subsubsection{Assumptions}

Note 1: All assumptions in this section are "similar to AN Farm."

Note 2: All drawings referenced by the above Note 1 in this section reflect the A.P Farm drawings in the WHC-SD-W314-CDR-001, Rev. 1. 
HNF-5109, Rev. 0

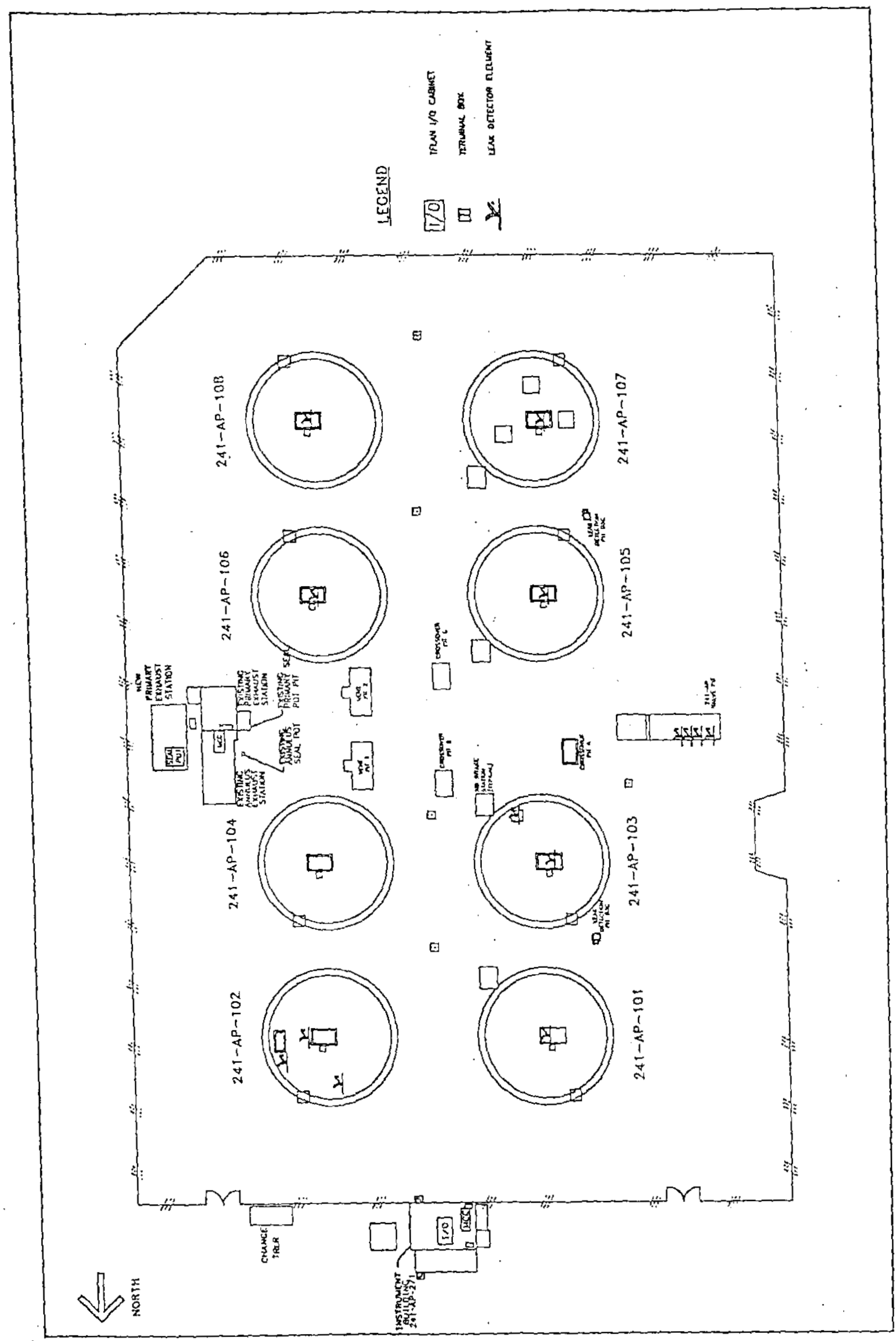

范 


\subsection{AW TANK FARM UPGRADES}

Refer to Figure 4.5 for an overview of AW Tank Farm Upgrades.

\subsubsection{INSTRUMENTATION AND CONTROL}

\subsubsection{Description}

I \& C upgrades to AW Tank Farm include primary tank systems, leak detection systems, and the new primary exhaust ventilation system. Selected existing alarms and signals, and signals from Phase 2 upgraded systems will be connected to the TFLAN system, except for Panalarm signals, which will be connected to TMACS.

NOTE: For all statements "similar to the AN Tank Farm description" in this section, any references in the AN Tank Farm description to the "241-AN-271 instrument building" are replaced with "241-AW-271 instrument building."

\subsection{Primary Tank}

\subsection{Liquid High-Level Measurement}

WBS: 5C4J22D

Similar to the AN Tank Farm description except for all six 241-AW tarks.

\subsection{Vapor Space Pressure Measurement}

WBS: 5C4A08A, 5C4B08A, 5C4C08A, 5C4D08A, 5C4E08A, and 5C4F08A

Similar to the AN Tank Farm description except for all six 241-AW tanks.

\subsection{Waste Transfer}

\subsection{Valve Position Indication}

Similar to AN Tank Farm description.

\subsection{Leak Detection}

\subsection{Process Pits}

WBS: 5C4A02, 5C4B02, 5C4B10, 5C4B11, 5C4C02, 5C4D02, 5C4E02, and 5C4F02

Similar to the AN Tank Farm description except for the new leak detection system which will be installed in the following process pits:

- Central Pump Pits 01A-06A

- Drair Pit 02D 
- Feed Pump Pit 02E

In addition, drain plug assemblies will be installed in all pits not entered by Phase 1. The following pits will require new drain plug assemblies:

- Central Pump Pits 01A-06A

- Drain Pit 02D

- Feed Pump Pit 02E

\subsection{Pipeline Encasement}

WBS: $5 \mathrm{C} 4 \mathrm{~J} 35$

Similar to the AN Tank Farm description, except the new leak detection system will be installed in the following waste transfer pipe encasements:

- DR-334 (Drair Pit 02D)

- DR-335 (Drain Pit 02D)

- DR-361 (Drair Pit 02D)

- SN-267 (Central Pump Pit 02A)

- SN-268 (Central Pump Pit 02A)

- SN-269 (Feed Pump Pit 02E)

- SN-270 (Feed Pump Pit 02E)

- SN-274 (Central Pump Pit 04A)

- SN-220 (Valve Pit AW - A)

- SL-168 (Valve Pit AW - A)

- V021 (Valve Pit AW - A)

- SL-167 (Valve Pit AW - B)

- SN-219 (Valve Pit AW - B)

- V023 (Valve Pit AW - B)

- V022 (Valve Pit AW - B)

\subsection{Power Panels}

WBS: 5C4J28

Similar to the AN Tank Farm description.

\section{4,3.1.1.4 Primary Ventilation Upgrades}

WBS: 5C3B00, 5C4J02, 5C4J22A, 5C4J28, and 5C2131

Similar to the AN Tank Farm description.

\subsection{Monitoring and Control}




\subsection{Alarms and Signals}

Similar to the AN Tank Farm description. Refer to "Miscellaneous Alarms and Signals" section for additional AW Tank Farm work scope and associated WBS numbers.

\subsection{TFLAN PLC Equipment}

WBS: 5 C4J22B

Similar to the AN Tark Farm description.

\subsubsection{Demolition}

\subsection{Primary Tank}

\subsection{Liquid High-Level Measurement}

WBS: $5 \mathrm{C} 4 \mathrm{~J} 22 \mathrm{E}$

Similar to the AN Tank Farm description except for all six 241-AW tanks.

\subsection{Vapor Space Pressure Measurement}

WBS: 5C4A08B, 5C4B08B, 5C4C08B, 5C4D08B, 5C4E08B and 5C4F08B

Similar to the AN Tank Fann description except for all six 241-AW tanks.

\subsection{Leak Detection}

\subsection{Process Pit Leak Detectors}

WBS: 5C4A024, 5C4B024, 5C4B104, 5C4B114, 5C4C024, 5C4D024, 5C4E024, and 5C4F024

Similar to the AN Tank Farm description.

\subsection{Pipeline Leak Detectors}

WBS: 5 C4J35C

Similar to the AN Tank Farm description.

\subsection{Primary Ventilation}

WBS: 5C4J26F

Similar to the AN Tank Farm description.

\subsection{Monitoring and Control}


Similar to the AN Tank Farm description. Refer to "Miscellaneous Alarms and Signals" under "Other Upgrades" for additional AW Tank Farm work scope and associated WBS numbers.

\subsubsection{Assumptions}

\subsection{General}

It is assumed that:

Similar to the AN Tank Farm description.

\subsection{Primary Tank}

It is assumed that:

Similar to the AN Tank Farm description.

\subsection{Leak Detection}

Similar to the AN Tark Farm description, except for the following:

\subsection{Primary Ventilation}

Similar to the AN Tank Farm description.

\subsection{Monitoring and Control}

Similar to the AN Tank Farm description.

\subsection{Demolition}

Similar to the AN Tank Farm description.

\subsubsection{VENTILATION}

\subsubsection{Description}

There are two ventilation systems for the AW Tank Farm,: the primary ventilation system and the annulus ventilation system. Planned upgrades only include the primary ventilation system. The functions of the AW Tank Farm primary ventilation system are:

1. Maintain a negative pressure within the vapor space of each of the six primary tanks.

2. Control the buildup of flammable gases within the vapor space of each of the six primary tanks.

3. Remove heat from the vapor space of each of the six primary tanks.

The AW Tank Farm primary ventilation system can be divided into five major subsystems. These five subsystems are: 
1. Air control stations

2. The six primary tanks in the tank farm

3. Exhaust manifold

4. Exhaust station

5. Condensate drain subsystem

The air control stations (see drawing H-2-85646), the primary tanks, and the exhaust manifold are existing and will not be modified or upgraded. The AW Tank Farm ventilation system upgrades include a new exhaust station and a new condensate drain subsystem. The new primary exhaust station and the new condensate drain subsystem are similar to the AN Tank Farm description.

\subsection{Exhaust Station}

WBS: 5C4J02, 5C4J05 and 5C4J34

Similar to the AN Tank Farm exhaust station.

\subsection{Condensate Drain Subsystem}

WBS: 5C4J07 and 5C4J08

Similar to the AN Tank Farm condensate drain subsystem.

\subsubsection{DEMOLITION}

\subsection{Ventilation System}

WBS: 5C4J26F

The existing primary ventilation exhaust station will be removed after installation and startup of the new exhaust station and condensate drain subsystem. The concrete foundations will be left in place. The old ventilation system equipment will be removed and treated as mixed waste unless investigation determines otherwise. The old drain pit, if not reused, will be retired in place with the old drain lines cut and capped at their point of entry into the drain pit.

\subsubsection{Assumptions}

The assumptions for the AW Tank Farm are similar to those for the AN Tank Farm.

\subsubsection{ELECTRICAC}

\subsubsection{Description}

The electrical system upgrades include a new electrical breaker as the power source to the primary ventilation system and a panel including transformer. In addition, the following upgrades will be provided: 
- Connections for a diesel generator to supply back-up power with a panel with at least (4) ground fault duplex receptacles including transformer

- Purchasing of a spare main breaker

- Upgrading and connecting to the existing ground grid, cathodic protection and freeze protection systems

- Installing (3) new circuit breakers into the existing "A" panel board in the 241-AW-271 building.

NOTE 1: For all references stating "sinilar to the AN Tank Farm description" in this section, the AN text referring to the AN271 Building is changed to the AW271 Building.

NOTE 2: For all references stating "similar to the AN Tank Farm description except for ... " in this section will state alterations or differences from the AN text.

\subsection{Main Power Feed to Primary Ventilation Skid}

WBS: 5C4J26A

Similar to the AN Tank Farm description

\subsection{Power Receptacle for Portable Diesel Generator}

WBS: 5C4J26B

Similar to the AN Tank Farm description with the following addition;

Also provide, install, and wire an existing generator set; a new enclosed $100 \mathrm{AF} / 100 \mathrm{AT}, 3$ pole, 600 Vac circuit breaker; and a $3 \mathrm{kVA}$ mini-power center with 120 Vac ground fault receptacles. All wire will be routed via a NEMA 4 wire gutter. Also install the reel mounted $100 \mathrm{~A}, 4$ pole, and $4 \mathrm{~W}$ power cord with plug to match the power receptacle for connecting to ventilation skid.

\subsection{Spare Circuit Breaker for AW241-EDS-ENCL-100, $1000 \mathrm{kVA}$ Loadcenter (C8S35)}

WBS: 5C4J26C

Similar to the AN Tank Farm description

\subsection{Ventilation Skid Ground Grid and Bonding}

WBS: 5C4J26D

Similar to the AN Tank Farm description.

\subsection{Freeze Protection for Primary Ventilation Drainage Systems}

WBS: 5C4J26E

Similar to the AN Tank Farm description. 


\subsection{Circuit Breakers for Panelboard "AW271-EDS-DP-102A"}

WBS: $5 \mathrm{C} 4 \mathrm{~J} 26 \mathrm{~A}$

Procure and install three (3) new single pole, 100AF/20AT, 600 Vac circuit breakers in panelboard AW271-EDS-DP-102A located in the AW Farm AW271 building. These breakers for support of instrumentation power requirements.

\subsubsection{Demolition}

\subsection{Primary Ventilation}

WBS: $5 \mathrm{C} 4 \mathrm{~J} 26 \mathrm{~F}$

Similar to the AN Tank Farm description.

\subsubsection{Assumptions}

Note 1: All assumptions in this section are "similar to AN Farm."

Note 2: All drawings referenced by the above Note 1 in this section reflect the AW Farm drawings in the WHC-SD-W314-CDR-001, Rev. 1. 
HNFF-5109, Rev. 0
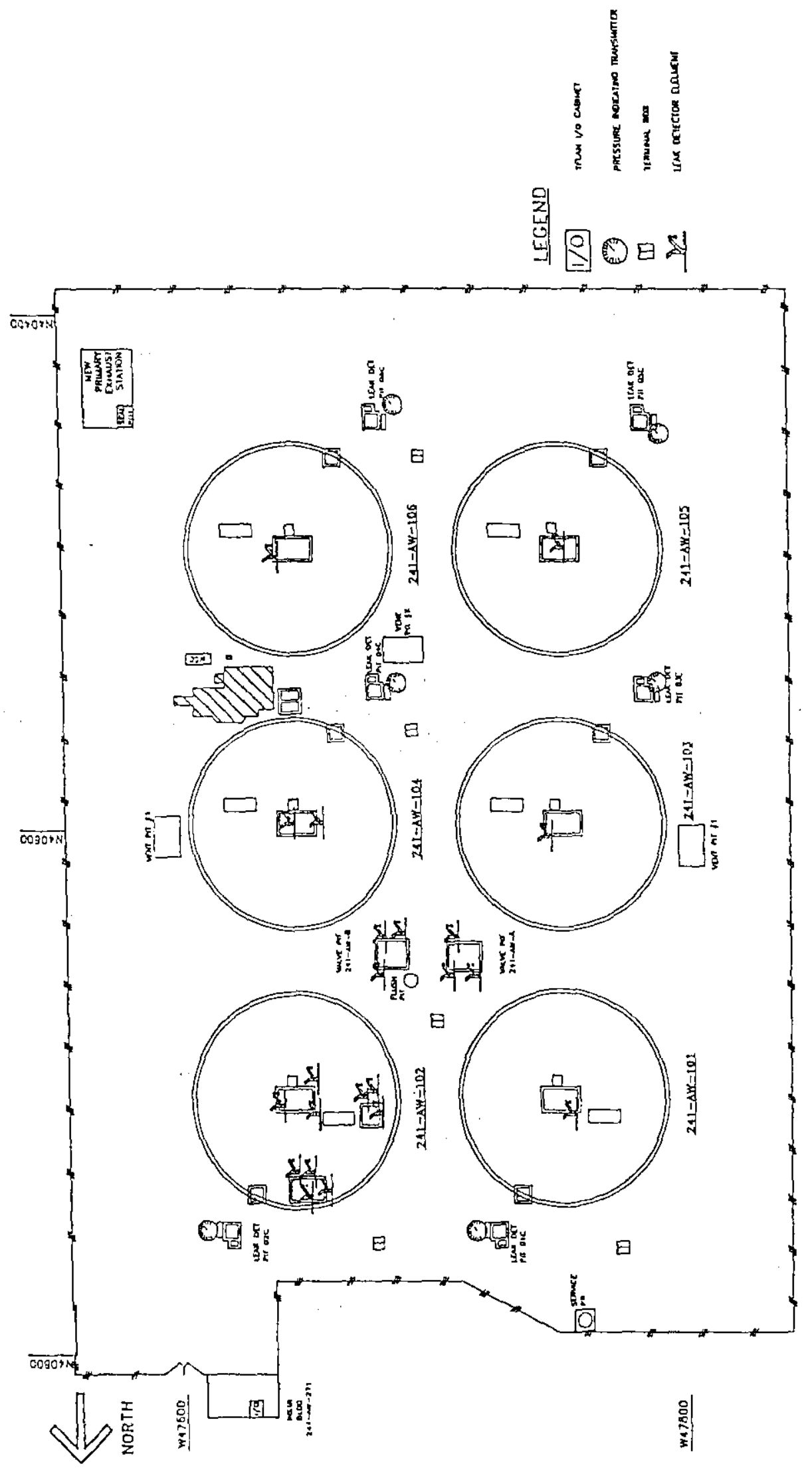

岁 


\subsection{AY TANK FARM UPGRADES}

Refer to Figure 4.6 for an overview of AY Tank Farm Upgrades.

\subsubsection{INSTRUMENTATION AND CONTROL}

\subsubsection{Description}

Instrumentation and control upgrades to AY Tank Farm include primary tank systems, and leak detection systems. Selected existing alarms and signals, and signals from Phase 2 upgraded systems will be connected to the TFLAN system, except for Panalarms and Micon signals, which will be connected to TMACS.

NOTE: For all statements "similar to the AN Tank Farm description" in this section, any references in the AN Tank Farm description to the "241-AN-271 instrument building" are replaced with "241-AY-801A instrument building" for existing tank farm instrumentation and "241-AZ-702 control building" for TFLAN connections.

\subsection{Primary Tank}

\subsection{Liquid High-Level Measurement}

WBS: 5D4J22E

Similar to the AN Tank Farm description except for both $241-$ AY tanks.

The high-level alarm signals from the two probes will be routed from the 241-AY-801A instrument building to a TFLAN PLC I/O panel located in the 241 -AZ-702 building.

\subsection{Vapor Space Pressure Measurement}

WBS: 5D4A.08A and 5D4B08A

Similar to the AN Tank Farm description except for both 241-AY tanks.

The pressure measurement signals from the electronic transmitters will be routed to a terminal box in the 241-AY-801 instrument building and from there to a TFLAN PLC 1/O panel located in the 241-AZ-702 building. No connections will be made to the existing primary exhaust ventilation system.

\subsection{Leak Detection}

\subsection{Pipeline Encasement}

WBS: $5 \mathrm{D} 4 \mathrm{~J} 29$

Similar to the AN Tank Farm description except for the new leak detection system will be installed in the following waste transfer pipe encasements: 
SL-505 (Pump Pit 01A)

SL-504 (Pump Pit 02A)

SL-503 (Pump Pit 02A)

4.4.1.1.2.2 Power Panels

WBS: 5D4J28

Similar to the AN Tank Farm description.

\subsection{Monitoring and Control}

4.4.1.1.3.1 Alarms and Signals

Similar to the AN Tank Farm description. Refer to "Miscellaneous Alarms and Signals" under "Other Upgrades" for additional AY Tank Farm work scope and associated WBS numbers.

\subsection{TFLAN PLC Equipment}

WBS: 5D4J22B

Similar to the AN Tank Farm description.

\subsubsection{Demolition}

4.4.1.2.1 Primary Tank

4.41.2.1.1 Liquid High-Level Measurement

WBS: 5D4J22F

Similar to the AN Tank Farm description.

4.4.1.2.1.2 Yapor Space Pressure Measurement

WBS: 5D4A08B and 5D4B08B

Similar to the AN Tank Farm description.

\subsection{Leak Detection}

4.4.1.2.2.1 Pipeline Leak Detectors

WBS: 5D4J29C

Similar to the AN Tank Farm description.

\subsection{Monitoring and Control}


Similar to the AN Tank Farm description. Refer to "Miscellaneous Alarms and Signals" section for additional AY Tank Farm work scope and associated WBS numbers.

\subsubsection{Assumptions}

\subsection{General}

Similar to the AN Tark Farm description.

\subsection{Primary Tank}

Similar to the AN Tank Farm description.

\subsection{Leak Detection}

Similar to the AN Tank Farm description.

\subsection{Monitoring and Control}

Similar to the AN Tank Farm description.

\subsection{Demolition}

Similar to the AN Tank Farm description except that no demolition of the existing primary exhaust stack instrument enclosure will be performed.

\subsubsection{ELECTRICAL}

\subsubsection{Description}

The electrical system up grades include a new motor control center (MCC) eiectrical breaker as the power source to the primary ventilation system and a $120 \mathrm{Vac}$ panel including transformer.

NOTE : For all teferences stating "Similar to the AN Tank Farm description." in this section, the AN text referring to the AN271 Building is changed to the AY271 Building.

\subsection{Motor Control Center for Primary Ventilation}

WBS: 5D4J26A

The existing MCC-AY1 will be replaced with a new one to accommodate the existing load as shown on 241-AY Tank Farm One-Line Diagram (Ref. WHC-SD-W314-CDR-001, Rev. 1, Figure E-4). The trip setting of the feeder breaker in the existing switchgear will be changed to provide overcurrent protection to the existing feeder to MCC-AY1. The switchgear is located at substation 241-A. A new mini-power center will be provided to supply power to the new instrumentation equipment and control panel. This mini-power center will be fed from the new MCC. The new motor control center will be bonded to the existing ground grid. 
HNF-5109, ReV, 0

\subsubsection{Demolition}

\subsection{Primary Ventilation}

WBS: 5D4J26C

Disconnect and remove the feeders of the primary fan motors. Disconnect and remove associated conduit, wiring, panels, and junction boxes.

\subsubsection{Assumptions}

\subsection{General}

Note 1: All assumptions in this section are "similar to AN Farm."

Note 2: All drawings referenced by the above Note 1 in this section reflect the AY Farm drawings in the WHC-SD-W314-CDR-001, Rev. 1. 
HNF-5 109, Rev. 0

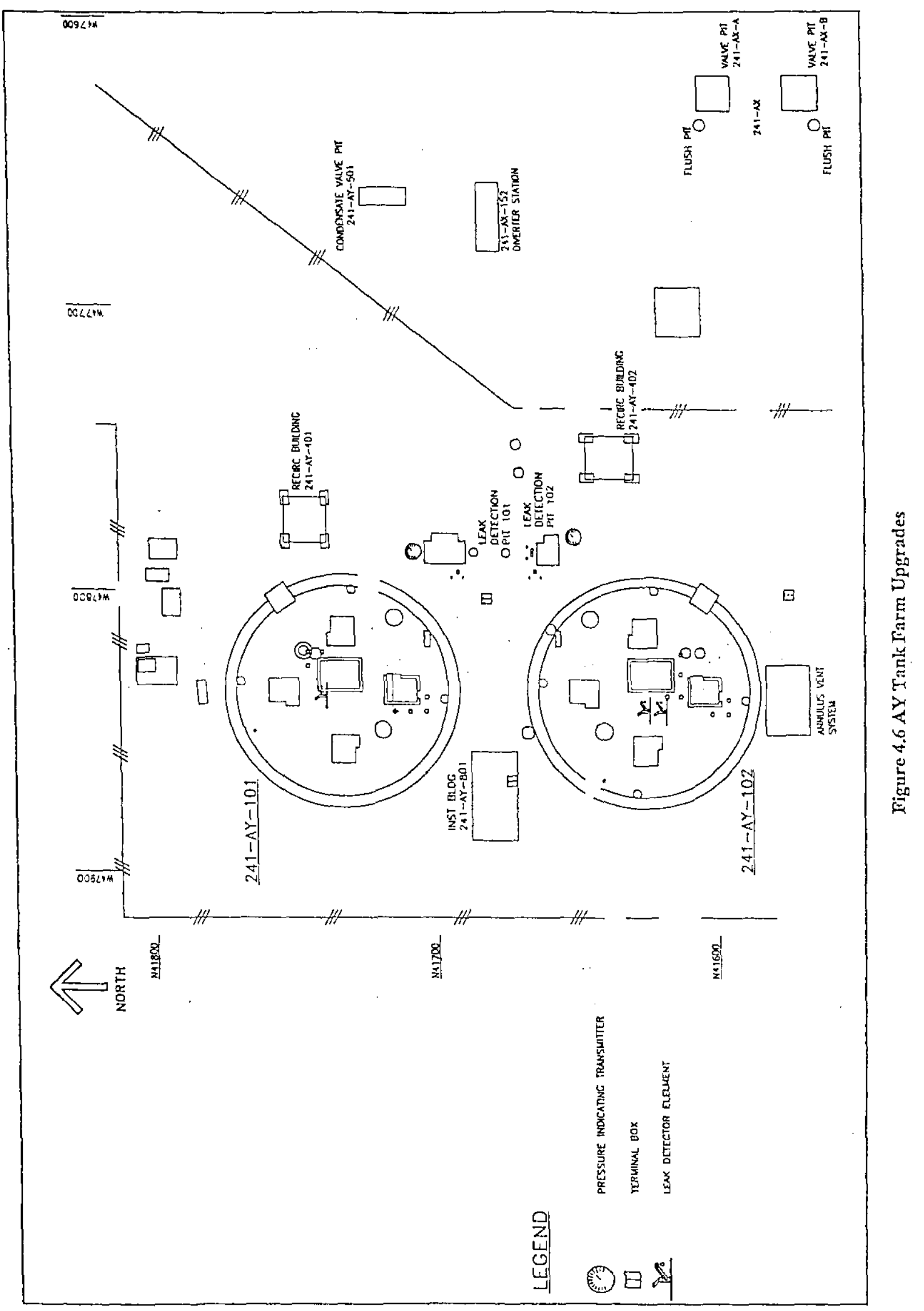


HNF-5109, Rev. 0

\subsection{AZ TANK FARM UPGRADES}

Refer to Figure 4.7 for an overview of AZ Tank Farm Upgrades.

\subsubsection{INSTRUMENTATION AND CONTROL}

\subsubsection{Description}

Instrumentation and control upgrades to AZ Tank Farm include primary tank systems and leak detection systems. Selected existing alarms and signals, and signals from Phase 2 upgraded systems will be connected to the TFLAN system, except for Panalarm Micon signals, which will be connected to TMACS.

NOTE: For all statements "similar to the AN Tank Farm description" in this section, any references in the AN Tank Farm description to the "241-AN-271 instrument building" are replaced with "241-AZ-801A instrument building" for existing tank farm instrumentation and "241-AZ-702 control building" for TFLAN connections.

\subsection{Primary Tank}

\subsection{Liquid High-Level Measurement}

WBS: 5E4J22E

Similar to the AN Tank Farm description except for both 241-AZ tanks.

The high-level alam signals from the two probes will be routed from the $241-\mathrm{AZ}-801 \mathrm{~A}$ instrument building to a TFLAN PLC VOO panel located in the 241-AZ-702 building.

\subsection{Vapor Space Pressure Measurement}

WBS: 5E4A08A and 5E4B08A

Similar to the AN Tank Farm description except for both 241-AZ tanks.

The pressure measurement signals from the electronic transmitters will be routed to a terminal box in the 241-AZ-801 A instrument building and from there to a TFLAN PLC I/O panel located in the $241-A Z-702$ building. No connections will be made to the existing primary exhaust ventilation system.

\subsection{Leak Detection}

\subsection{Pipeline Encasement}

WBS: 5E4J29

Similar to the AN Tank Farm description except for the leak detection signals which will be wired to a TFLAN PLC I/O panel located in building 241-AZ-702. Wires will be routed via a 
field terninal box to a terminal box in the 241-AZ-801A instrument building then to the PLC in building $241-\mathrm{AZ}-702$.

The following waste transfer pipe encasements will have a new leak detection system installed:

- PW-4507

- PW-4508

\subsection{Power Panels}

WBS: 5E4J28

Similar to the AN Tark Farm description.

\subsection{Monitoring and Control}

\subsection{Alarms and Signals}

Similar to the AN Tank Farm description. Refer to "Miscellaneous Alarms and Signals" section for additional AZ Tank Farm work scope and associated WBS numbers.

\subsection{TFLAN PLC Equipment}

WBS: $5 E 4 J 22 B$

Similar to the AN Tank Farm description.

\subsubsection{Demolition}

\subsection{Primary Tank}

\subsection{Liquid High-Level Measurement}

WBS: 5E4J22F

Similar to the AN Tank Farm description.

\subsection{Vapor Space Pressure Measurement}

WBS: $5 E 4 A 08 B$ and 5E4B08B

Similar to the AN Tank Farm description.

\subsection{Leak Detection}

\subsection{Pipeline Leak Detectors}

WBS: 5E4J29C

Similar to the AN Tank Farm description. 


\subsection{Monitoring and Control}

Similar to the AN Tank Farm description. Refer to "Miscellaneous Alarns and Signals" under "Other Upgrades" for additional AZ Tank Farm work scope and associated WBS numbers.

\subsubsection{Assumptions}

\subsection{General}

Similar to the AN Tank Farm description.

\subsection{Primary Tank}

Similar to the AN Tank Farm description.

\subsection{Leak Detection}

Similar to the AN Tank Farm description.

\subsection{Monitoring and Control}

Similar to the AN Tank Farm description.

\subsection{Demolition}

Similar to the AN Tank Farm description except that no demolition of the existing primary exhaust stack instrument enclosure will be performed.

\subsubsection{ELECTRICAL}

\subsubsection{Description}

The electrical system upgrades include a MCC, which will feed the mini-power center and a second MCC to replace the exiting MCC as the power source to the heater controllers.

NOTE : For all references stating "Similar to the AN Tank Farm description." in this section, the AN text referring to the AN271 Building is changed to the AZ271 Building.

\subsection{Motor Control Center for Primary Ventilation}

WBS: 5E4J26A

The existing EDS-MCC-704 will be replaced with a new MCC located inside the 241-AZ-801A building as shown on 241-AZ Tank Farm One-Line Diagram (Ref. WHC-SD-W314-CDR-001, Rev, 1, Figure E-5 and Figure E-5A). A new mini-power center will be provided to supply power to the instrumentation equipment and control panel. This mini-power center will be fed from the new EDS-MCC-704. The new MCC will be bonded to the existing ground grid. 
4.5.2.2 Demolition

\subsection{Primary Ventilation}

WBS: 5E4J26C

Similar to the AN Tank Farm description.

\subsubsection{Assumptions}

\subsection{General}

Note 1: All assumptions in this section are "similar to AN Farm."

Note 2: All drawings referenced by the above Note 1 in this section reflect the AZ Farm drawings in WHC-SD-W314-CDR-001, Rev. 1. 
HNF-5109, Rev. 0

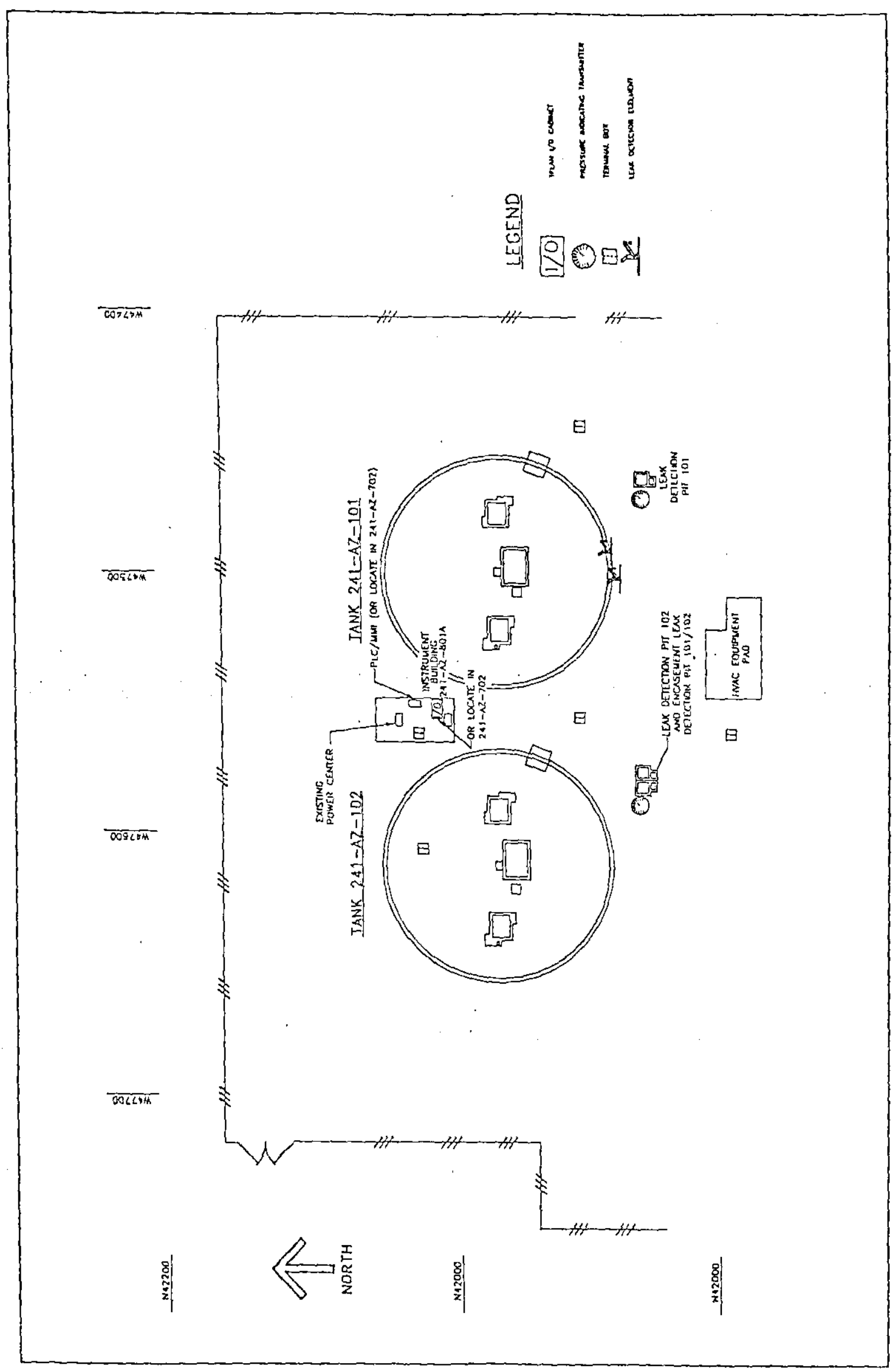




\subsection{SX TANK FARM UPGRADES}

\subsubsection{INSTRUMENTATION AND CONTROL}

Refer to Figure 4.8 for an overview of SY Tank Farm Upgrades.

\subsubsection{Description}

Instrumentation and control upgrades to SY Tank Farm include primary tank systems, leak detection systems, and the new annulus exhaust ventilation system. Selected existing alarms and signals, and signals from Phase 2 upgraded systems will be connected to the TFLAN system, except for Panalarm signals, which will be connected to TMACS.

NOTE: For all statements "similar to the AN Tank Farm description" in this section, any references in the AN Tank Farm description to the "241-AN-271 instrument building" are replaced with "241-SY-271 instrument building" for existing tank farm instrumentation and "242-S building" for TFLAN connections.

\subsection{Primary Tank}

\subsection{Liquid High-Level Measurement}

WBS: 5F4J22

New intrinsically safe resistive/conductivity liquid high-level probes will be installed in all three tanks. The high-level alarn signals from the three probes will connect to a TFLAN VOO panel in the 242 -S building. Signal wires will be routed via a field terminal box to a terninal box in the 241-SY-271 instrument building and then to the PLC in Building 242-S. The signals from the liquid high-level probes will be monitored by the TFLAN PLC and displayed on the TFLAN HMI.

\subsection{Vapor Space Pressure Measurement}

WBS: 5F4A08A, 5F4B08A, and 5F4C08A

Similar to the AN Tank Farm description except for all three 241-SY tanks.

\subsection{Waste Trausfer}

\subsection{Valve Position Indication}

Similar to AN Tank Farm description.

\subsection{Leak Detection}

4.6.1.1.3.1 Process Pits

WBS: 5F4A02, 5F4B02, 5F4B14, 5F4B15, 5F4C02, 5F4K01 and 5F4L01 
Similar to the AN Tank Farm description except for the new leak detection system, which will be installed in the following process pits:

- Central Pump Pits 01A-03A

- Flush Pits 02E

- Valve Pits A and B

- Drain Pit 02D

In addition, drain plug assemblies will be installed in all pits not entered by Phase 1. The following pits will require new drain plug assemblies:

- Central Pump Pits 01A-03A

- Flush Pits 02E

- Valve Pits A and B

- Drain Pit 02D

\subsection{Pipeline Encasement}

WBS: $5 \mathrm{~F} 4 \mathrm{~J} 35$

Similar to the AN Tank Farm description except for the new leak detection system which will be installed in the following waste transfer pipe encasements:

SL-178 (Pit 01A)

SN-278 (Pit 01A)

SL-177 (Pit 02A)

SN-277 (Pit 02A)

$\mathrm{PW}-475$ (Pit 02A)

$\mathrm{PW}-476$ (Pit 02A)

SL-179 (Pit 03A)

SN-279 (Pit 03A)

PW-479 (Pit 03A)

PW-480 (Pit 03A)

Valve Pit A

Valve Pit A

Valve Pit A

Valve Pit B

Valve Pit B

Valve Pit $B$

\subsection{Power Panels}

WBS: 5F4J28

Sirnilar to the AN Tank Farm description.

\subsection{Annulus Ventilation}

WBS: $13 Q$ 
The annulus ventilation system will be refurbished with components of similar capacity.

(I\&C) equipment will be supplied with the new annulus exhaust ventilation system to monitor the status and control the operation of the ventilation system. Refer to Figure 4.9 "Annulus Exhaust Station Flow Diagram."

The annulus ventilation exhaust station will consist of a single exhaust train containing a control/isolation valve, an inlet plenum, prefilter, test sections, HEPA filters, an outlet plenum, and an exhaust fan. The existing CAM will be reconnected to a new exhaust stack.

The ventilation system will be designed to operate under local manual control only. Instruments for measuring inlet and differential pressure and train temperature will be installed on the exhaust station. Hard-wired permissives/interlocks from the new differential pressure indicating switches, the existing CAM, and a temperature-indicating switch will control exhaust fan operation.

\subsection{Exhaust Station}

Inlet pressure: The exhaust train inlet pressure will be measured with respect to atmosphere by a differential pressure-indicating switch (PDIS). A pressure sense tap will be located on the exhaust manifold duct and routed to a local (high/low) PDIS. The PDIS will provide a local indication of inlet pressure and will provide permissives for starting or stopping the exhaust fan when the high or low-pressure setpoint is reached.

Differential pressure: Differential pressure across the prefilter and the two HEPA filters will be measured by differential pressure indicating switches. A pressure sense tap will be located on the housing on each side of the device measured and routed to a PDIS. Each PDIS will provide a local indication of differential pressure and an interlock to the exhaust fan.

Exhaust train temperature: The temperature of the inlet plenum will be measured by a temperature-indicating switch (TIS). The temperature element will be installed in a well mounted on the inlet plenum housing and the temperature signal from the sensor will be wired to the TIS. The TIS will provide a local indication of heater temperature.

Exhaust fan: The exhaust fan will be controlled by a magnetic starter. Power to the exhaust fan starter will be interrupted by a manual on/off switch and interlocks hard-wired to a starter relay from ventilation system instruments.

\subsection{Continuous Air Monitor}

The existing CAM will be connected to the new stack and an interlock from the CAM will be hard-wired to the exhaust fan.

\subsection{Ventilation System Monitoring and Control}

Local indicators and manual controls, including hard-wired interlocks, will be provided to facilitate manual operation of the ventilation system. At least one set of hard-wired interlocks 
(for high and low-pressure events) and a hard-wired relay from the CAM will be provided to initiate an exhaust shutdown.

NOTE: The need for remote monitoring of the annulus ventilation system at the TFLAN PLC/HMI will be evaluated during definitive design.

\subsection{Monitoring and Control}

\subsection{Alarms and Signals}

Similar to the AN Tank Farm description. Refer to "Miscellaneous Alarms and Signals" for additional SY Tank Farm work scope and associated WBS numbers.

\subsection{TFLAN PLC Equipment}

WBS: $5 F 4 J 22$

Similar to the AN Tark Farm description.

\subsubsection{Demolition}

\subsection{Primary Tank}

\subsection{Liquid High-Level Measurement}

WBS: N/A

SY tanks do not have high-level probes.

\subsection{Vapor Space Pressure Measurement}

WBS: 5F4A08B, 5F4B08B and 5F4C08B

Similar to the AN Tank Farm description except for all three 241-SY tanks.

\subsection{Leak Detection}

\subsection{Process Pit Leak Detectors}

WBS: 5F4A024, 5F4B024, 5F4B144, 5F4B154, 5F4C024, 5F4J164, 5F4J174, 5F4K014, and SF4L014

Similar to the AN Tank Fann description.

\subsection{Pipeline Leak Detectors}

WBS: $5 \mathrm{~F} 4 \mathrm{~J} 35 \mathrm{C}$

Similar to the AN Tank Fann description. 


\subsection{Annulus Ventilation}

WBS: 13 Q2, 13 Q4

Similar to the AN Tank Farm description, except for the annulus ventilation system. The existing stack CAM will not be removed.

\subsection{Monitoring and Control}

Similar to the AN Tank Farm description. Refer to "Miscellaneous Alarms and Signals" under "Other Upgrades" for additional SY Tank Farm work scope and associated WBS numbers.

\subsubsection{Assumptions}

\subsection{General}

Similar to the AN Tank Fam description, except for the following:

It is assumed that:

- The annulus exhaust stack instrument enclosure will not be removed

- The existing CAM will be reconnected to the new exhaust stack.

\subsection{Primary Tank}

Similar to the AN Tank Farm description, except for the following:

It is assumed that:

1. New intrinsically safe liquid high-level probe systems, one for each tank including associated cabling, have not been installed by others.

2. The new liquid high-level probes will be similar to the resistive-conductivity probes used for pit leak detection.

\subsection{Leak Detection}

Similar to the AN Tank Farm description.

\subsection{Annulus Ventilation}

Similar to the AN Tank Farm description, except for the annulus ventilation system and:

1. A condensate drain subsystem is not required.

2. A GEMS is not required.

3. A ventilation system PLC is not required.

\subsection{Monitoring and Control}

Similar to the AN Tank Fam description. 


\subsection{Demolition}

Sinilar to the AN Tank Farm description, except for the following:

It is assumed that:

The annulus exhaust stack instrument enclosure will not be removed.

\subsubsection{VENTILATION}

\subsubsection{Description}

Project W-314 Phase 2 ventilation upgrades to the SY Tank Famn consist of upgrading only the annulus ventilation system. The primary ventilation system upgrades are not part of the Project W-314, Phase 2 scope of work.

The SY annulus ventilation system can be subdivided into the following major subsystems:

- Inlet air filters (15 total)

- Tank farm anmulus portion of the double-shell tanks (three totai)

- Exhaust manifold

- Exhaust station

Oniy the exhaust station will be upgraded. A condensate drain subsystem is not required for the SY annulus ventilation system.

\subsection{Exhaust Station}

WBS: $13 \mathrm{Q} 2,13 \mathrm{Q} 4$

The SY Tank Farm annulus exhaust station system flow diagram is shown on Figure 4.9. The new annulus exhaust station will be designed, fabricated, tested, and installed as a modular unit. It will be installed on a concrete slab with anchor bolts. Components of the single train exhaust station will be standardized as much as possible with exhaust stations to be installed in the AN, AP, AW and tank farms. The exhaust station modular unit/units will be fabricated with lifting lugs so the exhaust station module or modules can be easily lifted and erected on a concrete slab/foundation.

The exhaust station instrumentation will be hard-wired to an instrumentation cabinet mounted at some convenient location on the structural steel supports of the exhaust station. The exhaust station equipment requiring electrical power will be hard-wired to an electrical power cabinet installed at some convenient location on the structural steel of the exhaust station. Heat-traced sight glasses shall be installed in the ducts, exhaust fans, and exhaust stack of the dual filter train exhaust station as a means of seeing and removing any condensation that may occur in the exhaust station equipment.

For standardization and ease of maintenance purposes, a GEMS designed by project W-420, Stack Monitoring System Upgrades, shall be installed to monitor and sample possible 
HNF-5109, Rev. 0

radionuclides that may exit the exhaust stack. The GEMS will be installed as part of the exhaust station.

The individual components of the annulus exhaust station are shown on the flow diagram (see Figure 4.9). The annulus exhaust station will pass an operational readiness review (ORR) and acceptance for beneficial use (ABU) tests. The old annulus exhaust station will be shut down and the new station connected to a tie-in flange on the existing annulus exhaust manifold.

Minimum downtime is desired.

A radioactive shielding wall is not needed around the exhaust station. A protective canopy with flood lighting installed below the canopy is not needed.

\subsection{DEMOLITION AND DISPOSAL}

WBS: $13 \mathrm{Q} 4$

The old annulus exhaust station shall be dismantled into manageable pieces upon acceptance and operation of the new station. That portion of the exhaust manifold downstream of the chosen tiein location will become waste. The waste shall be placed into approved containers, reduced in size if economical, and transported to the Hanford low-level burial grounds for storage/burial. All waste is expected to be radioactive, low-level, mixed waste until sampled and proved otherwise. It is desirable to leave old concrete slabs and piers in place if they will not interfere with operations.

\subsubsection{Assumptions}

The existing annulus exhaust manifold, upstream of the chosen tie-in location, will not be modified except for a tie-in connection to the new annulus exhaust station. No encasement is required for the existing annulus exhaust manifold.

1. The existing annulus exhaust manifold, upstream of the chosen tie-in location, will accommodate any potential new design flow.

2. The tank dome loading criteria will be met.

3. All waste is radioactive, low-level, mixed waste.

4. Old concrete footings/slabs will not be removed.

5. New air control stations similar to the existing design shown on drawings $\mathrm{H}-2-85646$ and $\mathrm{H}-2-85647$ are not required.

6. No drain pit, seal pot, or drain piping to and from the seal pot will be required.

7. The old exhaust station will be shut down only when the new station has been fully tested and is ready for tie-in.

8. The new exhaust station stack exhaust will be sampled and monitored with a GEMS used on Project W-420, Stack Monitoring System Upgrades. It is not necessary to monitor for toxic air pollutants (TAPs) and volatile organic compounds (VOCs). 
HNF-5109, Rev. 0

\subsubsection{ELECTRICAL}

\subsubsection{Description}

The electrical system upgrades include a new electrical breaker as the power source to the existing Ventilation Equipment Power Panel located on the existing vent skid pad fed from the MCC-241-SY-271 in the 241-SY-271 building. A mini-power center will provide a panel including transformer. Connections for a diesel genetator to supply back-up power with a 120 Vac panel with ground fault duplex receptacles including trans former. Upgrading and connecting to the existing ground grid.

NOTE: For all references stating "similar to the AN Tank Fam description" in this section, the AN text referring to the AN271 Building is changed to the SY271 Building.

\subsection{Main Power Feed to Annulus Ventilation Skid}

\section{WBS: $13 Q 4$}

A new $480 \mathrm{Vac}, 60 \mathrm{~Hz}$ circuit breaker will be installed to feed the existing ventilation equipment power panel located on the existing vent equipment pad and mini-power center for the new instrumentation control panel. A mini-power center will be installed to supply 120 Vac power to a new I\&C panel.

Power for the annulus ventilation system will be upgraded as follows:

1. Power to the new fans will be supplied for annulus exhaust and will replace the existing exhaust fans.

2. The existing circuit breaker to the annulus ventilation skid power panel will have the power feed cable replaced to support the upgraded load.

3. A new mini-power center will be provided to supply power to the instrumentation equipment and control panel. This mini-power center will be fed from the new ventilation equipinent.

\subsection{Power Receptacle for Portable Diesel Generator}

WBS: 13 Q2

Procure and install one new power receptacle for the portable diesel generator. This receptacle, transfer switch, and associated hardware will provide the capability to connect backup power to the annulus ventilation skid.

\subsection{Ground Grid and Bonding}

WBS: $13 Q 4$

Similar to the AN Tank Farm description. 


\subsubsection{Demolition}

\subsection{Annulus Ventilation}

WBS: $13 Q 4$

Similar to the AN Tank Farm description.

\subsubsection{Assumptions}

Note 1: All assumptions in this section are similar to AN Farm.

Note 2: Ali drawings referenced by the above Note 1 in this section reflect the SY Farm drawings in WHC-SD-W314-CDR-001, Rev. 1 
HNF-5109, Rev. 0

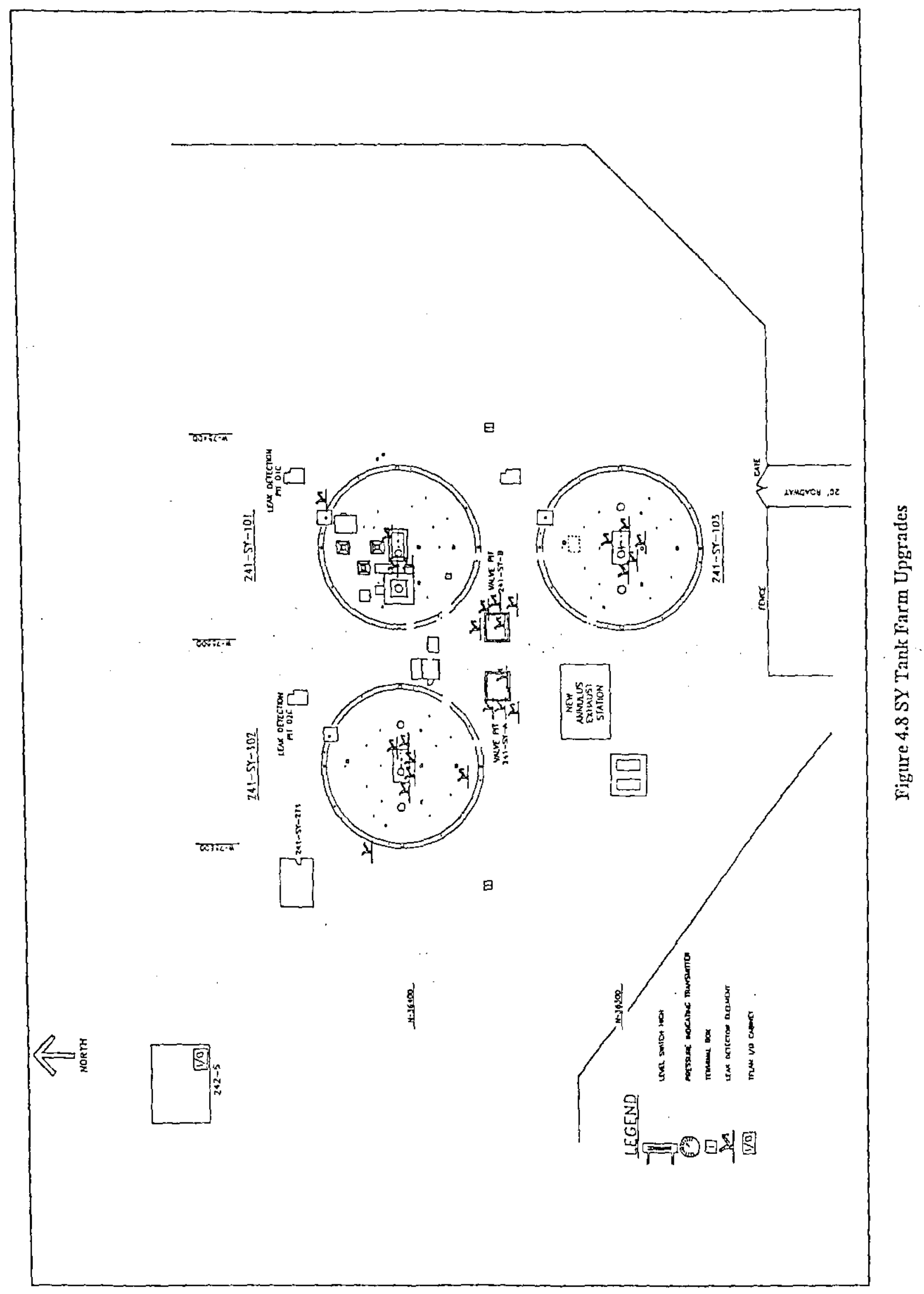


HNF-5109, Rev. 0

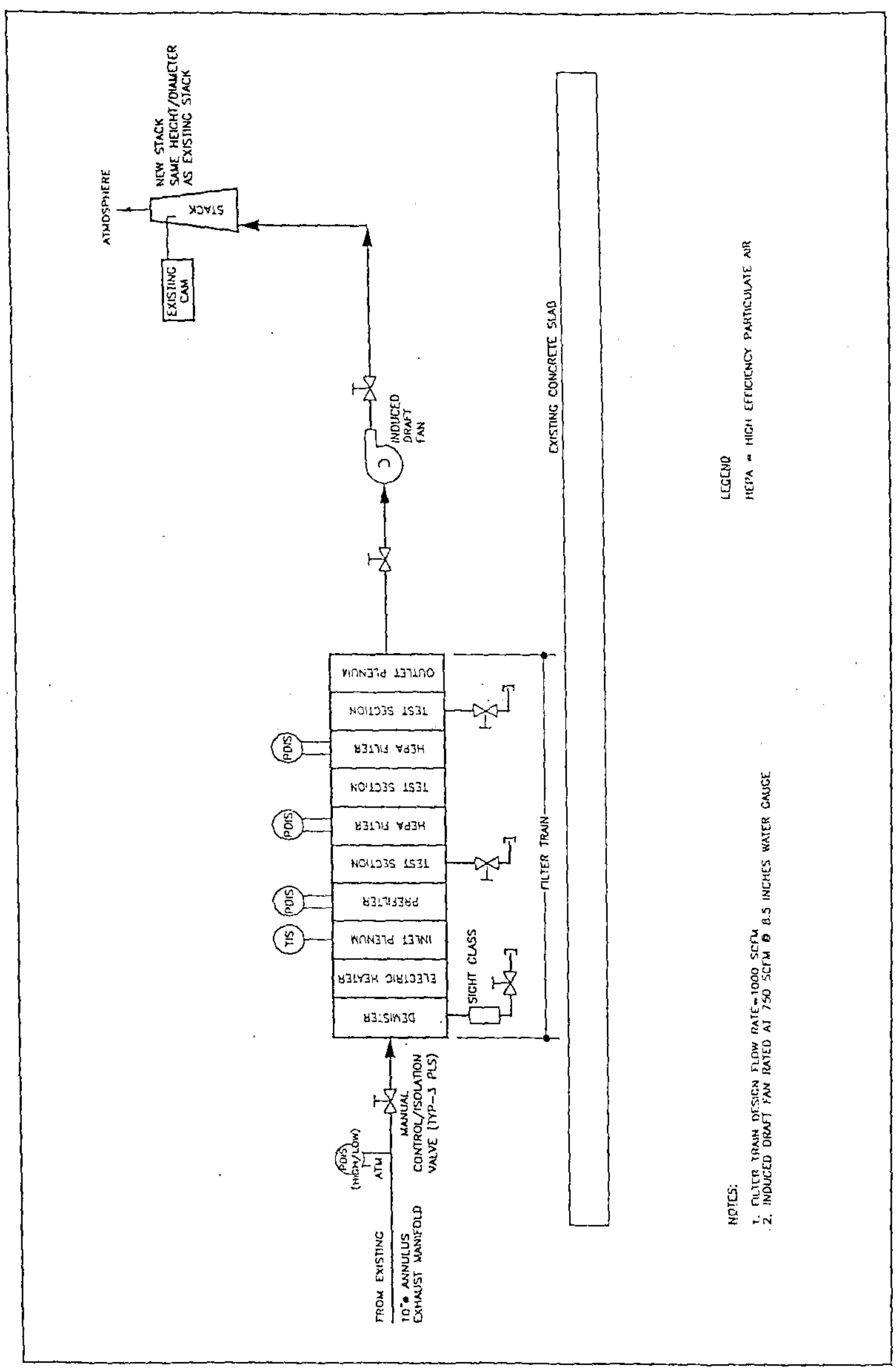

| 


\subsection{4-S DCRT UPGRADES}

Refer to Figure 4.10 for an overview of 244-S DCRT upgrades.

\subsubsection{INSTRUMENTATION AND CONTROL}

\subsubsection{Description}

Instrumentation and control upgrades to the 244-S DCRT primary tank systems, leak detection systems, and the new primary/annulus exhaust ventilation system. Selected existing alarms and signals, and signals from Phase 2 upgraded systems will be connected to the TFLAN system, except for temperature signals, that will be connected to TMACS.

NOTE: For all statements "similar to the AN Tank Farm description" in this section, any references in the AN Tank Farm description to the "241-AN-271 instrument building" are replaced with "244-S instrument building" for existing tank farm instrumentation and "242-S building" for TFLAN connections.

\subsection{Primary Tank}

\subsection{Waste Temperaiure Measurement}

WBS: 5H4B02A.

The existing thermocouple tree in 244-S DCRT will be replaced with a new temperature probe assembly. The signals from the temperature probe will be routed from the terminal box on the temperature probe assembly to a field terminal box and from there to a terminal box in the 244-S instrument building. The temperature signals will be parallel-wired in the 244-S instrument building with one branch routed to a TFLAN PLC 1/O panel located in the 242-S building. The signals input to the TFLAN UO parel will be monitored by the TFLAN PLC and displayed on the TFLAN HMI. The other branch of the temperature signal wiring will connect to a new local TMACS assembly in the 244-S instrument building where the temperature signals will be converted to RS-232 for transmission to TMACS via a modem.

\subsection{Vapor Space Pressure Measurement}

WBS: $5 \mathrm{H} 4 \mathrm{BI} \mathrm{A}$

Similar to the AN Tank Farm description except for the 244-S DCRT primary tank.

\subsection{Leak Detection}

\subsection{Tank Annulus Liquid Presence Detector}

WBS: $5 \mathrm{H} 4 \mathrm{BO}$

New annulus leak detection system will be installed in the tank annulus. The system shall provide a local and remote alarm. These devices will be located in the existing opening used by 
the specific gravity and weight factor tubes. These tubes are to be removed per the demolition section. The annulus leak detection wires will be routed via a field terminal box to a terninal box in the instrument building then to the TFLAN PLC in Building 242-S. The annulus leak detection signals will be monitored by the TFLAN PLC and displayed on the TFLAN HMI.

\subsection{Tank Pump Pit Liquid Presence Detector}

WBS: $5 \mathrm{H} 4 \mathrm{~B} 00$

New pump pit leak detection system will be installed in the tank pump pit. The system shall provide a local and remote alarm. These devices will be located in the existing opening used by the specific gravity and weight factor tubes. These tubes are to be removed per the demolition section. The annulus leak detection wires will be routed via a field terminal box to a terminal box in the instrument building then to the TFLAN PLC in building 242-S. The annulus leak detection signals will be monitored by the TFLAN PLC and displayed on the TFLAN HMI.

\subsection{Pipeline Encasement}

WBS: $5 \mathrm{H} 4 \mathrm{~B} 35$

Similar to the AN Tank Farm description except for the following waste transfer pipe encasements which will have a new leak detection system installed:

- V456

- V522

- V560

- V561

- V562

- Flush Pit Drain

- WT-SNL-5350-M17 (3)

4.7.1.1.2.4 Power Panels

WBS: $5 \mathrm{H} 4 \mathrm{~B} 16$

Similar to the AN Tank Farm description.

\subsection{Primary/Annulus Ventilation}

WBS: 5H3B00, 5H4B05, 5H4B12A and 5H4B16

I\&C equipment will be supplied with the new primary/annulus exhaust ventilation system to monitor the status and control the operation of the ventilation system. Refer to Figure 4.11 "Primary/Annulus Exhaust Station Flow Diagram." The major ventilation system components are:

- Exhaust station

- GEMS 
- Condensate drain subsystem

The primary exhaust ventilation station will consist of an inlet section containing a glycol heater and manual control/isolation valve; and a single train containing inlet plenum, test sections, HEPA filters, outlet plenum, and exhaust fan.

A new exhaust stack and GEMS will be provided by Project W-420. Connections from the GEMS to the new exhaust ventilation system will be performed by Project W-314 Phase 2 .

A new condensate drain subsystem will be installed to handle condensate from the exhaust housing sections. Included in the subsystem are a seal pot with level measurement equipment, drain piping, and an overflow pipe.

The ventilation system will be designed to operate under local manual control only. Instruments for measuring inlet and differential pressure, exhaust flow, glycol heater temperature, and train temperature will be installed on the exhaust station. Hard-wired permissives and interlocks from the differential pressure indicating switches, GEMS, and heater temperature switch will control exhaust fan operation.

NOTE: As an alternative to installing a new 244-S DCRT ventilation system, an evaluation will be performed during definitive design to determine whether a portable exhauster can be used.

\subsection{Exhaust Station}

Exhaust flow: A local flow indicator will be provided to measure exhaust flow at the tank inlet plenum.

Inlet pressure: The tank and vault inlet pressure will be measured with respect to atmosphere by differential pressure-indicating switches (PDIS). A pressure sense tap will be located on the exhaust manifold duct and routed to a local PDIS. The PDIS will provide a local indication of inlet pressure and will provide permissives for starting or stopping the exhaust fan when the high or low-pressure setpoint is reached.

Differential pressure: Differential pressure across the two HEPA filters will be measured by differential pressure indicating switches. A pressure sense tap will be located on the housing on each side of the device measured and routed to a PDIS. Each PDIS will provide a local indication of differential pressure and an interlock to the exhaust fan.

Exhaust train temperature: The temperature of the glycol heater and train at the test section will be measured by temperature-indicating switches (TIS). The temperature element will be installed in a well mounted on the device housing and the temperature signal from the sensor will be wired to the TIS. The temperature indication switches will provide local indications of heater and train temperatures.

Level detector: The coolant level in the glycol heater system will be measured by a level detector. The level detector sensor installed in the glycol heating system will be wired to the level indicator to provide local indication of glycol level. 
Exhaust heater: Power to the heater controller will be interrupted by a manual on/off switch or by deactivating a permissive interlock from the exhaust fan.

Exhaust fan: The exhaust fan will be controlled by a magnetic starter. Power to the exhaust fan starter will be interrupted by a manual on/off switch and by interlocks hard-wired to a starter relay from ventilation system instruments.

\subsection{Gaseous Effluent Monitoring System}

Similar to the AN Tank Farm description except that the GEMS PLC will perform all necessary data acquisition and control of the GEMS. The GEMS will be installed by Project W-420 and will be integrated into the 244-S DCRT ventilation system by Project W-314 Phase 2.

\subsection{Condensate Drain Subsystem}

The seal pot condensate level will be continually monitored by a resistive/conductivity level measurement system installed in the seal pot. Alarms for "low," "high," and "below fill" levels will be displayed locally.

\subsection{Ventilation System Monitoring and Control}

Local indicators and manual controls, including hard-wired interlocks, will be provided to facilitate manual operation of the ventilation system. At least one set of hard-wired interlocks (for high and low-pressure events) and a hard-wired relay from the GEMS will be provided to initiate an exhaust shutdown.

NOTE: The need for remote monitoring of the primary/annulus ventilation system at the TFLAN PLC/HMI will be evaluated during definitive design.

\subsection{Monitoring and Control}

\subsection{Alarms and Signals}

Similar to the AN Tank Farm description. Refer to "Miscellaneous Alarms and Signals" under "Other Upgrades" for additional 244-S DCRT work scope and associated WBS numbers.

\subsection{TFLAN PLC Equipment}

WBS: $5 \mathrm{H} 4 \mathrm{~B} 12 \mathrm{~B}$

Similar to the AN Tank Farm description.

\subsubsection{Demolition}

\subsection{Primary Tank}

\subsection{Waste Temperature Measurement}

WBS: $5 \mathrm{H} 4 \mathrm{~B} 02 \mathrm{~B}$ 
Remove and dispose of the existing temperature tree in the 244-S DCRT. The temperature tree will be disposed of in a flexible receiver container and treated as "long-length contained equipment." Remove and dispose of the temperature tree terminal box. Remove and dispose of the temperature transmitter and associated instrument panel tank temperature readouts and switches in the 241-SY-271 building. The volume of waste for the temperature tree is assumed to be an approximate total of 3 cubic feet of RMW material.

\subsection{Vapor Space Pressure Measurement}

WBS: $5 \mathrm{H} 4 \mathrm{~B} 11 \mathrm{~B}$

Similar to the AN Tank Farm description except for the 244-S DCRT primary tank.

\subsection{Leak Detection}

\subsection{Tank Anmulus Liquid Presence Detectors}

WBS: $5 H 4 B 03 B$

The three sensing legs into the annulus, the specific gravity and weight factor transmitters, and their readouts will be removed. Volume of this waste is ascumed to be 3 cubic fcct of RivW.

\subsection{Tank Pump Pit Liquid Presence Detectors}

WBS: 5 H4B004

The three sensing legs into the pump pit, the specific gravity and weight factor transmitters, and their readouts will be removed. Volume of this waste is assumed to be 3 cubic feet of RMW.

\subsection{Pipeline Leak Detectors}

WBS: $5 \mathrm{H} 4 \mathrm{~B} 35 \mathrm{C}$

Similar to the AN Tank Farm description.

\subsection{Primary/Annulus Ventilation}

WBS: None

The existing exhaust stack instrument enclosure will be removed by Project W-420.

\subsection{Monitoring and Control}

Similar to the AN Tank Farm description. Refer to "Miscellaneous Alarms and Signals" under "other Upgrades" for additional 244-S DCRT work scope and associated WBS numbers.

\subsubsection{Assumptions}

\subsection{General}


Similar to the AN Tark Farn description.

\subsection{Primary Tank}

Sinilar to the AN Tark Farm description, except for the following:

It is assumed that:

1. One existing temperature themocouple tree will be removed from the 244-S DCRT and a new temperature measurement assembly can be installed in the same riser.

2. The safety classification of the waste temperature measurement system is safety-significant.

3. The new temperature probe assemblies will be similar to the unit installed in Tank 241 -AN105 by Project W-211 with 18 resistance temperature detectors (RTDs) mounted.

4. The existing thermocouple tree is not connected to TMACS and new TMACS interface equipment must be added. The new temperature tree signals are required inputs to TFLAN. NOTE: The need for both TFLAN and TMACS connections from the temperature tree will be evaluated during definitive design.

\subsection{Leak Detection}

Similar to the AN Tank Farm description, except for the following:

It is assumed that:

1. An ENRAF type level instrument will be used for leak detection in the tank annulus. The use of the ENRAF type level instrument is what is planned by operations for the tank annulus systems in the SY Tank Farm.

\subsection{Primary/Annulus Ventilation}

Similar to the AN Tank Farm description, except for the primary/arnulus ventilation systern and:

1. The GEMS will be procured and installed by Project W-420 and will be connected to the new ventilation system by Project W-314 Phase 2.

2. A ventilation system PLC is not required.

\subsection{Monitoring and Control}

Similar to the AN Tank Farm description.

\subsection{Demolition}

Similar to the AN Tank Farm description, except for the following.

It is assumed that:

1. The existing themocouple tree will be classified as RMW and most contaminants will be removed from the trees when flushed with water during their removal from the tank. 
HNF-S109, Rev. 0

2. The temperature tree will be disposed of in a flexible receiver container and treated as longlength contained equipment.

3. The existing annulus leak detectors and leak detectors in the pipe encasements will be classified as RMW for waste management purposes.

4. The primary/annulus exhaust stack instrument enclosure will be removed by Project W420.

\subsubsection{VENTILATION SYSTEM}

\subsubsection{Description}

The 244-S DCRT is mainly an underground facility with a single tank (TK-244-S, 20,000 gallons of nominal capacity) located below a pump pit and filter pit (see drawings $\mathrm{H}-2-71052$ and $\mathrm{H}-2-71057$ ). Ore annulus air control station (see drawing $\mathrm{H}-2$-71048) conveys filtered air into the annulus space around tank $244-S$ DCRT. There is no air control station that conveys air into the primary vapor space of Tank 244-S DCRT, air infiltrates into the primary vapor space via risers. The primary exhaust and annulus exhaust duct merge in the filter pit upstream of the filter trains which are located in the subsurface filter pit (see drawing $\mathrm{H}-2-71047$ ).

Project W-314 Phase 2 vertilation upgrades to the 244-S DCRT facility will include:

- Installing a new primary air control station at grade elevation and ducting it to an existing riser that will convey filtered air directly into the primary vapor space of Tank $244-\mathrm{S}$ DCRT.

- Complete removal of all filter train equipment from the 244-S DCRT facility filter pit downstream of annulus exhaust connection $Z$ and primary exhaust connection $Y$ located in the filter pit (see drawing H-2-71057) and dispose of this equipment as radioactive, low-level mixed waste.

- Installing an annulus exhaust duct from connection $Z$ to above grade and installing a primary exhaust duct from connection $Y$ to above grade. The annulus and primary exhaust ducts will be merged upstream of the new primary/annulus exhaust station.

- Construction of a new primary/annulus exhaust station (see DCRT Ventilation System Flow Diagram, Figure 4.11). The ventilation system upgrades include the replacement of the existing ventilation equipment with a new exhaust station consisting of a single glycol heater at the system inlet, followed by a single exhaust train with two HEPA filters, induced draft fan, and one exhaust stack.

- Installation of a condensate drain subsystem (see Figure 4.3) consisting of a seal pot, drain lines from the exhaust station to the seal pot, and drain line from the seal pot to tank 244-S DCRT.

- Tying-in the exhaust station to the merged exhaust ducts, system testing, and turnover.

- Demolition and disposal of the old exhaust fan, exhaust stack, and stack monitoring equipment. 
HNF-5109, Rev. 0

NOTE: Project W-420, Stack Moritoring System Upgrades will be installing a new exhaust stack with new Gaseous Effluent monitoring equipment. Coordination with this project is necessary.

\subsection{Air Control Station}

WBS: 5H.4.B.10

A new, properly sized air control station is required to convey air directly into the vapor space of the 244-S DCRT. The standardized air control station design is shown on drawings H-2-85646 and $\mathrm{H}-2$-85647. This air control station consists of an airflow controller, pre-filter, HEPA filter, and vacuum relief valve. The primary purpose of this air control station is to regulate the flow of air into the vapor space of the primary tank and to remove radioactive particulate from the vapor in case of backflow from the primary tank.

A new primary air intake duct will be installed that will connect this air control station, located at ground level, to a spare primary tank riser located in the pump pit. The 244-S tank vapor space presently receives its inflow through leaking tank risers and miscellaneous other vapor space openings, which must be sealed after installation of the new primary air control station. Excavation and core drilling will be required to install the air intake duct through a wall of the pump pit.

The air control station shall be completely fabricated (except for the 6'x 5'x 0.67 ' concrete footing) and tested in the fabricator's shop prior to shipment to the 244-S DCRT. After successful shop testing the air control station shall be shipped to the 244-S DCRT and reassembled on its concrete footing and riser flange. Recommended spare parts (see drawings $\mathrm{H}-2-85646$ sheet 1 ) shall be delivered to the customer's warehouse. There are no instrumentation signals from the air control station that require routing. Digital pictures have been taken that show the one existing air control station connected to the six-inch annulus air inlet duct and are included in the references to aid the reader.

The existing 244-S DCRT annulus air intake assembly (see drawings H-2-71048, Section A) will not be replaced.

\subsection{Primary/Annulus Exhaust Station}

WBS: 5H.4.B.05 and 5H.4.B.06

Existing primary/annulus dual filter trains are located in the 11-foot $x 11$-foot $x 1$-foot subsurface filter pit (see drawing $\mathrm{H}-2-71057$ sheet 1 of 2). A new primary/annulus exhaust station, as shown on the DCRT Ventilation System Flow Diagram (Figure 4.11), will be installed on a concrete slab at grade. The exhaust station will be connected to the new primary and annulus exhaust ducts that originate at the $\mathrm{Y}$ and $\mathrm{Z}$ nozzles located in the filter pit. These nozzles are shown on drawing $\mathrm{H}-2-71057$, sheet 1 of 2 .

The location of the new primary/annulus exhaust station will be as close as possible to the DCRT filter pit to minimize exhaust duct lengths. The new primary exhaust duct and a separate annulus exhaust duct will route the exhaust gases from the $\mathrm{Y}$ and $\mathrm{Z}$ nozzles through the filter pit to above 
grade and merge before reaching the new exhaust station. A flow meter shail be installed above grade in the primary exhaust duct (see Figure 4-11). Pipe supports shall be required in the filter pit. The existing four-inch diameter exhaust pipe routed from the filter pit to above grade is assumed to be unfit for reuse. It shall be sealed at each end. Excavation and core drilling will be required to install the two exhaust ducts through a wall of the filter pit.

The new primary/annulus exhaust station will be designed, procured, and installed as a modular assembly. The exhaust station will be fabricated, assembled, and fully tested in the contractor's shop prior to delivery to the Hanford Site. The exhaust station modules will be hoisted (via built-in lifting lugs) off the transport truck, set on a concrete pad and tied down with anchor bolts. The exhaust station instruments will be wired to an instrument cabinet mounted in some convenient location on the structural steel of the exhaust station. The exhaust station equipment requiring electrical power will be wired to an electrical power cabinet mounted in some convenient location on the structural steel of the exhaust station. The stack GEMS will be installed as part of the exhaust station. When the new ventilation system passes acceptance testing, the old ventilation system will be shut down and the new equipment will be placed in service using minimum downtime.

A concrete shielding wall is not required around the exhaust station. A removable metal canopy will not be installed over the exhaust station. Flood lighting will not be installed.

\subsection{Condensate Drain Subsystem}

WBS: $5 \mathrm{H} 4 \mathrm{JO} 07$

The 244-S DCRT condensate drain subsystem is similar to the AN Tank Fam condensate drain subsystem except the overflow pipe will drain excess condensate from the seal pot through the wall of the 244-S DCRT pump pit and into a suitable riser that empties into primary tank 244-S.

\subsubsection{Demolition}

WBS: $5 \mathrm{H} 4 \mathrm{~B} 10$

The existing filter pit dual exhaust trains, exhaust fan, stack assembly and any other miscellaneous waste generated during the construction of the upgrades to the 244-S DCRT facility shall be removed, placed in approved containers, reduced in size, if economical, and transported to the Hanford low-level burial grounds for storage/burial.

Refer to drawing $\mathrm{H}-2-71048$ (plan view). The existing one-inch diameter stack drain piping shall be capped at grade upon removal of fan K1-5-1. All items that are declared waste will be checked for radiological contamination and disposed of as either clean or contaminated waste.

The filter pit and pump pit should be considered to have a general dose rate greater than 100 millirem/hr, be a high radiation area, high contamination area, and an airbome radioactivity area. A closed, certified containment tent may be required around the filter and pump pits prior to removing the pit cover blocks. 


\subsubsection{Assumptions}

1. The primary and annulus exhaust piping shall not require encasement.

2. A seal pot will be installed on the exhaust station slab because it will be less expensive than trying to install a seal pot inside the contaminated filter pit.

3. The pump pit wall must be core drilled to route the condensate drain overflow pipe into the pump pit.

4. There is a water supply in the area of the 244-S DCRT facility.

5. The old exhaust filter trains and exhaust fan/stack assembly shall be considered mixed waste.

6. The soil excavated to install the primary air intake duct, the two exhaust ducts, and the condensate drain subsystem overflow pipe will be placed back into the excavation and compacted; no excess soil will be created that would require removal.

7. The excavation needed to construct a concrete pad for the air control station and the primary/annulus exhaust station will be placed and compacted around the concrete pads. No soil will be hauled away.

8. Project W-420, Stack Monitoring System Upgrades will supply and install a GEMS and exhaust stack prior to the new exhaust station being built. Project W-314, Phase 2 will reuse this GEMS on the new exhaust station.

\subsubsection{ELECTRICAI}

\subsubsection{Description}

A new power system shall feed the new DCRT ventilation system from the panelboard and a new mini-power center shall supply power for the I\&C panel. A new circuit breaker shall be provided to feed an existing panel in the instrumentation and electrical control house.

NOTE : For all references stating "similar to the AN Tank Farm description" in this section, the AN text referring to the AN271 Building is changed to the 244-S DCRT Building.

\subsection{Existing Panclboard A to Primary Ventilation Skid}

WBS: $5 \mathrm{H} 4 \mathrm{~B} 14 \mathrm{~A}$

Install $480 \mathrm{Vac}$ power system from panelboard A to supply the DCRT ventilation system. Install new mini-power center to supply the $I \& C$ panel.

The new equipment will include a new circuit breaker to feed a new mini-power center with a circuit paneiboard in a NEMA type 4 enclosure. New circuit breakers and feeders for the primary ventilation fans to be powered from existing panelboard $A$. Two new ventilation exhaust heaters will be installed. 


\subsection{Ventilation Skid Ground Grid and Bonding}

WBS: 5H4B14D

The new primary ventilation system will be bonded to a new ground grid that will be conrected from the existing tank farm ground grid.

\subsection{Freeze Protection for Primary Ventilation Drainage Systems}

WBS: $5 \mathrm{H} 4 \mathrm{~B} 14 \mathrm{E}$

Freeze protection for the primary ventilation drainage system will be provided. The power for the freeze protection will be supplied from the mini-power center.

\subsubsection{Demolition}

WBS: $5 \mathrm{H} 4 \mathrm{B1} 4 \mathrm{~F}$

Similar to the AN Tank Farm description

\subsubsection{Assumptions}

Note 1: All assumptions in this section are similar to the AN Farm.

Note 2: All drawings referenced by the above Note 1 in this section reflect the DCRT Fann drawings in WHC-SD-W314-CDR-001, Rev. 1. 
HNF-5109, Rev. 0

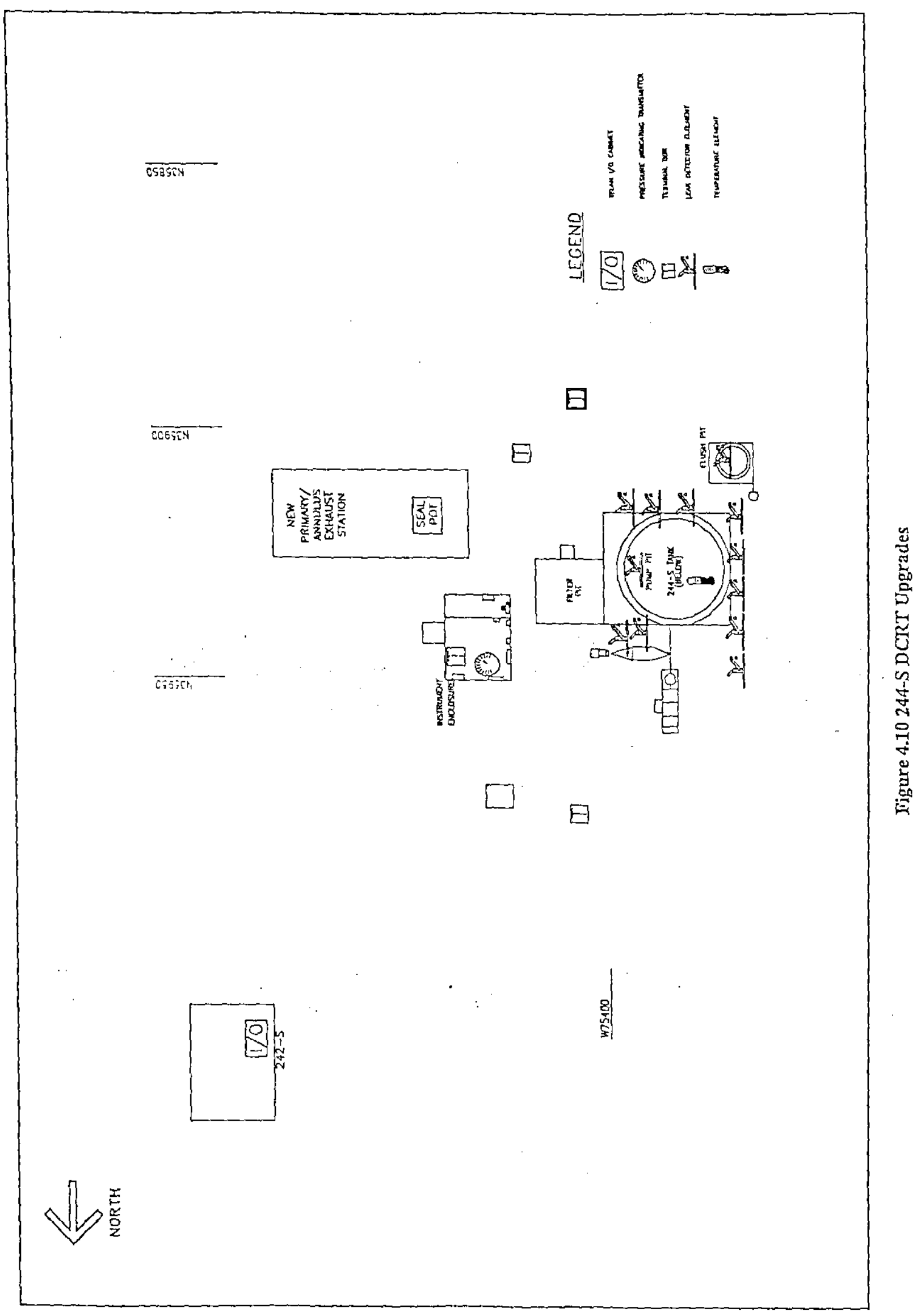



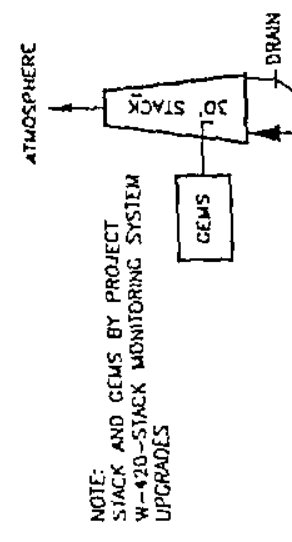

]$_{-2}^{3}$
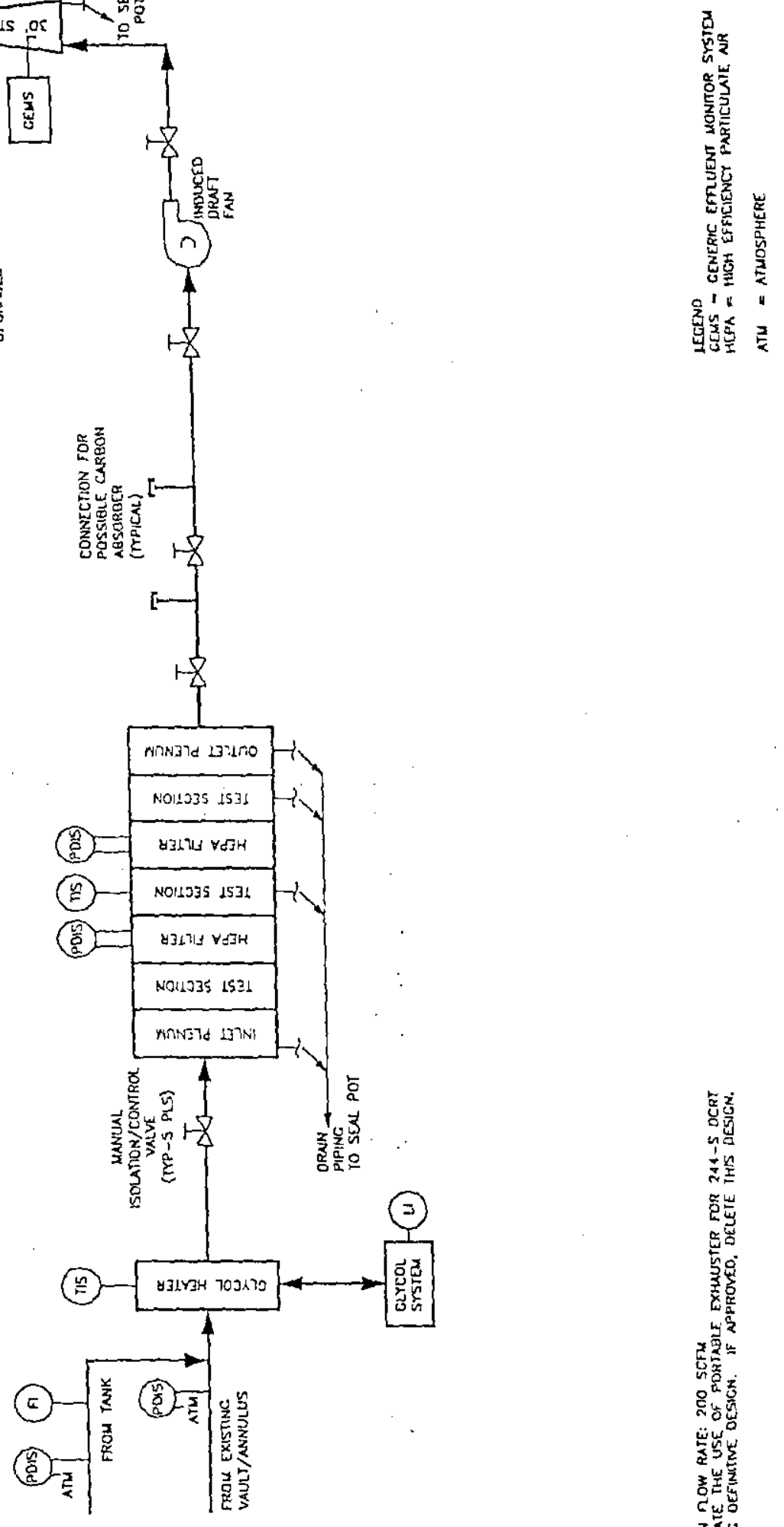

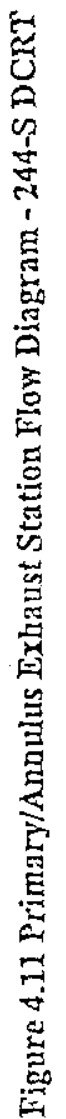




\subsection{EAST/WEST UPGRADES}

\subsubsection{INSTRUMENTATION AND CONTROL}

\subsubsection{Description}

I\&C upgrades to the 200 East and 200 West Areas. Included in this work scope are Panalam modifications in the A, BY, C, an U Tank Farms and the CR-271, 242-T, 244-AR, and 204-AR facilities. In addition, selected existing alarms and signals, including Gamewell alarms and selected 242-A DCS signals, will be connected to the TFLAN system; and Panalarm signals will be connected to TMACS.

NOTE: For all statements "Similar to the AN Tank Farm description" in this section, any references in the AN Tank Farm description to the "241-AN-271 instrument building" are replaced with "242-A building."

\subsection{Monitoring and Control}

\subsection{Alarms and Signals}

Similar to the AN Tank Farm description. Refer to "Miscellaneous Alanns and Signals" under "Other Upgrades" for additional 200 East/West Area work scope and associated WBS numbers.

\subsection{TFLAN PLC Equipment}

Similar to the AN Tank Farm description.

\subsubsection{Demolition}

Similar to the AN Tank Farm description. Refer to "Miscellaneous Alarms and Signals" for additional 200 East/West Area work scope and associated WBS numbers.

\subsubsection{Assumptions}

\subsection{Monitoring and Control}

Similar to the AN Tank Farm description.

\subsection{Demolition}

Similar to the AN Tank Farm description except for the following:

1. Leak detection systems are not applicable.

2. Primary exhaust stack instrument enclosure is not applicable 


\subsubsection{PIPING}

\subsubsection{Description}

241-A-A Valve Pit bypass for SN-220 and LIQW-702

WBS: $5 I 4 E$

A new buried waste transfer line will be provided to enable lines LIQW-702 and SN-220 to bypass Valve Pit 241-A-A. A conceptual layout of the bypass arrangement is shown in attached sketch SK-2-W314-A01. A section of each of these lines will be removed to facilitate the bypass connection. The portion of these lines connected to the pit will be capped. The new transfer line will include the transfer pipe, non-jacketed encasement for leak detection, and a cathodic protection system.

Leak detection for the bypass line will utilize the existing system in place for line SN-220. The new transfer line will slope down from the LIQW-702 connection towards SN-220. New leak detection instrumentation will not be required for the new transfer pipe.

New anodes will be added for the new encasement pipe. These will be connected to the existing cathodic protection system for LIQW-702 and SN-220.

The modification will negate the need to use and maintain $241-\mathrm{A}-\mathrm{A}$ and will allow continued transfers from 204-A-R.

The following work will be performed;

- Excavate a pipe trench from the bypass connection point on LIQW-702 to the connection point on SN-220. For estimating purposes, the bypass pipe is assumed to be six feet from the pit, connection to connection, and will be buried three feet below the surface.

- Excavate at both LIQW-702 and SN-220, a 4-foot deep by 6-foot square pit centered at the bypass connection point.

- Remove and contain a 3-foot section of each pipe, including enclosure pipe.

- Decontaminate, clean, and prepare for welding, the open ends of LIQW-702 and SN-220.

- Cap each pipe connected to 241-A-A.

- Fabricate bypass pipe assembly in field per ASME B31.3 and perform separate hydrostatic leak tests on the pipe and enclosure prior to connecting to existing pipe. It is assumed that existing LIQW-702 and SN-220 are code-compliant and currently meet the leakage requirements of ASME B31.3.

- Connect bypass pipe with enclosure to LIQW-702 and SN-220. Include code-required in-process examination

- Radiograph closure welds (100\% per ASME B31.3).

- Install anodes for cathodic protection and connect to system.

- Refill excavation and remove pipe sections for burial. 
Current anti-contamination requirements to enter the work area are one pair of Special Work Permits (SWPs). Assumed requirements for decontamination and tie-in of the piping are two pairs of SWPS and respirator with supplied air. The requirements for excavation are unknown at this time. Radiation levels will be monitored during excavation and appropriate work clothing will be required. Work intermption and upgraded anti-contamination requirements should be assumed.

\subsubsection{Demolition}

WBS: 5I4E03

The demolition portion of the piping modification is included in section 1.1 above.

\subsubsection{Assumptions}

The existing cathodic protection system for LIQW-702 and SN-220 will be used. Additional anodes only will be required for the bypass.

Assumed requirements for decontamination and tie-in of the piping are 2 pairs of SWPS and respirator with supplied air. 


\subsection{OTHER UPGRADES}

\subsubsection{INSTRUMENTATION AND CONTROL - MISCELLANEOUS ALARMS AND SIGNALS}

\subsubsection{Description}

This section describes the alarm and signal upgrades for the AN, AP, AW, AY, AZ, and SY Tank Farms, the 244-S DCRT, 200 East/West Areas, and single-shell tank (SST) farms. The work scope includes:

- connecting alarms from the Tank Farms Local Area Network (TFLAN) system to the 242-A Distributed Control System (DCS)

- connecting tank farm general local alarms to the TFLAN PLC

- upgrading the Gamewell Alarm systems in the DST Farns and 244-S DCRT

- moving selected alarm signals from Panalarms for the DST Farms; A, BY, C, and U SST Farms; and CR-271, 242-T, 244-AR and 204-AR Facilities to the TMACS

- connecting selected AY and AZ Tank Farm primary ventilation signals from the MICON system to the TMACS.

Figure 4.12 illustrates the anticipated tank farm instrument monitoring and control system configuration with Project W-314 Phase 1 and Phase 2 upgrades completed. The shaded components and connections depict existing items, items to be supplied by W-314 Phase 1 , or items supplied by others. Other than W-314 Phase 2 supplied ventilation systems, with ventilation system PLCs acting as separate TFLAN nodes, and modem connections to TMACS, W-314 Phase 2 upgraded systems all tie into TFLAN through a W-314 Phase 1 supplied PLC.

\subsubsection{TFLAN Connections}

Monitoring and control upgrades consist of connections of selected existing tank farm signals and Phase 2 supplied systems to PLCs attached to a new TFLAN system. The new TFLAN system will be installed prior to W-314 Phase 2 construction and will perform both tank farm monitoring and MPS functions.

Signals from new and upgraded tank farm instruments will be monitored by a TFLAN PLC installed in a local instrument building, control building, or operating center, and displayed on a TFLAN HMI.

\subsection{2-A DCS}

The 242-A DCS work scope consists of re-routing alarms disconnected during upgrades back to the 242-A DCS via the TFLAN. Approximately 30 alarms resident in the 242-A Building identified for AW, AY, and AZ tank fams and the MPS system will be reconnected to the 242-A DCS. Another six general building alarms from the DST instrument buildings will be re-routed to the 242-A DCS. These alarms will be transmitted from each facility over the TFLAN to the TFLAN PLC located in the 242-A Building. 


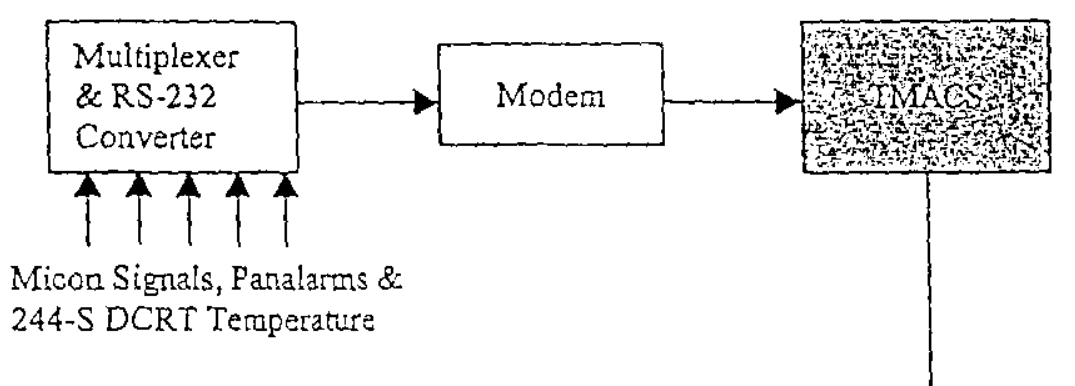

\section{HLAN}

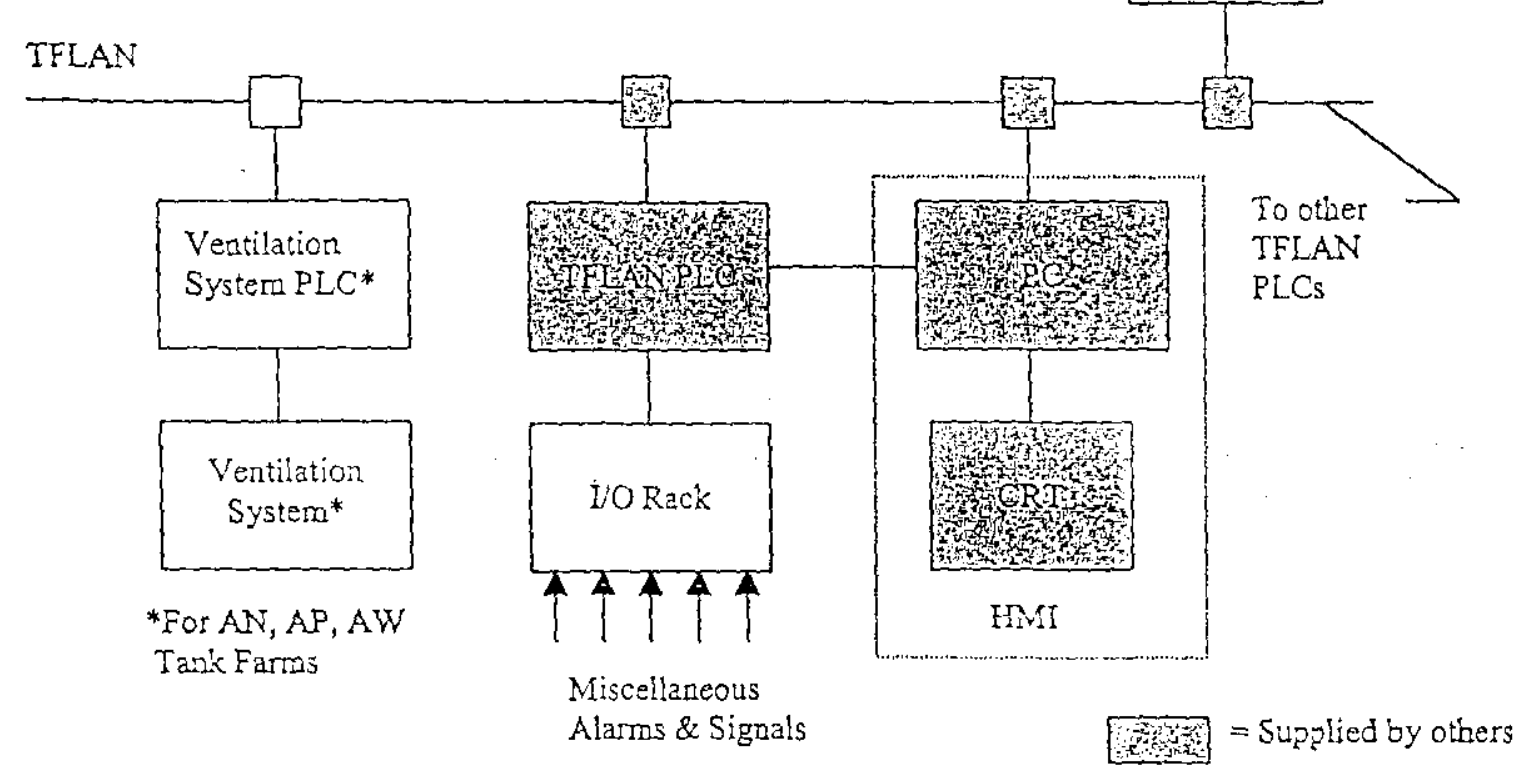

Figure 4.12. Project W-314 Monitoring and Control System Configuration

The TFLAN PLC in the 242-A building will relay the status of the approximately 36 alarms to the 242-A DCS employing I/O modules installed in the local TFLAN I/O rack. Following is a summary of this work scope:

\subsection{242-A Resident Alarms}

WBS: 5C4J22E, 5D4J22F, 5E4J22F and 5I4F04

1. Install relay output cards and an additional PLC panel in the 242-A Building to support the connection of 30 signals from the TFLAN to the 242-A DCS. 
2. Disconnect the 30 existing alarm relay contacts from the 242-A DCS and reconnect new TFLAN output signals corresponding to the existing alarms.

3. Modify the TFLAN software to output the 30 signals.

\subsection{General Building Alarms}

WBS: 5A4J22, 5B4J22, 5C4J22, 5E4J22, and 5F4J22

The general building alarms in 241-AN-271, 241-AP-271, 241-AW-271, 241-SY-271, 241-AZ702 , and 241-AZ-271 will be connected to TFLAN. Following is a summary of this work scope:

1. Parallel the signals from the master alarm panel in each instrument building to a TFLAN PLC VO rack in the same building.

2. Connect the signals to an existing TFLAN PLC digital input card (supplied by W-314 Phase 2).

3. Modify the TFLAN program to recognize the general building alam signals.

\subsection{Gamewell Alarms}

WBS: SA4J22D, 5B4J22D, 5C4J22E, 5D4J22F, 5E4J22F, 5F4J22E, and 5I4F03

Gamewell alarm work scope consists of connecting any active signal that feeds the Gamewell system located within the DSTs, 244-S DCRT (including SY Tank Farm), and 242-A building to the TFLAN system and removing the Gamewell boxes. There are approximately 30 signals that will be connected to TFLAN. The remaining work scope will be demolition work. Alarm signals will be taken from the input to the Gamewell systems and re-routed to a TFLAN PLC I/O panel. Existing TFLAN software will be modified to handle the 30 additional alarm signals. Following is a summary of this work scope:

1. Disconnect two Gamewell alarm signals located in each DST instrument building plus one Gamewell alarm in the 242-A building and recontect them to TFLAN.

2. Install analog input cards in the TFLAN PLC I/O panel.

3. Re-route displaced signals.

4. Modify the TFLAN program to recognize the 30 Gamewell alarm signals.

\subsubsection{TMACS Connections}

In addition to their connection to a PLC on the TFLAN, selected tark temperature signals will also be transmitted to the TMACS. A signal multiplexer and converter will be employed to convert tank farm instrument signals to EIA RS-232 serial data. The instrument serial data will then be transmitted by modem over telephone lines to TMACS. Communication between TMACS and the TFLAN HMIs will take place via the Hanford Local Area Network (HLAN). This connection permits signal information, e.g., TFM and MPS data on the PLCs to be monitored by TMACS.

\subsection{Panalarms}

WBS: 5A $4 J 22 \mathrm{C}, 5 \mathrm{~B} 4 \mathrm{~J} 22 \mathrm{C}, 5 \mathrm{C} 4 \mathrm{~J} 22 \mathrm{C}, 5 \mathrm{D} 4 \mathrm{~J} 22 \mathrm{C}, 5 \mathrm{E} 4 \mathrm{~J} 22 \mathrm{C}, 5 \mathrm{~F} 4 \mathrm{~J} 22 \mathrm{C}$, and $5 \mathrm{I} 4 \mathrm{~F} 02$ 
Panalarm work scope for the DSTs consists of paralleling the signals from the Panalarms to TMACS. This work scope involves only alarm signals that have not been connected to TFLAN by previous W-314 work scope. New ACROMAG V/O control modules, ACROMAG DC input modules, ACROMAG RS-485 to 232 converters, and modems will be installed in a new enclosure that will be mounted near the Panalams.

Power will be supplied to the ACROMAG enclosures from an existing 120 Vac distribution panel. Conduit and wiring will be supplied to connect the ACROMAG enclosure to Panalarm equipment. The signals will be paralleled from the input terminal block of the Panalarm to the new enclosure.

One ACROMAG will handle 16 signals and each ACROMAG will require an ACROMAG RS485 to RS-232 converter and modem. For ACROMAG details, refer to drawing H-2-140317, Item Nos. 5 and 7. For ACROMAG RS-485 to RS-232 converter details, refer to drawing H-2820812, Sheet 1, Item No. 6. The approximate number of signals to be paralleled to TMACS is given below:

- AN Farm:

35 signals

- AP Farm:

70 signals

- AW Farm:

20 signals

- AY/AZ Farms:

80 signals (40 signals/Farm)

- SY Farn:

40 signals

Total $=245$ signals

NOTE: Primary ventilation signals from the MICON systems in both AY and AZ Tank Farms are also included in the above estimate.

This work scope also includes moving selected SST and hazardous facility alarms from a Panalarm to the TMACS. For the selected alarm signals from Panalarms for A, BY, C, U Farms and CR-271, 242-T, 244-AR, and 204-AR Facilities to the TMACS. These Panalarms are allocated as follows:

- 271-A building (Three Panalanns)

- 271-CR building (One Panalarm)

- 204-AR building (One Panalarm)

- 244-AR building (One Panalarm)

- 242-T building (One Panalarm)

- 244-U building (One Panalarm)

- 244-BX building (One Panalarm)

An additional ACROMAG I/O and DC input module, ACROMAG RS-485 to RS-232 converter, and modem will be required for each Panalarm. It is assumed that a total of nine SST Panalarms will be required with 15 signals per Panalarm for a total of 135 signals. It is also assumed that all installations will be similar and that the ACROMAG enclosure will be mounted inside the appropriate building in close proximity to the Panalarm (within 50 feet); and that sufficient space exists for the equipment. 
Signals will be paralleled from each Panalarm input terminal block to the ACROMAG enclosure. All ACROMAGs, converters, and modems will be installed in a NEMA $3 R$ enclosure and mounted inside the corresponding building with the Panalarm. Each enclosure will be large enough to mount two ACROMAGs and their corresponding converters, modems, and terminal blocks. Following is a summary of this work scope:

1. Install NEMA 3R enclosures, ACROMAGs, ACROMAG RS-485 to RS-232 Converters, and modems.

2. Connect all signals between the ACROMAGs, converters, and modems.

3. Connect 120 Vac power to ACROMAG enclosures.

\subsubsection{Software Modifications}

\subsection{TFLAN Programming}

WBS: $5 \mathrm{All}$.

NOTE: TFLAN PLC and HMI programming is covered under Title II detailed design estimate.

Following is a summary of points per facility to be added to the TFLAN progran:

$\begin{array}{ll}\text { AN Farm: } & \text { One signal } \\ \text { AP Farm: } & 11 \text { signals } \\ \text { AW Fann: } & \text { One signal } \\ \text { AY Farm: } & \text { One signal } \\ \text { AZ Farm: } & \text { One signal } \\ \text { SY Farm: } & \text { Zero signals } \\ \text { 244S DCRT: } & \text { Zero signals } \\ \text { 200E/200W: } & 30 \text { signals for 242-A DCS } \\ & 10 \text { signals for 242-A Gamewell }\end{array}$

Total $=55$ signals

\subsection{TMACS Programming}

WBS: None. Other Project Cost (OPC) expense is estimated below to account for modifications to the TMACS software, testing, and engineering change notices (ECNs) for documentation changes to support the Panalarm work scope.

Man-hours per alarm: $\quad 5 \mathrm{M} / \mathrm{H}$

Number of alarms: $\quad 380$ alarms

Total hours $=1,900 \mathrm{M} / \mathrm{H}$ 


\subsubsection{Demolition}

The demolition for each alarm work scope is described below.

\subsection{2-A DCS}

WBS: 5I4F04

The 30 signals ( 60 wires) from the old contacts to the $242-\mathrm{A}$ DCS will be removed and the associated conduit inside the $242-\mathrm{A}$ building will be removed. It is assumed that 500 feet of conduit will require demolition. Where conduit leaves the 242-A building, the wiring will be cut back and the conduit capped and abandoned in place.

\subsection{Gamervell Alarms}

WBS: 5A4J22F, 5B4J22G, 5C4J22E, 5D4J22F, 5E4J22F, 5F4J22E and 5I4F04

Demolition will include the removal of seven Gamewell panels, associated wiring, and conduit. Where the conduit leaves the associated instrument building, the wires will be pulled back and the conduit capped and abandoned in place.

\subsection{Panalarms}

No demolition is anticipated for the Panalam work scope.

\subsubsection{Assumptions}

\subsection{General}

It is assumed that:

1. No radiological work or work in a contaminated area is necessary for this scope and no radiologically contaminated waste will be generated.

2. The new equipment installed will be general service.

3. No conduit will require underground burial. All work is inside work and conduit will be hung per existing requirements for runs inside buildings.

\subsection{2-A DCS}

It is assumed that:

1. Alarm signals to the 242-A DCS will be routed from the TFLAN PLC situated locally at the 242-A Building.

2. The general building alanns will be input to the local TFLAN PLC located in the associated instrument building. Alarm signals to the DCS will be transmitted from the 242-A PLC.

\subsection{Gamevell Alarms}

It is assumed that: 
1. Four of the seven Gamewell alarns have already had their associated signals deactivated or moved to TMACS and the only W-314 Phase 2 work scope required will be demolition of the Gamewell box and associated conduit and wiring.

\subsection{Panalarms}

It is assumed that:

1. There will be adequate room inside the associated instrument buildings to mount the identified equipment.

2. There is adequate space and capacity available in local $120 \mathrm{Vac}$ power distribution panels to supply power to the ACROMAG units.

3. Connection to TMACS will be through ACROMAGs and modems. W-314 work scope does not include installation and connection of telephone lines to the moderns.

4. Programming of the TMACS software to handle new signals will be performed by Operations and funded by Project W-314 Phase 2.

5. Signals from the SST Farm and Hazardous Facilities that are to be connected to TMACS are located in one Panalarm inside an instrument building. 


\subsubsection{REFERENCES}

HNF-4158, Rev B (draft), Level 2 Specifications for Double-Shell Tank Ventilation System, Prepared by Parsons Infrastructure \& Technology Group, July 2, 1999

HNF-S-0400 Rev. 1, Procurement Specification for Gaseous Effluent Monitoring System, dated 1 December 1998

HNF-S-0400, Rev. 1, GEMS Procurement Specification

HNF-SD-W314-RPT-003, Rev.3, Tank Farm Restoration and Safe Operations (TFRSO) Project W-314 Upgrade Scope Summary Report, Prepared by Lockheed Martin Hanford Corporation, July 22,1998

WHC-SD-W314-CDR-001, Rev. 1,Conceptual Design Report, Tank Farm Restoration And Safe Operations, Project W-314, Prepared for Numatec Hanford Corporation, Prepared by Fluor Daniel Northwest, Inc., November 1996

WHC-SD-W420-CDR-001, Rev. 0, Conceptual Design Report

WHC-SD-WM-CR-058, Rev. 0, Gaseous Effluent Monitoring System Design Criteria

WHC-SD-WM-ES-284, Rev 0, DST Ventilation Upgrade Engineering Study, (Tank Farm Restoration and Safe Operations/W-314), Prepared by Westinghouse Hanford Company, February 1994

WHC-SD-WM-TI-612, Rev 0, An Engineering Review of Tank Farm Ventilation Systems, Prepared by Los Alamos Technical Associates Inc., March 1993

\section{DRAWINGS}

Drawing H-2-85646 Rev. 0, sheets 1 through 6, Air Control Station

Drawing H-2-85647 Rev. 0, sheets 1 through 4, Airflow Controller

Drawing H-2-71057 Sheet 1 of 2

Drawing H-2-71047 Rev. 6

Drawing H-2-71048 Rev. 8

Drawing H-2-71085 Rev. 3

Drawing H-2-46786 Rey, 4

Drawing H-2-71050 Rev. 9, Sheet 1 of 2

Drawing H-2-71050 Rev. 2, Sheet 2 of 2 
Drawing H-2-85646 Rev 0, Sheets 1 thru 6

Drawing H-2-85647 Rev 0, Sheets 1 thru 4

Drawing H-14-020231 Sheet 1 of 3

Drawing H-14-020803, Sheets 1-5

Refer to the following drawings and sketches for systems configuration, equipment location, and cabling details as the best available design:

241-AN Tank Farm One-Line Diagram, Figure E-1 (Ref. WHC-SD-W314-CDR-001, Rev. 1).

241-AN Tark Farm Site Plan, Figure P-1. (Ref. WHC-SD-W314-CDR-001, Rev. 1).

Tank Farms Electrical Upgrades Engineering Study, (Tank Farm Restoration and Safe

Operations/W-314) WHC-SD-W314-ES-001, Rev. 1, ECN\#605193).

Drawing H-14-020801, Sheets 1-4.

Drawing $\mathrm{H}-2-140317$.

Pipe Codes M-9 and M-26 extracted from WHC-SD-W314-CDR-001, Rev. 1, pages E-20, 21

WHC-SD-WM-EV-040, Rev, 1, Page A-26

WHC-SD-W314-CDR-001, Rev. 1, Figure P-18

Extract from Drawing No. ES-314E-M40, Rev. 10

Sketch SK-W314-A01 


\subsection{RELATIVE RANKING OF MAJOR UPGRADES}

An effort was undertaken by a multi-discipline team to rank the Project W-314 Phase 2 work scope as identified in the CDR, WHC-SD-W-314 CDR-001 and the W-314 Upgrade Scope Summary Report, HNF-SD-W-314-RPT-003. The identified work scope was ranked in the order of importance to supporting the W-314 and RPP missions. The W-314 Phase 2 work scope was evaluated to determine if any of the identified requirements or needs had changed due to scope that may have already been completed by Operations or other projects, or due to changed operational/programmatic commitments or requirements. HNF-4403, "W-314 Phase 2 Work Scope Final Decision Report", September 1999, discusses this evaluation in detail. Table 4.10.1 below presents in summary the major scope elements of Project W-314 and their relative ranking according to importance in meeting the RPP and Waste Retrieval mission. The identified work is grouped into categories of similar upgrades. The ranking assigned to each work item shows the relative importance compared to all the work items listed. highest priorities indicated are for the 241-A-A bypass line, ventilation upgrades, electrical upgrades, and process pit upgrades.

Table 4.10.1: Relative Ranking of Major Scope Upgrades

\begin{tabular}{|c|c|c|c|}
\hline \multicolumn{4}{|c|}{ REMAINING PHASE 2 SCOPE RELATIVE RANKING } \\
\hline $\mathrm{Ranking}$ & W Majorscope Upgrade 1 & Wanking & WMajorop Uprade \\
\hline & PIPELINE UPGRADES & & ANNULUS LEAK DETECTION \\
\hline 1 & 241-A-A Valve Pit Bypass & 12 & $244-S-D C R T$ \\
\hline & & & \\
\hline & YENTLATION SYS. UPGRADES & & ALARMS \\
\hline 3 & 244-S DCRT & 14 & DST Gamewell Alarms \\
\hline 4 & AN Farm & 15 & 242-A DCS Alarms \\
\hline 5 & SY Fann & 20 & DST Panalarms to TMACS \\
\hline 6 & AP Farm & & \\
\hline 7 & AW Farm & & VAFOR SPACE PRESSURE \\
\hline & & 13 & AZ Farm \\
\hline & ELECTRICAL UPGRADES & 16 & AN Farm \\
\hline 2 & 244-S DCRT (HVAC electrical) & 16 & AW Farm \\
\hline 8 & AN Farm & 16 & SY Farm \\
\hline 8 & AP Farm & 17 & 244-S DCRT \\
\hline 8 & AW Farm & 19 & AP Farm \\
\hline 8 & SY Farm & 23 & AY Farm \\
\hline 11 & AY Fam & & \\
\hline 11 & AZ Farm & & LIQUDD HIGH-LEVEL ALARMS \\
\hline & & 18 & AY Farm \\
\hline & PROCESS PITS & 18 & AZ Farm \\
\hline 9 & AN Farm & 21 & SY Farm \\
\hline 9 & AP Farm & 22 & AN Farm \\
\hline 9 & AW Farm & 22 & AP Farm \\
\hline 9 & SY Farm & 22 & AW Farn \\
\hline 10 & 244-S DCRT (Pump Pit) & & \\
\hline
\end{tabular}




\subsection{CHANGES FROM PREVIOUS BASELINE/TRACEABILITY AND JUSTIFICATION}

The originally identified W-314 Phase 2 work scope was documented in HNF-SD-W314-RPT003, Tank Farm Restoration and Safe Operation Project W-314 Upgrade Scope Summary Report (USSR), Rev. 3, which modified the WHC-SD-W314-CDR-001, Conceptual Design Report for TFRSO, Rev. 1. The CDR-001 provided details of the work to be accomplished and the USSR, Rev, 3 refined that work scope to reflect later changes and requirements. Table 4.11.1 provided below lists each original work scope item, a reference back to the CDR and/or USSR where that work scope item is discussed, indicates if the work scope is still valid or if it has been removed, and a brief statement of reasons why it was retained or removed from the W314 Phase 2 scope.

Table 4.11.1: Changes From Previous Baseline

\begin{tabular}{|c|c|c|}
\hline 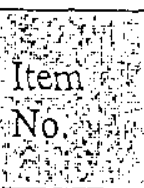 & 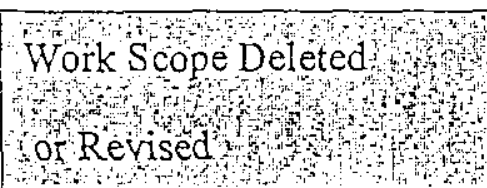 & 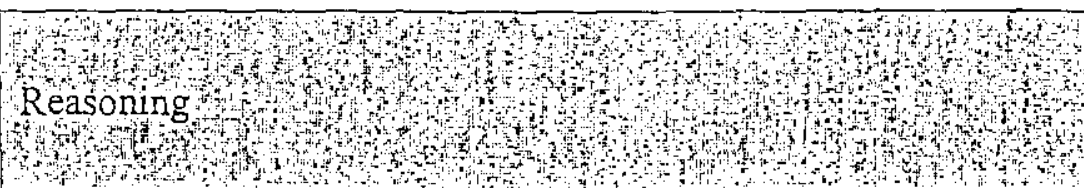 \\
\hline 1. & $\begin{array}{l}244 \text { A DCRT Upgrades } \\
\text { (CDR Pgs. } 68 \text { to } 75 \text { ) }\end{array}$ & $\begin{array}{l}\text { Not required to support retrieval mission. By-pass transfer } \\
\text { pipeline to be installed to support retrieval. . }\end{array}$ \\
\hline 2. & $\begin{array}{l}\text { A Complex Transfer } \\
\text { Piping } \\
\text { (CDR Pg } 84 \text { to } 86 \text { ) }\end{array}$ & $\begin{array}{l}\text { Not required to support retrieval mission. By-pass transfer } \\
\text { pipeline to be installed to support retrieval. }\end{array}$ \\
\hline 3. & $\begin{array}{l}\text { Level Transmitter Cards } \\
\text { (CDR Pg. 11-AN, Pg. 28- } \\
\text { AP, Pg. 35-AW, Pg. 42- } \\
\text { AY, Pg. 50-AZ, Pg. 59- } \\
\text { SY, USSR Pg. 19, 51) }\end{array}$ & Completed by plant forces. \\
\hline 4. & $\begin{array}{l}\text { DST Annulus CAMs } \\
\text { (CDR Pg. 13-AN, Pg. 29- } \\
\text { AP, Pg. 36-AW, Pg. 43- } \\
\text { AY, Pg. 51-AZ, Pg. 60- } \\
\text { SY, Pg. } 77244-S \text { DCRT, } \\
\text { USSR Pg. 18, 39) }\end{array}$ & To be installed now by plant forces. \\
\hline 5. & $\begin{array}{l}\text { Gamma Probes } \\
\text { (CDR Pg. Pg. 13-AN, Pg. } \\
\text { 29-AP, Pg. 36-AW, Pg. } \\
\text { 43-AY, Pg. 51-AZ, Pg. } \\
\text { 60-SY) }\end{array}$ & $\begin{array}{l}\text { Gamma probes no longer required by Operations. All scope in } \\
\text { Leak Detector Pits was deleted. Leak Detector Pits are not } \\
\text { required to support retrieval. Leak Detector Pits are not on the } \\
\text { active waste transfer system. }\end{array}$ \\
\hline
\end{tabular}




\begin{tabular}{|c|c|c|}
\hline 6. & $\begin{array}{l}\text { Clean-Out Boxes (COBs) } \\
\text { (CDR. Pg. 14-AN, Pg. } \\
\text { 36-AW, Pg. 44-AY, Pg. } \\
\text { 52-AZ, Pg. 60-SY, USSR } \\
\text { Pg. } 18,42 \text { ) }\end{array}$ & $\begin{array}{l}\text { All COBs in the waste transfer route have already received } \\
\text { intrinsically safe relays. A-Complex COBs in AY and AZ tank } \\
\text { farms are no longer required. Pipelines with these COBs are } \\
\text { not part of the active waste transfer system. }\end{array}$ \\
\hline 7. & $\begin{array}{l}\text { Move SY alarms from } \\
\text { 242- S } \\
\text { (CDR. Pg 63, 84, USSR } \\
\text { Pg. } 19,22,58)\end{array}$ & $\begin{array}{l}\text { No longer necessary. } 242-S \text { control room will be utilized for } \\
\text { cross-site transfers. }\end{array}$ \\
\hline 8. & $\begin{array}{l}244 \mathrm{~S} \text { DCRT } 13.8 \mathrm{kVA} / 480 \\
\text { VAC electrical upgrade } \\
\text { (CDR Pg. } 75, \text { USSR Pg. } \\
20,61)\end{array}$ & Being installed by plant forces in FY 99. \\
\hline 9. & $\begin{array}{l}\text { FIC liquid level instrument } \\
\text { replacement. } \\
\text { (CDR Pg. 11-AN, Pg. 28- } \\
\text { AP, Pg. 35-AW, Pg. 42- } \\
\text { AY, Pg. 50-AZ, Pg. 76- } \\
\text { 244-S DCRT, USSR Pg. } \\
\text { 19,51) }\end{array}$ & Being installed by plant forces in FY 96 thru FY 99. \\
\hline 10. & $\begin{array}{l}\text { SY primary ventilation } \\
\text { support systems } \\
\text { (CDR Pg. 61, 62, USSR } \\
\text { Pg. 53) }\end{array}$ & $\begin{array}{l}\text { New program strategy being developed by the program office } \\
\text { to address SY ventilation. }\end{array}$ \\
\hline 11. & $\begin{array}{l}\text { Central Pump Pits AP 02A, } \\
\text { 04A } \\
\text { (CDR Pg. 14,23, USSR } \\
\text { Pg. } 18,28,43 \text { ) }\end{array}$ & $\begin{array}{l}\text { W-211 completes the required upgrades in AP-02A and AP- } \\
\text { 04A. } \\
\text { W-314 Phase } 2 \text { installs a new leak detector, drain plug } \\
\text { assembly, and SPC in } 20 \mathrm{CPP} \text { : AN 02A, 03A, 05A, 06A, } \\
\text { 07A, AP 01A, 03A, 05A, 06A, 07A, O8A, AW 01A, 02A, } \\
\text { 03A, 04A, 05A, 06A, AY SY 01A, 02A, and 03A. } \\
\text { NOTE: All remaining pit work will be coordinated by Life- } \\
\text { Cycle Projects to minimize required pit entries and reduce } \\
\text { costs. }\end{array}$ \\
\hline 12. & $\begin{array}{l}\text { Annulus Pump Pits (28 } \\
\text { Total) } \\
\text { (CDR Pg. 14, 23-AN, Pg. } \\
\text { 29, 31-AP, Pg. 36, 38- } \\
\text { AW, Pg. 43, 46-AY, Pg. }\end{array}$ & $\begin{array}{l}\text { An Emergency Annulus Pumping Plan for all DST annuli } \\
\text { (including SY Farm) was delivered to Ecology in June 1999. It } \\
\text { outlines several options for pumping a DST annulus in the } \\
\text { unlikely event of a leak. It does not include prior upgrading of } \\
\text { all annulus pump pits. Option five (the preferable option) does }\end{array}$ \\
\hline
\end{tabular}




\begin{tabular}{|c|c|c|}
\hline & $\begin{array}{l}\text { 52, 54-AZ, Pg. } 60,64-S Y \\
\text { USSR Pg. } 18,28,43)\end{array}$ & $\begin{array}{l}\text { not include the use of the annulus pump pits (pumps directly } \\
\text { from an annulus riser back to the primary tank). There } \\
\text { nomally would be no transfers through these pits unless the } \\
\text { primary tank leaks. To upgrade now is deemed unwartanted. } \\
\text { The same is true for the transfer lines and encasement leak } \\
\text { detection going to/from the annulus pits. }\end{array}$ \\
\hline 13. & $\begin{array}{l}\text { Leak Detection Pits (28 } \\
\text { total) and sumps } \\
\text { (CDR Pg. 13, 23-AN, Pg. } \\
\text { 29, 31-AP, Pg. 36, 38- } \\
\text { AW, Pg. 43, 46-AY, Pg. } \\
\text { 51, 54-AZ, Pg. 60, 64-SY, } \\
\text { USSR Pg. } 18,28,40)\end{array}$ & $\begin{array}{l}\text { All work scope deleted (gamma probes, leak detectors, drain } \\
\text { plug assembly, and SPC) including pipe encasements. No } \\
\text { Regulatory, Operations, or Programmatic driver to perform this } \\
\text { work. }\end{array}$ \\
\hline 14. & $\begin{array}{l}\text { Service Pits (AN, AP, AW, } \\
\text { SY, 244-S DCRT, AY, } \\
\text { AZ) } \\
\text { (CDR Pg. 13, 14, 23-AN, } \\
\text { Pg. 28, 29, 31-AP, Pg. 36, } \\
38-A W, P g . ~ 43,46- \\
\text { AY/AZ, Pg. 54-AZ, Pg. } \\
\text { 59, 60, 64-SY, Pg. 76- } \\
\text { 244-S DCRT, USSR Pg. } \\
\text { 18, 19, 28, 43, 48, 49) }\end{array}$ & $\begin{array}{l}\text { Phase } 2 \text { scope was only: leak detector, and/or SPC, and/or water } \\
\text { meter, depending on the specific service pit. AN, AP, AW, SY, } \\
\text { and } 244-\mathrm{S} \text { DCRT do not require a leak detector, radiation back } \\
\text { flow detectors or SPC because they never receive waste. The } \\
\text { existing water meters are operating fine and meet Operations } \\
\text { requirements. Should Operations encounter problems with any } \\
\text { service pit, Operations Maintenance would immediately act } \\
\text { rather than wait for a capital funded project to provide the fix. } \\
\text { These pits are not required to meet the M- } 43 \text { compliance } \\
\text { milestone or Phase } 1 \text { of privatization. AY and AZ pits are no } \\
\text { longer required ("green field line"). }\end{array}$ \\
\hline 15 & $\begin{array}{l}\text { Flush Pits (AN, AP, AW, } \\
\text { SY-A, SY-B) } \\
\text { (CDR Pg. 14, 23-AN, Pg. } \\
\text { 29, 31-AP, Pg. 36, 38- } \\
\text { AW, Pg. 60, 64-SY, Pg. } \\
\text { 77- 244-S DCRT, USSR } \\
\text { Pg. 18, 19, 21, 22, 28, 43) }\end{array}$ & $\begin{array}{l}\text { Phase } 2 \text { scope for flush pits was only to install leak } \\
\text { detection in AN, AP, AW (also to receive a water meter), } \\
\text { SY-A, and SY-B (also to receive a drain plug assembly). } \\
\text { - Flush pits see only raw, uncontaminated water and are not } \\
\text { necessary to support waste transfer or compliance } \\
\text { requirements. } \\
\text { - Project W-058 bypassed the SY-A and SY-B flush pits. } \\
\text { The nozzle from the flushing system has been blanked off. } \\
\text { - Flush Pit SY-02E serves as a central pump pit and does see } \\
\text { contaminated water. Phase } 2 \text { will install an intrinsically } \\
\text { safe leak detector with signal to local TFLAN PLC, drain } \\
\text { plug assembly, and SPC. }\end{array}$ \\
\hline 16. & $\begin{array}{l}\text { Encasement Drain Pits } \\
\text { (AY, AZ) } \\
\text { (CDR Pg. 43, 46-AY, Pg. } \\
\text { 51, 54-AZ, USSRPg. 18, }\end{array}$ & $\begin{array}{l}\text { All work scope deleted (leak detector, drain plug assembly, and } \\
\text { SPC), including pipe encasements. No Regulatory, Operations, } \\
\text { or Programmatic driver to perform this work. }\end{array}$ \\
\hline
\end{tabular}




\begin{tabular}{|c|c|c|}
\hline & $28,43)$ & \\
\hline 17. & $\begin{array}{l}\text { Sluice Pits (AY-01B, 01C, } \\
01 \mathrm{D}, 01 \mathrm{E}, 02 \mathrm{~B}, 02 \mathrm{C}, 02 \mathrm{D}, \\
02 \mathrm{E}, \mathrm{AZ}-01 \mathrm{~B}, 01 \mathrm{C}, 02 \mathrm{~B}, \\
\text { and } 02 \mathrm{C} \text { ), including } \\
\text { pipeline encasement leak } \\
\text { detection. } \\
\text { (CDR Pg. 43, 46-AY, Pg. } \\
52,54-\mathrm{AZ}, \mathrm{USSR} \text { Pg. 18, } \\
28,43 \text { ) }\end{array}$ & $\begin{array}{l}\text { Project W- } 521 \text { is installing pumps in the four AY-101 sluice } \\
\text { pits, including a leak detector, drain plug assembly, and } \\
\text { SPC. By installing mixer pumps, these pits are removed } \\
\text { from the active transfer system. In addition, the AY- } \\
101 \text { sluice pits will not be used after June } 2005 \text { (while they } \\
\text { are non-compliant) until the pit upgrade is completed by W- } \\
521 \text { (making them compliant). } \\
\text { - Project W-211 is installing mixer pumps in each of the AY- } \\
102 \text { pits, including a leak detector and drain plug. } \\
\text { Once W-314 Phase } 1 \text { (new "green field" line) is completed AZ } \\
\text { sluice pits } 01 \mathrm{~B}, 01 \mathrm{C}, 02 \mathrm{~B} \text { and } 02 \mathrm{C} \text { will no longer be part of the } \\
\text { active waste transfer system. }\end{array}$ \\
\hline 18. & $\begin{array}{l}\text { AN Condensate Receiver } \\
\text { Pit } \\
\text { (CDR Pg. 14, 23-AN, } \\
\text { USSR Pg. } 43 \text { ) }\end{array}$ & $\begin{array}{l}\text { The condensate receiver pit is no longer in use and the } \\
\text { condensate from ventilation systems is no longer routed through } \\
\text { this pit. This pit is not part of the active waste transfer system. }\end{array}$ \\
\hline 19 & $\begin{array}{l}\text { AN Supernate Receiver } \\
\text { Pit. } \\
\text { (CDR Pg. 14, 23-AN, } \\
\text { USSR Pg. 43) }\end{array}$ & $\begin{array}{l}\text { Waste transfers involving this pit will no longer occur } \\
\text { following completion of interim stabilization of A-101/AX-101 } \\
\text { by September } 2003 \text {, at which time the transfer routes involving } \\
\text { this pit will be deactivated. This pit is not part of the active } \\
\text { waste transfer system. }\end{array}$ \\
\hline 20. & $\begin{array}{l}\text { AP Mixer Pump Pits, AP- } \\
\text { 07D, 07E, and 07F } \\
\text { (CDR Pg. 29, 31, USSR } \\
\text { Pg. 43) }\end{array}$ & $\begin{array}{l}\text { The mixer pump pits are not part of the active waste transfer } \\
\text { system. There are no transfer pipelines that lead into or from } \\
\text { these pits. }\end{array}$ \\
\hline 21. & $\begin{array}{l}\text { AP Jumper Storage Pit } \\
\text { (CDR Pg. 29, 31-AP, } \\
\text { USSR Pg. 43) }\end{array}$ & $\begin{array}{l}\text { The function of this pit is to store AP jumpers. It is not an } \\
\text { integral part of the waste transfer system. It is completely } \\
\text { isolated. }\end{array}$ \\
\hline 22. & $\begin{array}{l}\text { 244-S DCRT Filter Pit } \\
\text { (CDR Pg. 80) }\end{array}$ & $\begin{array}{l}\text { - Original scope called for complete demolition of this } \\
\text { concrete pit. } \\
\text { - Current plan is to re-use this pit, removing existing jumpers } \\
\text { and installing a non-filtered duct jumper. }\end{array}$ \\
\hline 23. & $\begin{array}{l}\text { DST waste temperature } \\
\text { measuring devices } \\
\text { (CDR Pg. 12-AN, Pg. 28- } \\
\text { AP, Pg. 35-AW, Pg. 42- } \\
\text { AY, Pg. 50-AZ, USSR Pg. } \\
\text { 18,51) }\end{array}$ & $\begin{array}{l}\text { To be done by Retrieval Projects as required. No need to } \\
\text { replace until mixer pump installed. }\end{array}$ \\
\hline
\end{tabular}




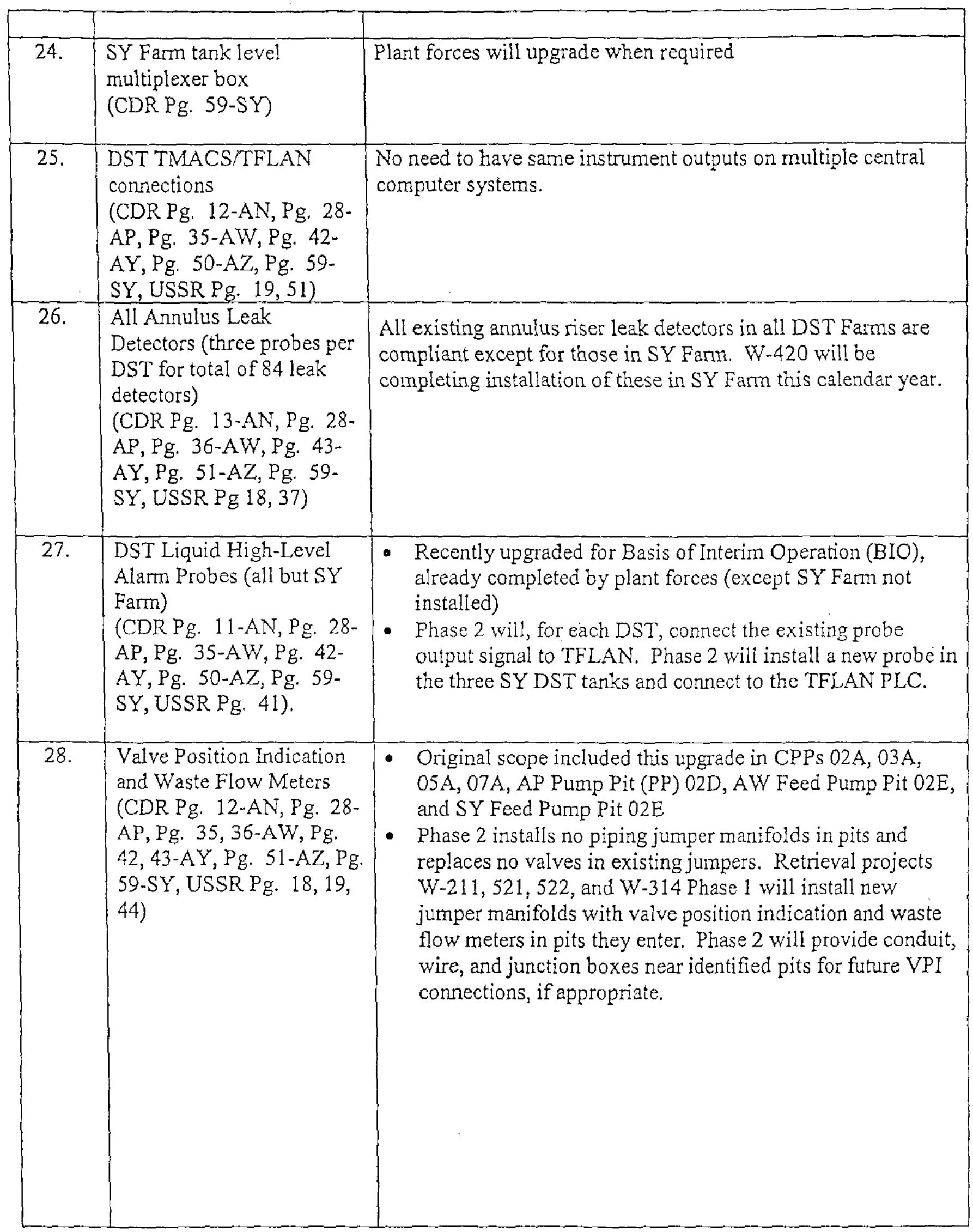




\begin{tabular}{|c|c|c|}
\hline 29. & $\begin{array}{l}\text { AN, AP, AW Primary } \\
\text { Ventilation Scope } \\
\text { Revisions (Current } \\
\text { Requirements) } \\
\text { - Dual Stack reduced to } \\
\text { single stack design } 30 \\
\text { ft high } \\
\text { - Condensate seal pot pit } \\
\text { and associated leak } \\
\text { detector } \\
\text { - Double-encased drain } \\
\text { lines reduced to single } \\
\text { pipe } \\
\text { - Motorized isolation } \\
\text { valves reduced to } \\
\text { manually operated } \\
\text { - Primary Ventilation } \\
\text { Inlet Filters and } \\
\text { Pressure Vacuum } \\
\text { Relief Devices (AN } \\
\text { and AW only) } \\
\text { - Refit Pad } \\
\text { - No lighting } \\
\text { - No Shielding } \\
\text { - No Cover } \\
\text { - PLC controlled with } \\
\text { manual operation } \\
\text { override } \\
\text { - Minimum remote } \\
\text { monitoring } \\
\text { - Use existing power } \\
\text { source } \\
\text { (CDR Pg. 20-AN, Pg. } 31- \\
\text { AP, Pg. 37-AW, USSR } \\
\text { Pg. } 18,34 \text { ) } \\
\text { Po }\end{array}$ & Safety Program already has completed this scope. \\
\hline 30. & $\begin{array}{l}\text { Primary ventilation inlet } \\
\text { stations in AN/AW Farms } \\
\text { (CDR Pg. 21-AN, Pg. 38- } \\
\text { AW, USSR Pg. 18, 34) }\end{array}$ & Safety program upgrade already completed this work. \\
\hline
\end{tabular}




\begin{tabular}{|c|c|c|}
\hline 31. & $\begin{array}{l}\text { SY primary stack monitor } \\
\text { (CDR Pg. 63-SY, USSR } \\
\text { Pg. 19,54) }\end{array}$ & $\begin{array}{l}\text { To be accomplished with SY ventilation upgrade strategy being } \\
\text { developed by the RPP Programs. }\end{array}$ \\
\hline 32 & $\begin{array}{l}\text { SY Annulus Ventilation } \\
\text { Scope Revisions. } \\
\text { - Single train similar to } \\
\text { existing site portable } \\
\text { systems } \\
\text { - Refit pad } \\
\text { - No lighting } \\
\text { - No shielding } \\
\text { - No cover } \\
\text { - Manually operated } \\
\text { - system (no PLC) } \\
\text { Minimum remote } \\
\text { monitoring } \\
\text { - Use existing power } \\
\text { source } \\
\text { (CDR Pg. 64-SY, USSR } \\
\text { Pg. } 18,35 \text { ) }\end{array}$ & $\begin{array}{l}\text { Modified design meets regulatory requirements and reduces } \\
\text { complexity and maintenance requirements. }\end{array}$ \\
\hline 33. & $\begin{array}{l}\text { 244-S DCRT Primary } \\
\text { Ventilation Scope } \\
\text { Revisions. } \\
\text { - Annulus inlet filters } \\
\text { deleted } \\
\text { - Primary inlet filter } \\
\text { added. } \\
\text { - Re-use existing filter } \\
\text { pit. Remove existing } \\
\text { jumpers and replace } \\
\text { with non-restricted } \\
\text { jumpers } \\
\text { - Manually-operated } \\
\text { system only (No PLC) } \\
\text { - Incorporates Project } \\
\text { W-420 installed GEMS } \\
\text { system } \\
\text { - No demister } \\
\text { (CDR Pg. 78- 244-S } \\
\text { DCRT, USSR Pg. 18, 36) } \\
\text { NOTE: If use of portable }\end{array}$ & $\begin{array}{l}\text { Modified design meets regulatory yequirements and reduces } \\
\text { complexity and maintenance requirements. }\end{array}$ \\
\hline
\end{tabular}


HNF-5 109, Rev. 0

\begin{tabular}{|c|c|c|}
\hline & $\begin{array}{l}\text { exhauster approved, } \\
\text { delete DCRT ventilation } \\
\text { upgrades completely. }\end{array}$ & \\
\hline 34. & $\begin{array}{l}\text { AY Tank Farm electrical } \\
\text { scope for HVAC control } \\
\text { panels and associated } \\
\text { heater controllers. } \\
\text { (CDR Pg. } 41-\mathrm{AY} \text {, USSR } \\
\text { Pg. } 19,59)\end{array}$ & $\begin{array}{l}\text { HVAC system was recently replaced in AY/AZ Farms and } \\
\text { meets all minimum requirements. }\end{array}$ \\
\hline 35. & $\begin{array}{l}\text { SST Upgrades, all } \\
\text { upgrades deleted. } \\
\text { (CDR Pg.67, 68-SSTs, } \\
\text { USSR Pg. 63) }\end{array}$ & $\begin{array}{l}\text { - Originally scoped to provide } 13.8 \mathrm{kV} / 480 \text { Vac transformers, } \\
\text { power meters, } 480 \mathrm{Vac} \text { power stations, mini power stations, } \\
\text { circuit breakers, steel racks, and lighting power. } \\
\text { - Not required to support retrieval mission. }\end{array}$ \\
\hline 36. & $\begin{array}{l}\text { AN/AP 242-A DCS signal } \\
\text { sharing with TFLAN. } \\
\text { (CDRPg. 18-AN, Pg. 33- } \\
\text { AP) }\end{array}$ & The evaporator does not need this information any longer. \\
\hline \multicolumn{3}{|c|}{ 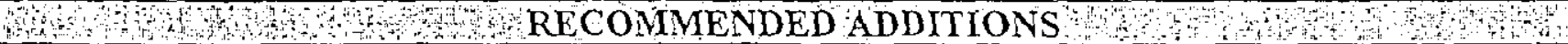 } \\
\hline 40. & $\begin{array}{l}\text { Add a diesel generator } \\
\text { power receptacle in SY } \\
\text { Tank Farm ventilation } \mathrm{MCC}\end{array}$ & $\begin{array}{l}\text { To correct mission in the CDR estimate. Needed to support } \\
\text { retrieval mission. }\end{array}$ \\
\hline
\end{tabular}




\subsection{ENVIRONMENTAL PERMITTING}

Environmenta1/pennitting documentation requirements for the TFRSO project have been developed consistent with the guidance in GPG-FM-021, Environmental Interfaces. Phase 2 permitting and required regulatory tasks are summarized in Table 5.1. A more thorough discussion of the required Air Permits, Resource Conservation and Recovery Act (RCRA), Dangerous Waste Regulations, and the National Environmental Policy Act is presented in the HNF-SD-W-314-PMP-001, Rev.3, Project Execution Plan, Tank Farm Restoration and Safe Operations, Project W-314. Further detailed definition and discussion of the above mentioned subjects is also available in HNF-3054, Rev. 0, Project W-314 Phase 1 Environmental Permits and Approvals Plan.

Phase 2 Permit Approval/ Requirement planning assumptions are summarized in Table 5.2.

\section{Table 5.1: Project W-314 Phase 2 Permits and Approvals}

\begin{tabular}{|c|c|c|c|c|}
\hline $\begin{array}{l}\text { Affected } \\
\text { Environment }\end{array}$ & $\begin{array}{l}\text { Pemit, Approvalor } \\
\text { Requirement }\end{array}$ & $\begin{array}{l}\text { Regulation } \\
\text { or Standard }\end{array}$ & $\begin{array}{l}\text { Resporsible } \\
\text { Agericy }\end{array}$ & $\begin{array}{l}\text { Applicabilify } \\
\text { (yes or no and assumed action) }\end{array}$ \\
\hline NEPA & NEPA Documentation & $\begin{array}{l}40 \text { CFR } 1500-1508 \\
10 \text { CFR } 1021 \\
\text { DOE Order } 451.1 \mathrm{~A}\end{array}$ & DOE & $\begin{array}{l}\text { Yes. } \\
\text { Review planned scope of work to } \\
\text { assure bounding of project scope } \\
\text { by existing NEPA } \\
\text { documentation (e.g., Tank Waste } \\
\text { Remediation System } \\
\text { Environmental Impact Statement }\end{array}$ \\
\hline SEPA & SEPA Documentation & WAC 197-11 & Ecology & $\begin{array}{l}\text { Yes. } \\
\text { Ecology will review the SA. No } \\
\text { separate SEPA Checklist will be } \\
\text { required. }\end{array}$ \\
\hline \multirow[t]{2}{*}{ All Media } & $\begin{array}{l}\text { Cultural Resource } \\
\text { Review }\end{array}$ & $\begin{array}{l}10 \text { CFR } 1021 \\
36 \text { CFR } 63 \\
36 \text { CFR } 800 \\
43 \text { CFR } 7\end{array}$ & $\left\{\begin{array}{l}\text { DOE } \\
\text { State Historic } \\
\text { Preservation } \\
\text { Office }\end{array}\right.$ & $\begin{array}{l}\text { Yes. } \\
\text { CRR has been approved for work } \\
\text { inside tank farms. Any work } 150 \\
\text { meters outside the existing fence, } \\
\text { removal of existing tanks, } \\
\text { modification or demolishing } \\
\text { existing structures will require a } \\
\text { separate CRR. }\end{array}$ \\
\hline & $\begin{array}{l}\text { Ecological Compliance } \\
\text { Review }\end{array}$ & $\begin{array}{l}10 \text { CFR } 1021 \\
\text { DOE Order } 5484.1 \\
50 \text { CFR } 17 \\
50 \text { CFR } 402.6 \\
\text { WAC } 232-12\end{array}$ & $\left\{\begin{array}{l}\text { DOE } \\
\text { USFWS } \\
\text { Ecology }\end{array}\right.$ & $\begin{array}{l}\text { Yes. } \\
\text { Annual update to the RPP } \\
\text { blanket tank farms ECR will be } \\
\text { required prior to start of } \\
\text { construction. If outside the } \\
\text { boundaries specified in the tark } \\
\text { farm ECR, a separate one would } \\
\text { be required. The annual update } \\
\text { to the tank farms ECR will be } \\
\text { reviewed for restrictions and/or } \\
\text { other impacts prior to obtaining } \\
\text { excavation permit }\end{array}$ \\
\hline
\end{tabular}


HNF-5109, Rev. 0

\begin{tabular}{|c|c|c|c|c|}
\hline \multirow[t]{3}{*}{ All Media } & $\begin{array}{l}\text { American Indian } \\
\text { Policies Review }\end{array}$ & $\begin{array}{l}\text { DOE } 1230.2 \\
\text { 42 USC } 1966\end{array}$ & $\begin{array}{l}\mathrm{DOE} \\
\mathrm{BIA}\end{array}$ & No. \\
\hline & Excavation Permit & 36 CFR 800 & $D O E$ & $\begin{array}{l}\text { Yes. } \\
\text { Includes review of NOC } \\
\text { conditions, \& review of } \\
\text { ECR/CRR. }\end{array}$ \\
\hline & $\begin{array}{l}\text { Preoperational } \\
\text { Monitoring of Facility, } \\
\text { Site, and Operations }\end{array}$ & DOE Order 5400.1 & $D O E$ & $\begin{array}{l}\text { Yes. } \\
\text { Document in memo-to-file the } \\
\text { conclusion that existing tank } \\
\text { farm monitoring will be } \\
\text { sufficient. }\end{array}$ \\
\hline & $\begin{array}{l}\text { General Public \& } \\
\text { Environmental } \\
\text { Protection; } \\
\text { Radiation Protection } \\
\text { Standards }\end{array}$ & $\begin{array}{l}\text { DOE Order } 5400.1 \\
\text { DOE Order } 5400.5\end{array}$ & $D O E$ & $\begin{array}{l}\text { Yes. } \\
\text { Covered by compliance with } \\
\text { radiological/ALARA } \\
\text { requirements in work packages } \\
\text { during construction. }\end{array}$ \\
\hline $\begin{array}{l}\text { All Air } \\
\text { Emissions }\end{array}$ & Air Operating Permit & WAC $173-401$ & $\begin{array}{l}\text { Ecology } \\
\text { WDOH } \\
\text { EPA }\end{array}$ & $\begin{array}{l}\text { Yes. } \\
\text { AOP will require revision for } \\
\text { both radionuclide and non- } \\
\text { radionuclide air emissions. } \\
\text { Prepare AOP modification } \\
\text { requests in parallel with NOC } \\
\text { development. }\end{array}$ \\
\hline \multirow[t]{4}{*}{$\begin{array}{l}\text { Non-Radioactive } \\
\text { Air Emissions }\end{array}$} & $\begin{array}{l}\text { New Source Review; } \\
\text { Source Registration }\end{array}$ & $\begin{array}{l}\text { WAC } 173-400-110 \\
\text { WAC } 173-400-101\end{array}$ & Ecology & $\begin{array}{l}\text { Yes. } \\
\text { Perform review in parallel with } \\
\text { the WAC } 173-460 \text { applicability } \\
\text { evaluation. }\end{array}$ \\
\hline & $\begin{array}{l}\text { Substantial Aiteration } \\
\text { of Emission Control } \\
\text { Technology }\end{array}$ & $\overline{\text { WAC } 173-400-114}$ & Ecology & $\begin{array}{l}\text { Yes. } \\
\text { Review will be performed in } \\
\text { parallel with the WAC } 173-460 \\
\text { applicability evaluation. }\end{array}$ \\
\hline & $\begin{array}{l}\text { Prevention of } \\
\text { Significant } \\
\text { Deterioration }\end{array}$ & WAC $173-400-141$ & Ecology & $\begin{array}{l}\text { Yes. } \\
\text { Criteria Pollutant evaluation } \\
\text { (e.g., particulate) will be } \\
\text { performed in parallel with the } \\
\text { WAC } 173-460 \text { applicability } \\
\text { evaluation. }\end{array}$ \\
\hline & $\begin{array}{l}\text { Toxic Air Pollutants } \\
\text { (TAP) NOC; } \\
\text { New Source Review }\end{array}$ & $\begin{array}{l}\text { WAC } 173-460-030 \\
\text { WAC } 173-460-040\end{array}$ & Ecology & $\begin{array}{l}\text { Yes. } \\
\text { Perform WAC } 173-460 \\
\text { applicability evaluation. Prepare } \\
\text { an application for approval to } \\
\text { construct and operate all } \\
\text { upgrades necessary to retrieve } \\
\text { and deliver waste from each tank } \\
\text { (assume five NOC applications } \\
\text { will be required). }\end{array}$ \\
\hline
\end{tabular}




\begin{tabular}{|c|c|c|c|c|}
\hline $\begin{array}{l}\text { Radioactive } \\
\text { Air Emissions }\end{array}$ & $\begin{array}{l}\text { Source ReviewNOC; } \\
\text { Radiation Protection - } \\
\text { Air Emissions }\end{array}$ & $\begin{array}{l}\text { WAC 246-247-060 } \\
\text { WAC 246-247 }\end{array}$ & WDOH & $\begin{array}{l}\text { Yes. } \\
\text { Prepare an application for } \\
\text { approval to construct and operate } \\
\text { all upgrades necessary to retrieve } \\
\text { and deliver waste feed from each } \\
\text { tank (assume five NOC } \\
\text { applications will be required). }\end{array}$ \\
\hline $\begin{array}{l}\text { Radioactive } \\
\text { Air Emissions }\end{array}$ & NESHAP & 40 CFR 61 Subpart H & EPA & $\begin{array}{l}\text { Yes. } \\
\text { Prepare an application for } \\
\text { approval to construct and operate } \\
\text { all upgrades necessary to retrieve } \\
\text { and deliver waste feed from each } \\
\text { tank (assume five NOC } \\
\text { applications will be required). }\end{array}$ \\
\hline \multirow[t]{2}{*}{$\begin{array}{l}\text { Domestic Waste } \\
\text { Water Disposal }\end{array}$} & $\begin{array}{l}\text { Septic Systems } \\
<14,500 \text { gpd capacity }\end{array}$ & WAC $246-272$ & WDOH & No. \\
\hline & $\begin{array}{l}\text { Septic Systems } \\
>14,500 \text { gpd capacity }\end{array}$ & $\begin{array}{l}\text { WAC } 173-216 \\
\text { WAC } 173-240 \\
\text { WAC } 173-221,-221 \text { A }\end{array}$ & Ecology & No. \\
\hline \multirow[t]{4}{*}{$\begin{array}{l}\text { Storn Water } \\
\text { Disposal }\end{array}$} & $\begin{array}{l}\text { Storm Water Discharge } \\
\text { Under General Permit }\end{array}$ & $\begin{array}{l}40 \text { CFR } 122 \\
\text { WAC } 173-226\end{array}$ & $\begin{array}{l}\text { EPA } \\
\text { Ecology }\end{array}$ & No. \\
\hline & $\begin{array}{l}\text { Storm Water } \\
\text { Discharge Under UIC } \\
\text { Permit }\end{array}$ & WAC $173-218$ & Ecology & No. \\
\hline & $\begin{array}{l}\text { Engineering Approval; } \\
\text { System ID. Number }\end{array}$ & WAC $246-290$ & $\mathrm{WDOH}$ & No. \\
\hline & Operator Certification & WAC 246-292 & WDOH & No. \\
\hline $\begin{array}{l}\text { Radioactive } \\
\text { Waste } \\
\text { Management }\end{array}$ & $\begin{array}{l}\text { Reprocessing, } \\
\text { Management, or } \\
\text { Disposal of Spent } \\
\text { Nuclear Fuel }\end{array}$ & $\begin{array}{l}\text { DOE Order 5820.2A } \\
\text { DOE Order 6430.1A } \\
10 \text { CFR } 952 \\
40 \text { CFR } 191\end{array}$ & $\begin{array}{l}\text { DOE } \\
\text { EPA } \\
\text { NRC }\end{array}$ & $\begin{array}{l}\text { Yes. } \\
\text { Covered by RPP procedures and } \\
\text { requirements in Work Packages. }\end{array}$ \\
\hline Solid Waste & $\begin{array}{l}\text { Solid Waste } \\
\text { Management }\end{array}$ & $\begin{array}{l}\text { WAC } 173-\overline{304} \\
\text { DOE } 5400.1\end{array}$ & $\begin{array}{l}\text { Ecology } \\
\text { DOE } \\
\text { BCHD }\end{array}$ & No. \\
\hline \multirow[t]{2}{*}{ Dangerous Waste } & $\begin{array}{l}\text { Dangerous Waste } \\
\text { Management }\end{array}$ & $\begin{array}{l}\text { WAC 173-303 } \\
40 \text { CFR } 260 \text { through } \\
268\end{array}$ & $\begin{array}{l}\text { Ecology } \\
\text { EPA }\end{array}$ & $\begin{array}{l}\text { Yes. } \\
\text { It is assumed the DST System } \\
\text { RCRA Part B Permit will be } \\
\text { issued. Modifications could } \\
\text { cause a delay of up to } 12 \text { months } \\
\text { between completion of design } \\
\text { and obtaining approval to } \\
\text { construct. Design submittal will } \\
\text { be critical to minimize potential } \\
\text { impacts to the project. Permit } \\
\text { negotiations will be monitored } \\
\text { closely to determine alt. } \\
\text { strategies to avoid delays. }\end{array}$ \\
\hline & Notice of Intent (NOI) & WAC 173-303-281 & Ecology & No. \\
\hline USTS & $\begin{array}{l}\text { Underground Storage } \\
\text { Tank Permit }\end{array}$ & $\begin{array}{l}\text { WAC } 173-360 \\
40 \text { CFR } 280\end{array}$ & $\begin{array}{l}\text { Ecology } \\
\text { EPA }\end{array}$ & No. \\
\hline
\end{tabular}


HNF-5109, Rev. 0

\begin{tabular}{|c|c|c|c|c|}
\hline $\begin{array}{l}\text { Affected } \\
\text { Environment }\end{array}$ & $\begin{array}{l}\text { Pemit, Approval or } \\
\text { Requirement }\end{array}$ & $\begin{array}{l}\text { Regulation } \\
\text { or Standadd }\end{array}$ & $\begin{array}{l}\text { Responsible } \\
\text { Agency }\end{array}$ & $\begin{array}{l}\text { Applicability } \\
\text { (yes or no and assumed action) }\end{array}$ \\
\hline \multirow[t]{6}{*}{$\begin{array}{l}\text { Special } \\
\text { Substances }\end{array}$} & $\begin{array}{l}\text { Polychlorinated } \\
\text { biphenyl's }\end{array}$ & $\begin{array}{l}40 \text { CFR } 761 \\
\text { WAC } 173-303\end{array}$ & $\begin{array}{l}\text { EPA } \\
\text { Ecology }\end{array}$ & $\begin{array}{l}\text { Yes. } \\
\text { This is covered by the DST } \\
\text { Waste Acceptance Criteria } \\
\text { review prior to any waste } \\
\text { transfer. }\end{array}$ \\
\hline & Used oils & $\begin{array}{l}\text { WAC } 173-303 \\
40 \text { CFR } 279\end{array}$ & $\begin{array}{l}\text { Ecology } \\
\text { EPA }\end{array}$ & No. \\
\hline & Asbestos & $\begin{array}{l}\text { BCCAA Reg. } 1, \\
\text { Article } 8 \\
40 \text { CFR } 61\end{array}$ & $\begin{array}{l}\mathrm{BCCAA} \\
\mathrm{EPA}\end{array}$ & No. \\
\hline & $\begin{array}{l}\text { Chlorofluoro- } \\
\text { Carbons } \\
\text { Ozone Depleting } \\
\text { Substances }\end{array}$ & 40 CFR 82 & $\overline{E P A}$ & $-1-1-1$ \\
\hline & $\begin{array}{l}\text { Pollution Prevention } \\
\text { Plans for Hazardous } \\
\text { Substances and Wastes }\end{array}$ & WAC $173-307$ & Ecology & $\begin{array}{l}\text { Yes. } \\
\text { This is covered by RPP internal } \\
\text { procedures. }\end{array}$ \\
\hline & $\begin{array}{l}\text { Notification } \\
\text { Reporting of } \\
\text { Hazardous Materials } \\
\text { Spills/Releases }\end{array}$ & $\begin{array}{l}40 \text { CFR } 302 \\
40 \text { CFR } 372 \\
\text { WAC } 173-340\end{array}$ & $\begin{array}{l}\text { EPA } \\
\text { Ecology }\end{array}$ & $\begin{array}{l}\text { Yes. } \\
\text { This is covered by site-wide and } \\
\text { RPP intemal procedures. }\end{array}$ \\
\hline
\end{tabular}

Table 5.1 Abbreviations

$\begin{array}{ll}\text { ALARA } & \text { as low as reasonably achievable } \\ \text { AOP } & \text { Air Operating Permit } \\ \text { BCCAA } & \text { Benton County Clean Air Authority } \\ \text { BCHD } & \text { Benton County Health Department } \\ \text { BIA } & \text { Bureau of Indian Affairs } \\ \text { CRR } & \text { Cultural Resourcs Review } \\ \text { CFR } & \text { Code of Federal Regulations } \\ \text { DOE } & \text { United States Department of Energy } \\ \text { Ecology } & \text { State of Washington Department of Ecology } \\ \text { ECR } & \text { Ecological Compliance Review EPA } \\ \text { EPA } & \text { U.S. Environmental Protection Agency } \\ \text { EIS } & \text { Effluent information systern } \\ \text { gPd } & \text { gallons per day } \\ \text { NEPA } & \text { National Environmental Policy Act } \\ \text { NESHAP } & \text { National Emission Standards for Hazardous Air Pollutants } \\ \text { NOC } & \text { Notice of Construction } \\ \text { NRC } & \text { U.S. Nuclear Regulatory Commission } \\ \text { PCB } & \text { Polychlorinated Biphenyl } \\ \text { PNNL } & \text { Pacific Northwest National Laboratory } \\ \text { PSD } & \text { Prevention of Significant Deterioration } \\ \text { RCRA } & \text { Resource Conservation and Recovery Act } \\ \text { RPP } & \text { River Protection Projects } \\ \text { SA } & \text { Safety Analysis } \\ \text { SEPA } & \text { State Environmental Policy Act } \\ \text { SWP } & \text { Special Work Permits (Protective Clothing) } \\ \text { TAP } & \text { Toxic Air Pollutants } \\ \text { UIC } & \text { underground injection control } \\ & \end{array}$


USC

USFWS

UST

WAC

WDOH
United States Code

U.S. Fish and Wildlife Service

underground storage tank

Washington Administrative Code

Washington State Department of Heaith 
Table 5.2 Project W-314 Phase 2 Permits/Regulatory Tasks Planning Assumptions

\begin{tabular}{|c|c|}
\hline Pent, $A$ poroval or Requirenent & 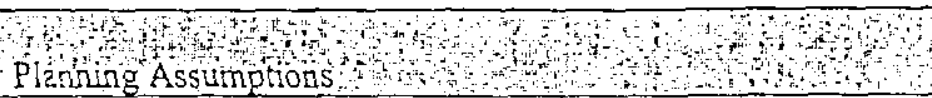 \\
\hline $\begin{array}{l}\text { National Environmental Policy Act } \\
\text { (NEPA) }\end{array}$ & $\begin{array}{l}\text { For planning purposes, a conservative assumption has been } \\
\text { made that assumes preparation of a Supplemental Analysis } \\
\text { (SA). The expected outcome is the existing NEPA } \\
\text { documentation (e.g., RPP EIS) and SA together will bound the } \\
\text { potential range of environmental impacts. }\end{array}$ \\
\hline State Environmental Policy Act (SEPA) & $\begin{array}{l}\text { Planning assumption is that Ecology will review the SA. The } \\
\text { expected outcome is that independent SEPA documentation } \\
\text { will not be necessary. }\end{array}$ \\
\hline Cultural Resources Review (CRR) & $\begin{array}{l}\text { A Cultural Resources exemption (Battelie letter dated } 8 / 16 / 94 \text { ) } \\
\text { has been approved by RL for the } 18 \text { tank farm areas on the } \\
\text { Hanford Site. The exemption does not include removal of } \\
\text { tanks, or modifying and/or demolishing any permanent } \\
\text { structure(s) w/in or } 150 \text { meters outside of the tank fams. } \\
\text { Planning assumption is that this project is adequately covered } \\
\text { by this existing exemption. No level of effort is planned. }\end{array}$ \\
\hline Ecological Compliance Review (ECR) & $\begin{array}{l}\text { A blanket Biological Review is performed annually by PNNL } \\
\text { for the tank farm facilities in the } 200 \mathrm{E} \text { and } 200 \mathrm{~W} \text { Areas ( } \# 98 \text { - } \\
200-047 \text { ). Planning assumption is that the requirements } \\
\text { specified in the biological review letter will apply to the } \\
\text { project. No level of effort is planned. }\end{array}$ \\
\hline Excavation Pentnit & $\begin{array}{l}\text { Planring basis is three excavation permits required for } \\
\text { construction activities associated with each of the seven tank } \\
\text { farms included within the scope of this project. Typical } \\
\text { environmental review activities assumed to support each } \\
\text { excavation permit include CRR, ECR, permit condition } \\
\text { implementation, and general technical compliance review. }\end{array}$ \\
\hline $\begin{array}{l}\text { Preoperational Monitoring of Facility, } \\
\text { Site, and Operations }\end{array}$ & $\begin{array}{l}\text { It is assumed that existing tank farm monitoring will be } \\
\text { sufficient for this project. Document with memo to file. No } \\
\text { level of effort is planned. }\end{array}$ \\
\hline $\begin{array}{l}\text { General Public \& Environmental } \\
\text { Protection, Radiation Protection } \\
\text { Standards }\end{array}$ & $\begin{array}{l}\text { These requirenents are captured in individual work packages, } \\
\text { intemal procedures, and in implementation of applicable } \\
\text { permit conditions. Planning basis is that environmental staff } \\
\text { will be asked to review work packages and to provide general } \\
\text { support for periodic design, construction, and implementation } \\
\text { assistance. }\end{array}$ \\
\hline Air Operating Permit (AOP) & $\begin{array}{l}\text { It is assumed the AOP will be final. The planned approach } \\
\text { will be to subrit a request for modification of the AOP at the } \\
\text { same time as both the radioactive \& non-radioactive NOC } \\
\text { applications are submitted to the regulatory agencies for } \\
\text { approval. Ventilation system upgrades, or upgrades to } \\
\text { ventilation system monitoring systems are assumed to be } \\
\text { classified as "significant modifications." It is assumed that } \\
\text { significant modifications will require an additional six months } \\
\text { beyond approval of the radioactive/nor-radioactive NOCs } \\
\text { before commencement of construction. }\end{array}$ \\
\hline
\end{tabular}




\begin{tabular}{|c|c|}
\hline $\begin{array}{l}\text { Pat } \\
\text { Permit, Appoval or Requirement }\end{array}$ & Planing Assumptions \\
\hline Permit, Approval or Requirement & Planning Assumptions \\
\hline $\begin{array}{l}\text { New Source Review; } \\
\text { Source registration }\end{array}$ & $\begin{array}{l}\text { Planning assumption is that the review will be performed in } \\
\text { parallel with the WAC } 173-460 \text { (TAP) evaluation. The } \\
\text { assumed outcome is no new source requiring source } \\
\text { registration. }\end{array}$ \\
\hline $\begin{array}{l}\text { Prevention of Significant Deterioration } \\
\text { (PSD) }\end{array}$ & $\begin{array}{l}\text { Planning assumption is that the PSD review will be performed } \\
\text { in parallel with the WAC } 173-460 \text { (TAP) evaluation. Planning } \\
\text { basis assumes that no PSD permit will be required. }\end{array}$ \\
\hline $\begin{array}{l}\text { Notice of Construction (NOC) - Toxic } \\
\text { Air Pollutants (TAP) }\end{array}$ & $\begin{array}{l}\text { Planning basis is each of the NOCs will encompass both } \\
\text { construction and operation. For planing purposes, it is } \\
\text { assumed that five NOC applications will be required for } \\
\text { ventilation and monitoring system upgrades in S ( } 244-\mathrm{S} \\
\text { DCRT), AN, AW, AP, and SY Farms. Work scope associated } \\
\text { with creation of potential fugitive emissions (e.g., excavation) } \\
\text { in those and other farms will be included in the NOC } \\
\text { applications above. Approval must be obtained prior to the } \\
\text { start of construction. }\end{array}$ \\
\hline NOC - Radioactive Air Emissions & $\begin{array}{l}\text { It is assumed that NOC approval will be recuired for } \\
\text { radioactive air emissions. The planning basis assumes five } \\
\text { NOC applications will be required for ventilation and } \\
\text { monitoring system upgrades in } S(244-S \text { DCRT), AN, AW, } \\
\text { AP, and SY Farms. Work scope associated with creation of } \\
\text { potential fugitive emissions in those and other farms will be } \\
\text { included in the NOC applicat:ons above. Approval must be } \\
\text { obtained prior to the start of construction. }\end{array}$ \\
\hline $\begin{array}{l}\text { Resource Conservation and Recovery Act } \\
\text { (RCRA) }\end{array}$ & $\begin{array}{l}\text { Planning basis is that the DST RCRA Part B Permit will be } \\
\text { issued and in force. The planning assumption is that } \\
\text { significant tima lags ( } 6 \text { months to I year) will be likely } \\
\text { between completion of definitive design and approval to } \\
\text { construct to allow for public comment. It is also assumed that } \\
\text { the Tri-Party Agreement (TPA) Milestone for upgrading non- } \\
\text { compliant lines (2005) will be applicable to all transfer lines } \\
\text { for this project. Compliance with WAC } 173-303 \text { technical } \\
\text { standards (e.g., secondary containment) and other conditions of } \\
\text { the permit will be mandatory, unless modified by separate } \\
\text { regulatory agreement. }\end{array}$ \\
\hline Hazardous Waste Reduction & $\begin{array}{l}\text { It is assumed that existing site-wide programs and RPP interual } \\
\text { procedures will satisfy applicable requirements. No level of } \\
\text { effort is planned. }\end{array}$ \\
\hline Polychlorinated biphenyls (PCBS) & $\begin{array}{l}\text { The waste must meet DST Waste Acceptance Criteria prior to } \\
\text { transfer. Evaluation for potential PCBs will be required as part } \\
\text { of this process. Any project level of effort is included as part } \\
\text { of design review. }\end{array}$ \\
\hline $\begin{array}{l}\text { Notification and Reporting of Hazardous } \\
\text { Materials Spills/Releases }\end{array}$ & $\begin{array}{l}\text { It is assumed that existing site-wide programs and RPP internal } \\
\text { procedures will satisfy applicable requirements. No additiona! } \\
\text { project scope is planned. }\end{array}$ \\
\hline
\end{tabular}


HNF-5 109, Rev. 0

\subsection{COST ESTIMATE}

The total cost of Phase 2 is $\$ 128 \mathrm{M}$.

Section 6.1 presents the Phase 2 cost estimate with the Cost Estimate Basis. Section 6.2 presents the changes from the previous baseline.

Cost Estimating Methodology: Work scope packages were prepared by system for each farm/area in the project scope. A Cost Estimating Structure (CES) was developed assigning the Work Scope Package tasks to the appropriate element of the project WBS.

With the CES as a foundation, takeoffs from the scope and drawings were made. Additional adders included general conditions (Hanford), construction management, and health physics technician costs. This total represented the unburdened Direct Construction Costs. Mark-up burdens were applied to arrive at the fully burdened Total Construction Cost (TCC).

The development of the Total Estimated Constructed Cost (TECC) was accomplished by adding the burdened Title II and III engineering costs to the TCC. The Total Project Cost (TPC) was then determined by adding the estimated other project costs (OPC), which included client inputs, to the TECC.

Estimate Credibility: The cost estimate was generated using information from:

- The USSR, Rev. 4

- Phase 2 scope definition with assumptions

- Drawings based on plant physical layouts and dimensions

- Use of Phase 1 cost of definitive design information for like items

- Lessons learned, tank farm environment, and downtime costs of the current AN construction

- Estimating team with more than collective 100 years cost estimating Hanford-related experience

- Use of vendor quotes

- Cost data obtained from standard databases (e.g., Richards, RS Means, Corps of Engineers, Saylor, and established Hanford labor rates)

- Incorporation of cost and schedule information from Phase 1 activities. 
HNF-S109, Rev. 0

\subsection{DETAUED COST ESTIMATE}

(consisting of the following 46 pages) 

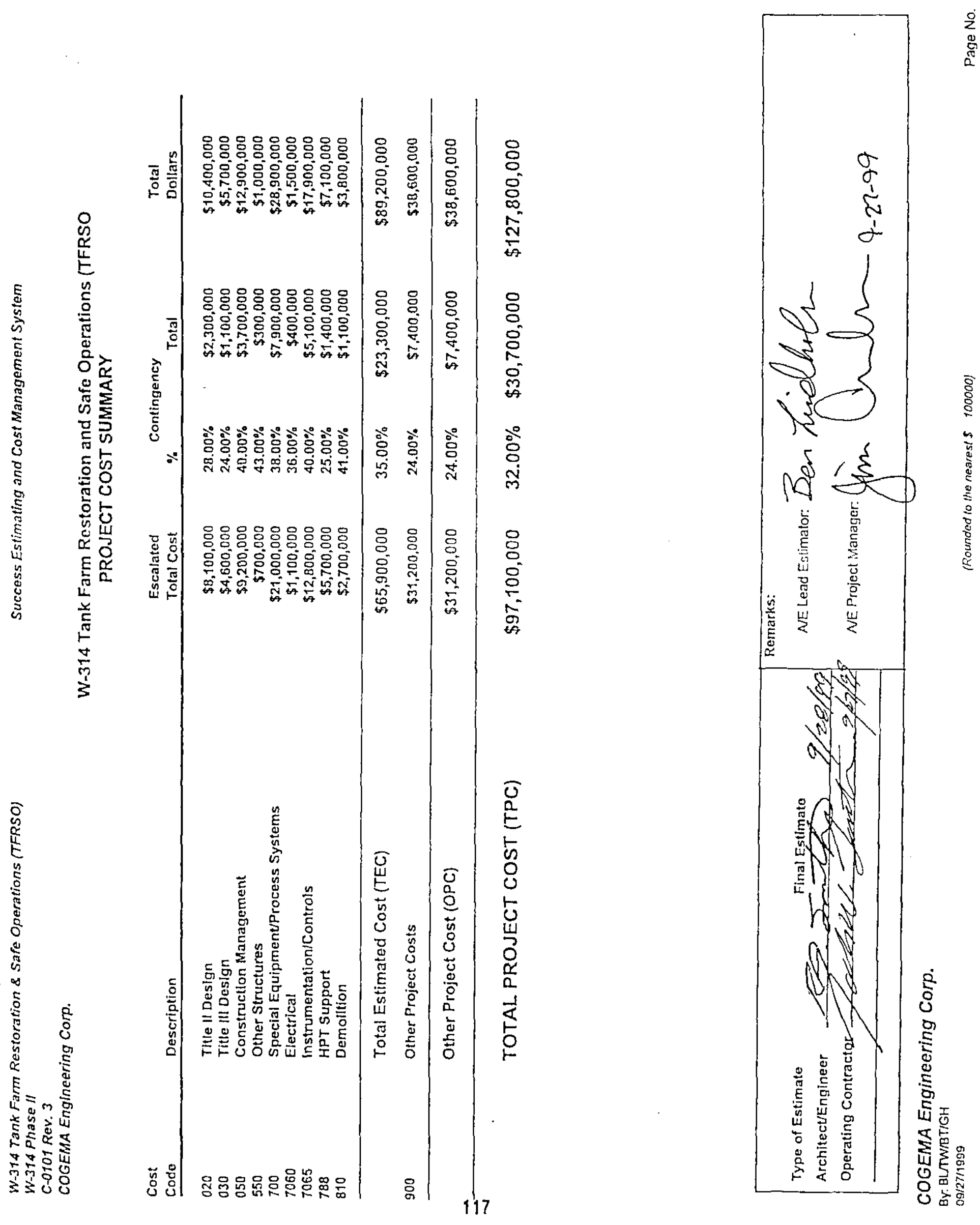


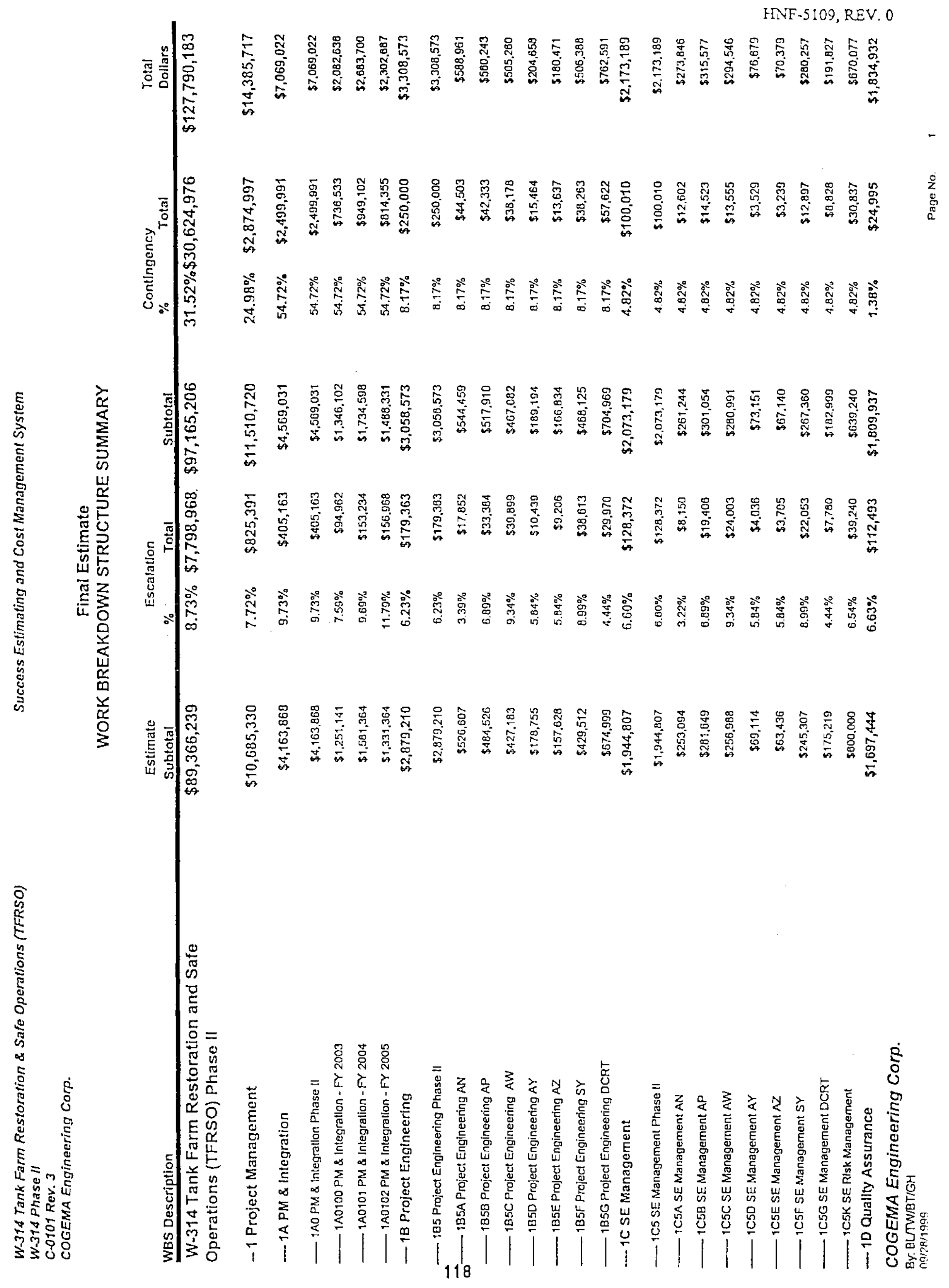




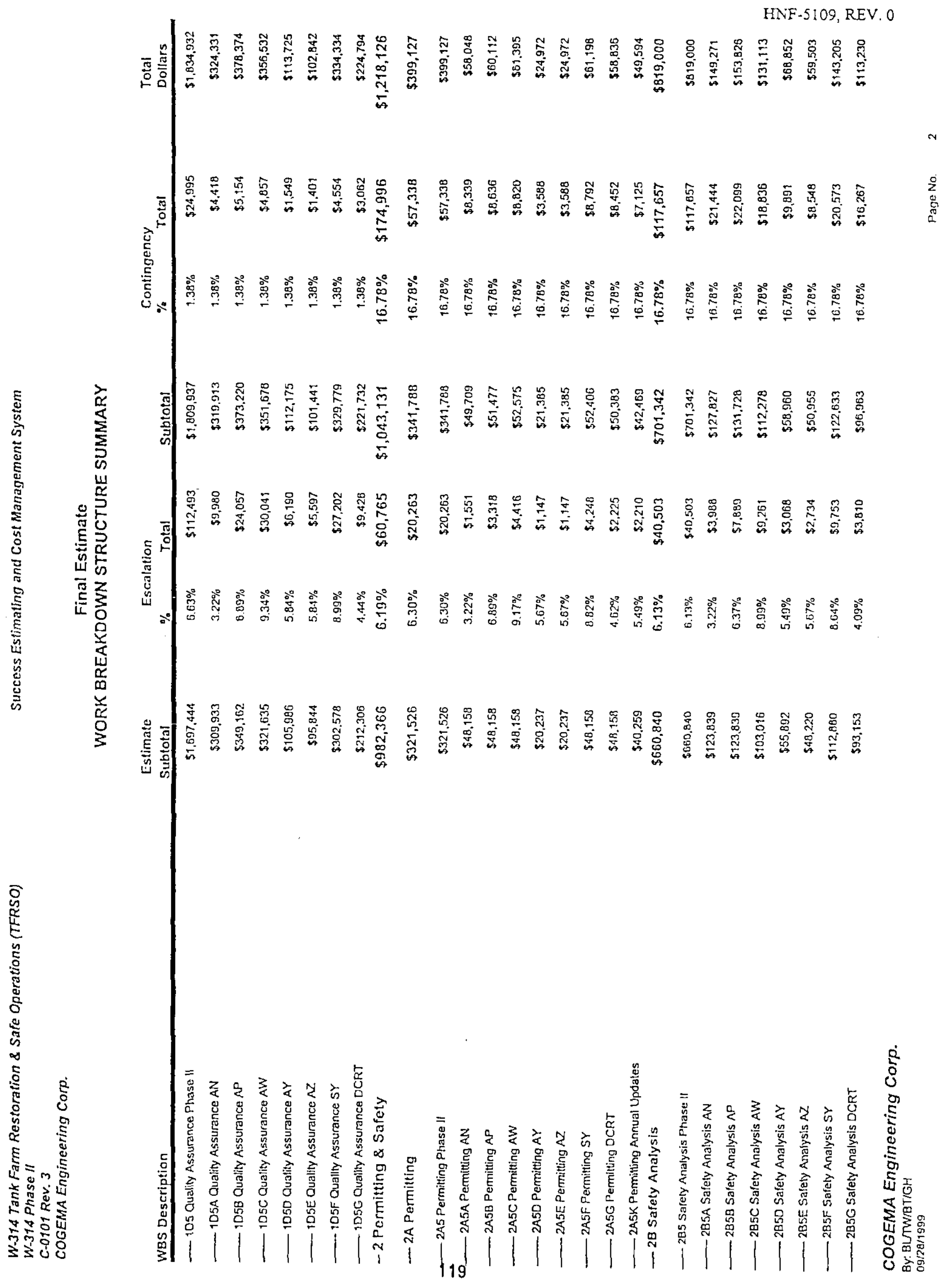




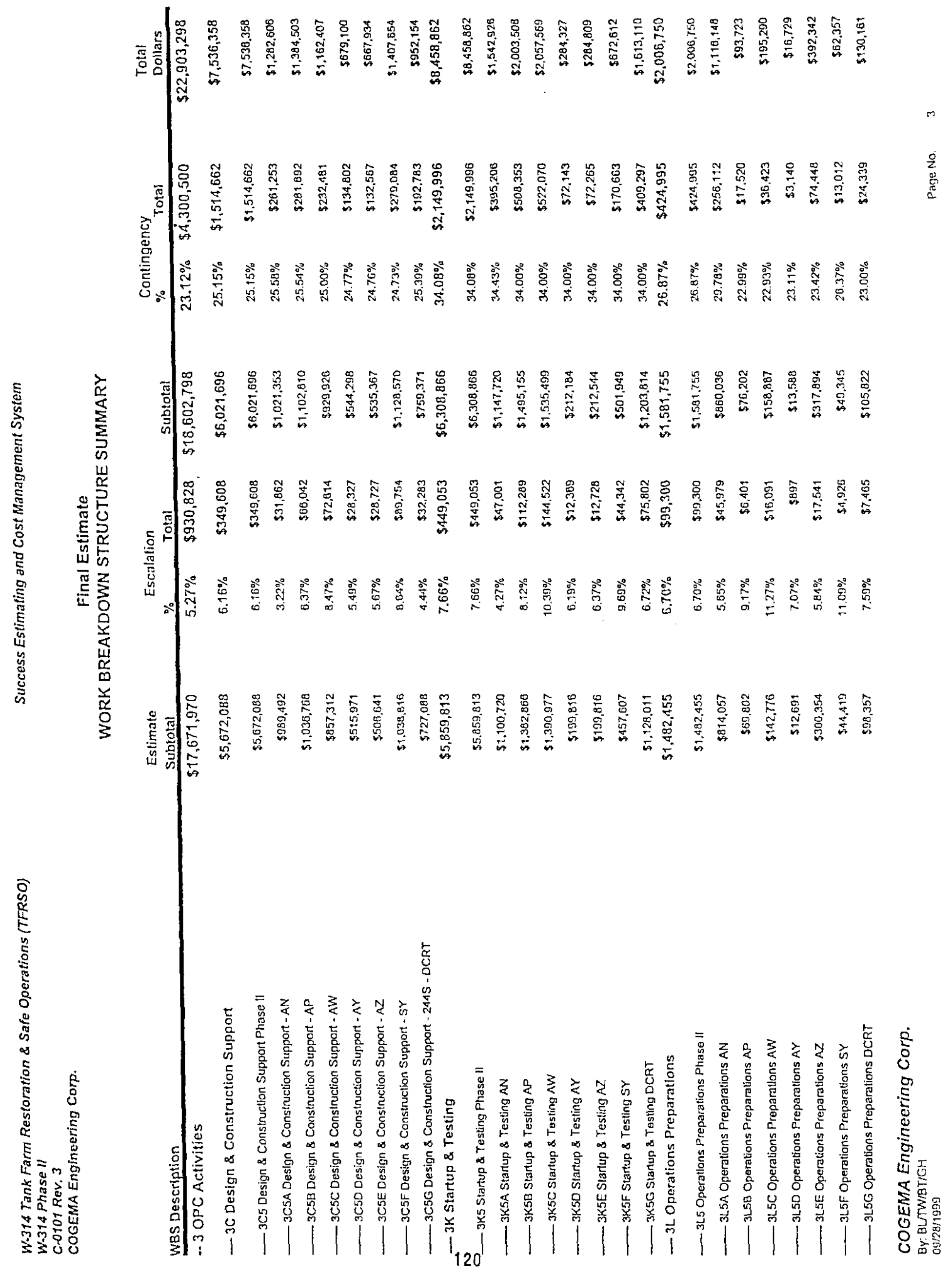




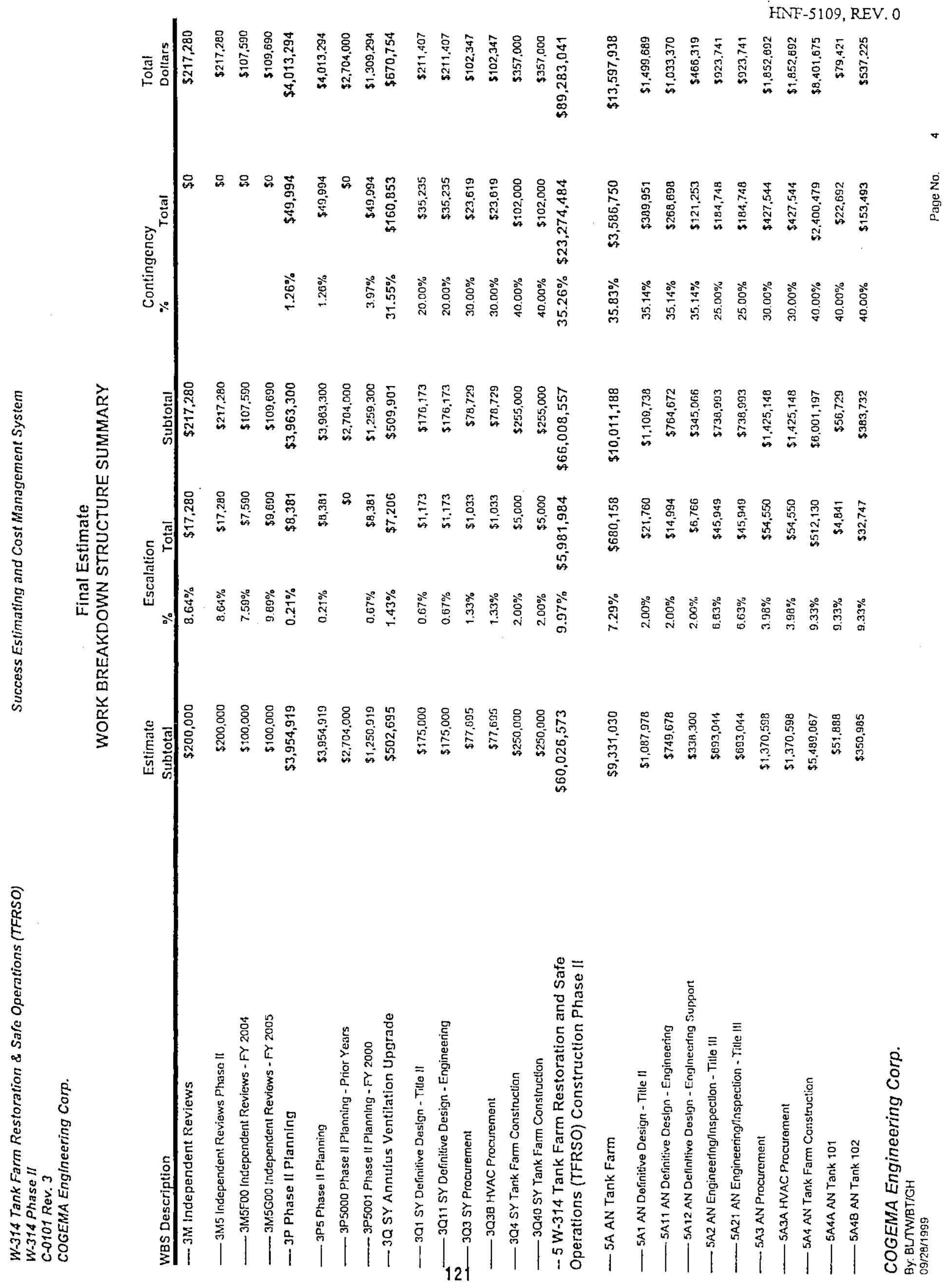


HNE-5109, REV. 0

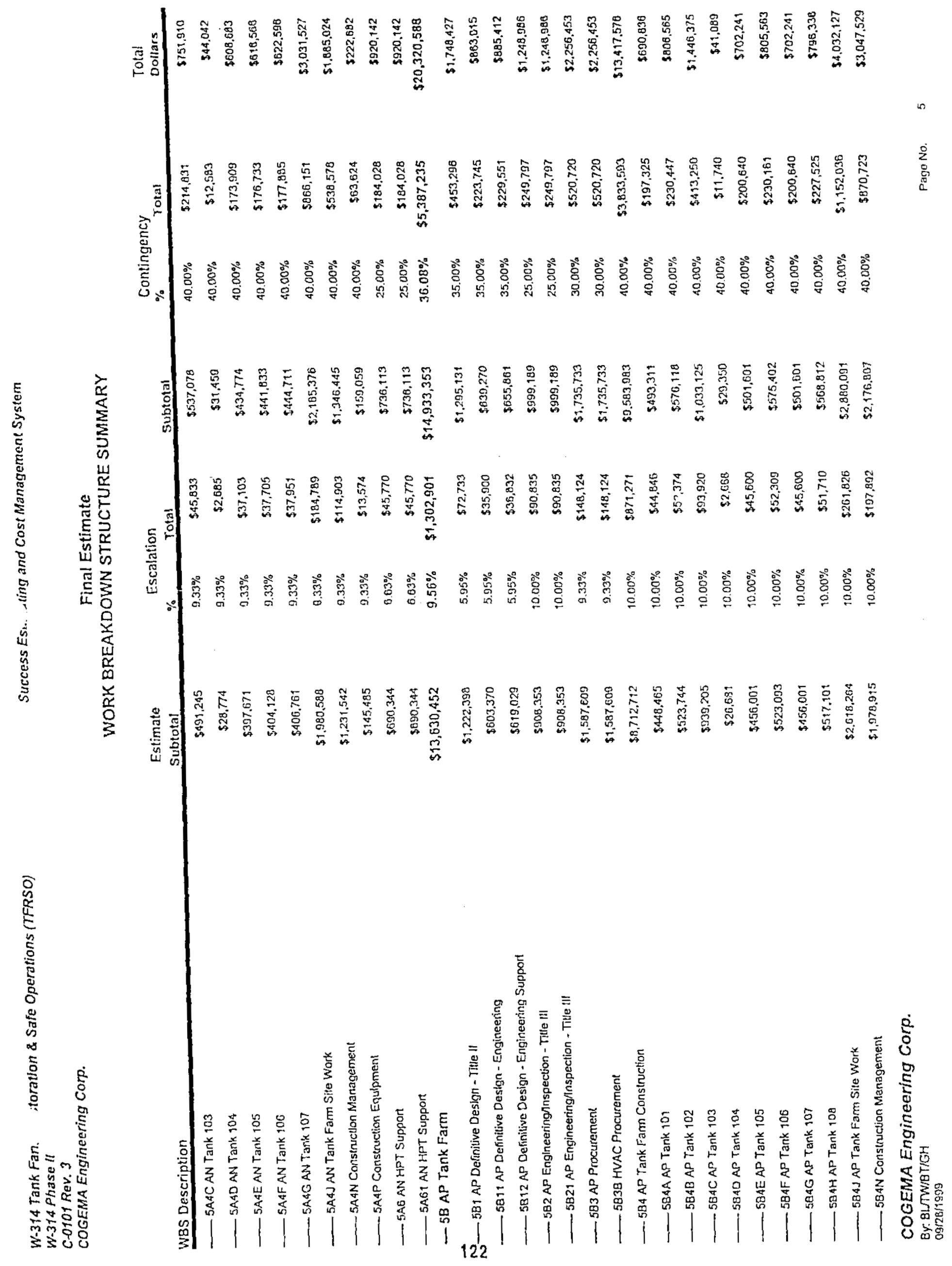




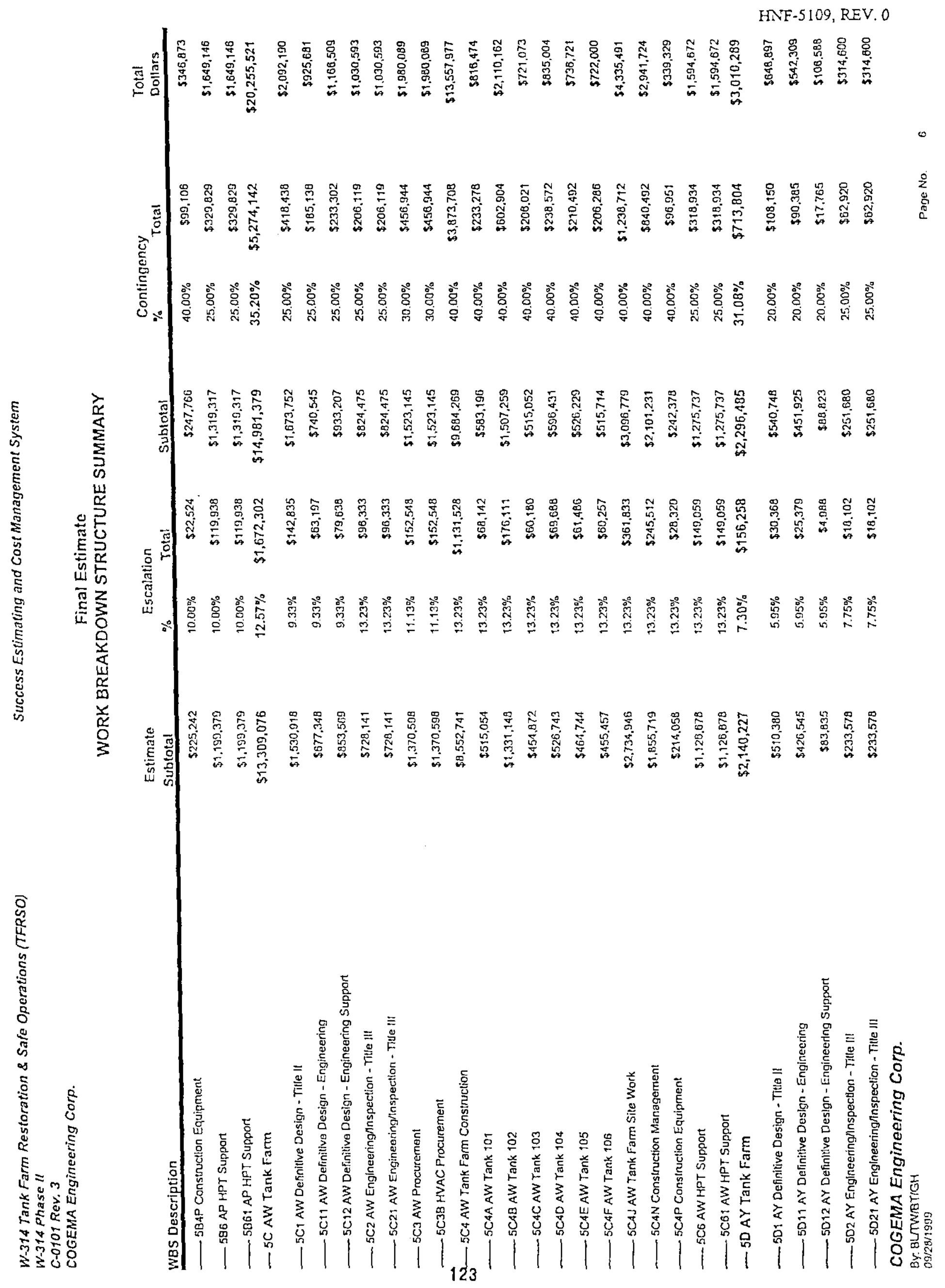




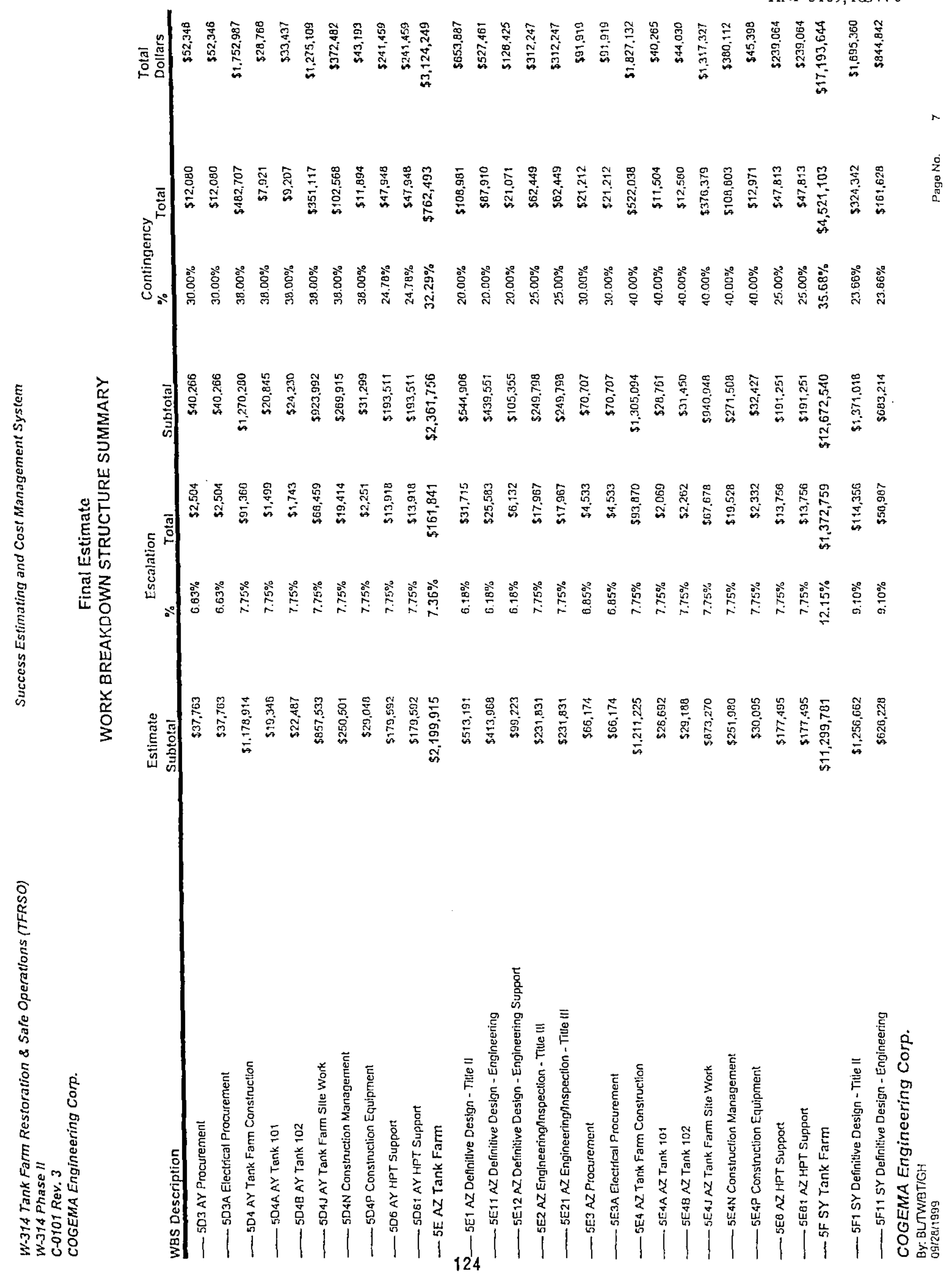




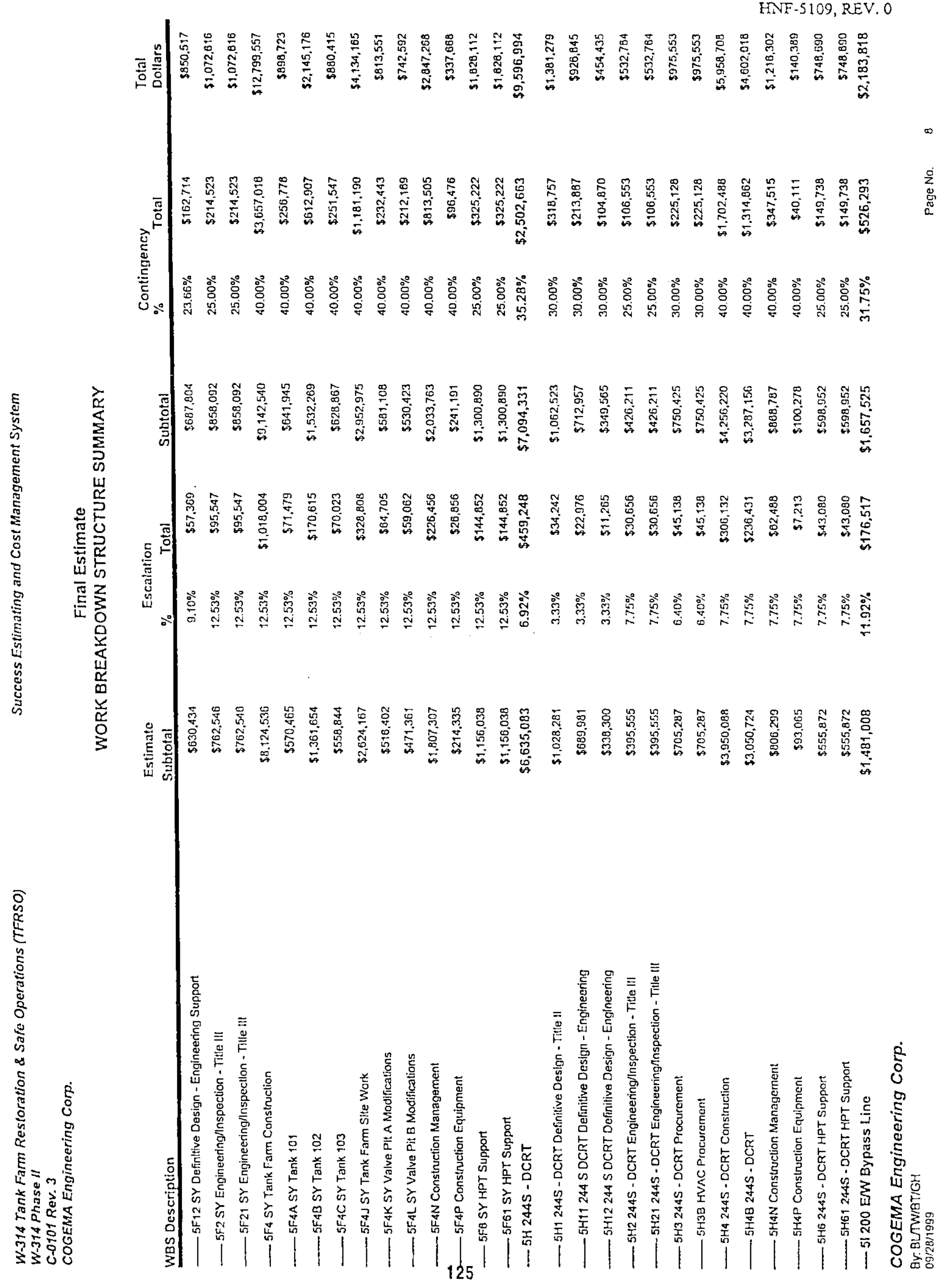




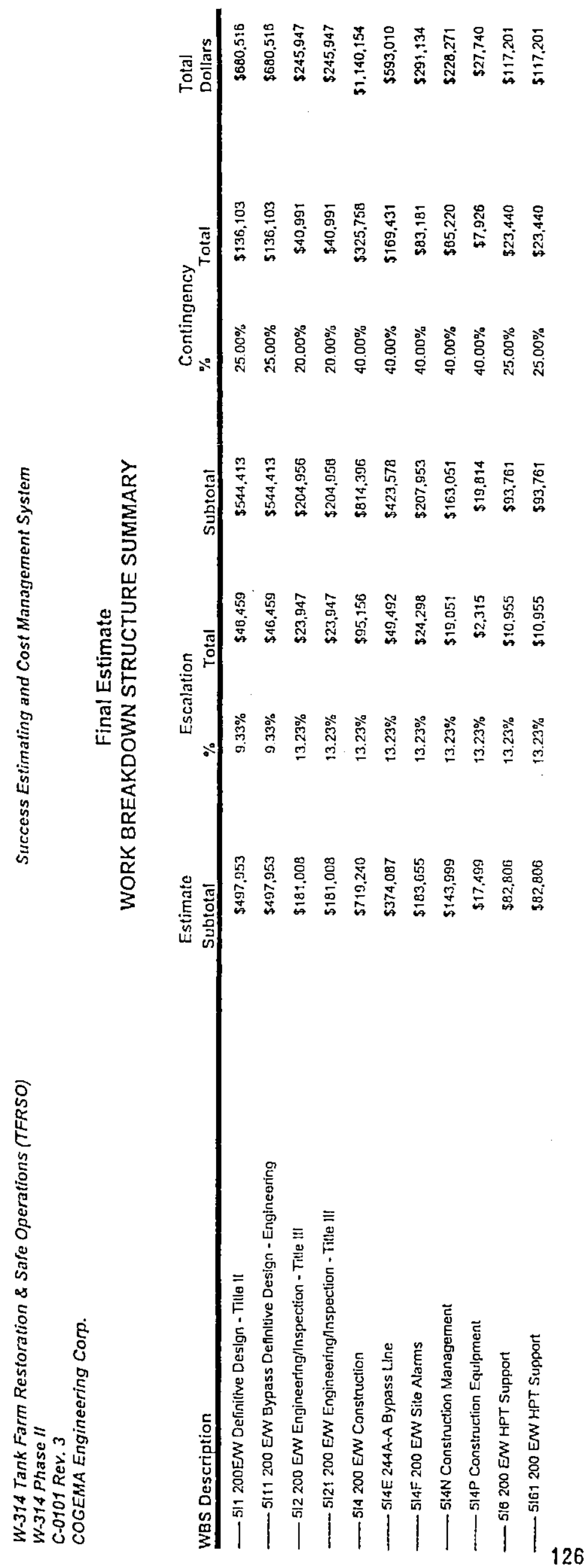




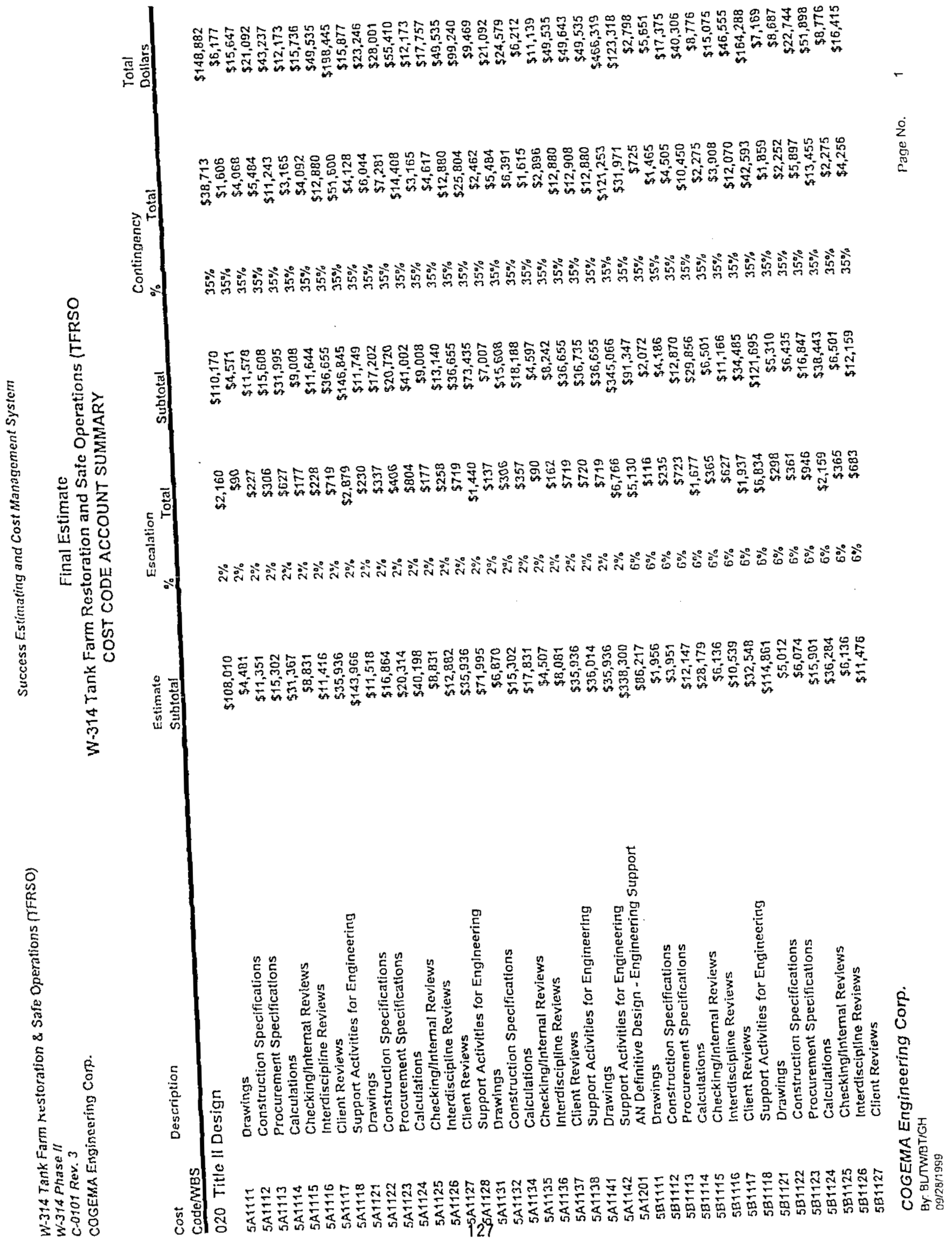


$\stackrel{\wp}{\mathscr{0}}$

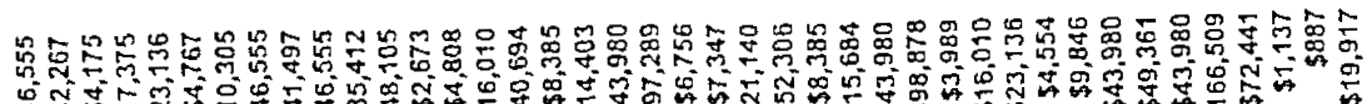

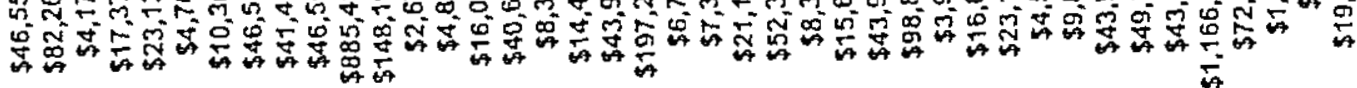

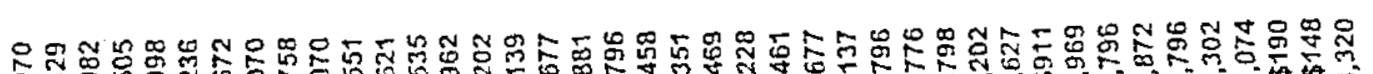

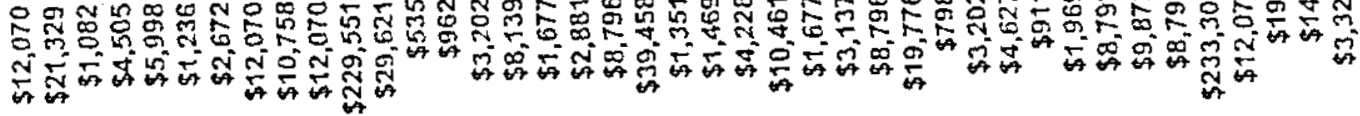

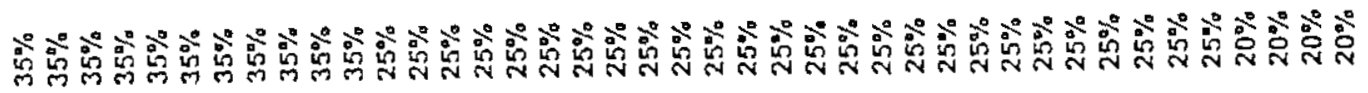

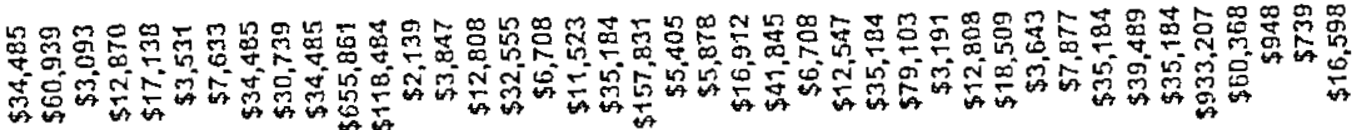

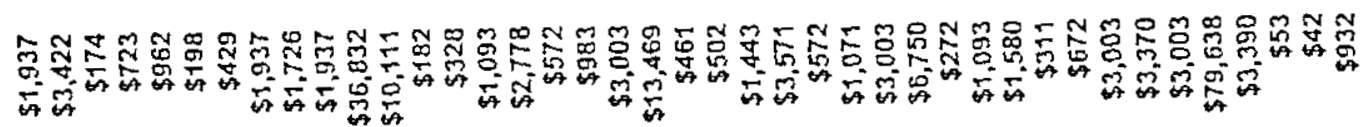

仓ั

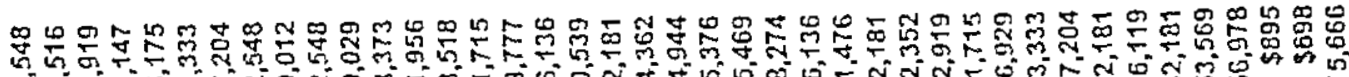

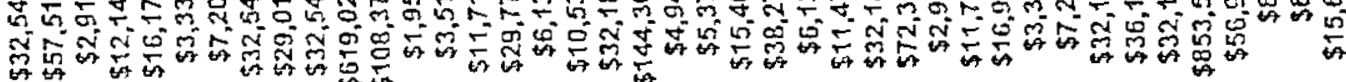




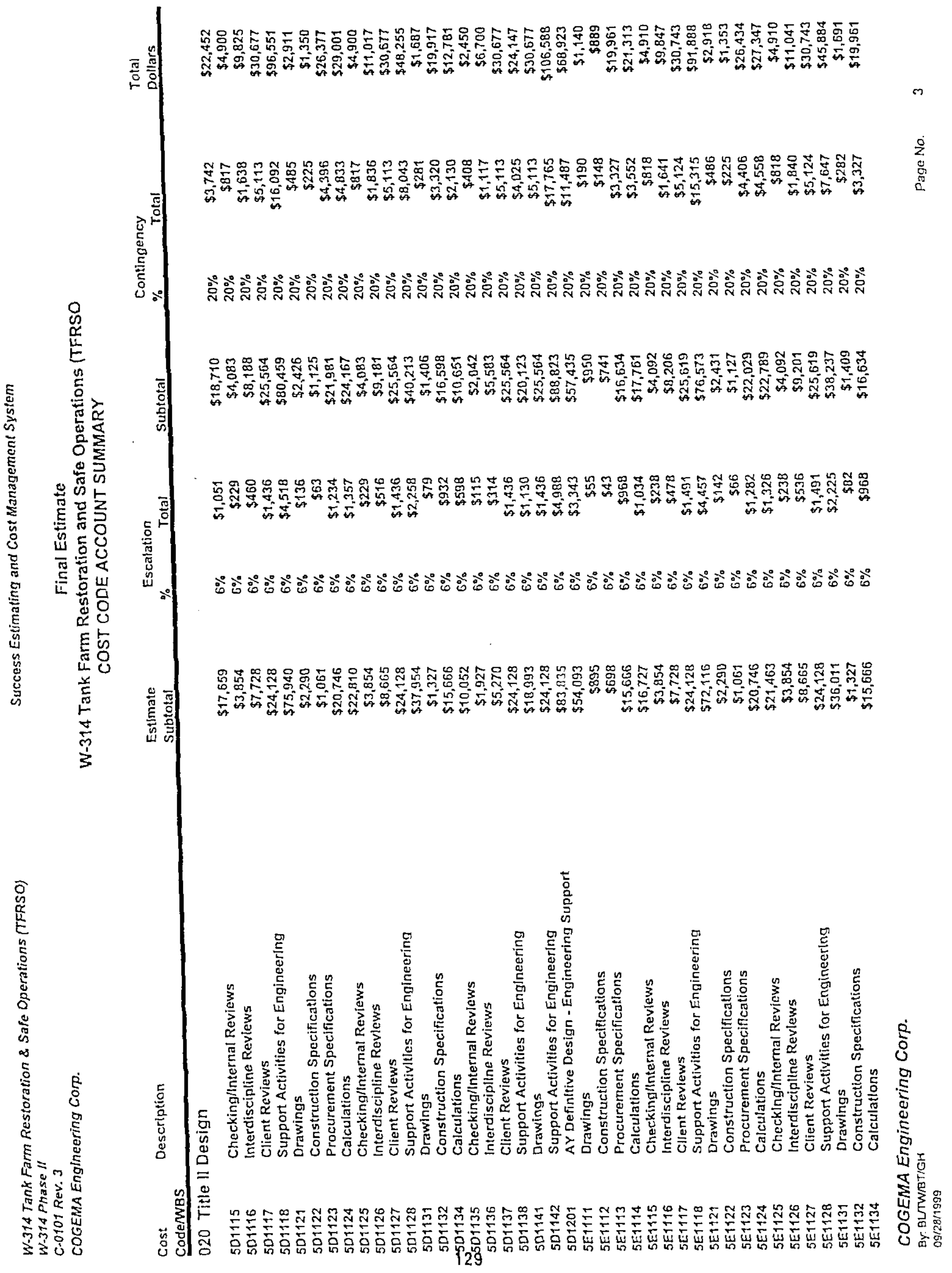




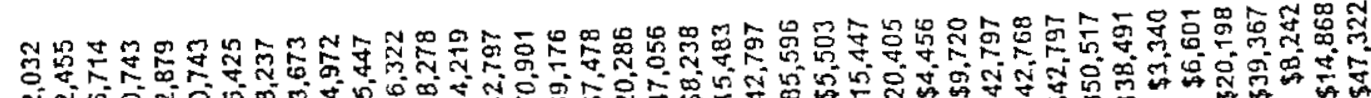

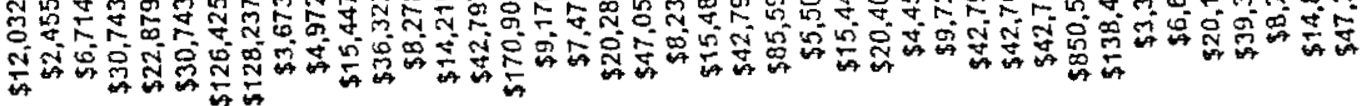

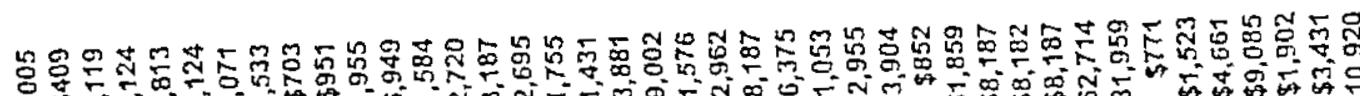

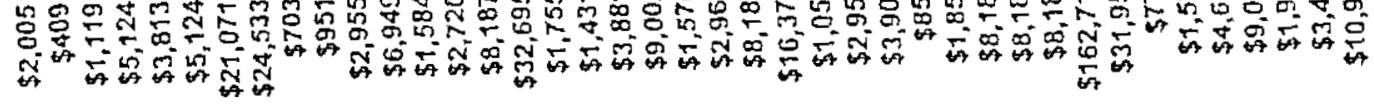

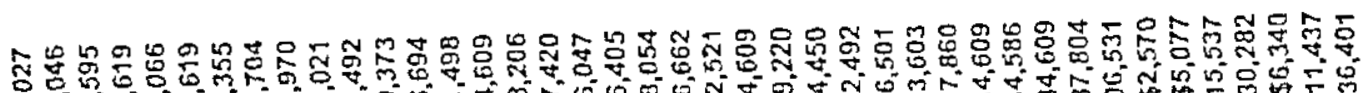

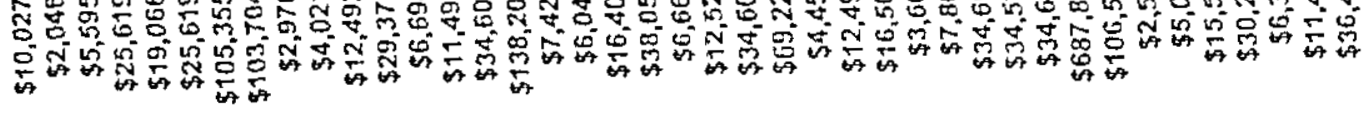

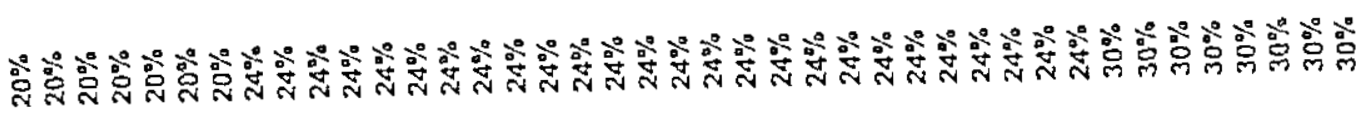

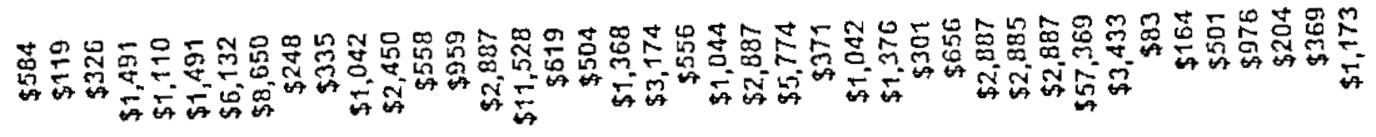

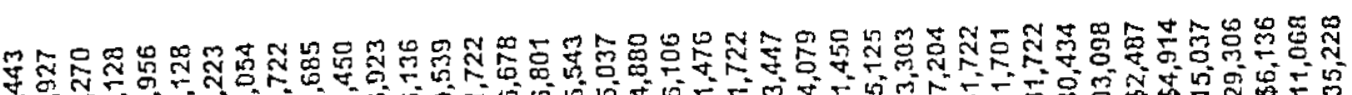

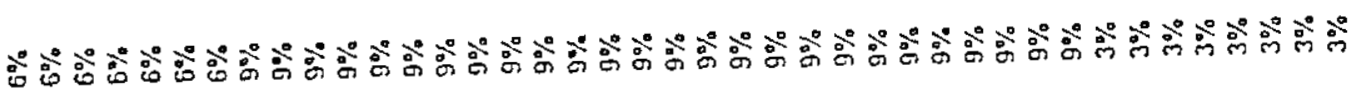

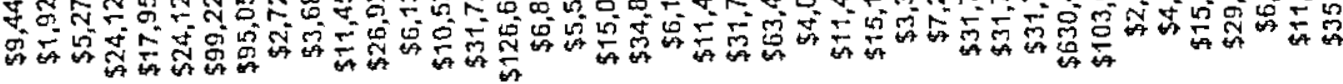


尊

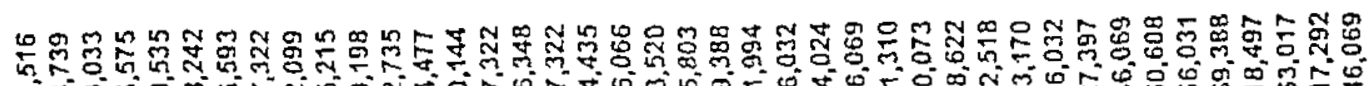

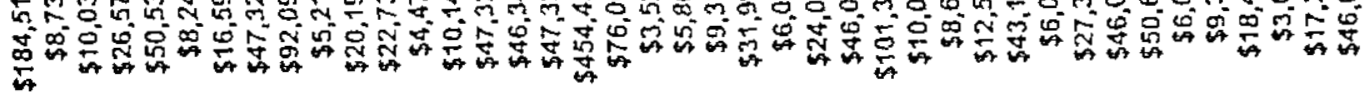

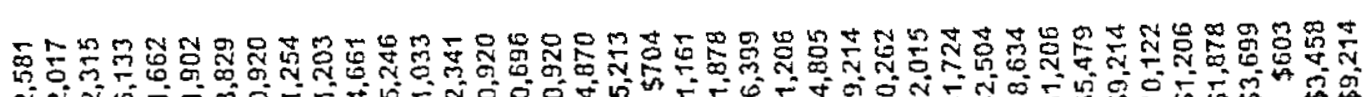

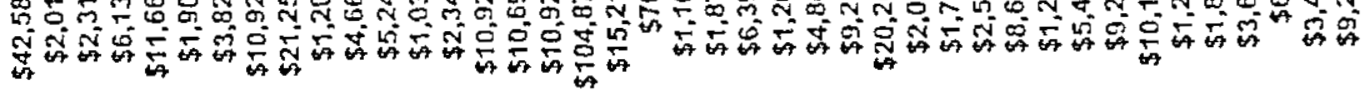

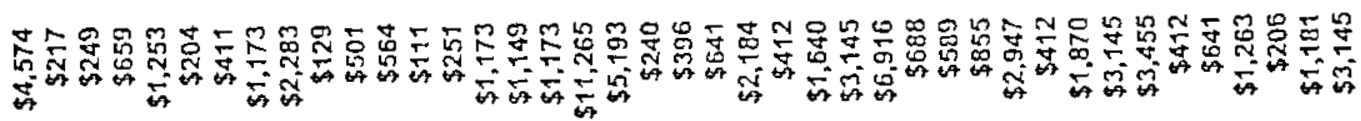
คํำํํำ

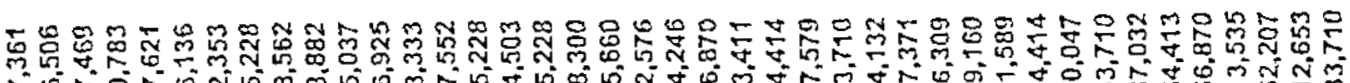

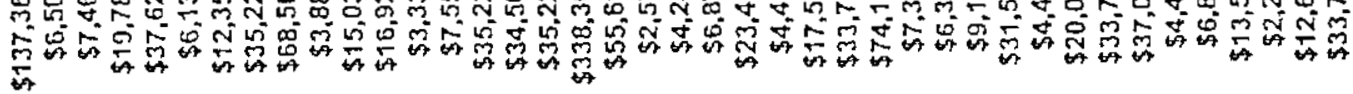

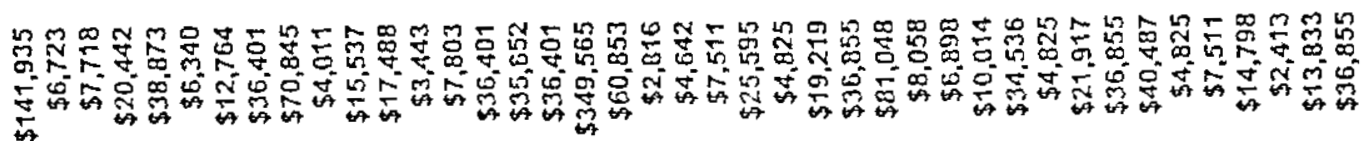

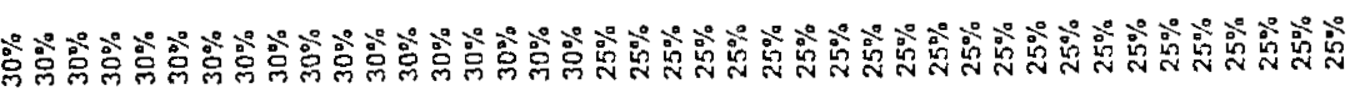

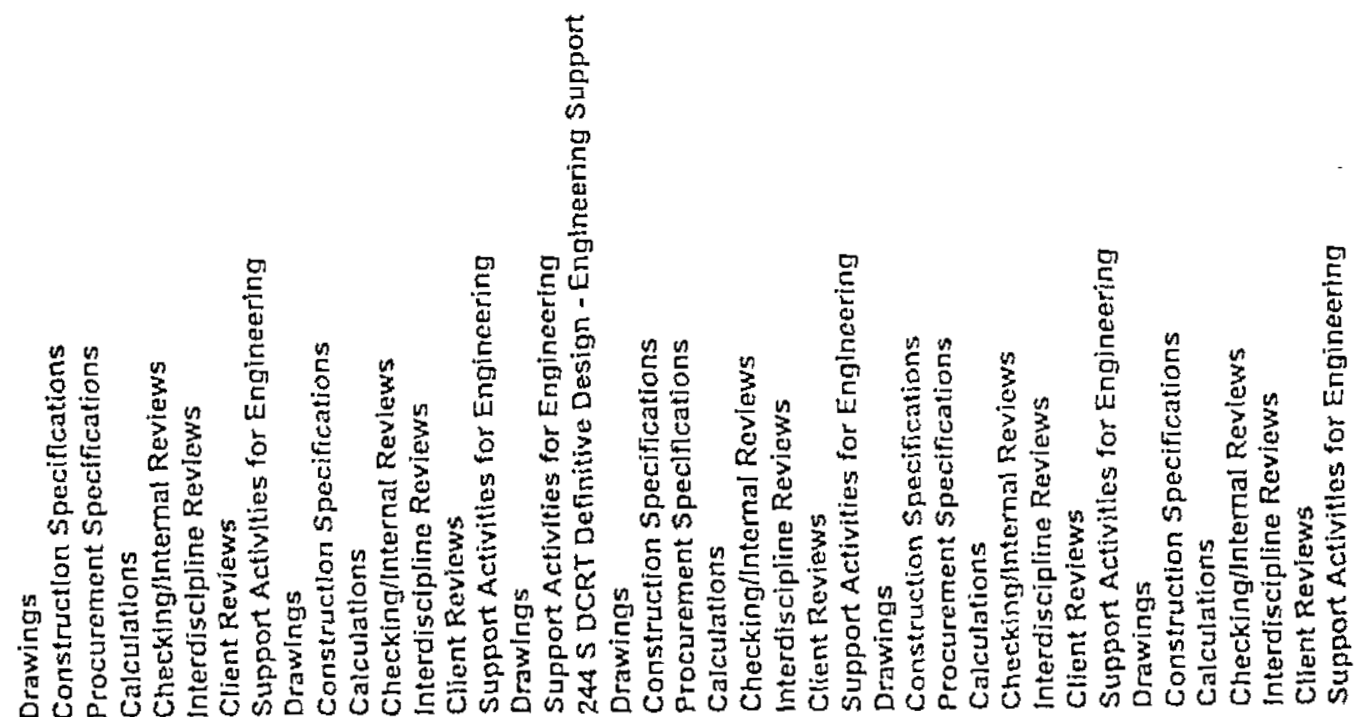

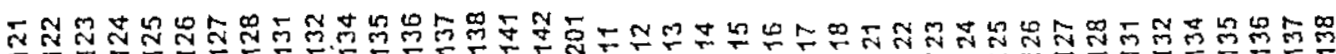

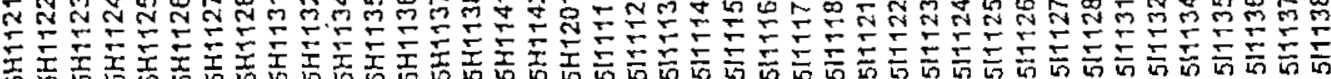




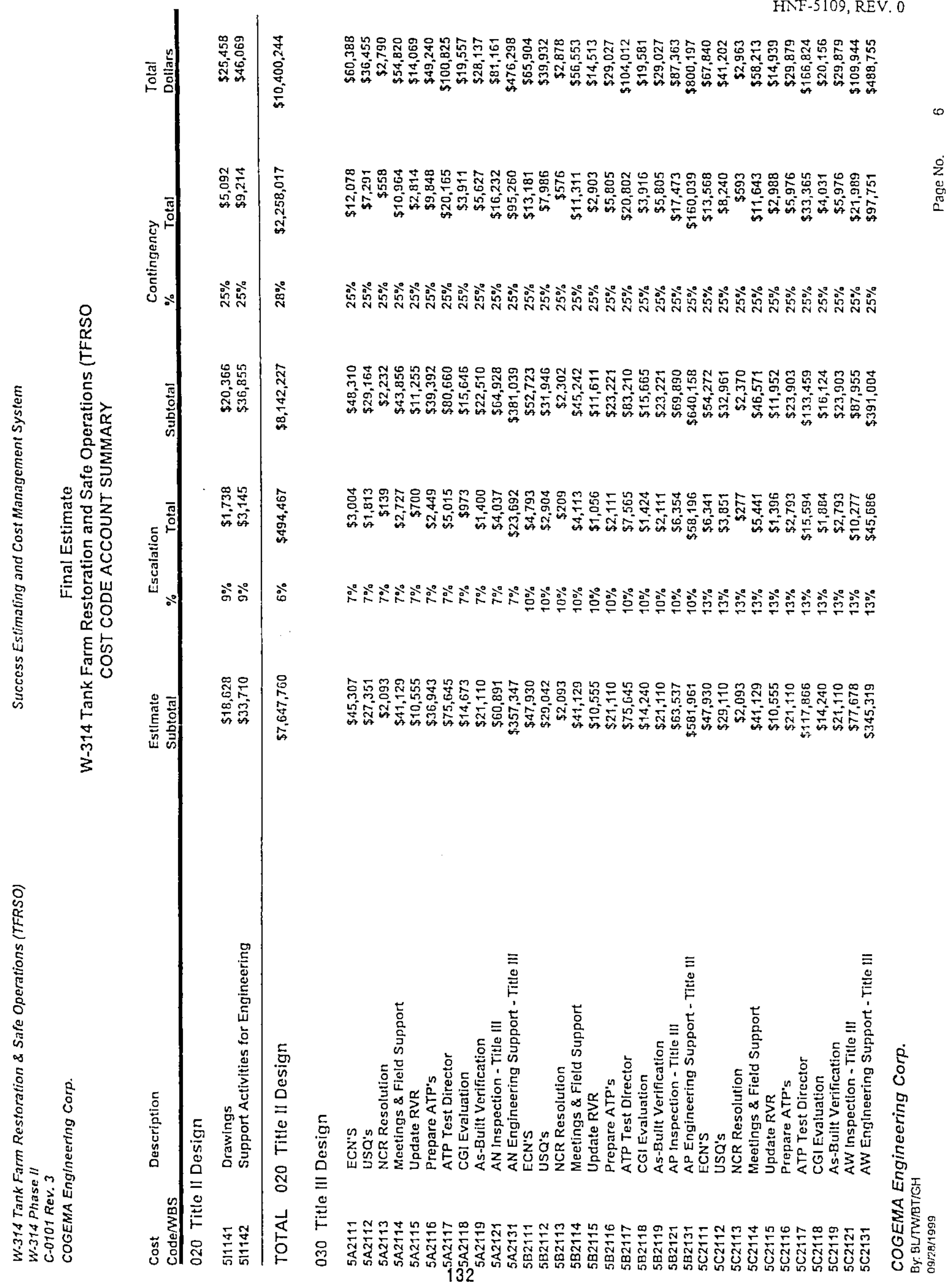




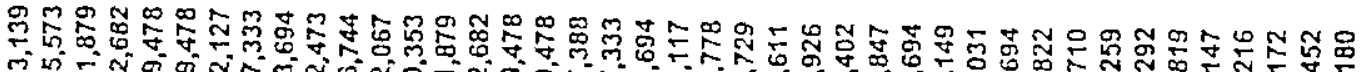

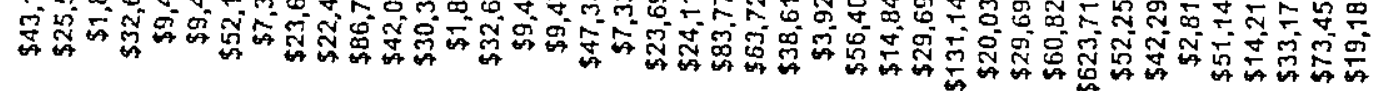

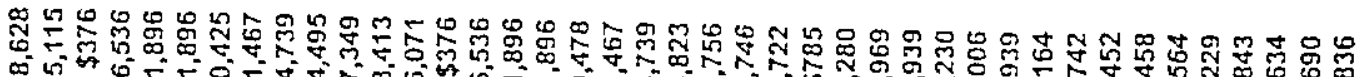

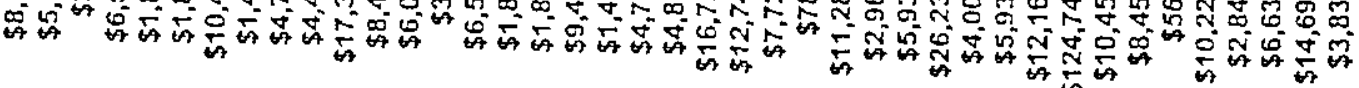

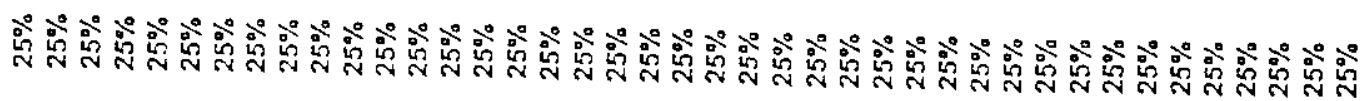

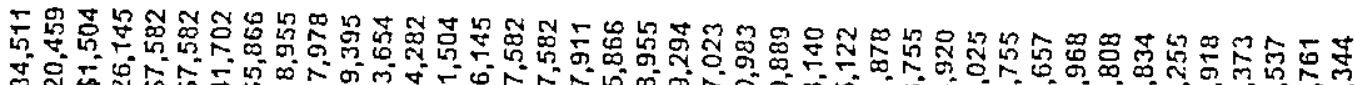

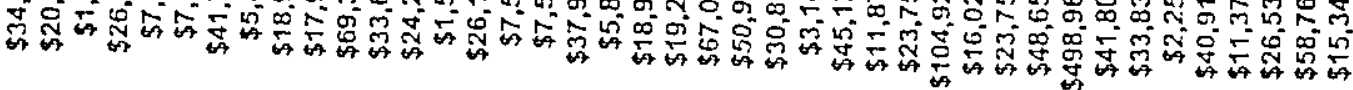

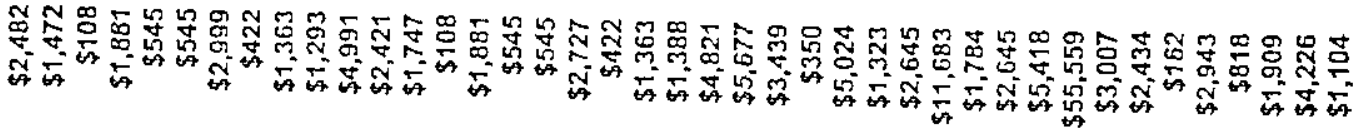

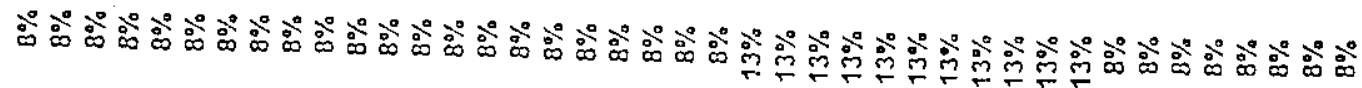

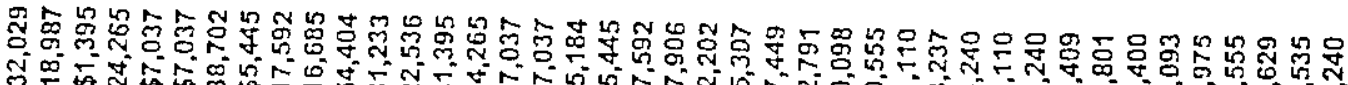

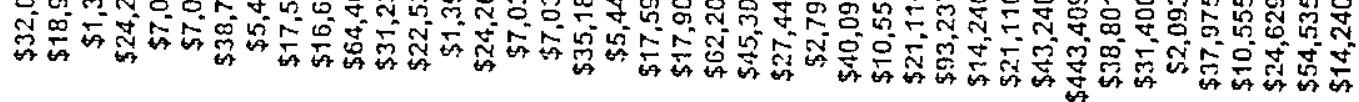




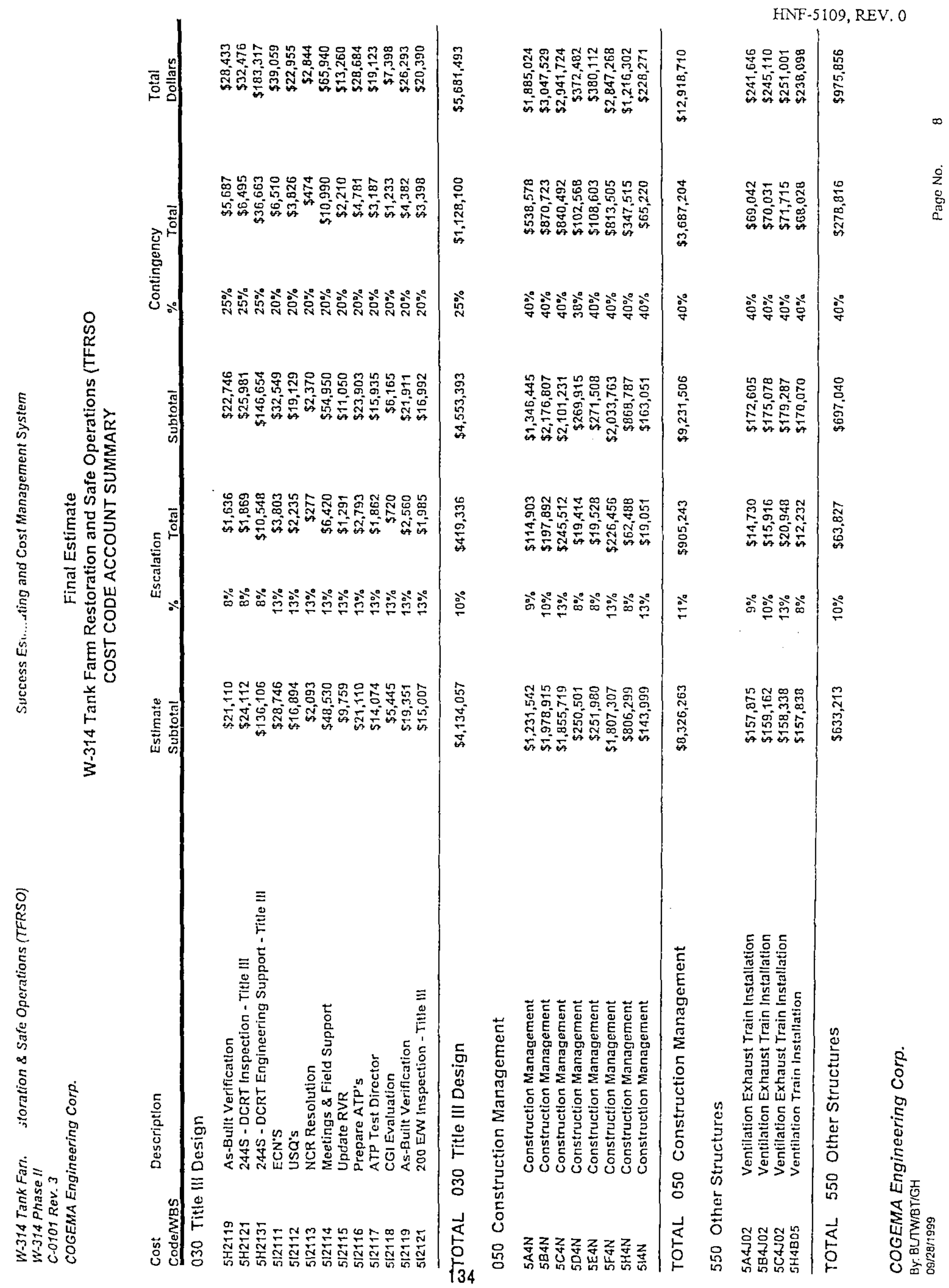




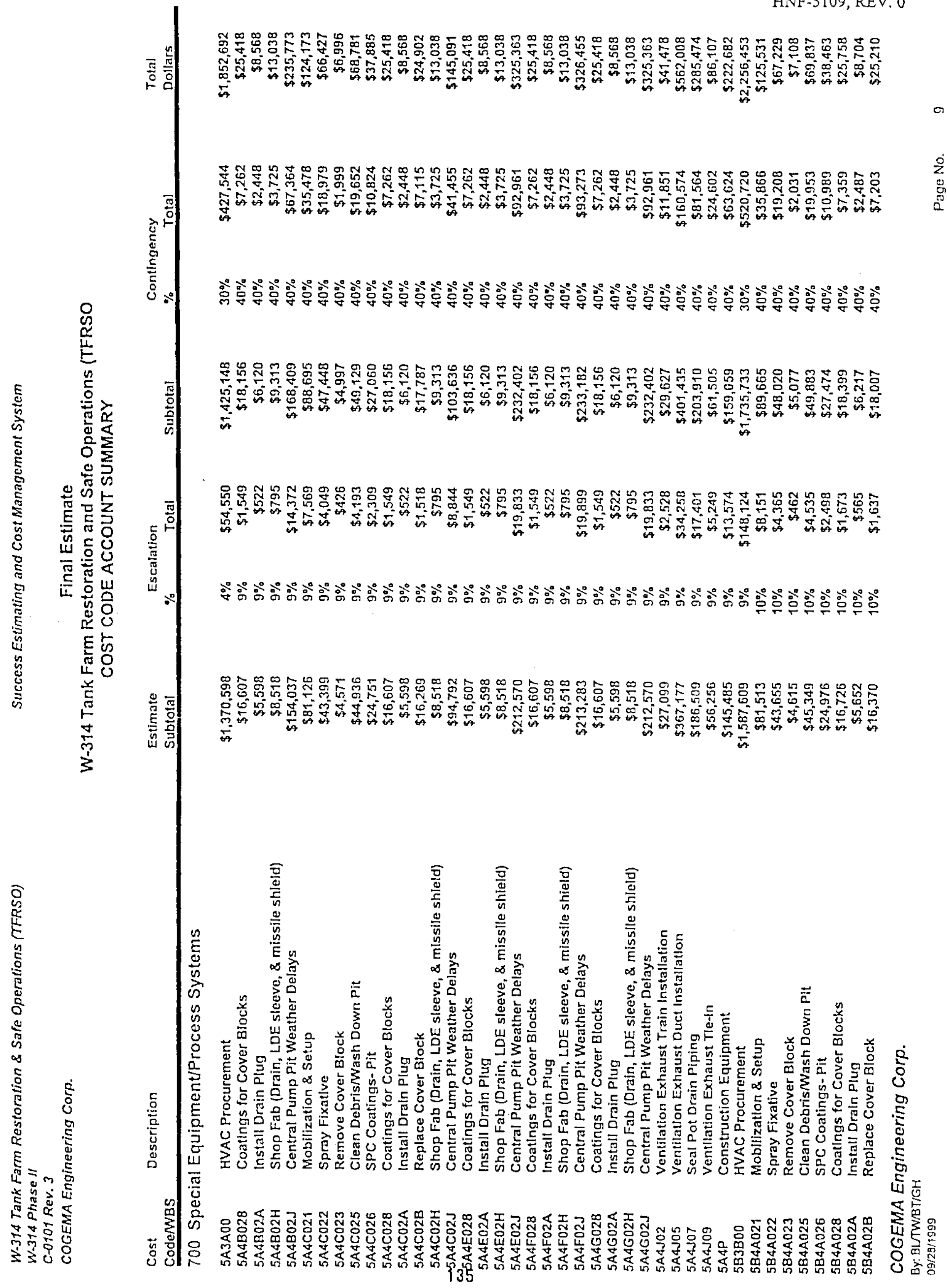




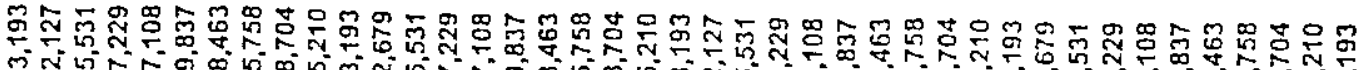

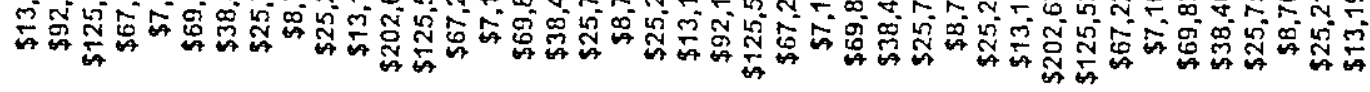

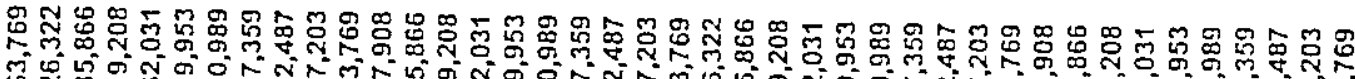

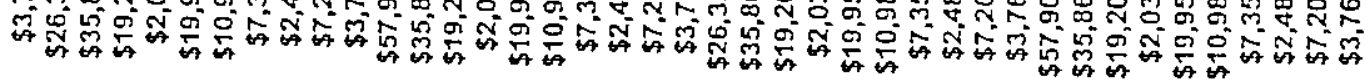

0
0
0
岁

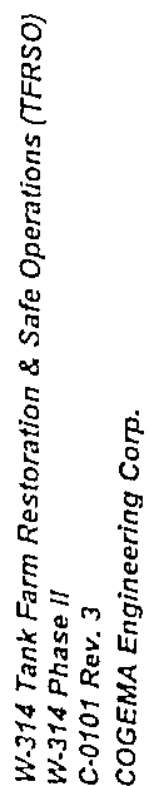

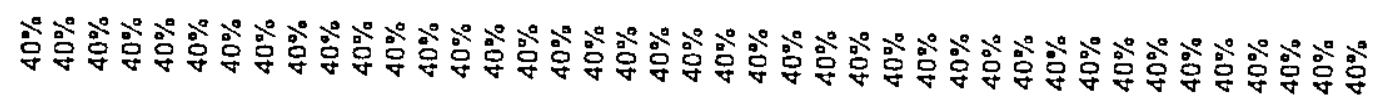

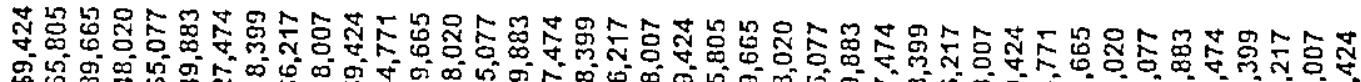

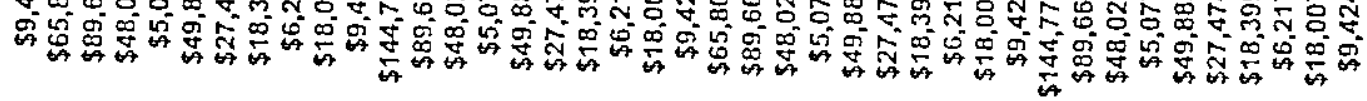

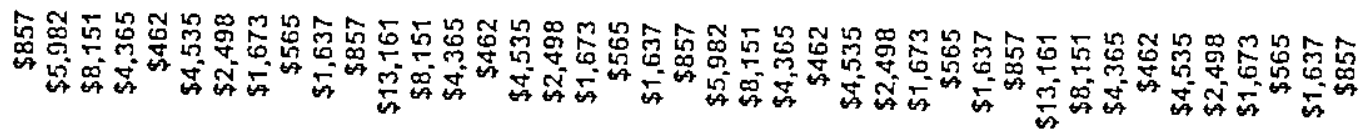

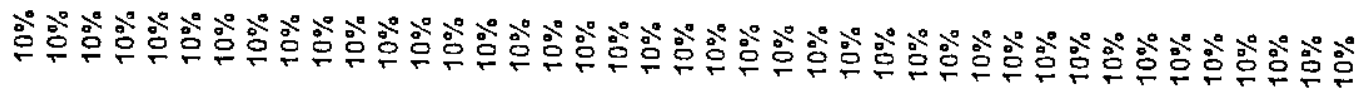

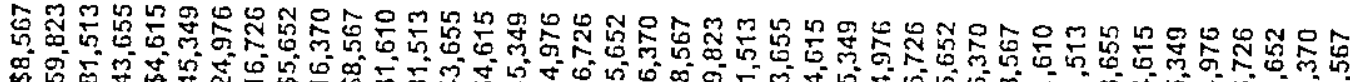

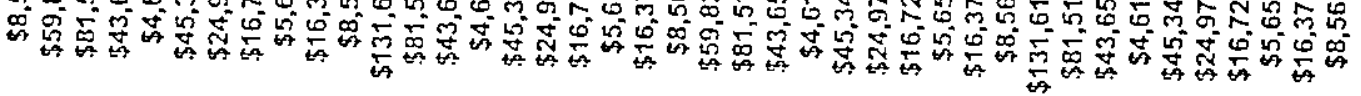

흘

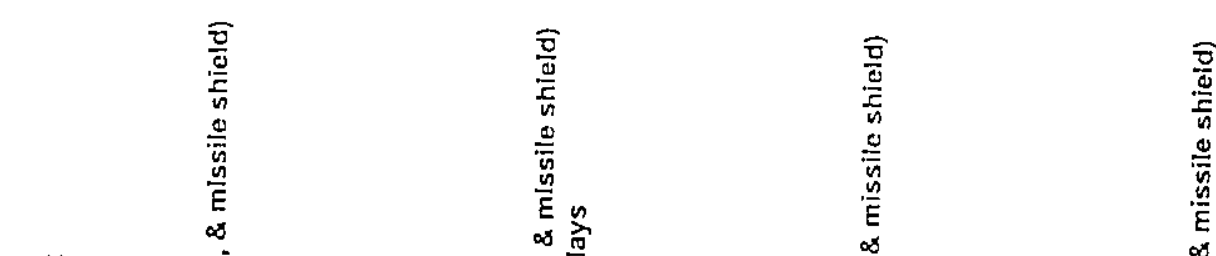

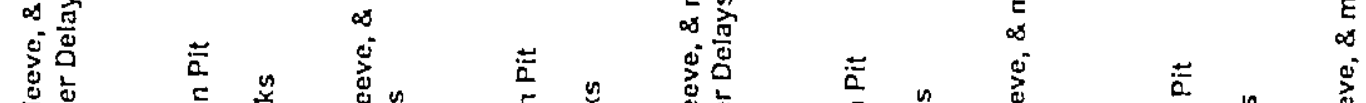

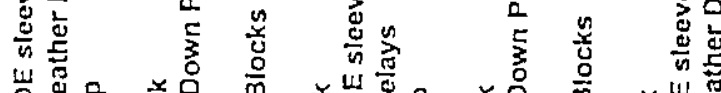

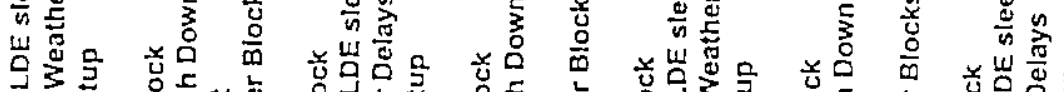

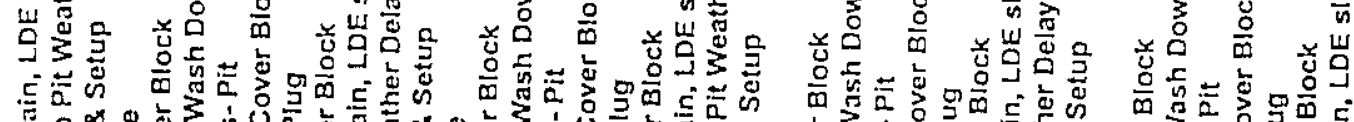

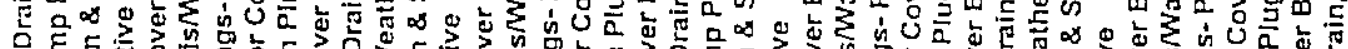

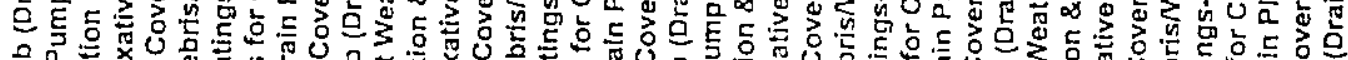

氛

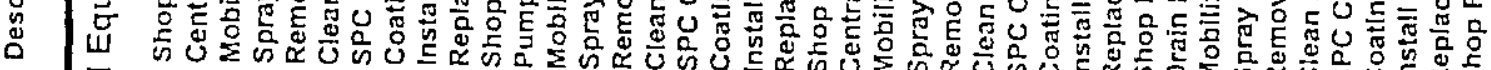

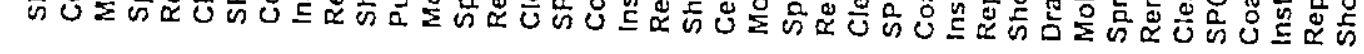




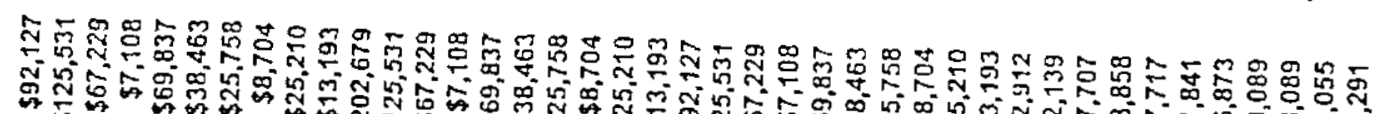

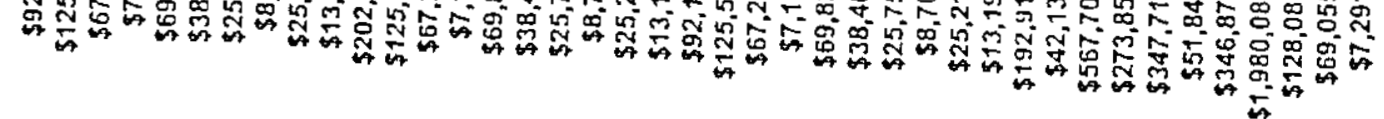

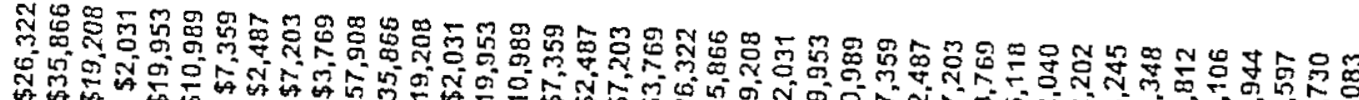

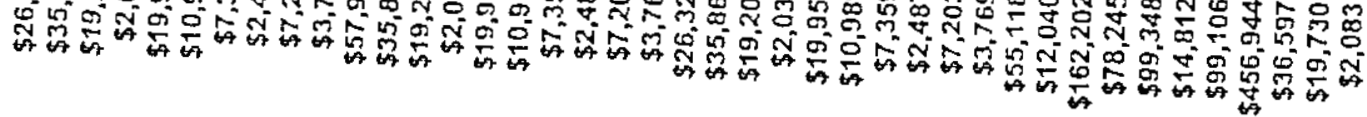

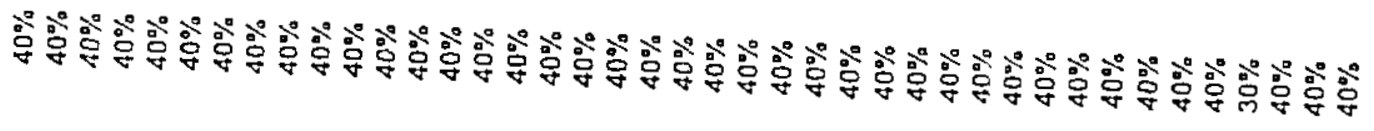

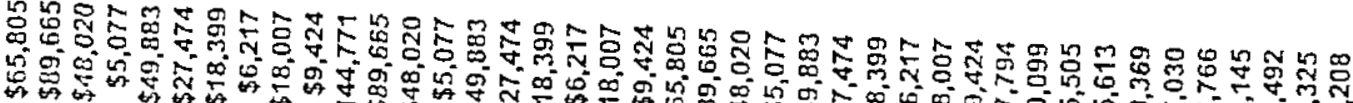

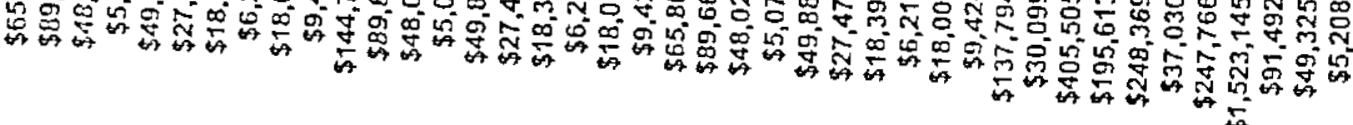

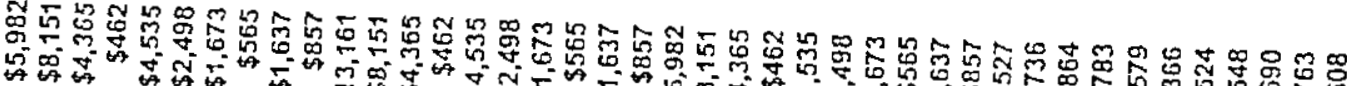

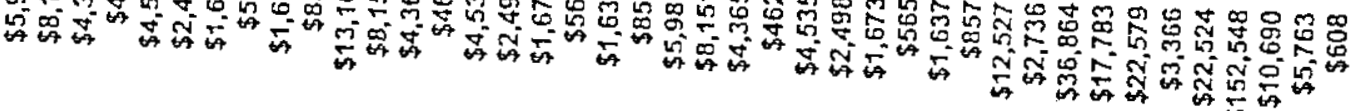

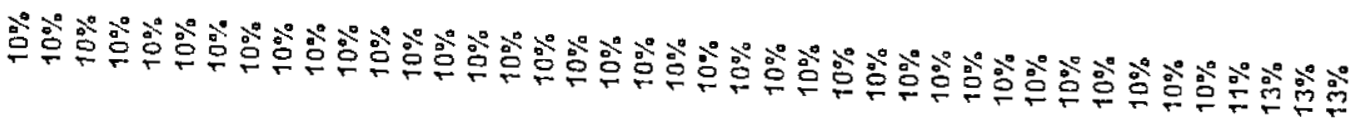

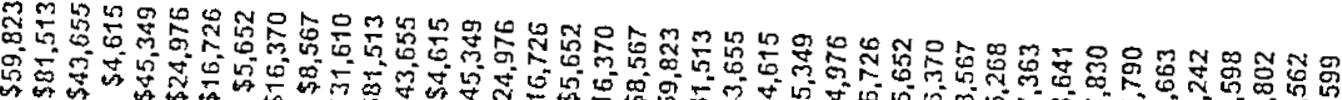

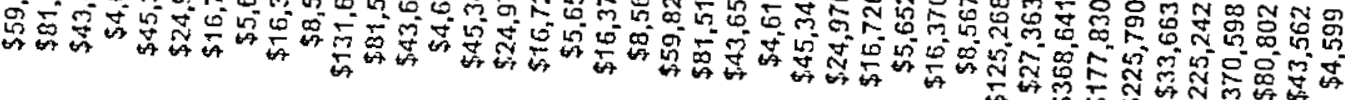




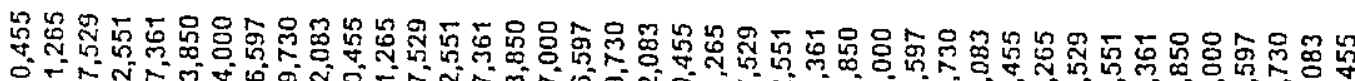

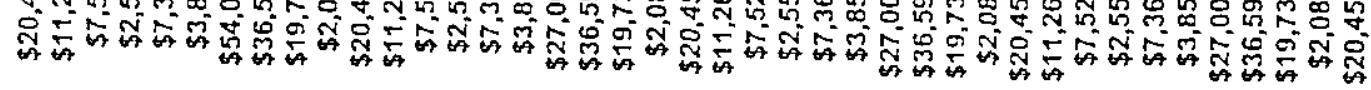

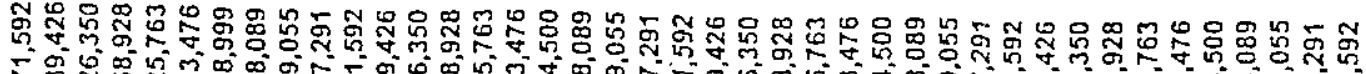

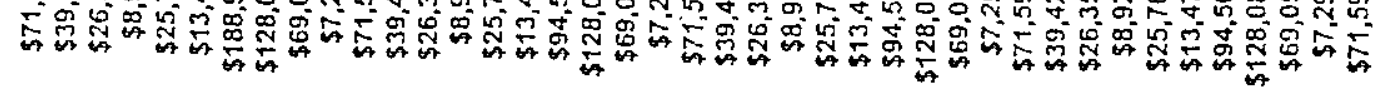

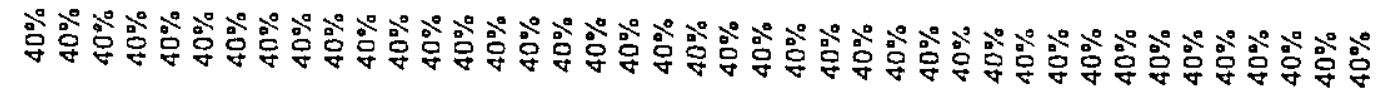

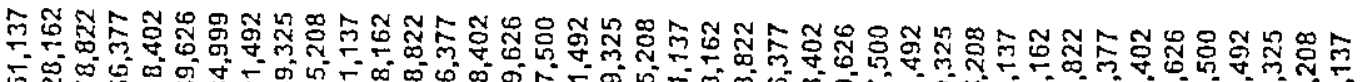

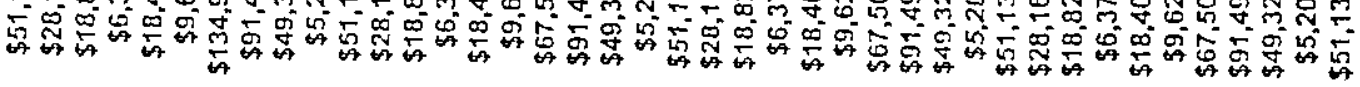

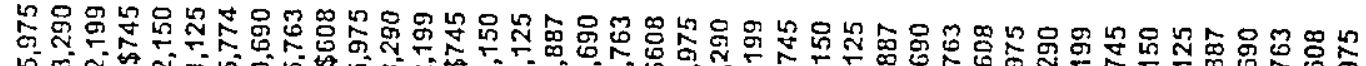

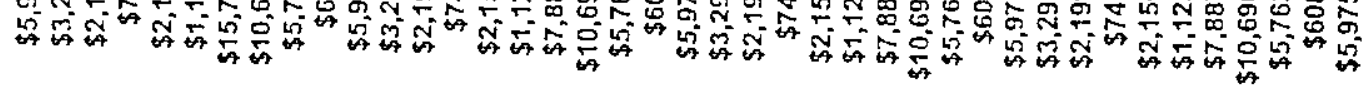

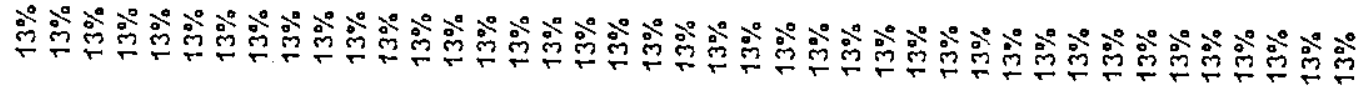

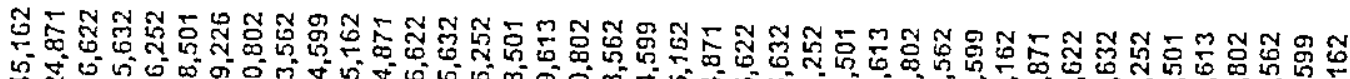

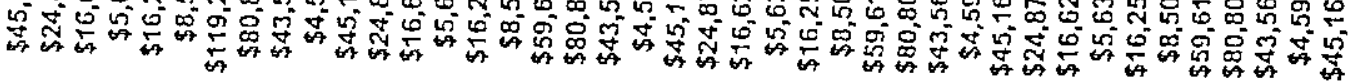




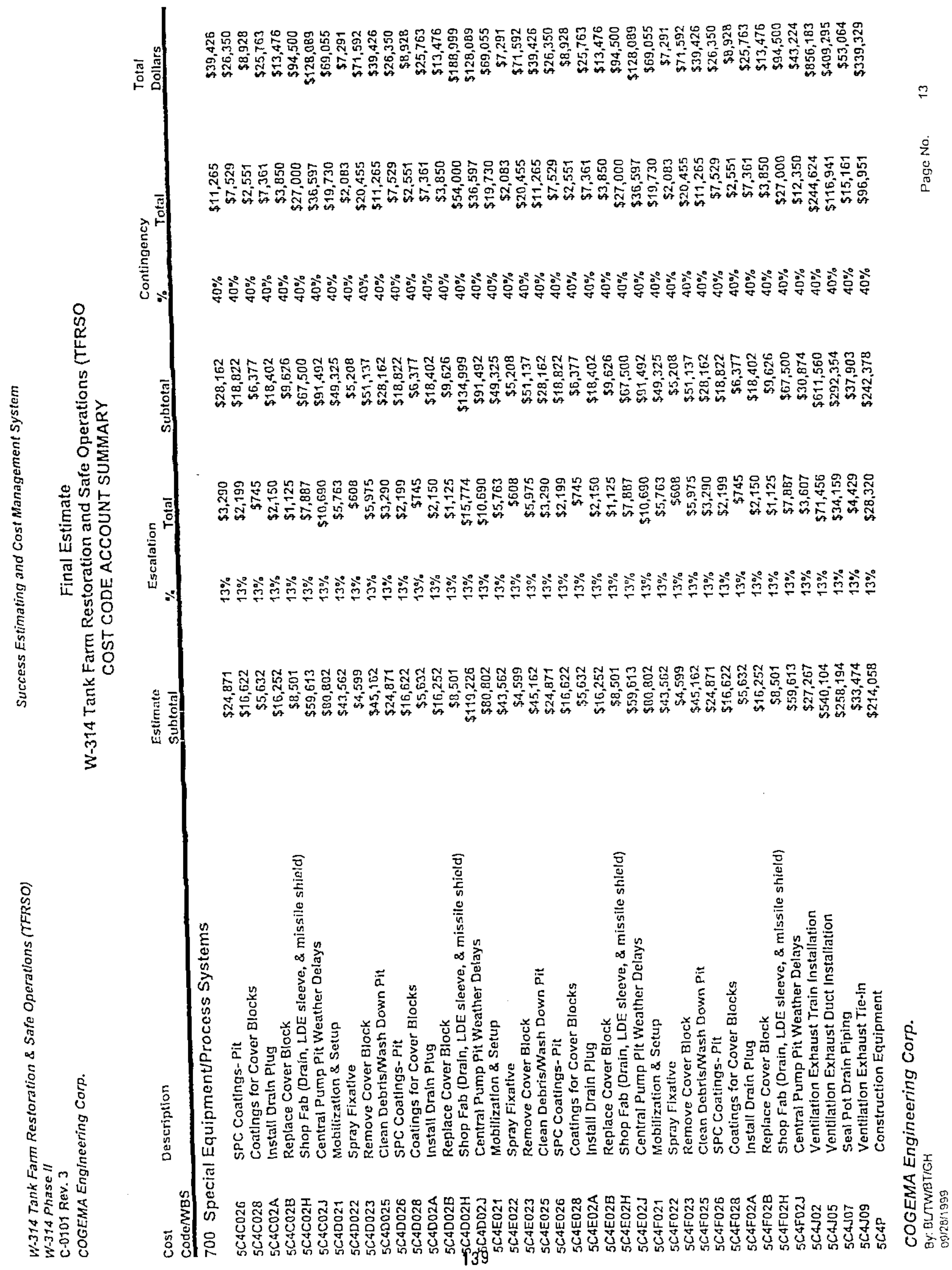




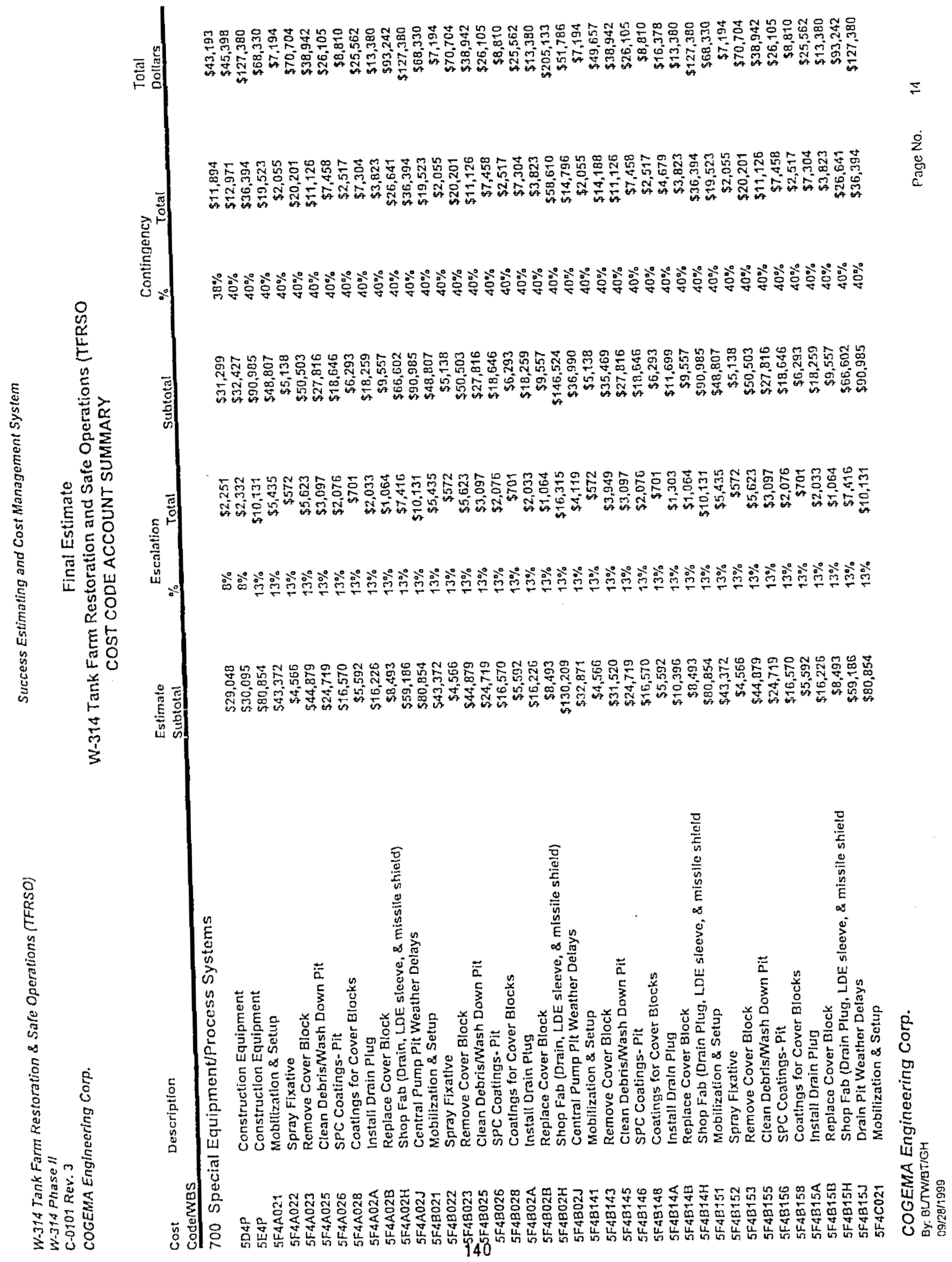




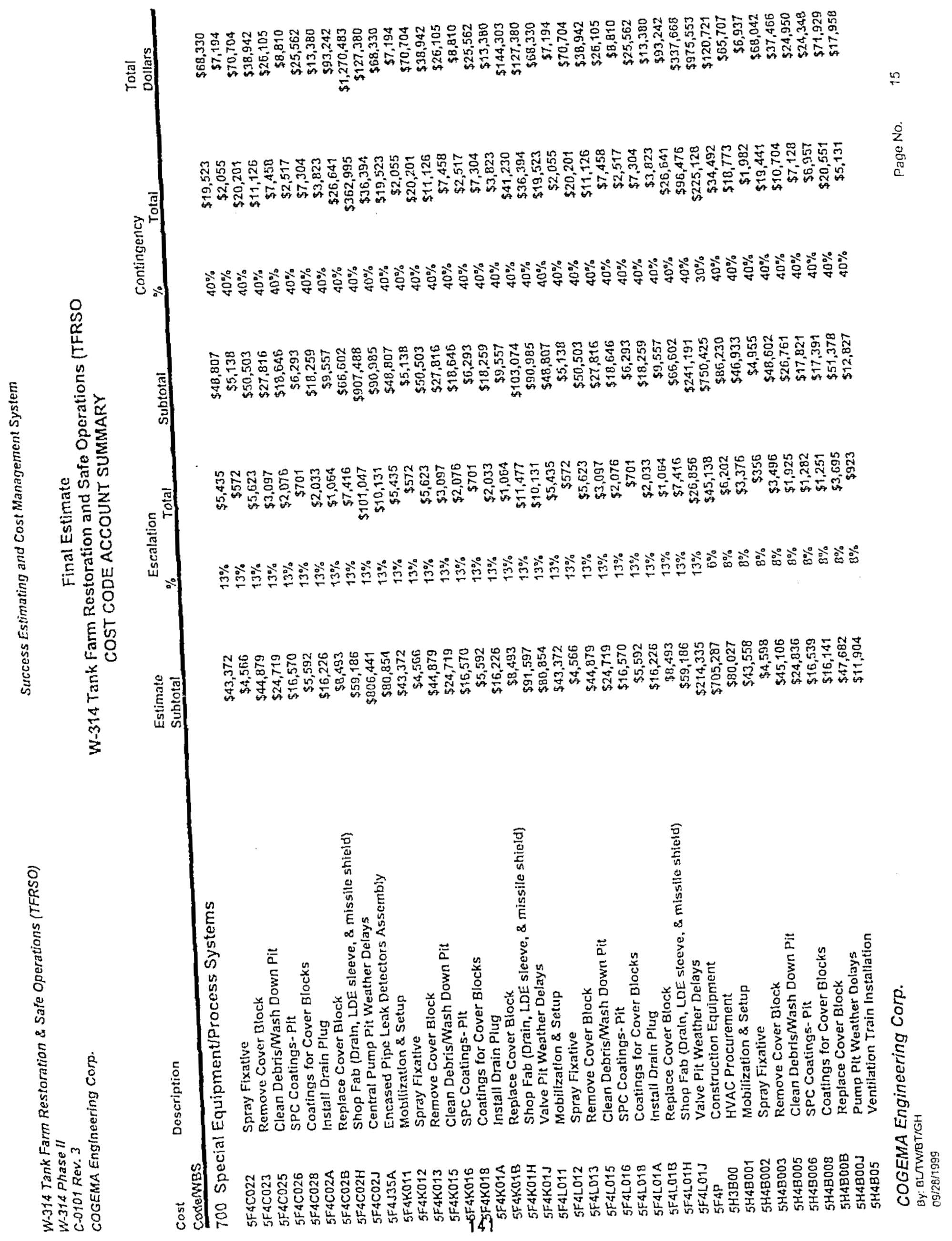




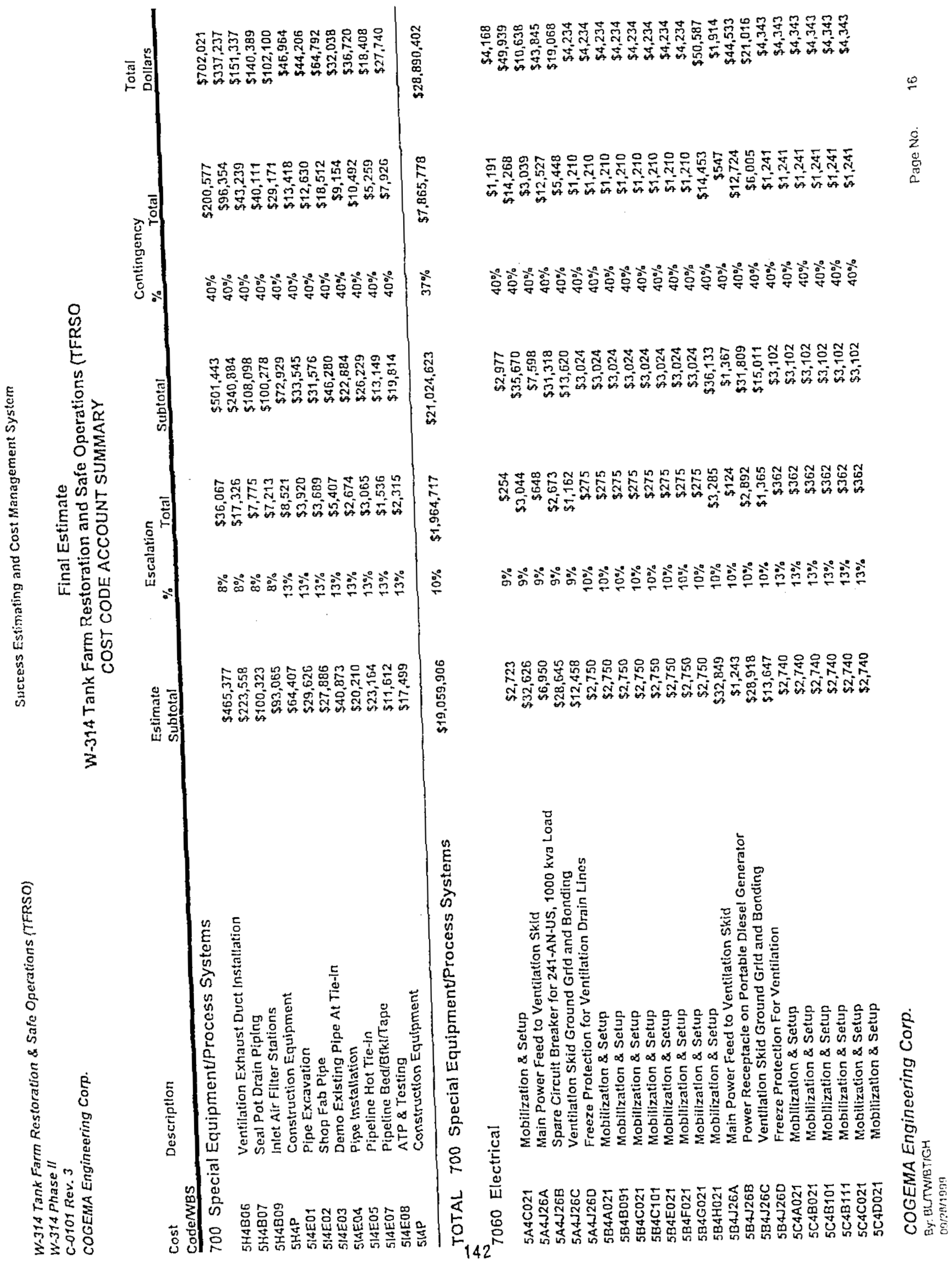




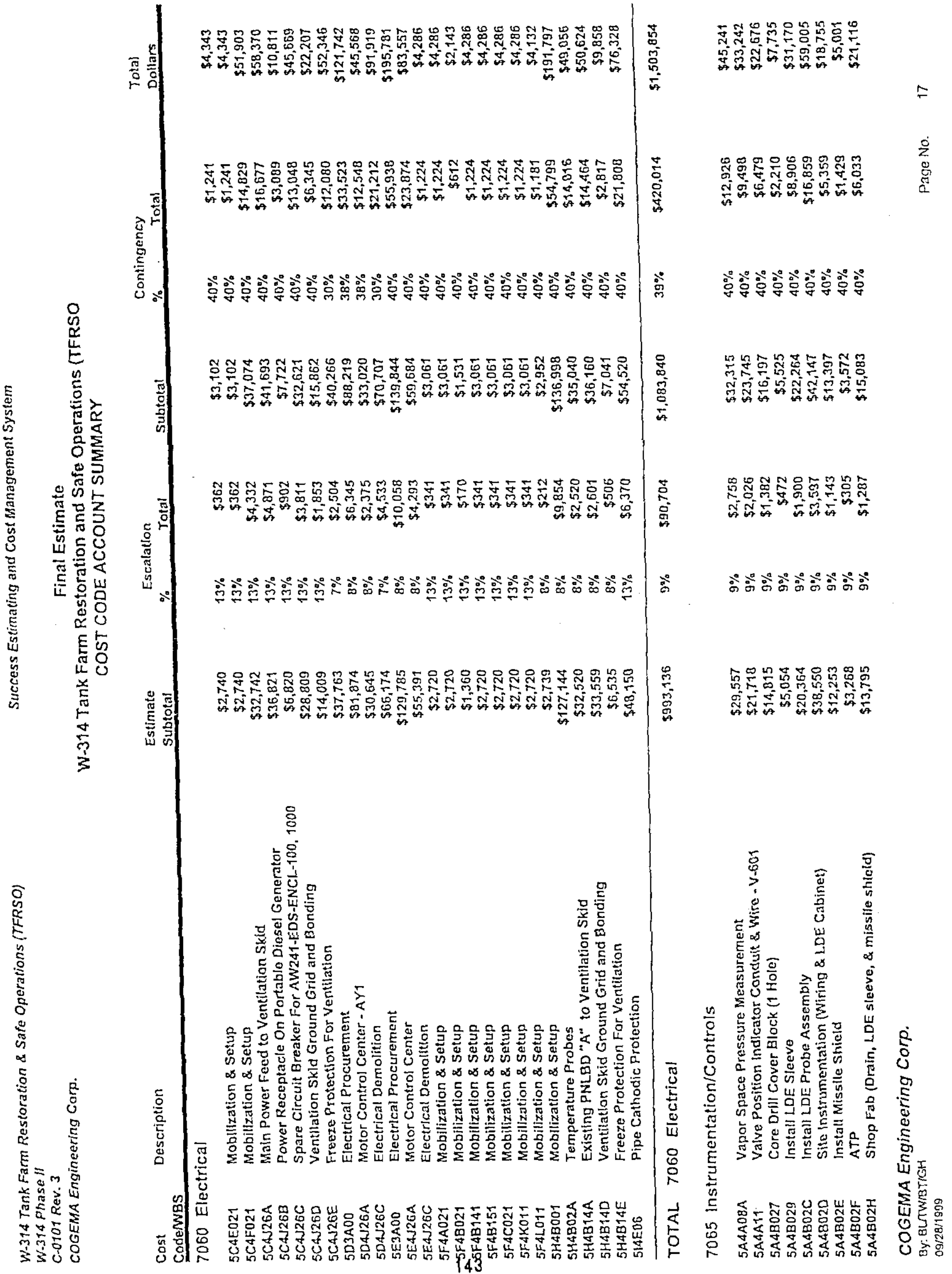




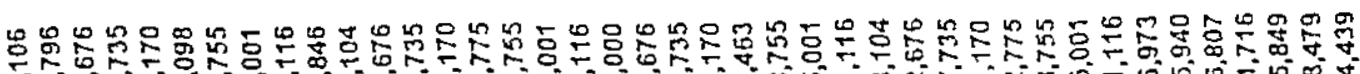

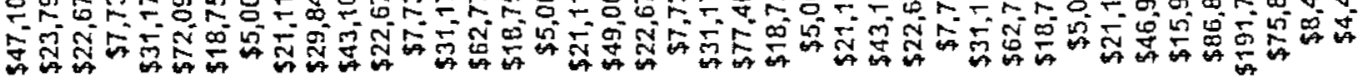

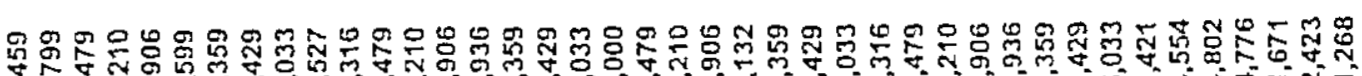

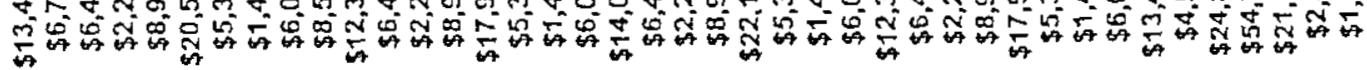

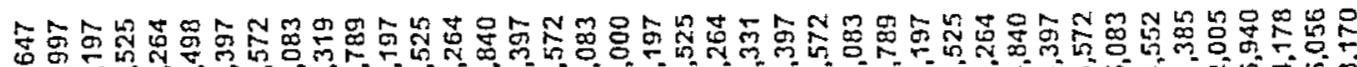

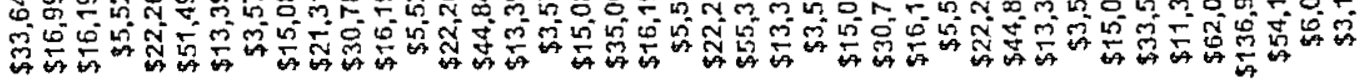

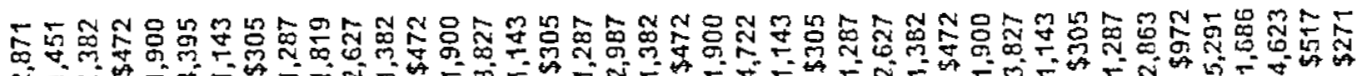

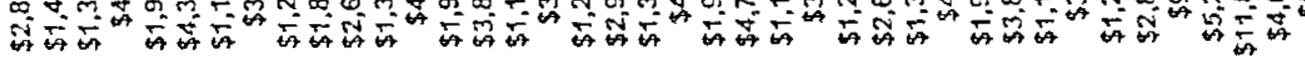

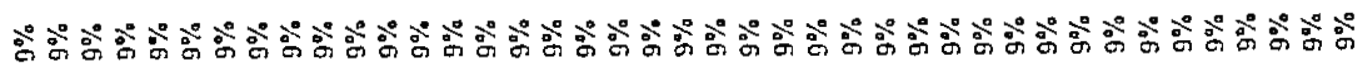

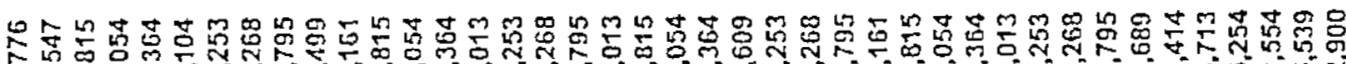

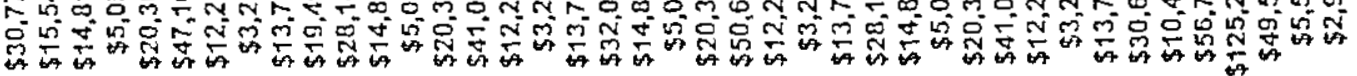

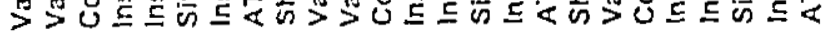


造 출

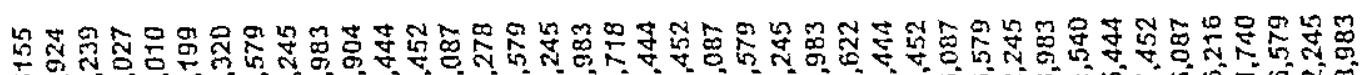

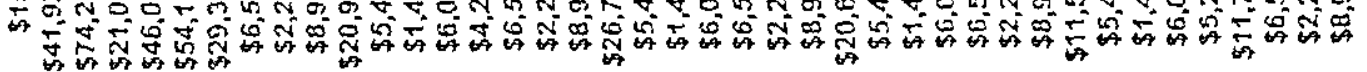

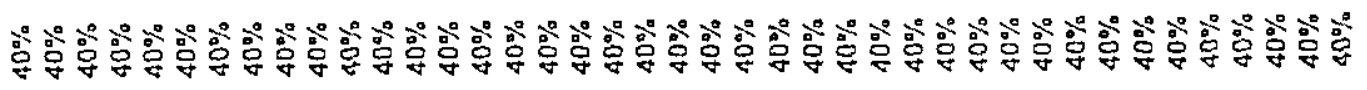

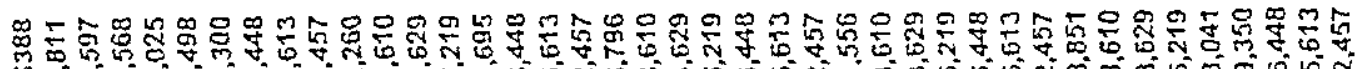

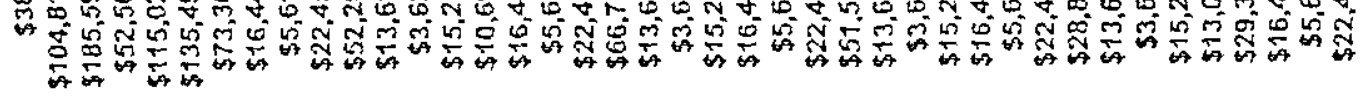

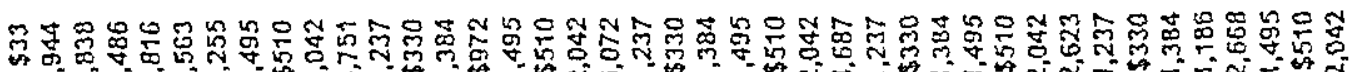

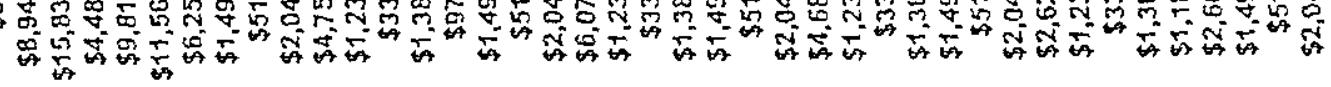

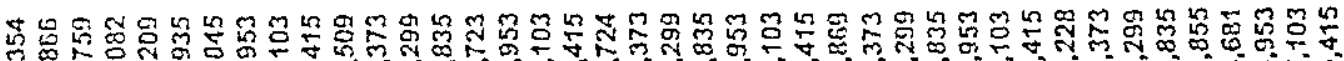

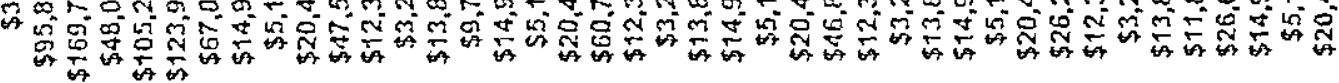

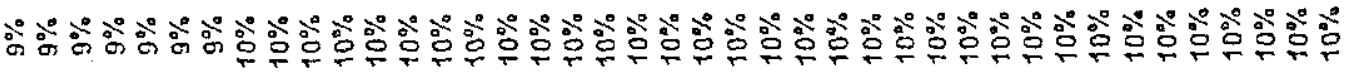

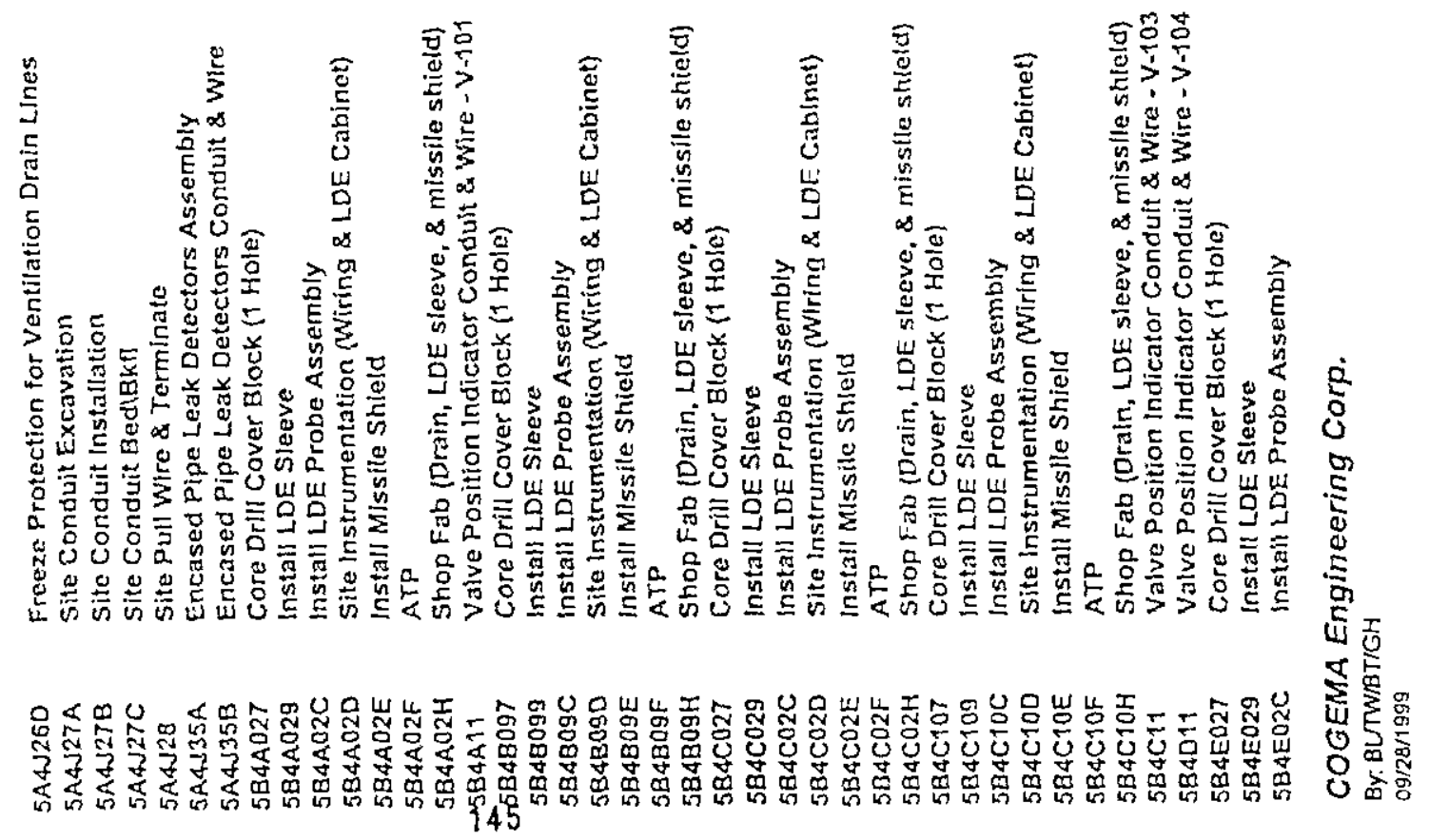




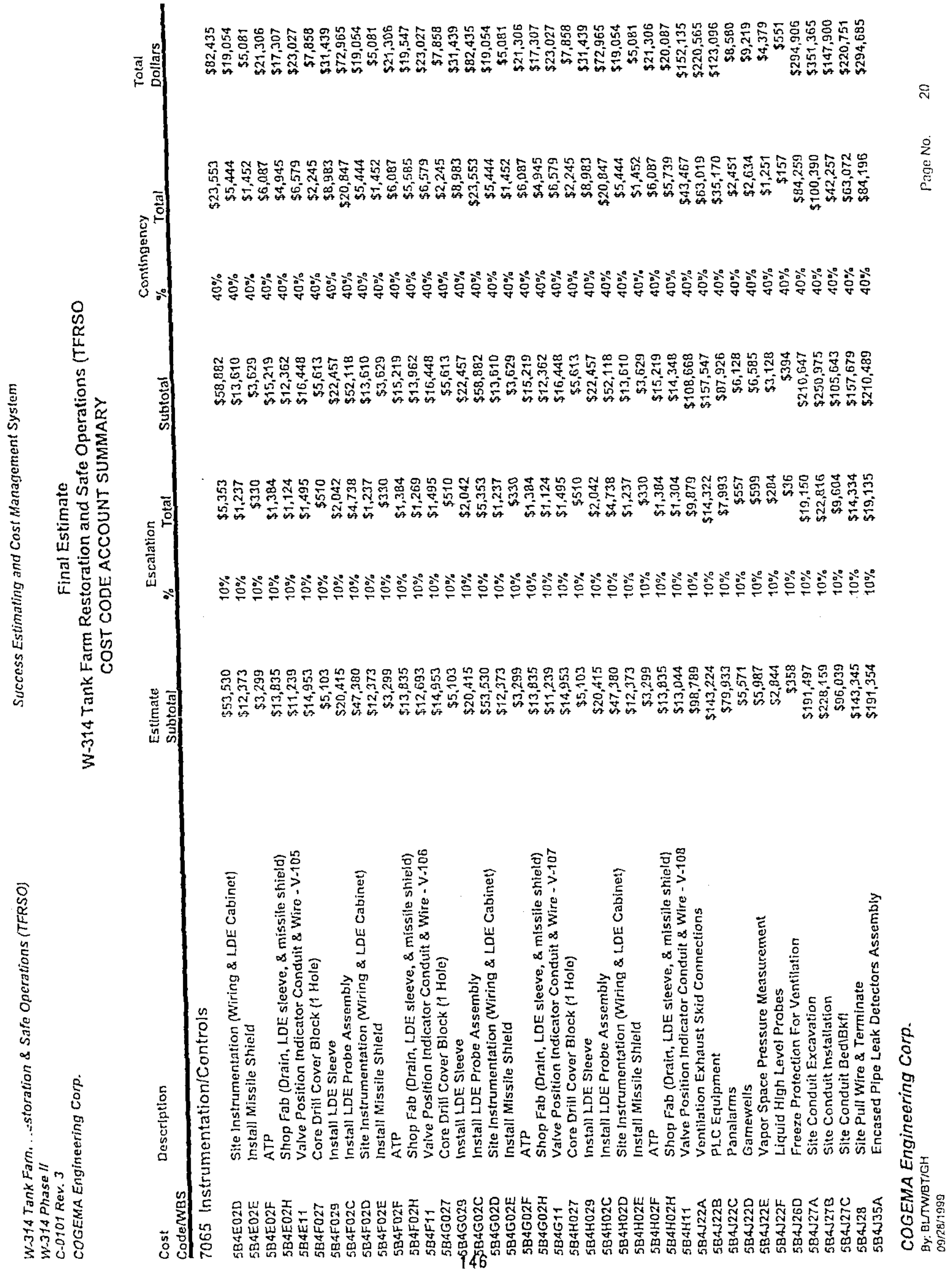




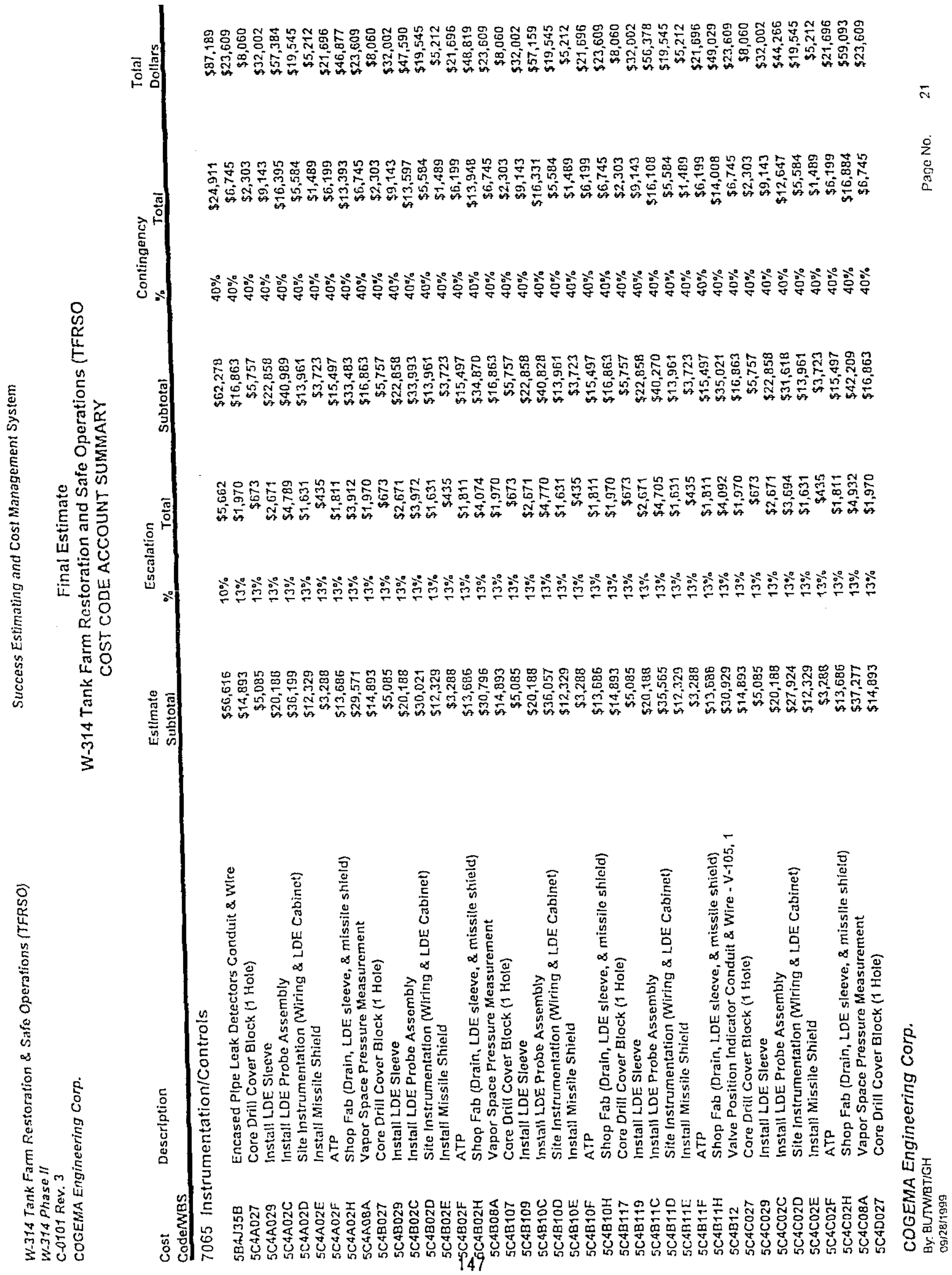




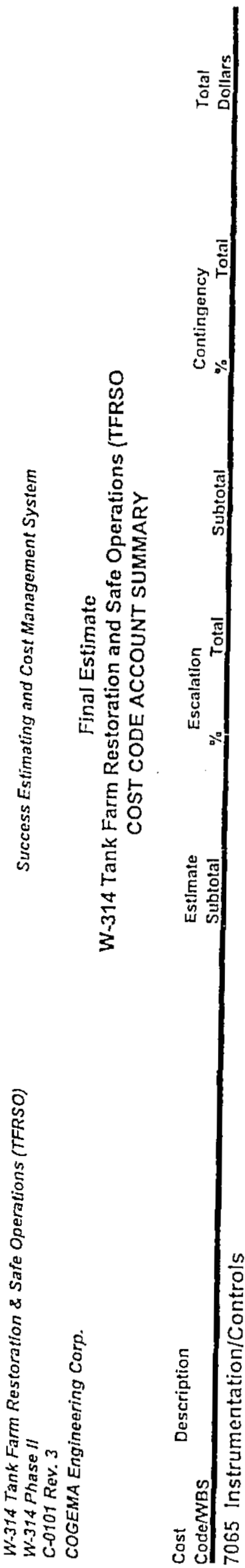

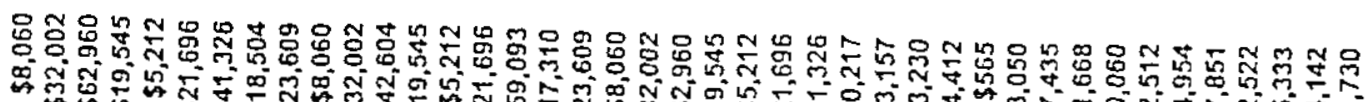

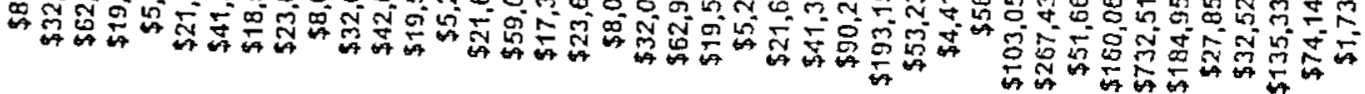

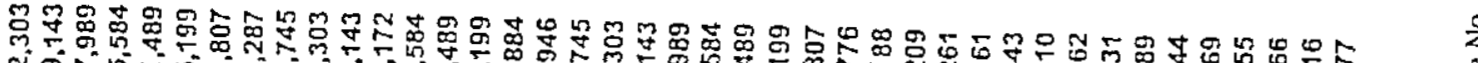

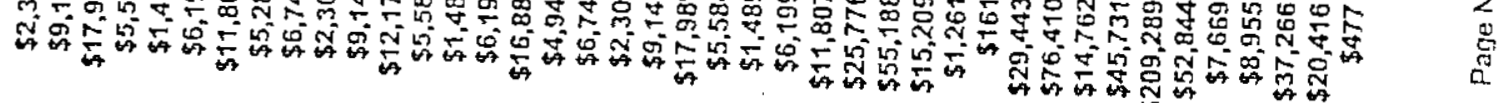

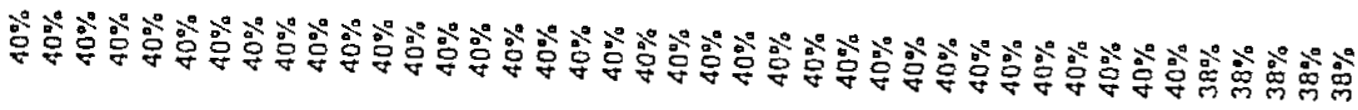

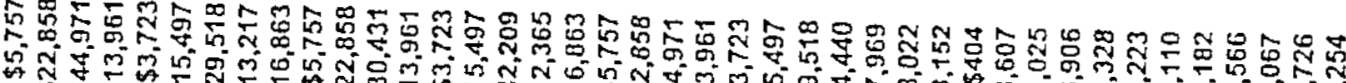

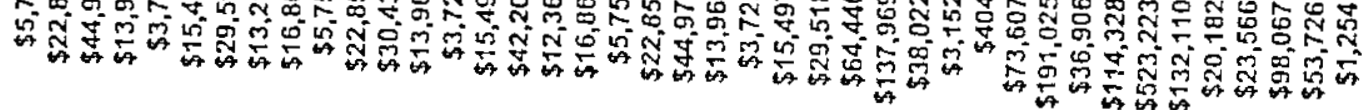

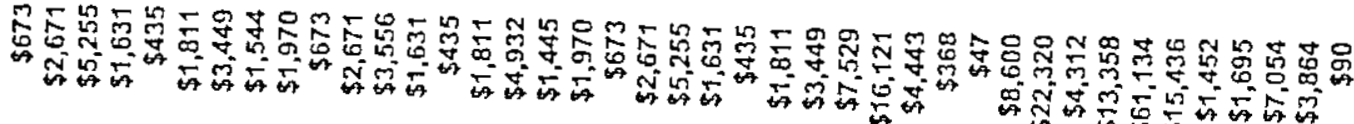

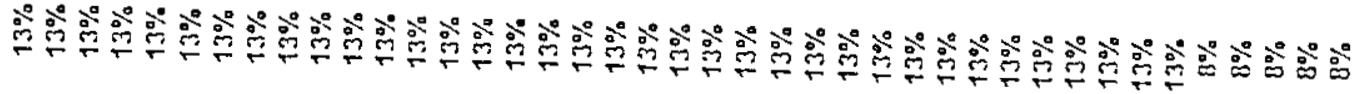

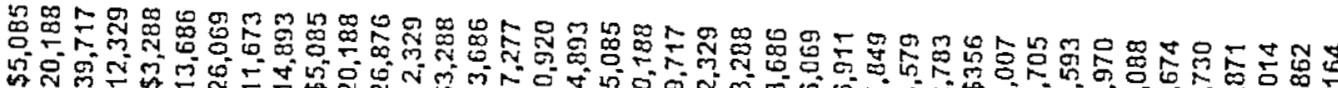

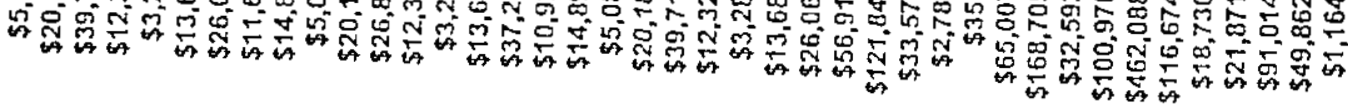
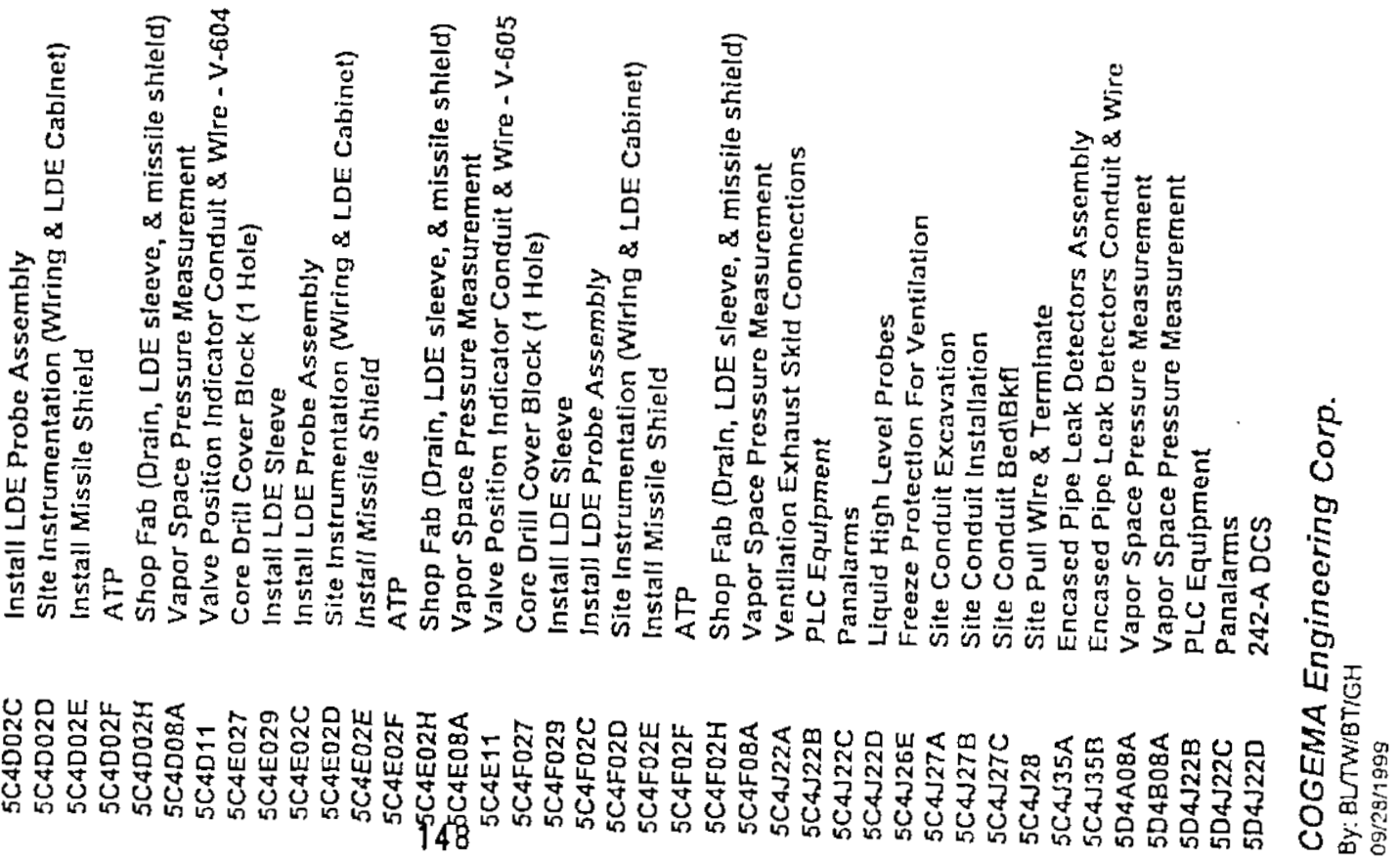


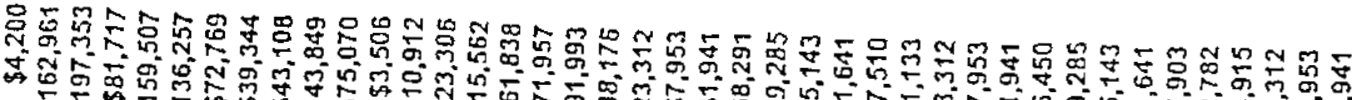

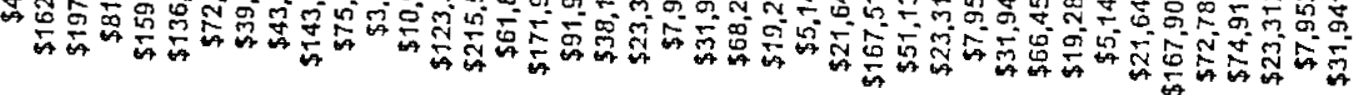

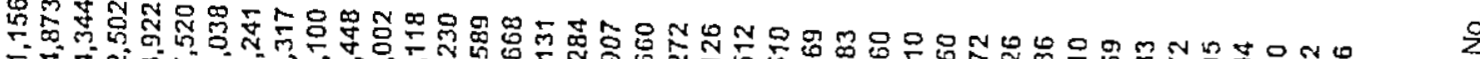

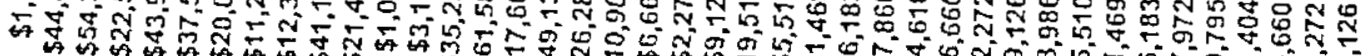

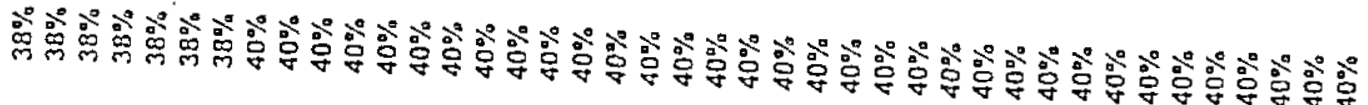

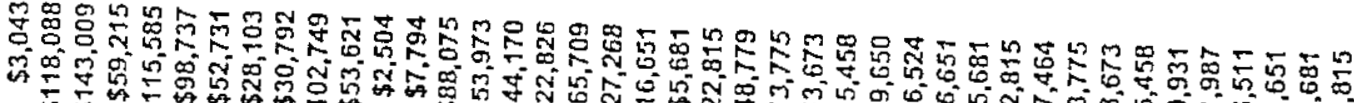

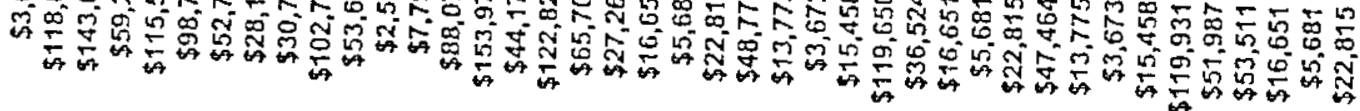

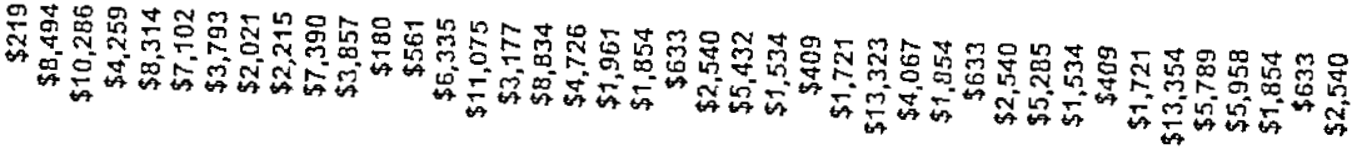

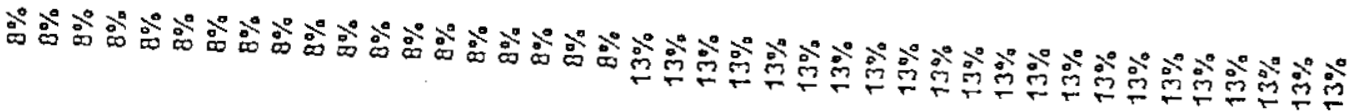

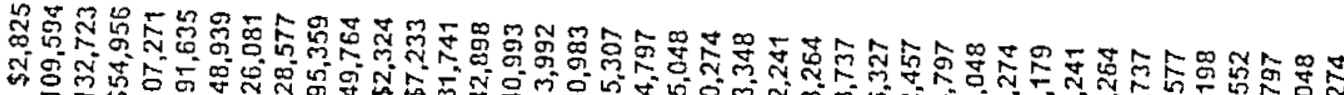

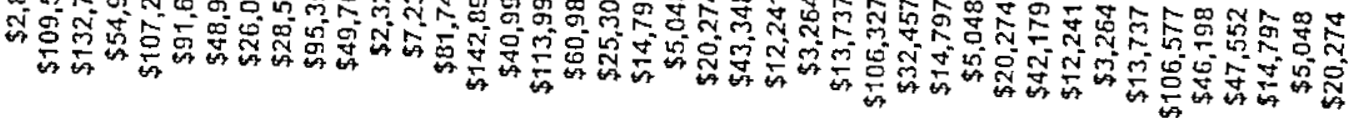

\section{传}

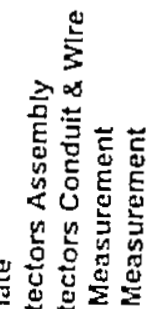

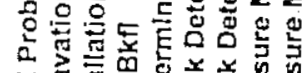

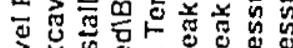

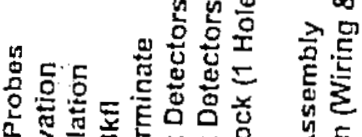

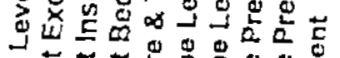

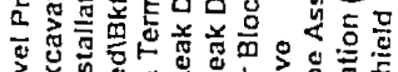

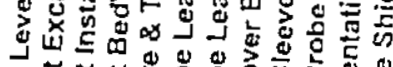

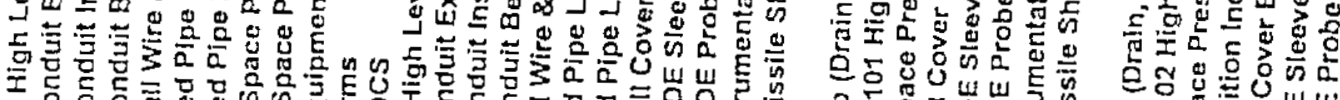

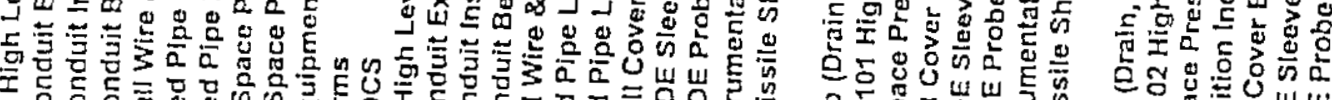

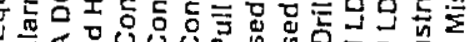

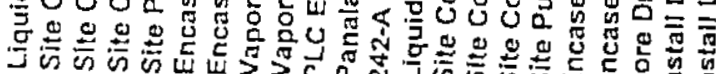

要空。

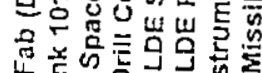

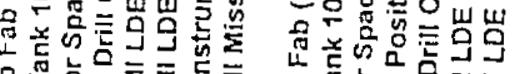
等

崖苛通

8
0
0
0
0

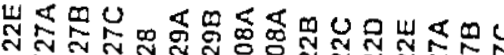

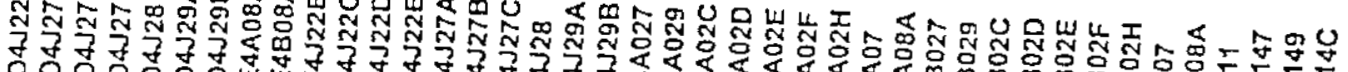

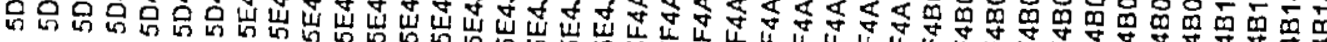

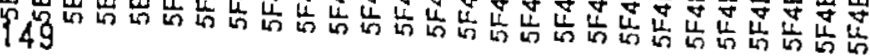




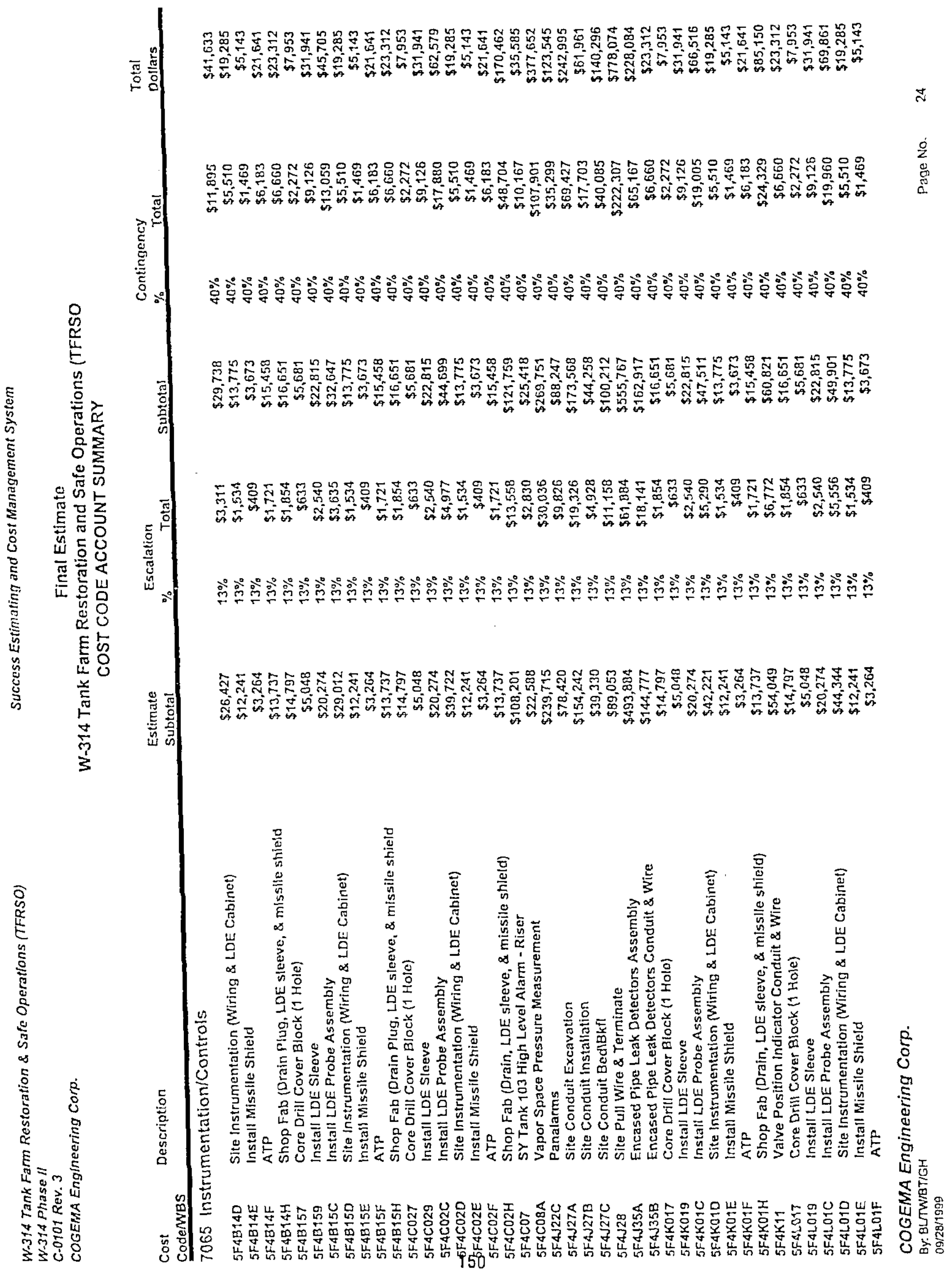




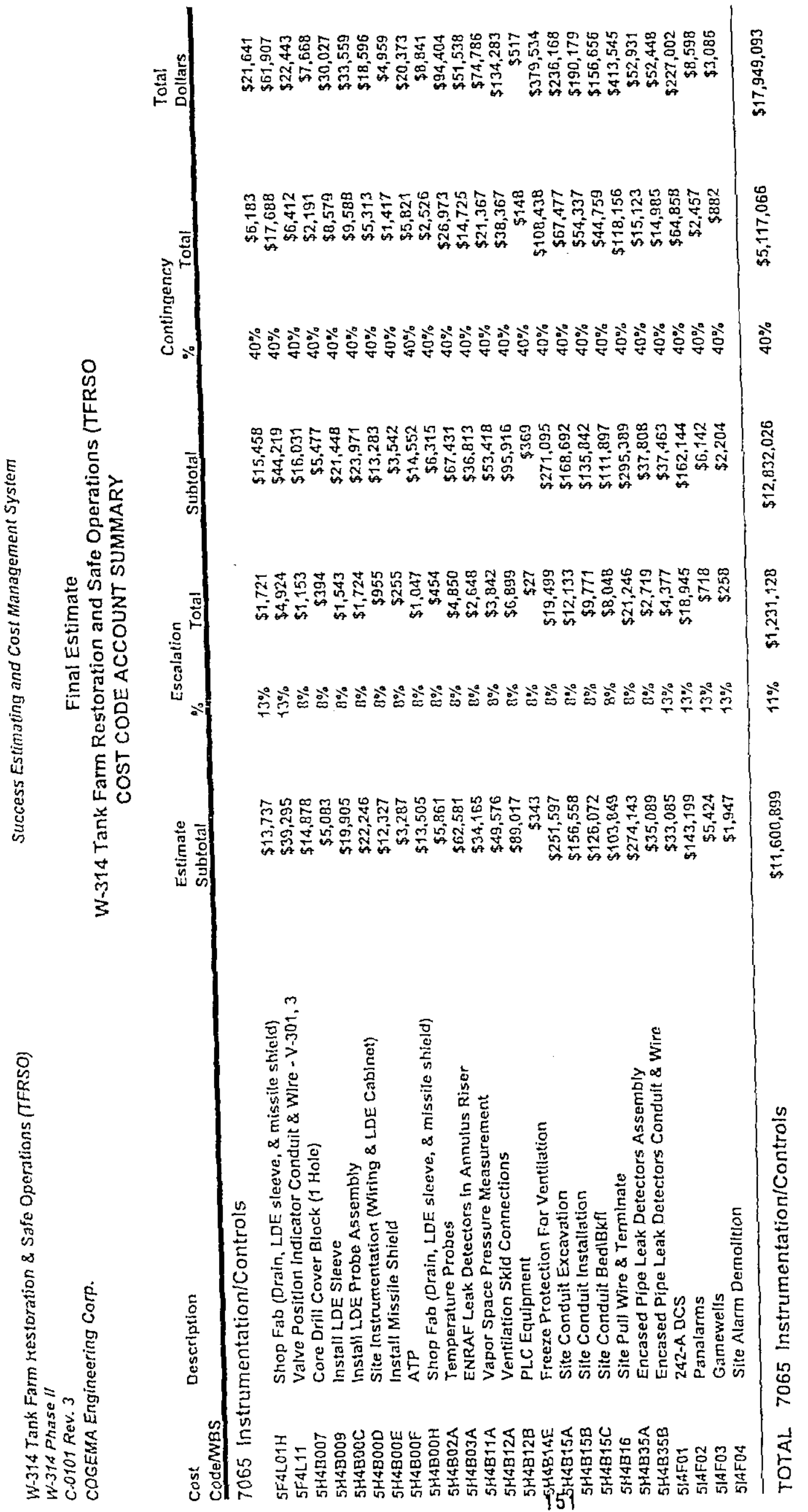

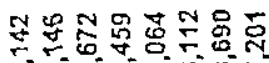

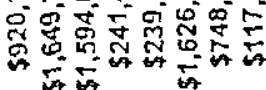

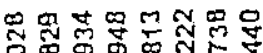

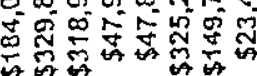

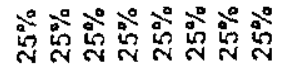

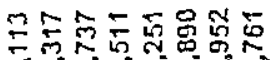

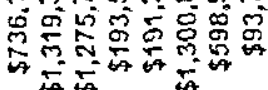

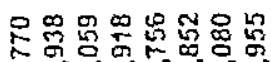

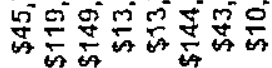

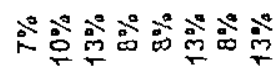

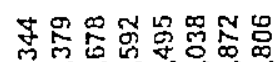

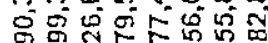

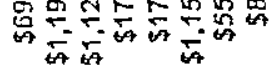

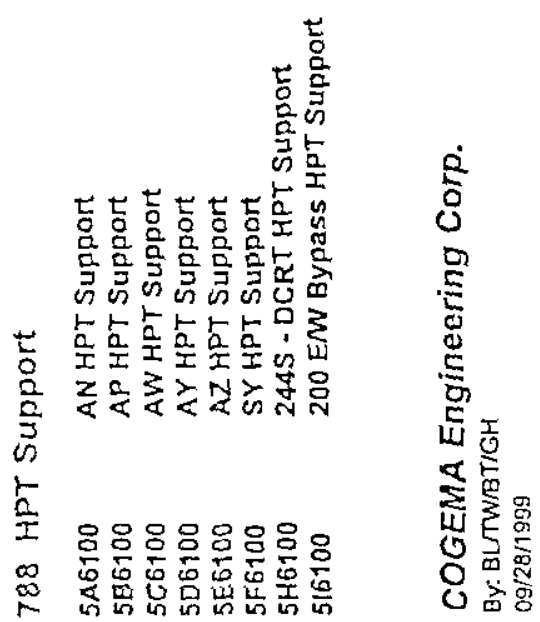




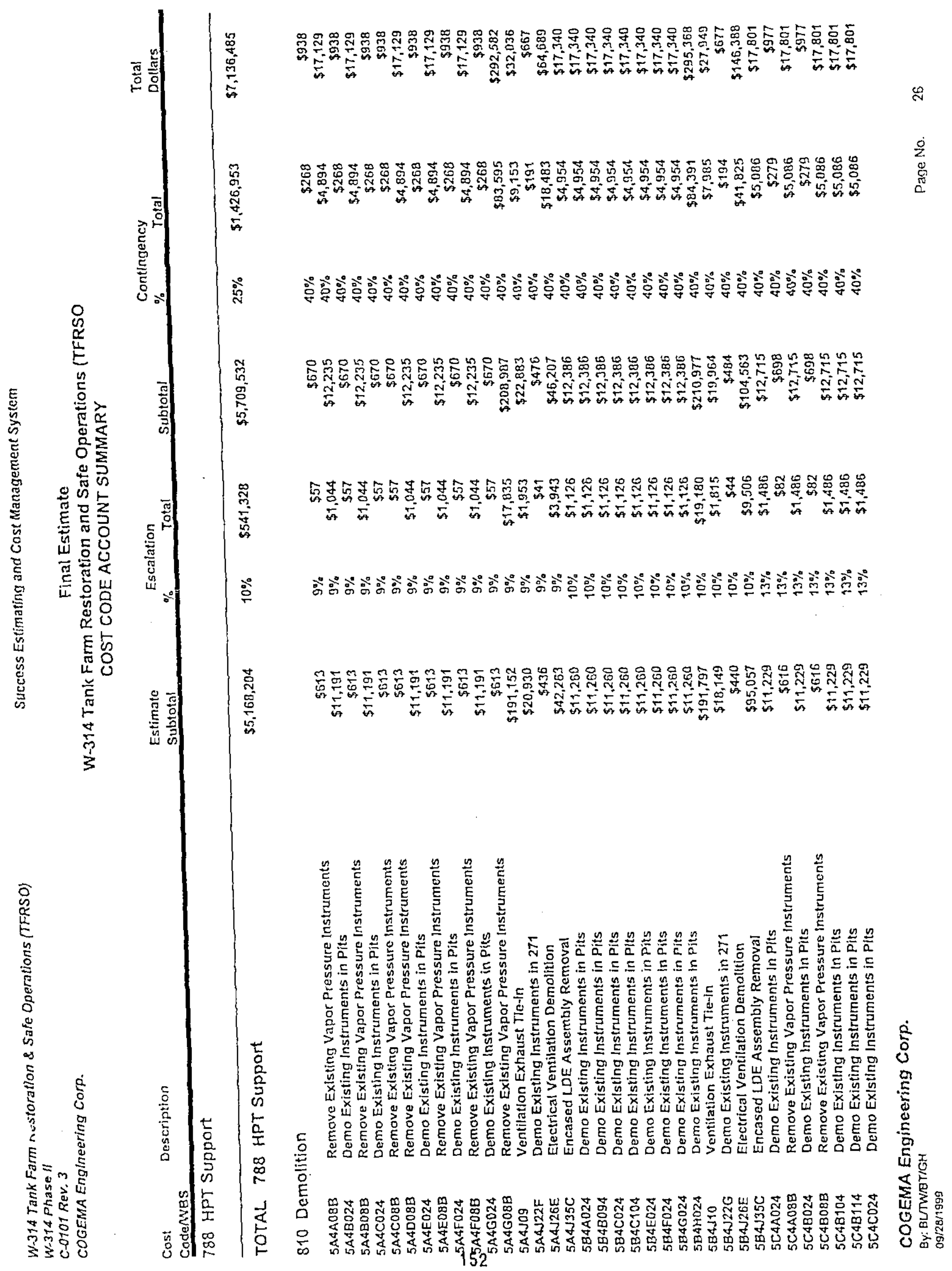




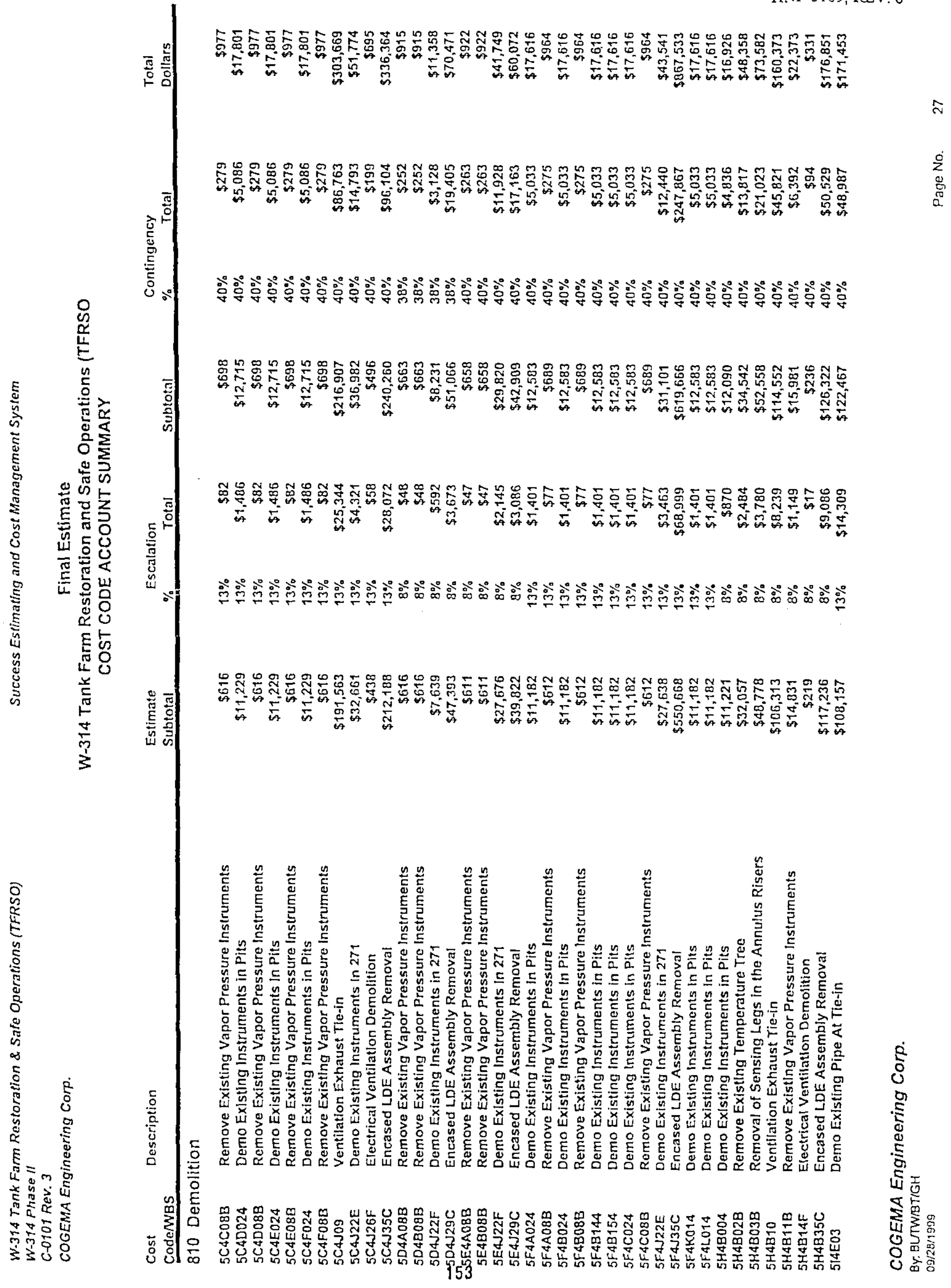




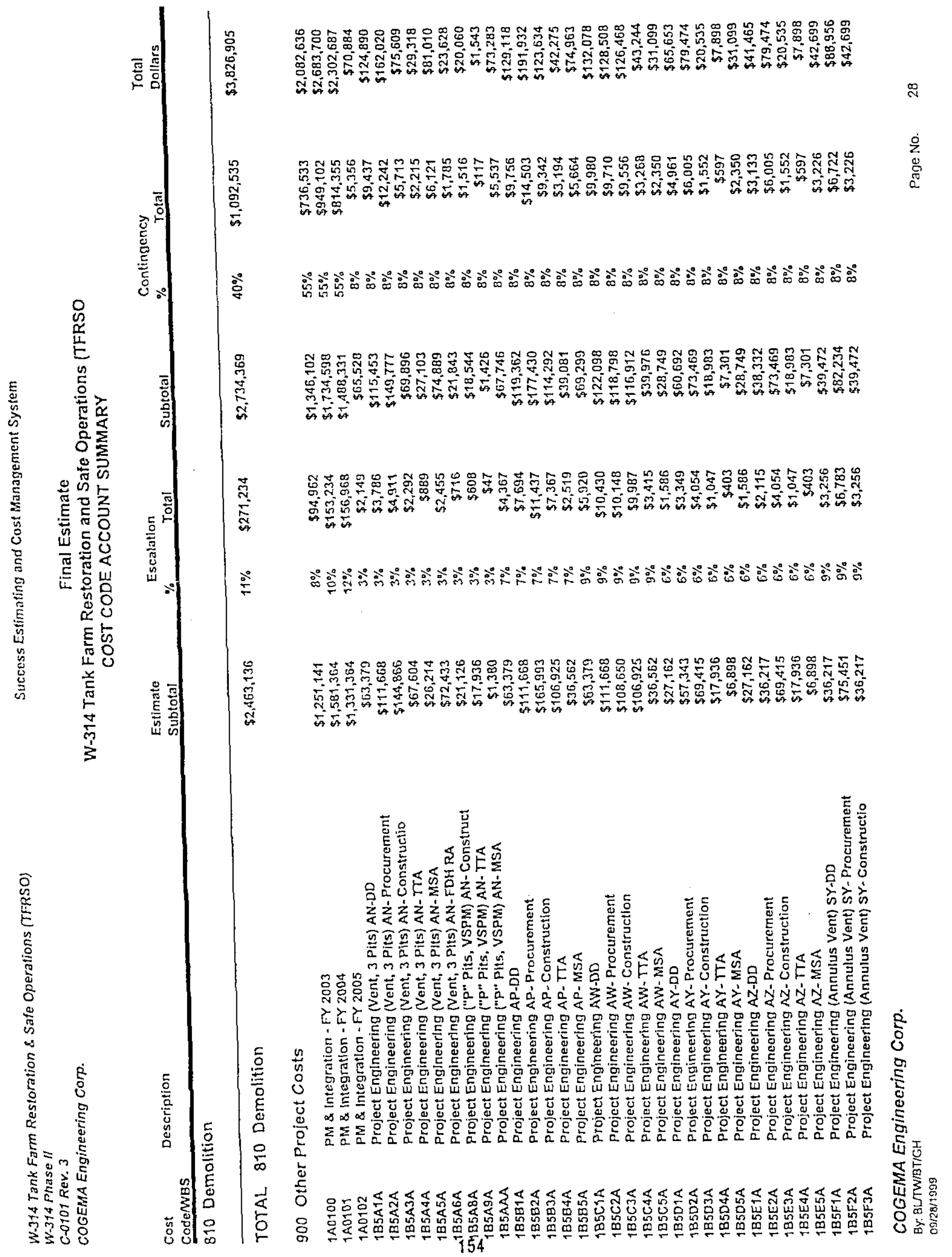




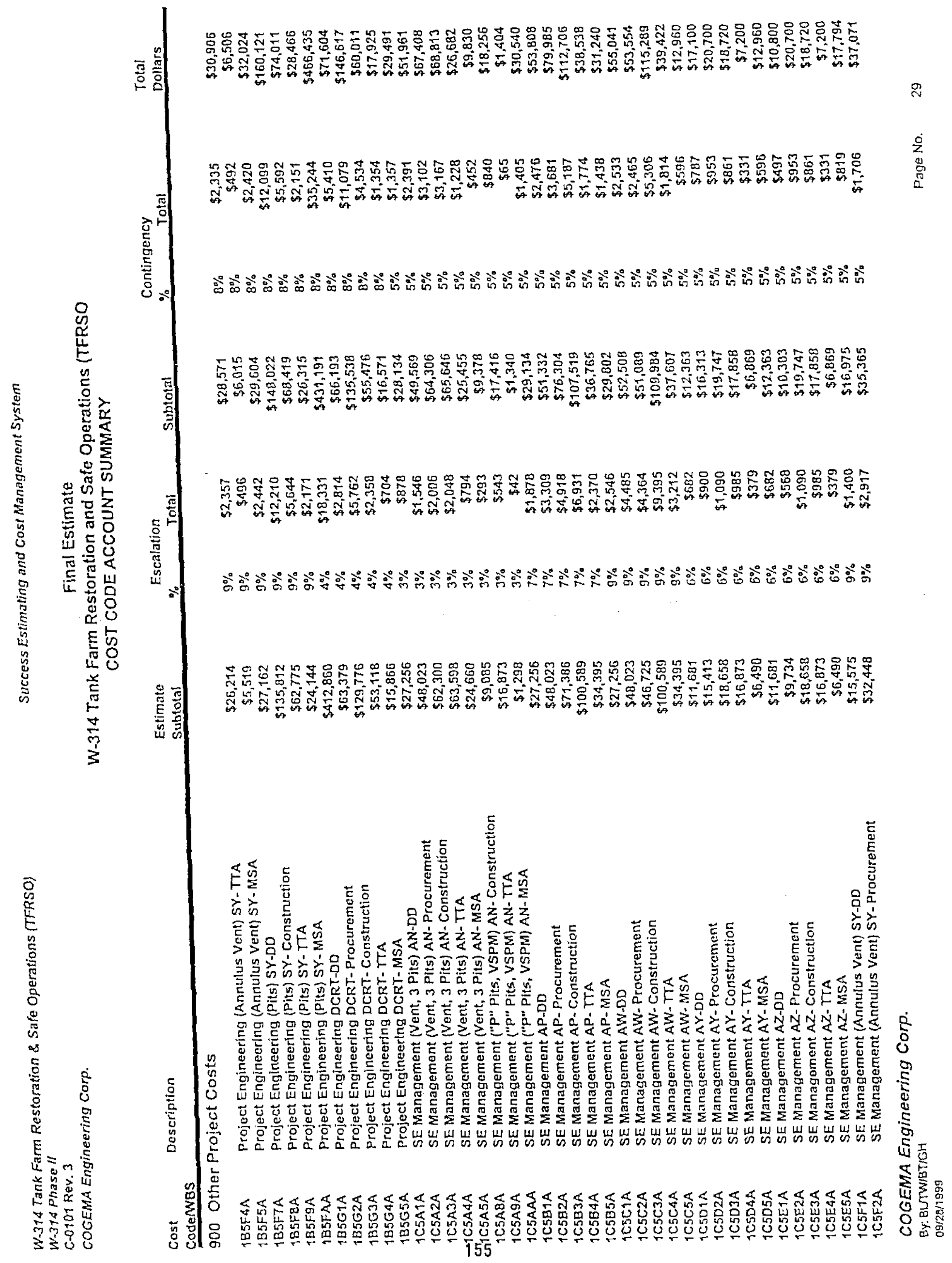




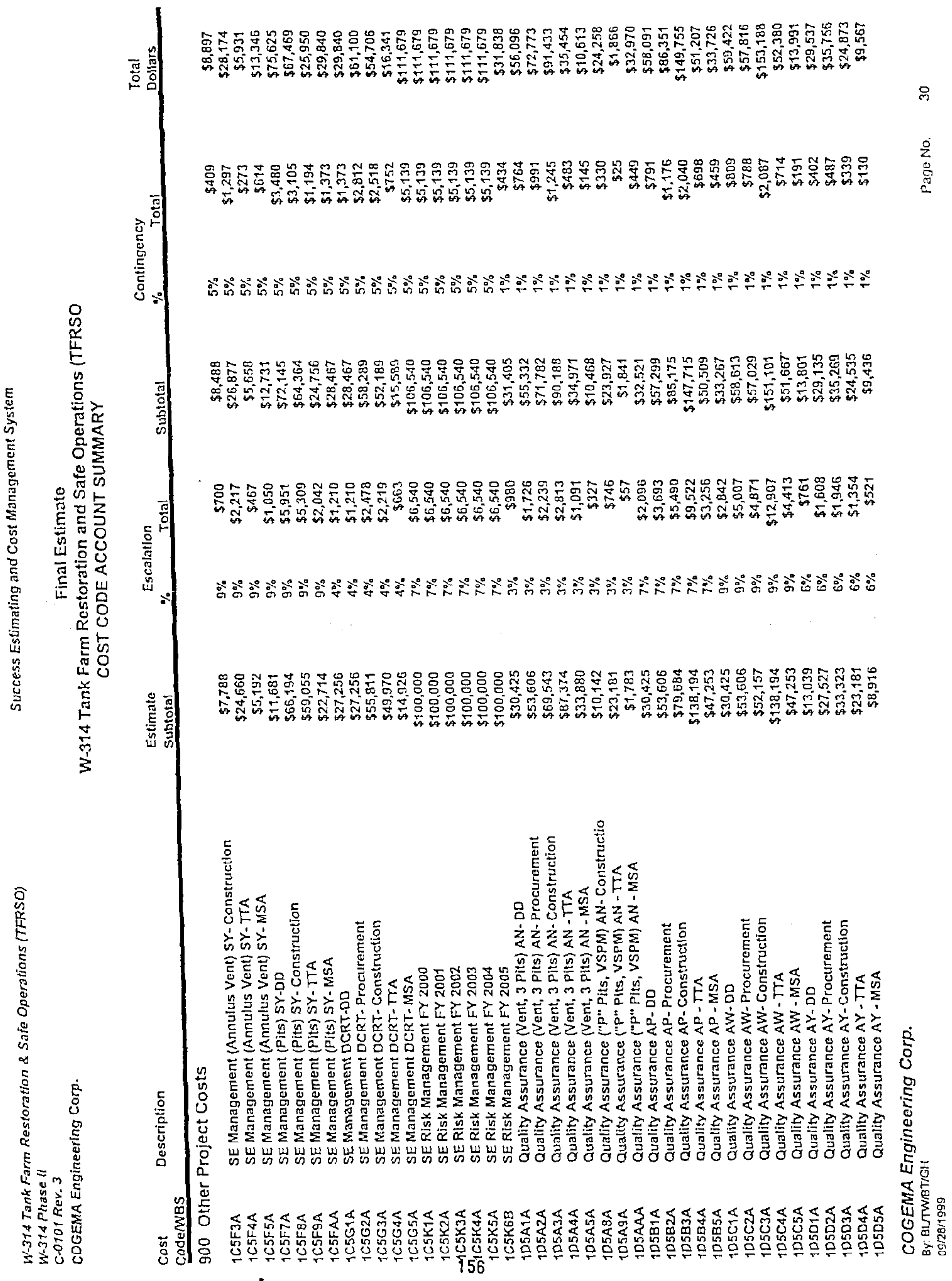




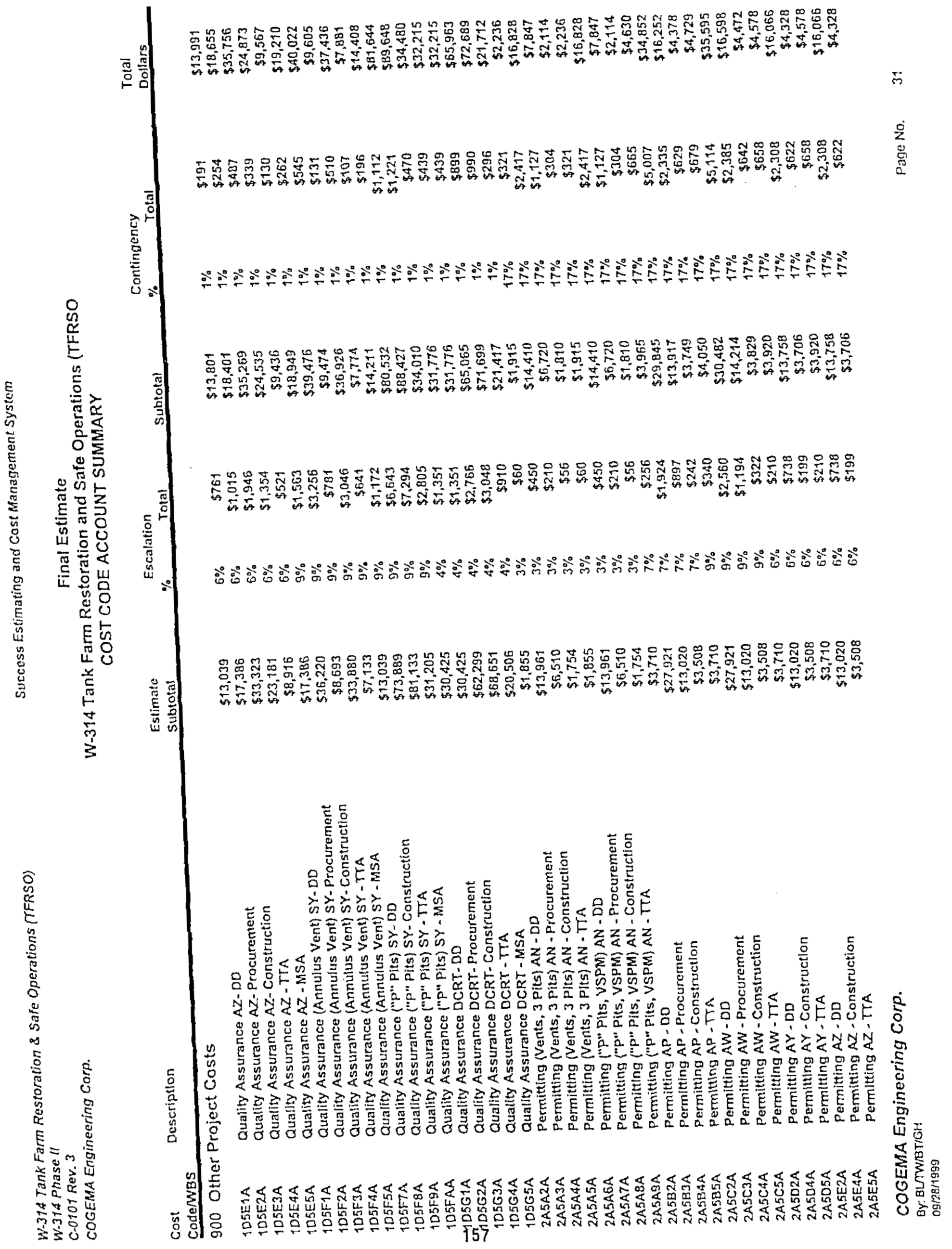




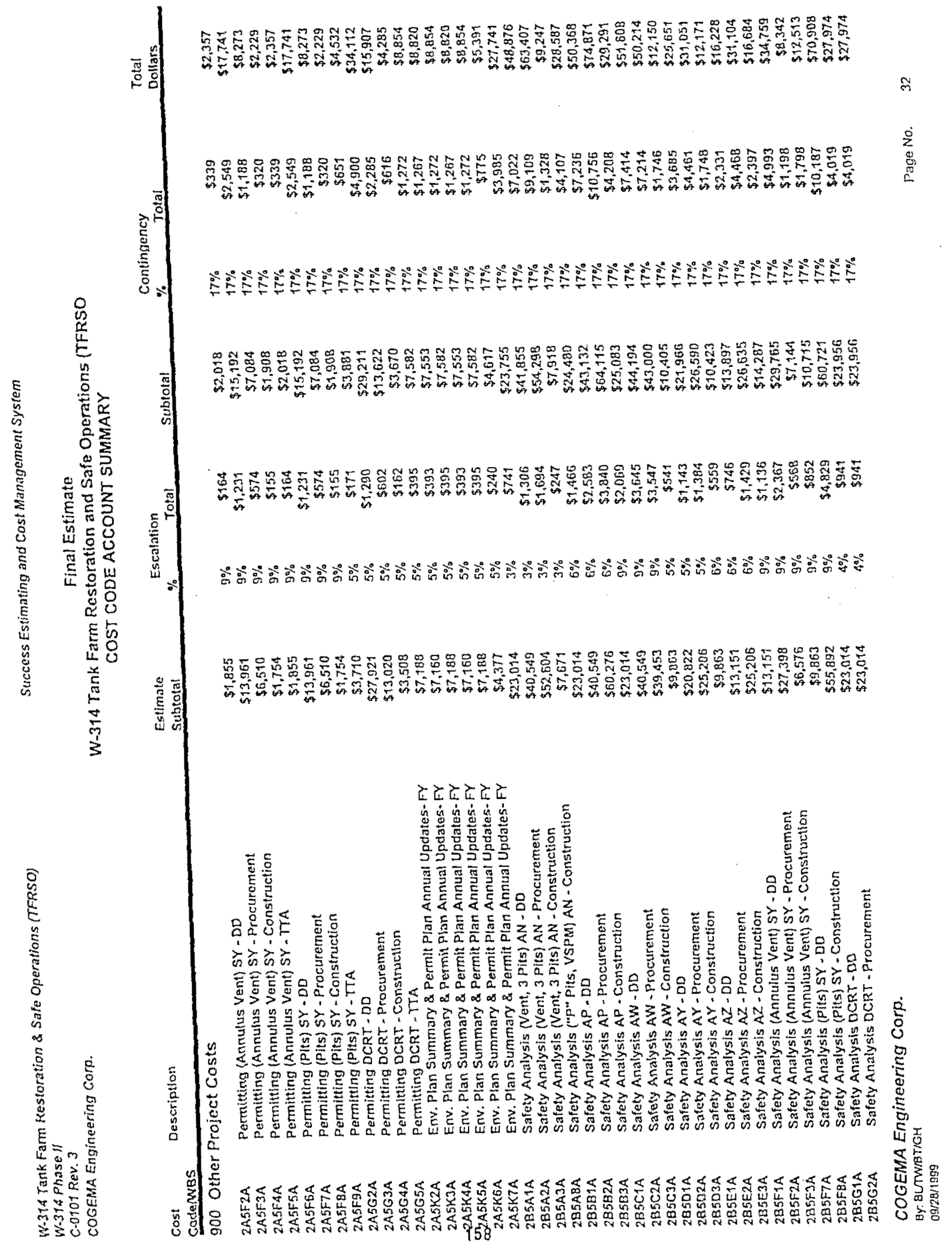




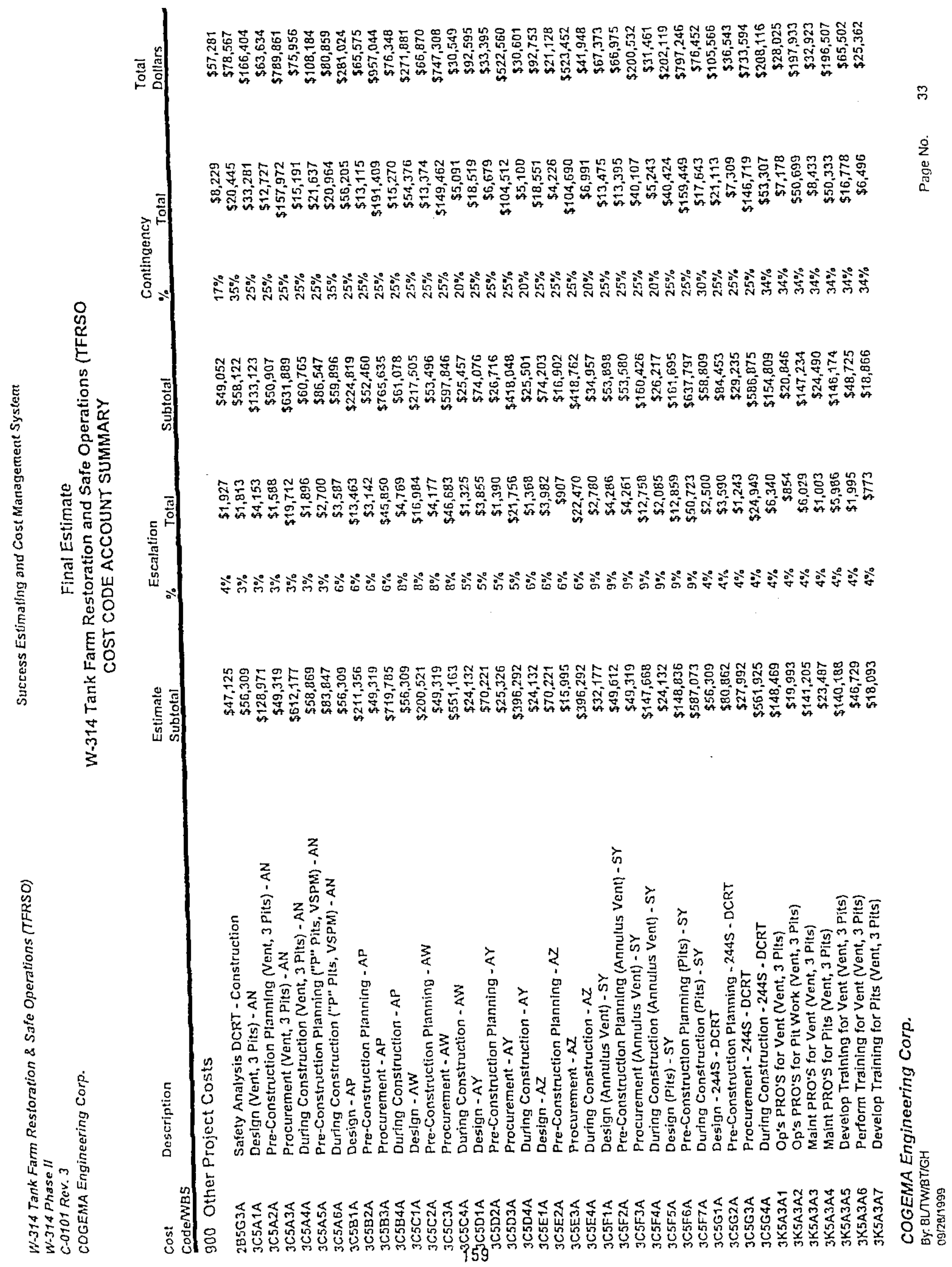




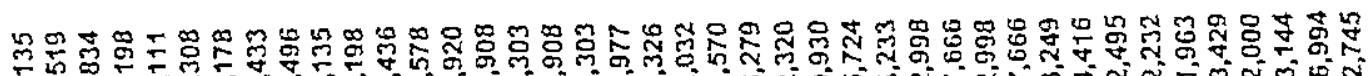

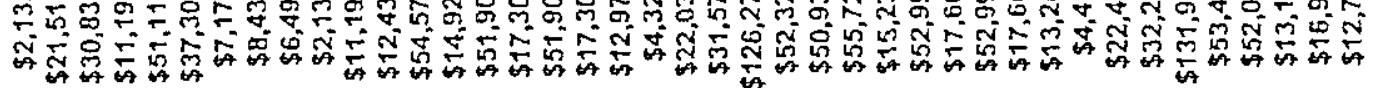

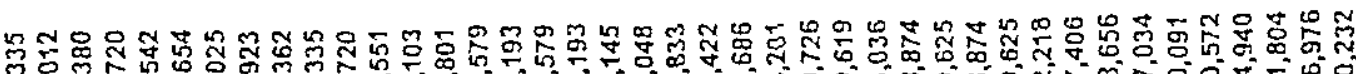

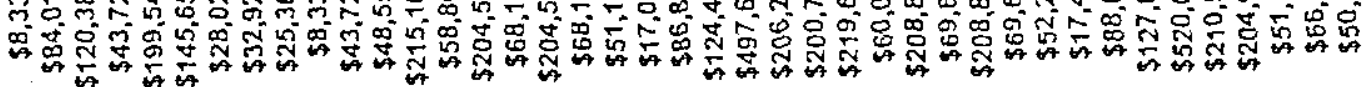

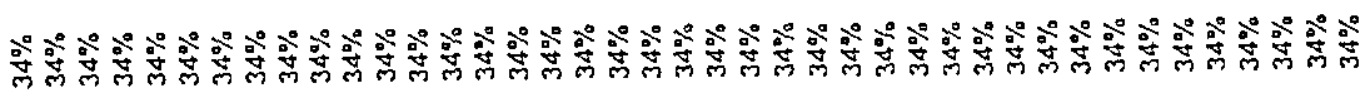

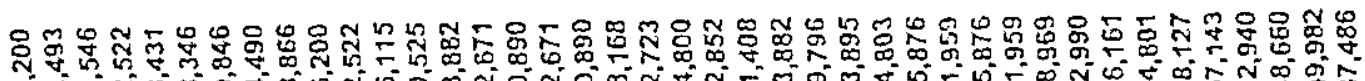

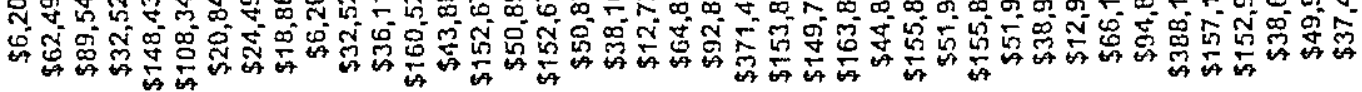

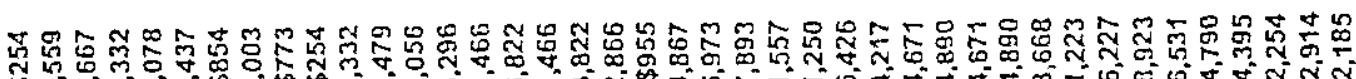

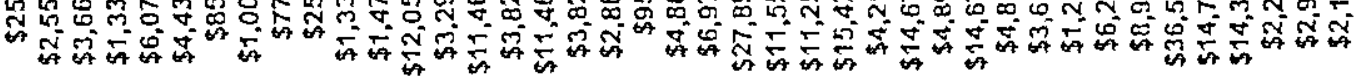

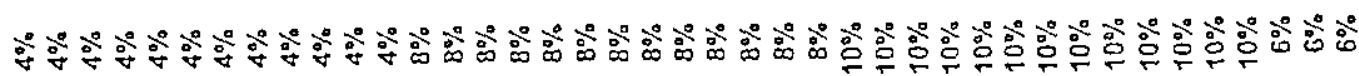

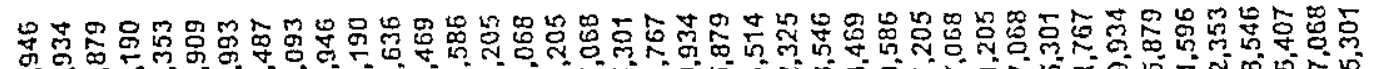

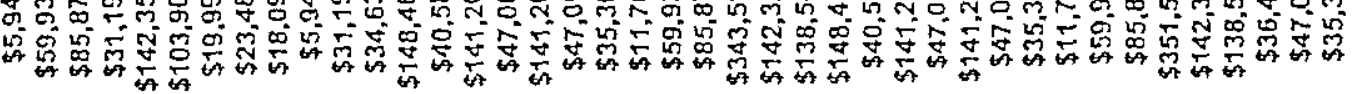




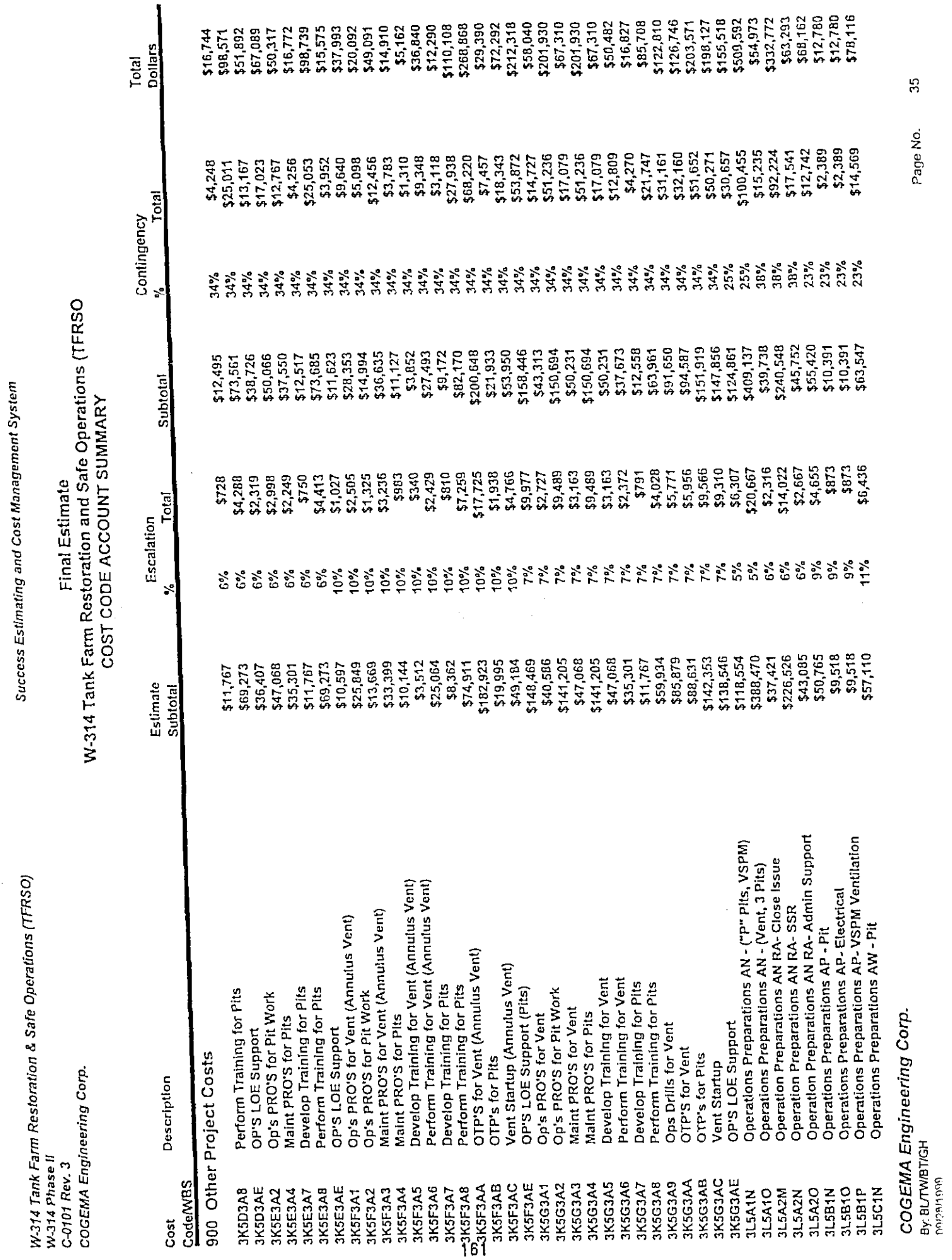


HNF-5109, REV. 0

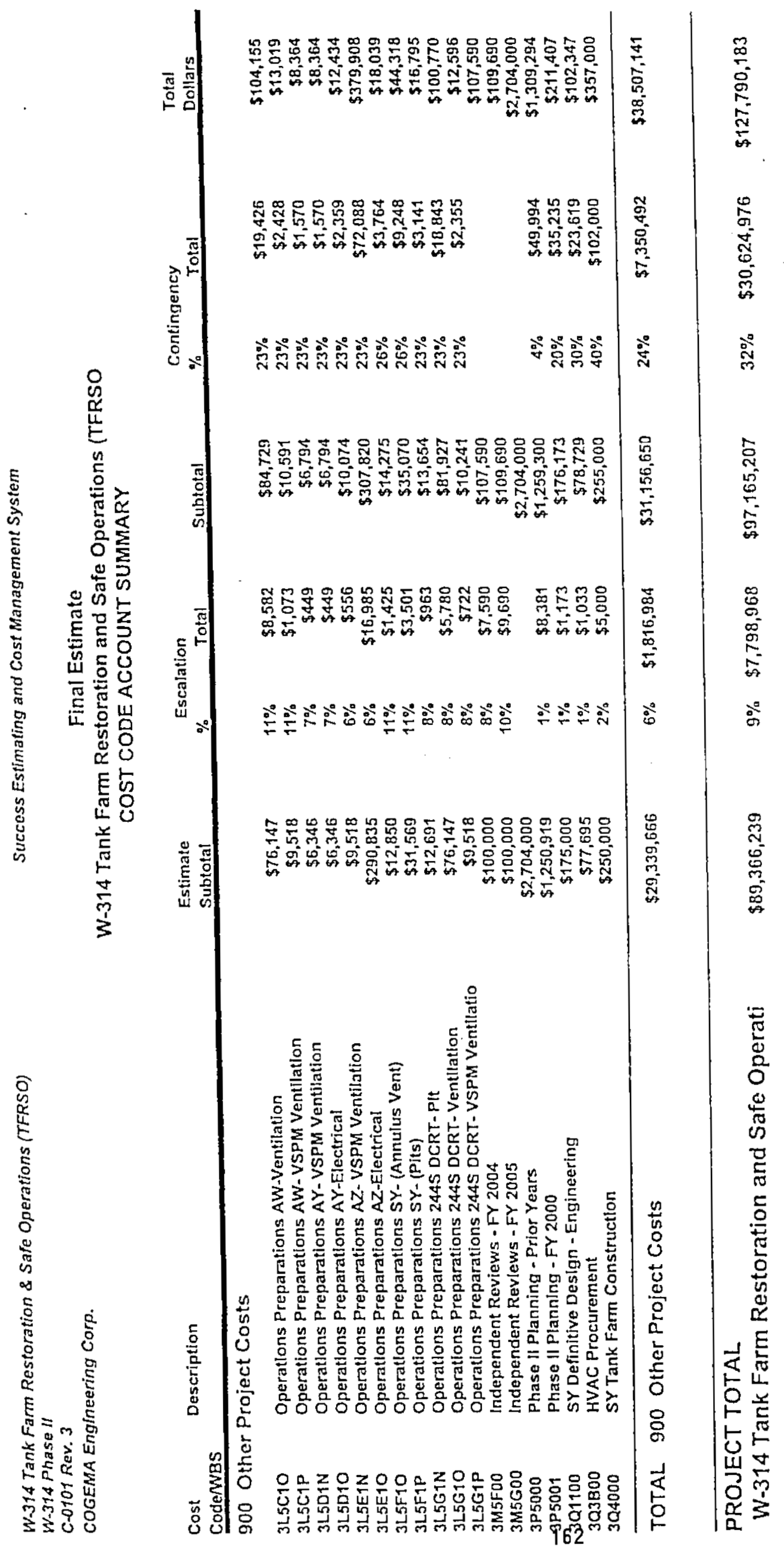

0
0
2
0
0
0

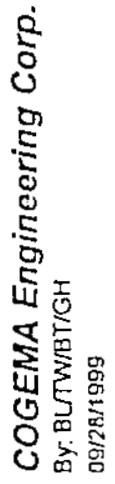




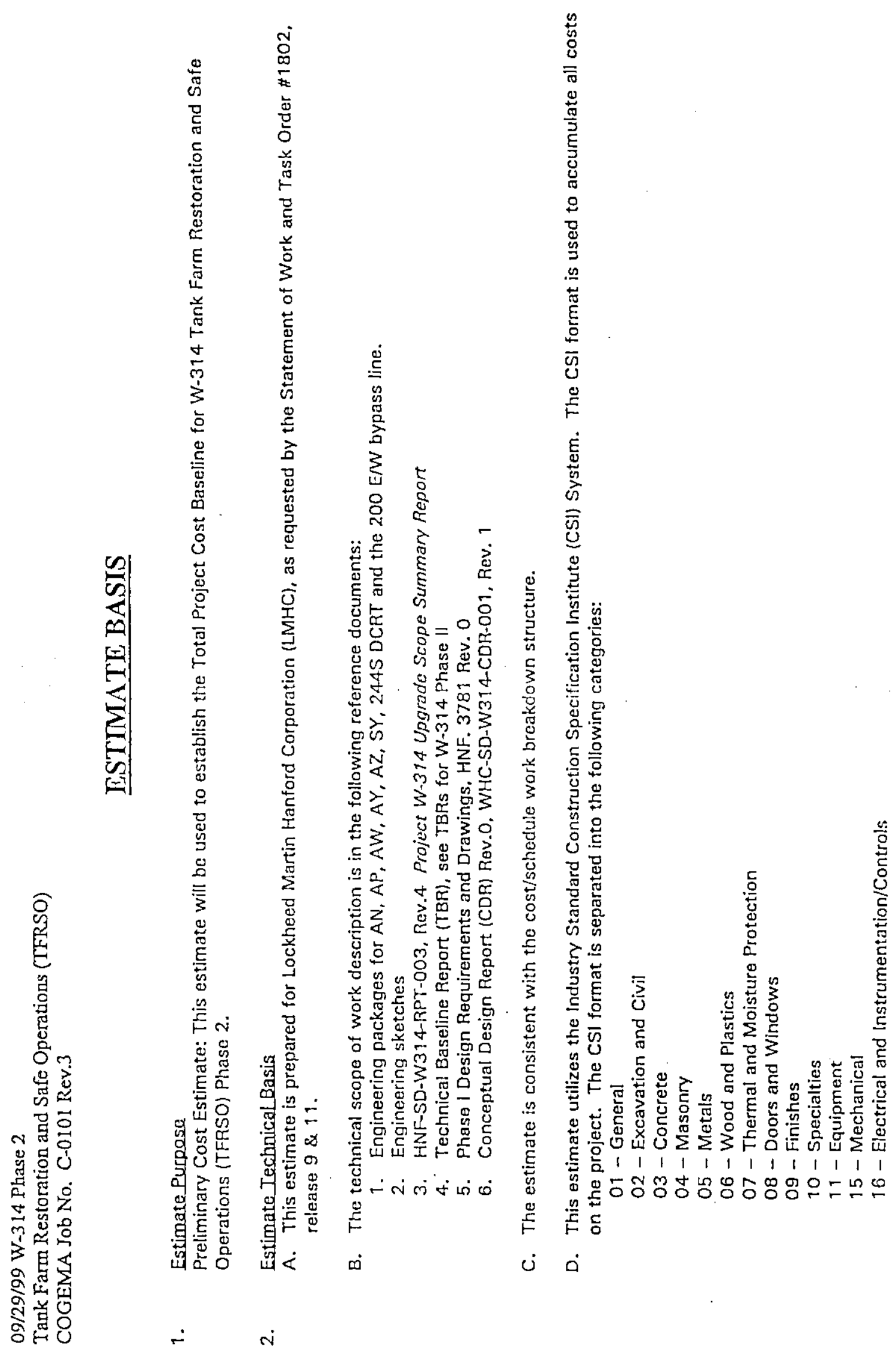




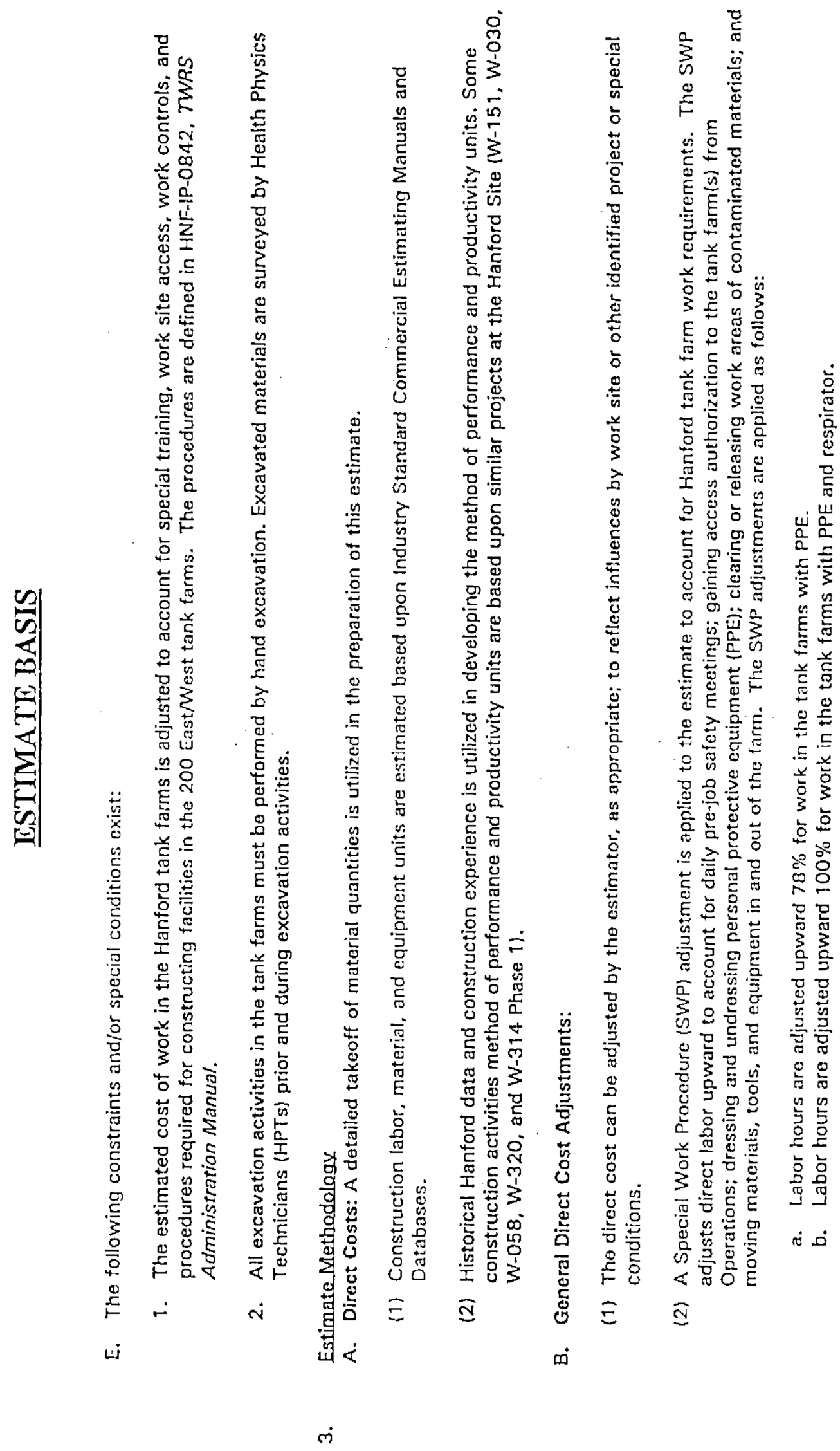




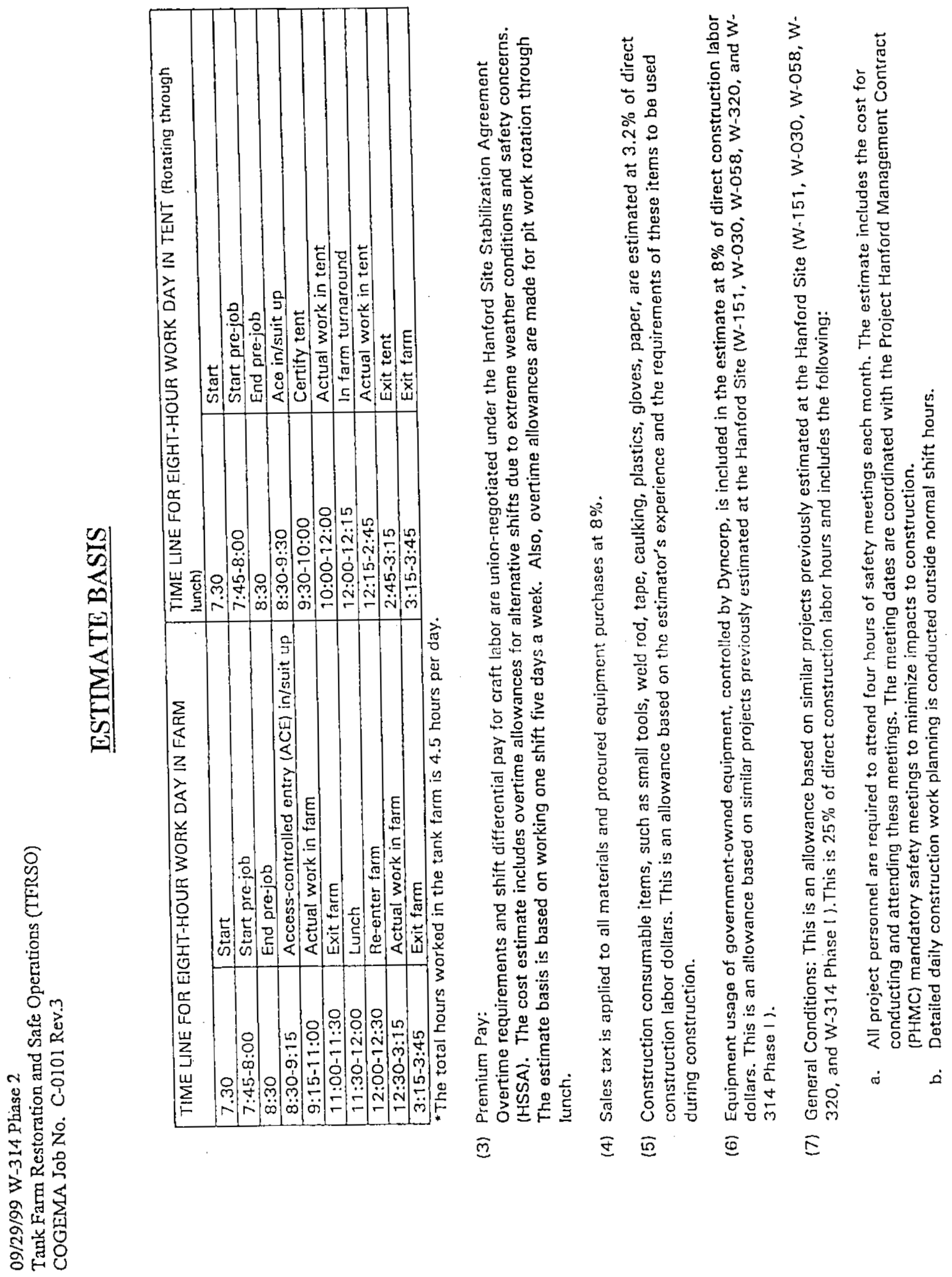




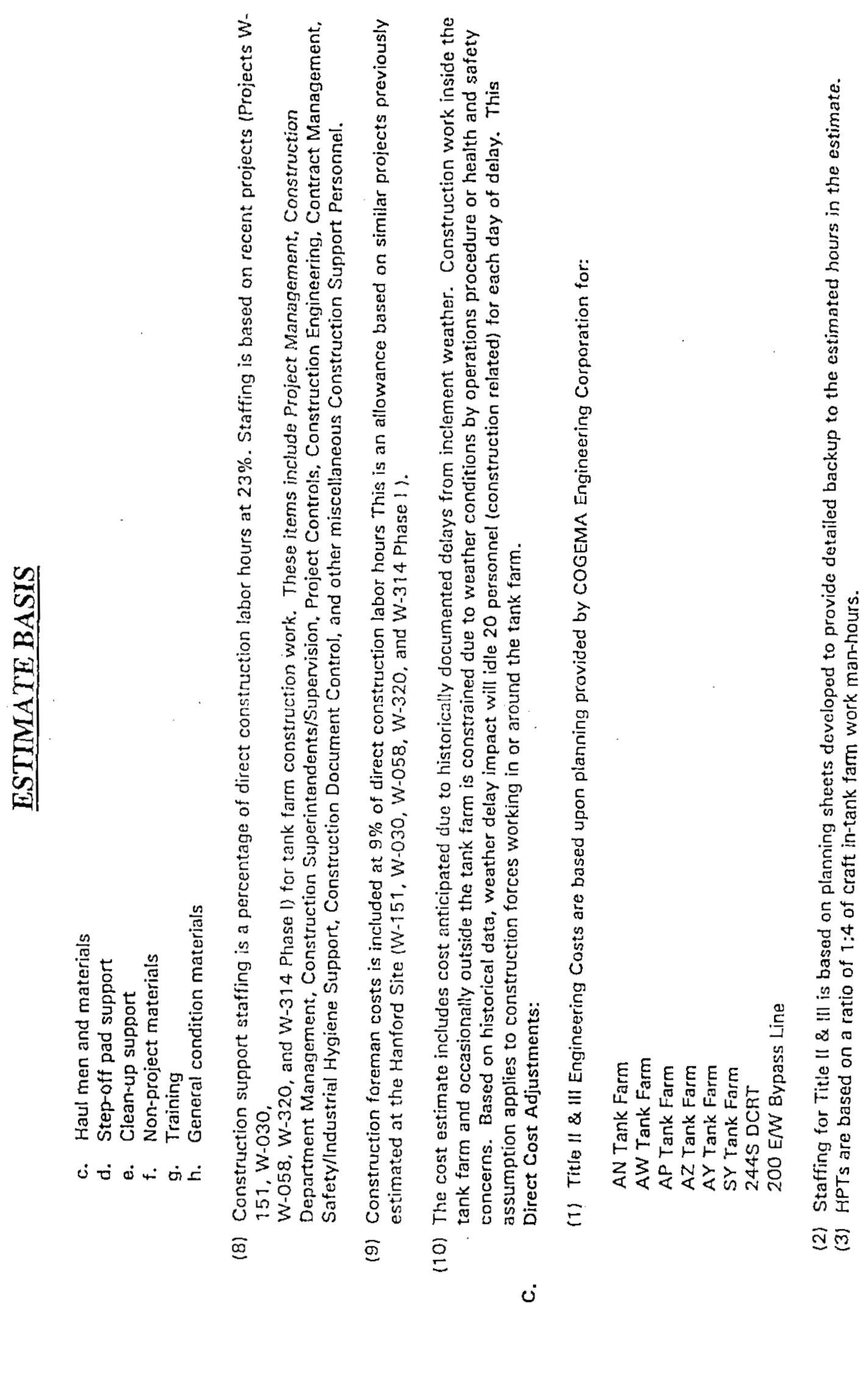




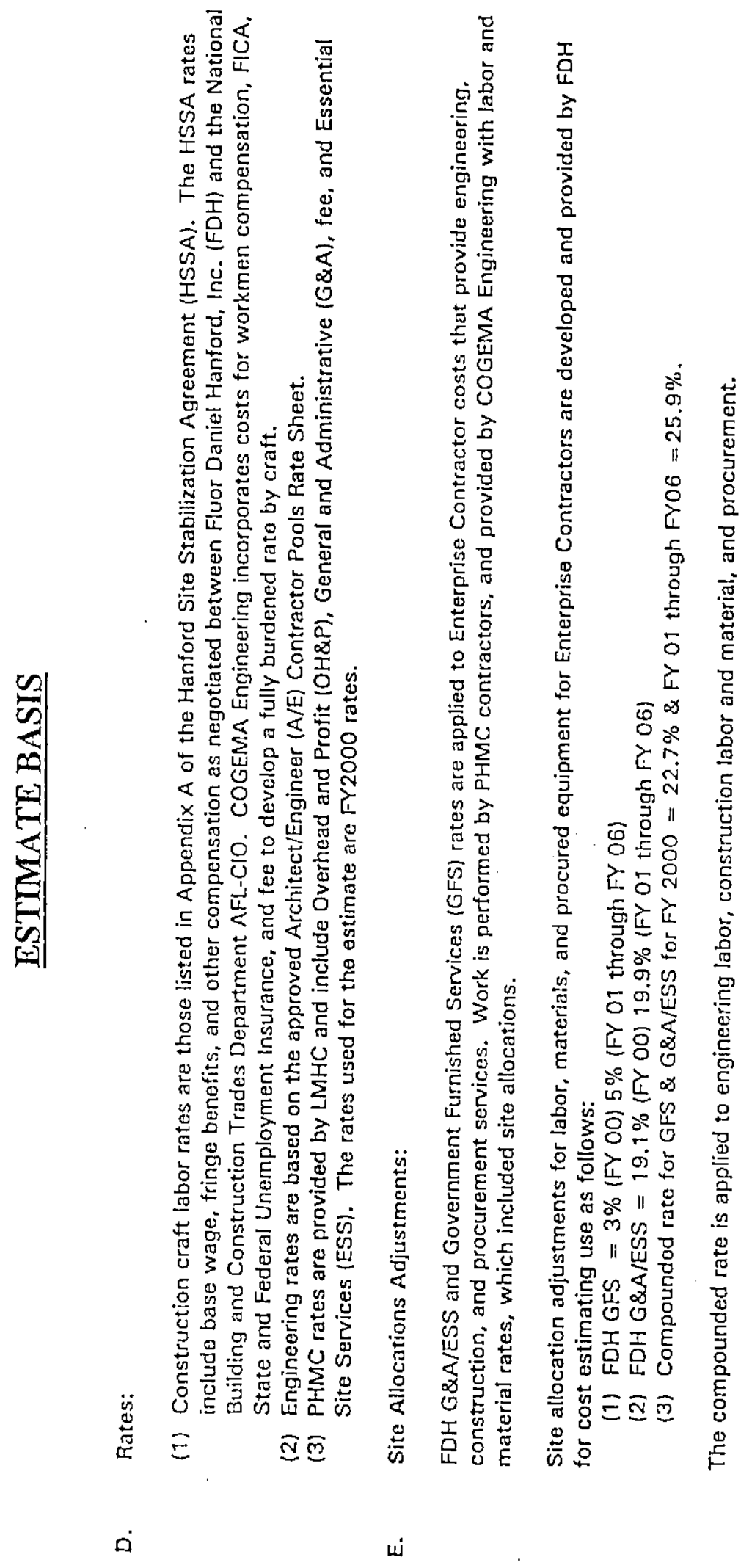


HNF-5109, Rev. 0
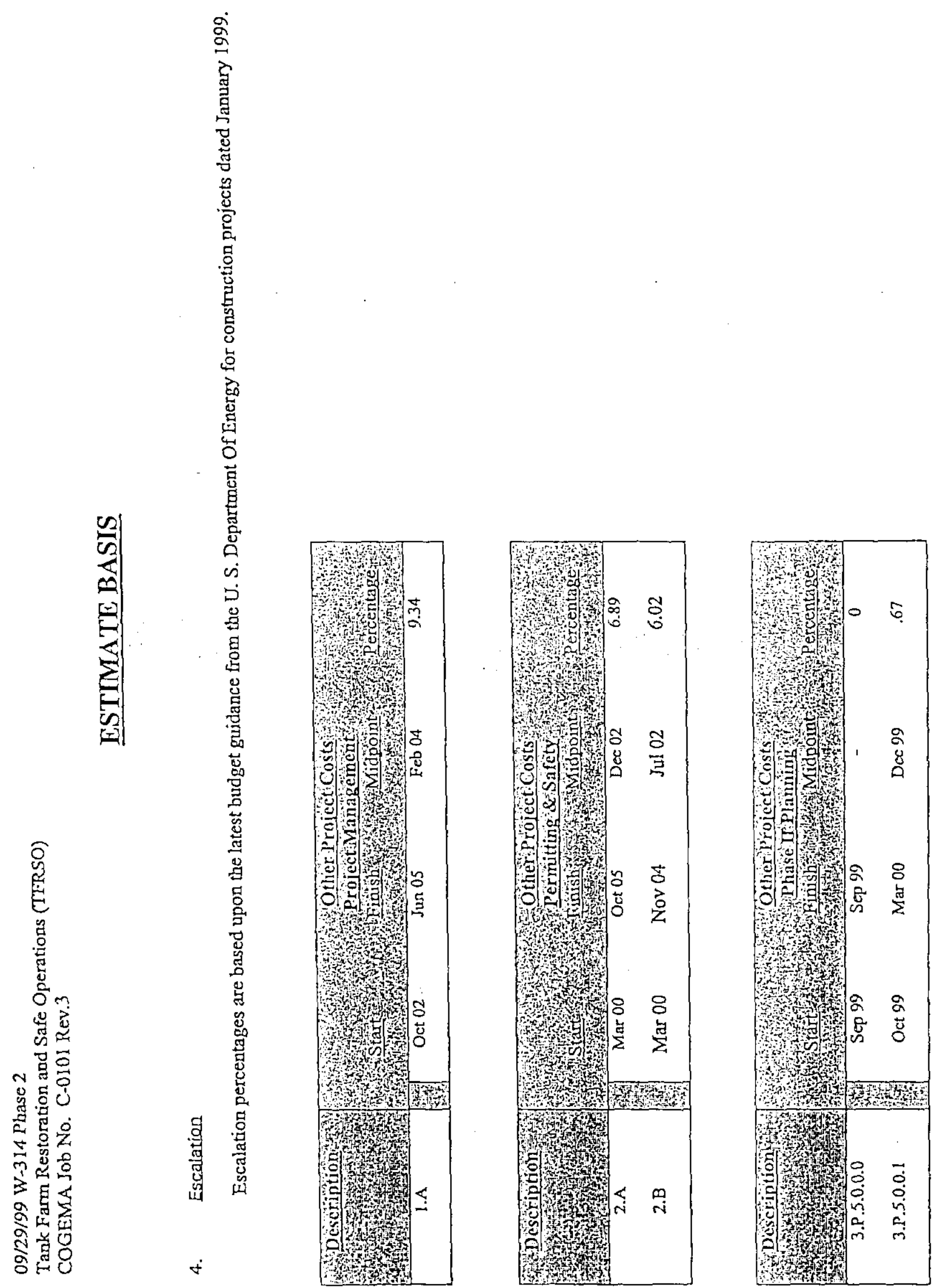


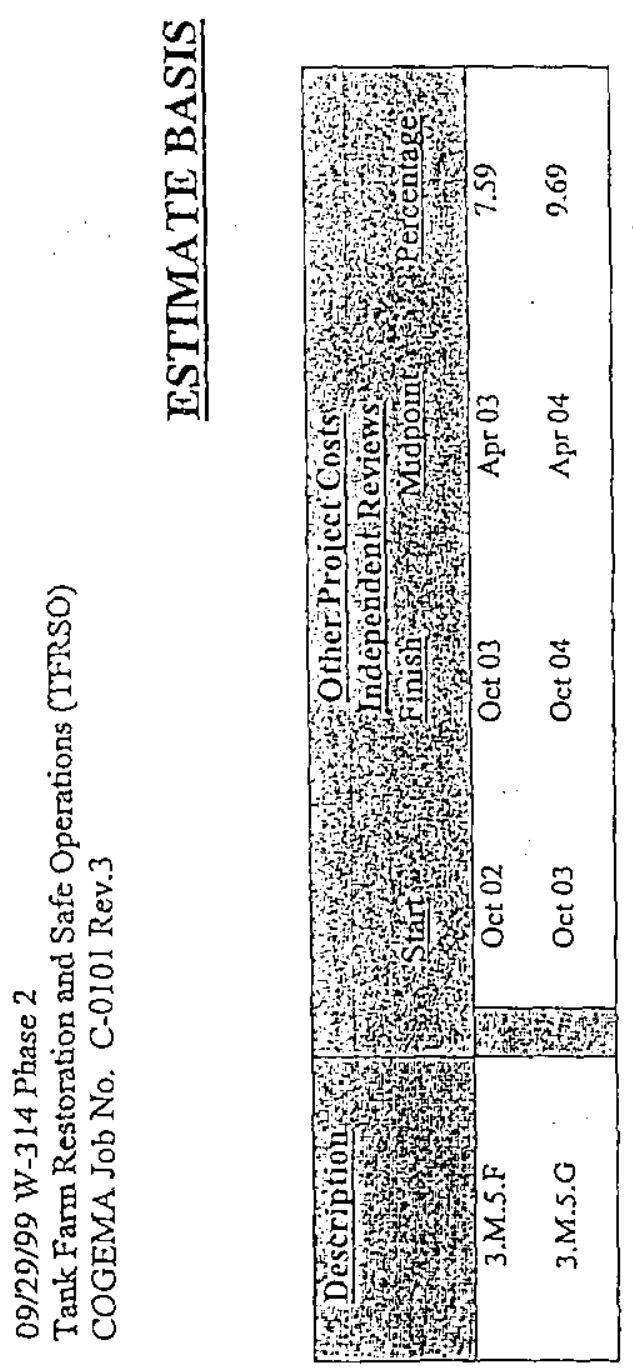

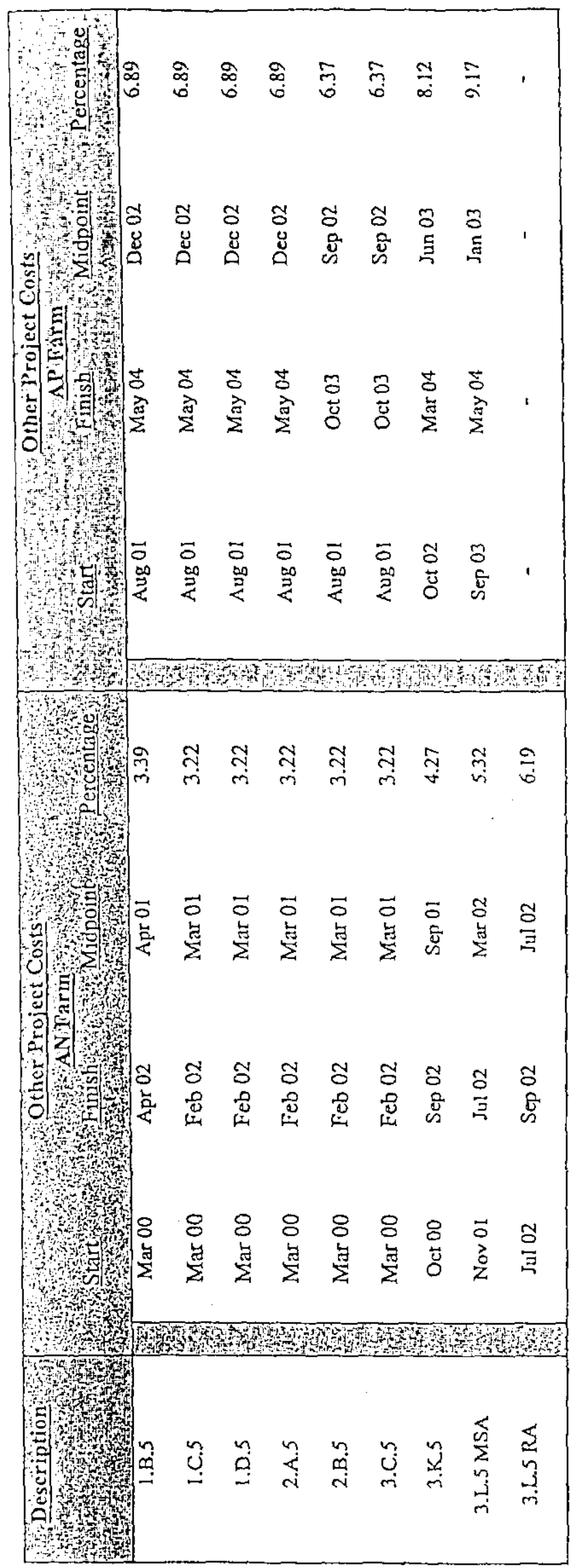




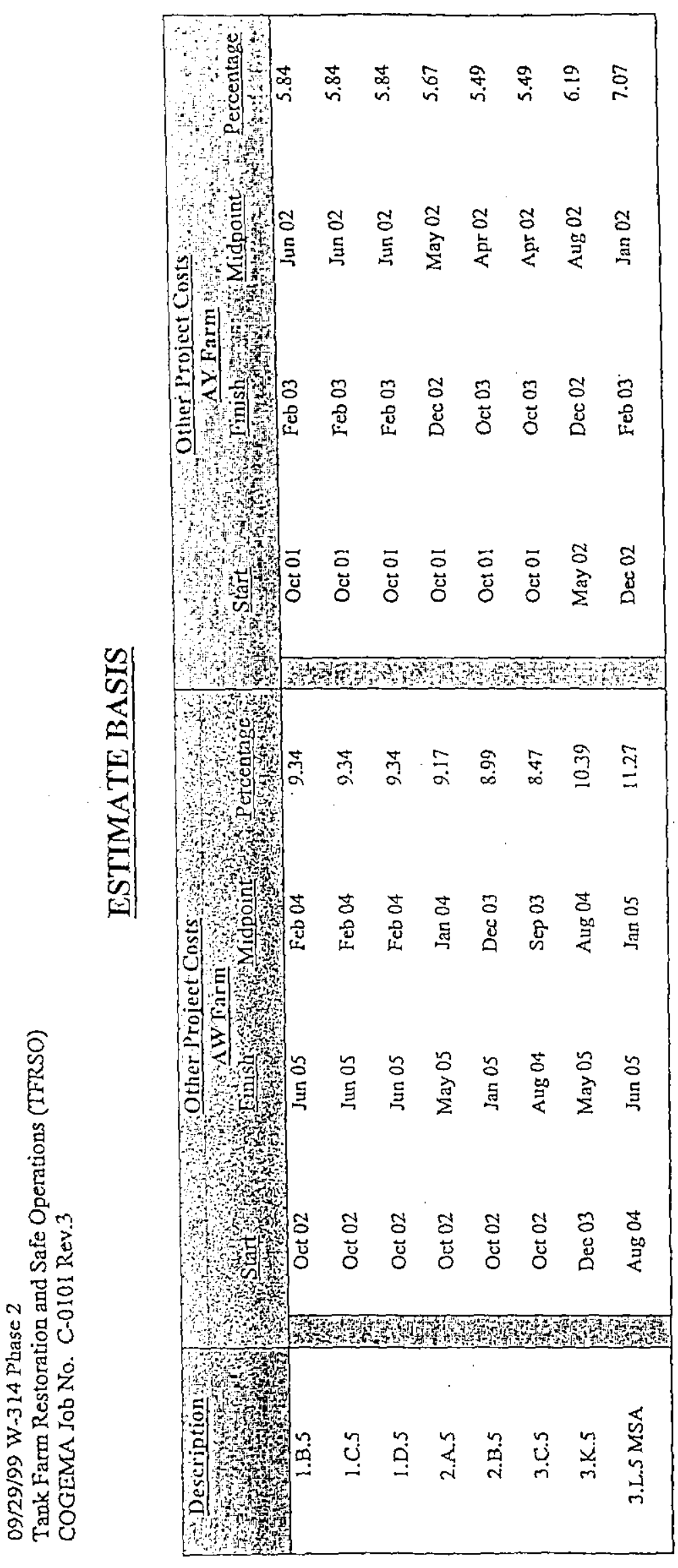




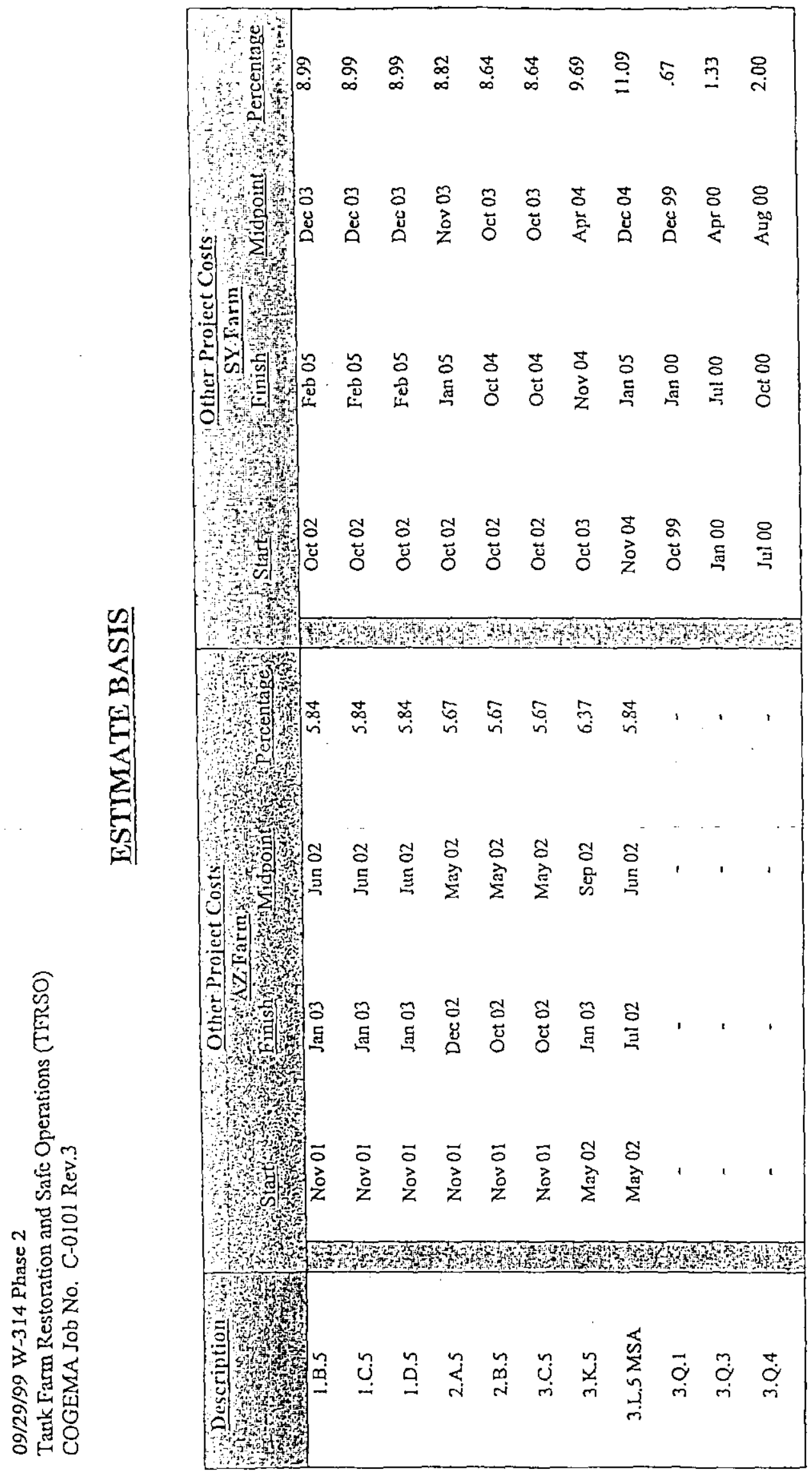


HNF-5109, Rev. 0

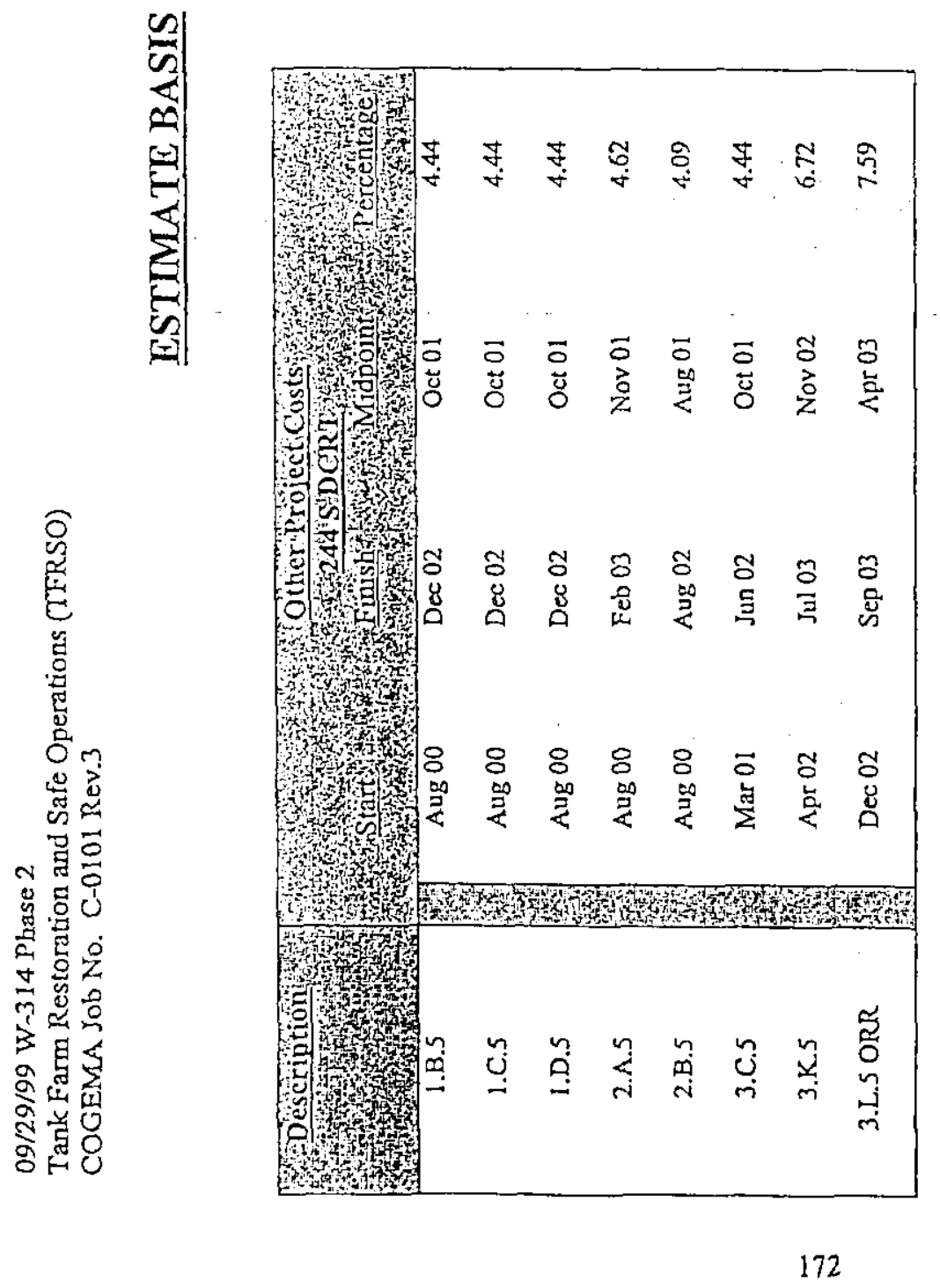


HNF-5109, Rev. 0

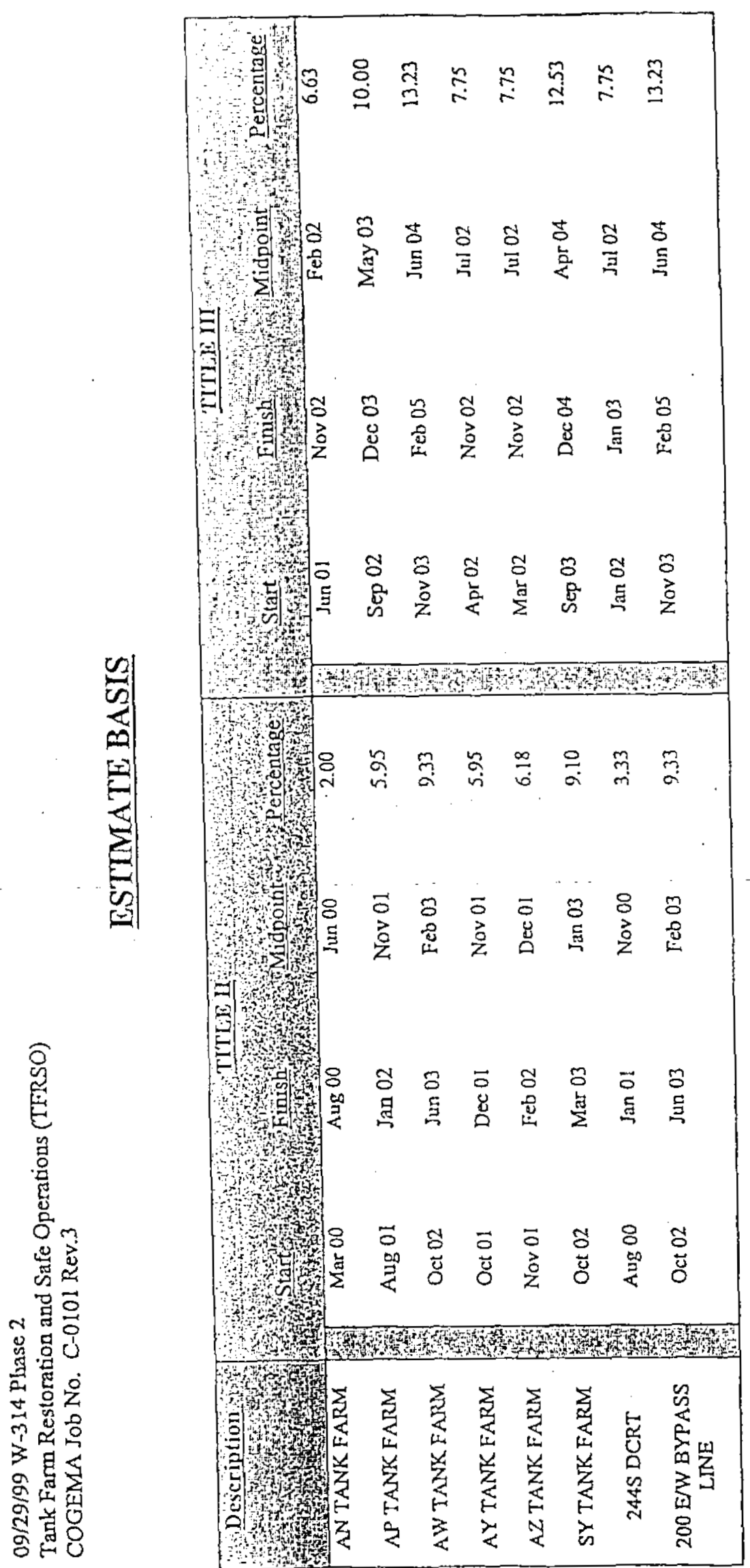




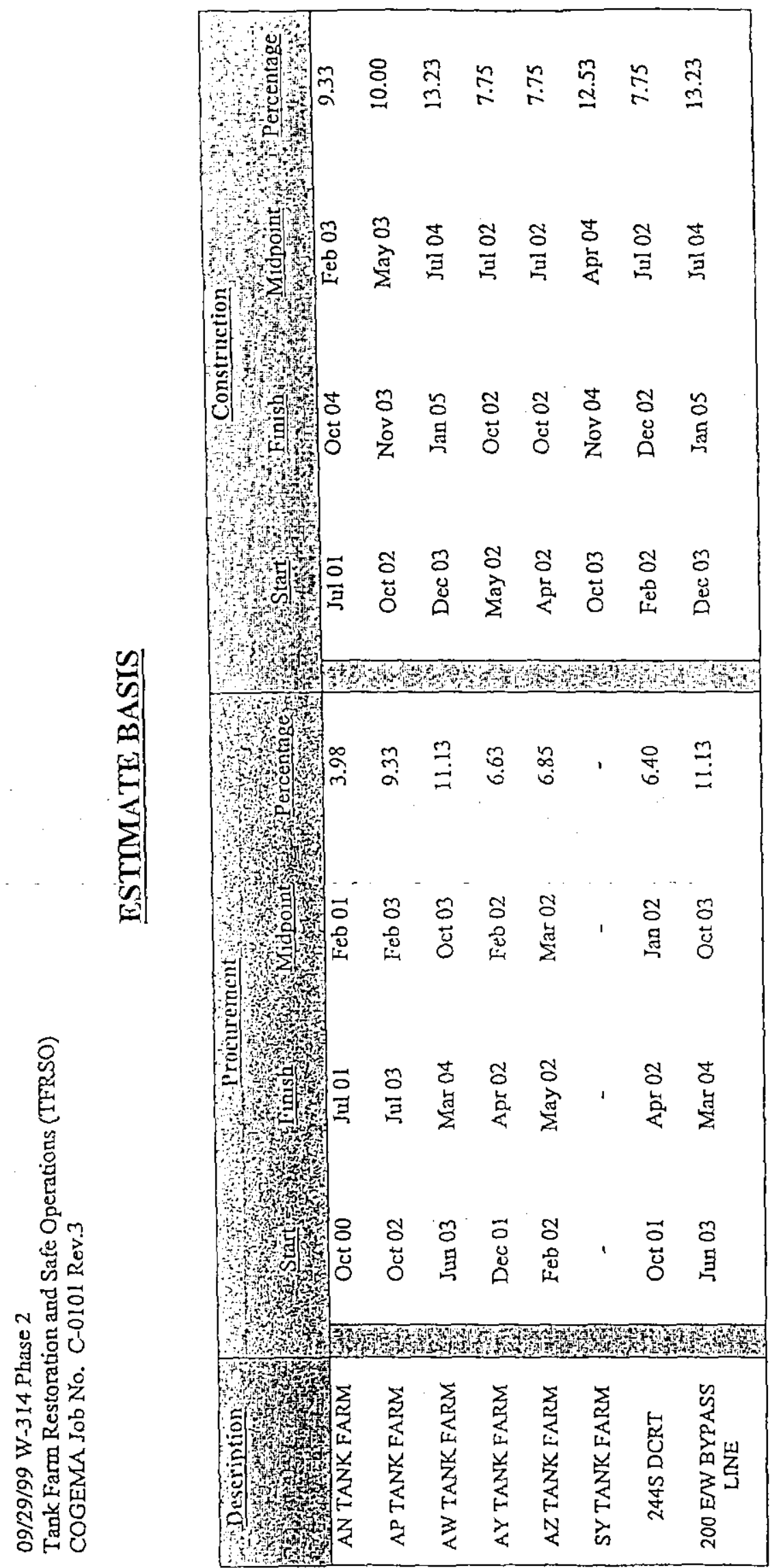


HNF-5109, Rev. 0

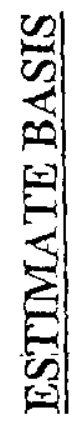
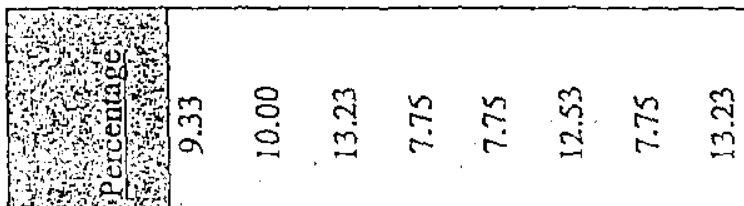

.

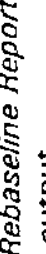

○)

资

焉

\&

i.

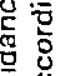

$\sum$ 정

政

要

당

兽

造点

品

焉

흥

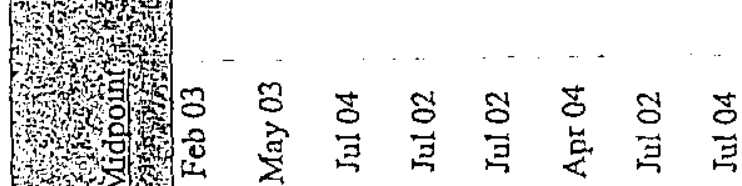

官
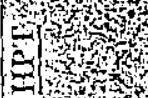

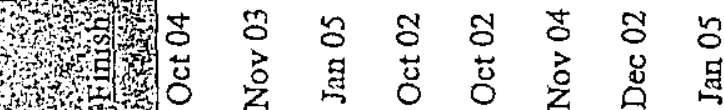

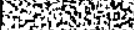

7)

Wพy

W.

si

พ
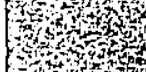

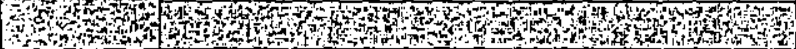
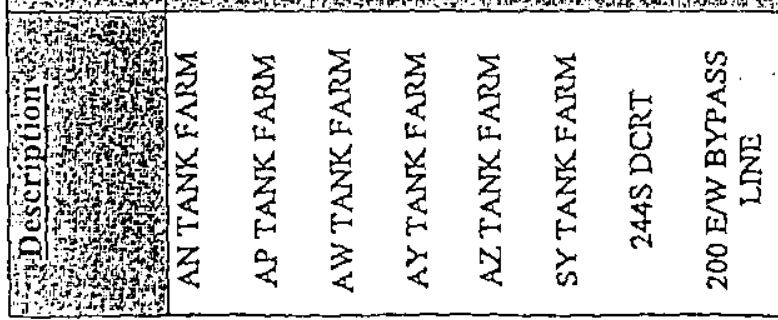

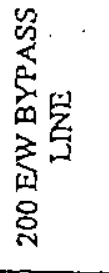

跑客

곤돈

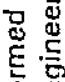

这岕

忿出

30

.

坖完

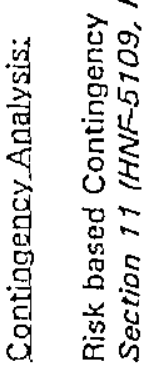

aे

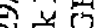

종ํํำ 

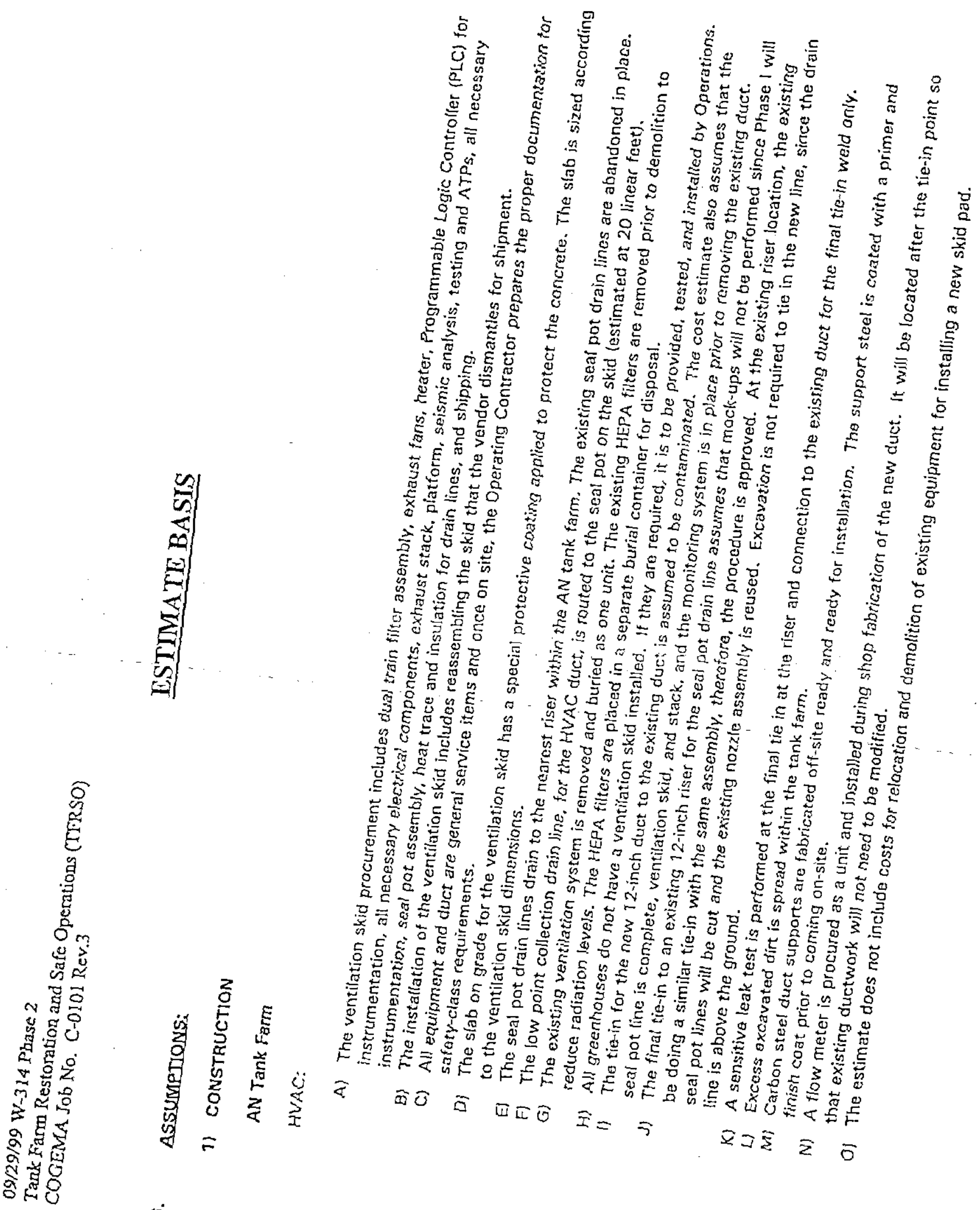

胥

$6^{\circ}$ 


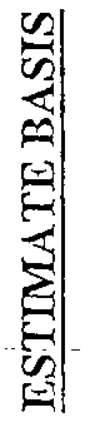

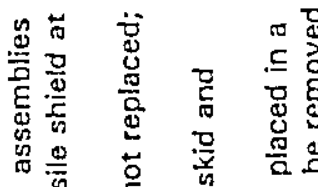

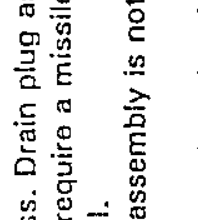

要紫

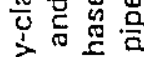

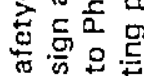

号要

ठ을

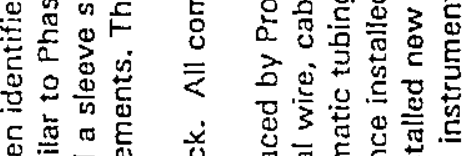

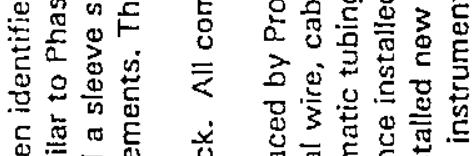

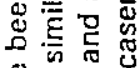

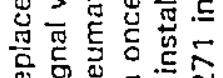

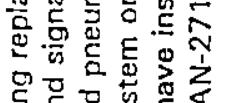

岕氞

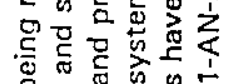

돈

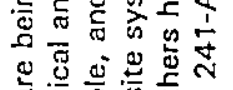

了幽

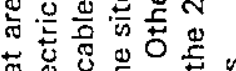

苞

言密怘

들

氙兘

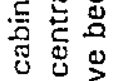

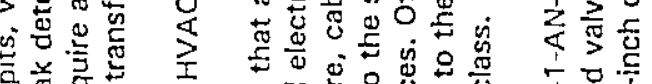

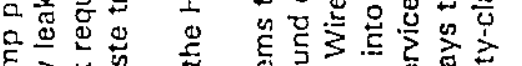

है

离离学

蛋

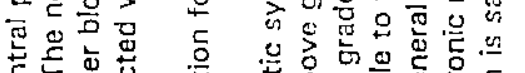

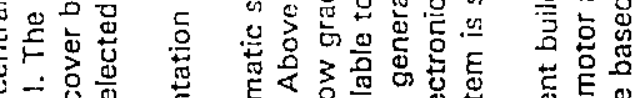

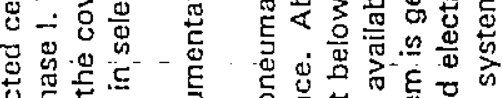

월

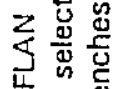

空密

造造兘

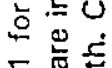

下范䓪

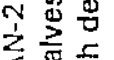

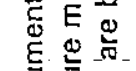

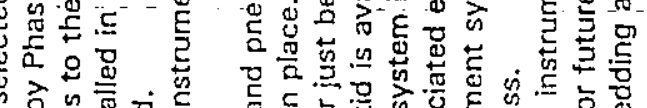

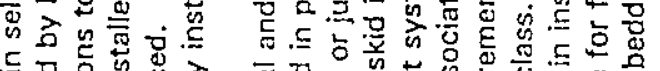

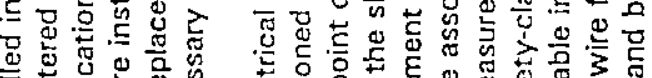

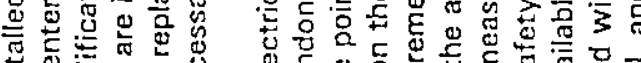

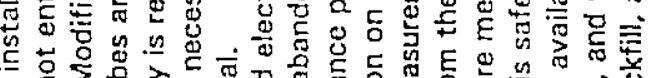

อิ

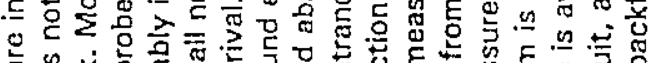

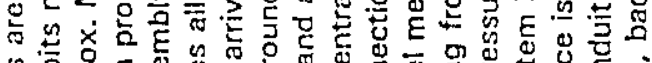

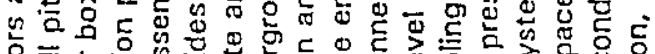

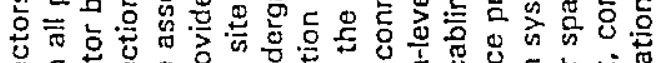

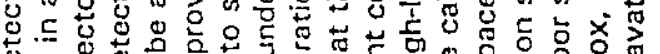

莡

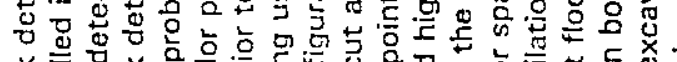

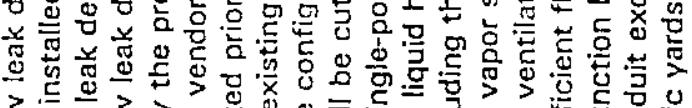

$\stackrel{2}{3}$

ก 㝘옹

輑兄

굴

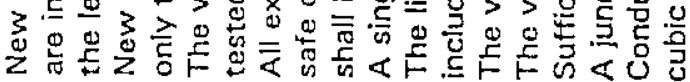

$\bar{\nabla} \bar{\oplus} \overline{0}$

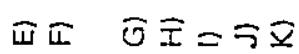

$\pm$

$\gtreqless \stackrel{e}{z}$

웅ㅇㅁㅇ

氜

空

옹ํㅕㄴ 


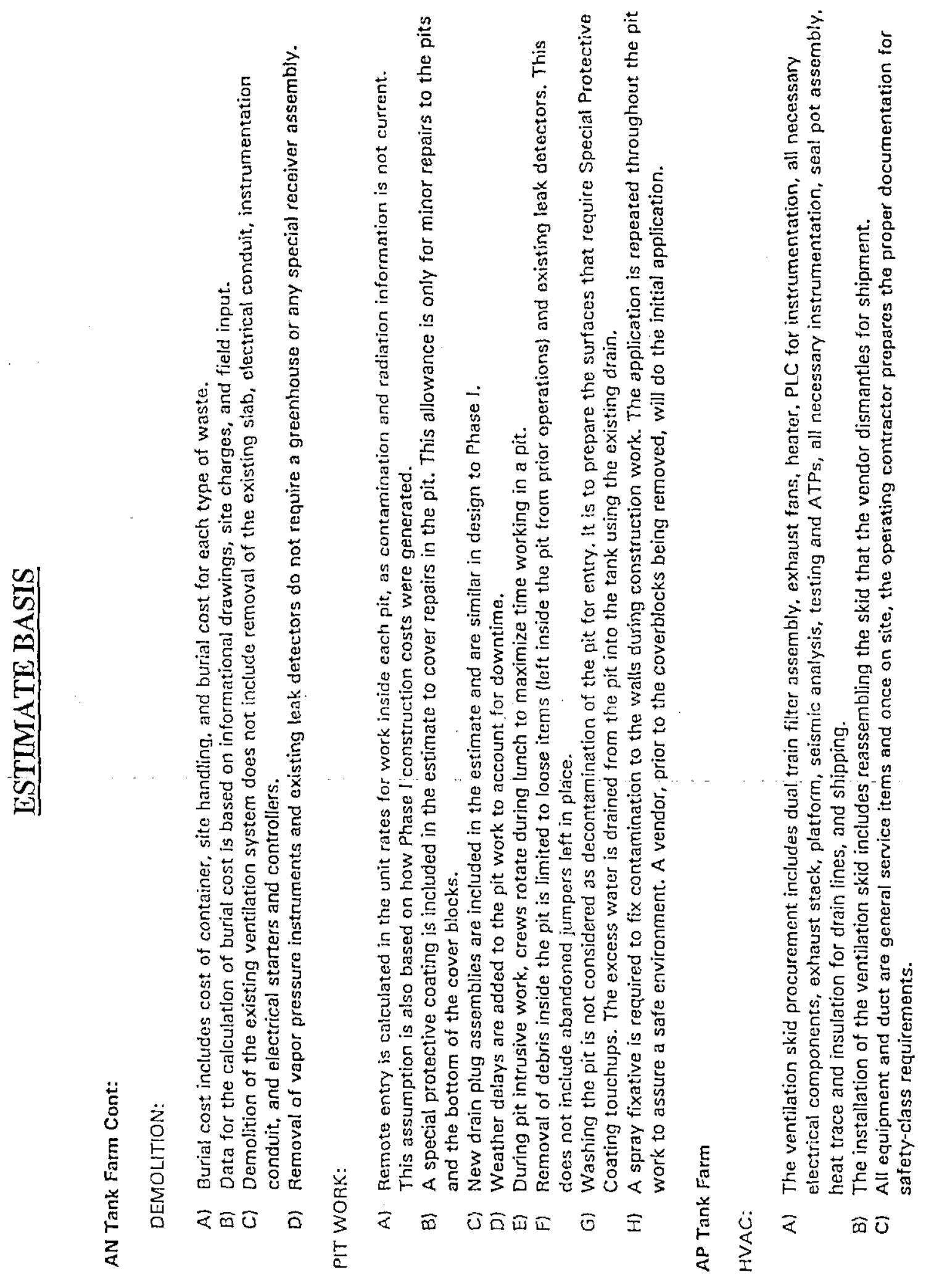

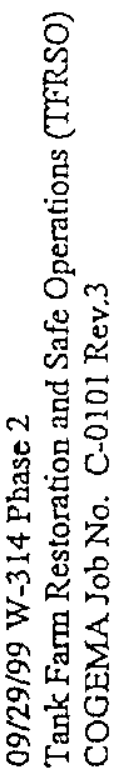




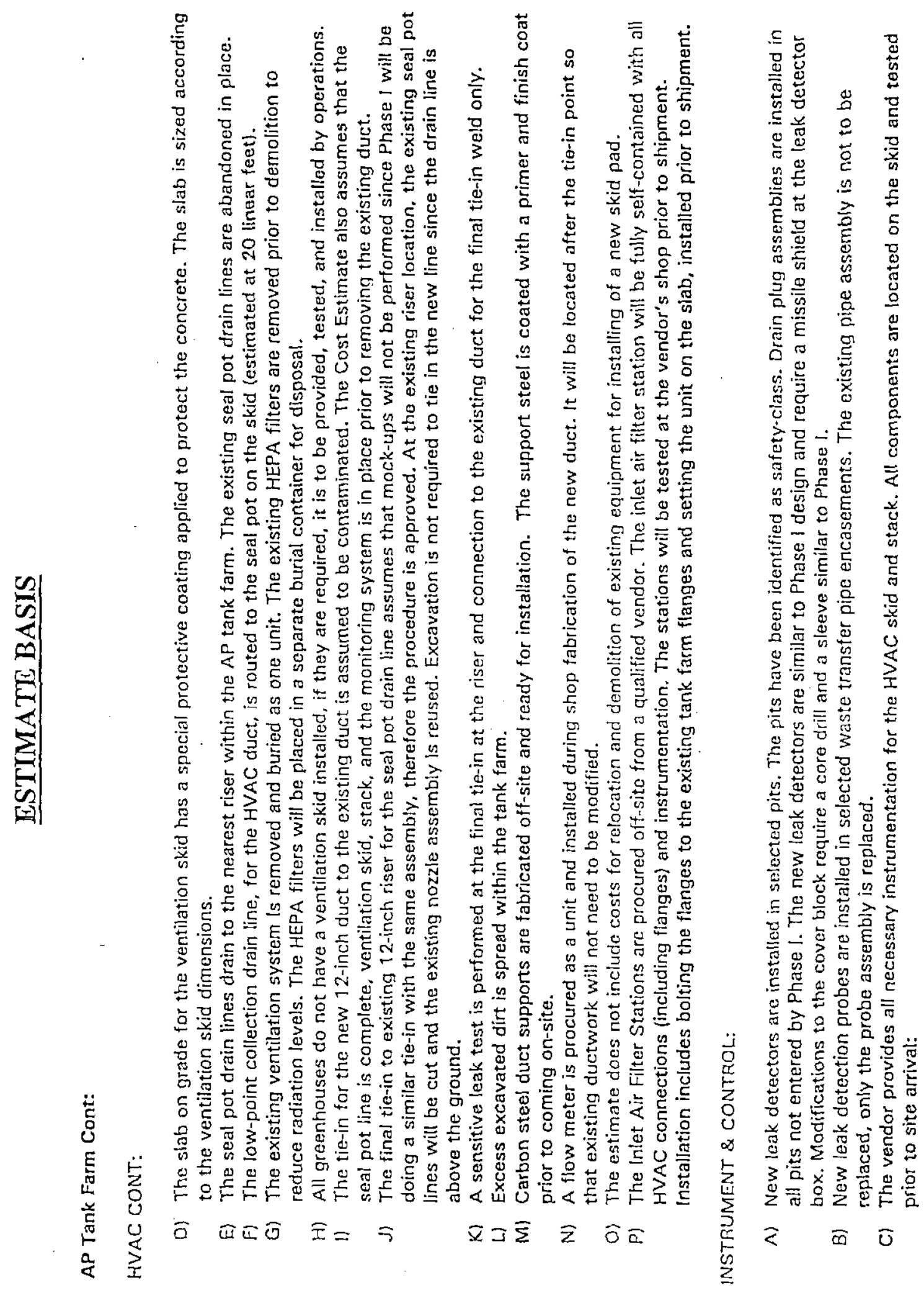




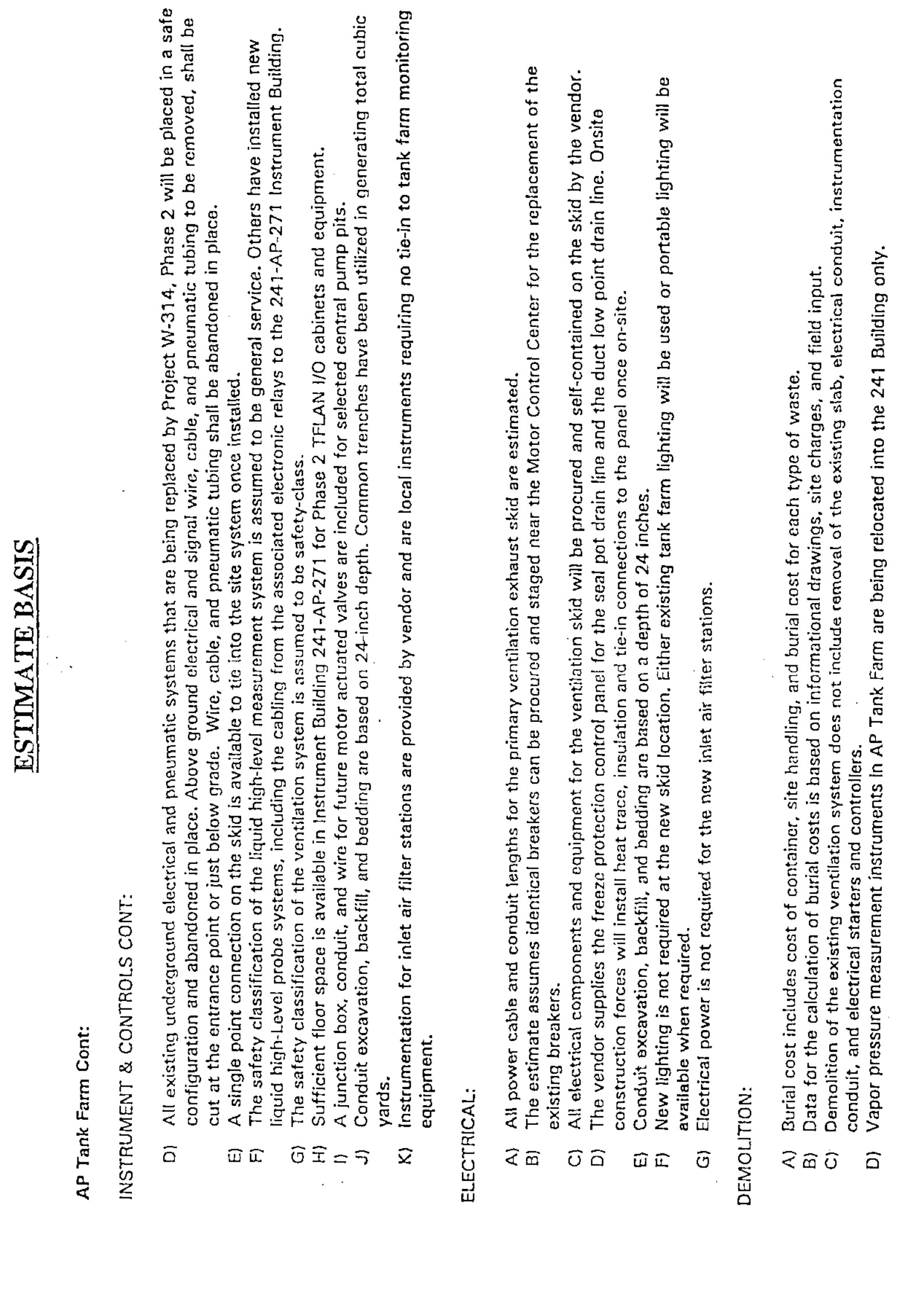




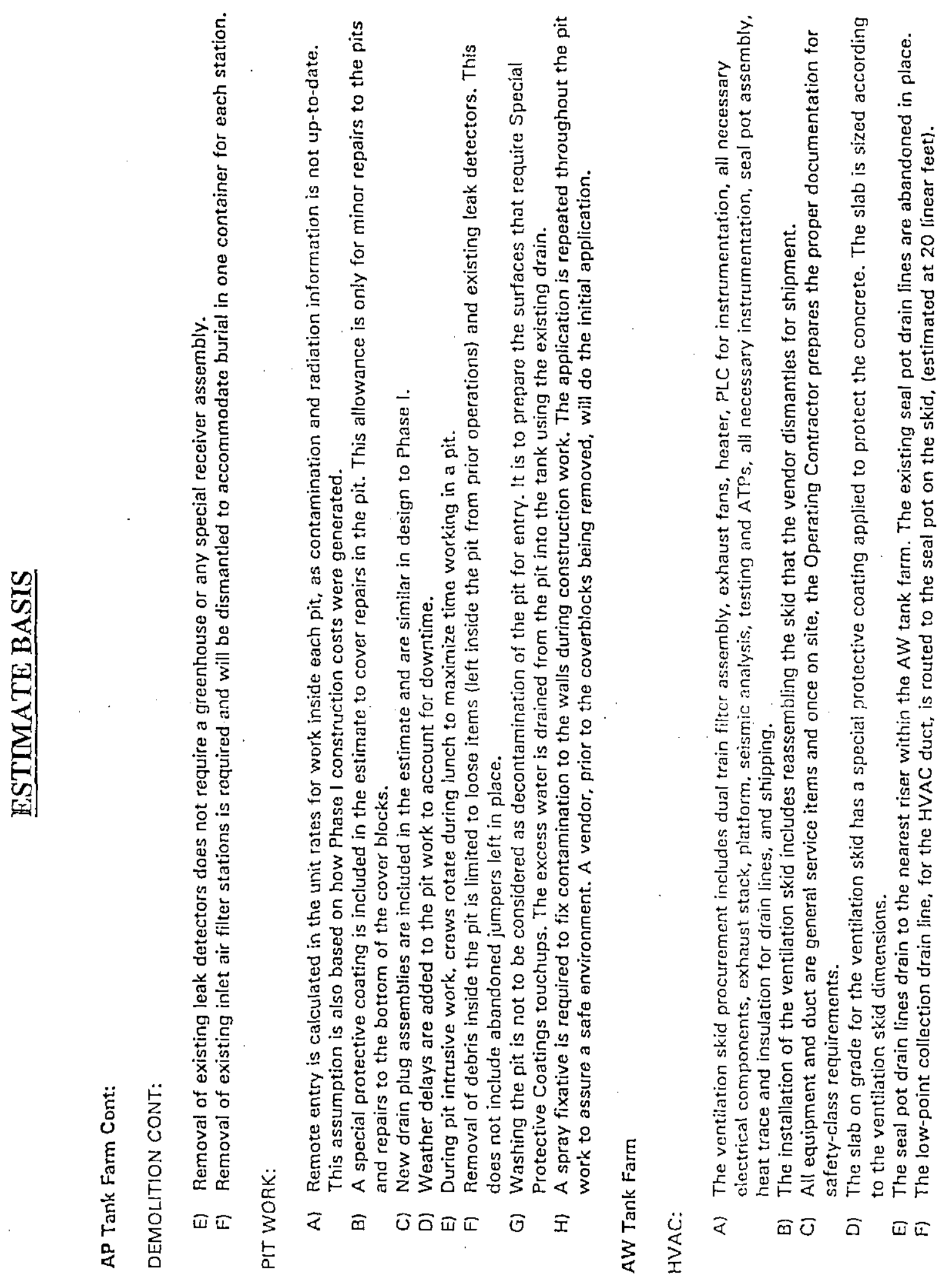




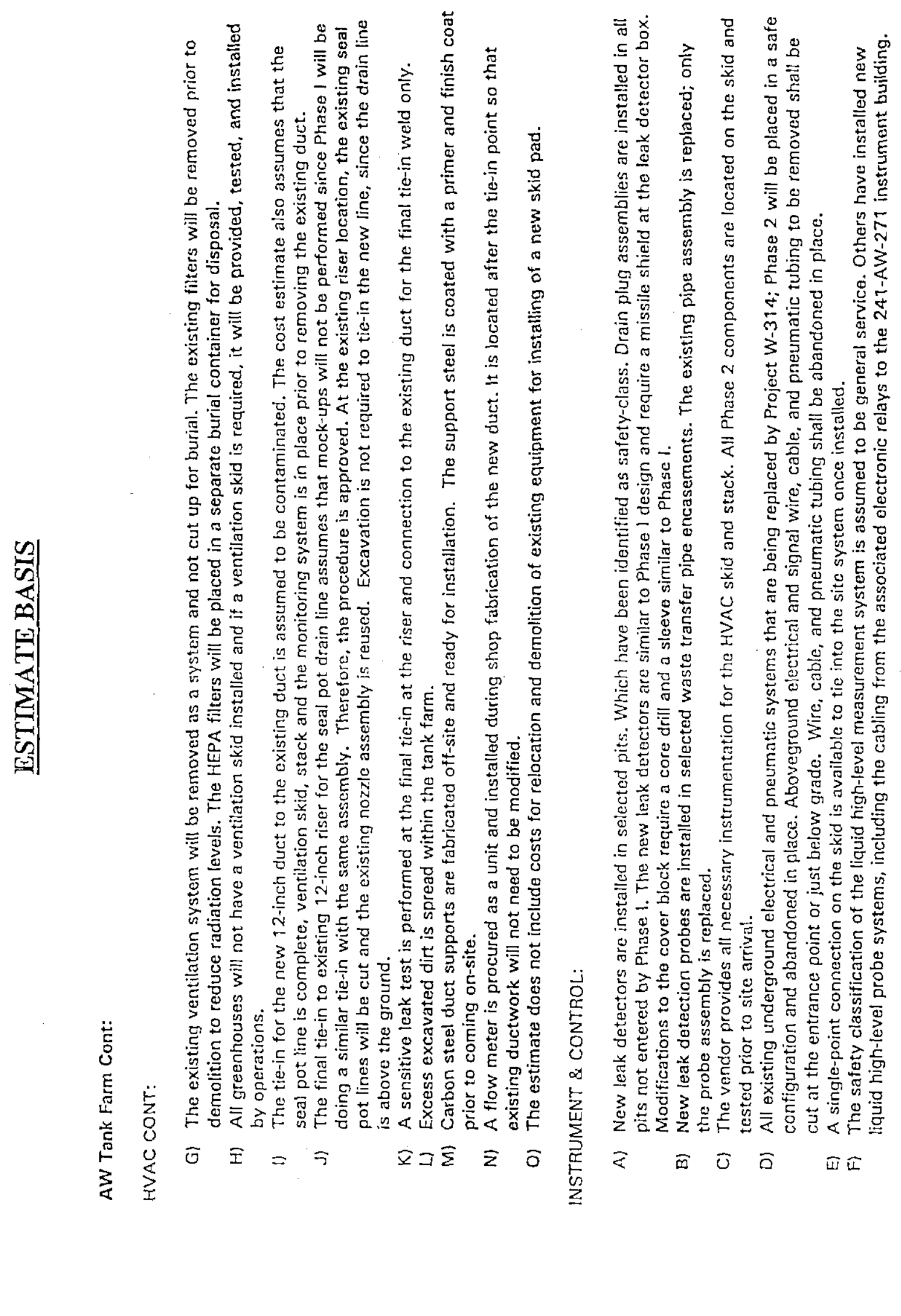



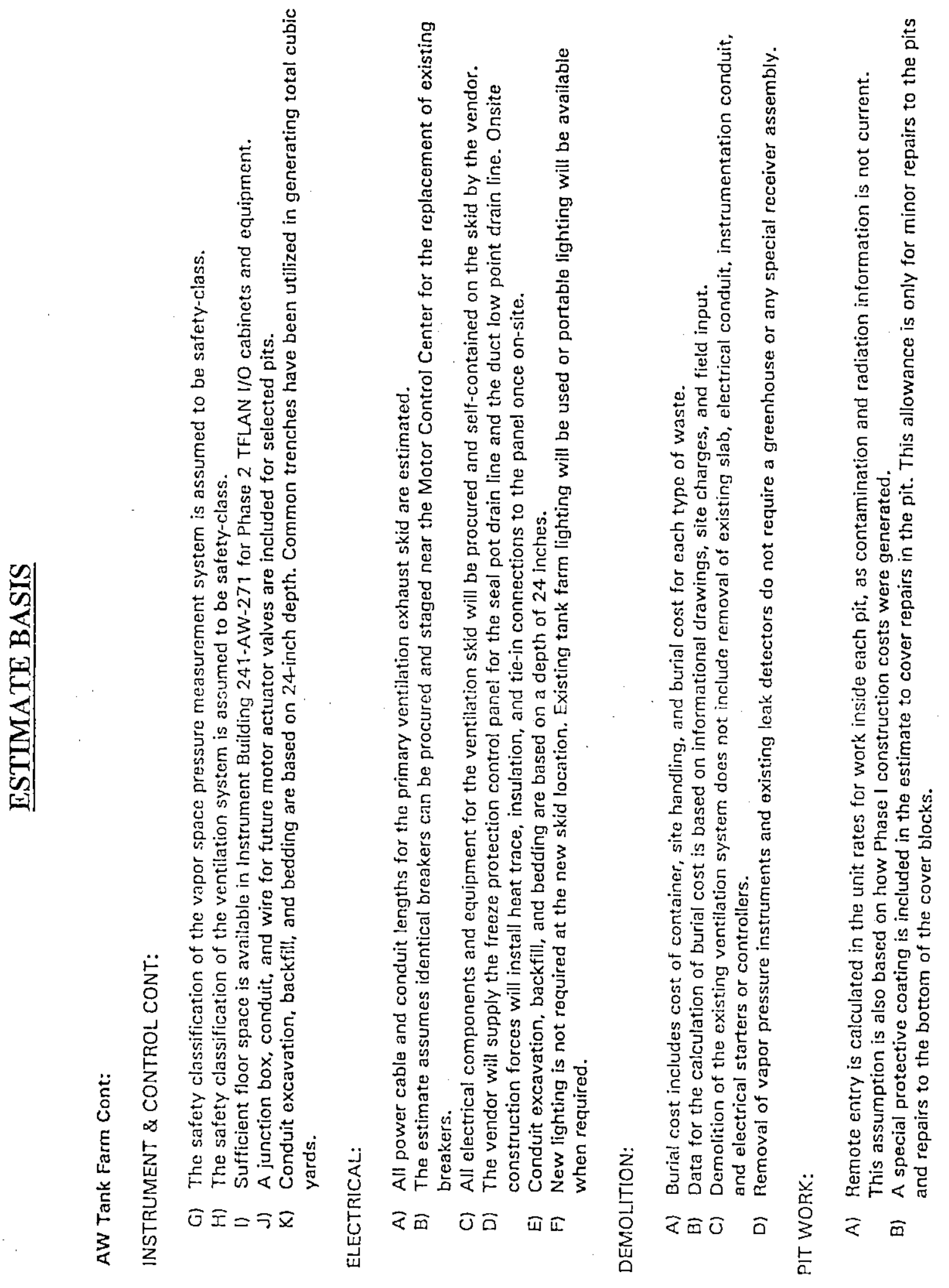


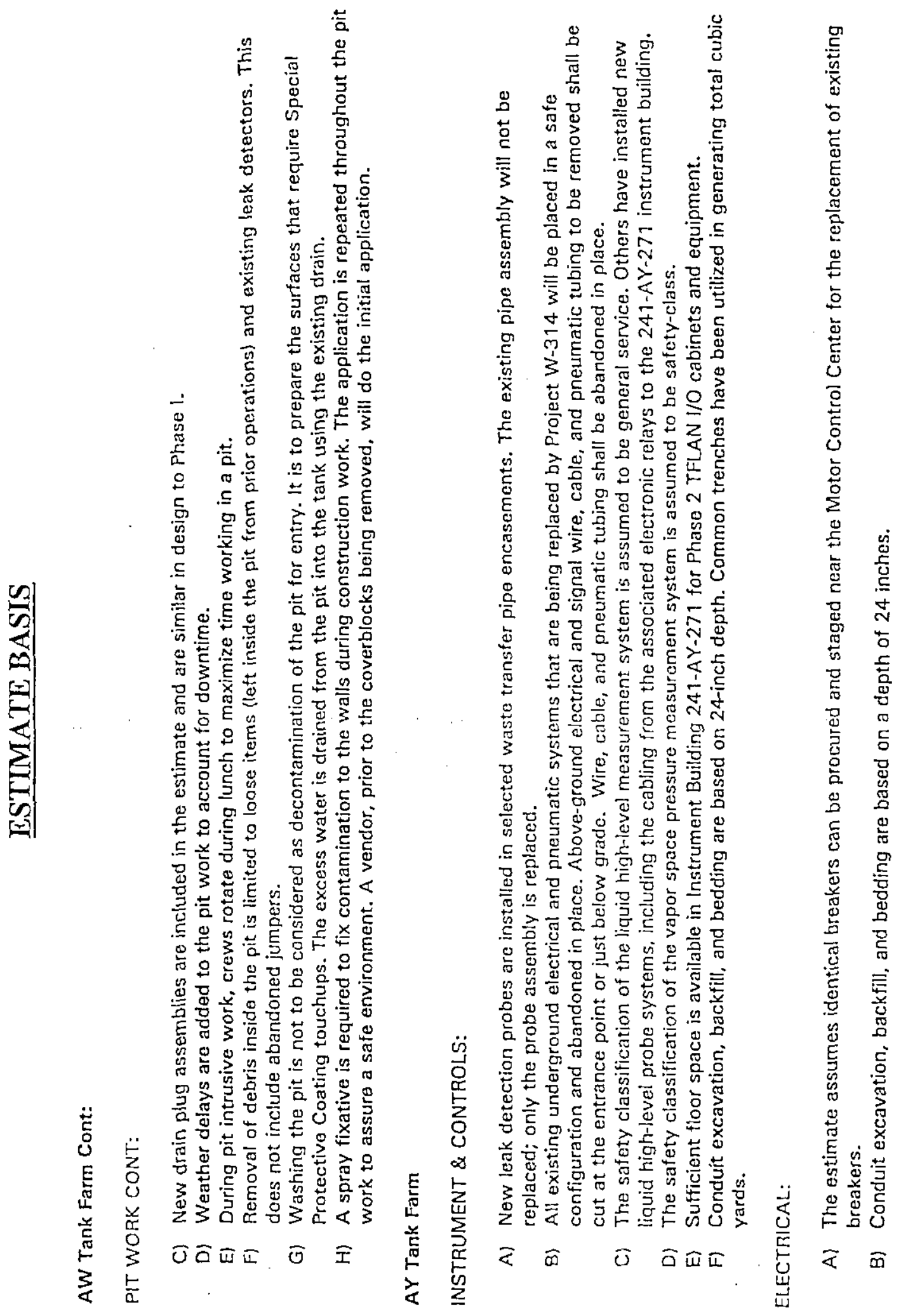




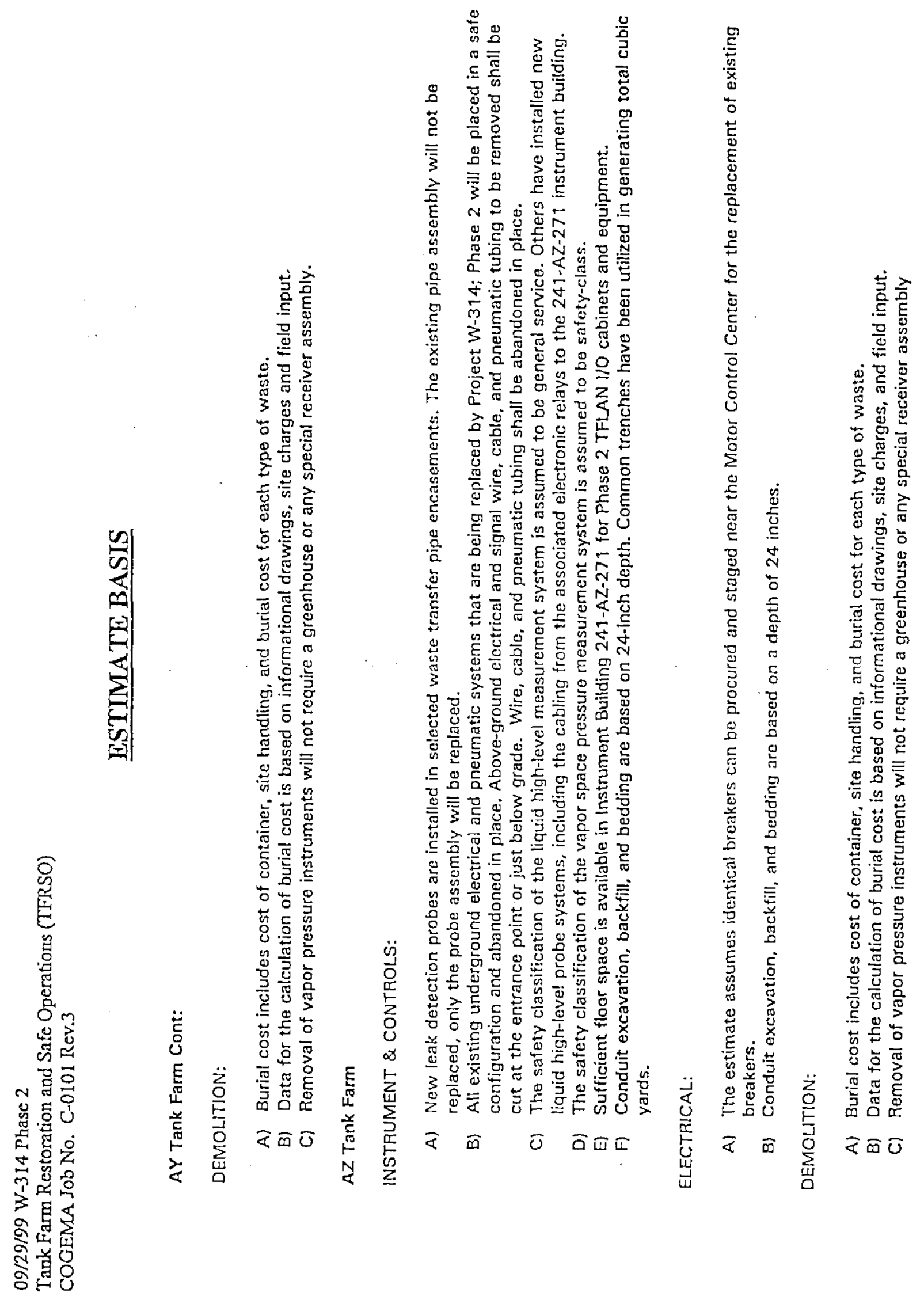




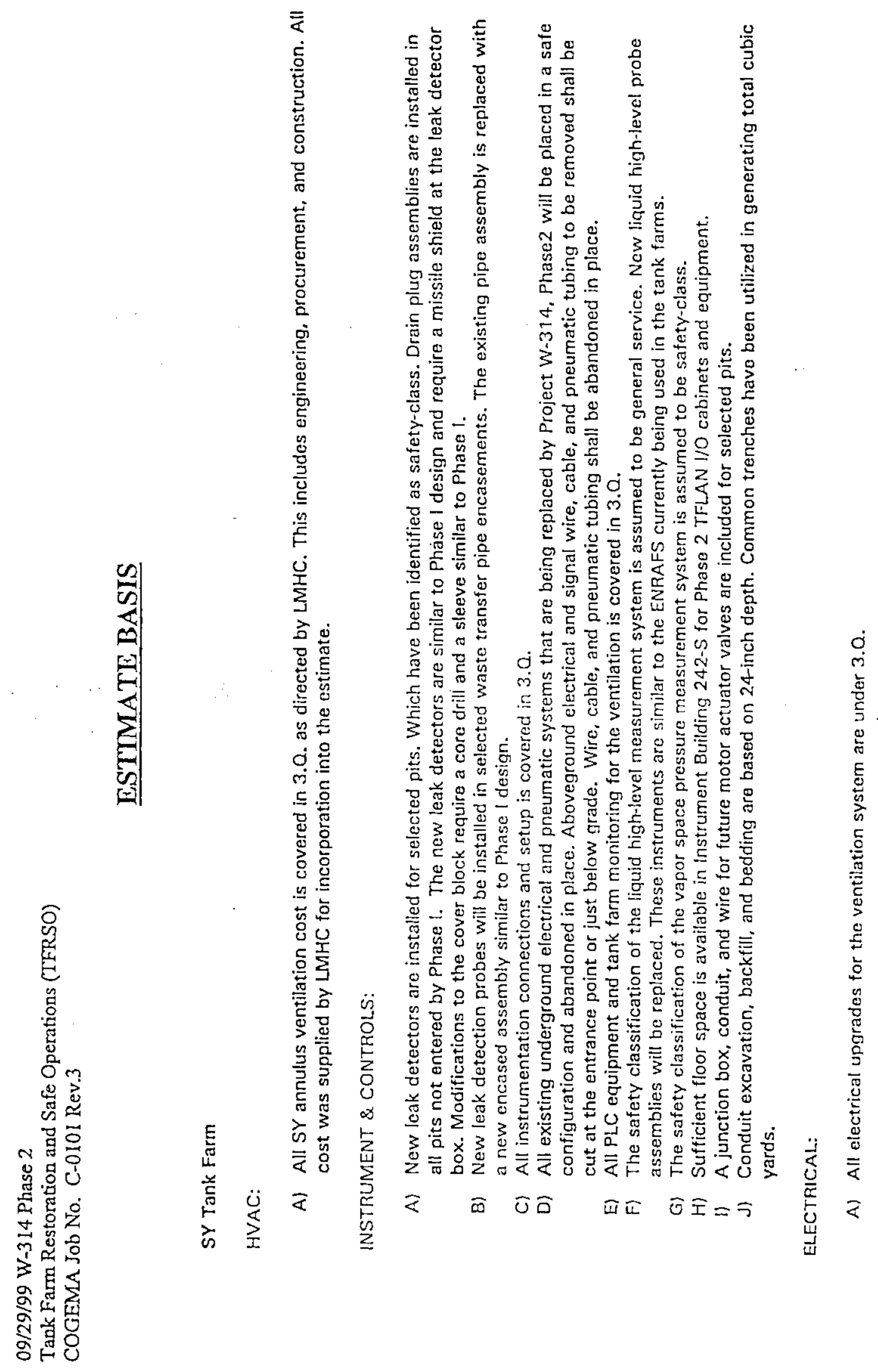


HNF-5109, Rev. 0
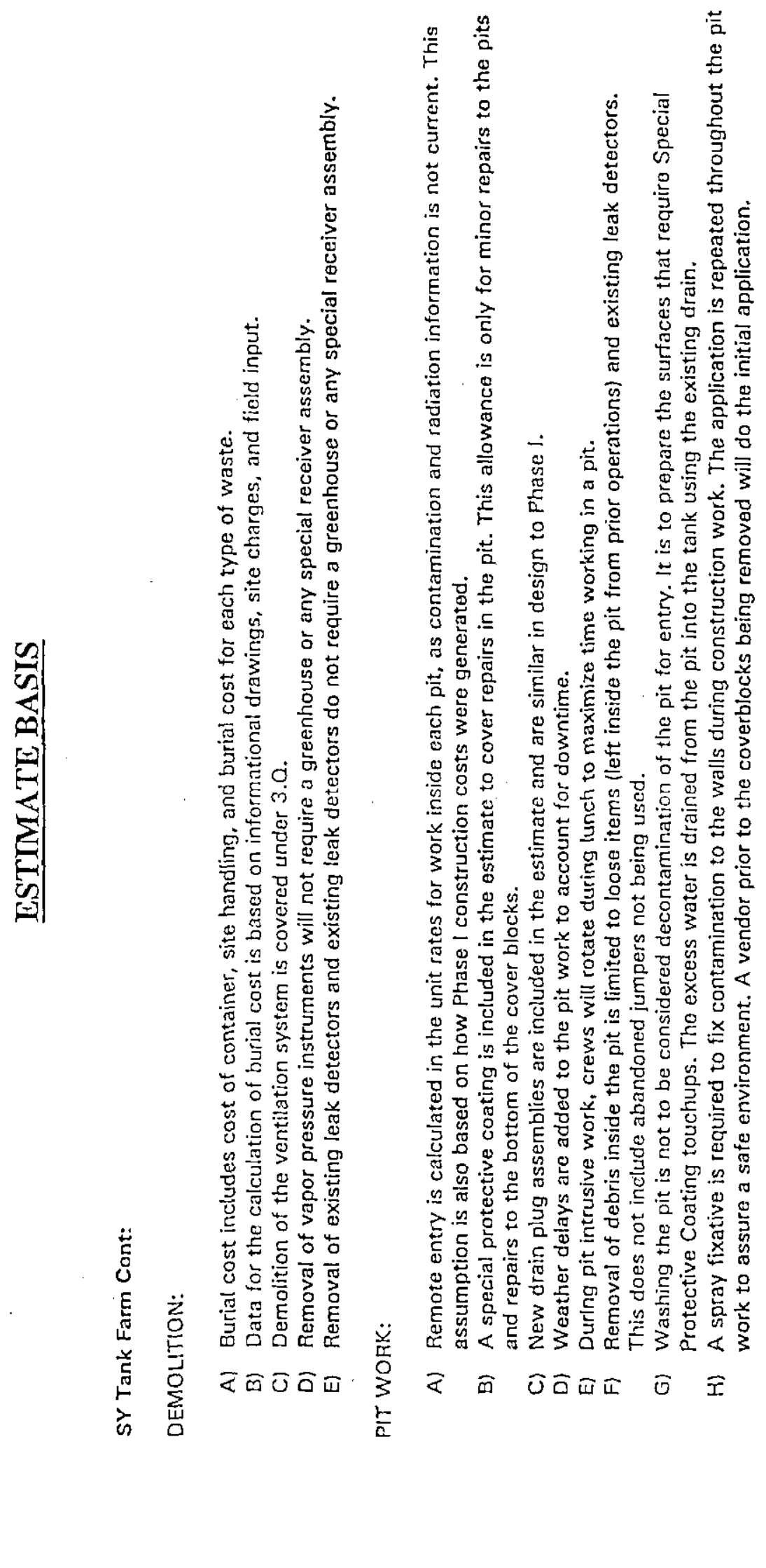
HNF-5109, Rev. 0
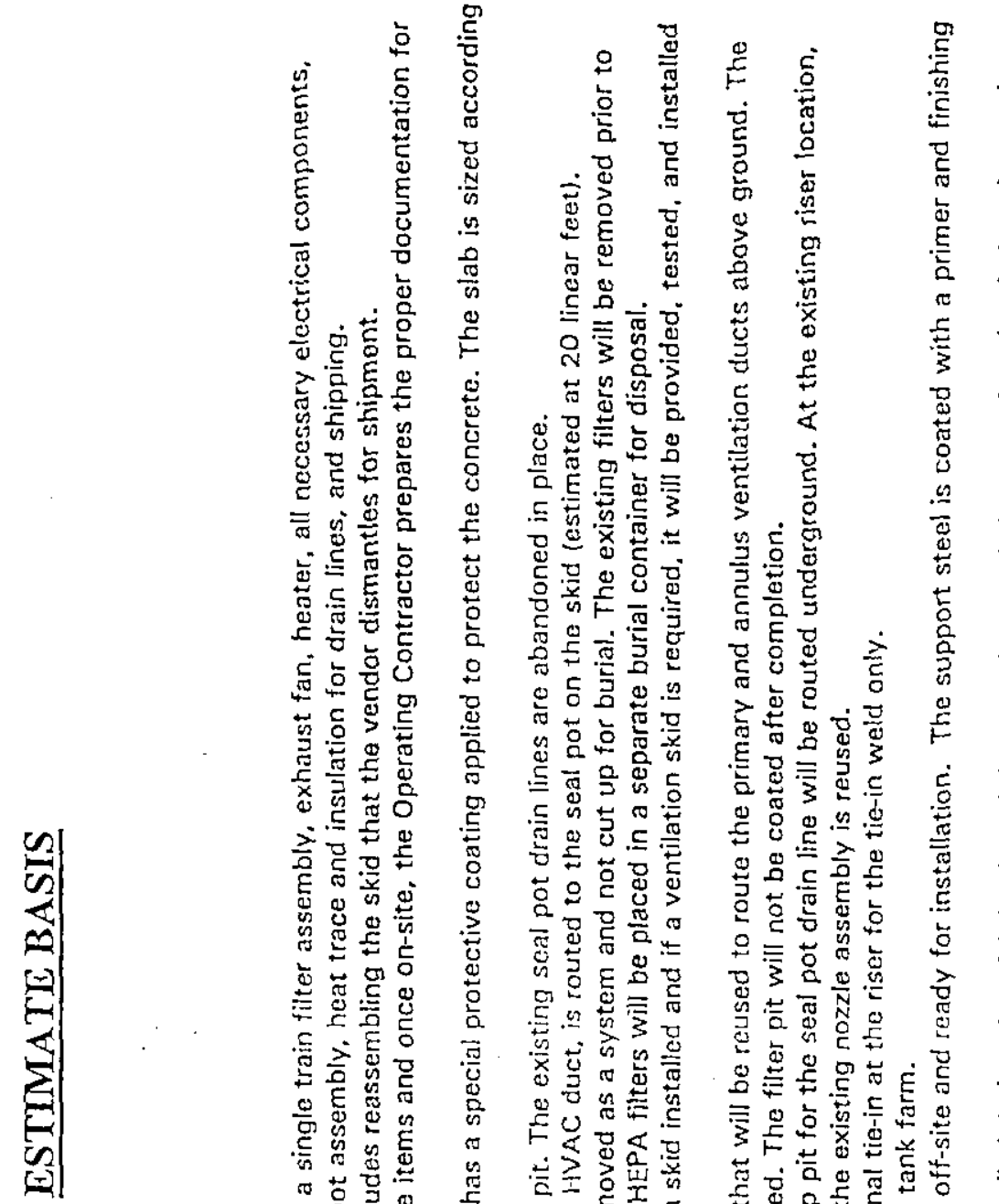

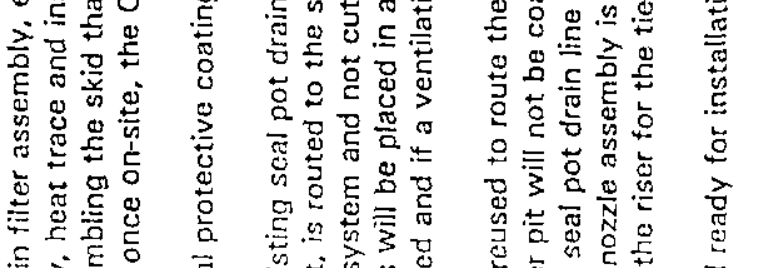

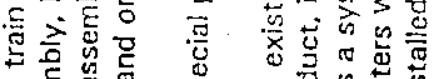

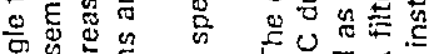

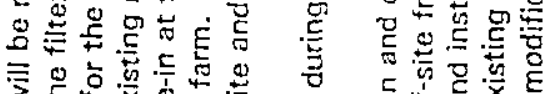

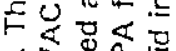

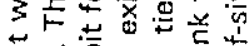

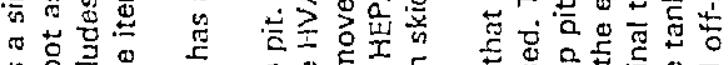

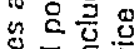

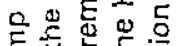

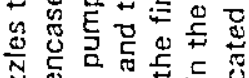

गु

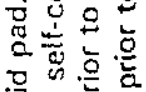

릉응

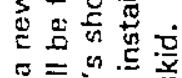

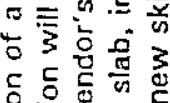

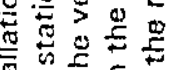

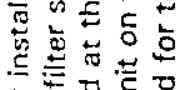

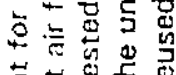

岛志氙

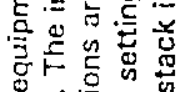

号客焉员㟔

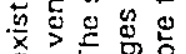

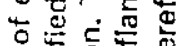

등

至要要

व 苞可品

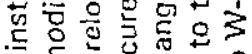

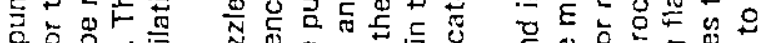

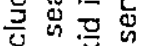

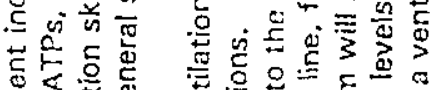

O

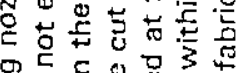

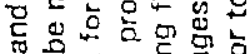

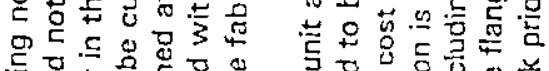

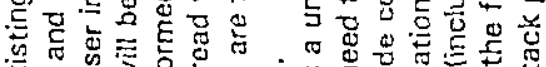

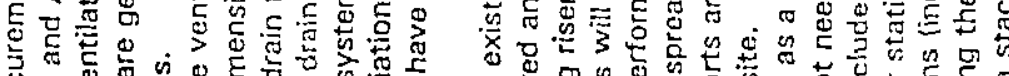

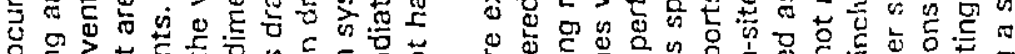

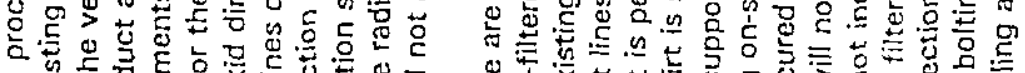

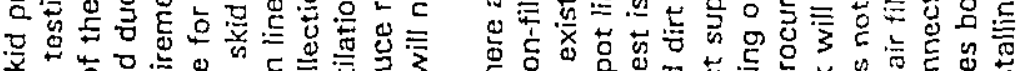

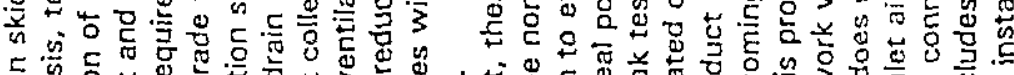

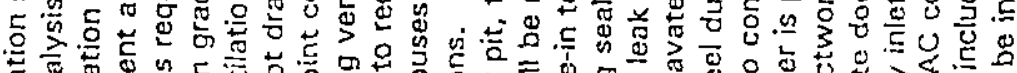

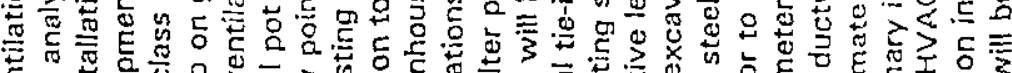

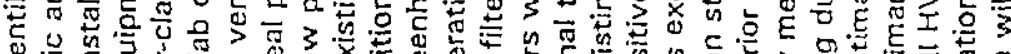
究这 N

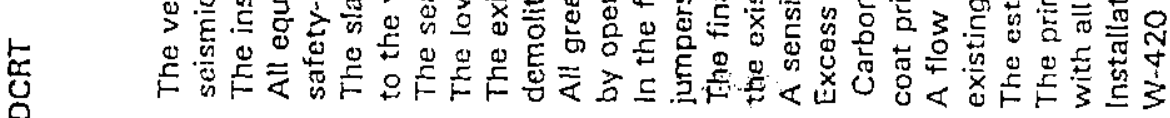
ษั है $\forall$ 인 ㄹㅇㅇ용

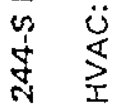
₹ o Шᄄ口 


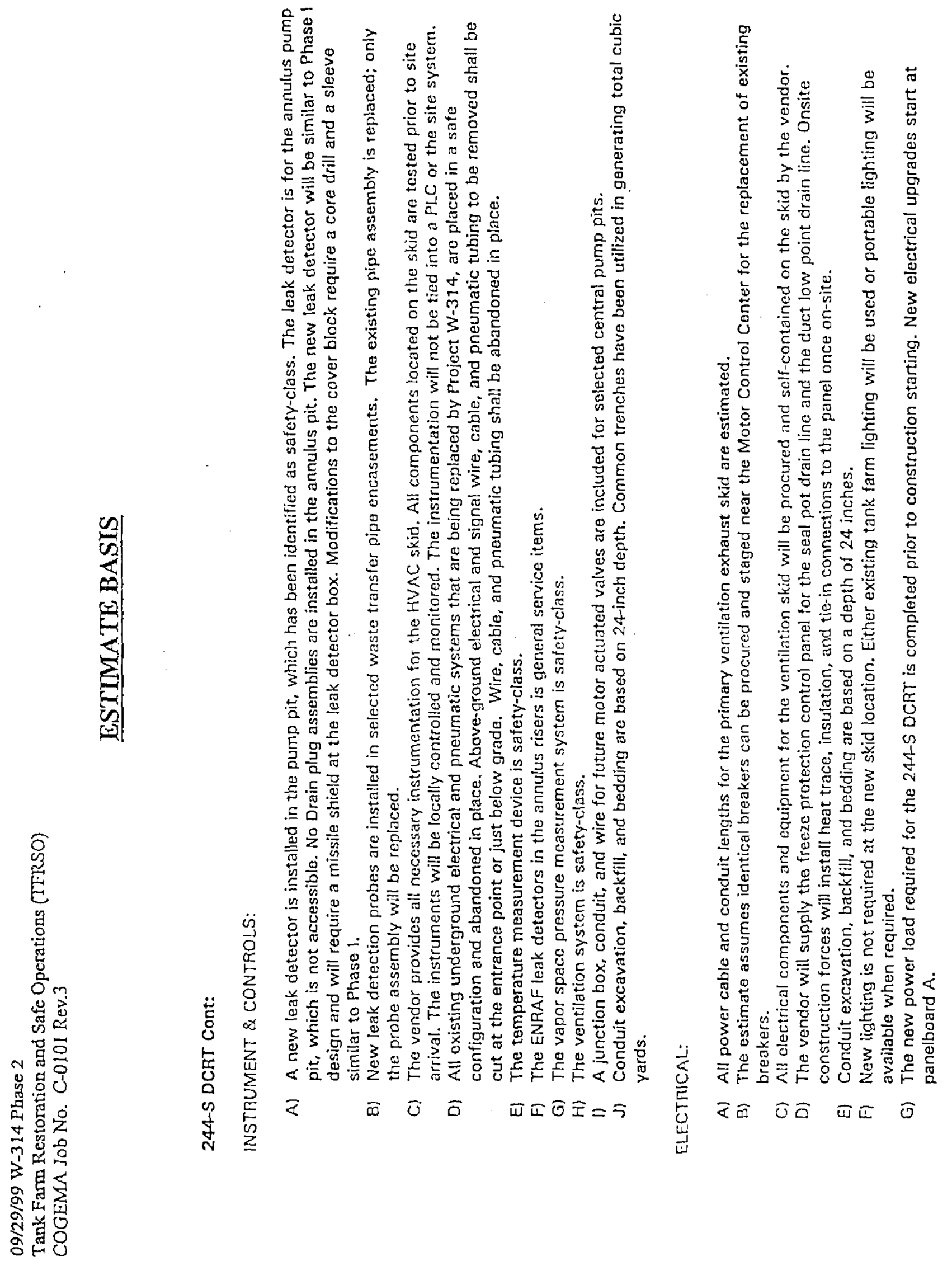




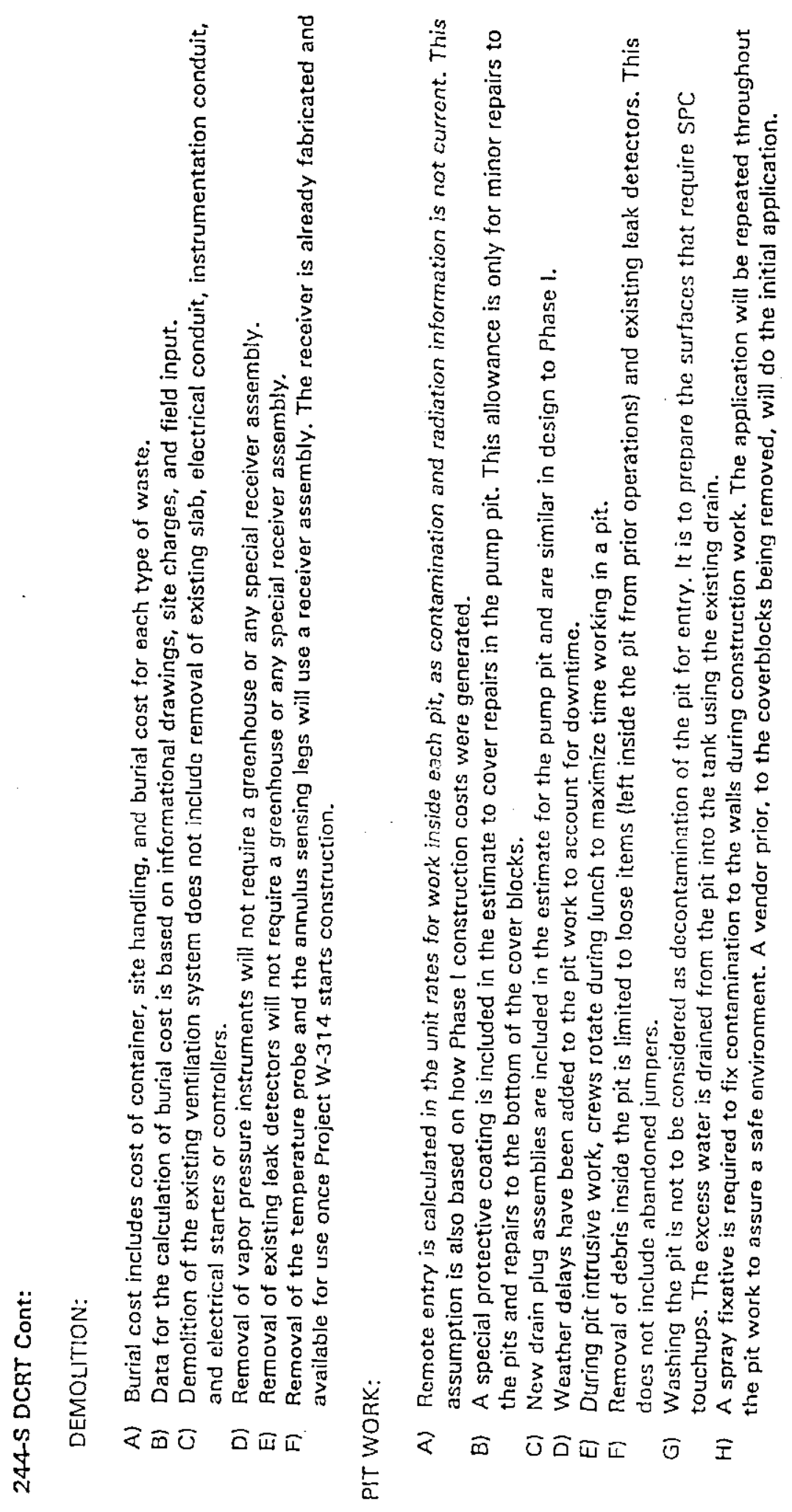



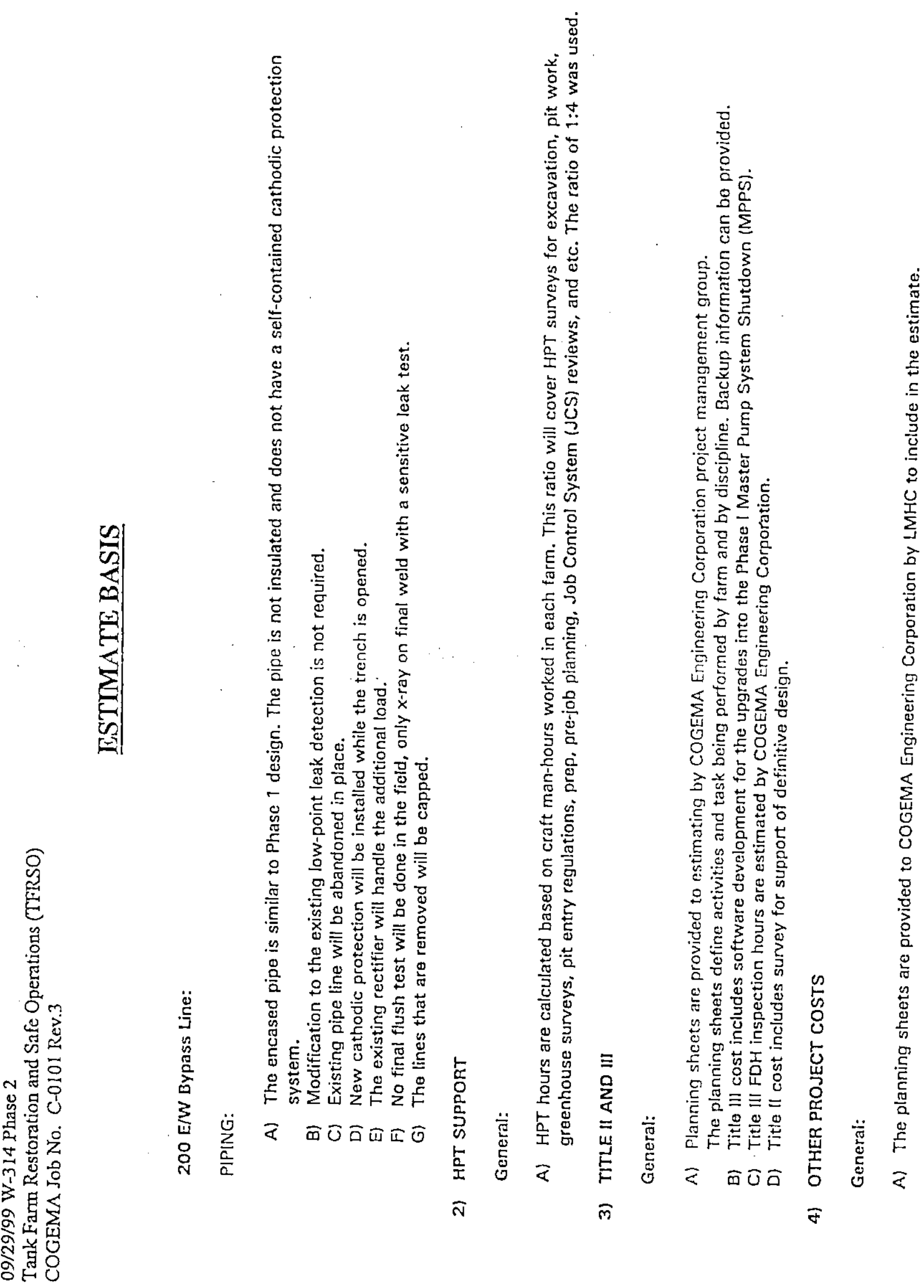


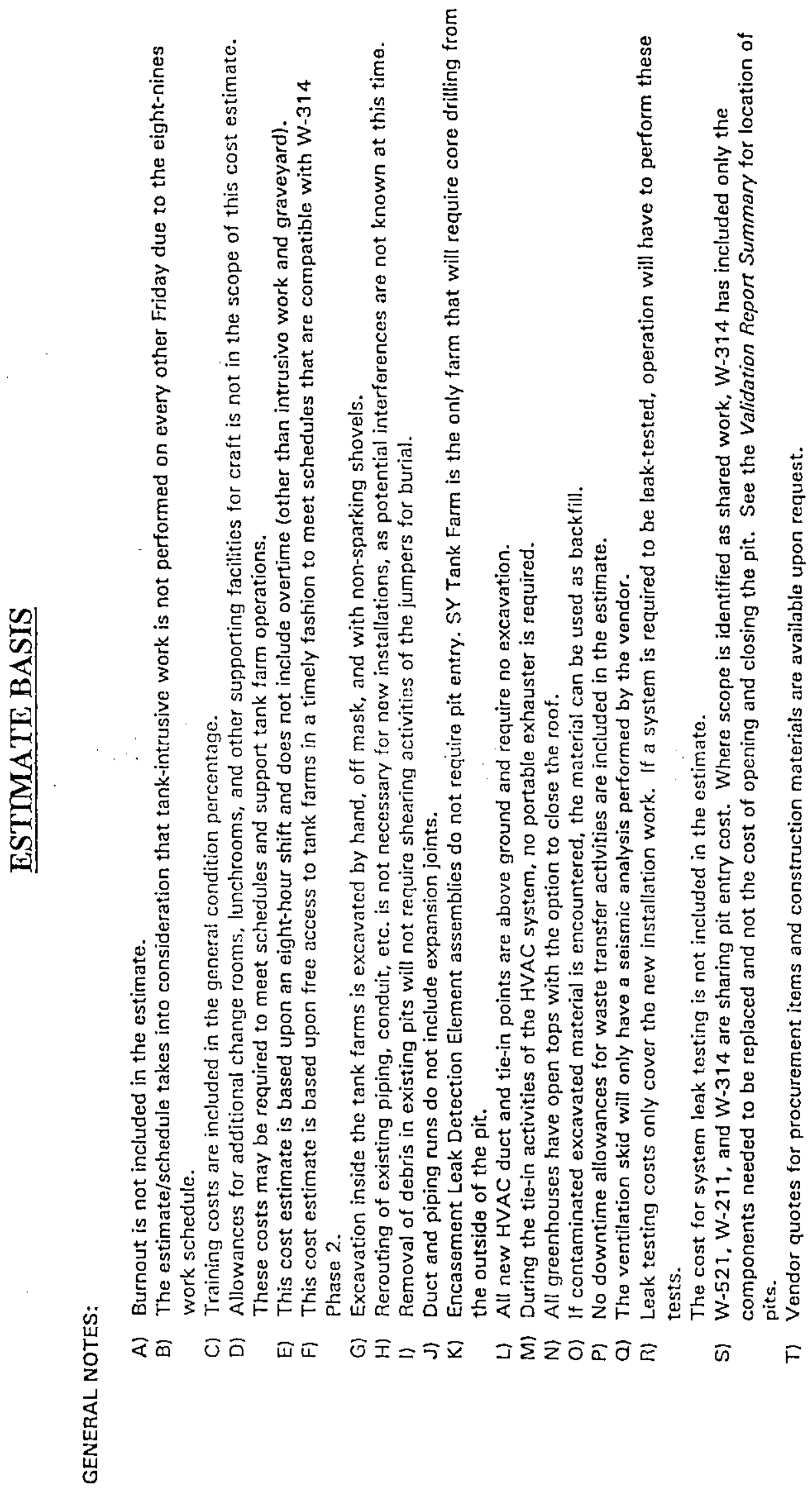


HNFF-5109, Rev. 0

\subsection{CHANGES FROM PREVIOUS BASELINE}

(consisting of the following five pages) 


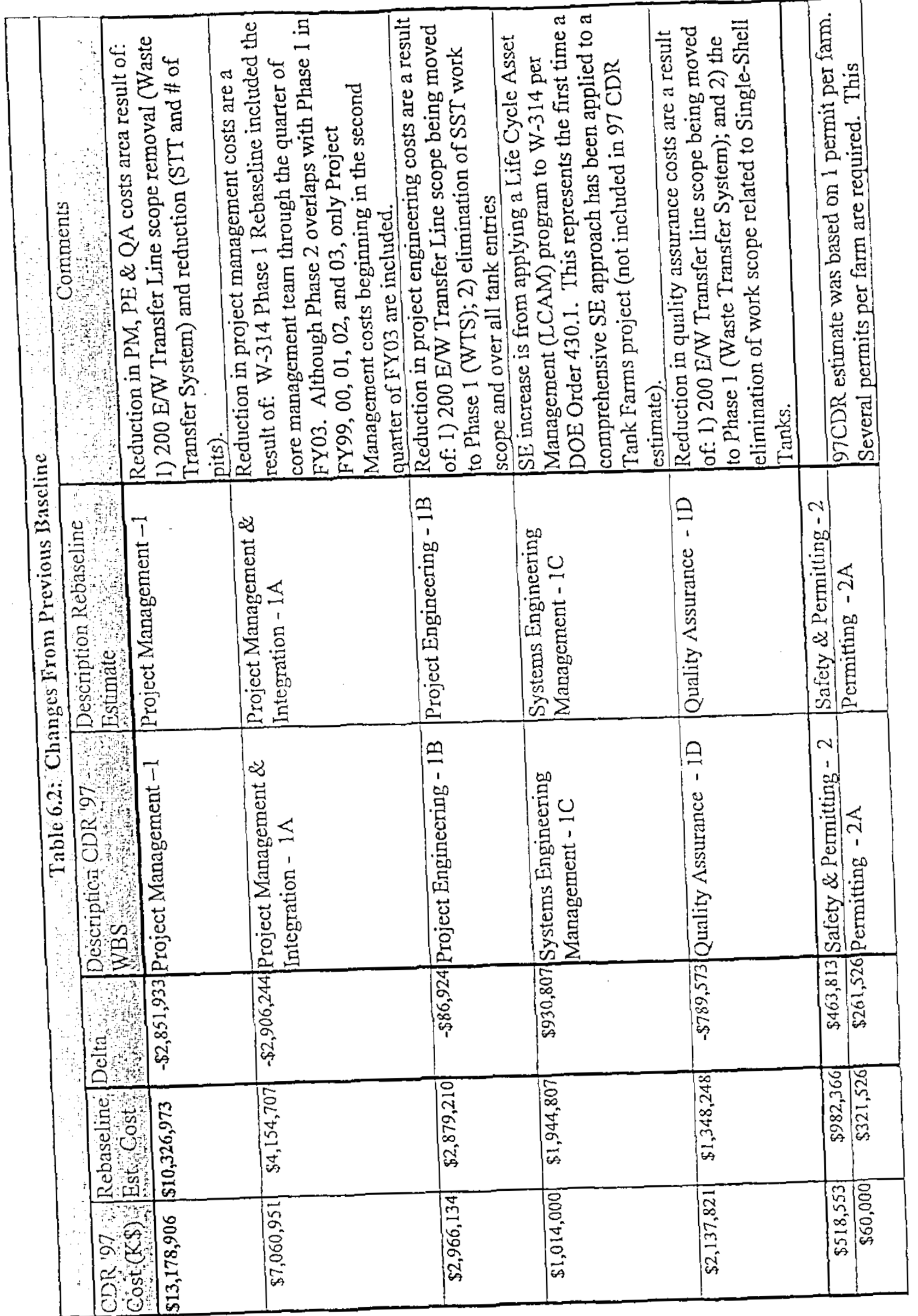




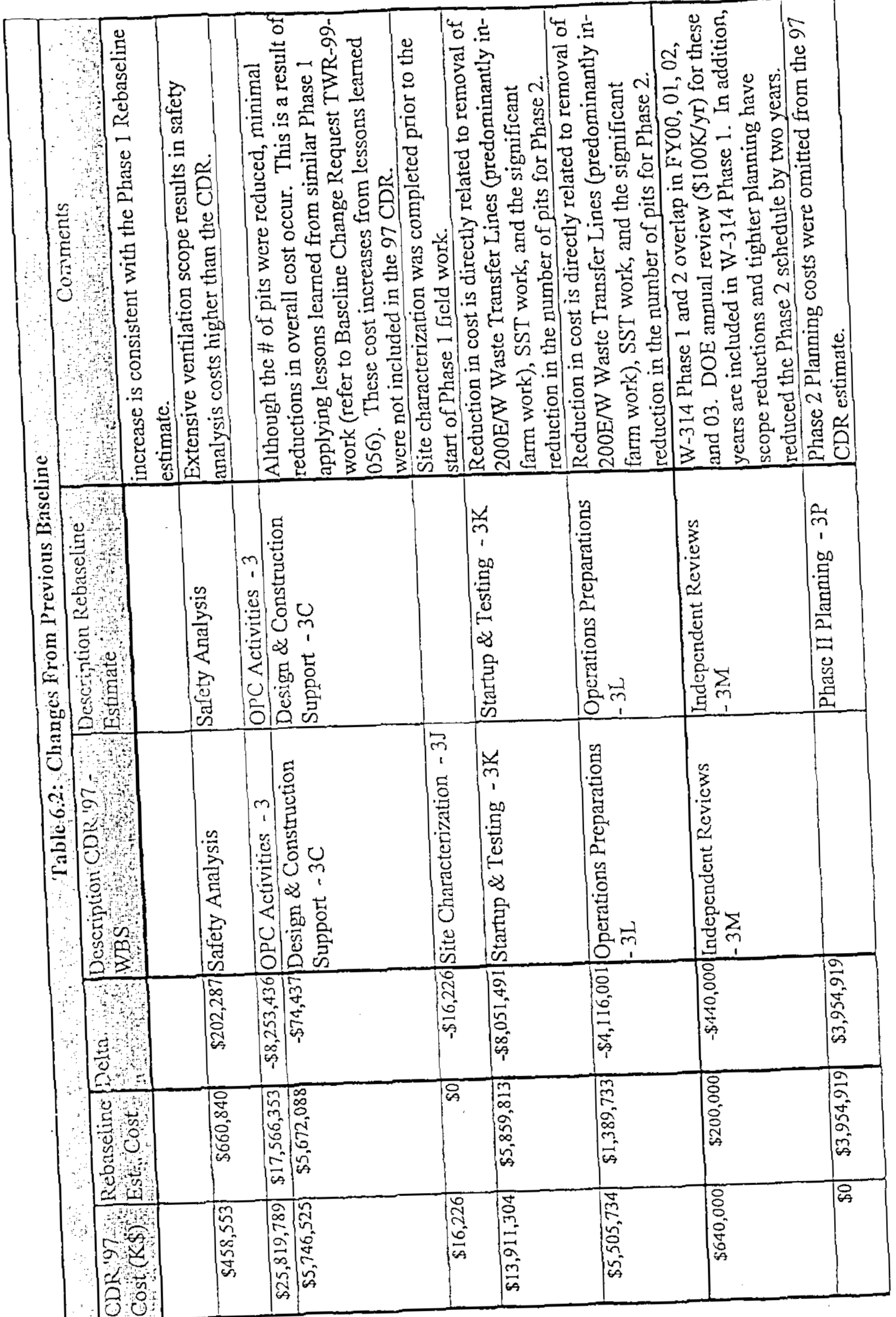




\begin{tabular}{|c|c|c|c|c|c|}
\hline$\Xi$ & 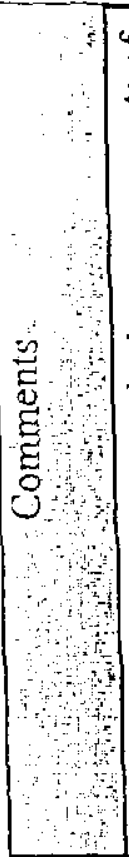 & 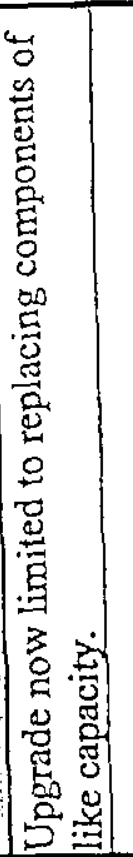 & & 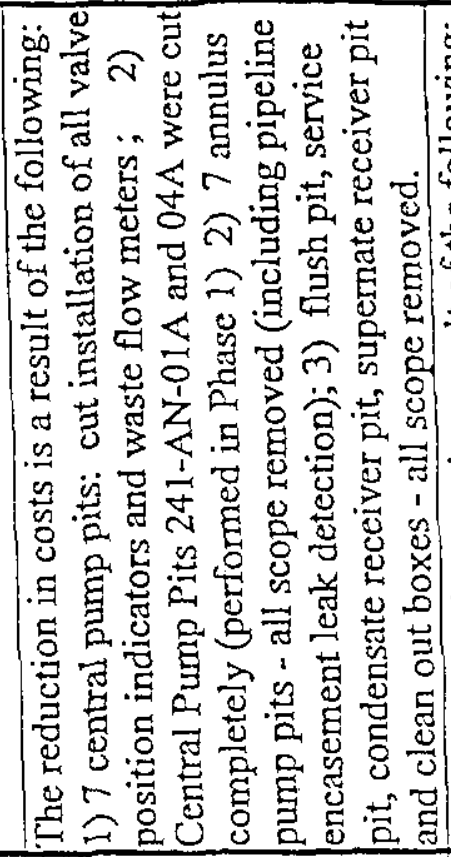 & 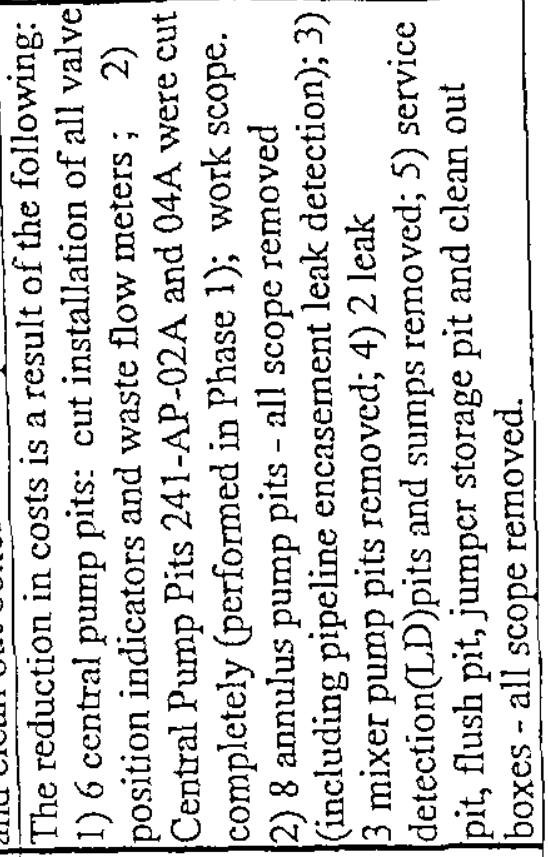 \\
\hline 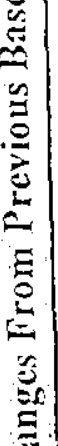 & 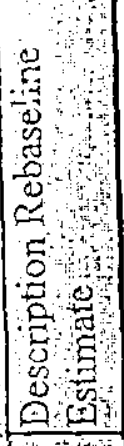 & 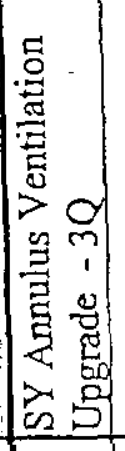 & 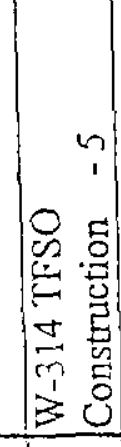 & 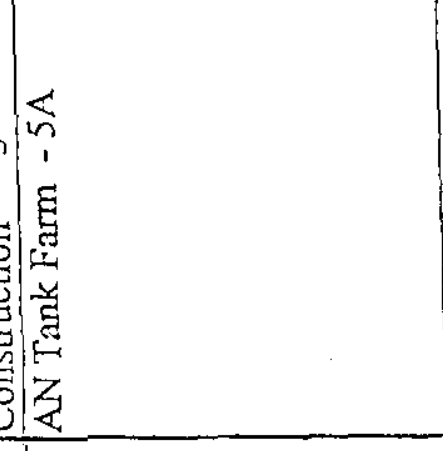 & 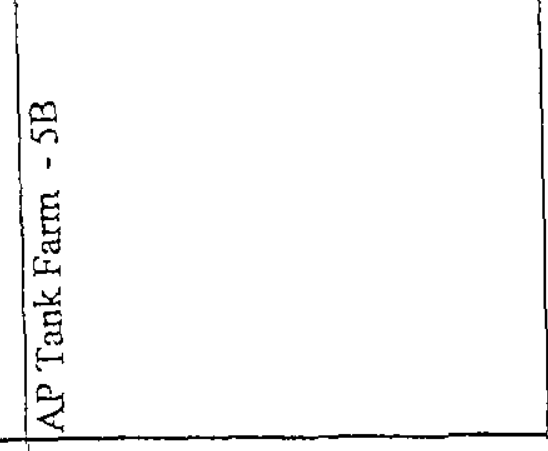 \\
\hline 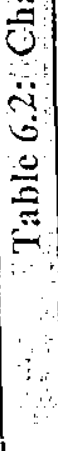 & 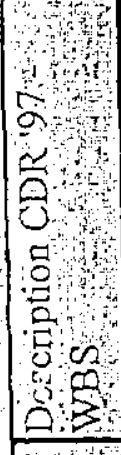 & & $\begin{array}{l}n \\
1 \\
\sim \\
u \\
u \\
g \\
a \\
\end{array}$ & 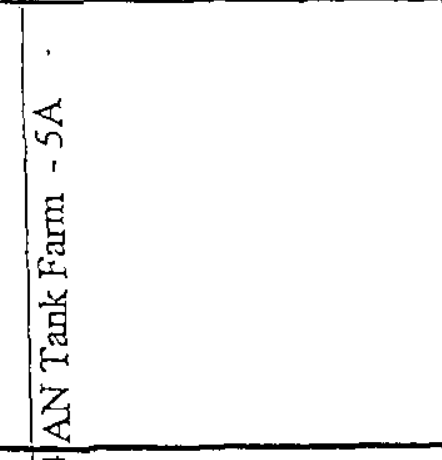 & 㸃 \\
\hline & ( & $\begin{array}{l}0 \\
0 \\
0 \\
0 \\
0 \\
0 \\
0 \\
0\end{array}$ & 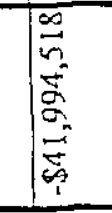 & 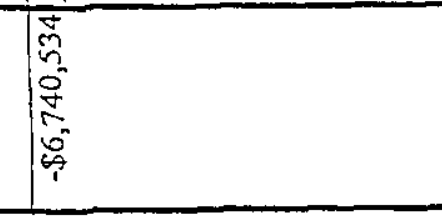 & 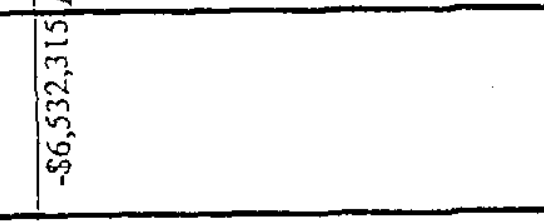 \\
\hline & 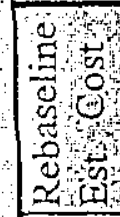 & $\begin{array}{l}8 \\
0 \\
0 \\
0 \\
0 \\
0 \\
0\end{array}$ & 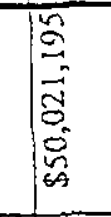 & 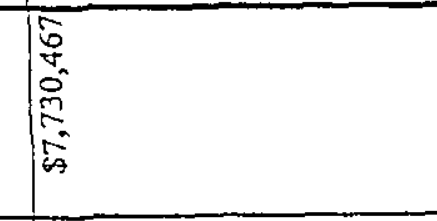 & 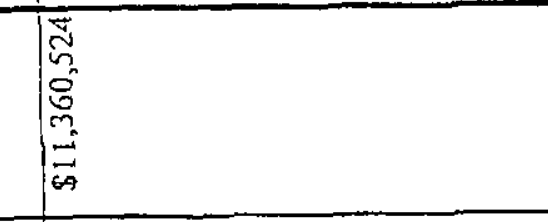 \\
\hline & 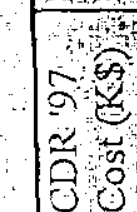 & 8 & $\begin{array}{l}m \\
2 \\
0 \\
0 \\
0 \\
0 \\
0 \\
0 \\
0\end{array}$ & 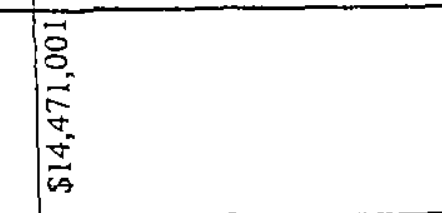 & 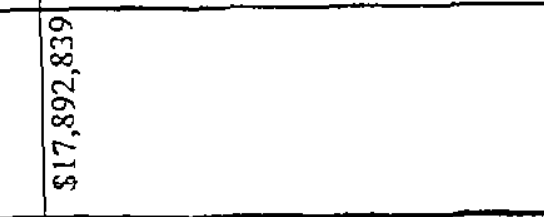 \\
\hline
\end{tabular}




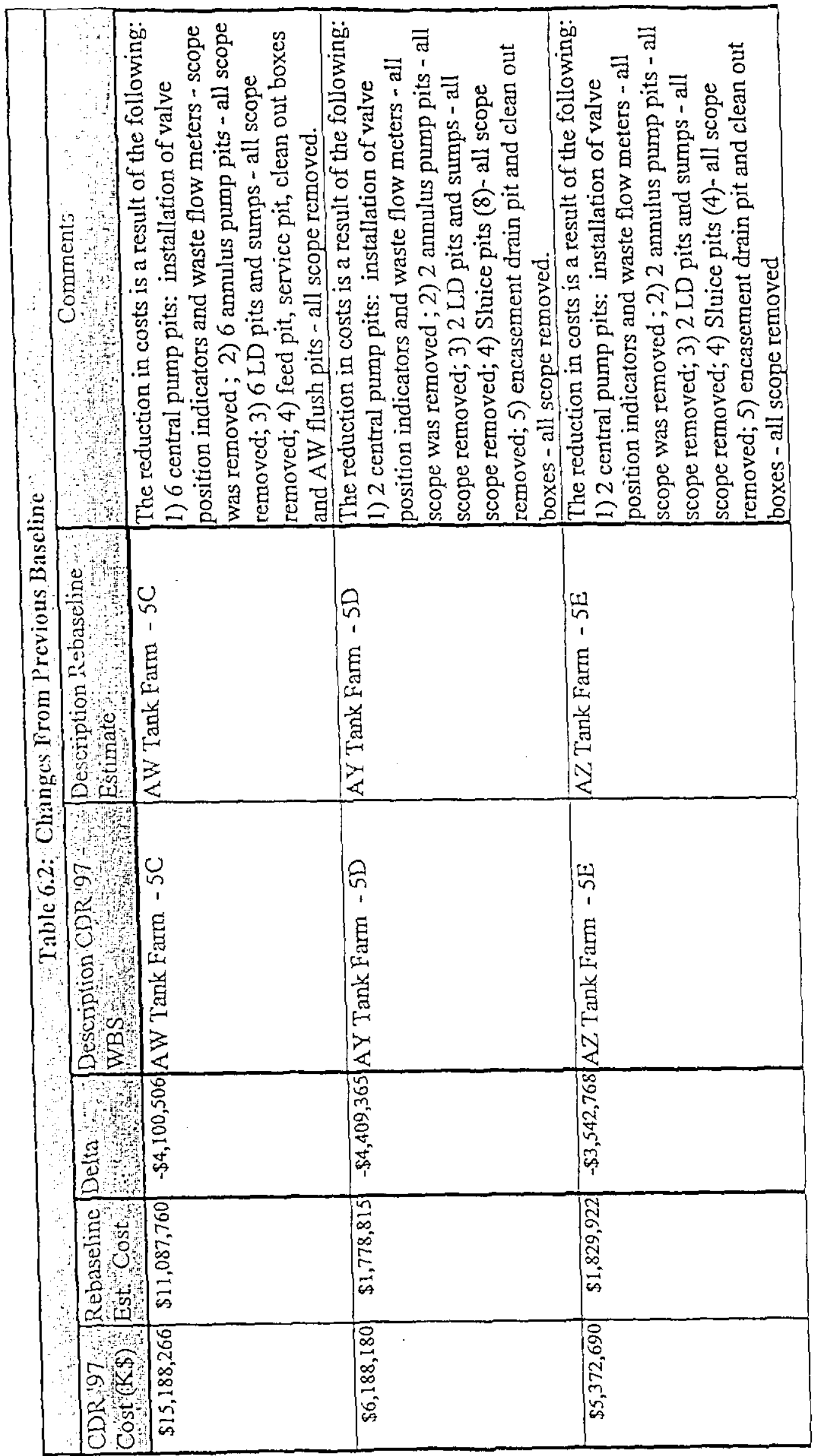


HNE-5109, REV. 0

\begin{tabular}{|c|c|c|c|c|c|c|c|c|c|c|}
\hline 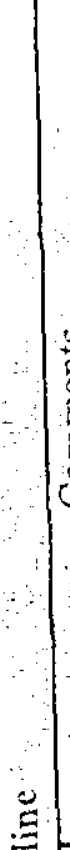 & (a) & 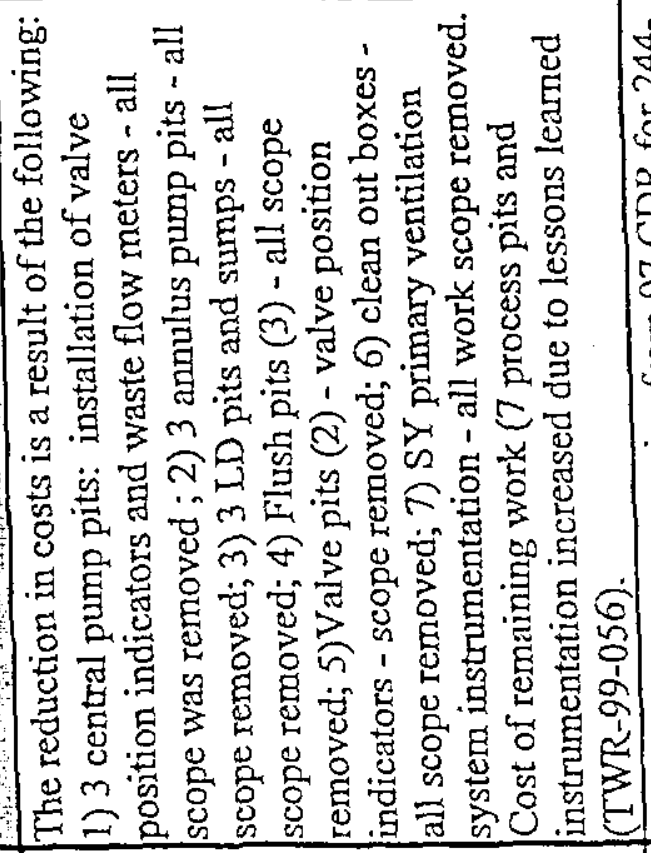 & 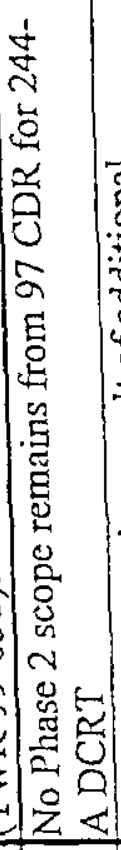 & 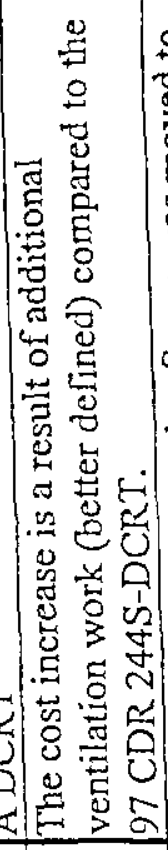 & 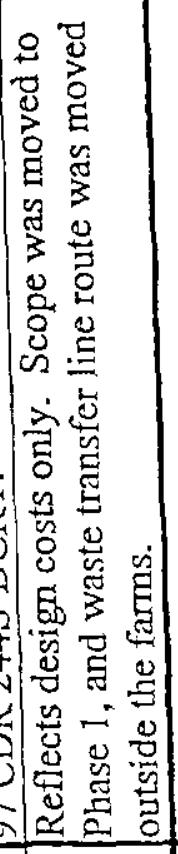 & & & & & \\
\hline 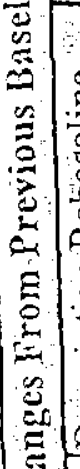 & 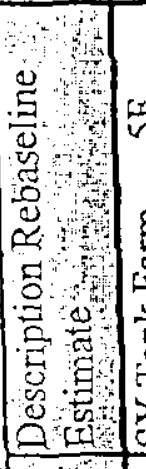 & 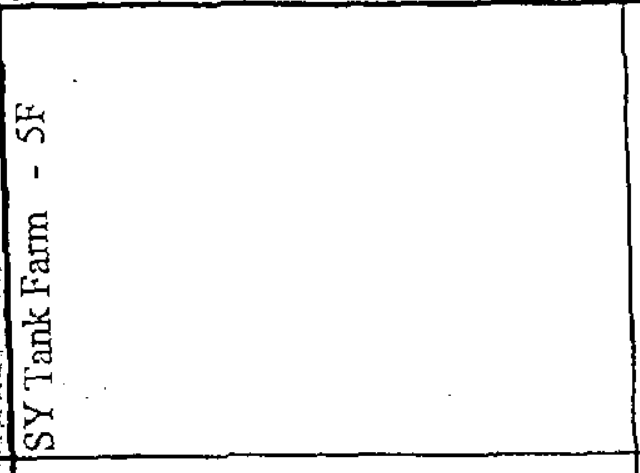 & & 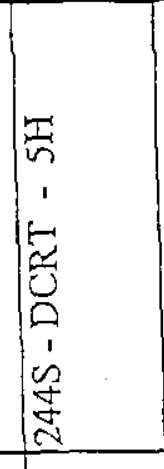 & 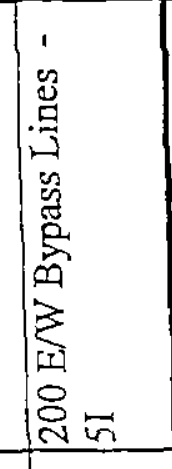 & & & & & \\
\hline 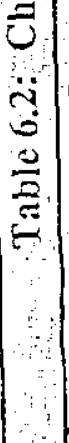 & 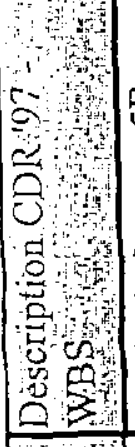 & 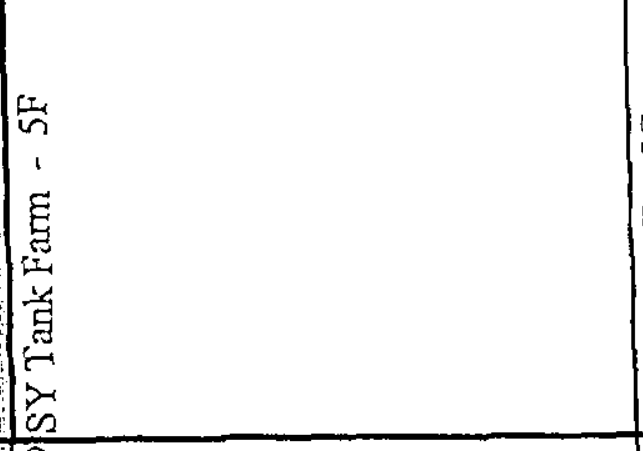 & 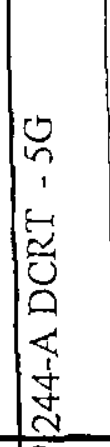 & 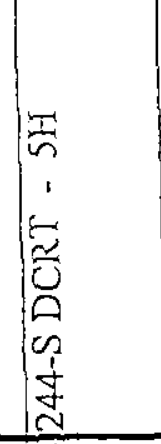 & 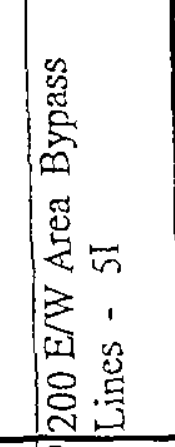 & 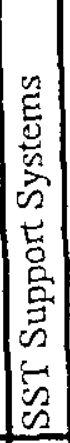 & 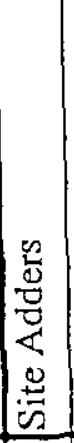 & 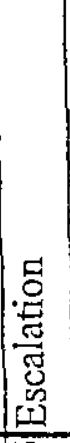 & $\begin{array}{l}\text { 离 } \\
0 \\
0 \\
.0 \\
0 \\
0 \\
0\end{array}$ & 位 \\
\hline & 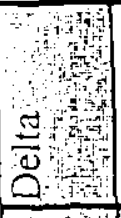 & 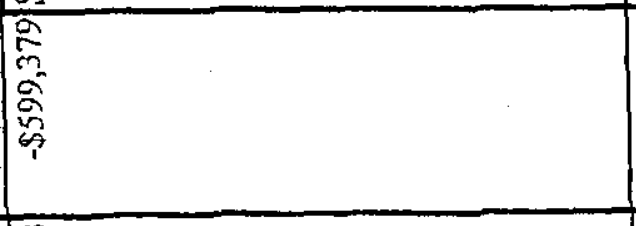 & 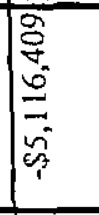 & {$\left[\begin{array}{l}\infty \\
\infty \\
\infty \\
\infty \\
6 \\
6\end{array}\right.$} & $\begin{array}{l}\text { क } \\
0 \\
0 \\
2 \\
0 \\
0 \\
0 \\
0\end{array}$ & $\begin{array}{c}\frac{5}{2} \\
2 \\
\infty \\
\infty \\
0 \\
6 \\
6 \\
6\end{array}$ & 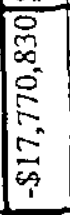 & 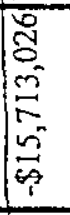 & 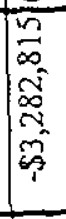 & 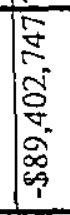 \\
\hline & $\begin{array}{l}0 \\
0 \\
0 \\
0 \\
0 \\
0 \\
0\end{array}$ & 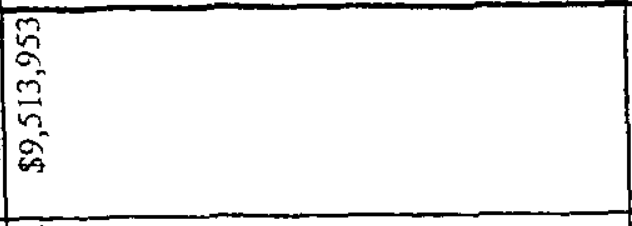 & 8 & 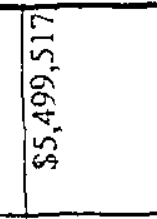 & 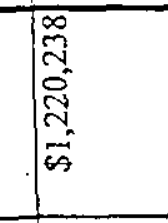 & Dis & 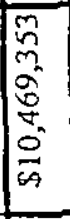 & $\begin{array}{l}\infty \\
\infty \\
2 \\
\infty \\
2 \\
2 \\
\infty \\
\infty \\
\infty\end{array}$ & 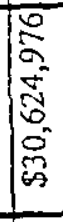 & 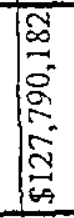 \\
\hline & 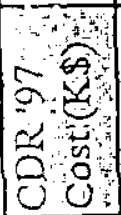 & 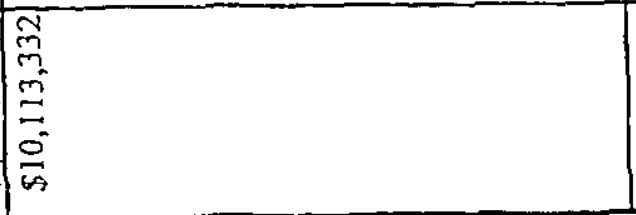 & 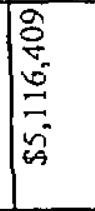 & 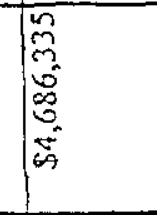 & $\begin{array}{l}\sqrt{\infty} \\
2 \\
2 \\
2 \\
2 \\
\alpha \\
a\end{array}$ & $\begin{array}{l}m \\
m \\
m \\
\infty \\
\infty \\
m \\
m \\
m \\
\infty\end{array}$ & 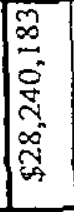 & 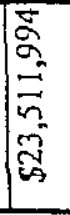 & 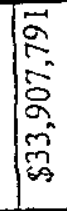 & 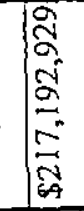 \\
\hline
\end{tabular}




\subsection{SCHEDULE}

Planning Basis: The scheduling of project activities for the Phase 2 rebaseline effort was based upon assumed funding constraints in the fiscal years 2000 and 2001, assumed schedule constraints posed by the planned timetable for transfer of waste to the privatized vitrification facility (and therefore the need date for upgraded ventilation systems), TPA Milestone M-43, "Compliance Upgrades," required integration with other ongoing RPP activities, and resource leveling requirements. Tables 7.1 and 7.2 below, identify funding and schedule assumptions.

Table 7.1: Funding Assumptions

\begin{tabular}{|l|l|}
\hline Fiscal Xear & Fundino Assumptions (\$1000s) \\
\hline 2000 & $\$ 5.433 \mathrm{M}(2.941$ Capital +2.492 Expense \\
\hline 2001 & $\$ 8.477 \mathrm{M}(5.399$ Capital +3.078 Expense $)$ \\
\hline
\end{tabular}

Table 7.2: Schedule Assumptions

\begin{tabular}{|l|r|}
\hline PUP & Date \\
\hline Complete AN Primary Ventilation Construction & 2003 \\
\hline Complete AY I\&C and Electrical Construction & 2003 \\
\hline Complete AZ I\&C and Electrical Construction & 2003 \\
\hline Complete 244-S DCRT Ventilation Construction & 2004 \\
\hline Complete AP Primary Ventilation Construction & 2004 \\
\hline Complete AW Primary Ventilation Construction & 2004 \\
\hline Complete SY Annulus Ventilation Construction & 2005 \\
\hline Complete "Other" AP Farm Construction & 2006 \\
\hline Complete "Other AW Farm Construction & 2006 \\
\hline Complete W-314 Project's Portion of TPA M-43-00* & 2005 \\
\hline
\end{tabular}

The above construction completion dates allow enough time for subsequent startup, testing, and other readiness activities required to transfer waste per the current vitrification timetable.

TPA Milestone M-43: The required completion date of TPA Milestone M-43 "Compliance Upgrades" is Jurze 2005. Specifically what this entails is still being negotiated with the State. For purposes of this rebaseline of W-314 Phase 2, completion of all activities were assumed to be required by June 2005 .

Integration: Integration will be achieved with River Protection Projects (RPP) W-211 and W521 to minimize Phase 2 pit upgrade costs, particularly four central pump pits, AN-102, AN-105, AN-106, and AN-107. W-314 Phase 2 plans to accomplish the installation of a leak detector and drain plug assembly, and repair of the SPC on the interior pit walls during the planned W211 upgrade of central pump pit AN-105. Similarly, W-314 Phase 2 pit work will be coordinated during the planned W-521 upgrades of AN-102, 106, and 107. A more detailed discussion of the required integration is included in Section 8.0. 
Resource Leveling: The scheduling of Phase 2 project activities also includes the adjustment of activity time phasing to avoid annual funding and critical resource peaks and valleys. The results are represented in the BA/BO schedule outlay, Section 8 , and the Phase 2 required Critical Resources, Section 10.

Phase 2 Schedule: The W-314 Phase 2 Schedule, Figure 7.1, provides five key ventilation system upgtades including "Tumover to Operations" (includes start up, testing, and turnover activities) by the required programmatic need dates. Activities highlights by fiscal year are:

FY00: Activities include: SY annulus ventilation refurbishment, the preparation of required system engineering documents (Project Design Concepts, Project Design Specifications, and Project Interface Control Documents), AN Farm and 244-S DCRT definitive design.

FY 01: Activities include completion of 244-S DCRT definitive design, AN Farm primary ventilation procurement activities, one AN Farm process pit upgrade, and AP definitive design.

FY02: Activities include: AN Farm primary ventilation construction and upgrades of two AN process pits, AY Farm definitive design, and 244-S DCRT ventilation procurement and construction.

FY03: Activities include: AP construction (site instrumentation and electrical upgrades, process pit upgrades), AW primary ventilation system procurement, AY and AZ Farm construction (site instrumentation and electrical upgrades and process pit upgrades), and completion of 244-S DCRT ventilation system upgrades.

FY04: Activities include: Completion of AN Farm construction (upgrades of two AN process pits), completion of AP Farm construction (process pit upgrades), AW Farm process pit upgrades, AW Farm primary ventilation system construction, and SY process pit upgrades

FY05: Activities include: AW construction completion, SY construction completion

Figure 7.1 Detailed Schedule (consisting of the following 53 pages) 


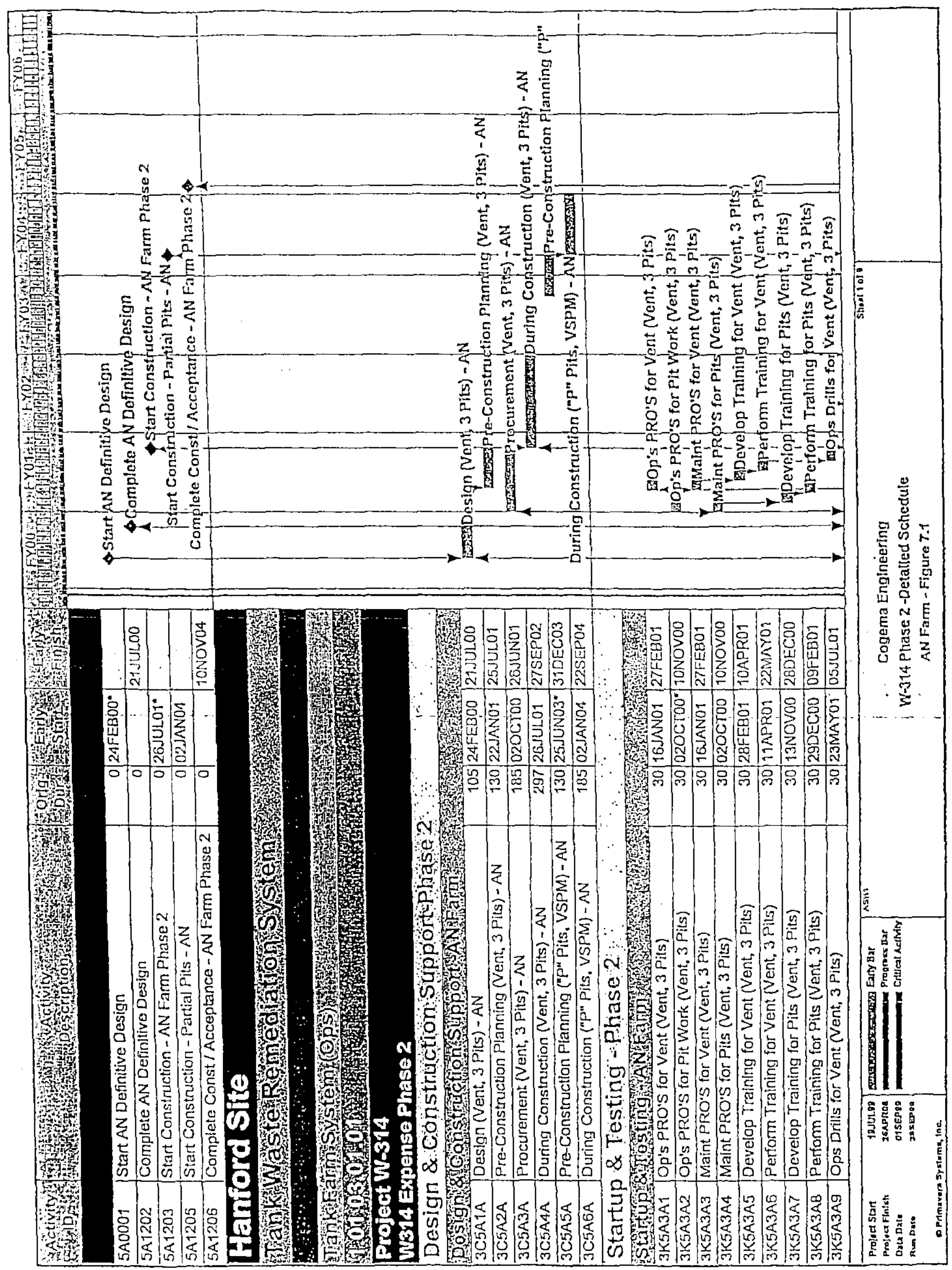


FIN -5109 , REV. 0

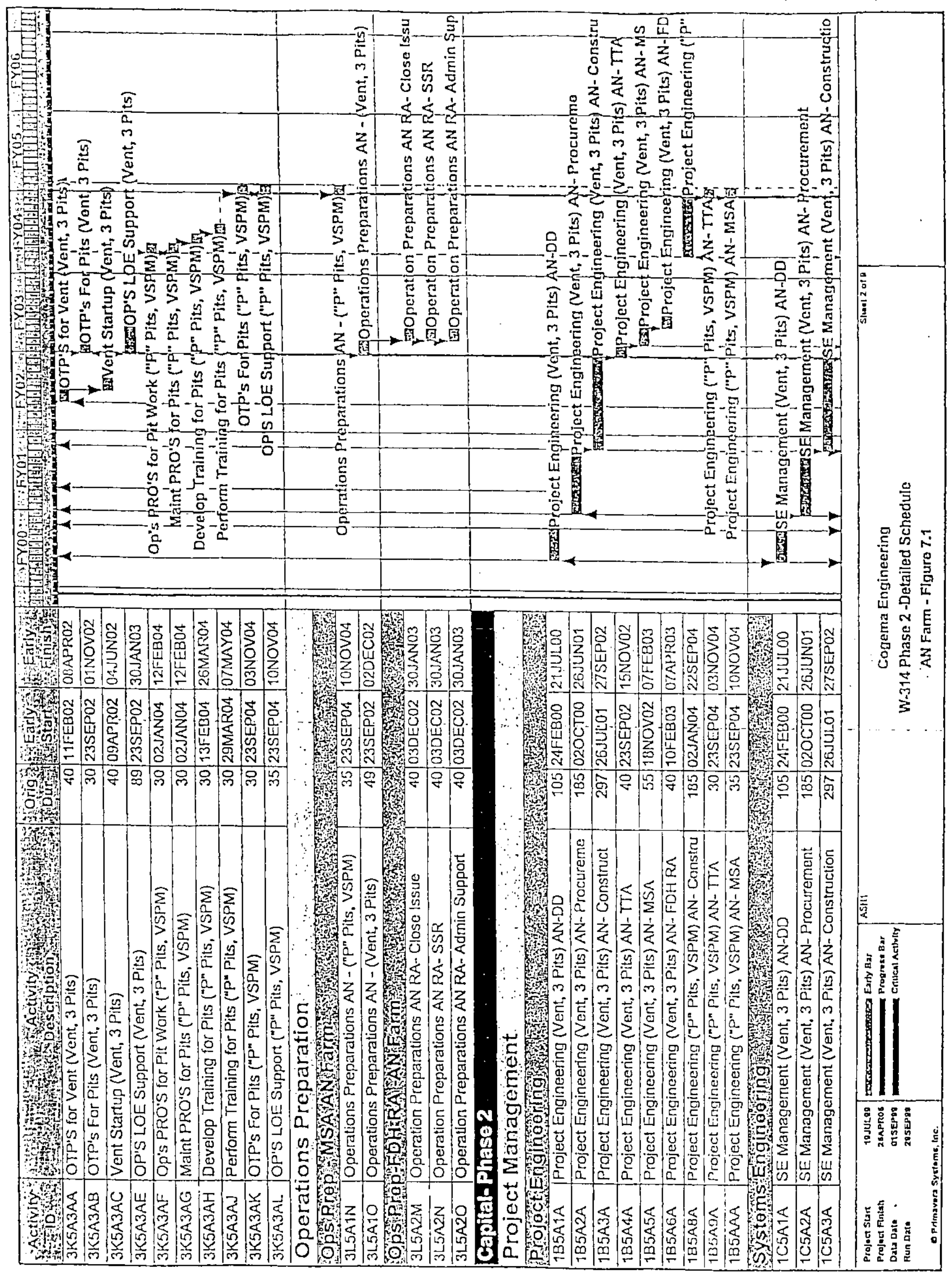




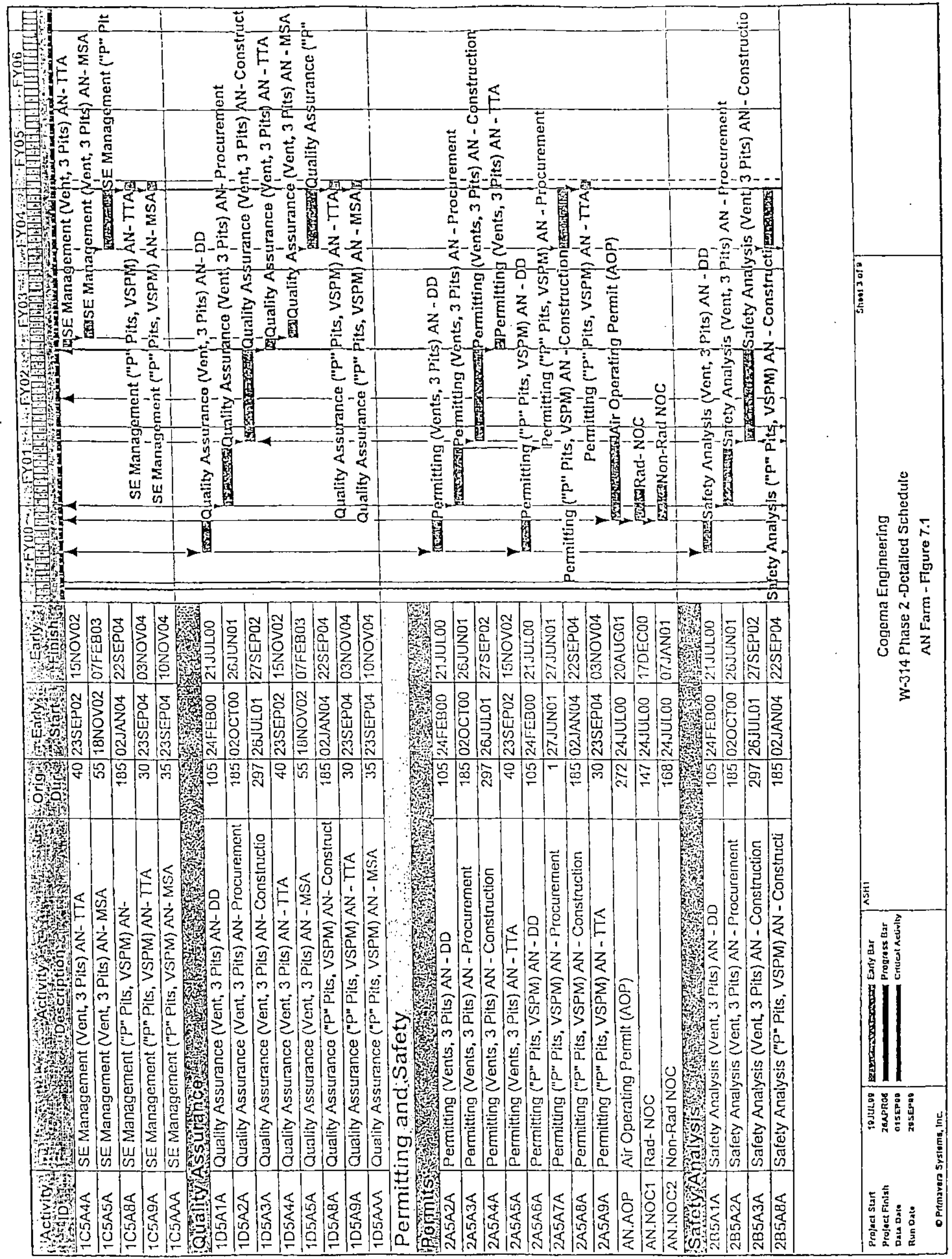




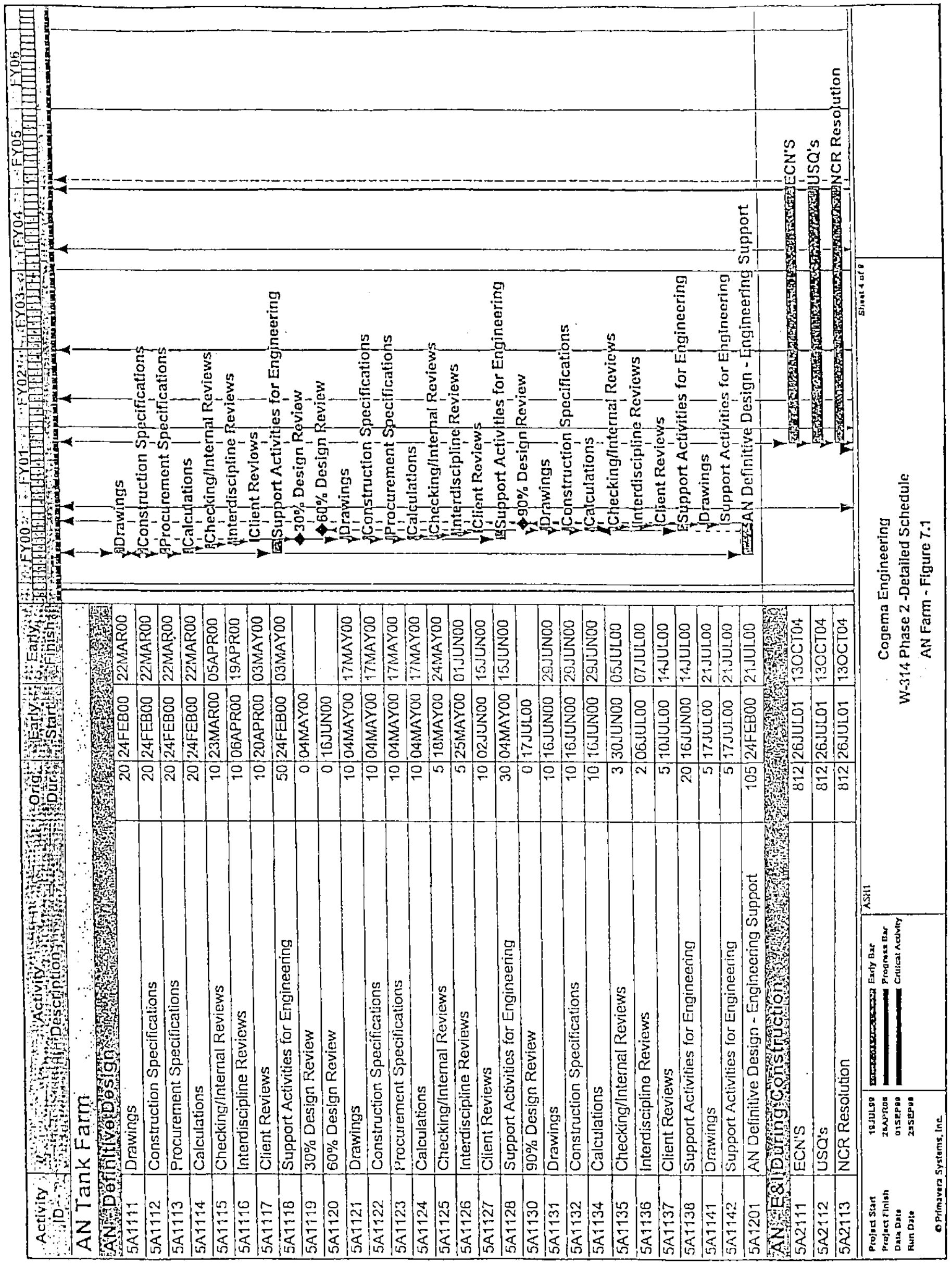



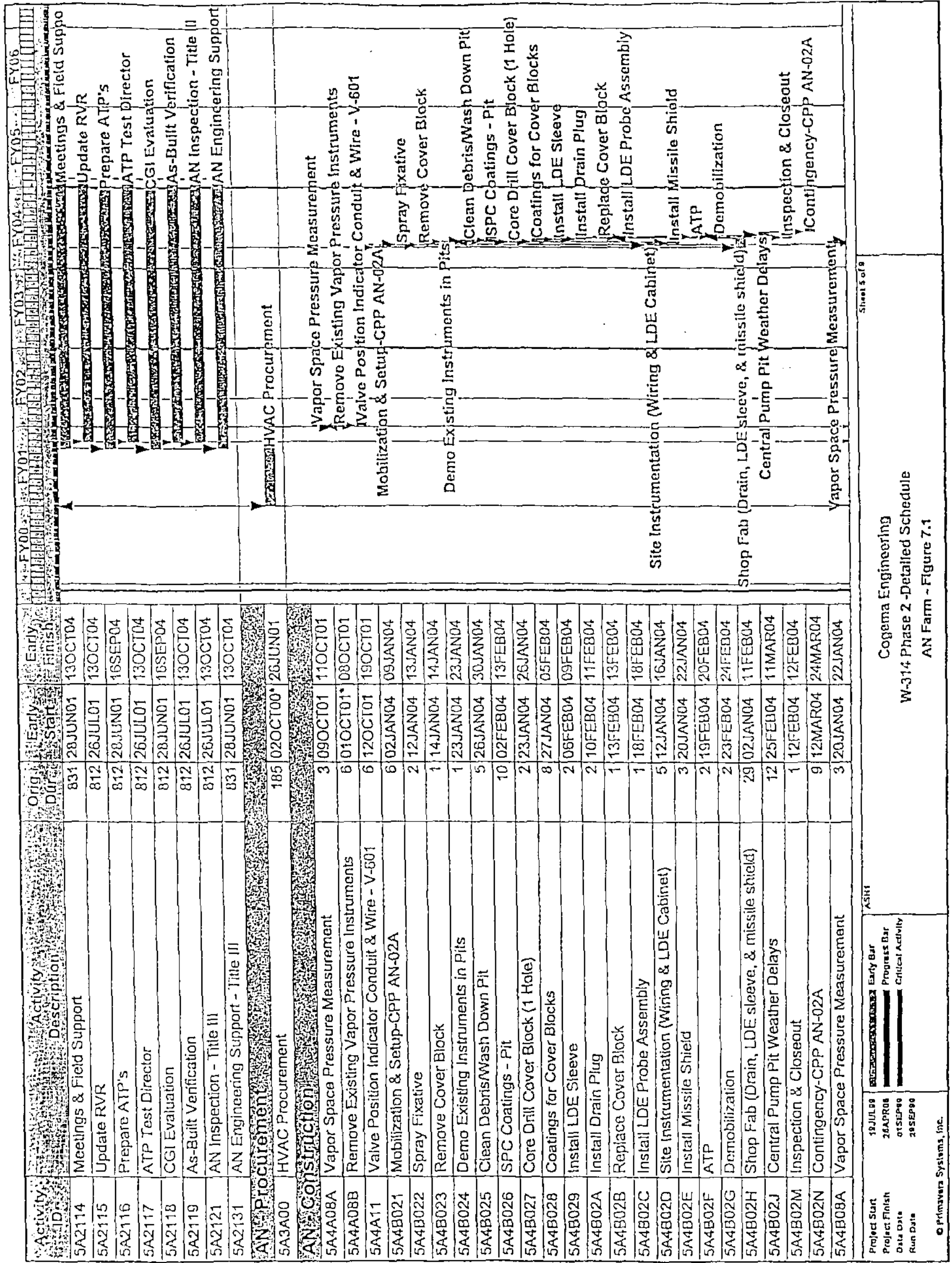


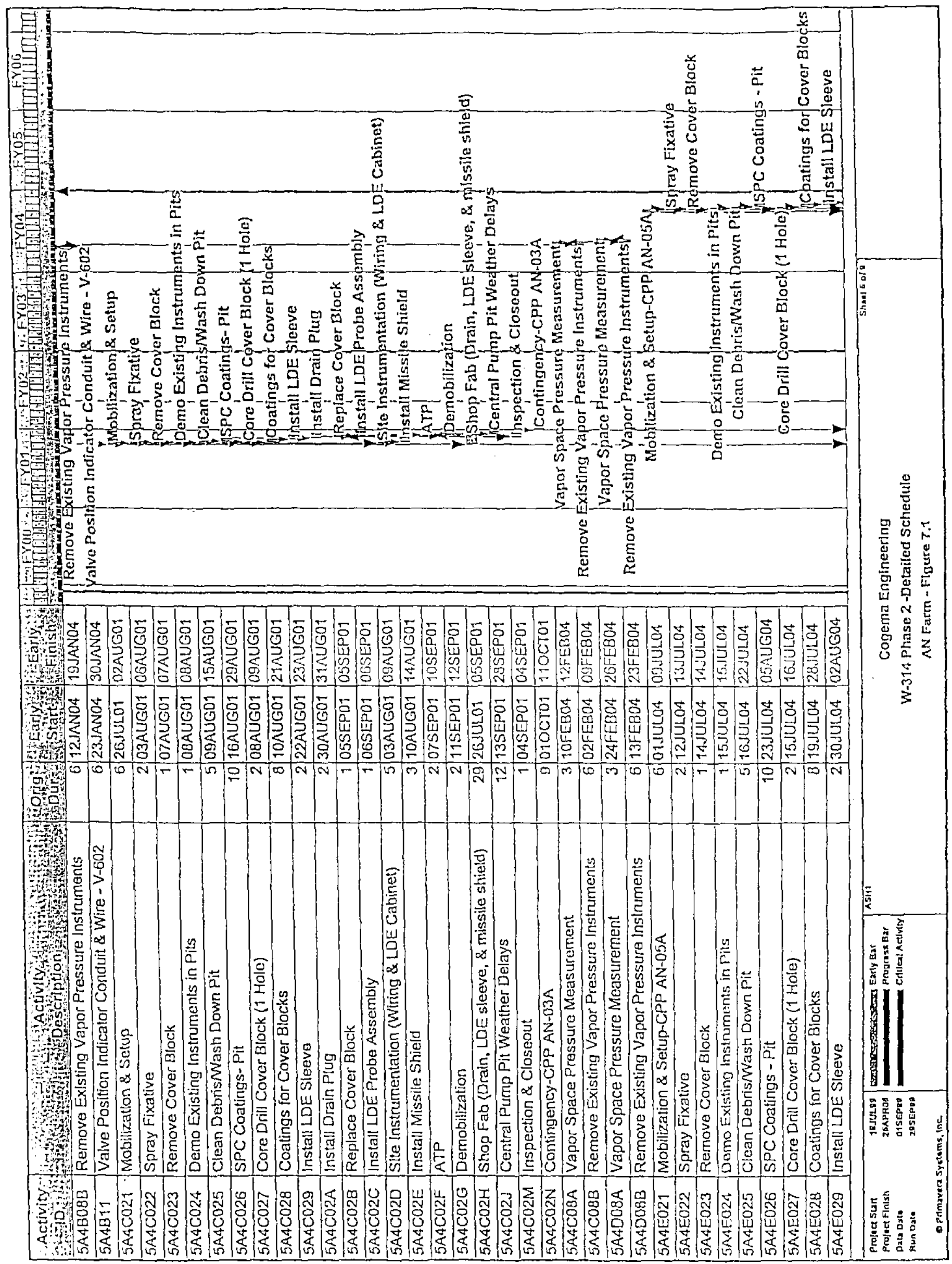




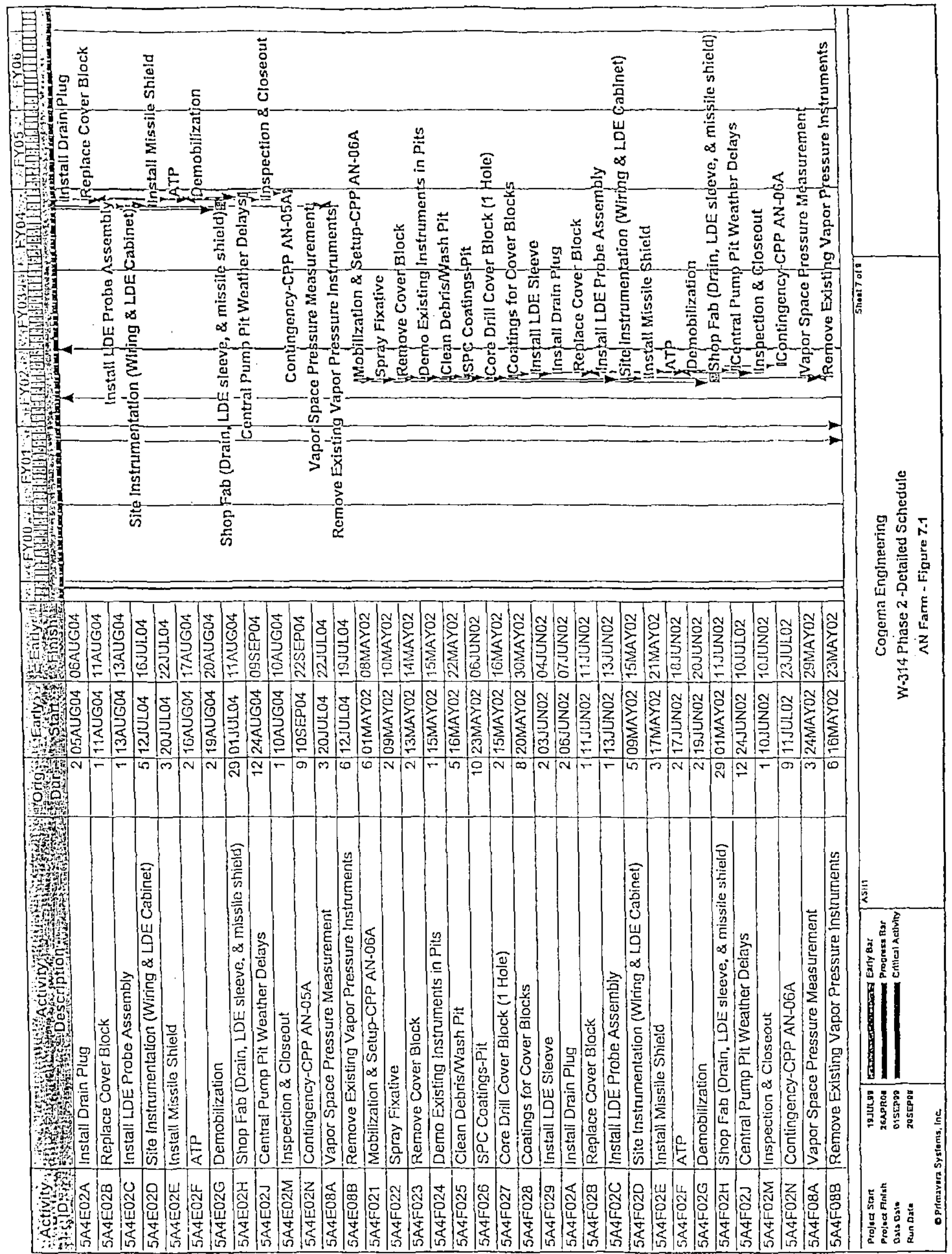




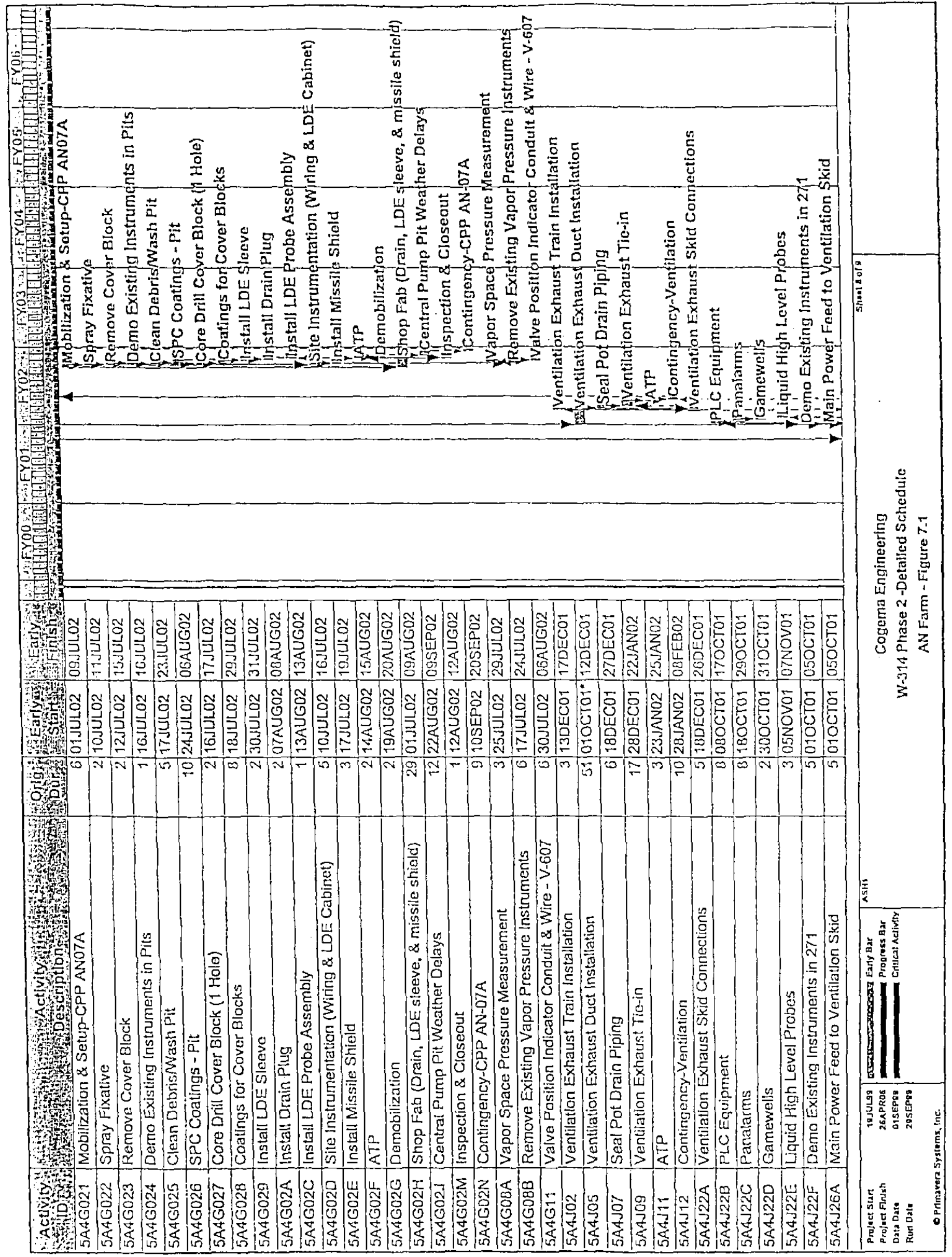




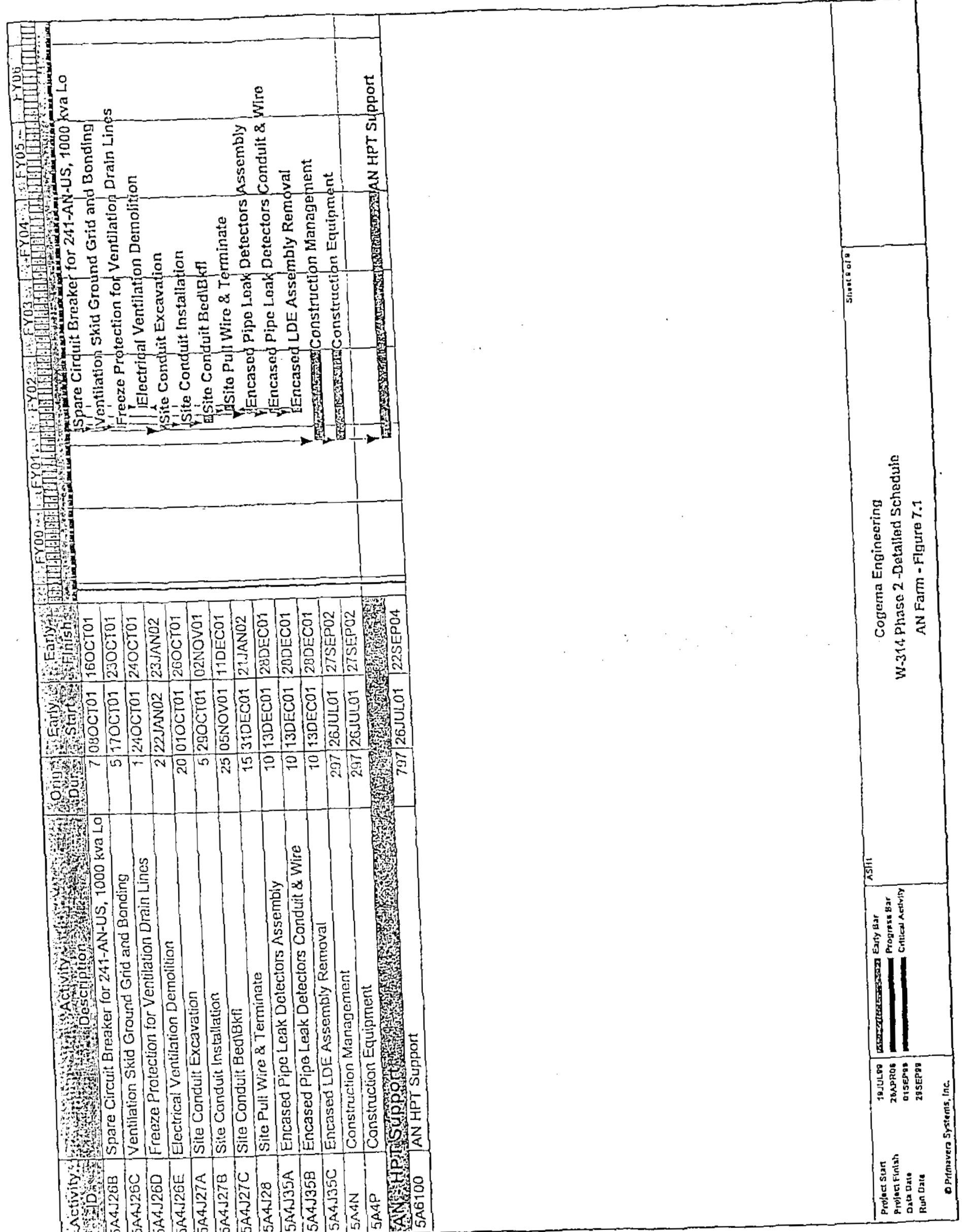




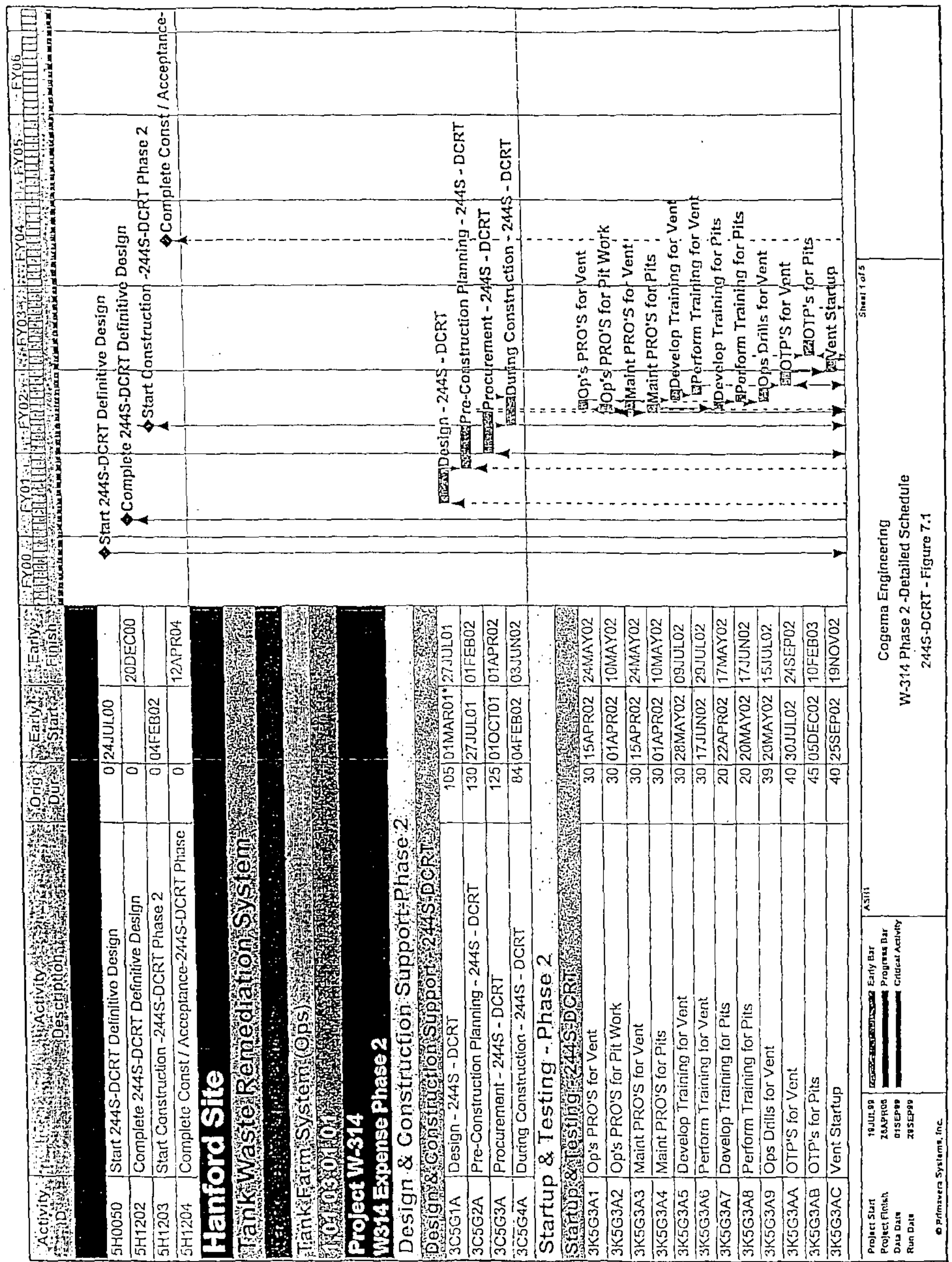


HNF-5109, REV. 0

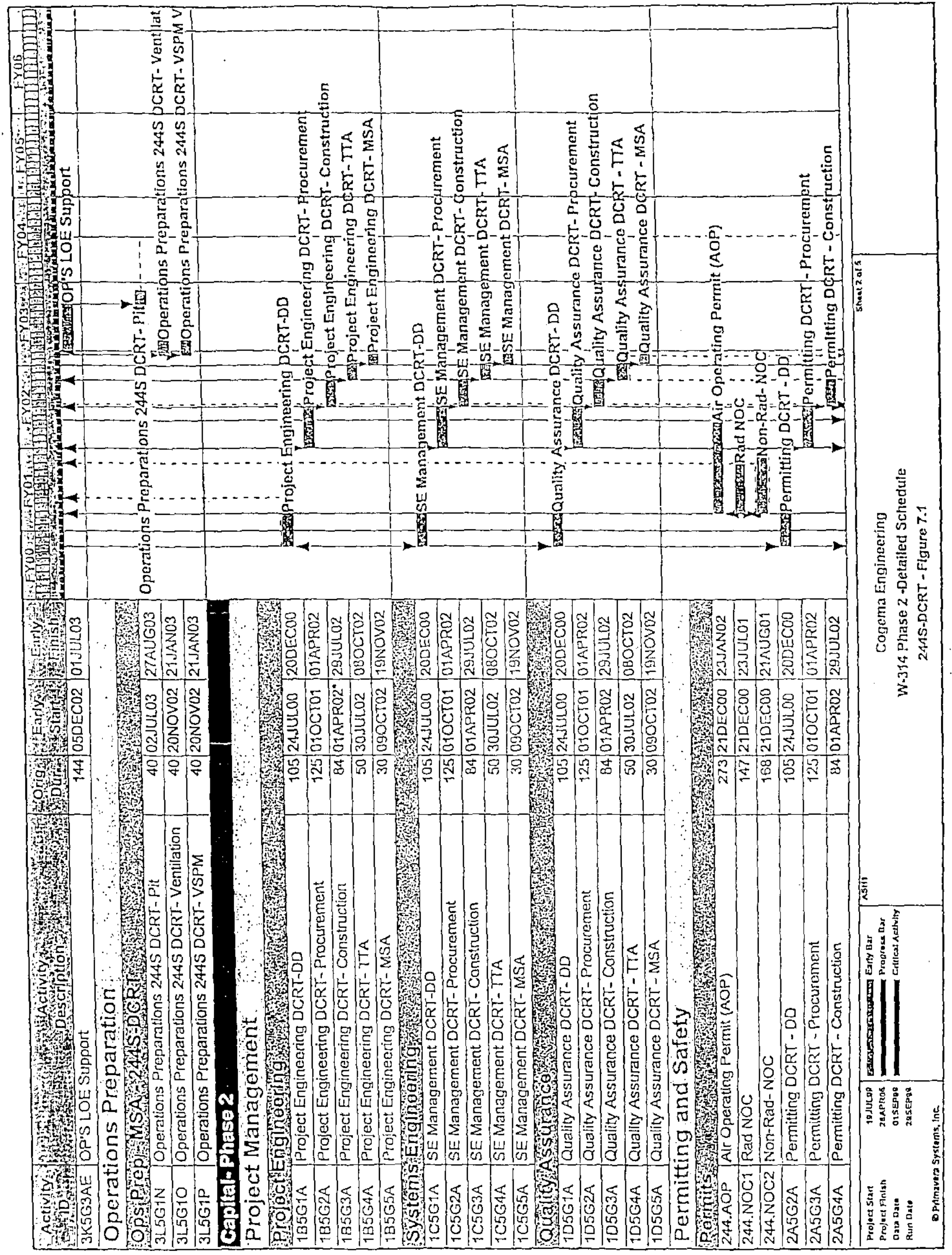




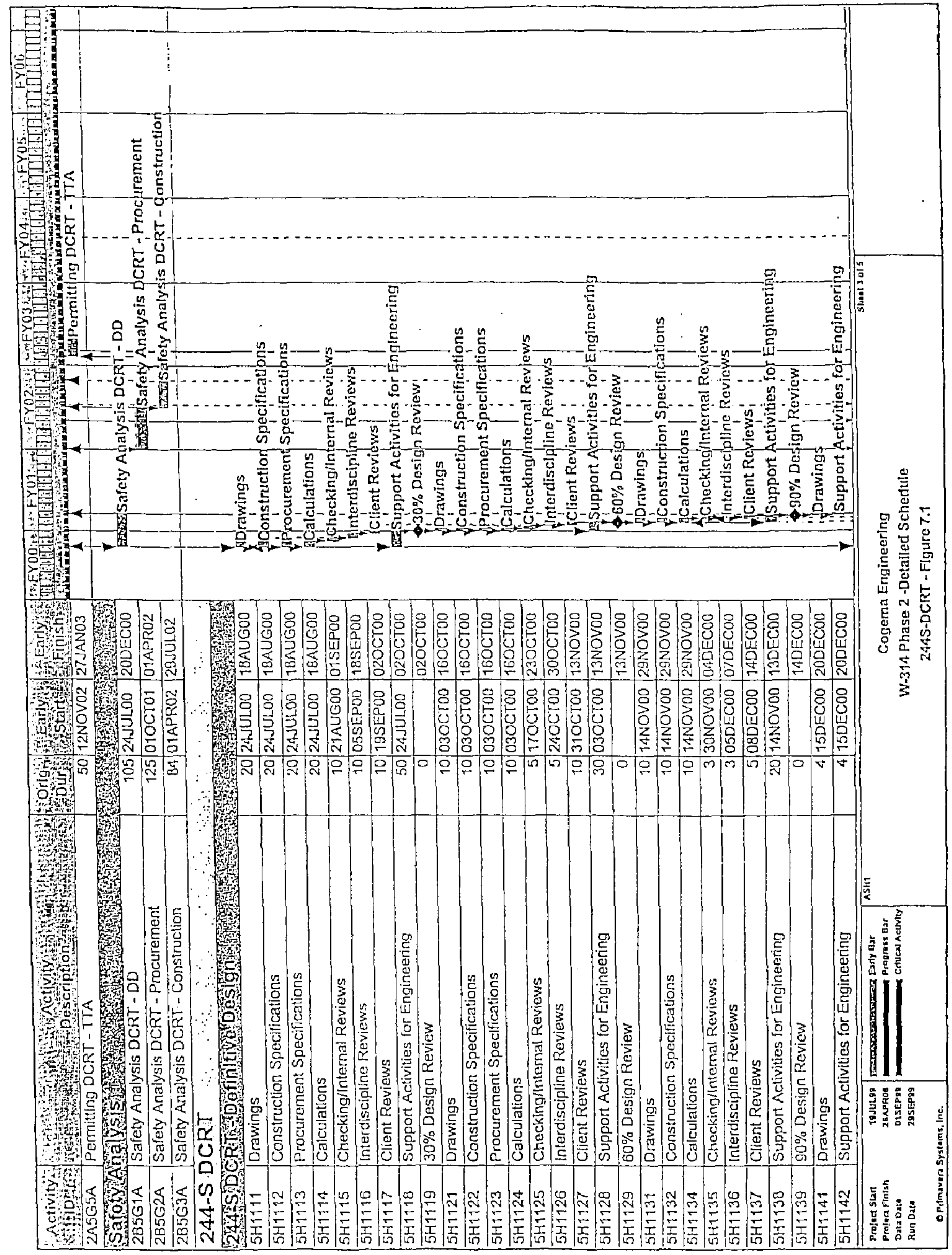


INT-5109, REV.0

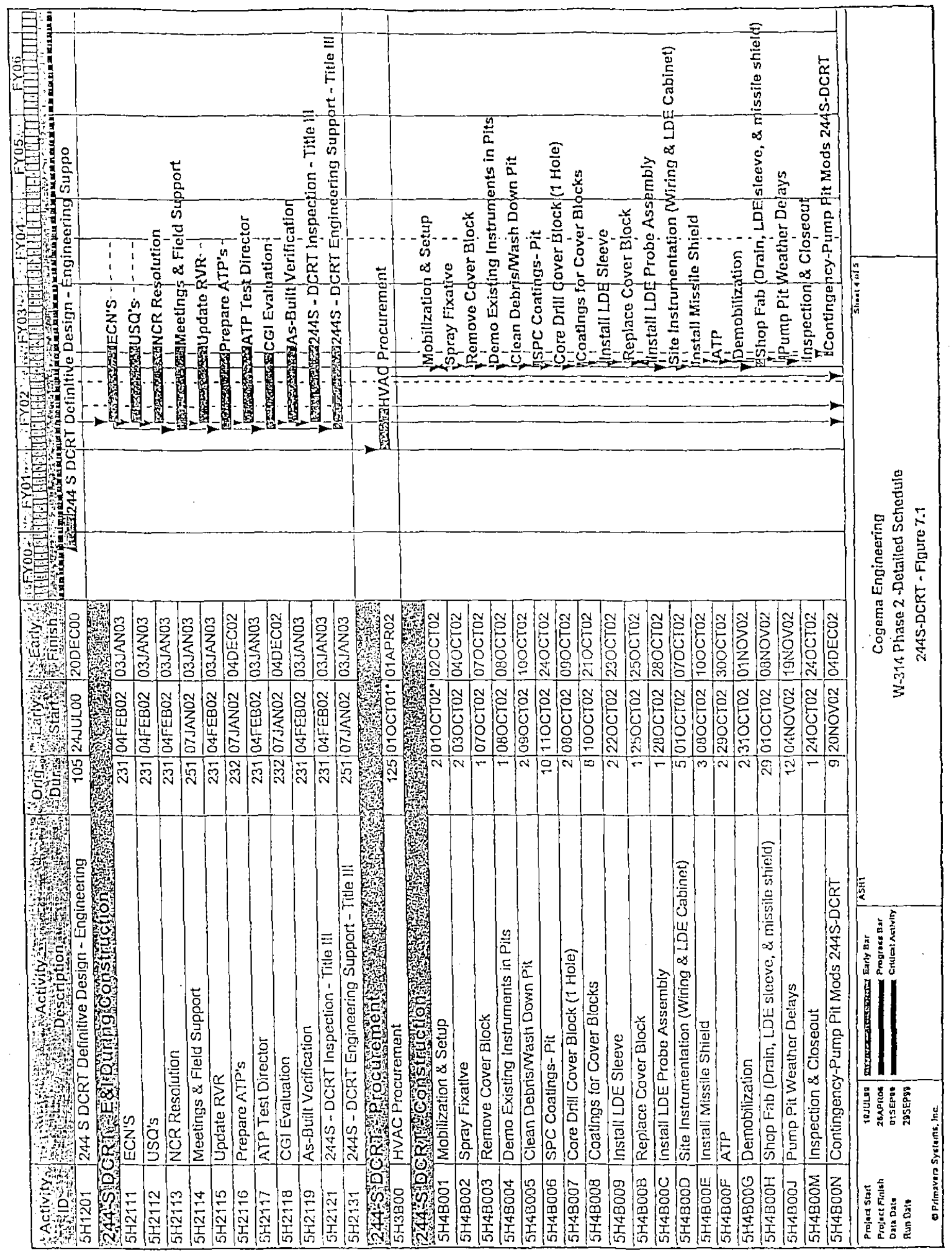


HNF-5109, REV. 0

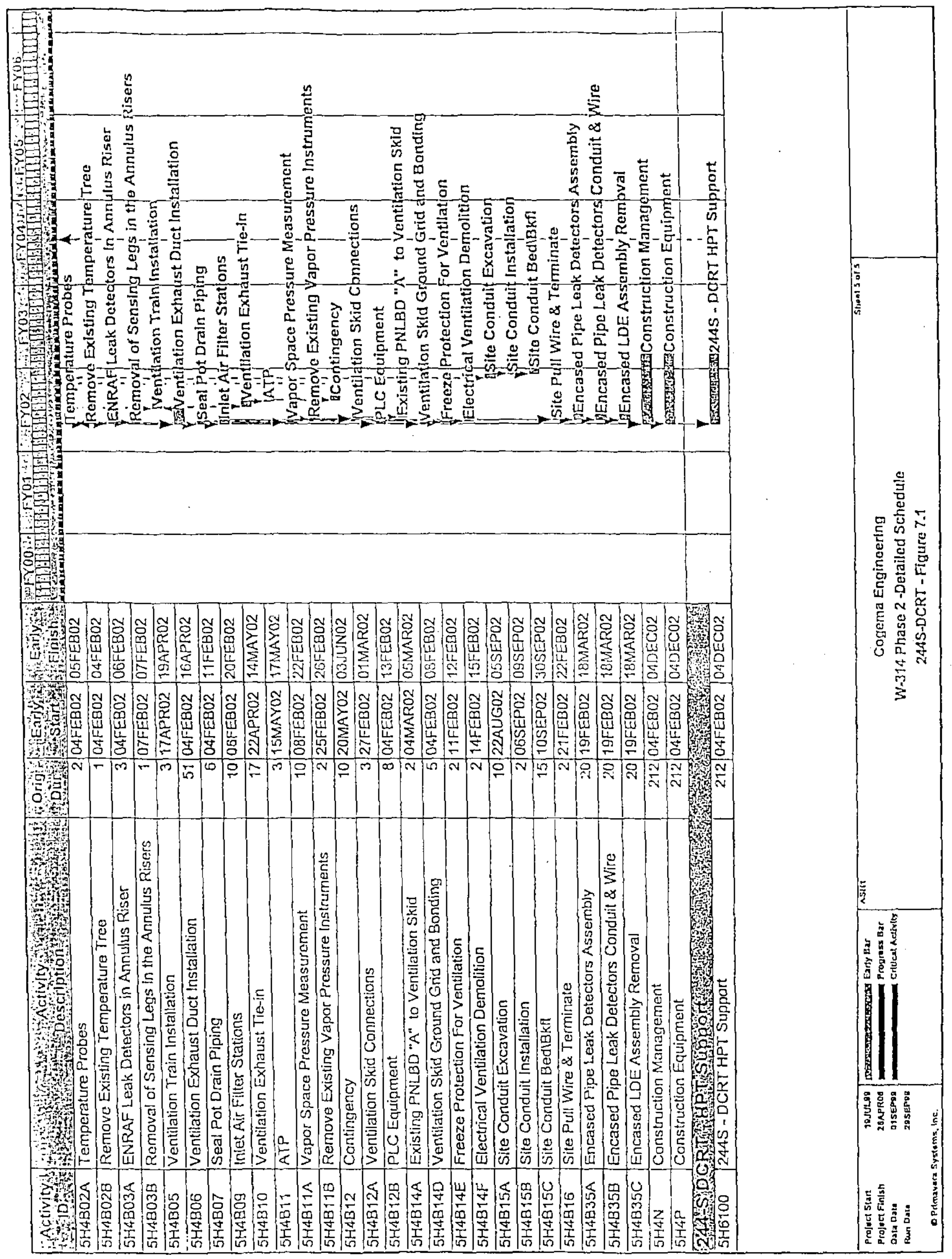




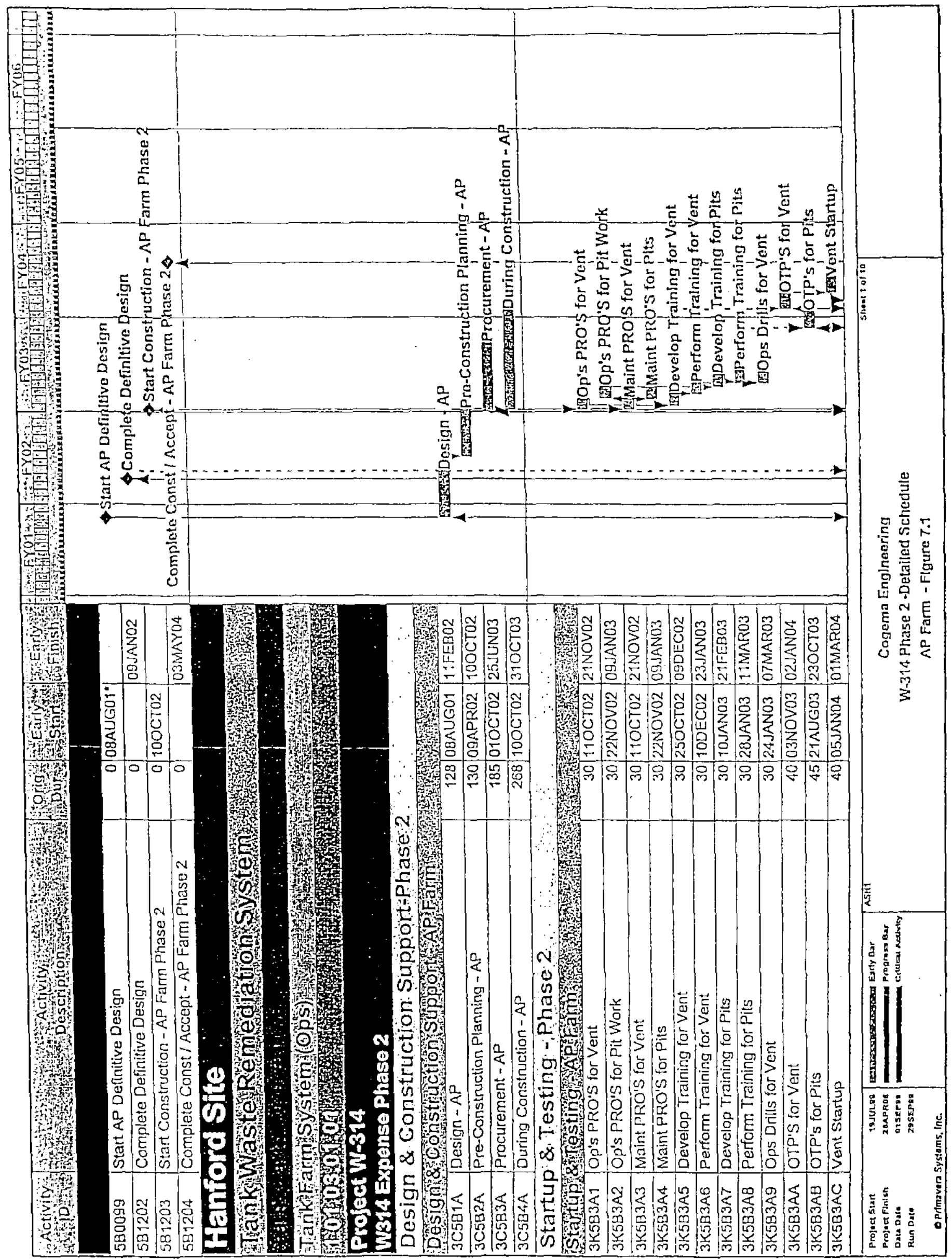


HNF-5109, REV. 0

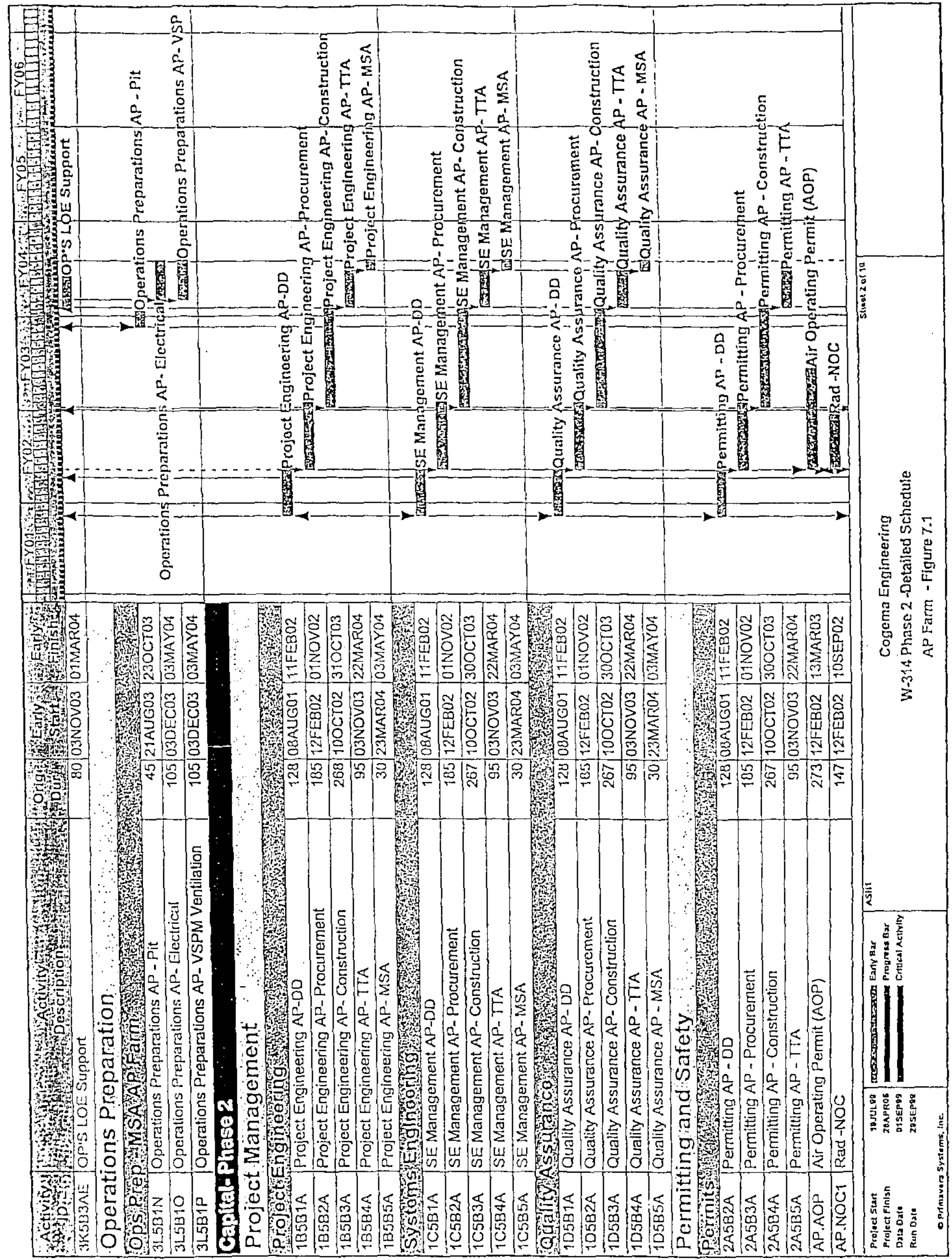




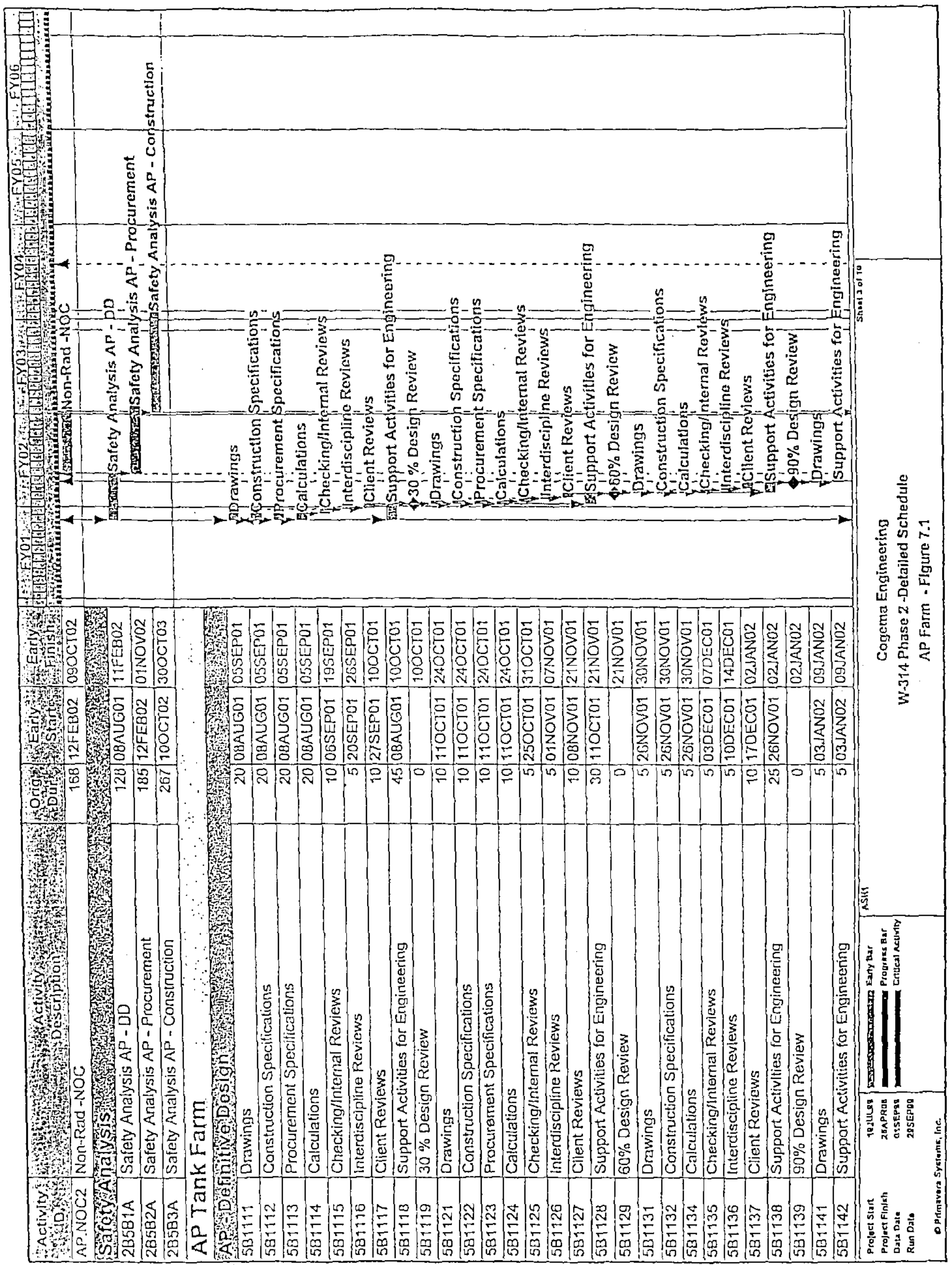




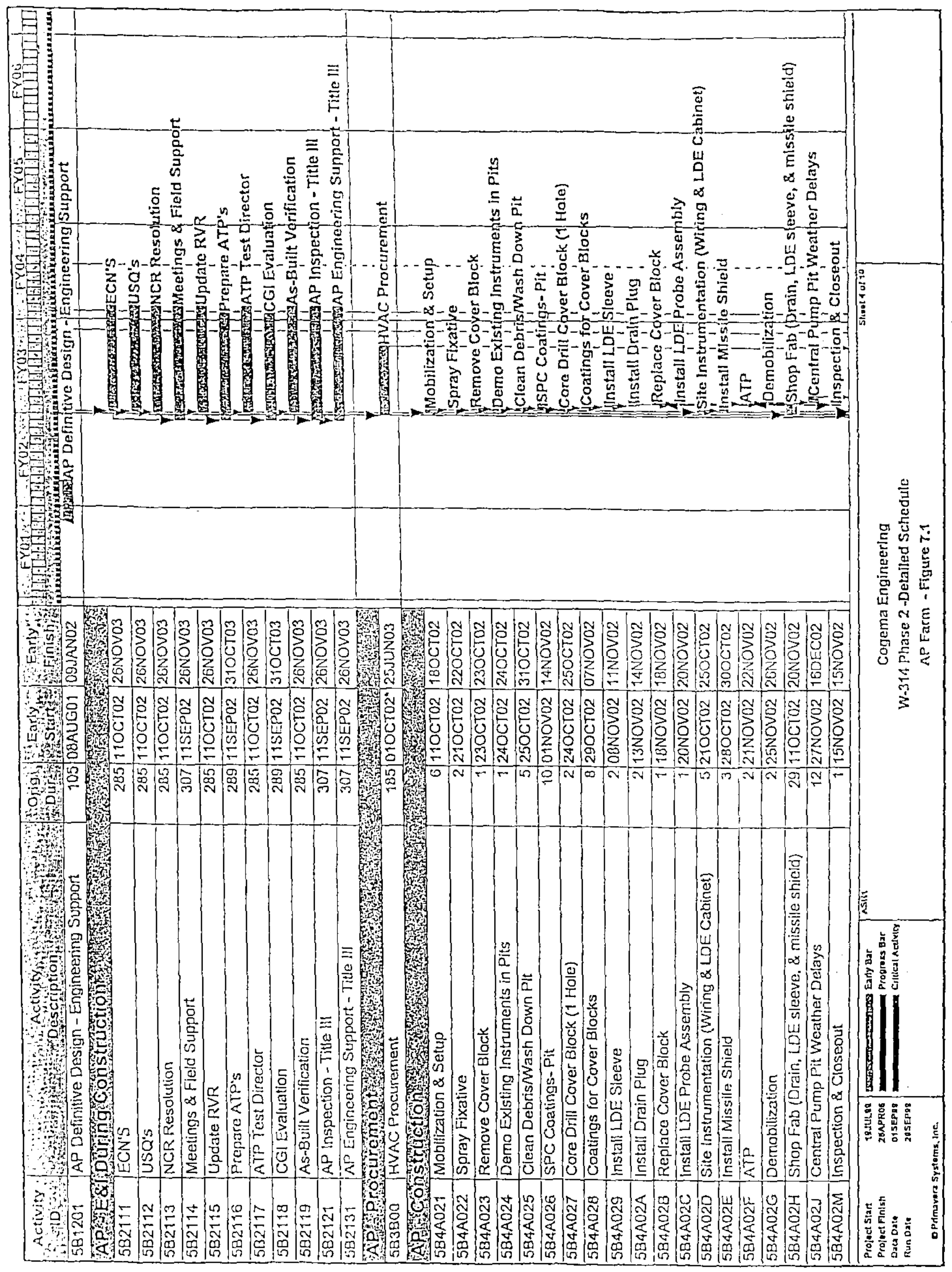




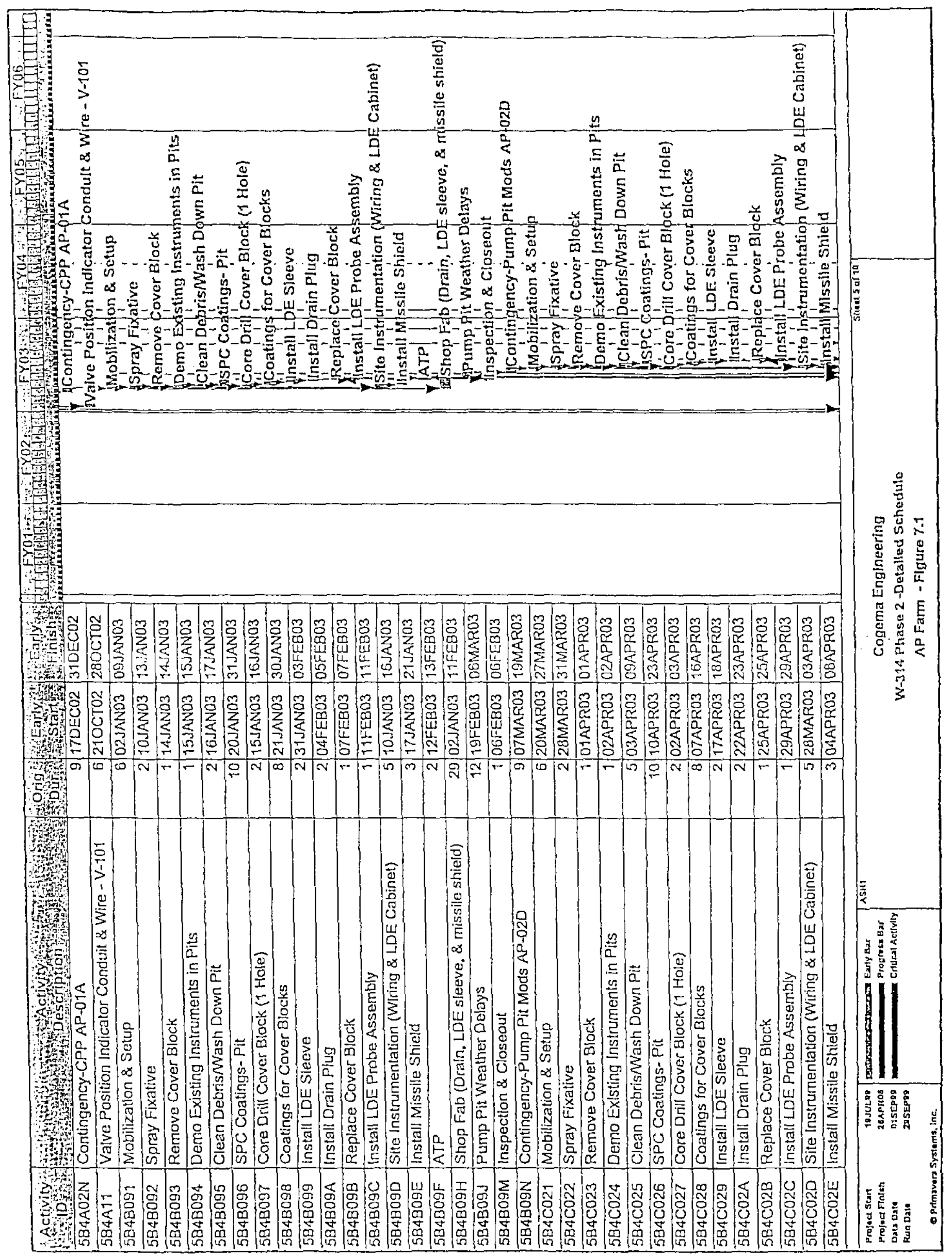




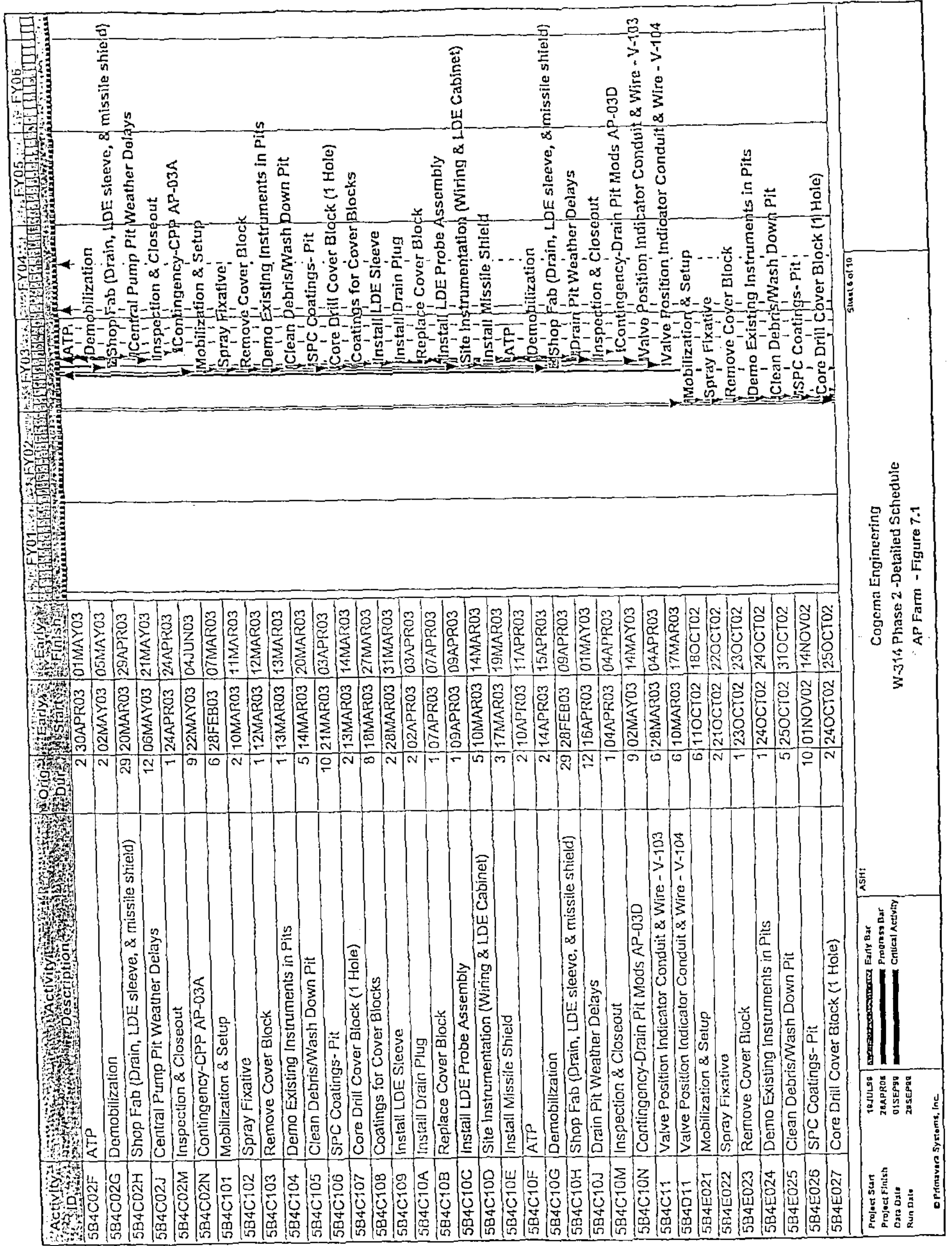




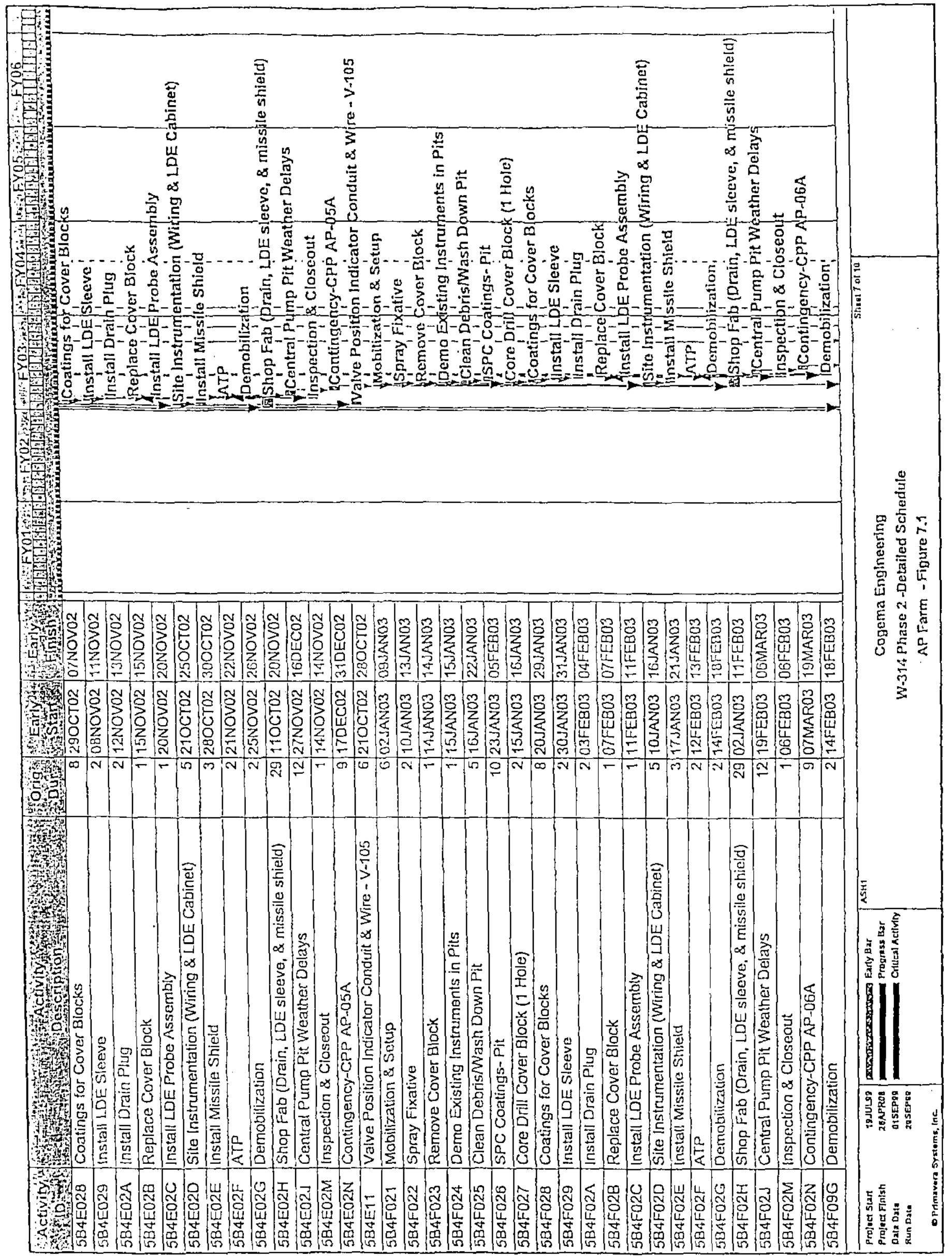




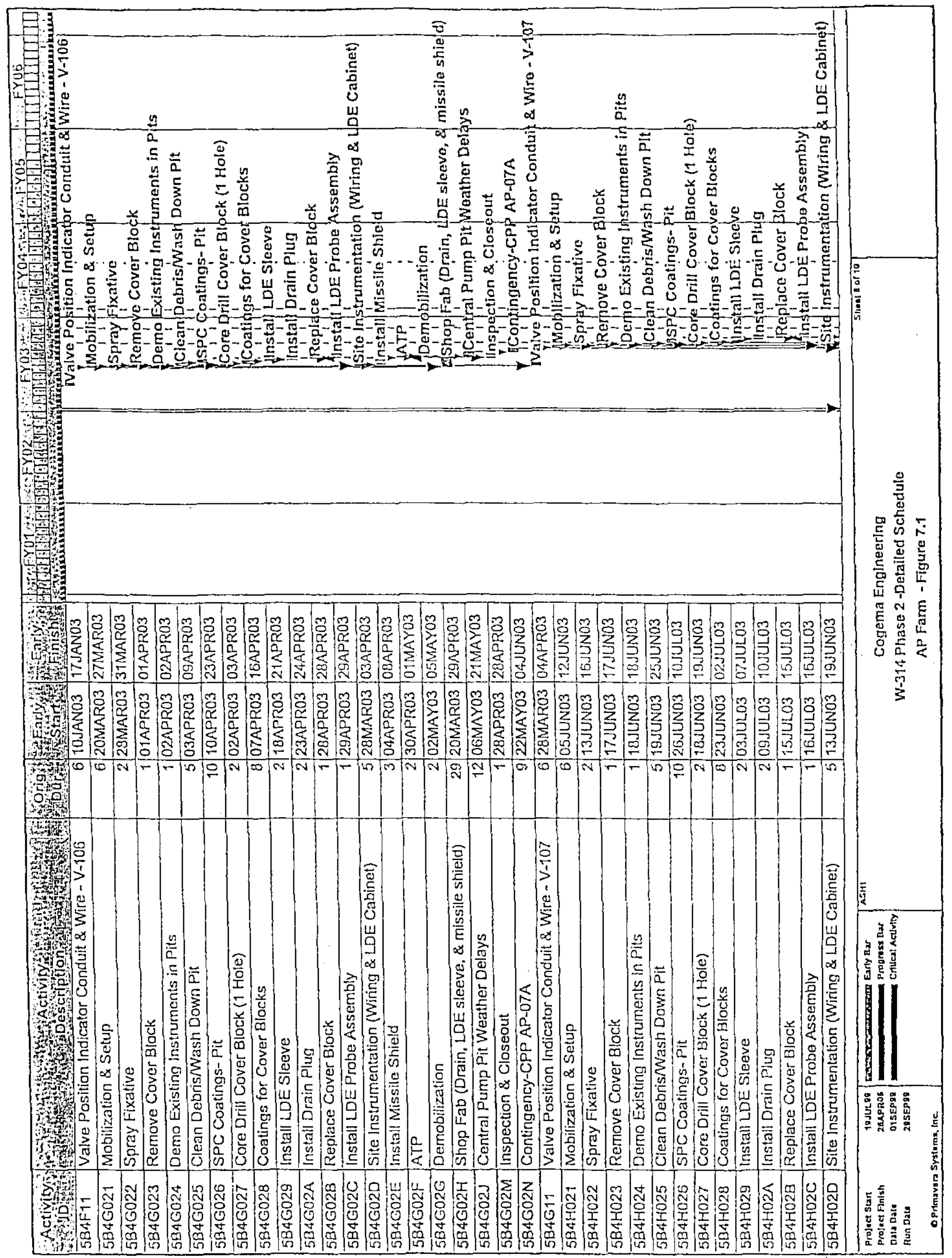




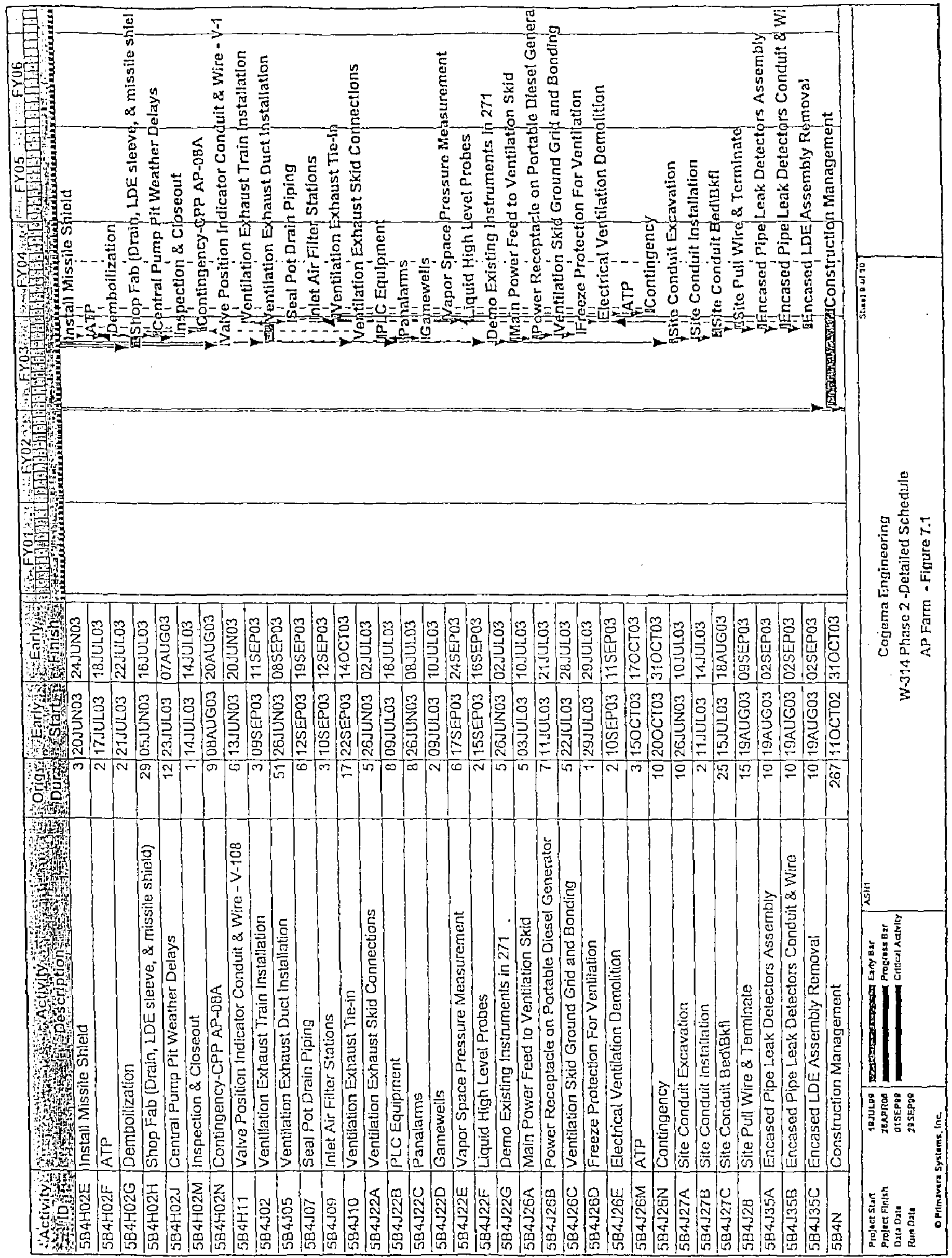




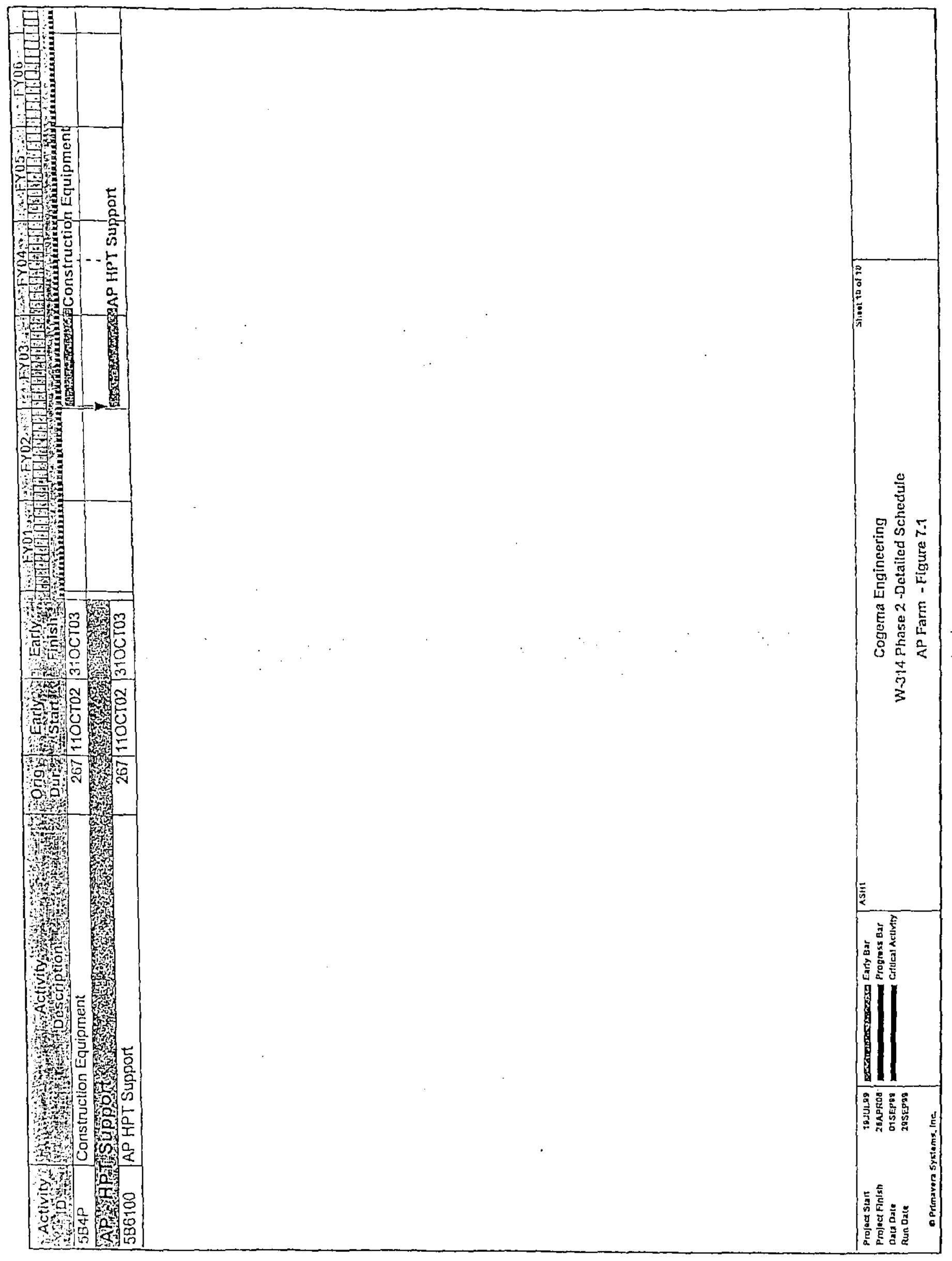




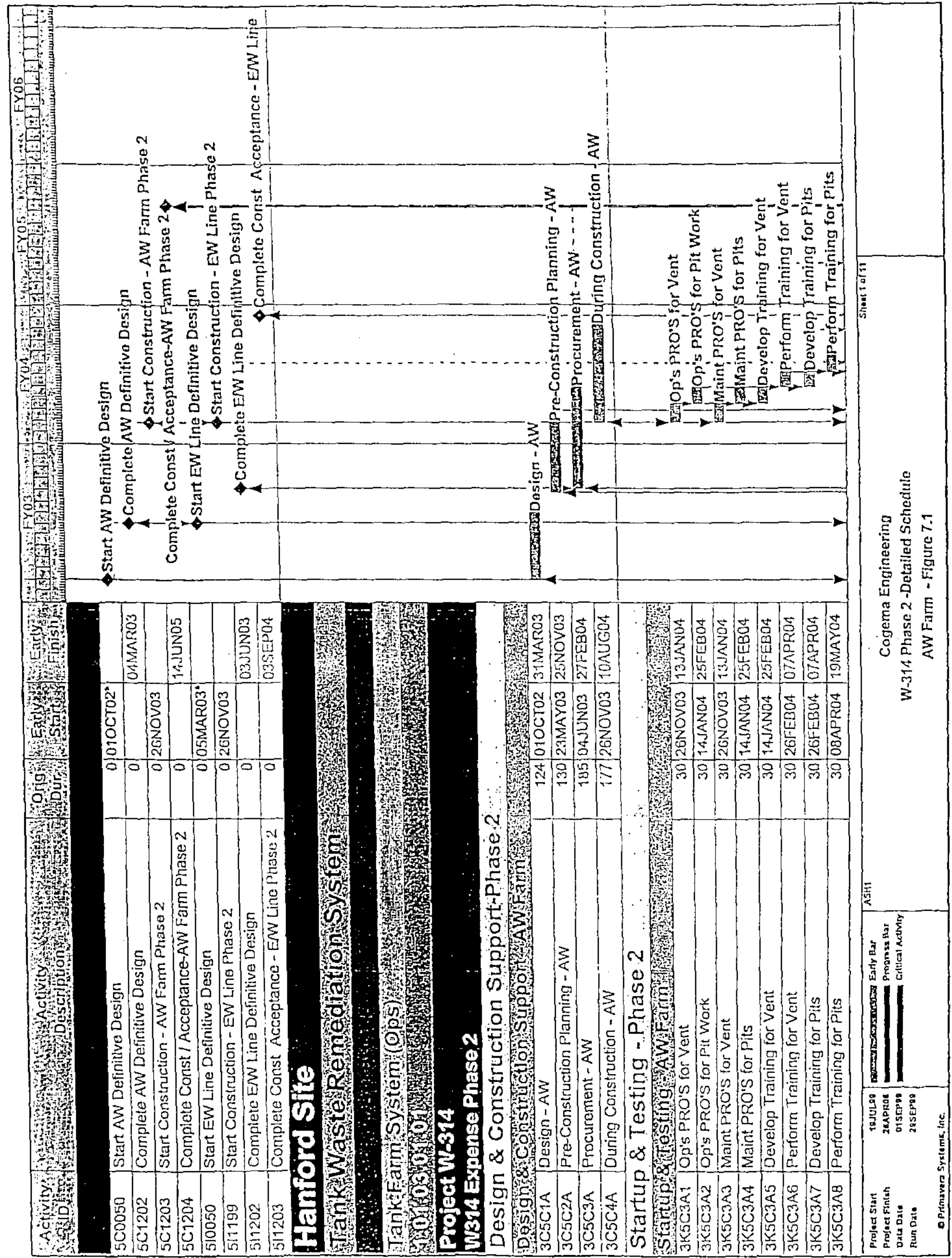


FNF-5109, REV. 0

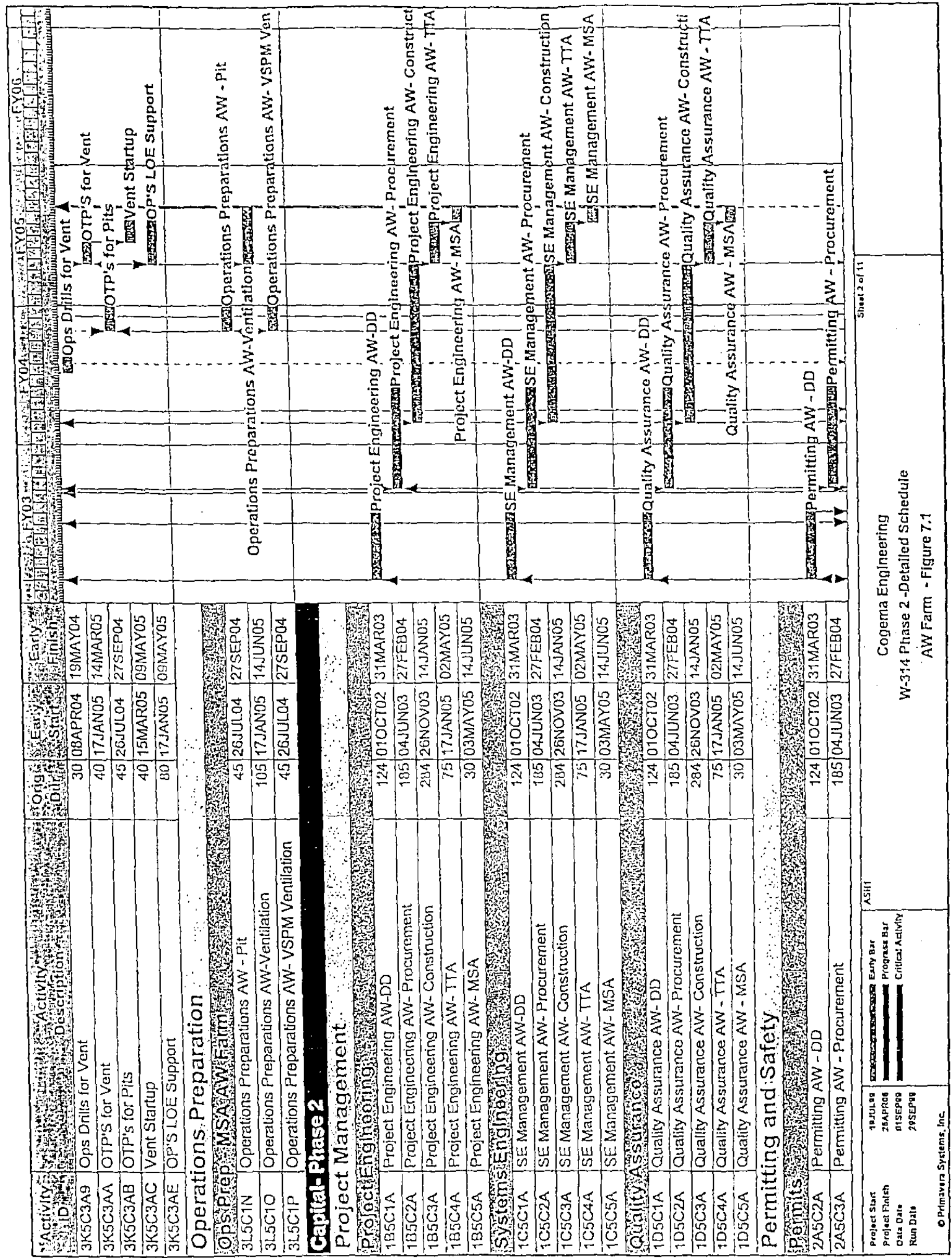


HNF-5109, REV, 0

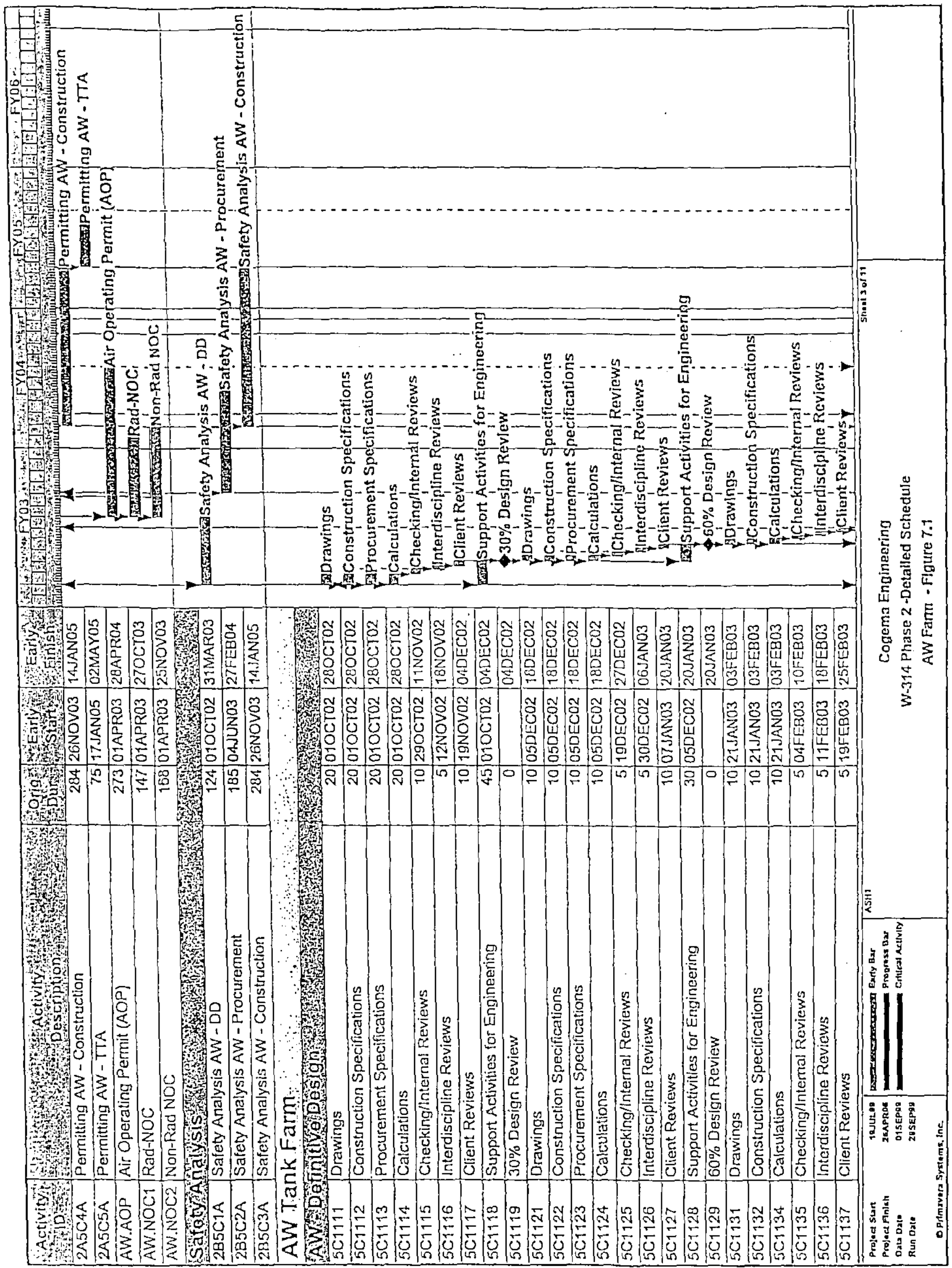




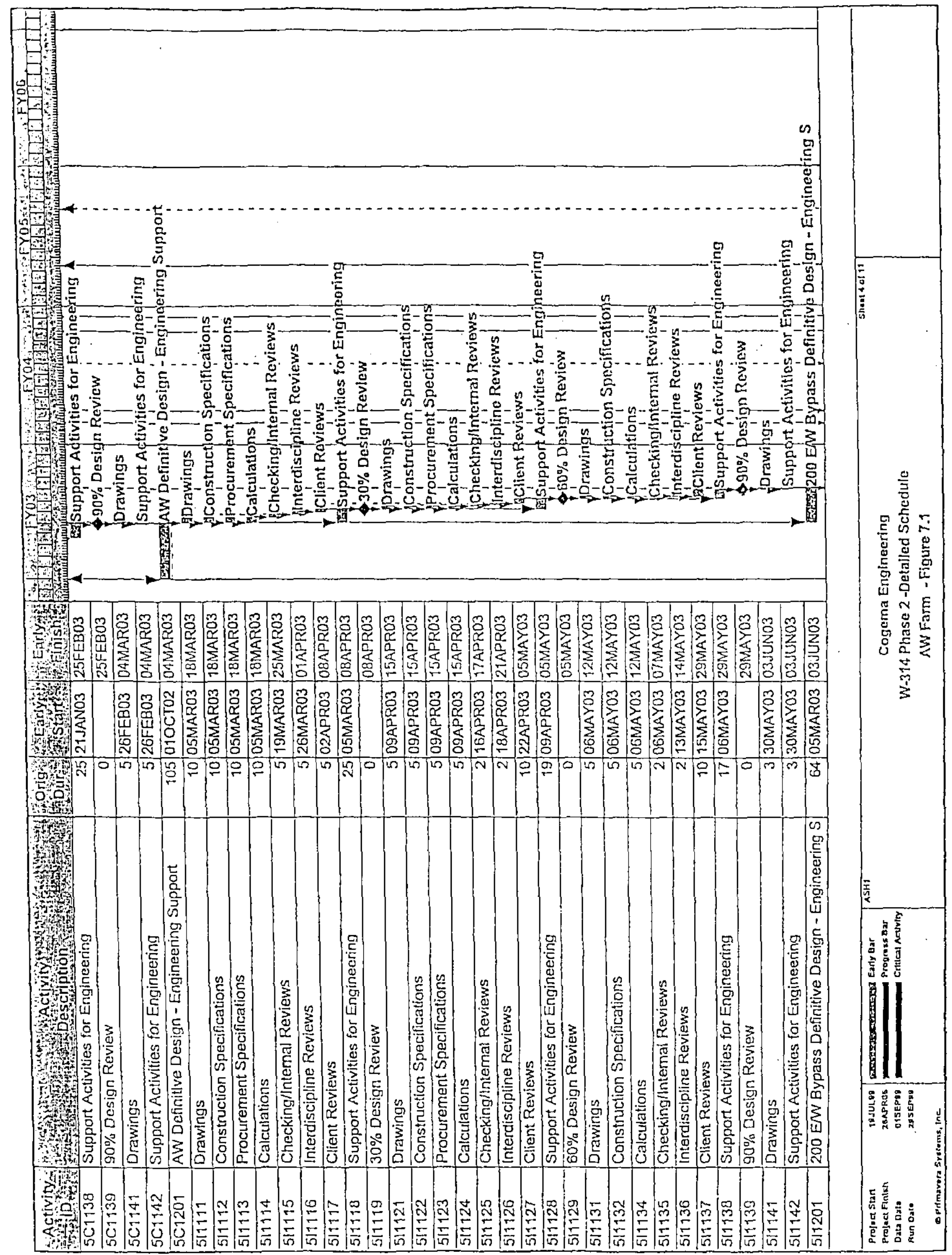




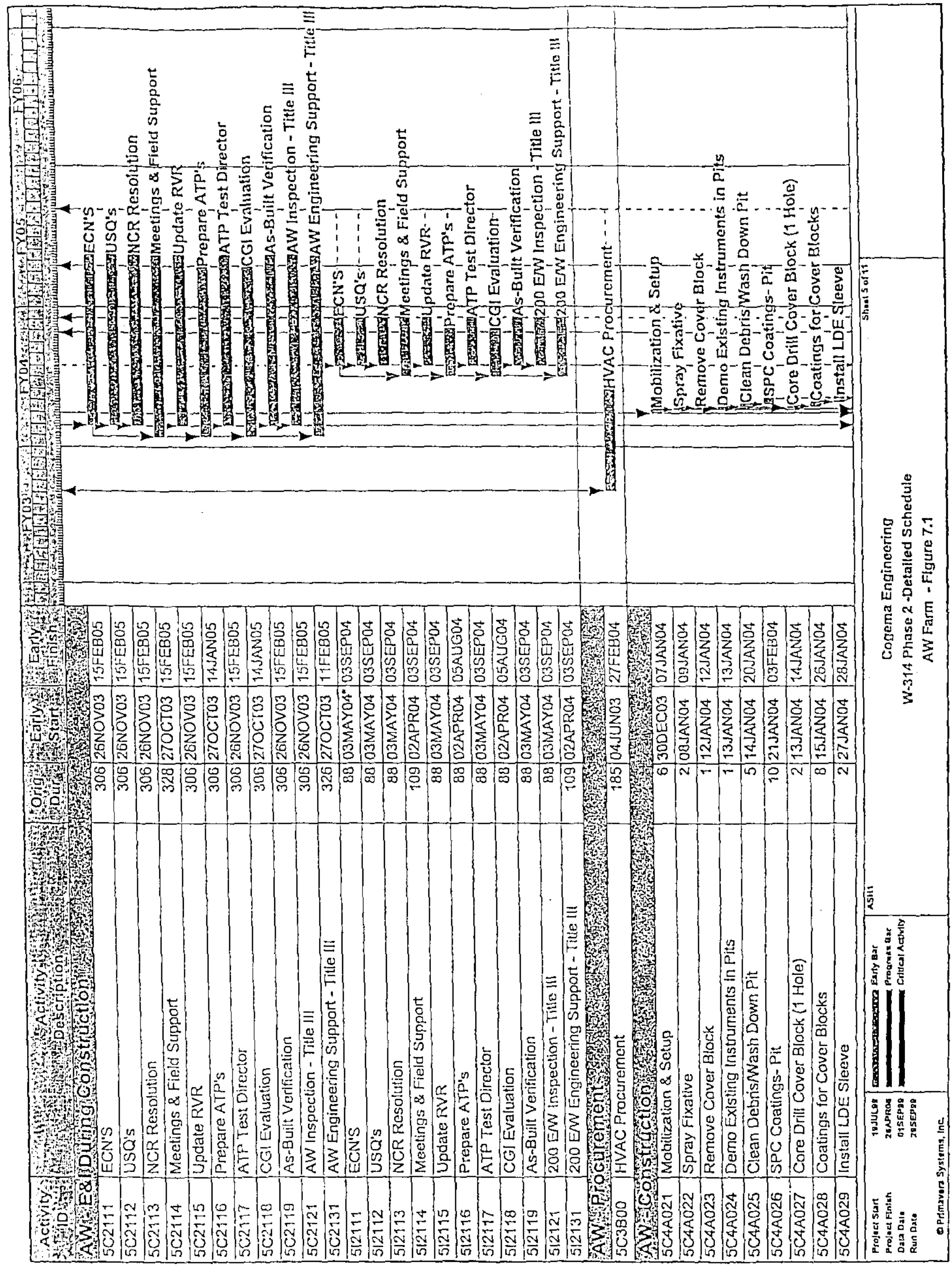




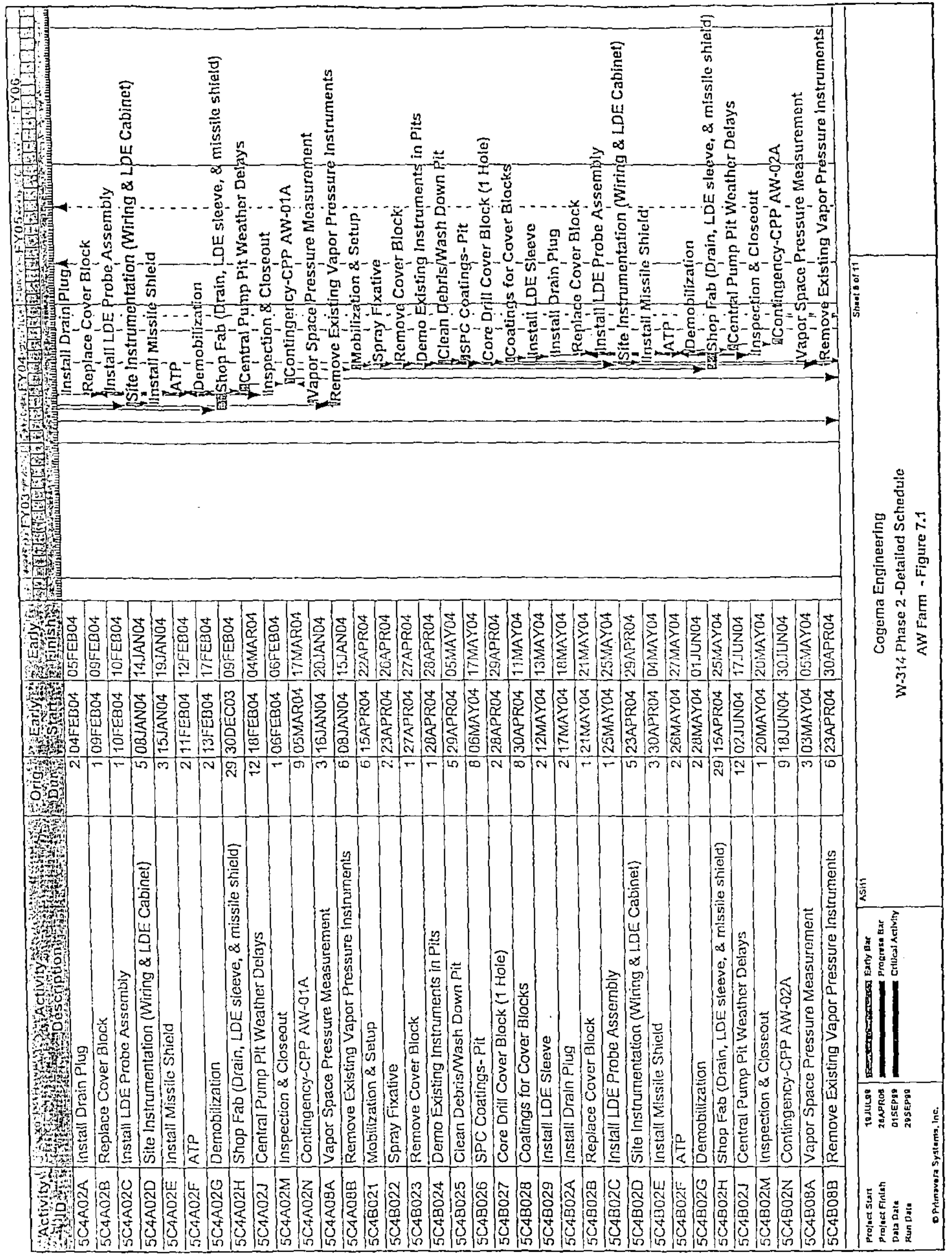




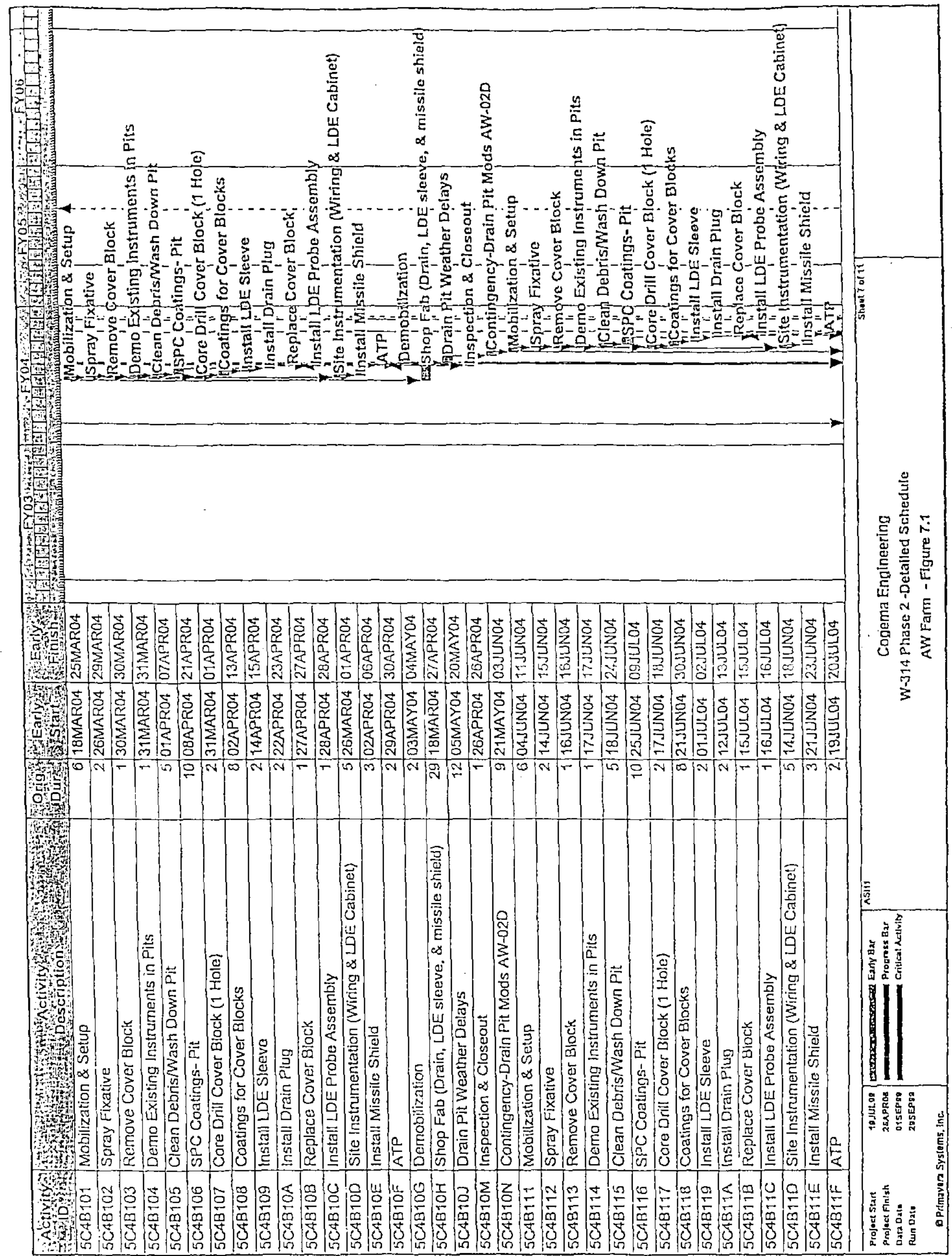


NAF-5109, REV. 0

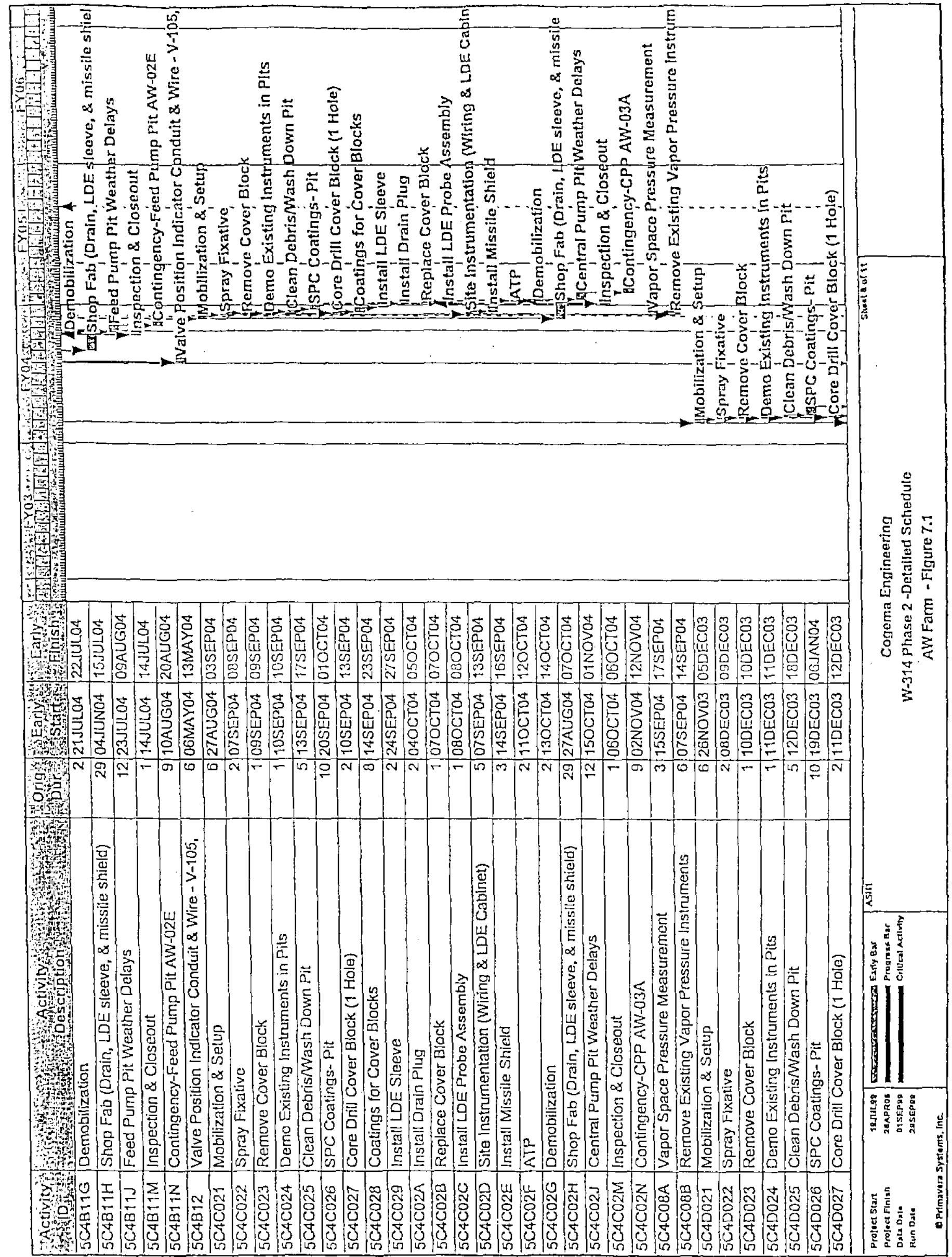


HNF-5109, REV. 0

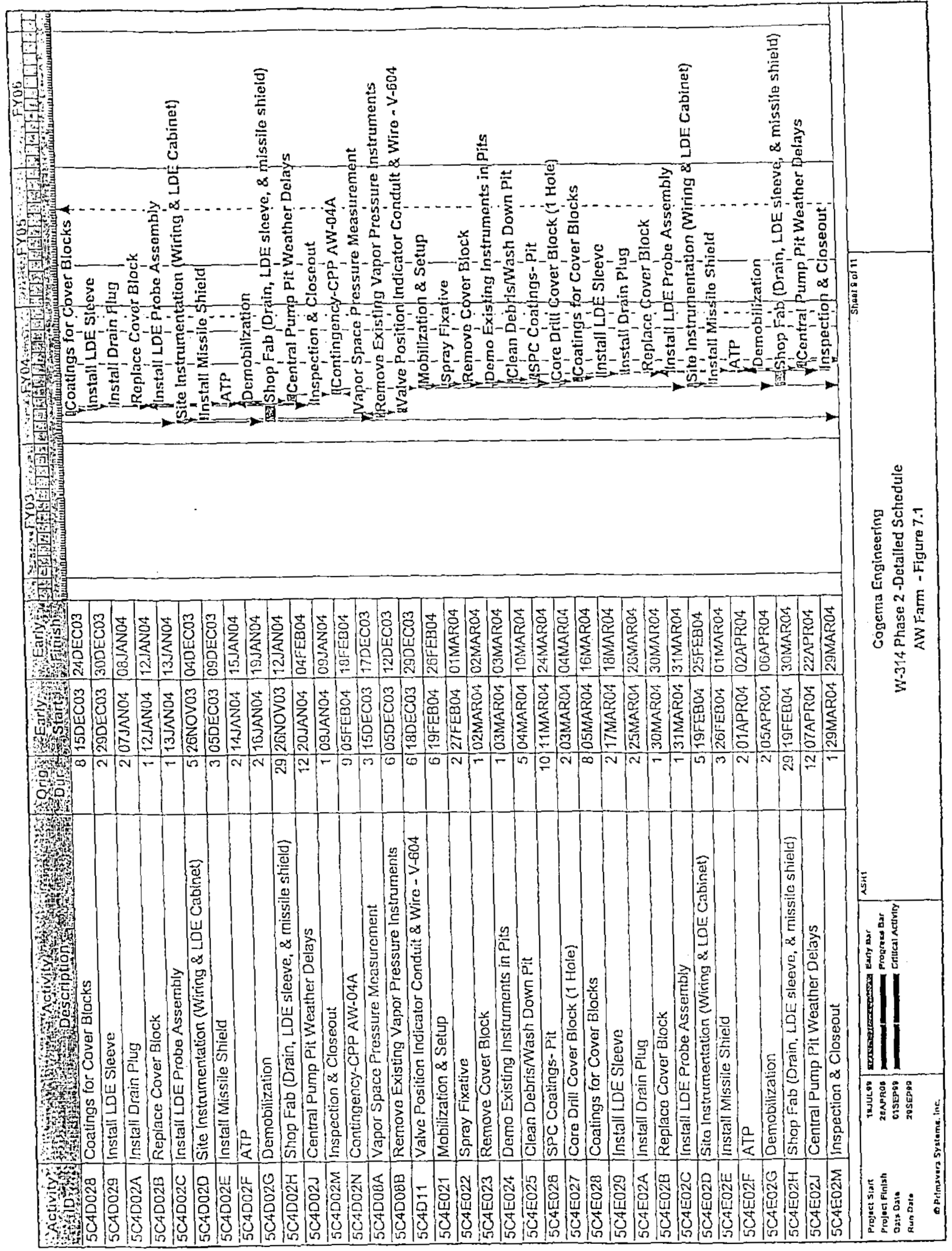




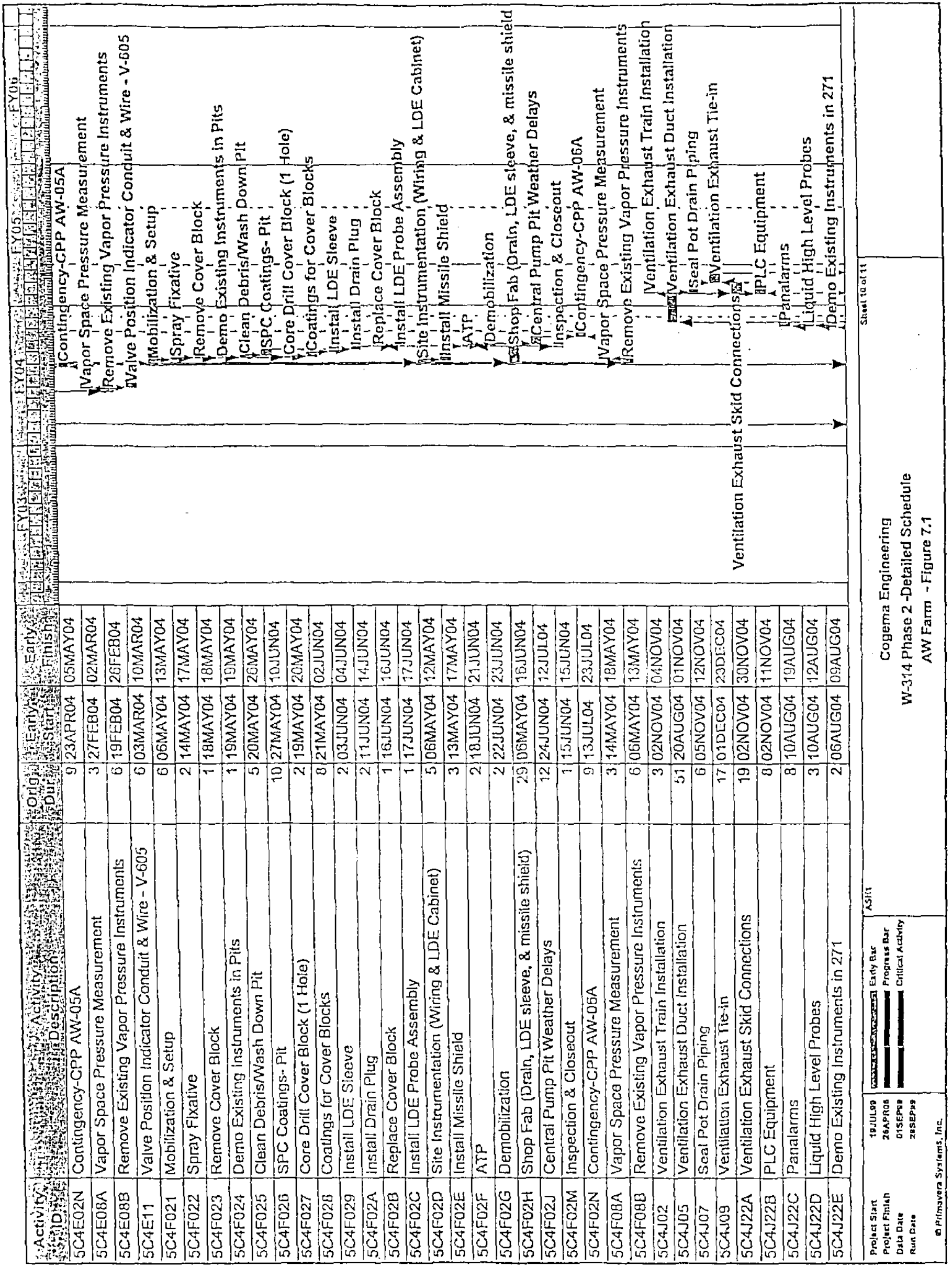




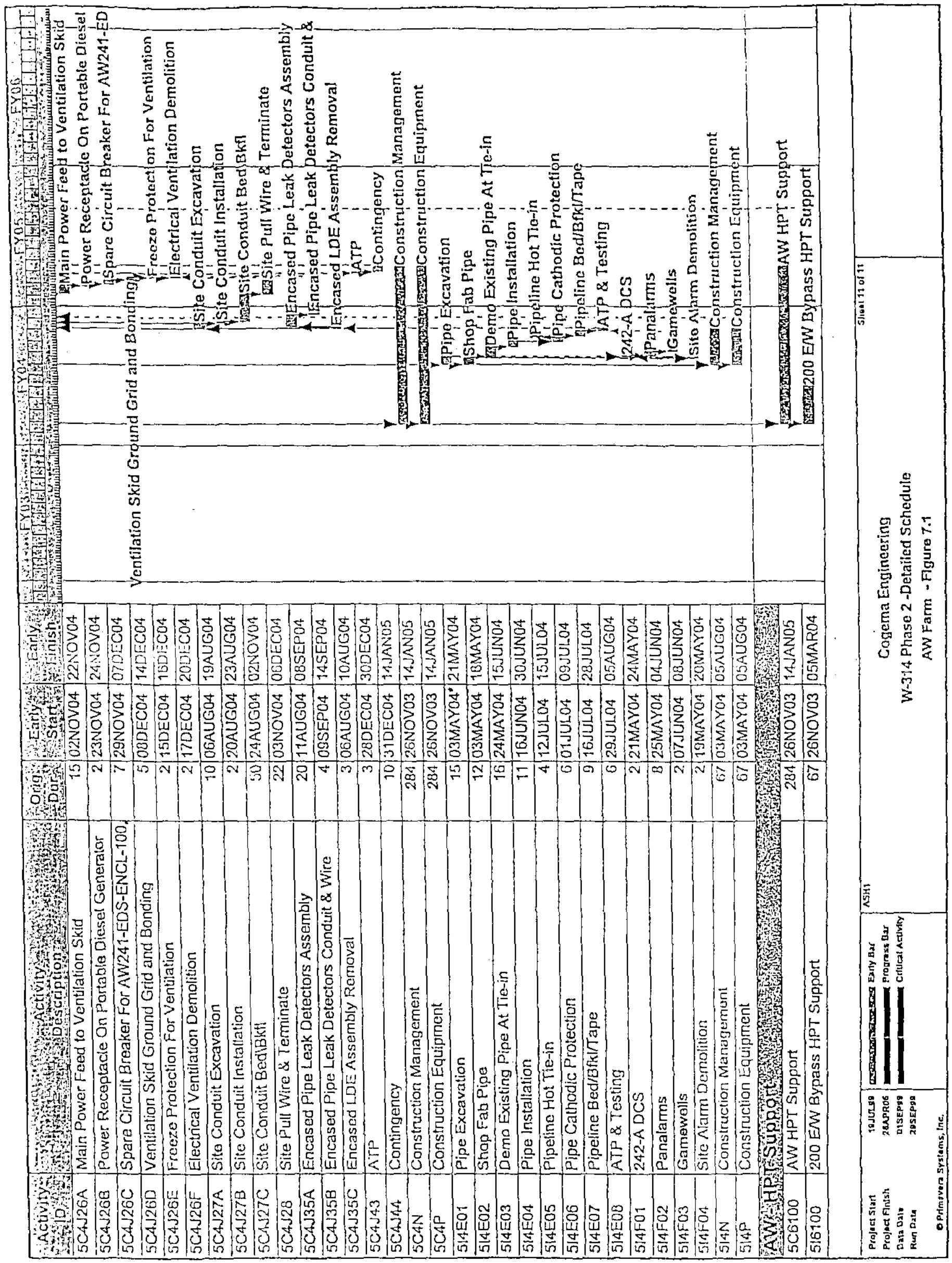


FNVE-5109, REV. 0

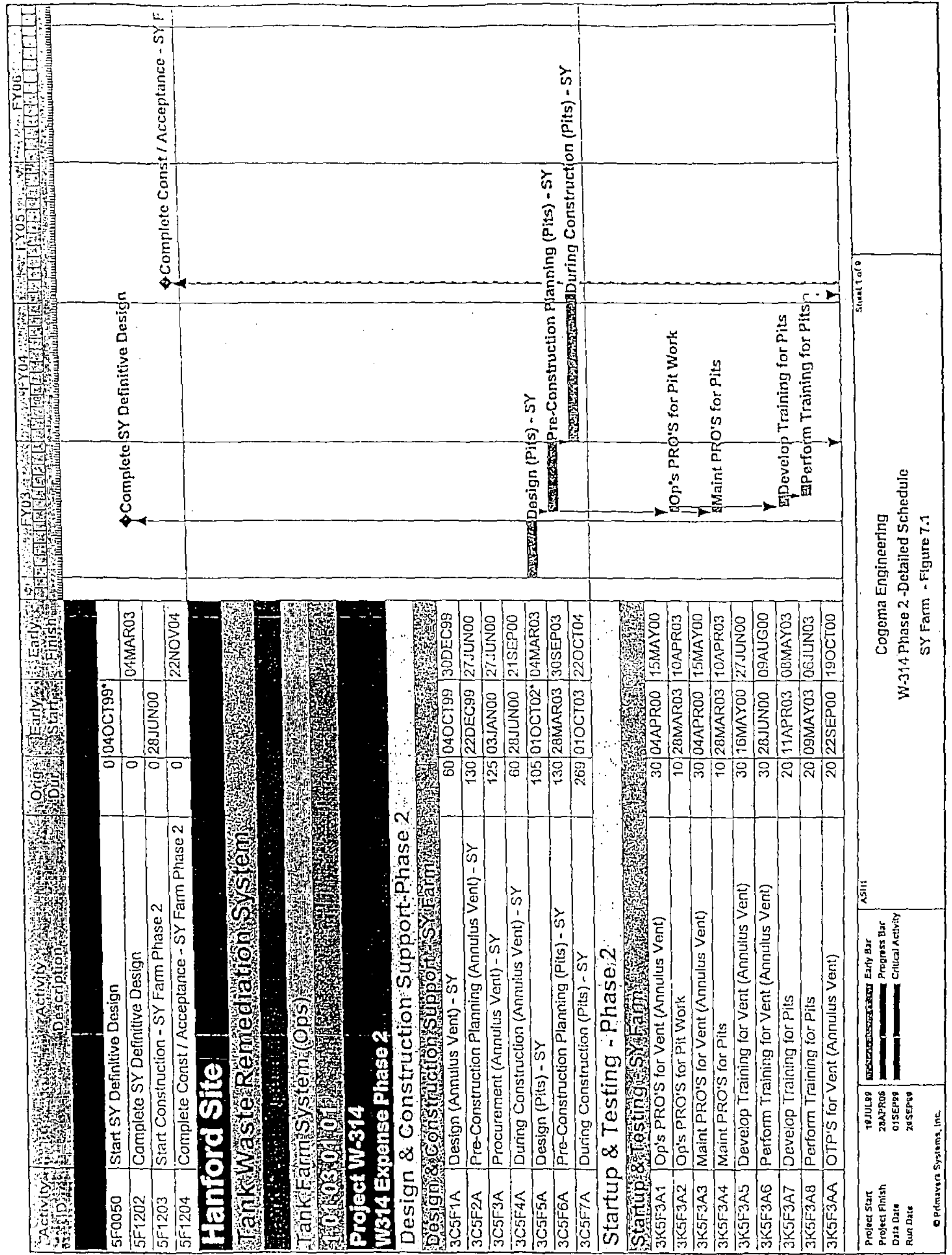


HNE.5109, REV. 0

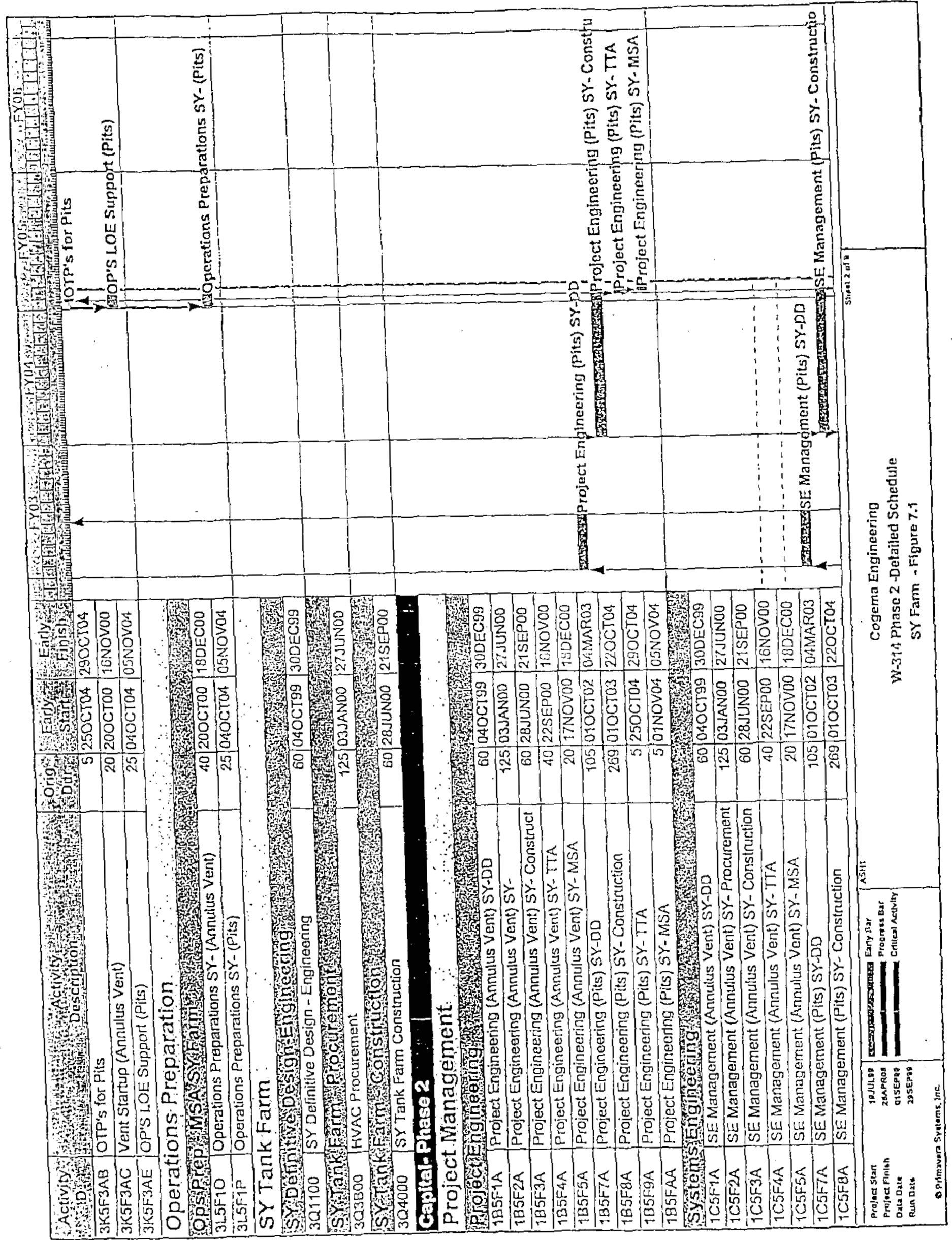


FNF-5109, REV. 0

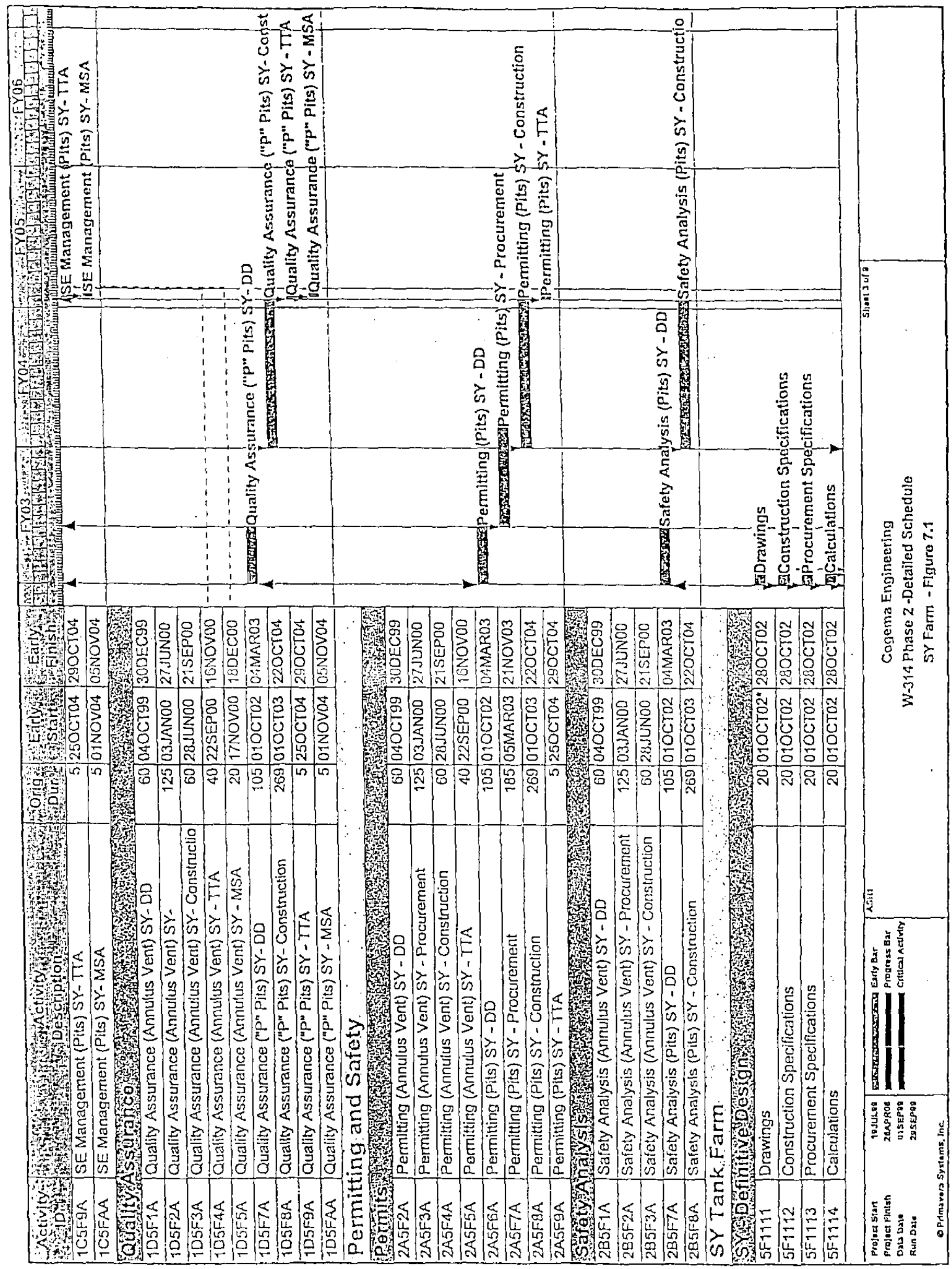




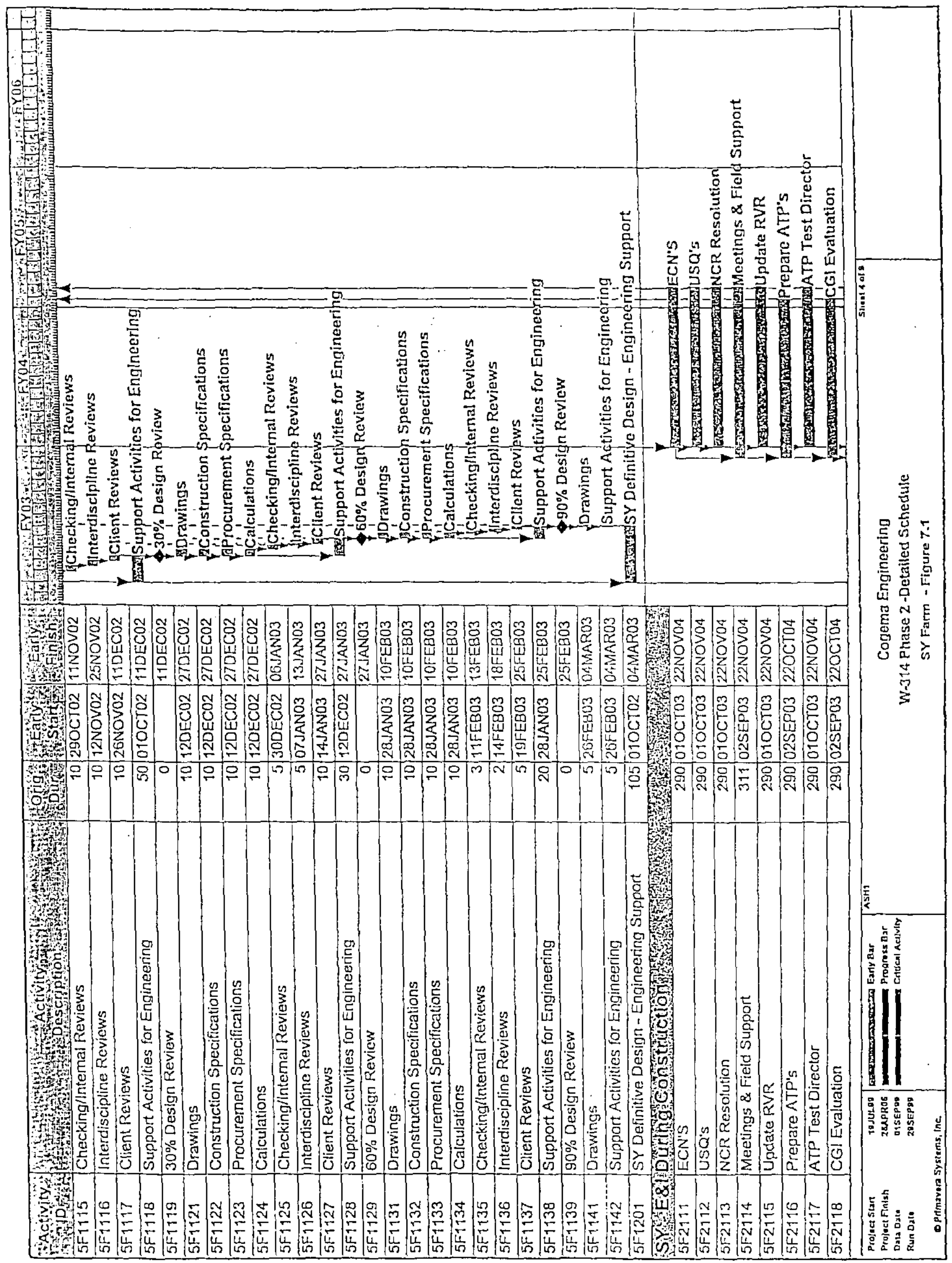




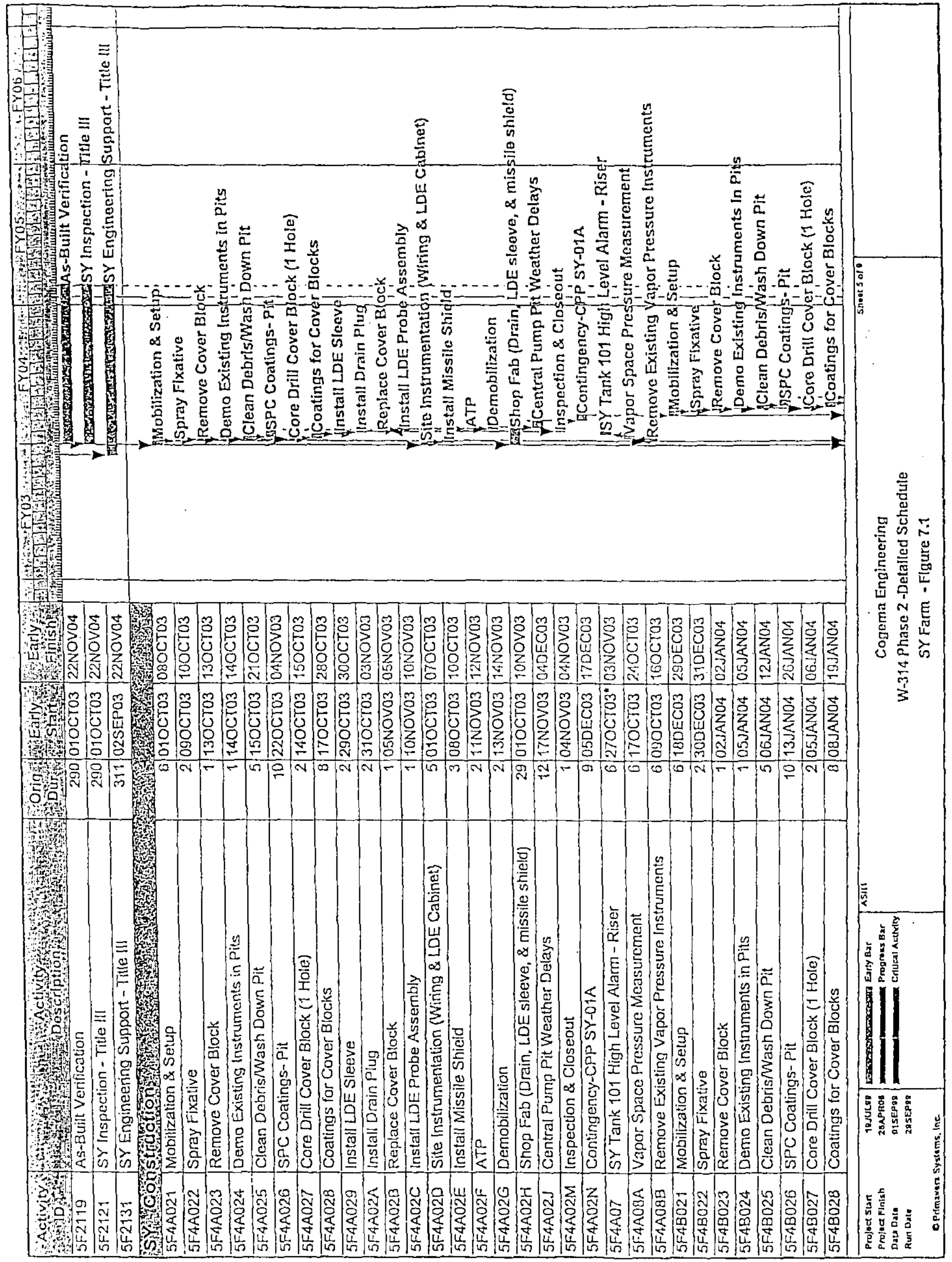




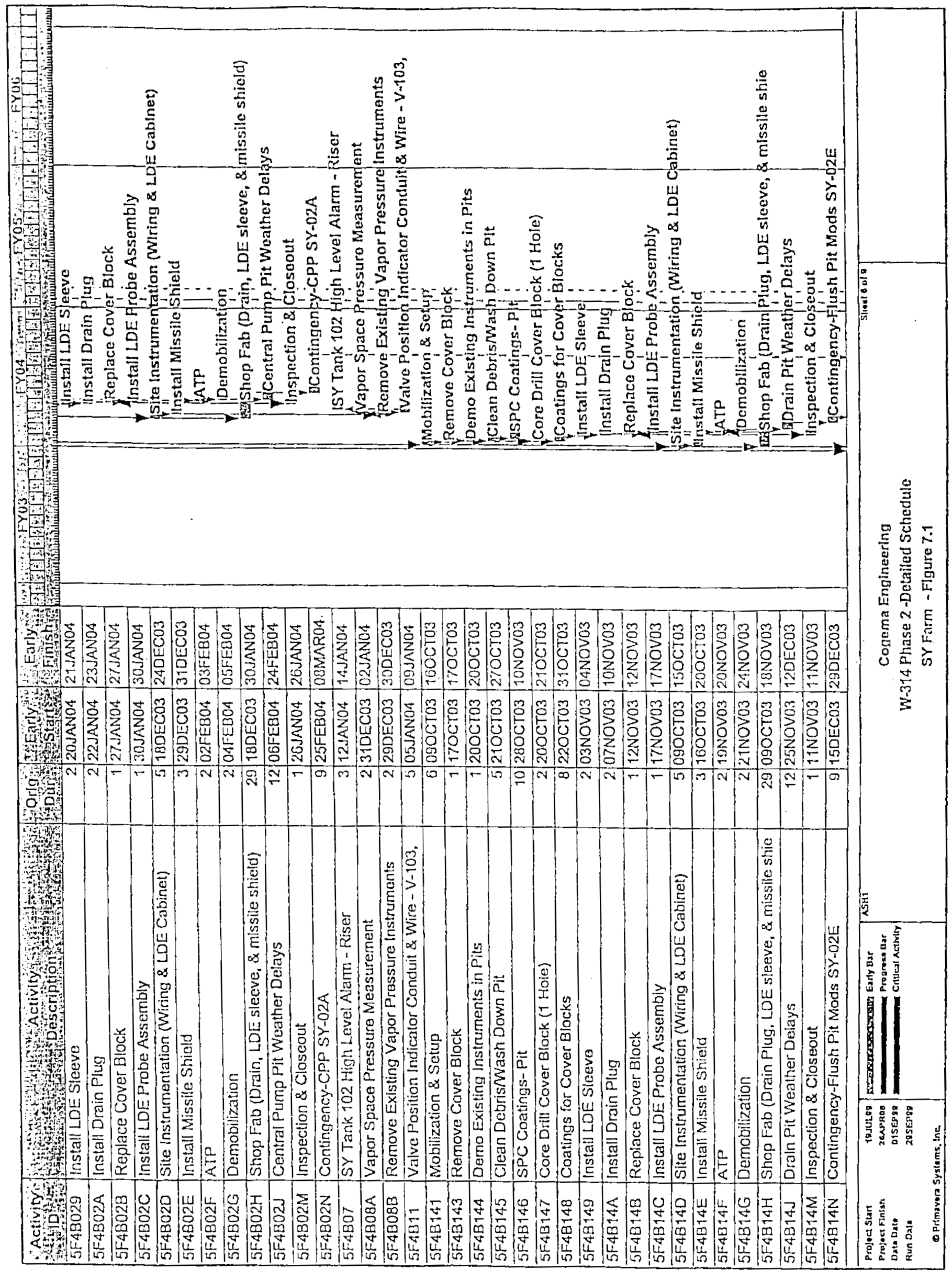




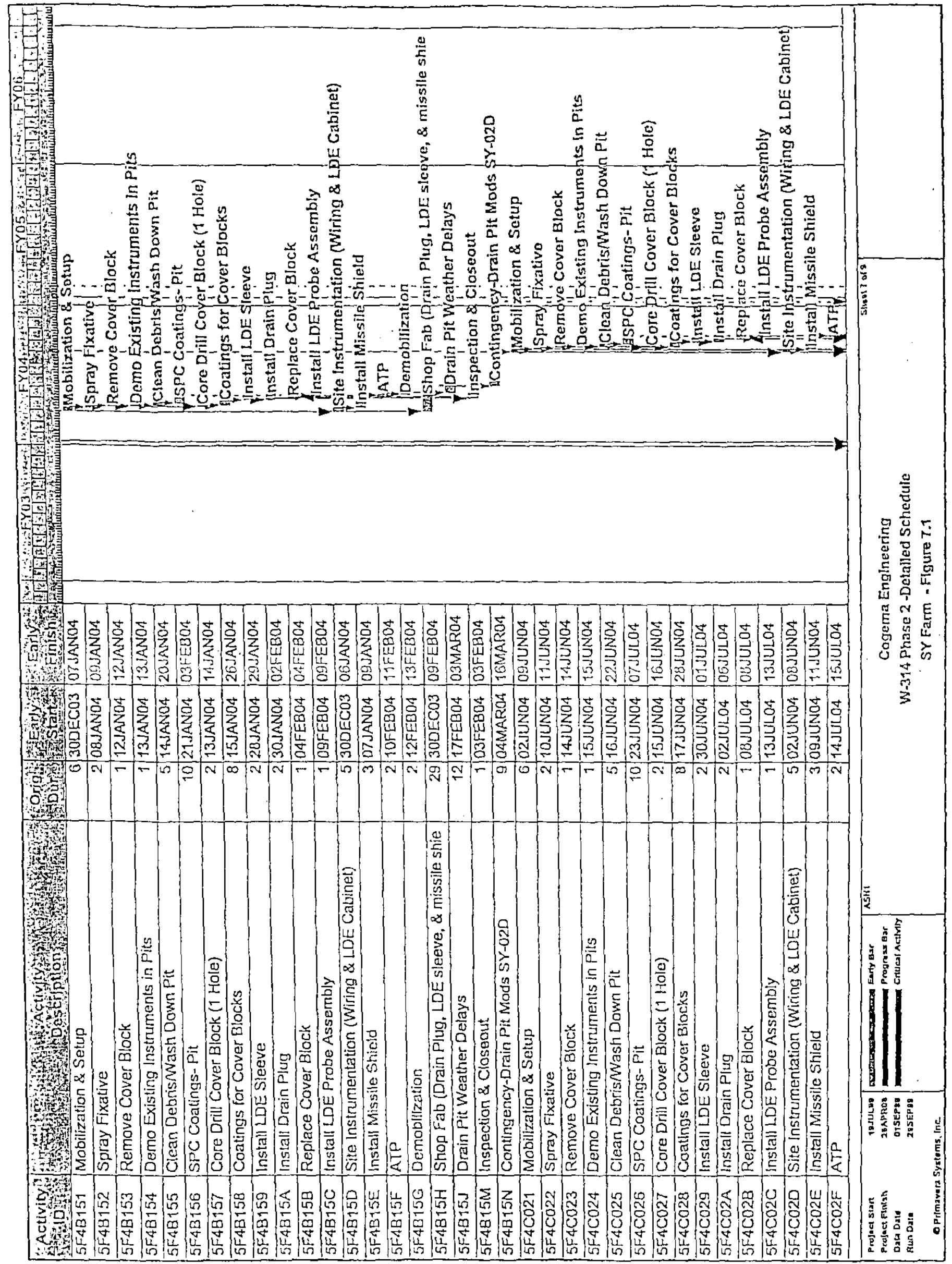




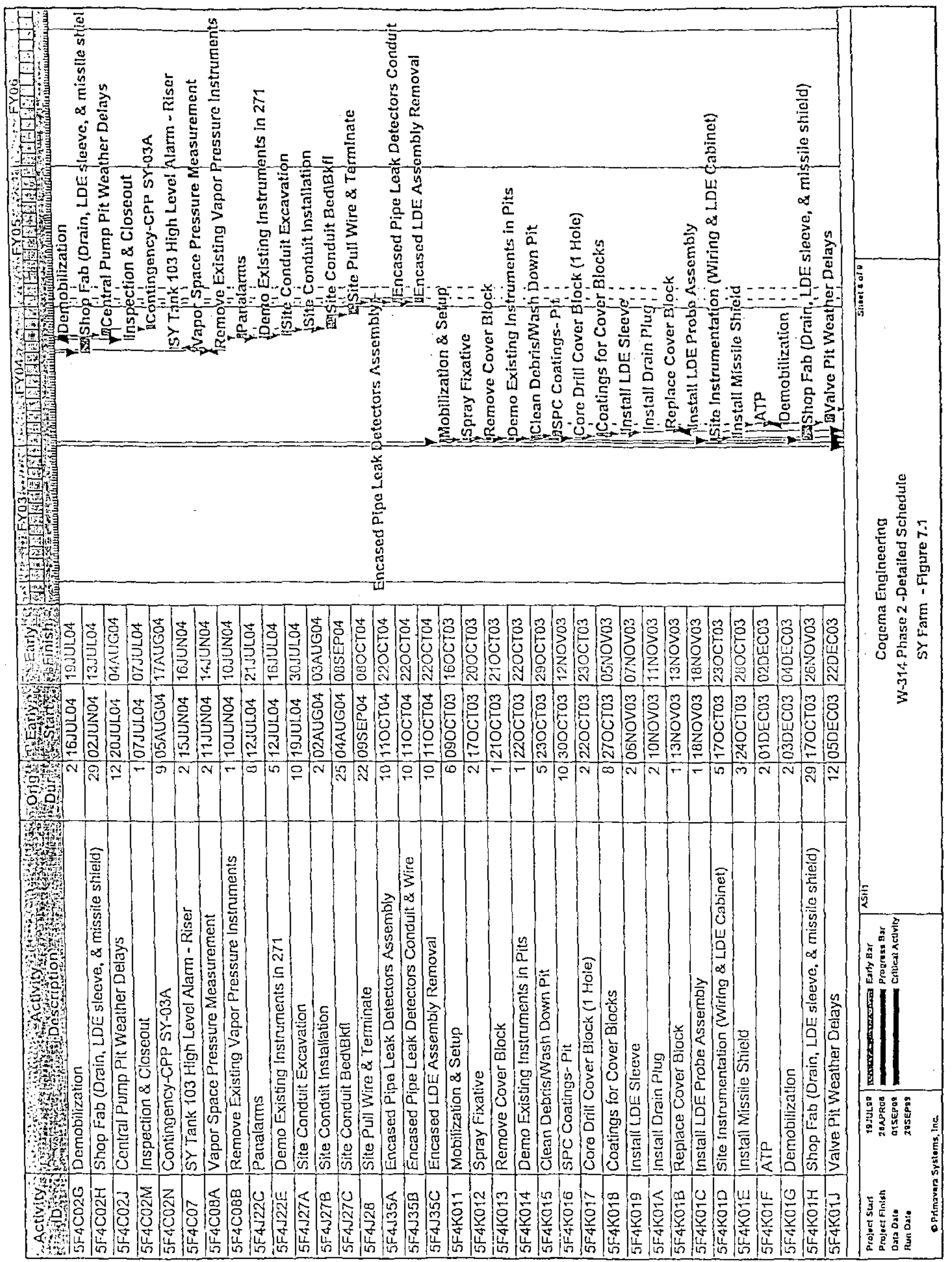




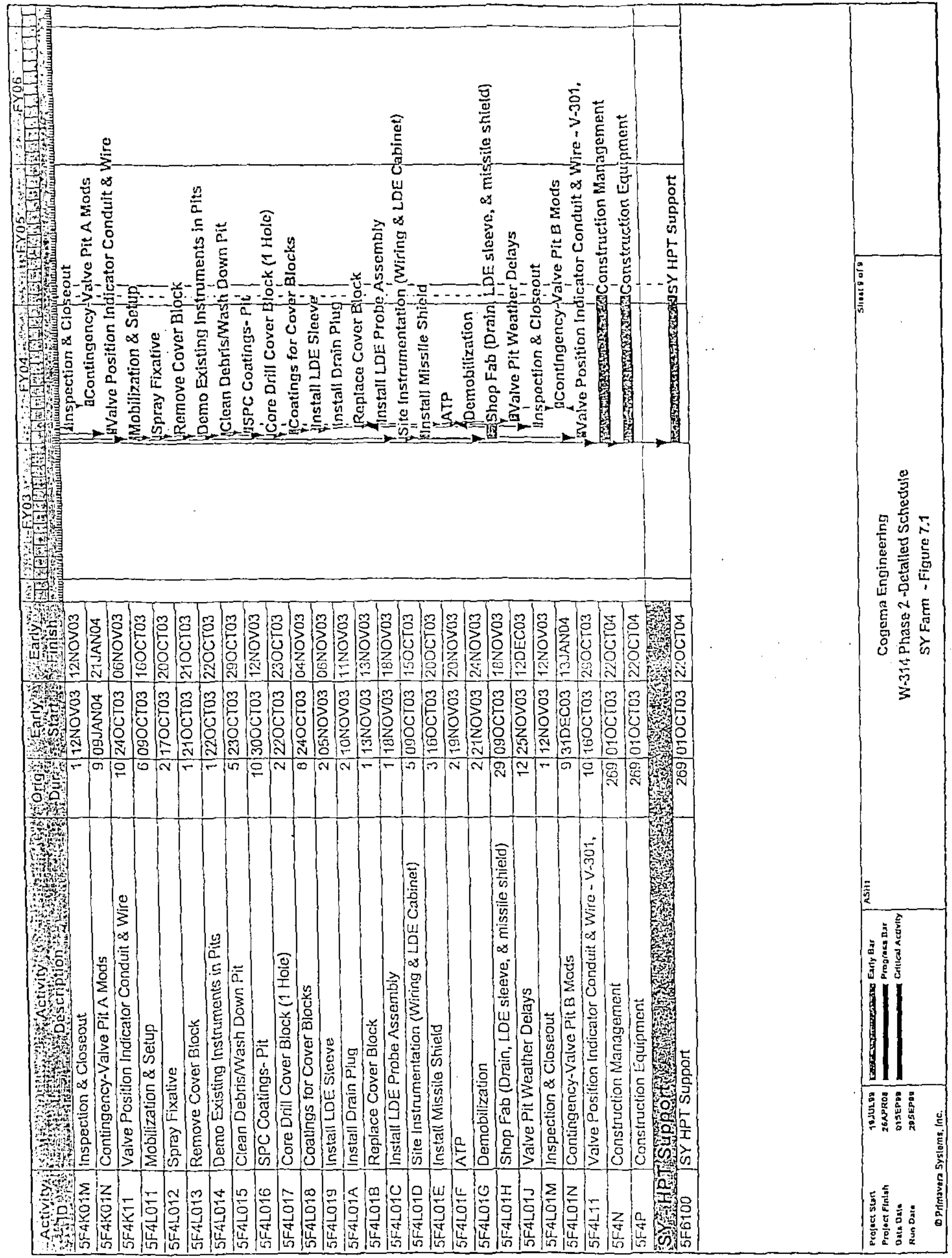




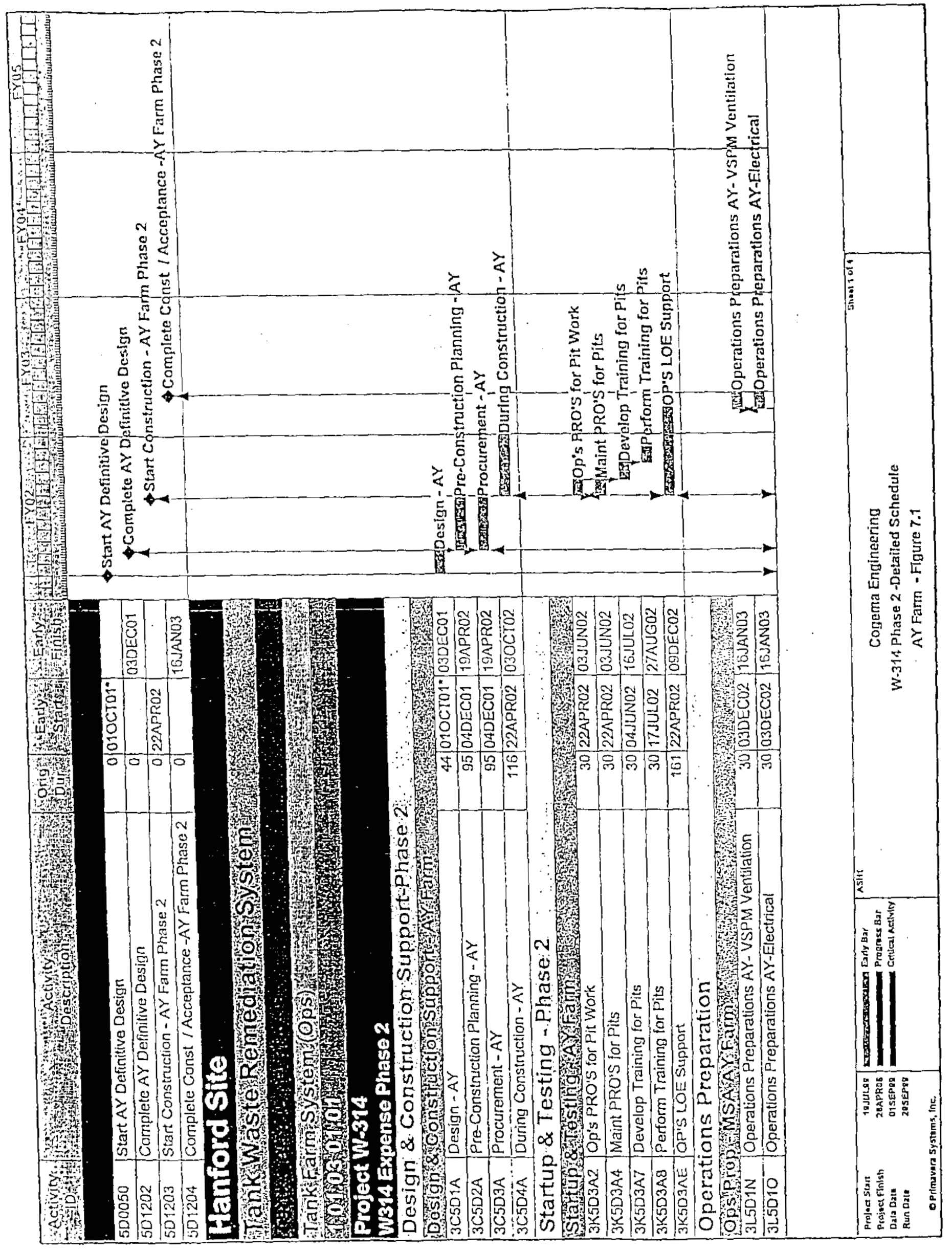




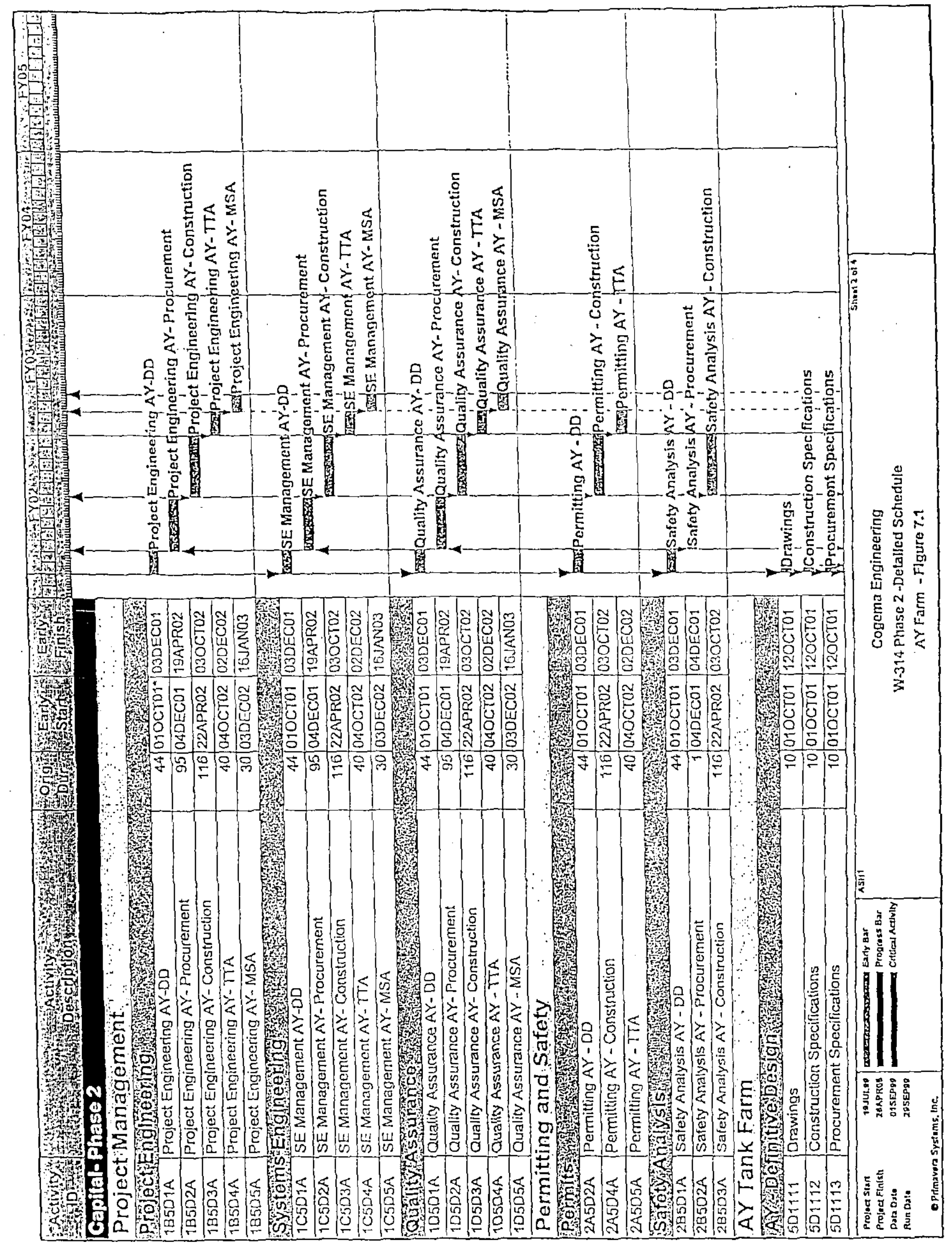




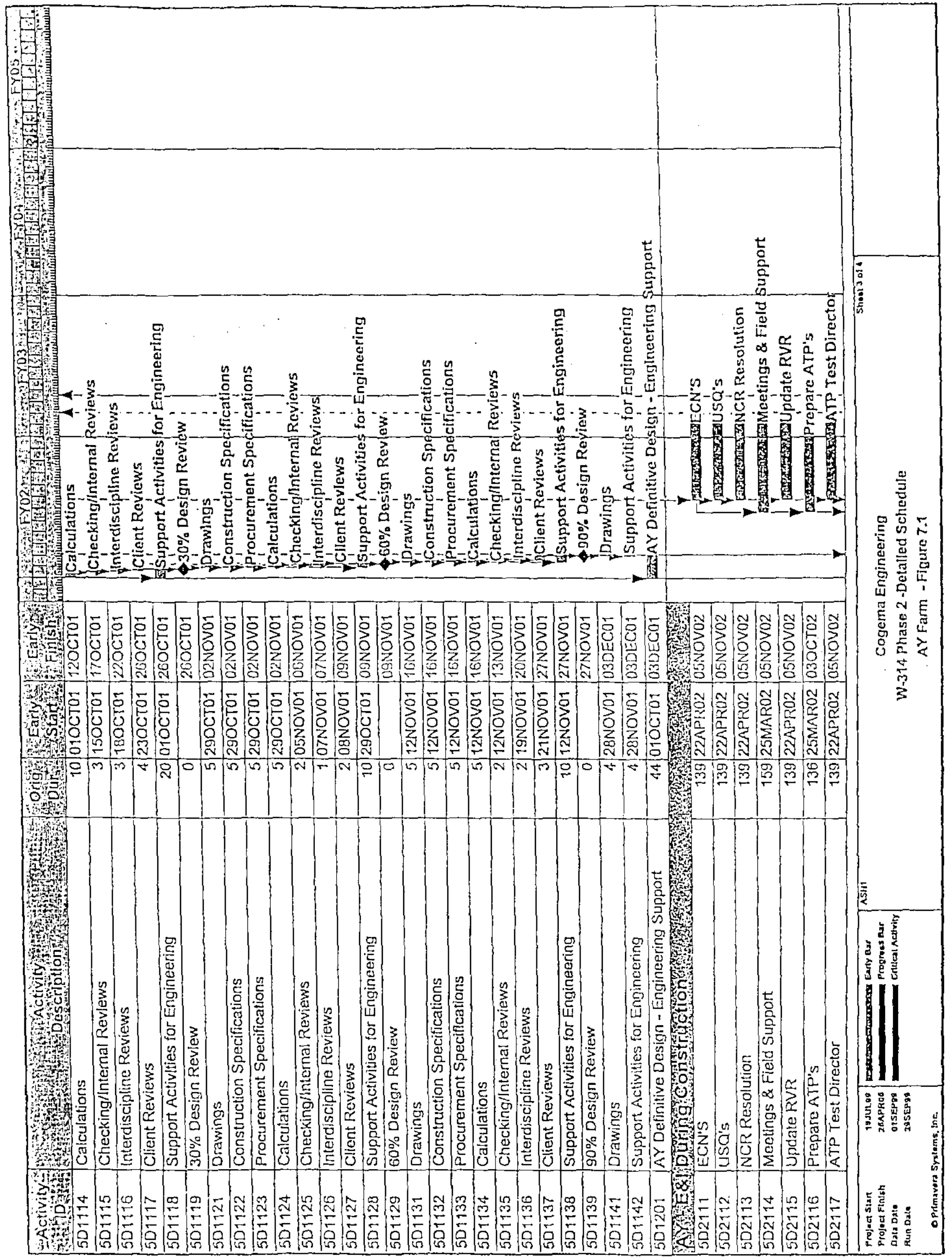




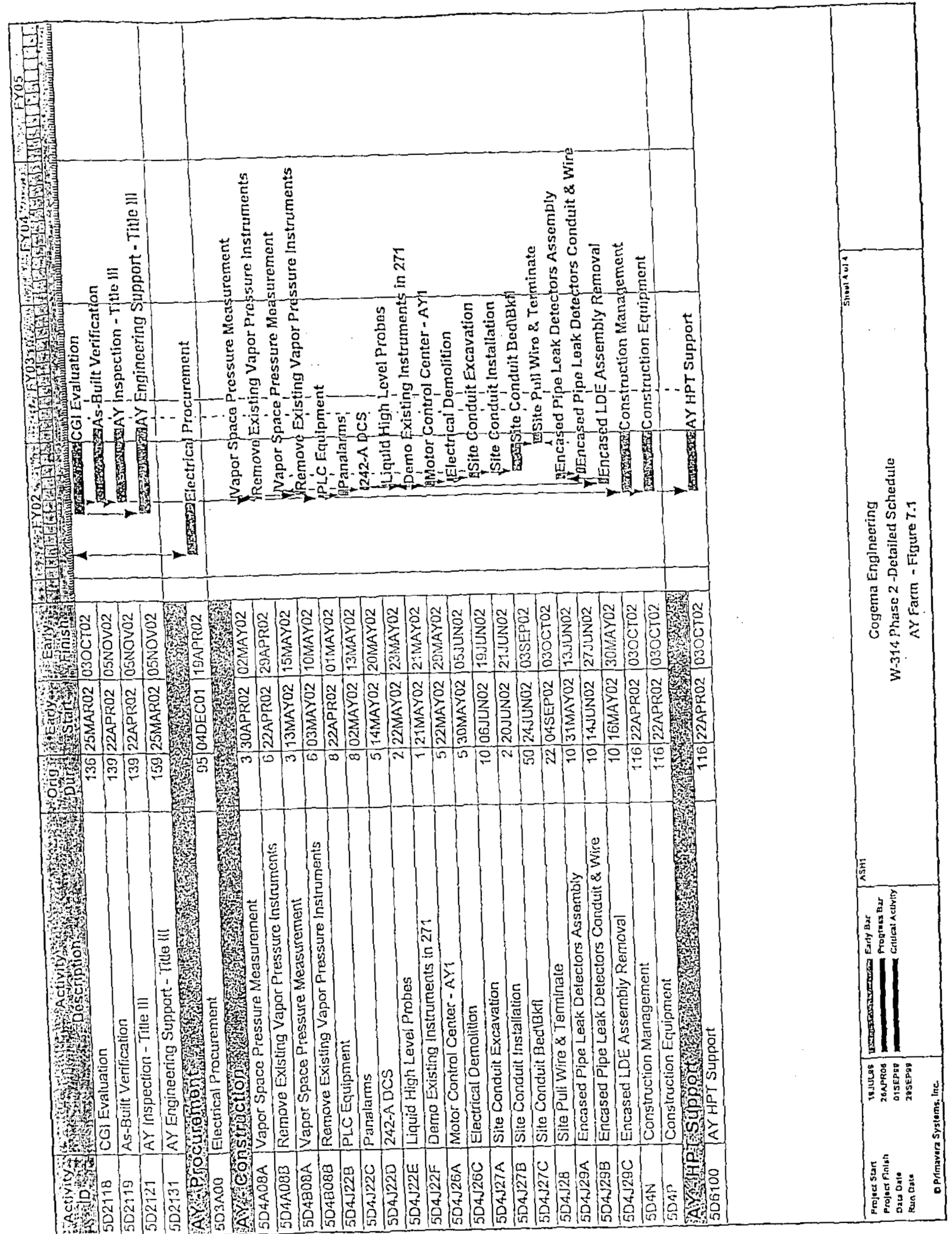




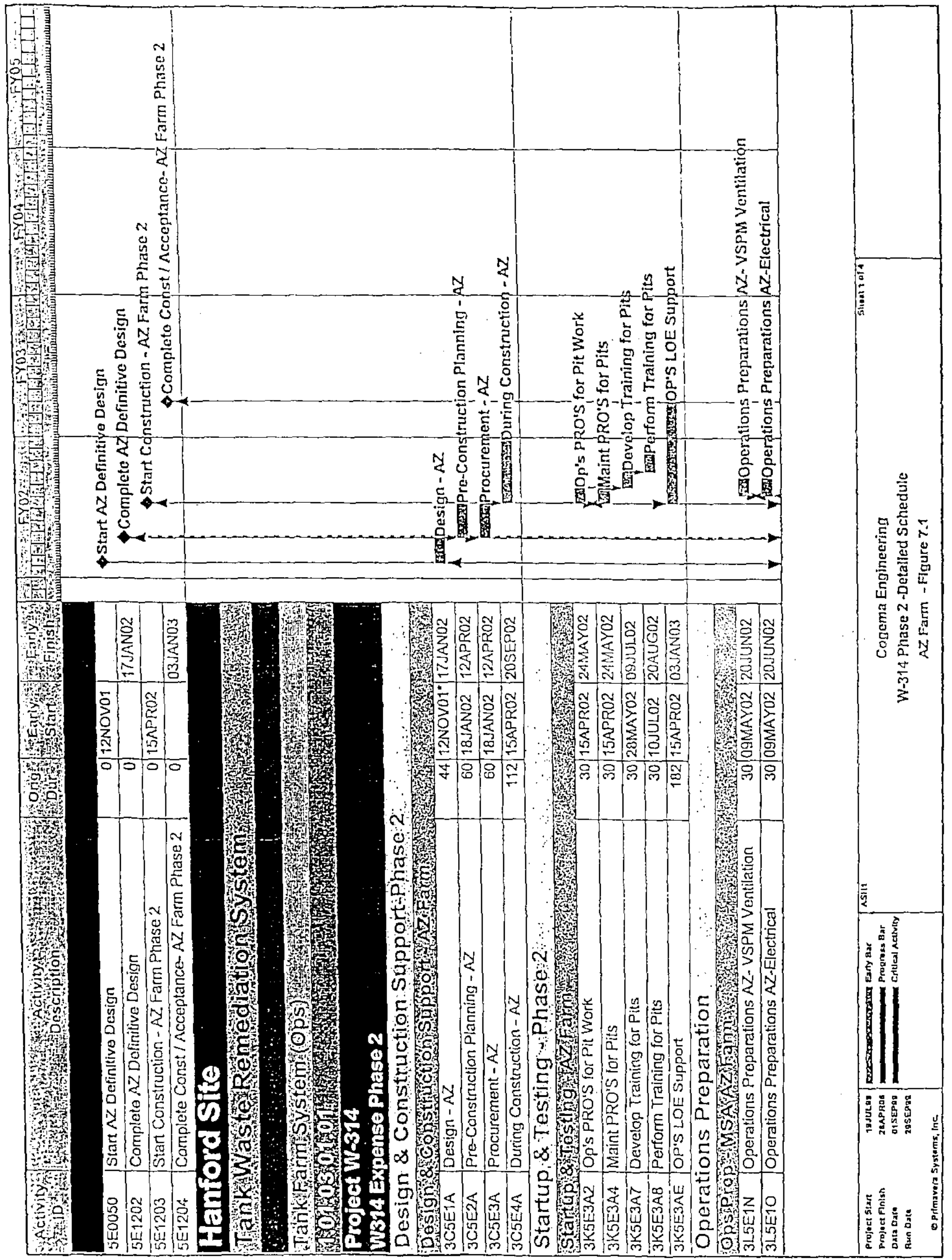




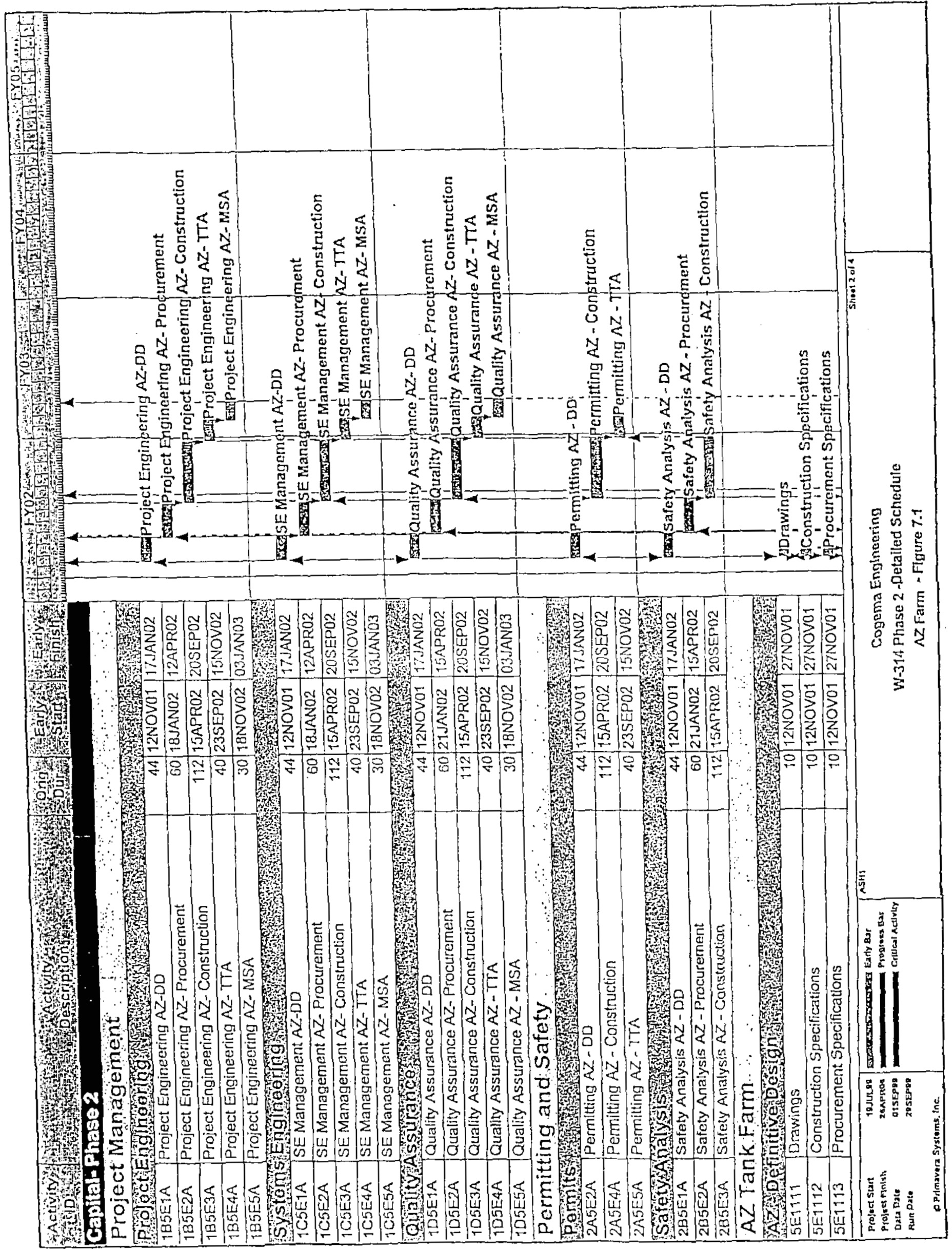




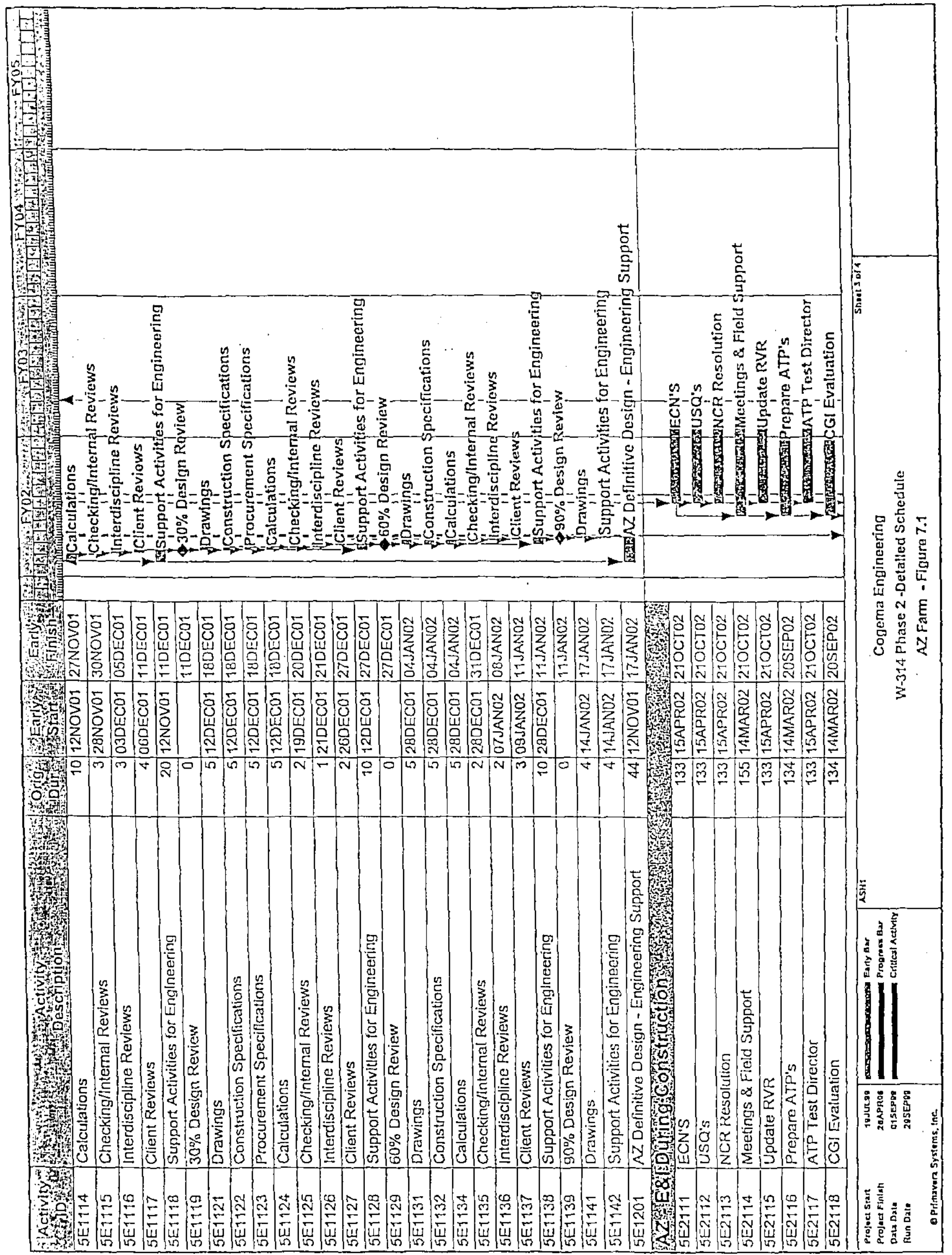


HNF-5109, REV. 0

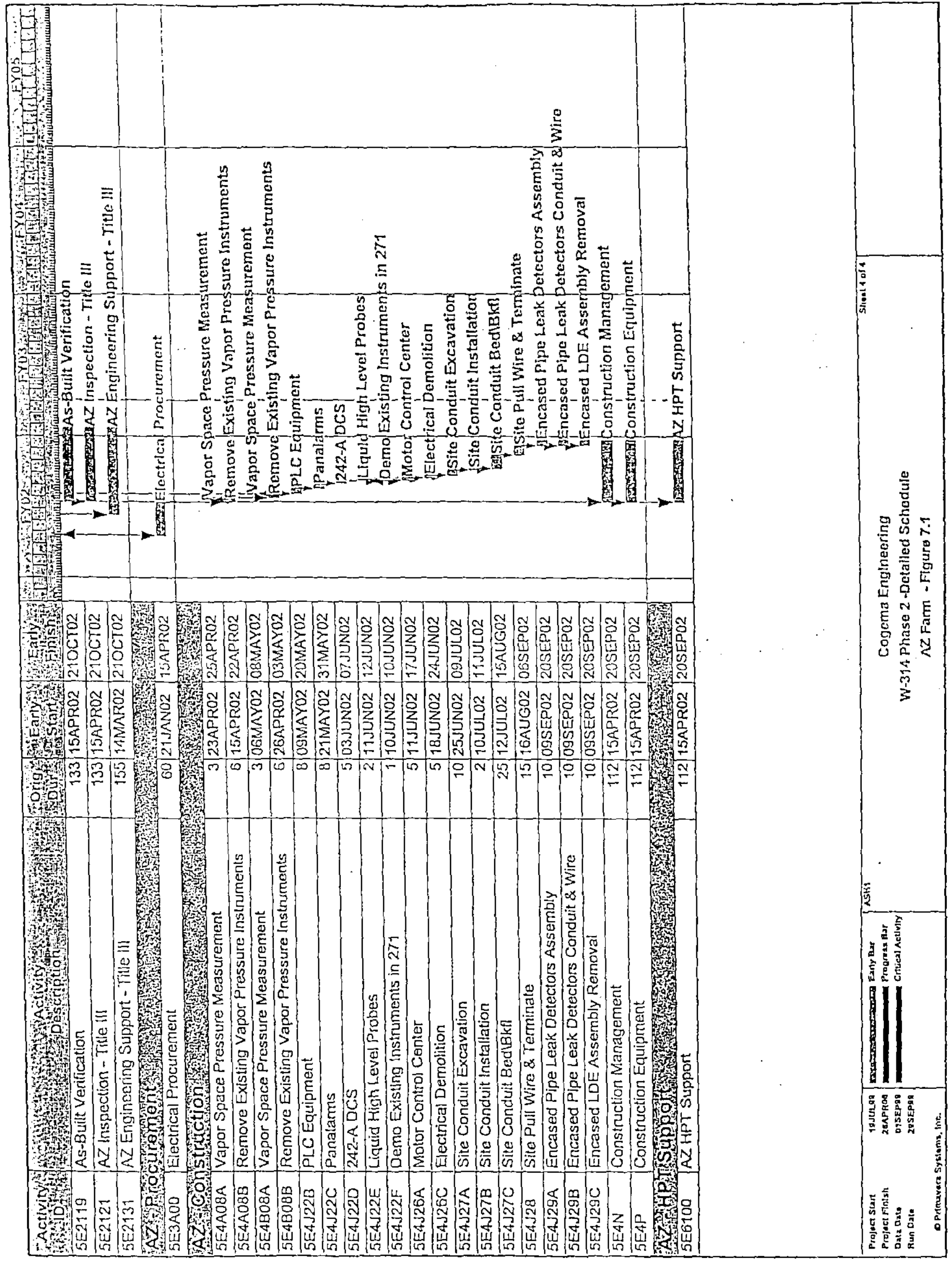




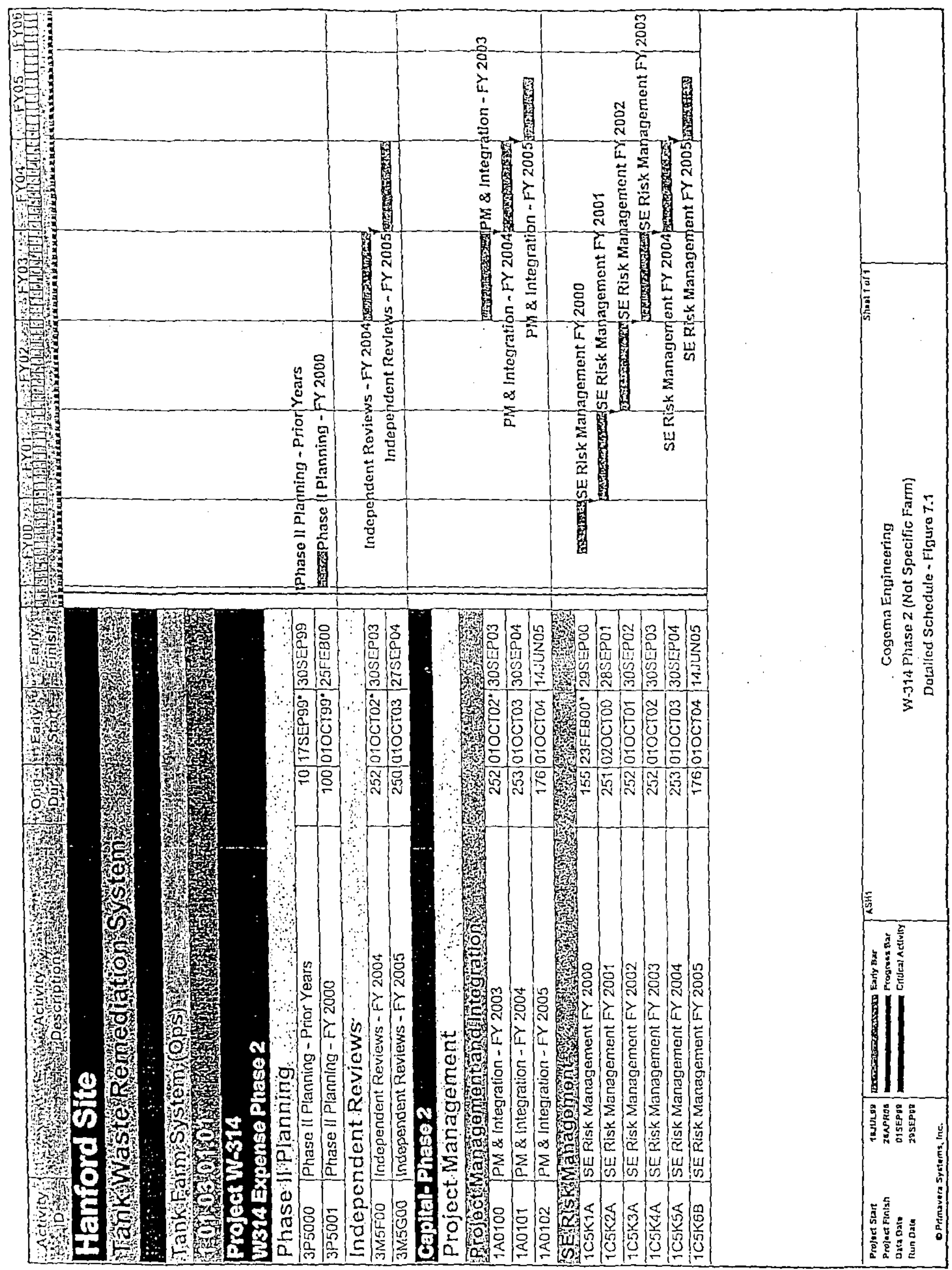


HNF-5109, Rev. 0

\subsection{BUDGET AUTHORIZED/BUDGET OUTLAY SCHEDULE}

(consisting of the following 3 pages) 


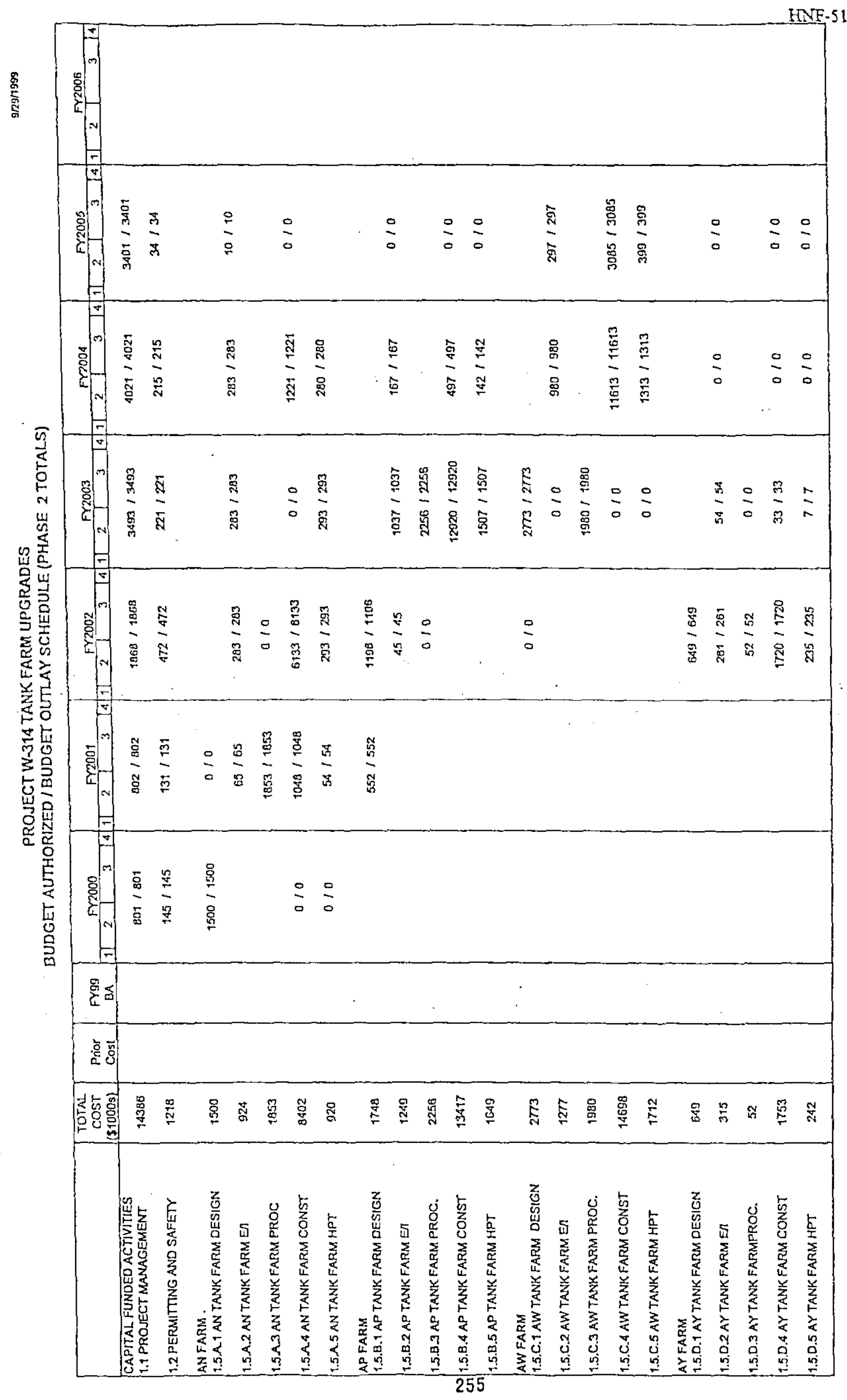




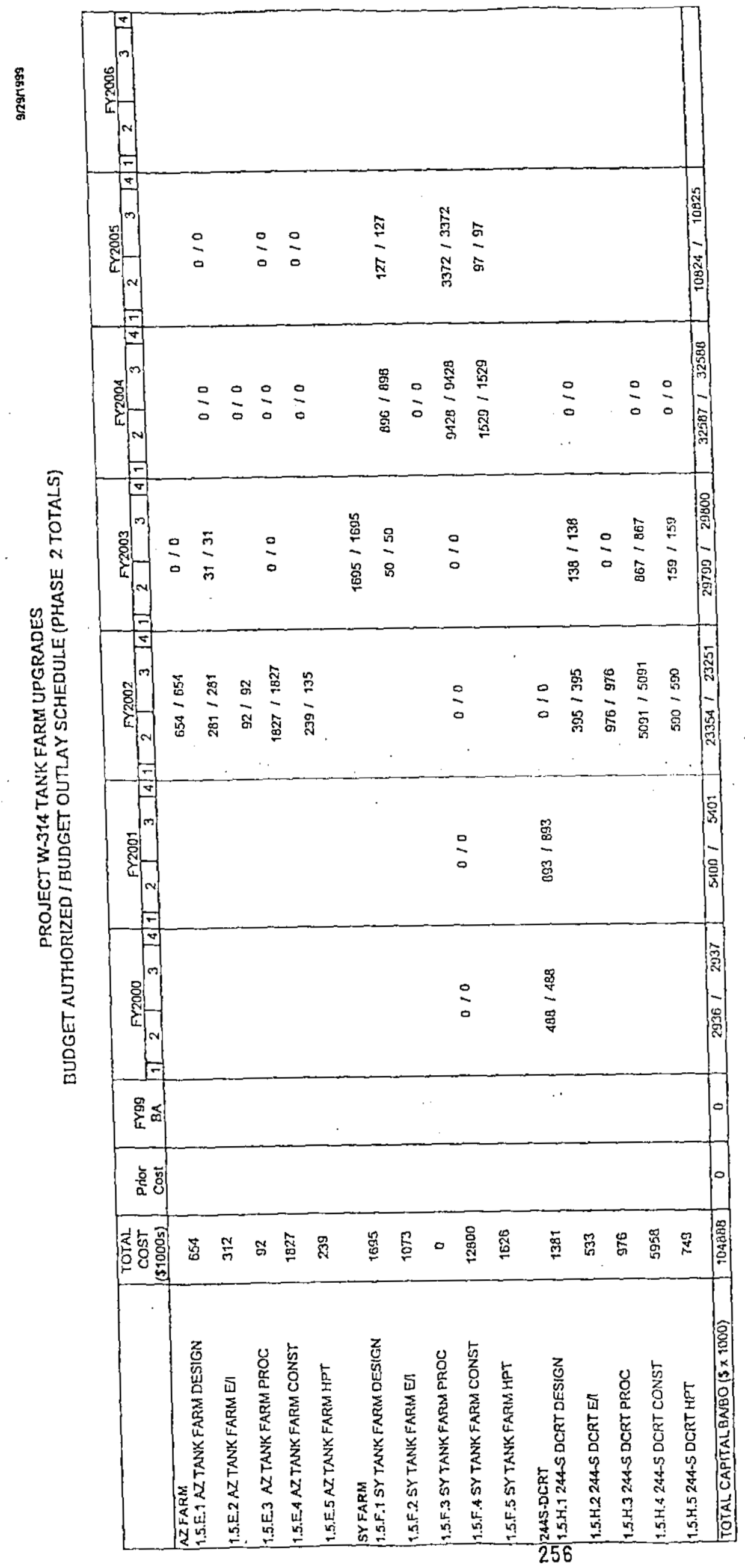

HNE-5109, REV. 0 


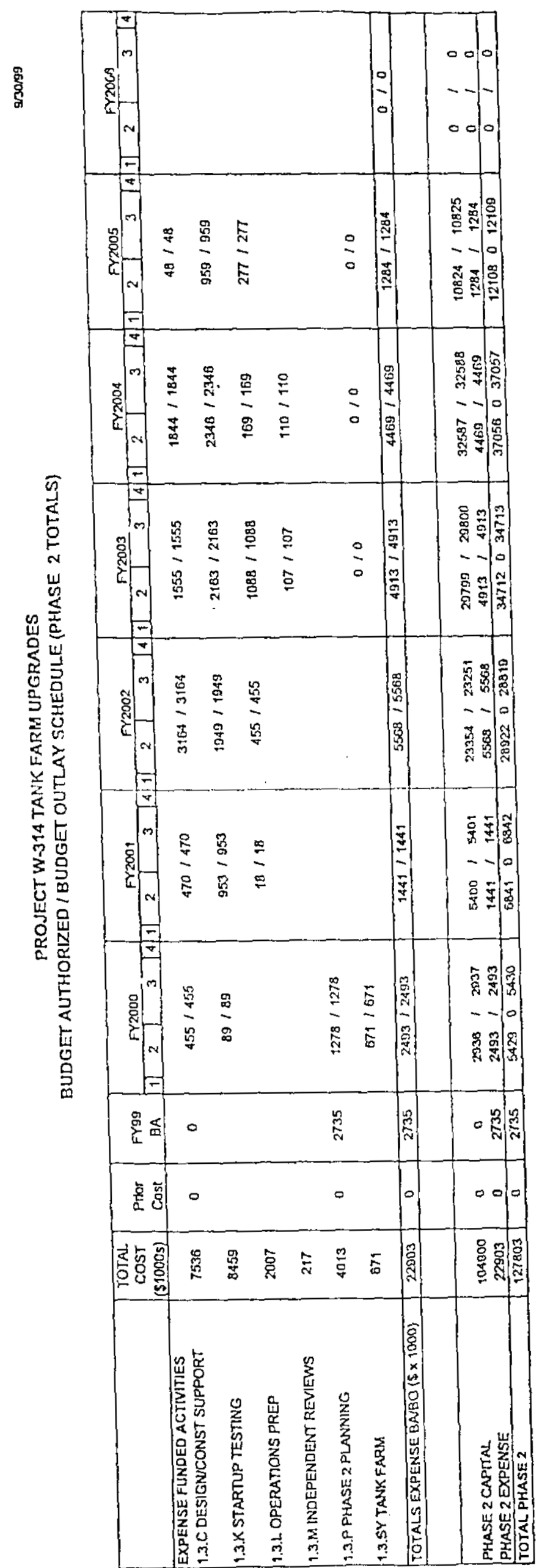




\subsection{FLELD COORDINATION}

A significant number of piping process pits, i.e., central pump pits, sluice pits, drain pits, pump pits, valve pits, will be entered and modified by several different projects. Each time a pit is entered, significant costs are incurred to open and close the pit. Pit opening activities include mobilizing construction and support crews and equipment, setting up a containment tent around the pit, flushing the pit and applying contaminant fixative to the pit interior walls and floor, removing the multi-ton concrete pit cover block (requires a crane), removing debris, and washing down the pit walls and floor. Pit closing activities include touching up the protective coating on the pit walls, floor and cover block bottom as necessary, replacing the cover block, removing the containment tent, and demobilizing construction and support crews and equipment. These pits are highly contaminated and require special work practices to protect workers during these activities. As a part of rebaselining Phase 2 of Project W-314, an attempt has been made to mininsize the number of process pit entries in order to minimize costs.

Table 9.1 "Coordination of Pit Upgrades" identifies specific pits that will be modified and how. It identifies projects that will be performing pit modifications and when. It identifies what modifications will be made by each project. Finally, for those pits where multiple projects are planning modifications, it identifies which project will bear the cost of opening and closing the pit.

Table 9.1 indicates integration can be achieved with River Protection Projects W-211 and 521 to minimize Phase 2 pit upgrade costs, particularly four central pump pits, AN-102, AN-105, AN106, and AN-107. W-314 Phase 2 plans to accomplish the installation of a leak detector and drain plug assembly, and repair of the SPC on the interior pit walls during the planned W-211 upgrade of central pump pit AN-105. Similarly, W-314 Phase 2 pit work will be coordinated during the planned W-521 upgrades of AN-102, 106, and 107. With this integrated approach as the planning basis, the W-314 Phase 2 cost estimate does not include the pit opening and closing costs for these four pits. These costs are borne by Project W-211 and W-521. The planned W314 Phase 2 pit modifications for these four pits are scheduled coincidentally with the W-211 and $W-521$ schedules.

Table 9.1: Coordination of River Protection Projects' Pit Upgrades (consisting of the following 6 pages) 


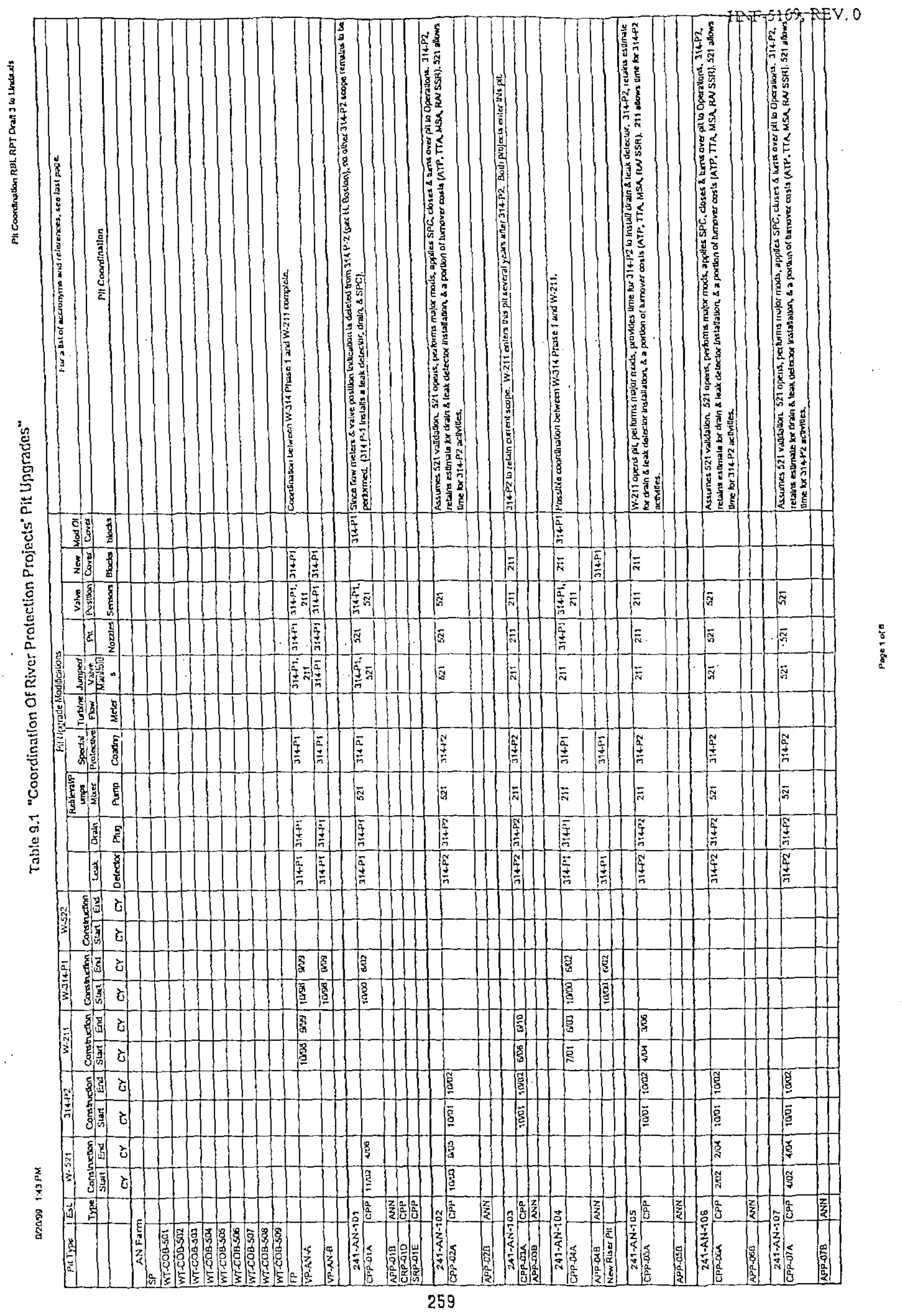




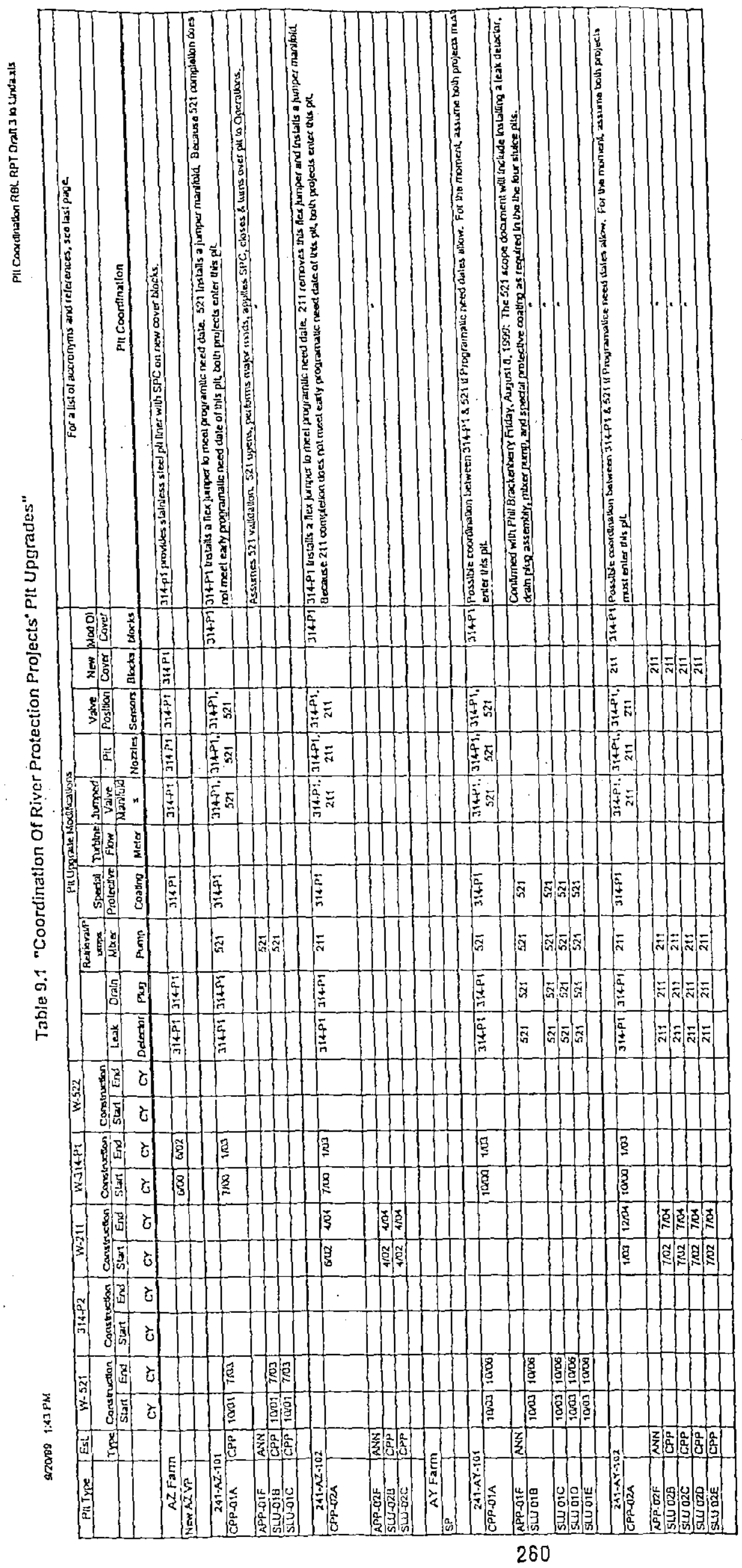

HNF-5109, REV. 0 

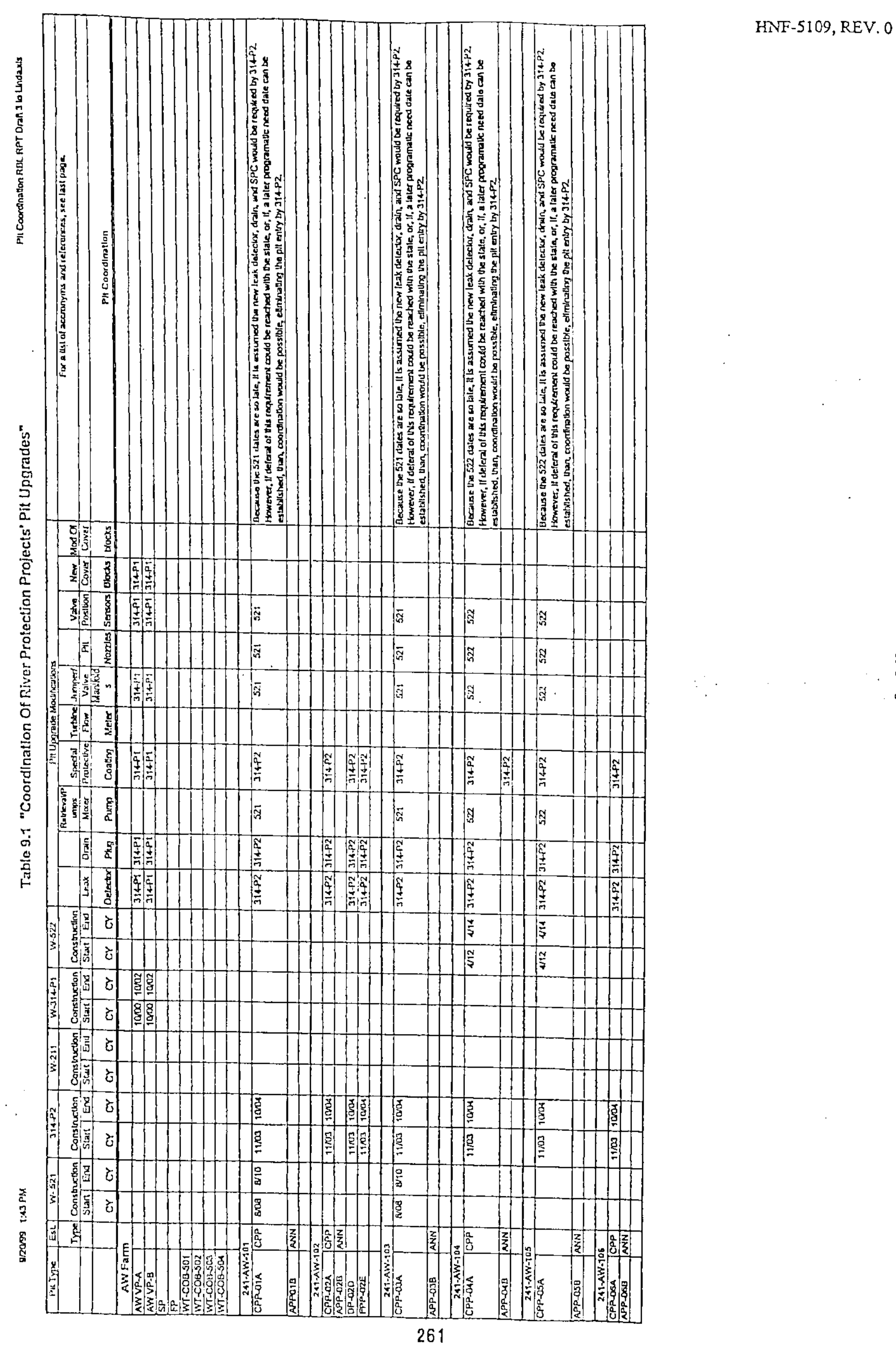


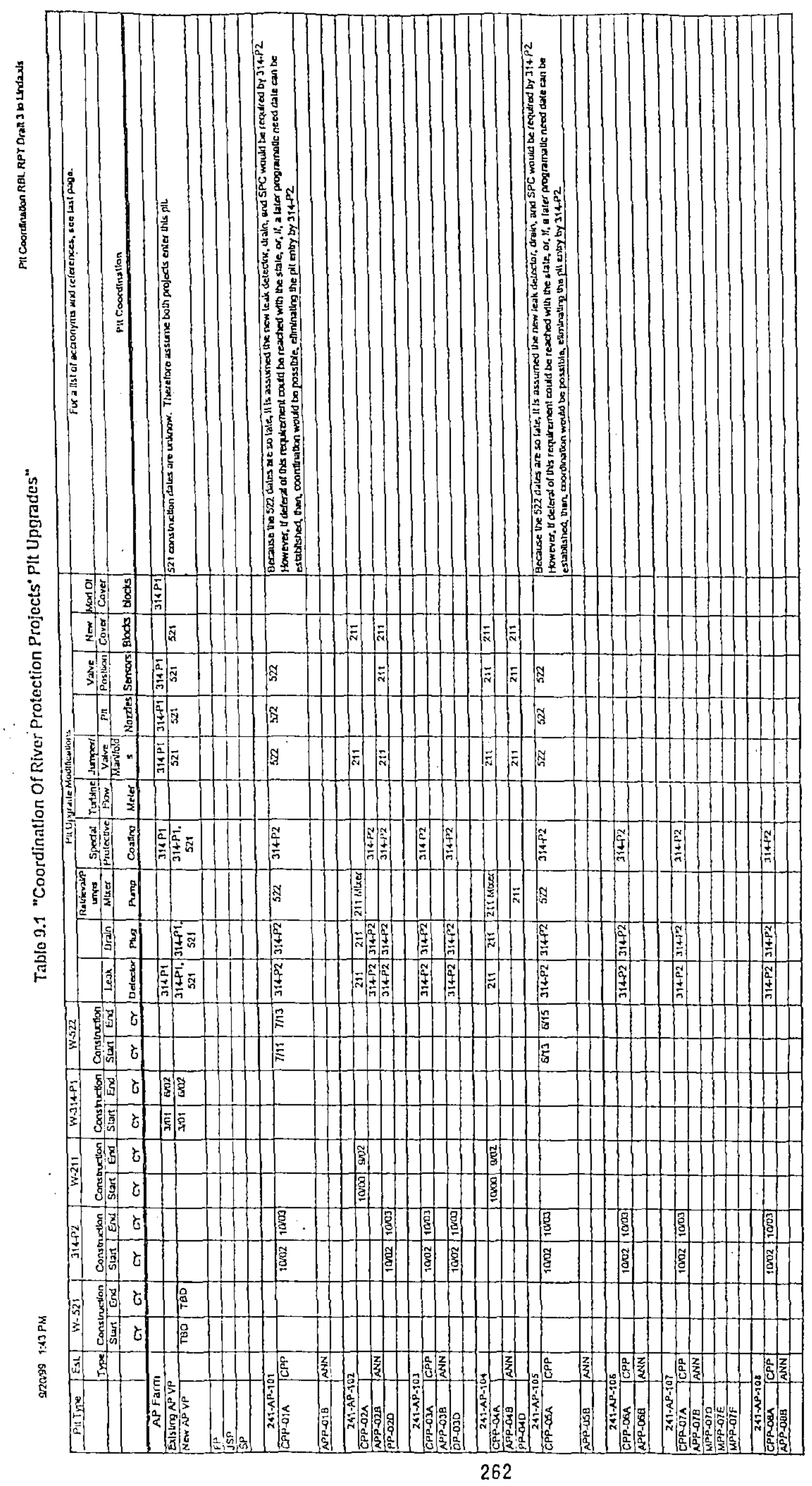

HNF-5109, REV. 0 


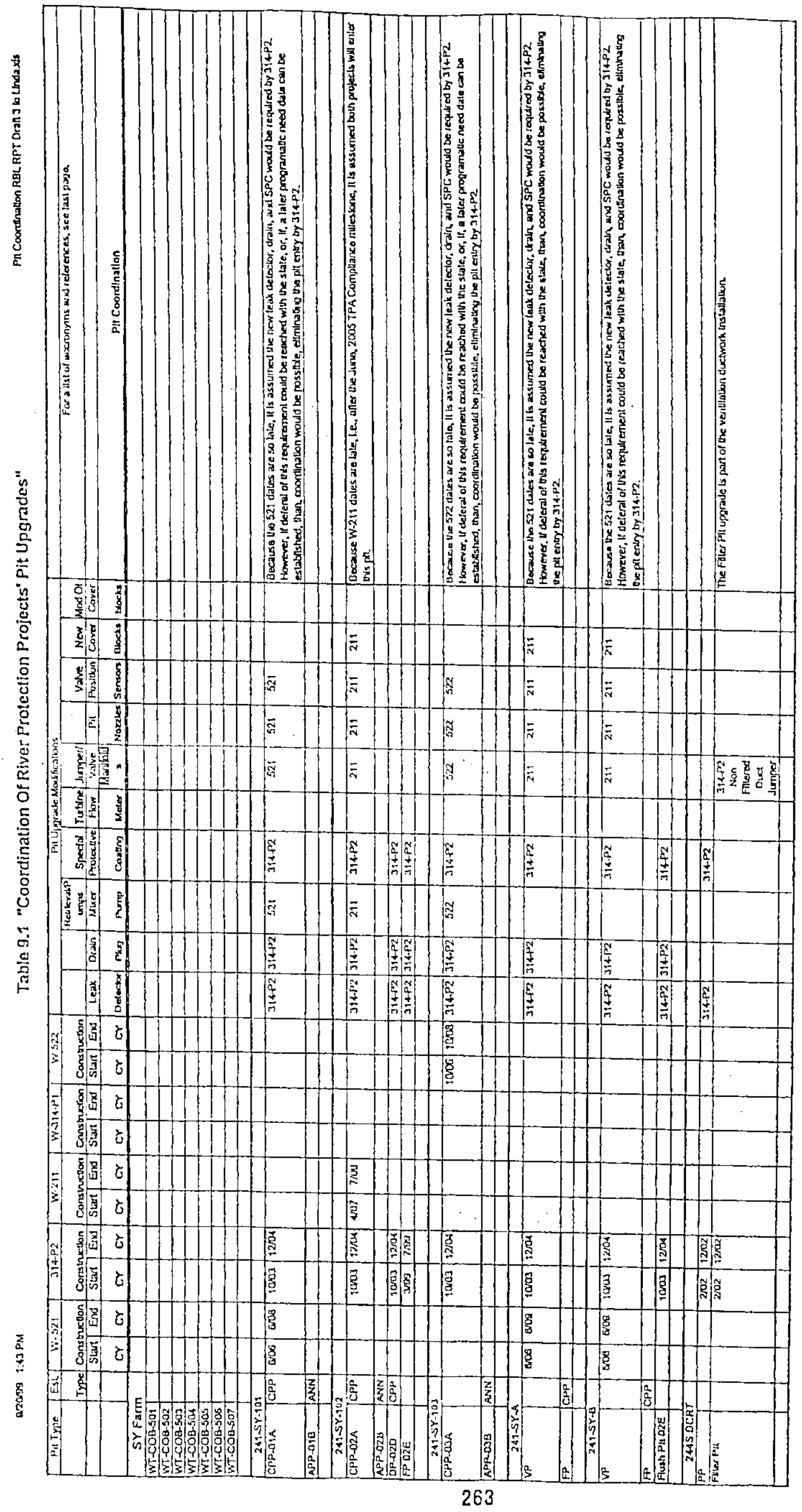

HNF-5109, REV. 0 


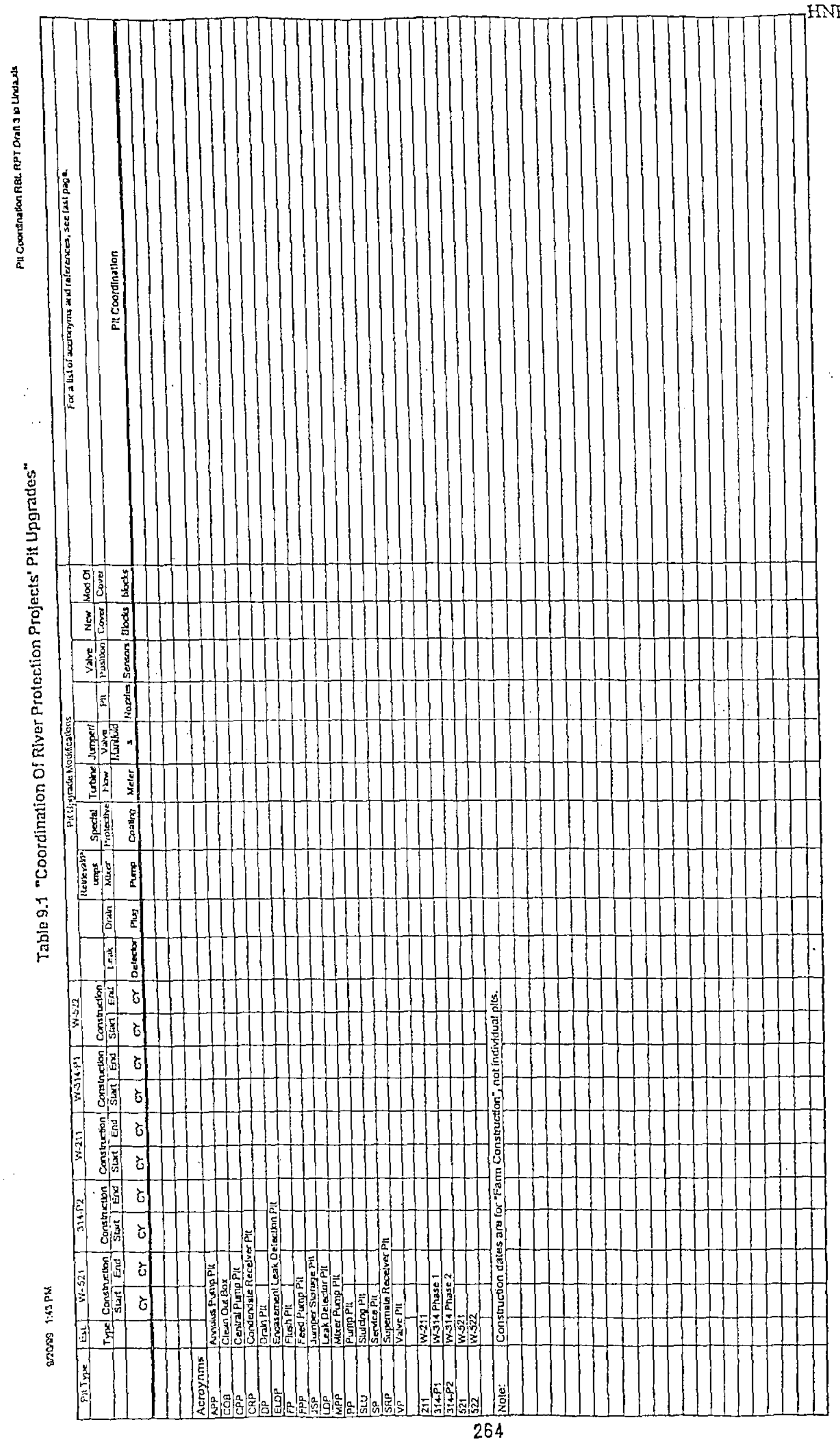


HNF-5109, Rev. 0

\subsection{CRITICAL RESOURCES}

(consisting of the following 29 pages) 
HNF-5109, REV. 0

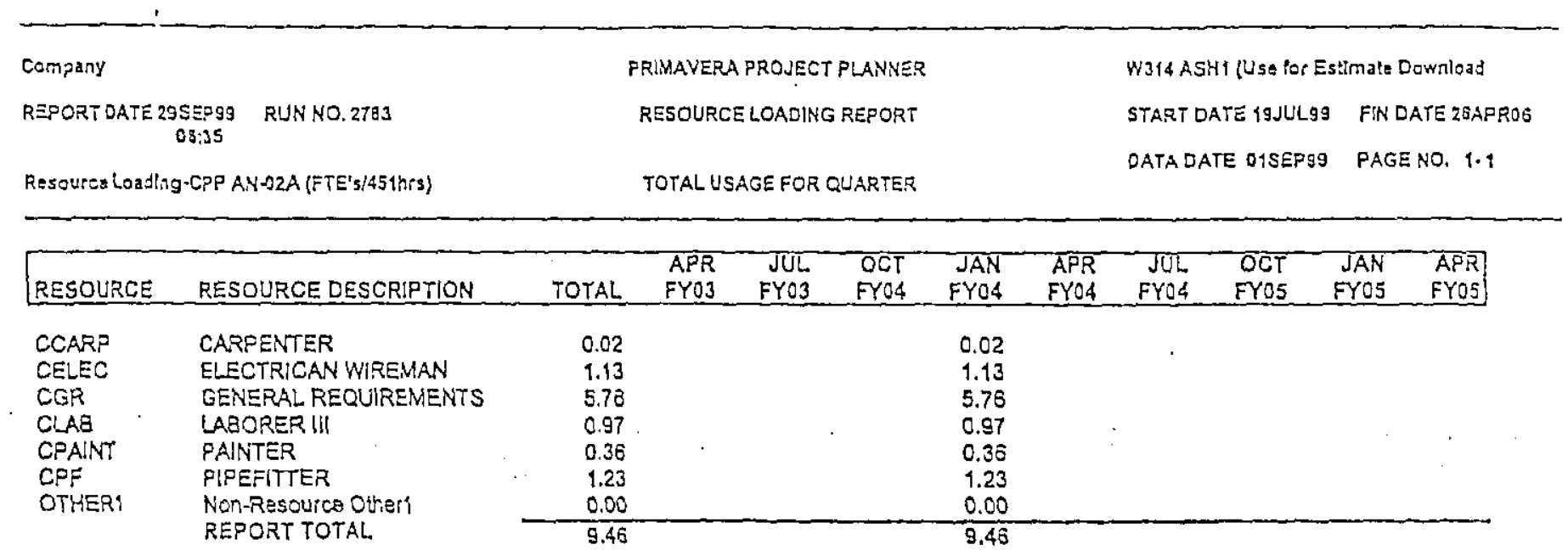


HNF-5109, REV. 0

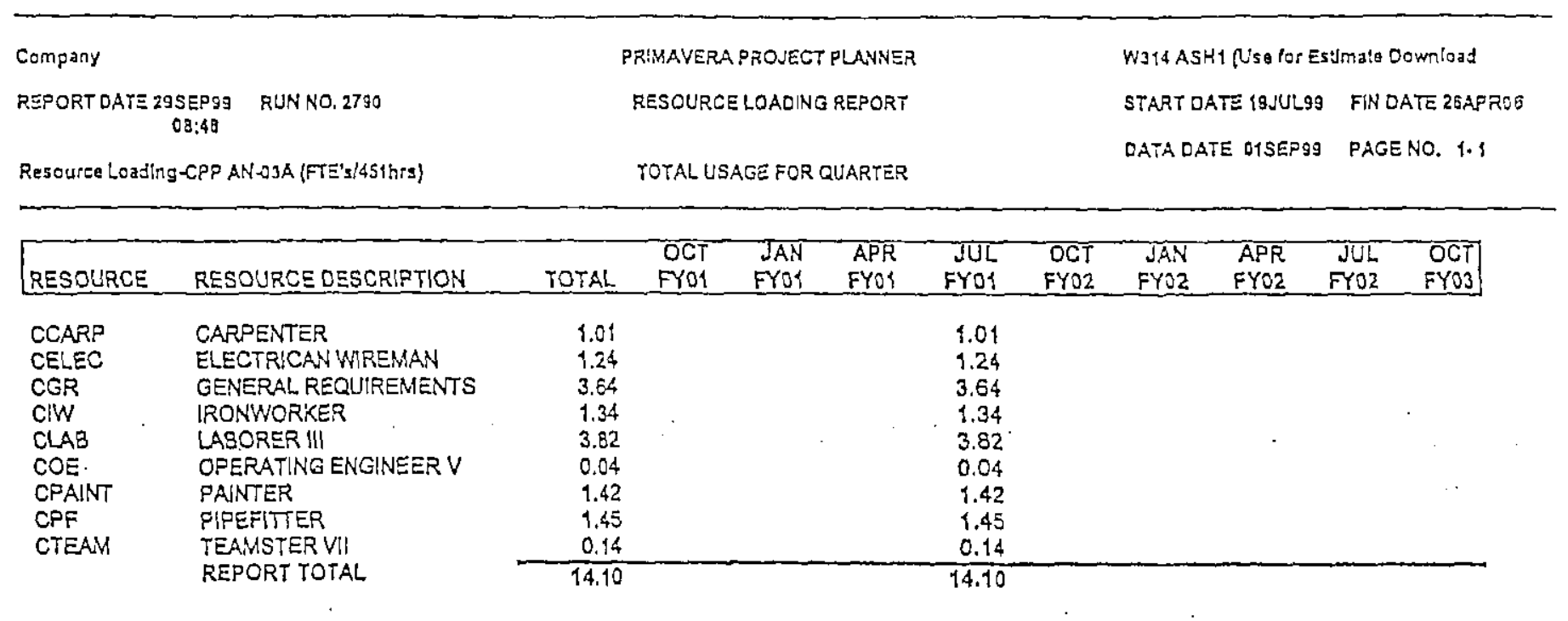


HNF-5109, REV. 0

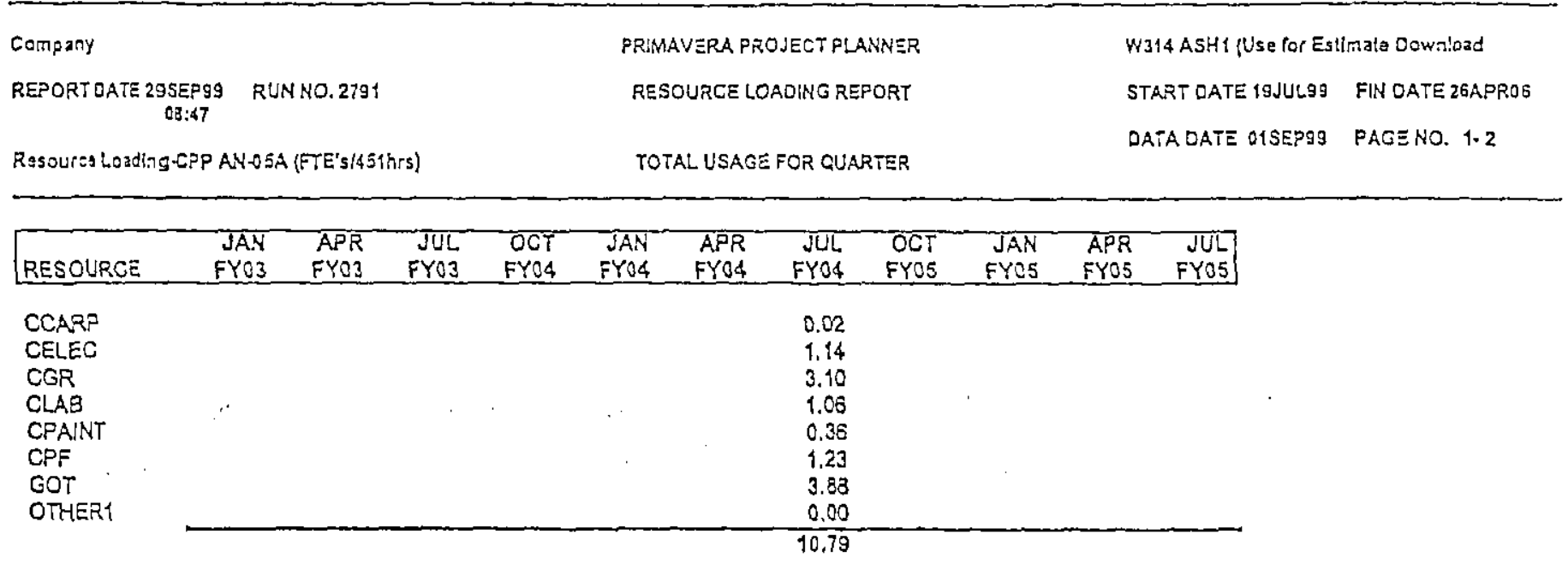


HNF.5109, REV. 0

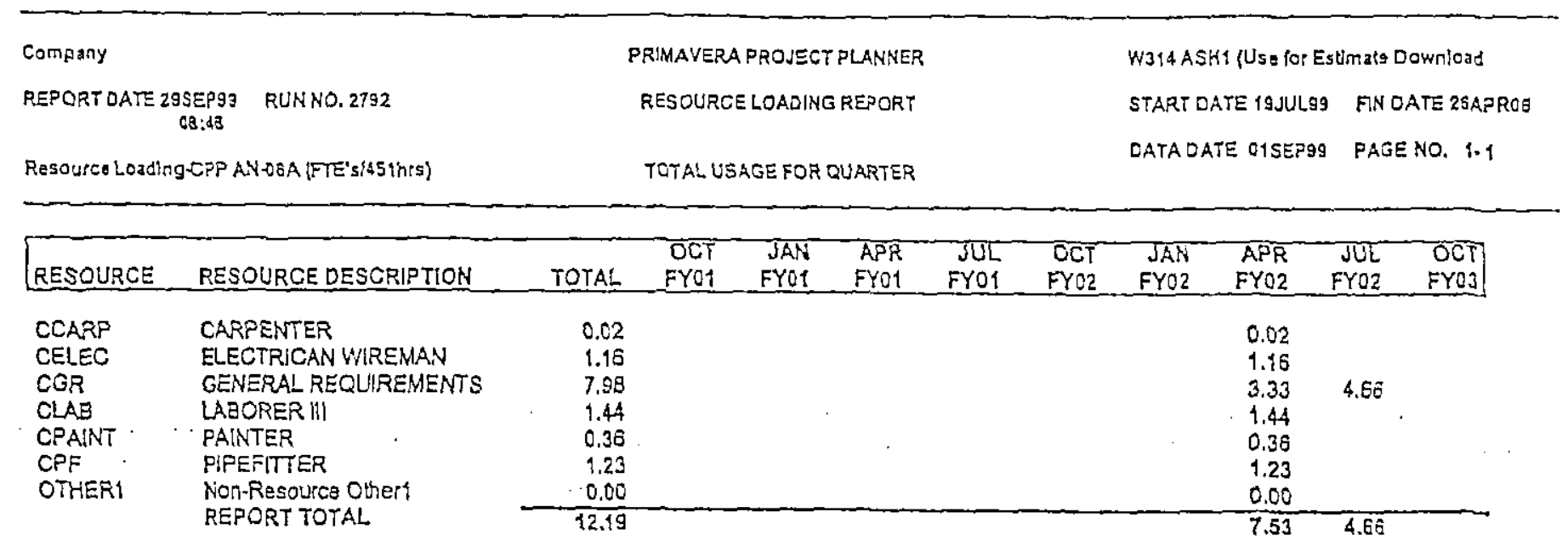


HNF-5109, REV. 0

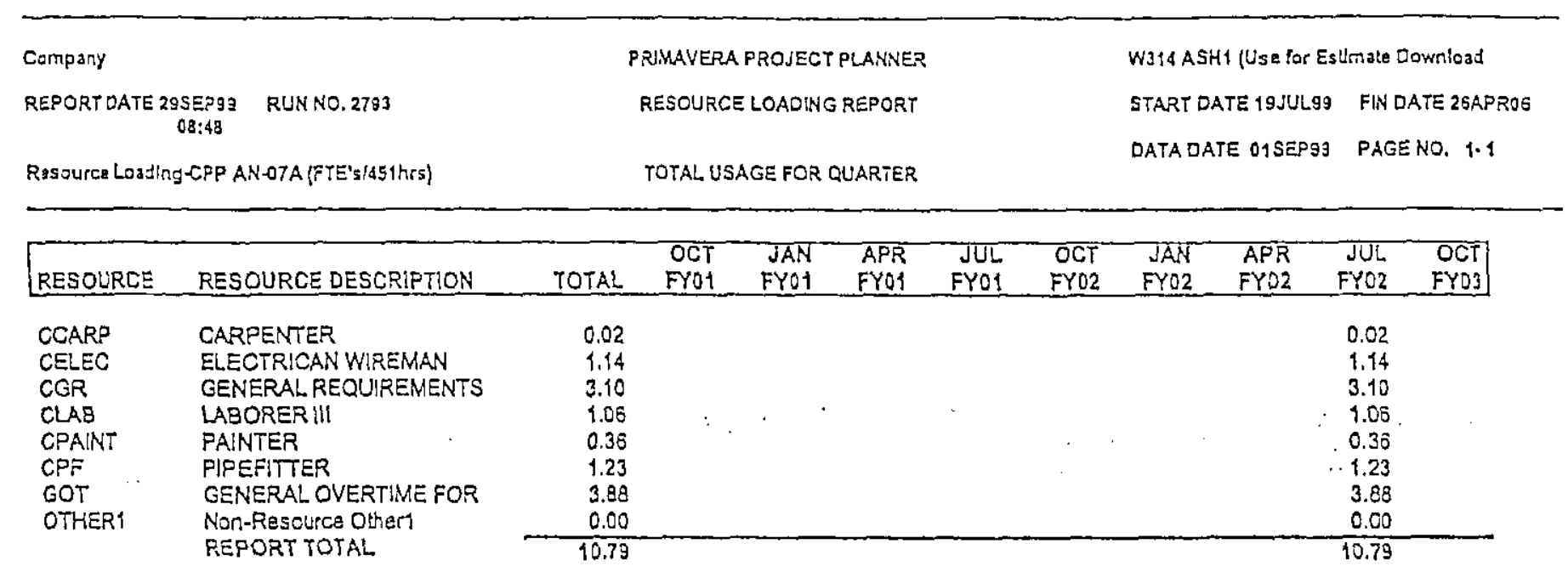


HNF-5109, REV. 0

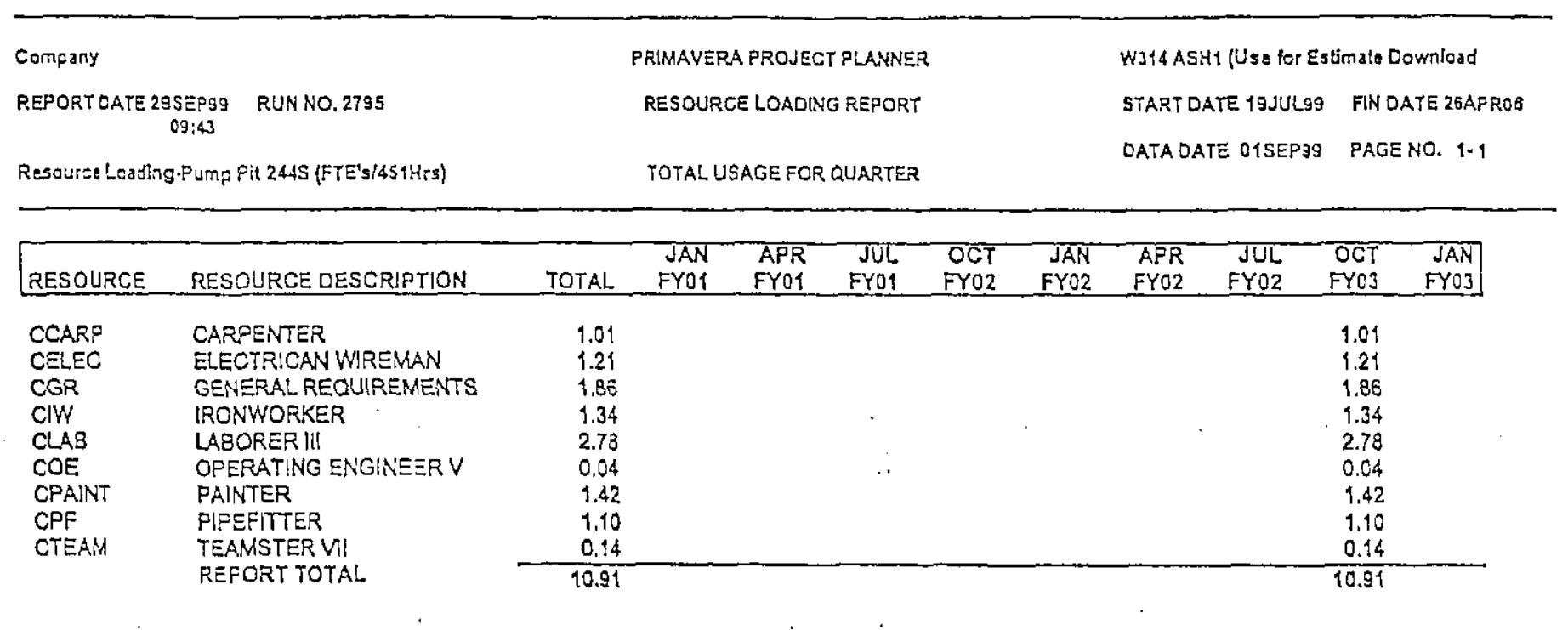




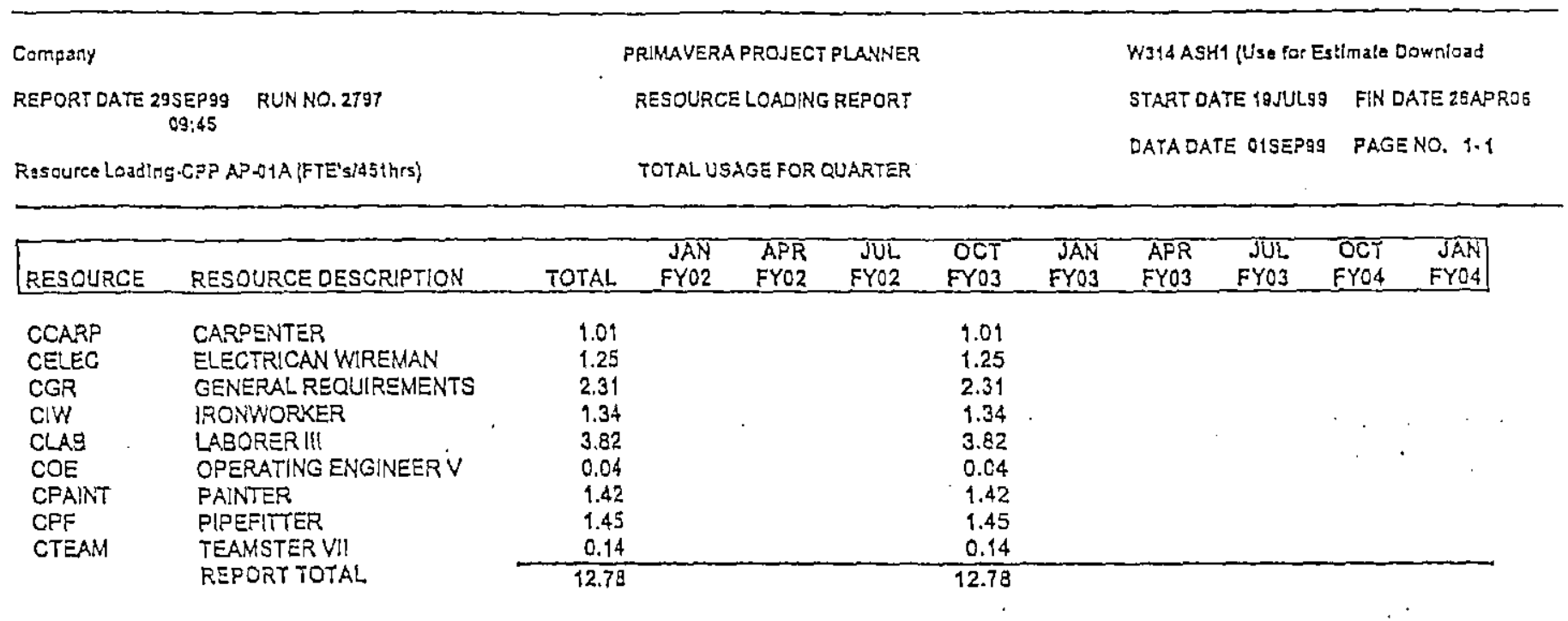




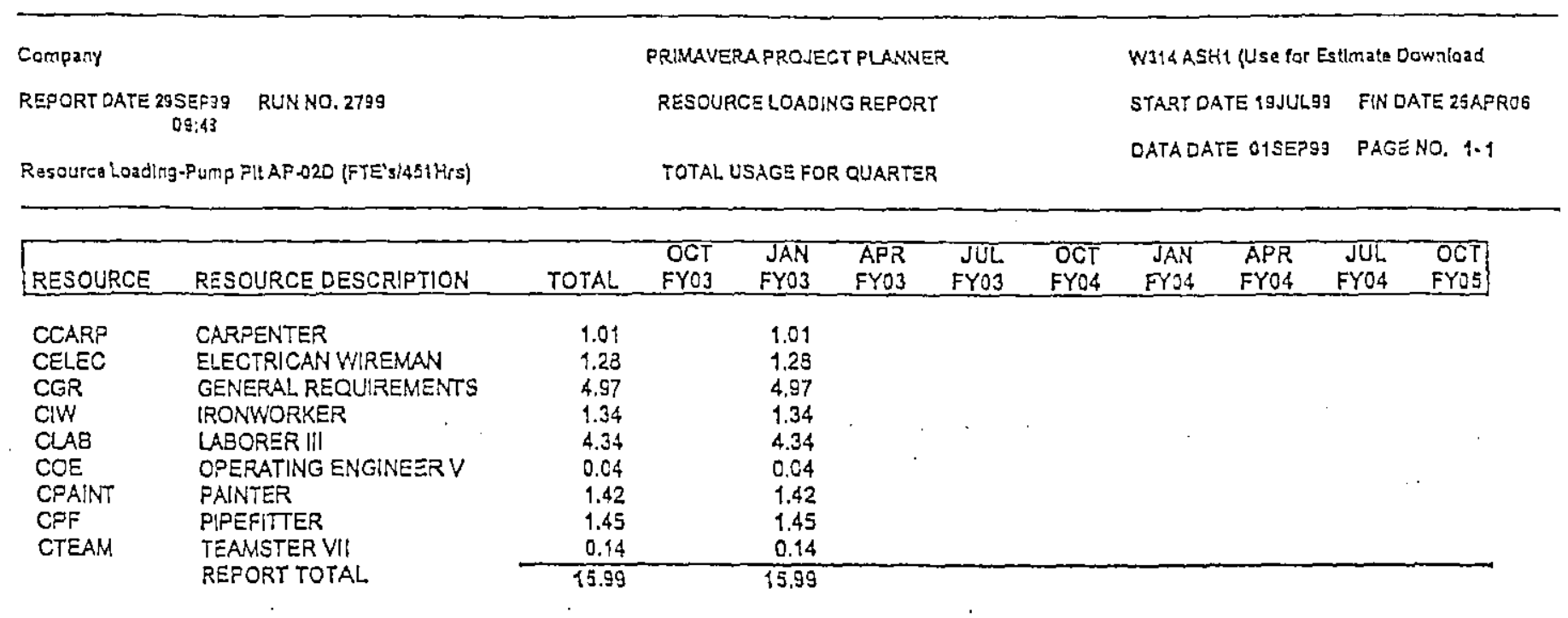




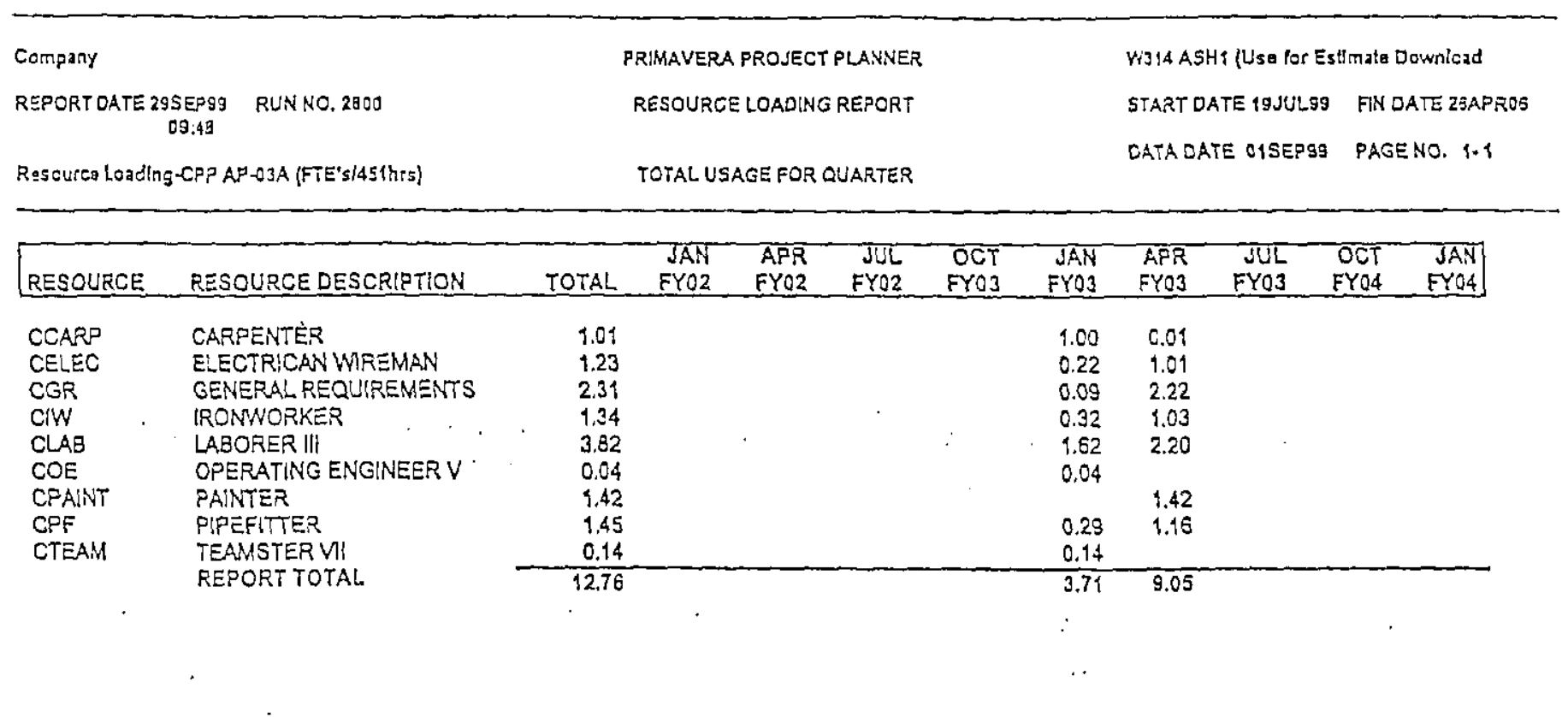


HNE-5109, REV. 0

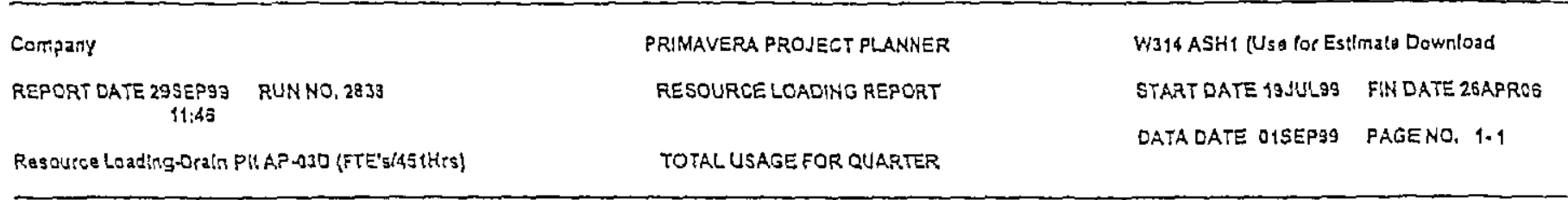

\begin{tabular}{|c|c|c|c|c|c|c|c|c|c|c|c|}
\hline RESOURCE & RESOURCE QESCRIPTION & TOTAL & $\begin{array}{r}\text { OCT } \\
\text { FYO3 }\end{array}$ & $\begin{array}{l}\text { JAN } \\
\text { FYO3 }\end{array}$ & $\begin{array}{l}\text { APR } \\
\text { FY03 }\end{array}$ & $\begin{array}{l}\text { JUL } \\
\text { EYO3 } \\
\end{array}$ & $\begin{array}{c}\text { OCT } \\
\text { FYO4 }\end{array}$ & $\begin{array}{l}\text { JAN } \\
\text { FYO4 }\end{array}$ & $\begin{array}{l}\text { APR } \\
\text { FYOA } \\
\end{array}$ & $\begin{array}{l}\text { JUL } \\
\text { FYO4 }\end{array}$ & $\begin{array}{r}\text { OCT } \\
\text { FYO5 } \\
\end{array}$ \\
\hline $\begin{array}{l}\text { CCARP } \\
\text { CELEC } \\
\text { CGR } \\
\text { CIW } \\
\text { CLAB } \\
\text { COE } \\
\text { CPAINT } \\
\text { CPF } \\
\text { CTEAM }\end{array}$ & $\begin{array}{l}\text { CARPENTER } \\
\text { ELECTRICAN WIREMAN } \\
\text { GENERAL REQUIREMENTS } \\
\text { IRONWORKER } \\
\text { LABORER III } \\
\text { OPERATING ENGINEER V } \\
\text { PAINTER } \\
\text { PIPEFITTER } \\
\text { TEAMSTER VI }\end{array}$ & $\begin{array}{l}1.01 \\
1.22 \\
4.97 \\
1.34 \\
2.92 \\
0.04 \\
1.42 \\
1.45 \\
0.14 \\
\end{array}$ & & $\begin{array}{l}1.01 \\
0.81 \\
0.09 \\
1.18 \\
2.80 \\
0.04 \\
1.11 \\
1.22 \\
0.14\end{array}$ & $\begin{array}{l}0.40 \\
4.88 \\
0.16 \\
0.32 \\
\\
0.32 \\
0.23\end{array}$ & & & & & & \\
\hline & REPORT TOTAL & 14.51 & & 8.20 & 6.31 & & & & & & \\
\hline
\end{tabular}




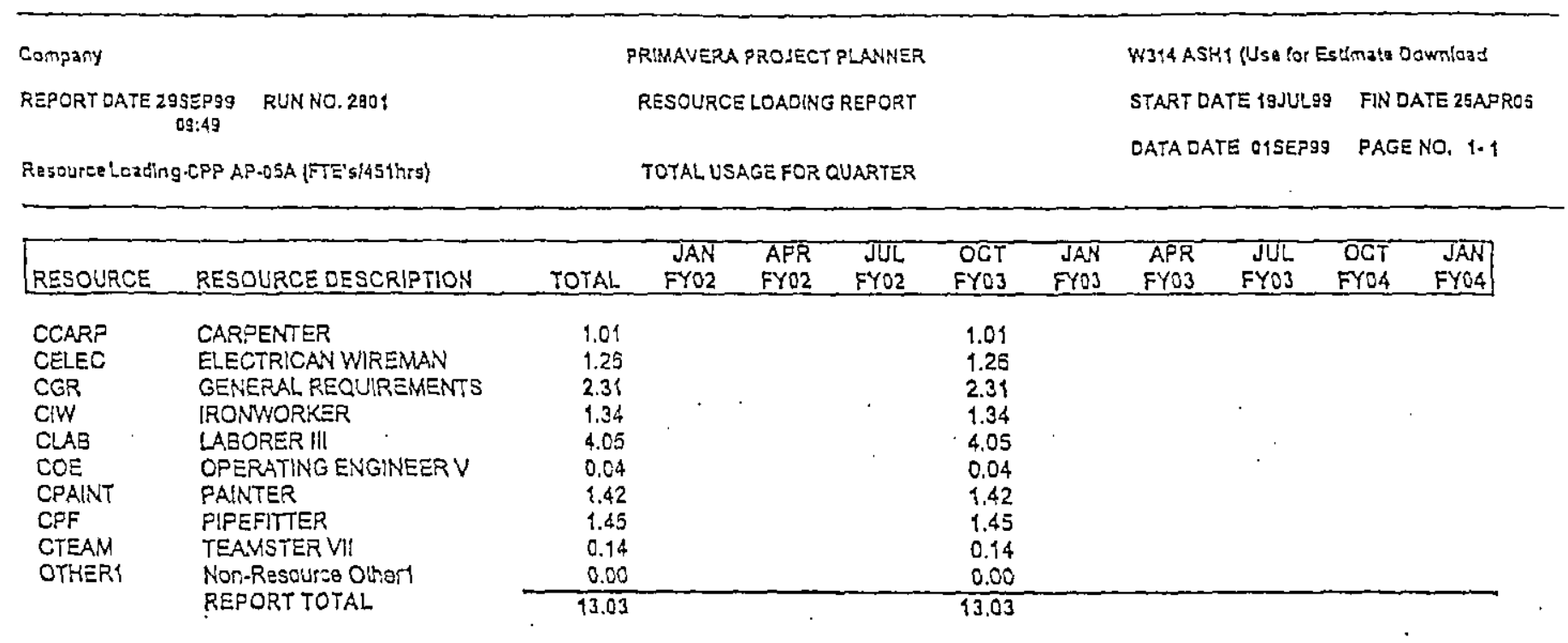




\begin{tabular}{|c|c|c|c|}
\hline Company & PRIMAVERA FROJECT PLANNER & W314 ASH1 (US8 for Est & imale Downioad \\
\hline $\begin{array}{c}\text { REPORT DRTE 29SEPYG } \\
\text { O9:49 }\end{array}$ & RESOURCE LOADING REPORT & STARTDATE 19JUL9S & FWN DATE 2BAPRDG \\
\hline Rasourca Loading.CPP AP-OGA (FTE's/451hrs) & TOTAL USAGE FOR QUARTER & DATA DATE OISEP9S & PAGENO. 91 \\
\hline
\end{tabular}

\begin{tabular}{|c|c|c|c|c|c|c|c|c|c|c|c|}
\hline RESOUREE & RESOUREE DESCRIPTIOH & TOTAL & $\begin{array}{l}\text { JAN } \\
\text { FYO2 }\end{array}$ & $\begin{array}{l}A P R \\
F Y O 2\end{array}$ & $\begin{array}{l}\text { JUL } \\
\text { FY02 }\end{array}$ & $\begin{array}{l}\text { OCT } \\
\text { FYO3 }\end{array}$ & $\begin{array}{l}\text { JAN } \\
\text { FYOS } \\
\end{array}$ & $\begin{array}{l}\text { APR } \\
\text { FYO3 }\end{array}$ & $\begin{array}{l}\text { JuL } \\
\text { FYO3 }\end{array}$ & $\begin{array}{l}\text { OCT } \\
\text { FYO4 }\end{array}$ & $\begin{array}{l}\text { JAN } \\
\text { FYO4 }\end{array}$ \\
\hline $\begin{array}{l}\text { CCAEP } \\
\text { CELEC } \\
\text { CGR } \\
\text { CIW } \\
\text { CLAB } \\
\text { COE } \\
\text { CPAINT } \\
\text { CPF } \\
\text { CTEAM }\end{array}$ & $\begin{array}{l}\text { CARPENTER } \\
\text { ELECTRICAN WIREMAN } \\
\text { GENERAL REQUIREMENTS } \\
\text { IRONWORKER } \\
\text { LABORER III } \\
\text { OPERATING ENGINEERV } \\
\text { PAINTER } \\
\text { PIPEFITTER } \\
\text { TEAMSTER VII }\end{array}$ & $\begin{array}{l}1.01 \\
1.24 \\
4.97 \\
1.34 \\
3.82 \\
0.04 \\
1.42 \\
1.45 \\
0.14 \\
\end{array}$ & r & .. & . & & $\begin{array}{l}1.01 \\
1.24 \\
4.97 \\
1.34 \\
3.82 \\
0.04 \\
1.42 \\
1.45 \\
0.14 \\
\end{array}$ & & $\cdot$ & & \\
\hline & REPORT TOTAL & 15.43 & & & & & 15.43 & & & & \\
\hline
\end{tabular}




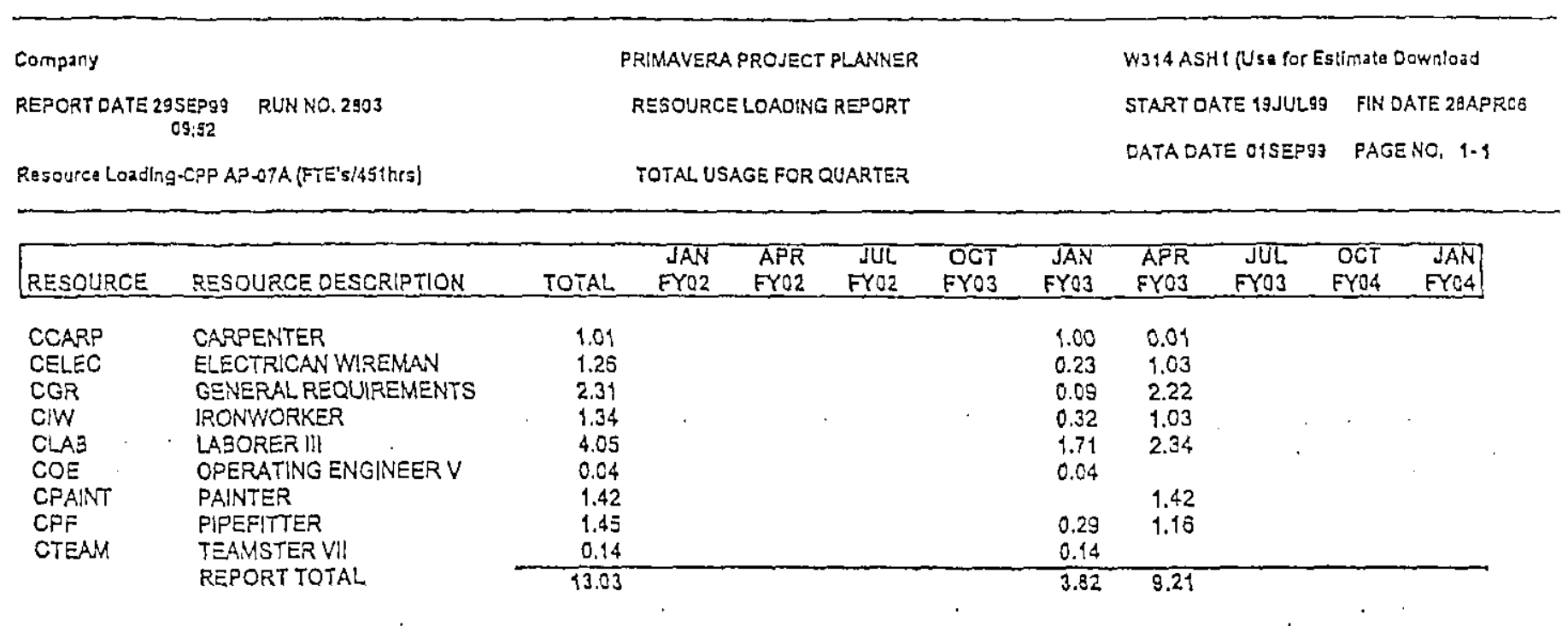




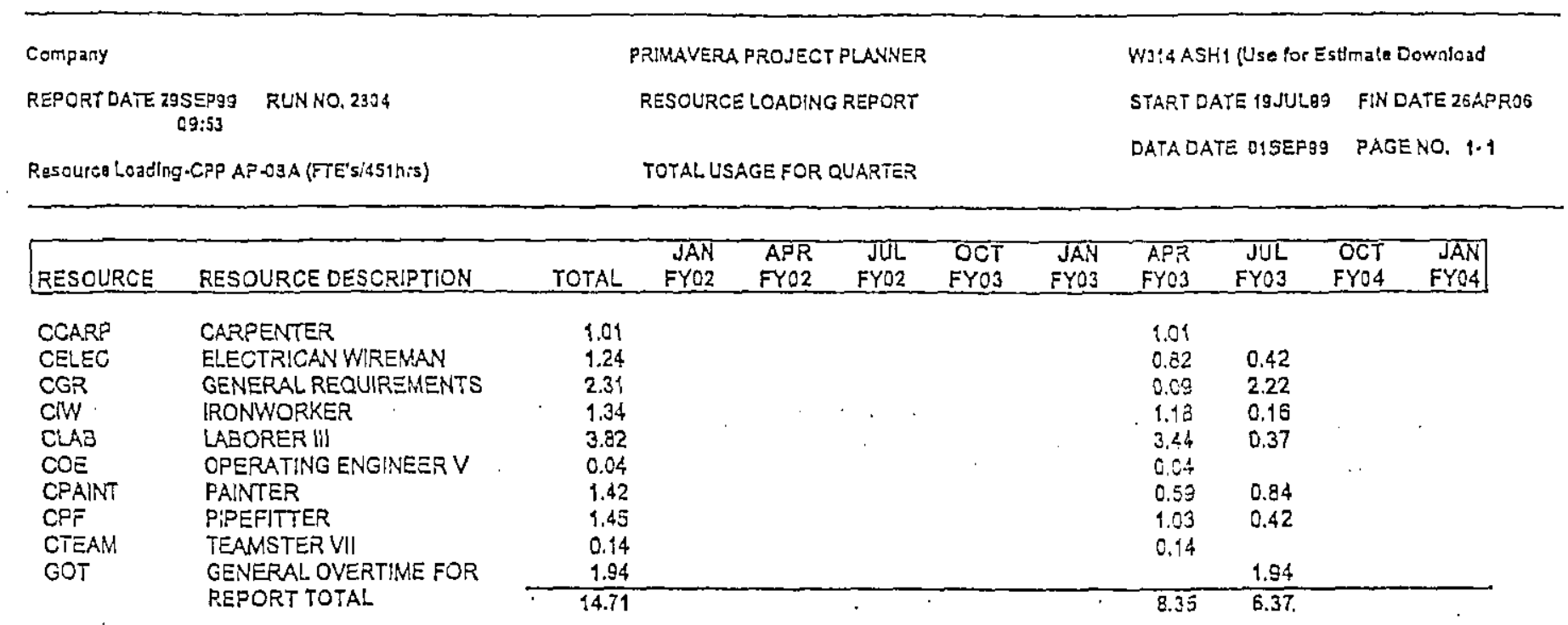


FNF-5109, REV.0

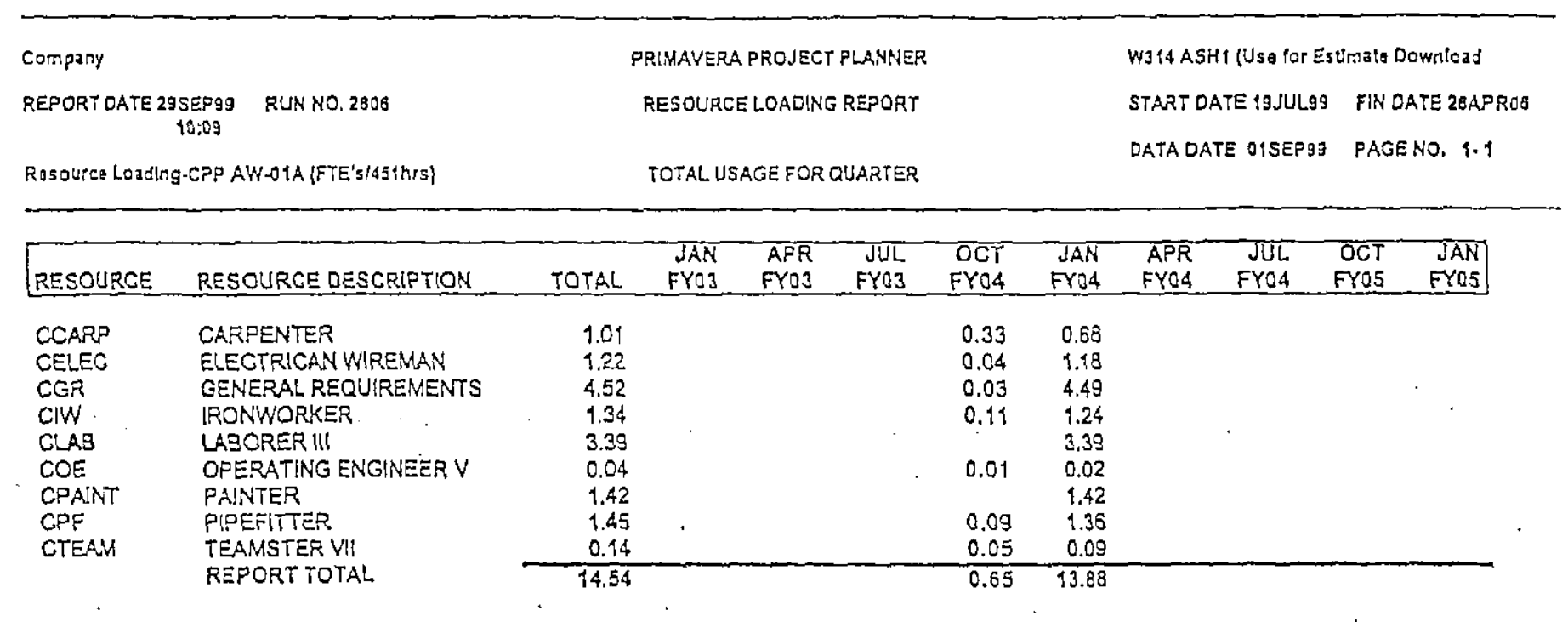




\begin{tabular}{|c|c|c|c|c|c|c|c|c|c|c|c|}
\hline \multicolumn{2}{|l|}{ Company } & \multicolumn{6}{|c|}{ PRMAVERA PROJECT PLANNER } & \multicolumn{4}{|c|}{ W314 ASH1 (Use for Estimate Downioad } \\
\hline \multicolumn{2}{|c|}{$\begin{array}{c}\text { REPORT DATE 235EPGg } \\
10: 10\end{array}$} & \multicolumn{5}{|c|}{ RESOURCE LOADING REPORT } & & \multicolumn{2}{|c|}{$\begin{array}{l}\text { START OATE 19JULSO } \\
\text { DATA OATE O1SEP99 }\end{array}$} & \multicolumn{2}{|c|}{ FIN DATE 2SAPRJ } \\
\hline \multicolumn{2}{|c|}{ Rasource Losdlng-CPP AW-O2A (FTE's/4Ethrs) } & \multicolumn{5}{|c|}{ TOTALUSAGE FOR QUARTER } & & & & FMue & \\
\hline RESOURCE & RESOURCEDESCRIPTION & TOTAL. & $\begin{array}{l}\text { JAN } \\
\text { FYO3 }\end{array}$ & $\begin{array}{l}\text { APR } \\
\text { EYO3 }\end{array}$ & $\begin{array}{r}\text { JUL } \\
\text { FYO3 } \\
\end{array}$ & $\begin{array}{l}\mathrm{OCT} \\
\mathrm{FYO4}\end{array}$ & $\begin{array}{l}\text { JAN } \\
\text { FYO4 }\end{array}$ & $\begin{array}{l}\text { APR } \\
\text { FYO4 }\end{array}$ & $\begin{array}{l}\text { JOL } \\
\text { FYO4 }\end{array}$ & $\begin{array}{l}\text { OCT } \\
\text { EYOS }\end{array}$ & $\begin{array}{l}\text { JAN } \\
\text { FYO5 }\end{array}$ \\
\hline $\begin{array}{l}\text { CCARP } \\
\text { CELEC } \\
\text { CGR } \\
\text { CIW } \\
\text { CLAS } \\
\text { COE } \\
\text { CPAINT } \\
\text { CPF } \\
\text { CTEAM }\end{array}$ & $\begin{array}{l}\text { CARPENTER } \\
\text { ELECTRICAN WIREMAN } \\
\text { GENERAL REQUIREMENTS } \\
\text { IRONWORKER } \\
\text { LABORER II! } \\
\text { OPERATING ENGINEERV } \\
\text { PAINTER } \\
\text { PIPEFITTER } \\
\text { TEAMSTER VI }\end{array}$ & $\begin{array}{l}1.01 \\
1.22 \\
2.31 \\
1.34 \\
3.11 \\
0.04 \\
1.42 \\
1.45 \\
0.14\end{array}$ & & . & . & & . & $\begin{array}{l}1.01 \\
1.22 \\
2.31 \\
1.34 \\
3.11 \\
0.04 \\
1.42 \\
1.45 \\
0.14\end{array}$ & & & \\
\hline & REPORT TOTAL & 12.04 & & & & & & 12.04 & & & \\
\hline
\end{tabular}


HNF-5109, REV. 0

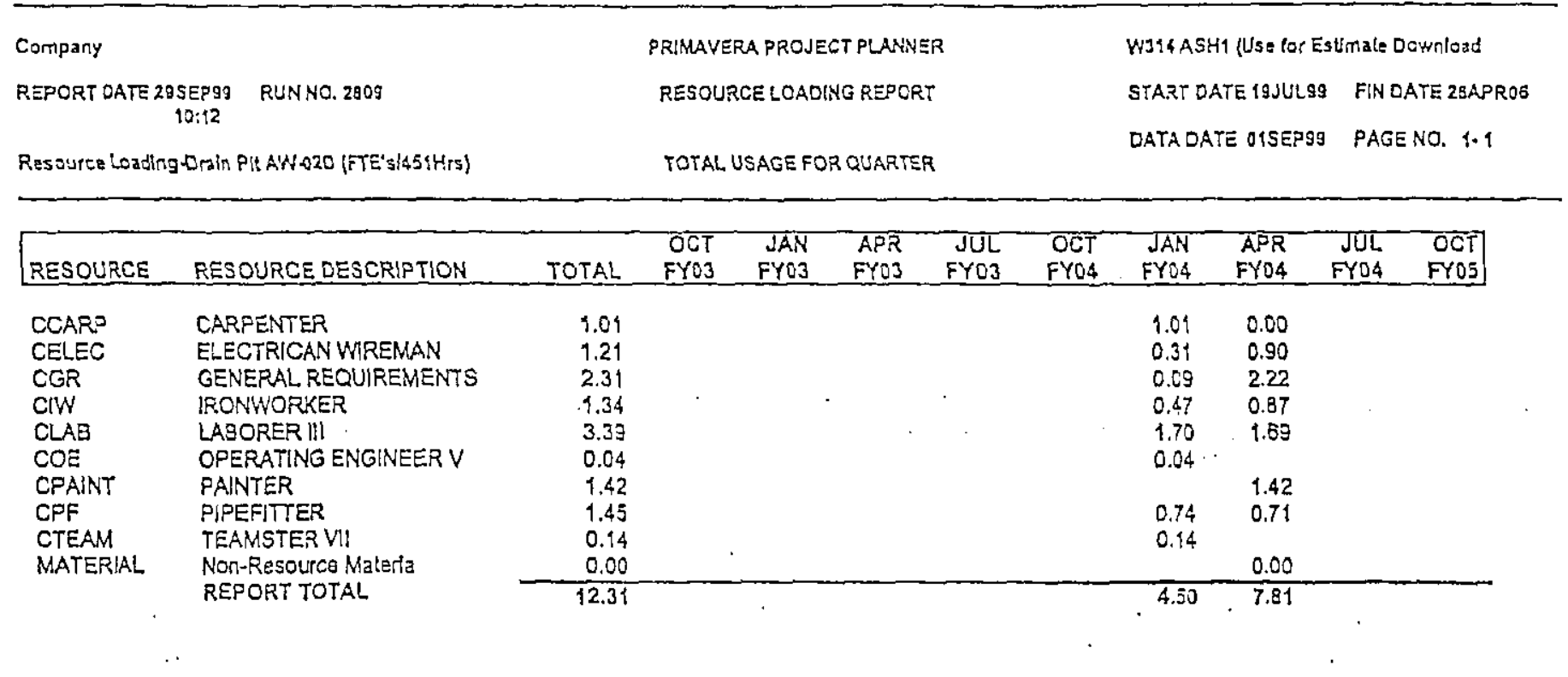




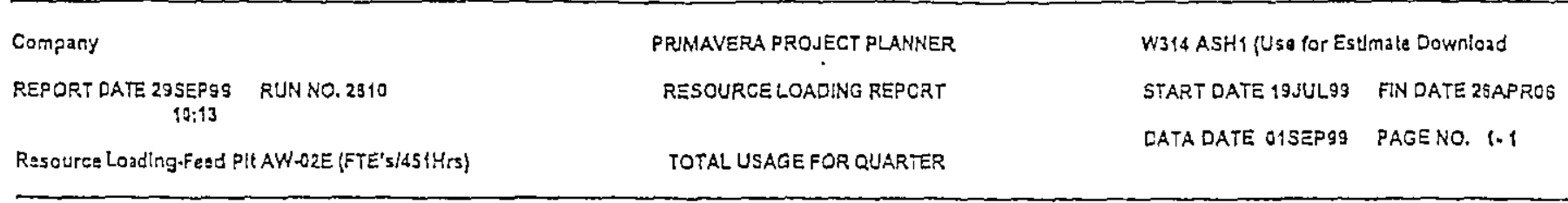

\begin{tabular}{|c|c|c|c|c|c|c|c|c|c|c|c|}
\hline RESOLRCE & RESOURCE DESCRIPTION & TOTAL & $\begin{array}{l}\text { OCT } \\
\text { FYO3 }\end{array}$ & $\begin{array}{l}\text { JAN } \\
\text { FYO3 }\end{array}$ & $\begin{array}{l}\text { APR } \\
\text { FYO3 }\end{array}$ & $\begin{array}{l}\text { JUL } \\
\text { FYO3 }\end{array}$ & $\begin{array}{l}00 T \\
\text { FYO4 }\end{array}$ & $\begin{array}{l}\text { JAN } \\
\text { FYO4 }\end{array}$ & $\begin{array}{l}\text { APR } \\
\text { FYO4 }\end{array}$ & $\begin{array}{l}\text { JUL } \\
\text { FYO4 }\end{array}$ & $\begin{array}{l}\text { OCT } \\
\text { FYO5 }\end{array}$ \\
\hline $\begin{array}{l}\text { CCARP } \\
\text { CELEC } \\
\text { CGR } \\
\text { CIW } \\
\text { CLAB } \\
\text { COE } \\
\text { CPAINT } \\
\text { CPE } \\
\text { CTEAY }\end{array}$ & $\begin{array}{l}\text { CARPENTER } \\
\text { ELECTRICAN WIREMAN } \\
\text { GENERAL REQUIREMENTS } \\
\text { IRONWORKER } \\
\text { LABORER III } \\
\text { OPERATING ENGINEERV } \\
\text { PAINTER } \\
\text { PIPEFITTER } \\
\text { TEAMISTER VII }\end{array}$ & $\begin{array}{l}1.01 \\
1.20 \\
2.31 \\
1.34 \\
3.39 \\
0.04 \\
1.42 \\
1.45 \\
0.14 \\
\end{array}$ & & . & & & & & $\begin{array}{l}1.01 \\
0.78 \\
0.09 \\
1.18 \\
3.08 \\
0.04 \\
0.79 \\
1.04 \\
0.14\end{array}$ & $\begin{array}{l}0.42 \\
2.22 \\
0.16 \\
0.32 \\
\\
0.54 \\
0.41\end{array}$ & \\
\hline & REPORT TOTAL & 12.30 & & & & & & & 8.14 & 4.16 & \\
\hline
\end{tabular}




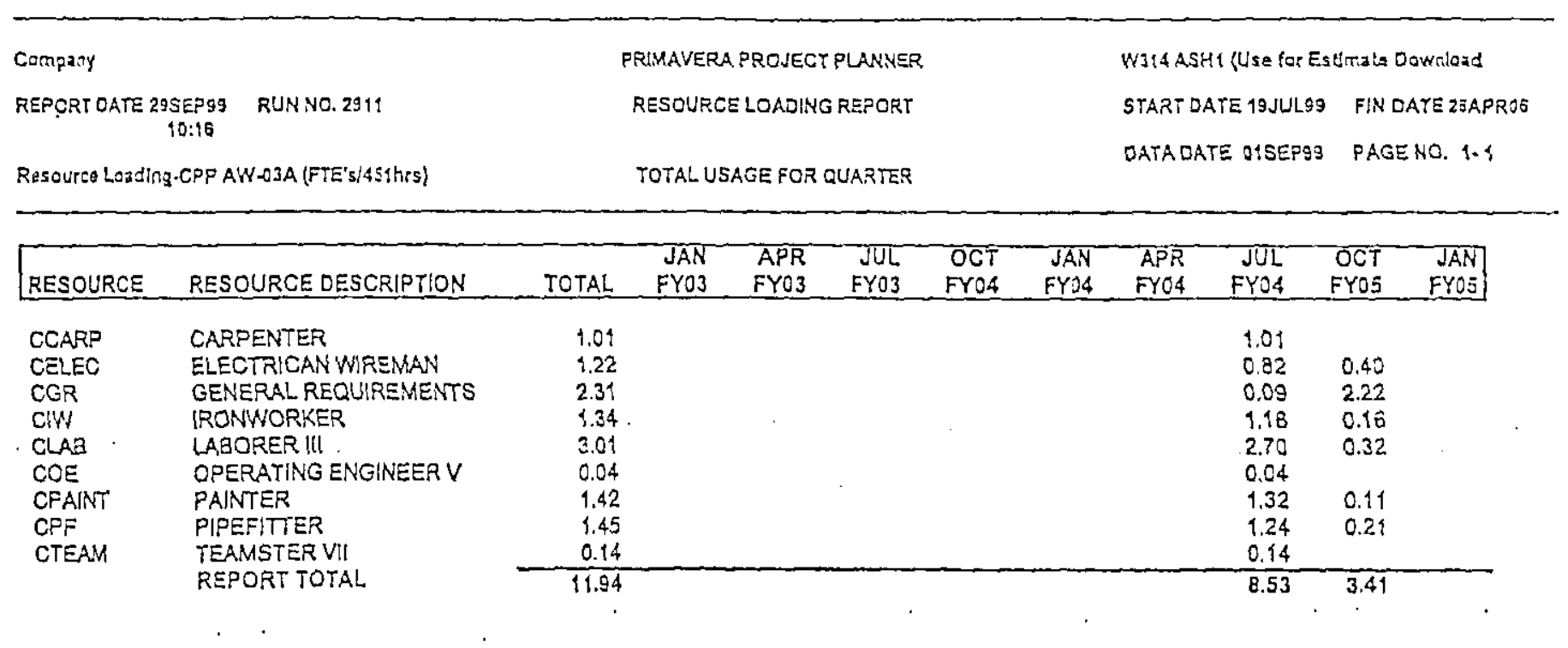




\begin{tabular}{|c|c|c|c|}
\hline $\begin{array}{c}\text { REPORT DATE 29SEPG9 RUN NO.23:2 } \\
10: 17\end{array}$ & RESOURCE LOADING REPORT & START DATE ISJULS9 & FIN DATE 25APROG \\
\hline
\end{tabular}

\begin{tabular}{|c|c|c|c|c|c|c|c|c|c|c|c|}
\hline RESOURCE & RESOURCE DESCRIPTION & TOTAL & $\begin{array}{l}\text { JAN } \\
\text { EYOS }\end{array}$ & $\begin{array}{l}\text { APR } \\
\text { FYO3 }\end{array}$ & $\begin{array}{l}\text { JUL } \\
\text { EYO3 }\end{array}$ & $\begin{array}{l}\text { OCT } \\
F Y 04\end{array}$ & $\begin{array}{l}\text { JAN } \\
\text { FYO4 }\end{array}$ & $\begin{array}{l}A P R \\
\text { FYOS }\end{array}$ & $\begin{array}{r}\text { JUL } \\
\text { FYO4 }\end{array}$ & $\begin{array}{l}\text { OCT } \\
\text { FYOS }\end{array}$ & $\begin{array}{l}\text { JAN } \\
\text { FYOS }\end{array}$ \\
\hline $\begin{array}{l}\text { CCARP } \\
\text { CELEC } \\
\text { CGR } \\
\text { CIW } \\
\text { CLA3 } \\
\text { COE } \\
\text { CPAINT } \\
\text { CPF } \\
\text { CTEAM }\end{array}$ & $\begin{array}{l}\text { CARFENTER } \\
\text { ELECTRICAN WIREMAN } \\
\text { GENERAL REQUIREMENTS } \\
\text { IRONWORKER } \\
\text { LABORERIU } \\
\text { OPERATING ENGINEERV } \\
\text { PAINTER } \\
\text { PIPEFITTER } \\
\text { TEAMSTER VII }\end{array}$ & $\begin{array}{l}1.01 \\
1.22 \\
4.52 \\
1.34 \\
3.53 \\
0.04 \\
1.42 \\
1.45 \\
0.14 \\
\end{array}$ & & . & & $\begin{array}{l}1.01 \\
0.82 \\
0.09 \\
1.18 \\
3.22 \\
0.04 \\
1.11 \\
1.22 \\
0.14\end{array}$ & $\begin{array}{l}0.40 \\
4.43 \\
0.16 \\
0.32 \\
\\
0.32 \\
0.23\end{array}$ & & . & & \\
\hline & REPORT TOTAL & 14.69 & & & . & 8.82 & 5.86 & & & & \\
\hline
\end{tabular}




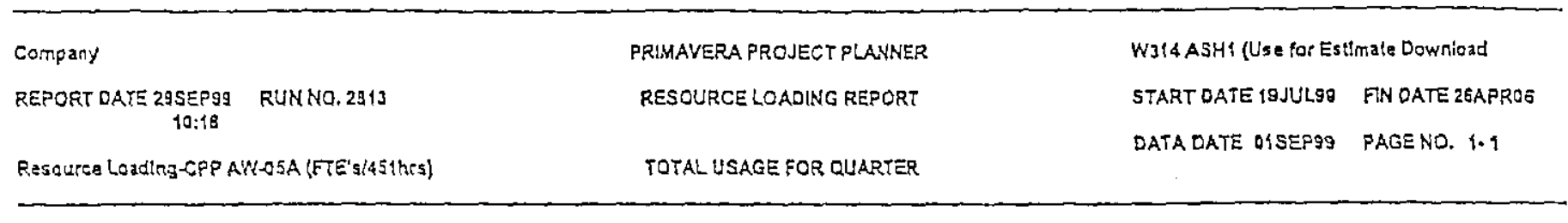

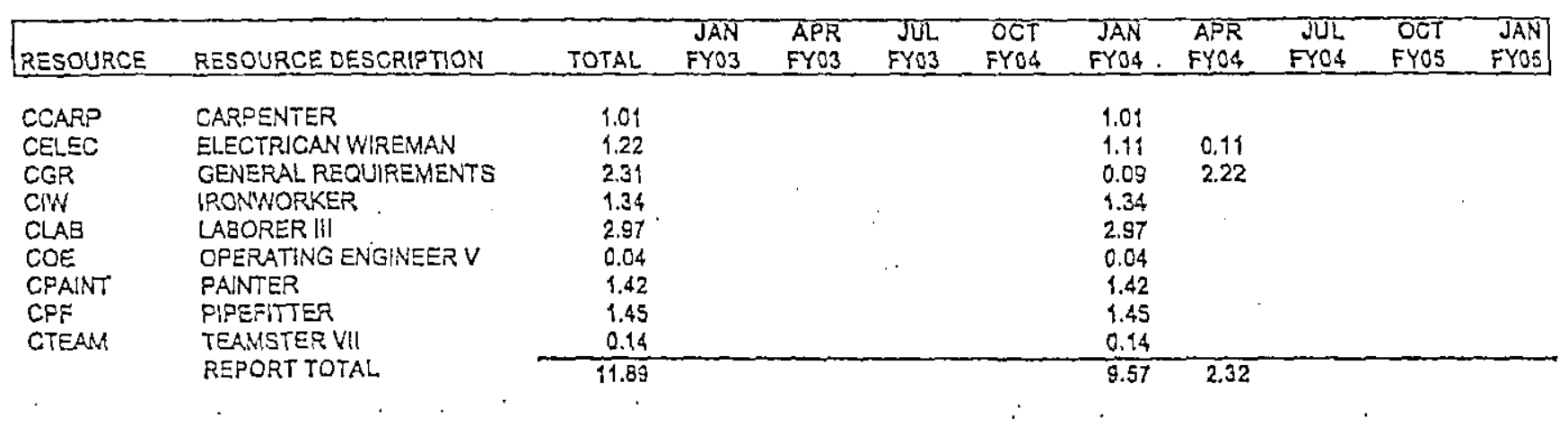




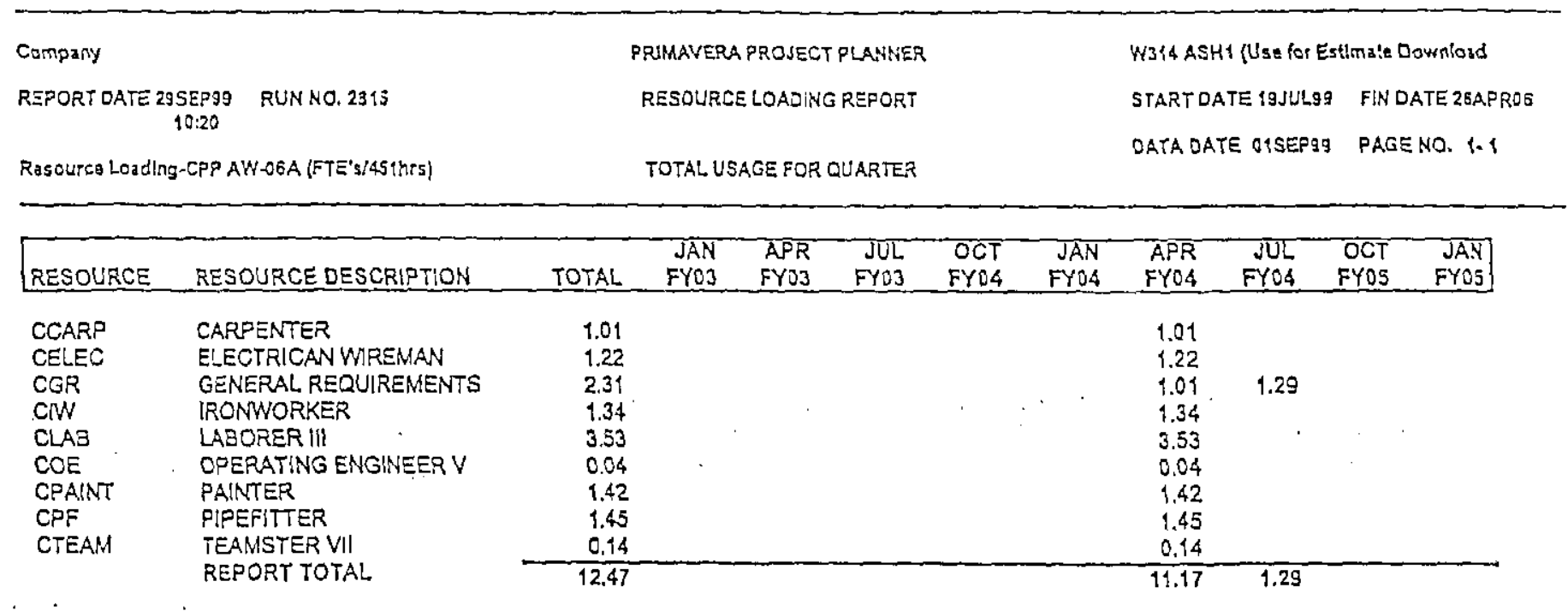




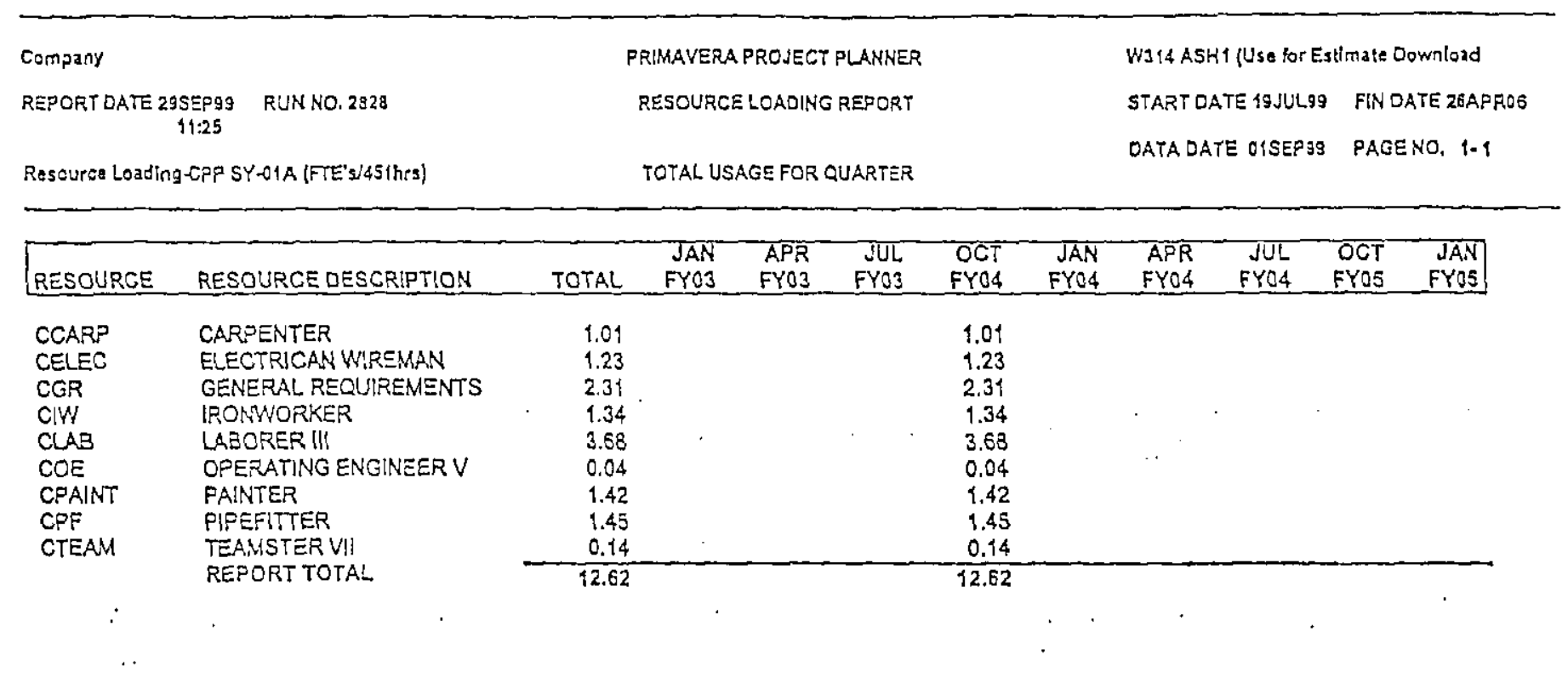




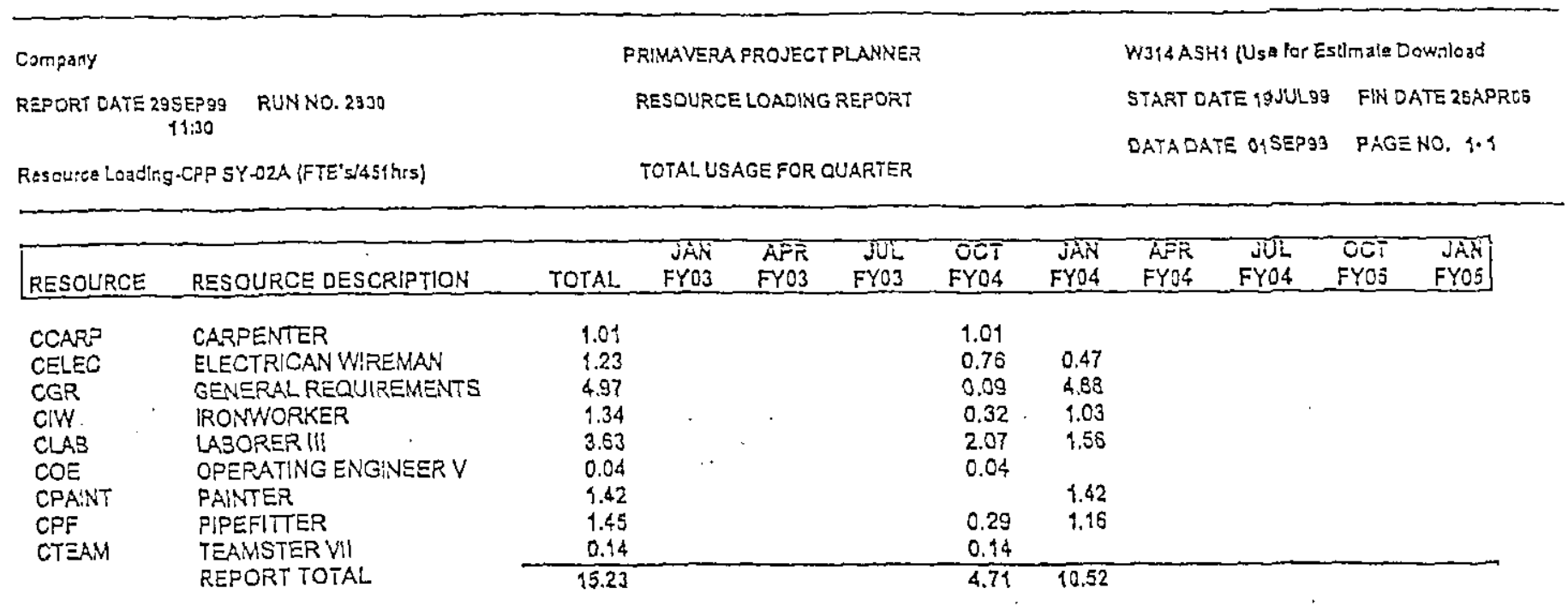




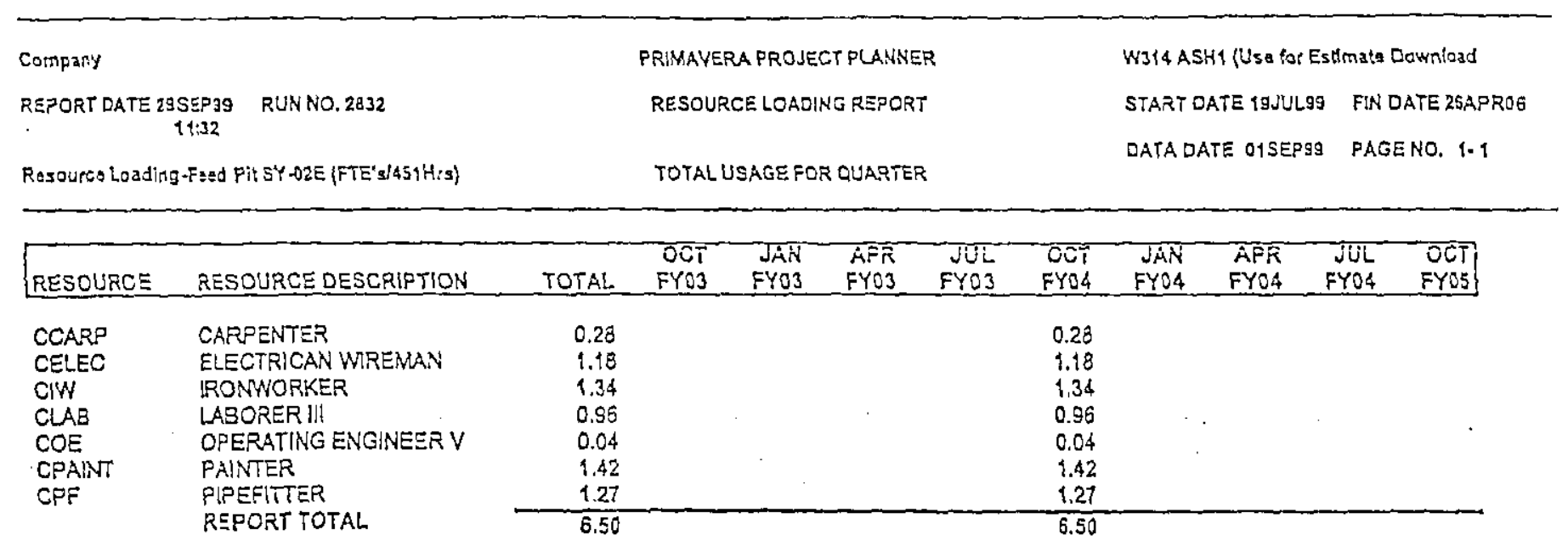




\begin{tabular}{|c|c|c|c|}
\hline $\begin{array}{c}\text { REPORT OATE 19SEPY9 RUNNO.2933 } \\
11: 34\end{array}$ & RESOURCE LOADING REPORT & START DATE YGJULIS & FIN DATE ZGAFROS \\
\hline
\end{tabular}

\begin{tabular}{|c|c|c|c|c|c|c|c|c|c|c|c|}
\hline RESQURCE & RESOURCE DESCRIPTION & TOTAL & $\begin{array}{r}\mathrm{OCT} \\
\text { FYO3 }\end{array}$ & $\begin{array}{l}\text { JAN } \\
\text { FYO3 }\end{array}$ & $\begin{array}{l}\text { APR } \\
\text { FYO3 }\end{array}$ & $\begin{array}{l}\text { JUL } \\
\text { FYO3 }\end{array}$ & $\begin{array}{l}\text { OCT } \\
\text { FYO4 }\end{array}$ & $\begin{array}{l}\text { JAN } \\
\text { FYO4 }\end{array}$ & $\begin{array}{l}\text { APR } \\
\text { FYO4 }\end{array}$ & $\begin{array}{l}\text { JUL } \\
\text { FYO4 }\end{array}$ & $\begin{array}{r}\text { OCT } \\
\text { FYos } \\
\end{array}$ \\
\hline $\begin{array}{l}\text { CCARP } \\
\text { CELEC } \\
\text { CGR } \\
\text { CIW } \\
\text { CLAB } \\
\text { COE } \\
\text { CPAINT } \\
\text { CPF } \\
\text { CTEAH }\end{array}$ & $\begin{array}{l}\text { CARFENTER } \\
\text { ELECTRICAN WIREMAN } \\
\text { GENERAL REQUIREMENTS } \\
\text { RRONWORKER } \\
\text { LABORERII! } \\
\text { OPERATING ENGINEER V } \\
\text { PAINTER } \\
\text { PIPEFITTER } \\
\text { TEAMSTER VI! }\end{array}$ & $\begin{array}{l}1.01 \\
1.24 \\
2.31 \\
1.34 \\
3.01 \\
0.04 \\
1.42 \\
1.45 \\
0.14\end{array}$ & & . & & & $\begin{array}{l}0.34 \\
0.14 \\
0.03 \\
0.11 \\
0.10 \\
0.01 \\
0.09 \\
0.05\end{array}$ & $\begin{array}{l}0.67 \\
1.10 \\
2.28 \\
1.24 \\
2.91 \\
0.02 \\
1.42 \\
1.36 \\
0.09\end{array}$ & . & & \\
\hline & REPORT TOTAL & 11.96 & & & & & 0.86 & 11.10 & & & \\
\hline
\end{tabular}




\begin{tabular}{|c|c|c|c|}
\hline Company & PRIMAVERA PROJECT PLANNER & \multicolumn{2}{|c|}{ W314 ASH1 (Use for Es Ltmate Downlozd } \\
\hline REPORTOATE 29SEP99 & RESOURCE LOADING RSPORT & START DATE 19JUL9S & FIN DATE 2GAPROS \\
\hline Regourcs Lodding.CPP 5Y.03A (FTE's/45/hrs) & TOTAL USAGE FOR QUARTER & DATADATE OISEPSY & PAGENO, 1.1 \\
\hline
\end{tabular}

\begin{tabular}{|c|c|c|c|c|c|c|c|c|c|c|c|}
\hline RESQURGE & RESOURGE DESGRIPTION & TOTAL & $\begin{array}{l}\text { JAN } \\
\text { FYO3 }\end{array}$ & $\begin{array}{l}\text { AFE } \\
\text { FYO3 }\end{array}$ & $\begin{array}{c}\text { JUL } \\
\text { FYO3 }\end{array}$ & $\begin{array}{l}\text { OCT } \\
\text { FYO4 }\end{array}$ & $\begin{array}{l}\text { JAN } \\
\text { FYO4 }\end{array}$ & $\begin{array}{l}\text { APR } \\
\text { FYO4 }\end{array}$ & $\begin{array}{l}\text { JUL } \\
\text { FYO4 }\end{array}$ & $\begin{array}{l}\text { OCT } \\
\text { FYOS }\end{array}$ & $\begin{array}{l}\text { JAN } \\
\text { EY05 }\end{array}$ \\
\hline $\begin{array}{l}\text { CCARP } \\
\text { CELEC } \\
\text { CGR } \\
\text { CIW } \\
\text { CLAB } \\
\text { COE } \\
\text { CFAINT } \\
\text { CPF } \\
\text { CTEAM }\end{array}$ & $\begin{array}{l}\text { CARPENTER } \\
\text { ELECTRICAN WIREMAN } \\
\text { GENERAL REQUIREMENTS } \\
\text { RRONWORKER . } \\
\text { LABORER !II } \\
\text { OPERATING ENGINEERV } \\
\text { FAINTER } \\
\text { PIPEFITTER } \\
\text { TEAMSTER VII }\end{array}$ & $\begin{array}{l}1.01 \\
1.22 \\
2.31 \\
1.34 \\
3.53 \\
0.04 \\
1.42 \\
1.45 \\
0.14\end{array}$ & & & & & . & $\begin{array}{l}1.01 \\
0.81 \\
0.09 \\
1.13 \\
3.22 \\
0.04 \\
1.00 \\
1.13 \\
0.14\end{array}$ & $\begin{array}{l}0.41 \\
2.22 \\
0.16 \\
0.32 \\
0.43 \\
0.32\end{array}$ & & . \\
\hline & REPORT TOTAL & 2.47 & & & & & & 8.63 & 3.84 & & \\
\hline
\end{tabular}


HNE-5109, REV. 0

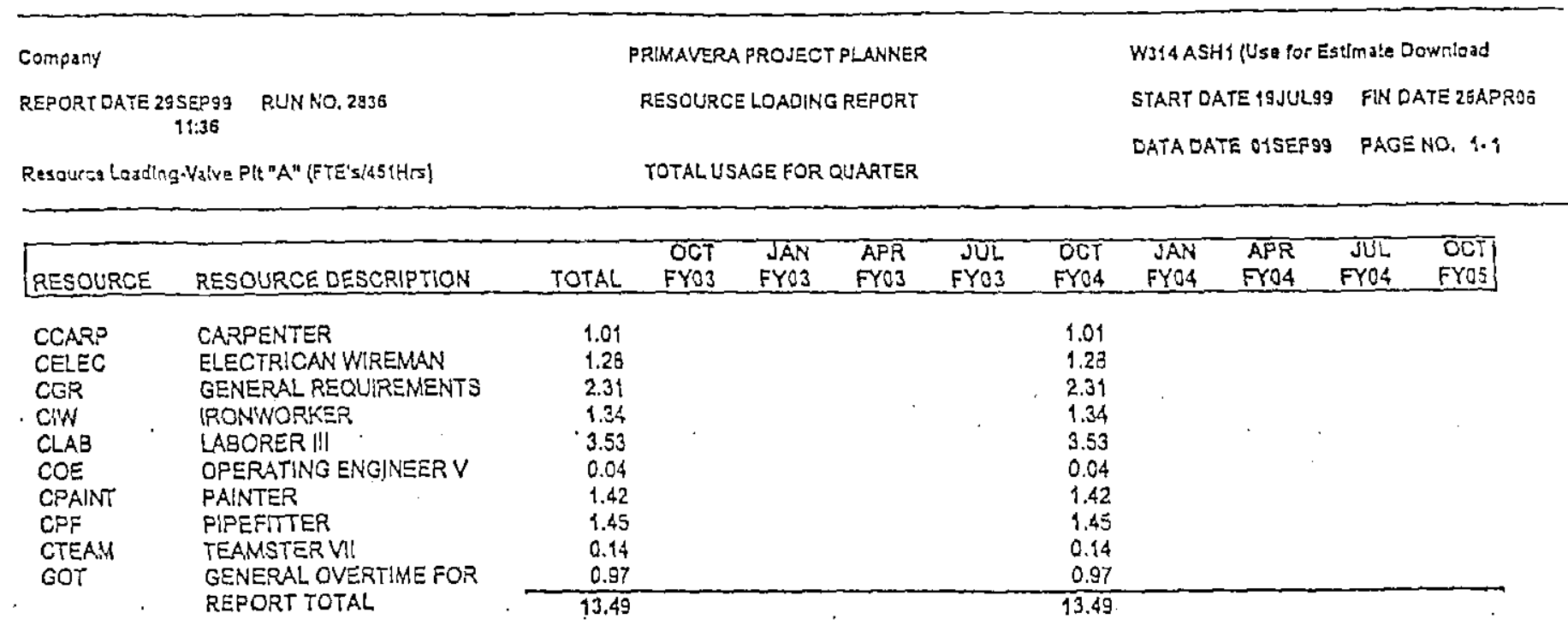




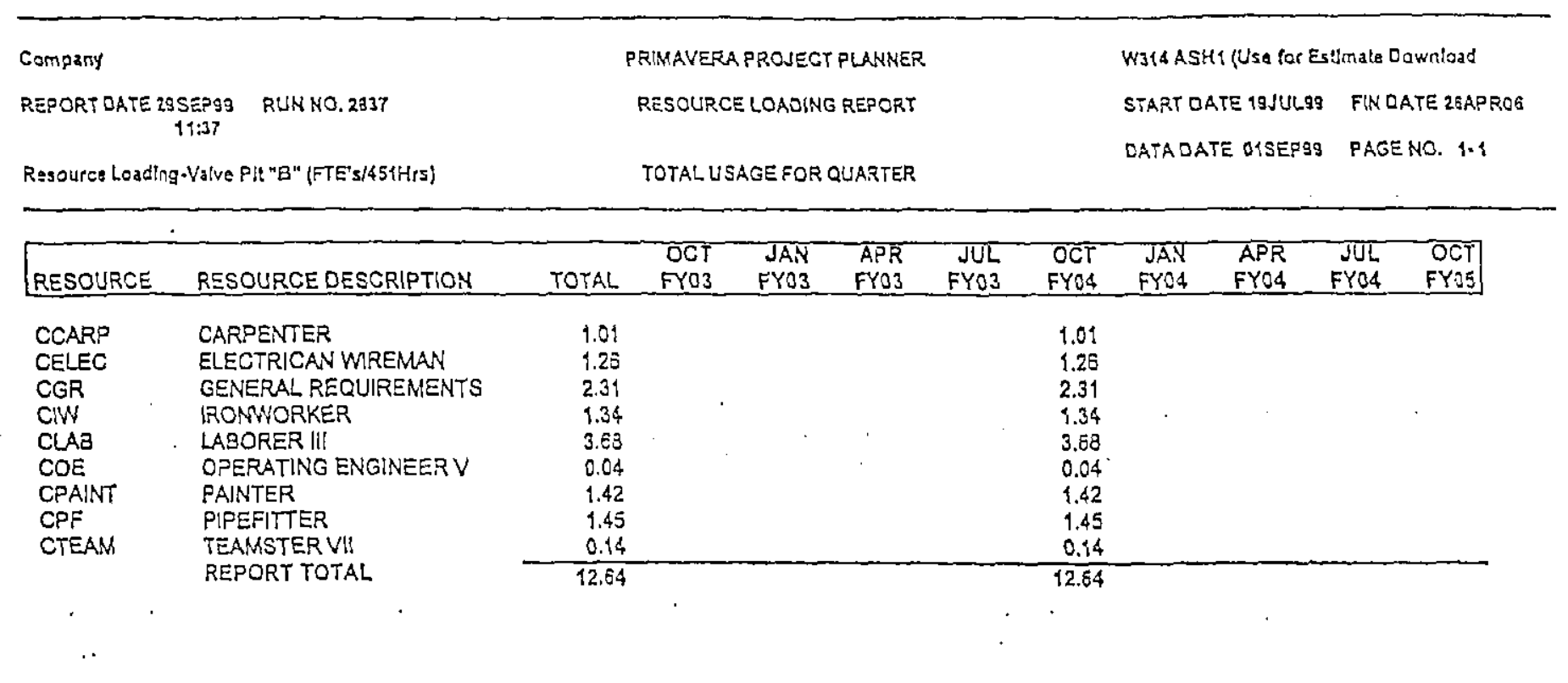


HNF-5109, Rev. 0

\subsection{CONTINGENCY}

Contingency for Phase 2 totals $\$ 30.6$ million, or a $32 \%$ of estimated costs. The new DOE guidance for Project Contingency, as noted in the draft Waste Management Project Contingency Analysis (Table 4 - Modifications Required to Existing Hardware), recommends a range of $30 \%$ to $40 \%$ in project contingency at the conceptual stage. Although $32 \%$ is on the lower end of the recommended range, this amount is reasonable considering the major work involved in Phase 2 (ventilation system, process pit, vapor space pressure monitoring, and electrical upgrades) has been performed numerous times on site before. A good historical basis is therefore available for this type of work.

The contingency amount was established using the DOE Order 430.1, Life-Cycle Asset Management (LCAM), GPG-FM-007 guidance. Functional subject matter experts performed a qualitative risk analysis using engineering judgement to establish the potential consequences and likelihood of risk events. Both technical and programmatic risks were analyzed. As a result of this analysis the major project risks are identified as:

- Possibility of project failure due to the lack of financial support to the end of the project;

- Potential for changes to the project due to changed or new technical requirements;

- Potential for changes to the project from various programmatic and project documents and analyses yet to be completed that contain technical data affecting the project;

- Potential changes in scope implementation and interface by operational requests and other projects;

- Potential changes in tumover activities - may be raised to a higher level of inquiry (e.g., Readiness Assessments);

- Potential changes in project scope due to inaccurate scoping/estimate assumptions and/or inaccurate, detailed, integrated planning; and

- Potential for qualified personnel or contractors to be unavailable when needed.

The risk analysis established the Phase 2 risks, and associated frequencies and potential consequences. Consequences were expressed in terms of cost and time impacts. Each of the risks were converted to contingency dollars by multiplying the most likely frequency times most likely consequence dollars. Finally, risk dollars were allocated to each of the project tasks. The allocation of contingency can be summarized as $\$ 3.1 \mathrm{M}$ to Project Management, $\$ 2.4 \mathrm{M}$ to Design, $\$ 22.6 \mathrm{M}$ to Procurement/Construction, $\$ 2.2 \mathrm{M}$ to Test and Turnover, and $\$ 0.4 \mathrm{~K}$ to Management Self Assessment/Readiness.

A more detailed discussion of the risk analysis methodology can be found in the Project Execution Plan, HNF-SD-W-314-PMP-001, Rev 3, Appendix F, Risk Management Plan. Actual dollar values of the resultant contingencies at the project activity level can be found in the Phase 2 Rebaseline cost estimate, Section 6.0 . 
Table 11.1 Contingency Presents The Contingency Spread By Major WBS Element.

\begin{tabular}{|c|c|c|c|c|}
\hline WBS & $14+4 \mathrm{~W} 314 \mathrm{Phase} 2 \mathrm{C}$ & ontingency & $\begin{array}{l}\text { Alocation } \\
\text { Contingency } \$\end{array}$ & 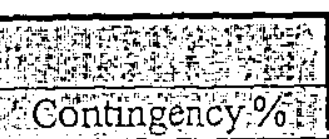 \\
\hline$\overline{1.1}$ & Project Management & $11,510,720$ & $2,874,997$ & $25.0 \%$ \\
\hline 1.2 & Permitting \& Safety & $1,043,131$ & 174,996 & $16.8 \%$ \\
\hline $1.3 . \mathrm{C}$ & Other Project Costs & $6,021,695$ & $1,514,662$ & $25.2 \%$ \\
\hline $1.3 . \mathrm{K}$ & Startup \& Testing & $6,308,865$ & $2,149,996$ & $34.1 \%$ \\
\hline $1.3 . \mathrm{L}$ & Operations Preparations & $1,581,754$ & 424,995 & $26.9 \%$ \\
\hline $1.3 . \mathrm{M}$ & Independent Reviews & 217,280 & 0 & $0.0 \%$ \\
\hline $1.3 . \mathrm{P}$ & Phase 2 Planning & $3,963,300$ & 49,994 & $1.3 \%$ \\
\hline 1.3.Q & SY Ventilation & 509,902 & 160,853 & $31.5 \%$ \\
\hline $1.5 . \mathrm{A}$ & AN Tank Farm & $10,011,189$ & $3,586,750$ & $35.8 \%$ \\
\hline $1.5 . \mathrm{B}$ & AP Tank Farm & $14,933,353$ & $5,387,235$ & $36.1 \%$ \\
\hline $1.5 . \mathrm{C}$ & AW Tank Farm & $14,981,378$ & $5,274,142$ & $35.2 \%$ \\
\hline $1.5 . \mathrm{D}$ & AY Tank Farm & $2,296,485$ & 713,804 & $31.1 \%$ \\
\hline $1.5 . \mathrm{E}$ & AZ Tank Farm & $2,361,756$ & 762,493 & $32.3 \%$ \\
\hline $1.5 . \mathrm{F}$ & SY Tank Farm & $12,672,540$ & $4,521,103$ & $35.7 \%$ \\
\hline $1.5 . \mathrm{H}$ & 244-S DCRT & $7,094,331$ & $2,502,663$ & $35.3 \%$ \\
\hline 1.5 .1 & $200 \mathrm{E} / \mathrm{W}$ & $1,657,526$ & 526,293 & $31.8 \%$ \\
\hline $4 x^{2}$ & 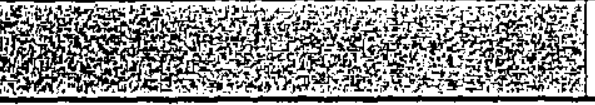 & $97,165,206$ & $30,624,976$ & $31.5 \%$ \\
\hline
\end{tabular}

Project Management (WBS 1.1): The 25\% identified provides \$2.9M contingency for Project Management and Integration, Project Engineering, Systems Engineering, and Quality Assurance. The contingency risks expressed in this area are programmatic and readiness risks. Programmatic risks $(-\$ 900 \mathrm{~K})$ include items, such as fluctuating funding, changes in DOE direction, Oversight group recommendations, and changes to project documentation. Phase 2 is currently planning a Readiness Assessment for AN Tank Farm Upgrades. If other Tank Farm upgrades require more than the ABU process, costs would increase to cover added readiness activities. This is contained in the Readiness portion of the risk $(\sim \$ 2 \mathrm{M})$

Permitting and Safety (WBS 1.2): The 17\% identified provides $\$ 0.2 \mathrm{M}$ contingency for environmental support of design, construction, startup and testing, and readiness activities, as well as the obtaining of appropriate permits, including state air permits. This process is well understood and warrants a relatively low contingency.

OPC Activities (WBS 1.3.C): The 25\% identified provides $\$ 1.5 \mathrm{M}$ contingency for Operations personnel support of design and construction. A historical basis for this familiar type of project work warrants a relatively moderate contingency. 
Startup \& Testing (WBS 1.3.K): The 34\% identified provides $\$ 2.2 \mathrm{M}$ contingency for the Startup, and Testing and Tumover processes, including the ABU process. A historical basis for this familiar type of project work warrants a relatively moderate contingency.

Operations Preparations (VVBS 1.3.L): The $27 \%$ identified provides $\$ 0.4 \mathrm{M}$ contingency for the Management Self Assessment processes and the Readiness Assessment for AN Tank Farm Upgrades. A historical basis for this familiar type of project work warrants a relatively moderate contingency.

Independent Reviews (WBS 1.3.M): The 0\% identified provides $\$ 0 \mathrm{M}$ contingency for DOE independent reviews. This is a budget allocation and therefore does not require contingency.

Phase 2 Planning (WBS 1.3.P): The $1 \%$ identified provides $\$ 50 \mathrm{~K}$ contingency for the remaining planning of Phase 2. Much planning was accomplished in 'FY99 and a little over the $50 \%$ of the cost aforementioned was spent in FY99. This process is well understood and warrants a very low contingency.

AN Farm (WBS 1.5.A): The 36\% identified provides $\$ 3.6 \mathrm{M}$ contingency for the primary ventilation system upgrade, five process pit upgrades, and vapor space pressure monitoring upgrades. This farm warrants one of the highest \% contingency because it is the first farm to be addressed. Subsequent farms should benefit from lessons leamed and therefore warrant a slightly smaller \% contingency.

AP Farm (WBS 1.5.B): The 36\% identified provides $\$ 5.4 \mathrm{M}$ contingency for the primary ventilation system upgrade, cight process pit upgrades, and vapor space pressure monitoring upgrades. This will be the third ventilation system (second primary system) to be upgraded and therefore warrants one of the highest percentages of contingency.

AW Farm (WBS 1.5.C): The 35\% identified provides $\$ 5.3 \mathrm{M}$ contingency for the primary ventilation system upgrade, eight process pit upgrades, and vapor space pressure monitoring upgrades. This will be the third primary ventilation system to be upgraded and therefore warrants a slightly smaller (than AP Farm) contingency.

AY Farm (WBS 1.5.D): The 31\% identified provides $\$ 0.7 \mathrm{M}$ contingency for vapor space pressure monitoring and electrical upgrades. Because no ventilation upgrade is addressed in this farm, it warrants a relatively smaller contingency than those farms with ventilation upgrades.

AZ Farm (WBS 1.5.E): The 32\% identified provides $\$ 0.8 \mathrm{M}$ contingency for vapor space pressure monitoring and electrical upgrades. Because no ventilation upgrade is addressed in this farm it, warrants a relatively smaller contingency than those farms with ventilation upgrades.

SY Farm (WBS 1.5.F): The 36\% identified provides $\$ 4.15 \mathrm{M}$ contingency for the SY Annulus Ventilation System, six process pits, and vapor space pressure monitoring upgrades. Because of the ventilation upgrades, this system warrants one of the highest percentages of contingency.

244-S DCRT (WBS 1.5.H): The 35\% identified provides $\$ 2.5 \mathrm{M}$ contingency for ventilation system upgrade, two process pits, and vapor space monitoring upgrades. This is the second 
ventilation system to be upgraded following the AN Farm and therefore warrants one of the highest percentages of contingency.

200 E/W AREA (WBS 1.5.I): The 32\% identified provides $\$ 0.5 \mathrm{M}$ contingency for installation of a bypass line around a process pit. Because a sound historical basis for this type of work exists, it warrants a relatively moderate contingency. 


\subsection{WBS DICTIONARY}

The project's WBS was initially developed and approved during the conceptual phase based on the RPP technical objectives. The WBS provides the basis for organizing, planning, estimating, scheduling, and reporting performance for RPP work. A detailed WBS dictionary with definitions for each WBS element can be found in HNF-SD-W-314-PMP-001, Project Execution Plan for TFRSO Project W-314, Appendix A. This dictionary has been modified to add an additional expense funded activity (WBS 1.3.Q) for the SY Tank Farm annulus ventilation work. Additionally, the WBS element 1.5.I, $200 \mathrm{E} / \mathrm{W}$ Area, was modified to include work scope for the LIQW-701 to SN-220 transfer line connection and WBS element 1.5.J, Single-Shell Support System, was modified to delete Phase 2 work scope. 